\title{
La etnobotánica de los
Chácobo en el siglo XX
}

\author{
Narel Y. Paniagua Zambrana, Rainer W. Bussmann, \\ Carolina Téllez, Carlos Vega (editores)
}

\section{Investigacíon}

\section{Resumen}

A pesar de la gran diversidad de grupos indígenas que existen en Bolivia, muy pocos estudios han documentado de forma detallada su conocimiento y uso de los recursos naturales. Los Chácobo son un pueblo de la familia de los Pano, con aproximadamente 500 miembros ubicados en el norte del Depto. del Beni y que al igual que muchos otros grupos indígenas de la Amazonía han empleado diferentes estrategias para satisfacer sus necesidades de subsistencia, que inicialmente cuando aún eran nómadas estaba basada en la recolección de productos del bosque y aun lo hicieron durante todo el proceso de su establecimiento en las que ahora son sus comunidades actuales.

La importancia que los Chácobo le dan a los recursos naturales, es el reflejo de un conocimiento que ha sido transmitido y adquirido a lo largo de muchas generaciones, de su contacto con la naturaleza y de su continua experimentación. Lamentablemente, no cuentan con información que documente como su conocimiento ha ido cambiando con las nuevas generaciones, si se mantiene o se está perdiendo, y cuáles son las razones. De esta manera los Chácobo podrían afrontar mejor el desafío de conservar sus recursos naturales, y lo más importante, de conservar el conocimiento que les ha permitido hacer un uso sostenible y racional de los mismos (ellos) a lo largo de muchas generaciones.
Esta publicación es uno de los primeros esfuerzos por recuperar y repatriar información disponible acerca de los Chácobo y su cultura, y devolverlo a sus propietarios, que bajo el Protocolo de Nagoya sobre acceso a recursos genéticos y participación justa y equitativa en los beneficios provenientes de su utilización, les corresponde a los Chácobo. Muchos de estos trabajos han sido publicados y difundidos en el exterior; sin embargo, limitaciones como el idioma o su limitada accesibilidad, han hecho que hasta ahora sean desconocidos para los Chácobo. Aunque Bolivia todavía no ha ratificado el Protocolo de Nagoya, consideramos que todo el conocimiento del pueblo Chácobo es propiedad intelectual del mismo.

Con esta edición especial de Ethnobotany Research and Applications tratamos de llevar el tema de investigaciones interdiciplinarios y e intercientificos a un público más amplio.

\section{Correspondencia}

Narel Paniagua Zambrana, Saving Knowledge, Avenida Principal 92, Chicani, Casilla 13092, La Paz, Bolivia,

Narel.Paniagua@savingknowledge.org

Rainer W. Bussmann, Saving Knowledge, Avenida Principal 92, Chicani, Casilla 13092, La Paz, Bolivia,

Rainer.Bussmann@savingknowledge.org

Carolina Téllez, San Martín 375, Trujillo, Perú

Carlos Vega, San Martín 375, Trujillo, Perú

Ethnobotany Research \& Applications 16(1):1-393 (2017) 


\section{LOS CHÁCOBO Y SU HISTORIA EN EL SIGLO XX}

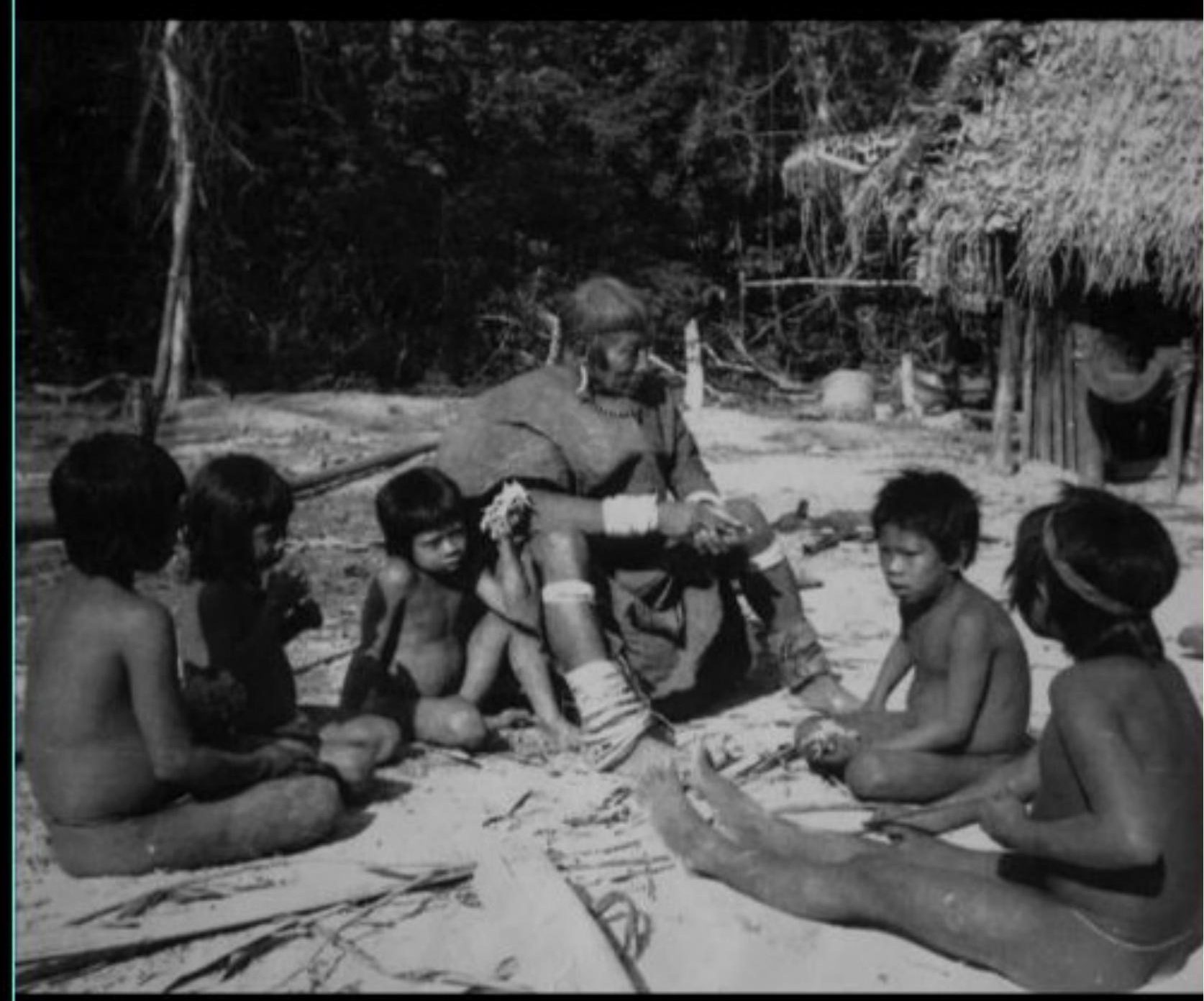

Paniagua-Zambrana, Bussmann, Téllez \& Vega EDITORES 


\section{LOS CHÁCOBO Y SU HISTORIA EN EL SIGLO XX}




\section{Los Chácobo y su historia en el siglo XX}

Este libro forma parte del material generado como parte del Proyecto

Etnobotánica de los Chácobo y las instituciones colaboradoras

\section{Editores:}

Narel Paniagua Zambrana, Rainer W. Bussmann, Carolina Téllez y Carlos

Vega.

Todos los trabajos se ejecutaron bajo el reglamento del "Protocolo de Nagoya sobre acceso a los recursos genéticos y participación justa y equitativa en los beneficios que se deriven de su utilización al Convenio sobre la Diversidad Biológica" y se mantiene el derecho de autoría de sus conocimientos tradicionales de todos los informantes. Cualquier uso comercial de la información presentada en esta publicación requiere del consenso previo con los informantes y comunidades, y un acuerdo sobre la distribución de beneficios.

प 


\section{PROLOGO}

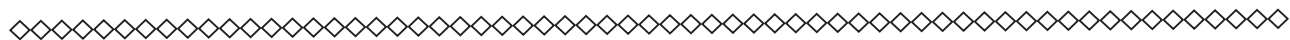

A pesar de la gran diversidad de grupos indígenas que existen en Bolivia, muy pocos estudios han documentado de forma detallada su conocimiento y uso de los recursos naturales. Los Chácobo son un pueblo de la familia de los Pano, con aproximadamente 500 miembros ubicados en el norte del Depto. del Beni y que al igual que muchos otros grupos indígenas de la Amazonía han empleado diferentes estrategias para satisfacer sus necesidades de subsistencia, que inicialmente cuando aún eran nómadas estaba basada en la recolección de productos del bosque y aun lo hicieron durante todo el proceso de su establecimiento en las que ahora son sus comunidades actuales.

La influencia de los grupos misioneros del Instituto Lingüístico de Verano (SIL), que convivieron con los Chácobo entre 1953 y 1980, causaron cambios culturales muy profundos en su cultura y tradiciones. En 1955 fueron obligados a dejar su vida nómada y a establecerse en aldeas permanentes, comenzando así un proceso de aculturación, que incluyó el abandono de su vestimenta y sus ceremonias tradicionales. Hasta entonces los Chácobo se caracterizaban como cazadores, recolectores y horticultores seminómadas, ocupando tres áreas de la cuenca del río Benicito (al norte y sur de Puerto Limones y cerca del río Caimanes), y un área de la cuenca del río Yata. Hasta 1965 no contaban con un territorio legalmente reconocido, pero ese año el gobierno les concedió el reconocimiento de una Reserva Indígena de 45.000 has, aunque esta correspondía solamente el 10\% de su territorio original, y en la cual además incluyeron en el área a algunas familias Pacahuara que fueron trasladadas del norte de la región.

Durante la última década los Chácobo recibieron el título legal de su territorio de aproximadamente 480.000 hectáreas, que es aproximadamente el área equivalente a su territorio tradicional ancestral. La salida de los misioneros, la sedentarización, el acceso a los mercados (mayor en los últimos años), así como el territorio más amplio, todos cambios ocurridos en los últimos 50 años, ha influido notablemente el uso de sus recursos. Durante varias décadas la recolección de la goma y la venta del caucho fue un ingreso muy importante para la economía Chácobo; sin embargo, en los últimos años se ha intensificado la explotación de la castaña, al haberse instalado en Riberalta una empresa procesadora y comercializadora de este producto, aunque el pago por la venta del producto tiene precios desventajosos y endeuda a la población.

La primera investigación etnobotánica con los Chácobo fue realizada entre 1983 y 1984, por Brian Boom un botánico del Jardín Botánico de Nueva York (Boom 1987). Este trabajo realizado aproximadamente 30 años después de su sedentarización, 
mostró que su conocimiento y uso de las plantas aún permanecía entre las personas, encontrando 305 plantas útiles, entre ellas ocho variedades de plátanos y siete de yuca, como su principal fuente de alimento. En el 2010 un estudio etnobotánico realizado solamente con palmeras, encontró 21 especies de palmeras útiles y 85 usos diferentes; sin embargo, muchos de los usos mencionados ya no se practican actualmente y solo son conocidos por las personas mayores. En esta investigación también se pudo evidenciar el cambio en el uso de ciertas especies de uso tradicional hacia usos con fines comerciales, como el Asaí (Euterpe precatoria), importantes en la construcción, ahora solo se comercializan como palmito (Paniagua-Zambrana et al. 2011).

La importancia que los Chácobo le dan a los recursos naturales, es el reflejo de un conocimiento que ha sido transmitido y adquirido a lo largo de muchas generaciones, de su contacto con la naturaleza y de su continua experimentación. Lamentablemente, no cuentan con información que documente como su conocimiento ha ido cambiando con las nuevas generaciones, si se mantiene o se está perdiendo, y cuáles son las razones. De esta manera los Chácobo podrían afrontar mejor el desafío de conservar sus recursos naturales, y lo más importante, de conservar el conocimiento que les ha permitido hacer un uso sostenible y racional de los mismos (ellos) a lo largo de muchas generaciones.

Esta publicación es uno de los primeros esfuerzos por recuperar y repatriar información disponible acerca de los Chácobo y su cultura, y devolverlo a sus propietarios, que bajo el Protocolo de Nagoya sobre acceso a recursos genéticos y participación justa y equitativa en los beneficios provenientes de su utilización, les corresponde a los Chácobo. Muchos de estos trabajos han sido publicados y difundidos en el exterior; sin embargo, limitaciones como el idioma o su limitada accesibilidad, han hecho que hasta ahora sean desconocidos para los Chácobo. Aunque Bolivia todavía no ha ratificado el Protocolo de Nagoya, consideramos que todo el conocimiento del pueblo Chácobo es propiedad intelectual del mismo.

El primer capítulo de este libro corresponde al trabajo del viajero sueco Erland Nordenskjöld que visitó los Chácobo en 1909, e incluyó sus observaciones sobre este grupo en el libro titulado "Indianer und Weisse in Nordostbolivien", en el que habla de la explotación económica a la que estaban sujetos los indios en la región, y que fue publicado en Alemán 1922 (Nordenskjöld1922). La reseña de su experiencia con los Chácobo, su cultura y tradiciones, incluye fotografías y dibujos de los artefactos que aun eran utilizados en esa época.

En el segundo capítulo, encontramos el trabajo de la antropóloga Wanda Haenke que visitó a los Chácobo en el 1953, antes de que el grupo de misioneros evangelistas de EE.UU. comenzara su trabajo con ellos. Su trabajo titulado "Los indios Chácobos del río Benicito" fue publicado en la revista municipal de artes y letras Khanaen 1957 (Haenke 1957), y un año después "The Chácobo in Bolivia" era publicado en la revista de antropología Ethnos (Haenke 1958). Su trabajo describe la forma de 
vida de los Chácobo en ese entonces, sus hábitos de convivencia, detalla los grupos familiares que encontró, describe sus actividades diarias, sus hábitos alimenticios, la fabricación de utensilios, vestimenta y adornos y el entorno espiritual que rodea las creencias de la tribu. Presenta también una clasificación del idioma, proporciona el alfabeto y 360 vocablos usado por los Chácobo. En sus conclusiones alerta acerca de la potencial desaparición de la tribu, sus costumbre e idioma, por el incremento en el mestizaje. En este se incluyen fotografía de la vida diaria, vestimenta y ceremonias de los Chácobo que fueron tomadas por el trotamundos alemán Heinz Rox-Schulz que los visitó en 1959.

El tercer capítulo contiene el trabajo de Marian D. Prost, misionera del Instituto Lingüístico de Verano (SIL), que trabajó con los Chácobo entre 1953 y 1980 (Prost 1970). Esta corresponde a una obra inédita que fue elaborada en 1970 sobre las costumbres y forma de vida de los Chácobo, con un fuerte enfoque en el desarrollo evangelista de la tribu, que era la meta principal del SIL. Este trabajo debió ser publicado bajo el auspicio del Ministerio de Educación y Medio Ambiente, pero nunca lo fue. Esta es una de las numerosas publicaciones del SIL producto de su trabajo con los Chácobo.

El cuarto capítulo, recoge el trabajo realizado por el antropólogo alemán Heinz Kelm que visitó a los Chácobo en 1970, durante el periodo en que el Instituto Lingüístico de Verano (SIL) trabajaba con la tribu. Este artículo fue publicado en la revista Tribus del Linden Museum en Stuttgart en Alemania (Kelm 1972). En este trabajo Kelm describe la historia de los Chácobo hasta entonces, su estructura social y forma de vida actual, así como las características de sus asentamientos, de sus construcciones, vestimenta, adornos; habla también acerca de los cultivos tradicionales, sus actividades de caza, pesca y recolección en el bosque. También menciona la práctica de actividades económicas modernas, como la extracción de la goma y la incursión de la tribu en la crianza de ganado vacuno. En muchos puntos de su trabajo comenta acerca de impacto del trabajo del SIL y el cambio de las costumbres de los Chácobo.

El capítulo quinto, presenta el trabajo del primer estudio etnobotánico que fue realizado con los Chácobo. Este trabajo fue realizado por Brian Boom, botánico del Jardín Botánico de New York, que entre 1983 y 1984 desarrollo trabajo de campo documentando el conocimiento de la tribu acerca del uso de las plantas, y que en 1987 fue publicado como un número especial de la revista Advances in Economic Botany del Jardín Botánico de New York (Boom 1987). El trabajo incluye la descripción del uso de 305 diferentes especies de plantas silvestres y cultivadas que son utilizadas para diferentes fines por los Chácobo, incluye nombres científicos, nombres Chácobo y la descripción de su uso, además de referencias de colecciones botánicas depositadas en el Herbario Nacional de Bolivia en La Paz.

El último capítulo, incluye el trabajo realizado por la botánica francesa Sylvie Bergeron, acerca del Uso de las Plantas por los Chácobo de Alto Ivon, y es el resultado de un trabajo de investigación que fue desarrollado entre 1992-1993. El 
trabajo incluye información acerca de la diversidad florística y las formaciones vegetales que son más importantes para la tribu, incluye también información acerca del sistema tradicional de clasificación de las plantas, y una guía de las 50 plantas más importantes para los Chácobo. Este corresponde a un informe que fue preparado en 1998 por el Institut Franjáis d'Etudes Andines (IFEA) (Bergeron 1998), pero que nunca se publicó

\section{REFERENCIAS}

Bergeron, S. 1998. El uso de las plantas por los Chácobos (Alto Ivon, Beni, Bolivia). Institut Franjáis d'Etudes Andines (IFEA). La Paz, Bolivia.

Boom, B.M. 1987. Ethnobotany of the Chácobo Indians, Beni, Bolivia. Advances in Economic Botany, Vol.4, Pp.1-68.

Bussmann, R.W. \& N.Paniagua-Zambrana. 2011. La etnobotánica de los Chácobo: Traducción de The Ethnobotany of the Chácobo Indians, Beni, Bolivia, de B. Boom. Trujillo, Graficart.

Haenke, W. 1957. Los indios Chácobos del río Benicito. Revista Municipal de Cultura Khana, Vol. 27/28, Pp. 39-55.

Haenke, W. 1958. The Chácobo in Bolivia. Ethnos, Vol. 23, Pp.100-125.

Kelm, H. 1972. Chácobo 1970: Eine Restgruppe der Südost-Pano im Orient Boliviens. Tribus, 21, 129-246 (en Inglés). 


\section{Los Chácobo y su historia en el siglo XX}

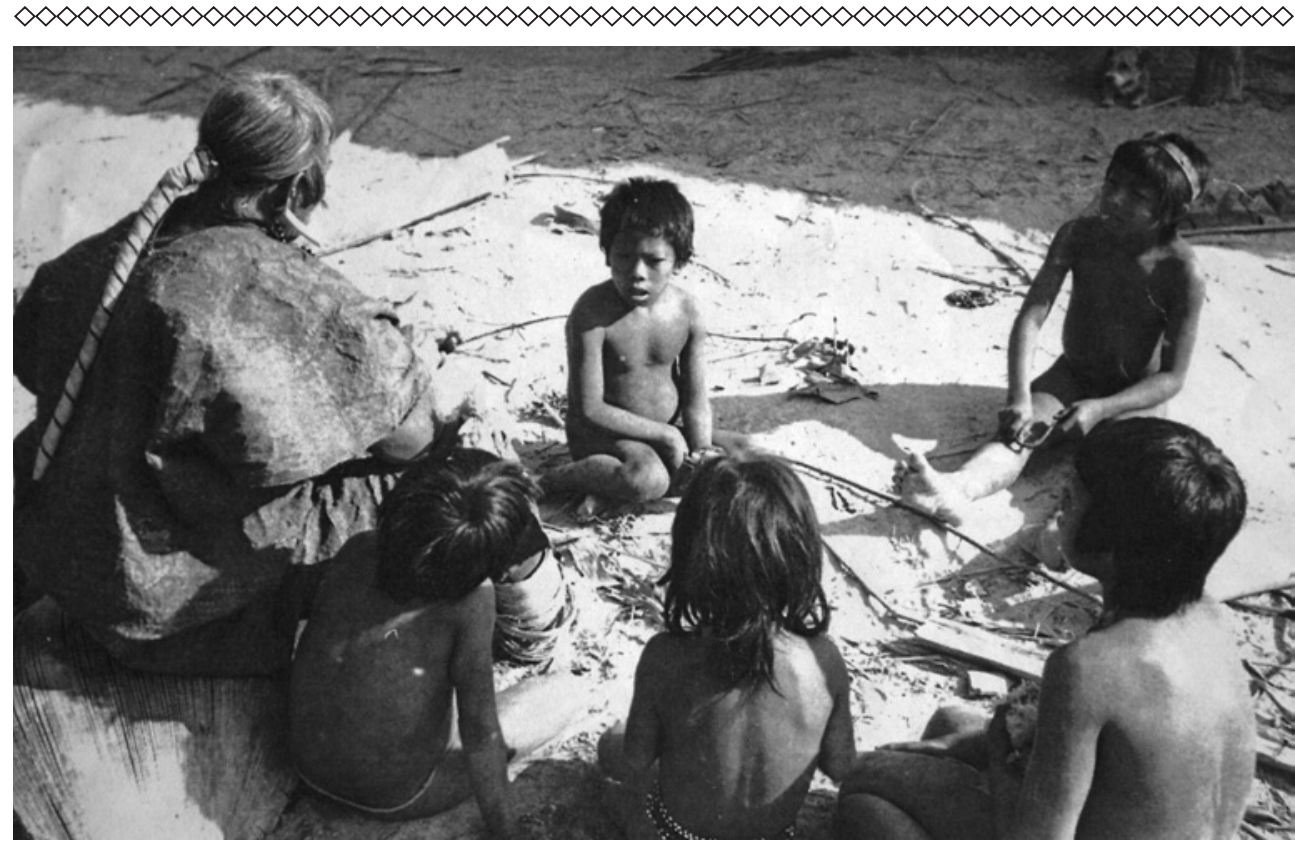

Compendio de las investigaciones

1. NORDENSKJÖLD E 1922. Indianer und Weisse im Nordosten Boliviens. Strecker und Schröder, Stuttgart (en Aleman).

2. HAENKE W 1957. Los indios Chácobos del río Benicito. Khana, 27/28, 39-55 (en Español). Y HAENKE W 1958. The Chácobo in Bolivia. Ethnos 23, 100-125 (en Inglés). Con fotografias de Heinz Rox-Schulz 1959.

3. PROST MD 1970. Costumbres, habilidades y cuadro de vida entre los Chacobos. Instituto Lingüistico de Verano, La Paz, Bolivia (en Español, no publicado).

4. Kelm, H. 1972. Chácobo 1970: Eine Restgruppe der Südost-Pano im Orient Boliviens. Tribus, 21, 129-246 (en Inglés).

5. BOOM BM 1987. Ethnobotany of the Chácobo Indians, Beni, Bolivia. Advances in Economic Botany v.4, p.1-68. (en Inglés). Traducido como: BUSSMANN RW, PANIAGUA ZAMBRANA NY 2011. La etnobotánica de los Chácobo: Traducción de "Boom, B. - The Ethnobotany of the Chácobo Indians, Beni, Bolivia". Trujillo, Graficart.

6. BERGERON S 1998. El uso de las plantas por los Chácobos (Alto Ivon, Beni, Bolivia). Institut Franjáis d’Etudes Andines (IFEA), La Paz, Bolivia (en Español, no publicado). 



\section{CAPITULO 1}

\section{INDIANER UND WEISSE IM NORDOSTEN BOLIVIENS \\ ERLAND NORDENSKJÖLD,1922}

EL LIBRO ORIGINAL ESTÁ ESCRITO EN ALEMÁN, ESTE CAPÍTULO CONTIENE LA TRADUCCIÓN AL ESPAÑOL DEL EXTRACTO DE LO QUE CORRESPONDE A SU EXPERIENCIA CON LOS CHÁCOBO 


\section{Reseña de nuestra visita a los indios Chácobo}

En las áreas que reportamos aquí encontramos indios pacíficos como los Chácobo que viven completamente independiente de los blancos.

En lo profundo de la selva, donde la tierra no se inunda, nos encontramos con grandes campos de yuca, plátano, papaya y camote, así como la caña de azúcar. Algunos campos estan parcialmente quemados, cabañas en ruinas y abandonadas. También hay un gran número de grandes vasijas de cerámica, las cuales son muy pesadas, por lo que los indios no podían llevarlas con ellos cuando emigraron.

La parte más extraña y lo mejor del área de los Chácobo es que hay muy pocos mosquitos.

Un pueblo abandonado se llama "Huátahue" en Chácobo, la que estamos es "Mashishoya".

Fuimos invitados por los Chacobo de vivir en la "casa comunal". Esta es una estructura octogonal muy sólida, es una de las casas nativas mejor construidas que he visto. En el centro de la casa se encuentra una gran vasija cerámica con cerveza de yuca, a los costados hay pequeños taburetes hechos de madera clara y hojas de palmera. Bajo el techo hay flechas, arcos, y muchos adornos hechos con plumas de colores.

Las mujeres generalmente se sientan en el suelo y no en los taburetes como los hombres. Si alguien visita un pueblo Chácobo se le permite llegar armado, pero se ve muy mal que los visitantes, traigan consigo enseres para dormir, antes de haber sido invitados a quedarse.

Si uno es invitado por los Chacobo para beber, se debe devolver el recipiente vacío y su comida es muy sabrosa, aunque siempre sin sal. Tenemos maíz en la hoja, mandioca tostada, mandioca - harina y pescado cocido con maíz.

Los hombres bailan en la "casa comunal", alrededor de un gran recipiente con cerveza de yuca, abrazados por los hombros y tocando flautas de pan. Utilizan pequeños mazos de madera de palma durante los bailes.

Los hombres hacen las armas, cestas, adornos de plumas y otras cosas en la "casa comunal".

Dos cosas que me parecieron especialmente impresionante entre los Chácobo: Primero la elegancia de los hombres y segundo las grandes y bellas casas.

Los hombres Chácobo tienen el pelo largo, cortado por la parte delantera con la mandibula de una palometta, con pelo largo delante de las orejas. El pelo largo en la parte posterior se envuelve con una cinta de algodón en algo así como una trenza. Las cejas y a veces el cabello bajo las axillas se afeitan con una hierba aguda. El pelo púbico se deja de crecer. 


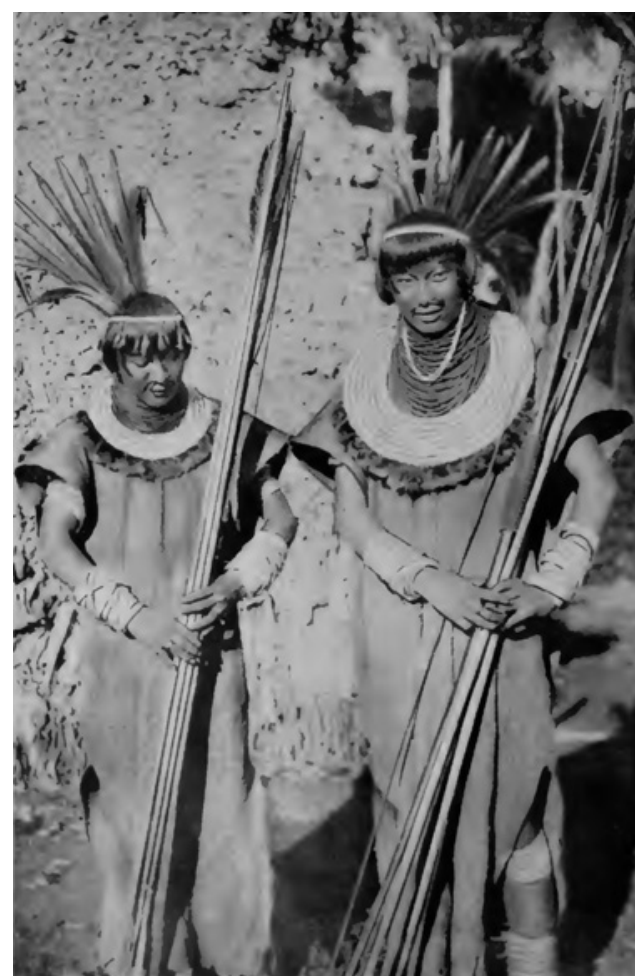

Fig 1. Hombres Chácobo, ataviados con con sus ropas y adornos y flechas, listos para ir a cazar.

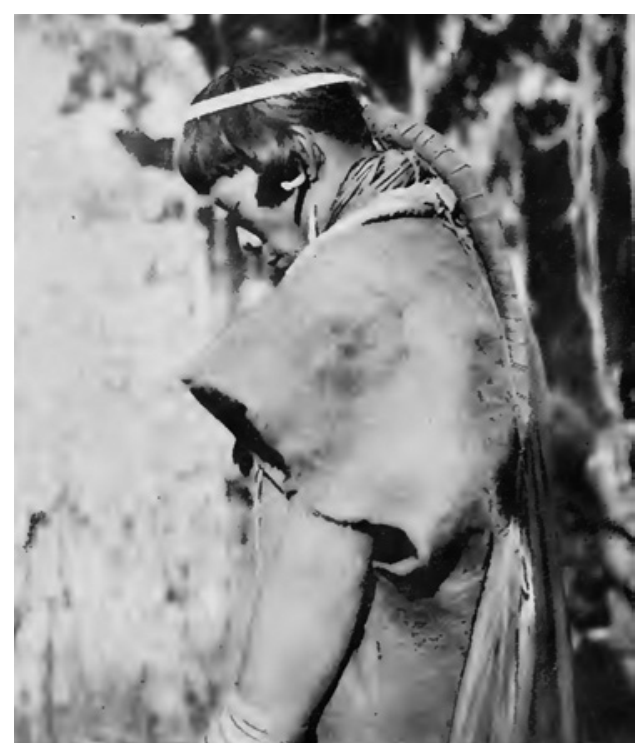

Fig 2. Los hombres Chácobo envuelven su pelo largo con una cinta de algodón formando una trenza muy especial.
Los Chácobo pintan a veces sus rostros. Rojo (de Bixa) se utiliza para la cara, azul-violeta (de Genipa) se utiliza para los brazos. De lo contrario los Chacobo no utilizan plantas ornamentales.

A a una edad de 10 a 12 años a todos los niños Chácobo, se les perfora el tabique de la nariz y mientras que la herida va cicatrizando, se les inserta un pequeño trozo de madera.

Después de la curación se añaden en ambos lados plumas de tucán de color rojo.

Pasada la pubertad, entre los 16 a 19 años, se les perforan los lóbulos de las orejas. Durante del proceso de curación se insertan trozos de madera, después se insertan colmillos de capibara. Para evitar perderlos, se sostienen en su lugar con cera.

Los hombres usan para su cabeza, una banda hecha de un trozo de madera o de algodón y fibras negras, a menudo adornados con pequeños penachos de plumas, que tienen que ser de color negro, rojo y amarillo.

Los hombres Chácobo llevan Ilevan colosales collares de semillas negras y duras, alrededor del cuello y las consideran una de sus posesiones mas valiosas, aun más que la magnífica joyería de pecho hecha con dientes de mono a la que consideran menos costosa.

Nadie quiere regalar un collar completo, ni siquiera lo quieren cambiar por un hacha. Los hombres Chácobo tienen su pene presionado contra su estómago. El extremo se sujeta con un cinturón 
de hilos de algodón y por lo tanto esta protegido contra los insectos. Los hombres se envuelven los brazos, las piernas y los muslos con tiras de madera blanda. Además de todo esto poseen una camisa de corteza. Frecuentemente en los días de semana regulares y para el trabajo guardan la mayor parte de sus adornos o joyas y ropa. Los cuales son usados intensivamente durante sus festividades.

Con frecuencia usan plumas arara alrededor del cuello y para su pecho lucen un trofeo muy lindo, fabricado con los dientes delanteros de un mono y decorado con plumas rojas de tucán. Esta pieza contiene 1506 dientes y dado

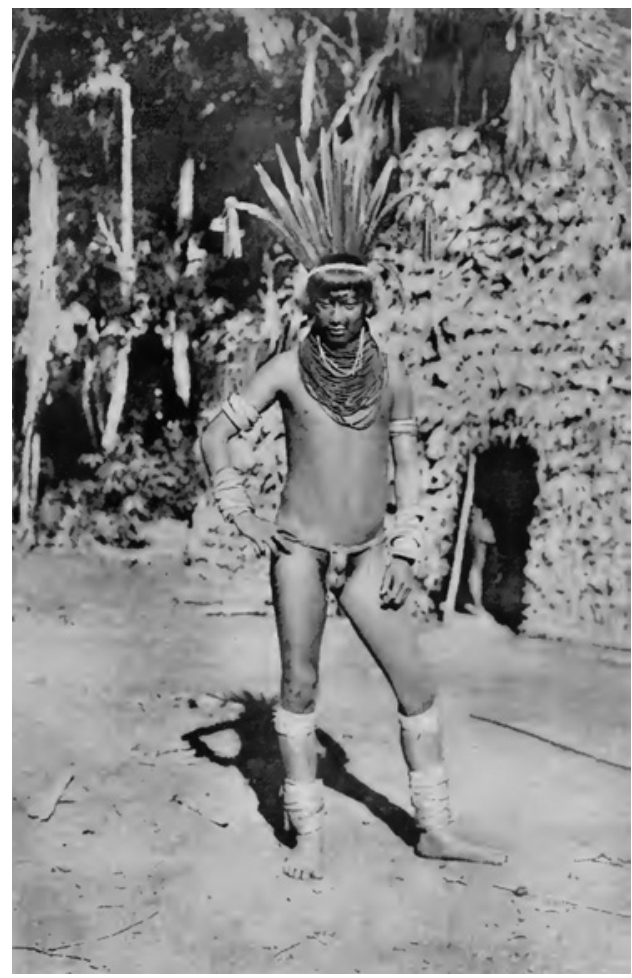

Fig. 4 Hombre Chácobo, con su vestimenta de días no festivos.

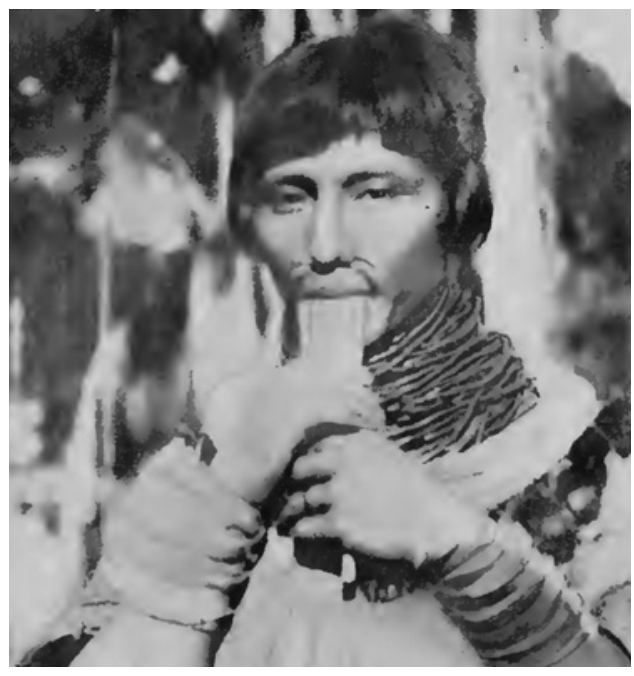

Fig. 3. Los Chácobo durante sus festividades adornan su cuello con un collar de semillas, también adornan su pecho con un collar de dientes de mono y plumas de tucán. Observamos tocando un instrumento de viento

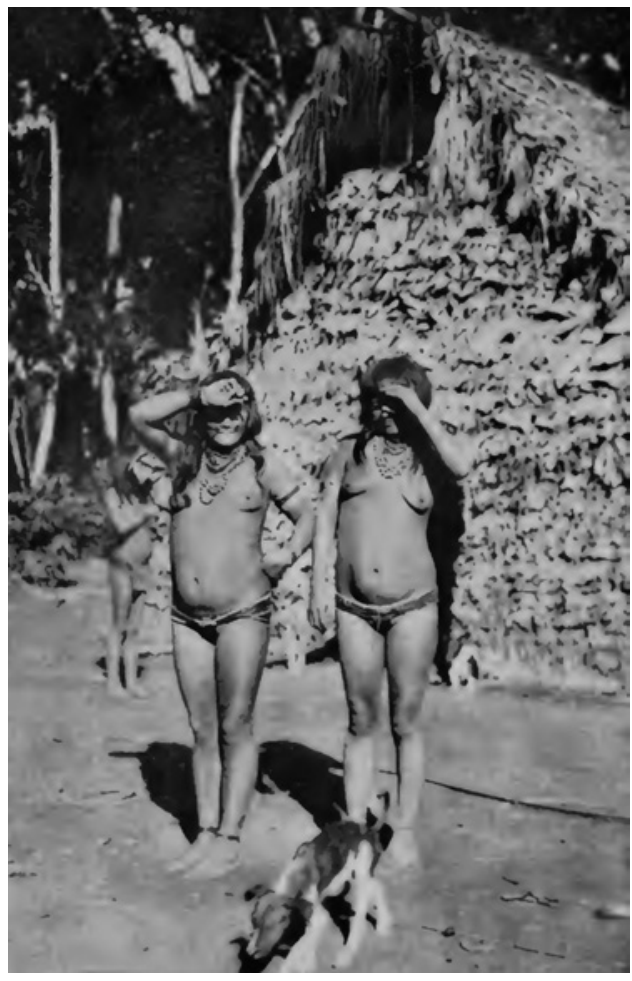

Fig. 5. Mujeres Chácobo, con sus vestimentas tradicionales. 
que cada mono tiene sólo ocho dientes frontales, hay que admitir que este peculiar ornamento, implica que es un premio para un excelente tirador, lo cual es todo un honor. Disparar y matar a 189 monos en los árboles altos de la selva con el arco y flecha no es tan fácil.

Alrededor de la parte superior del brazo los hombres Chácobo usan cintas, decoradas con plumas de loro y largas cintas de plumas hacia abajo. Como perfume usan la vainilla, que es muy abundante en sus bosques.

Las mujeres disponen de adornos menos ostentosos que los hombres. Su "ropa" se limita a una hoja que le cubre los genitales y se mantiene sujetada por un cordón de hilos de algodón y fibras negras. Actualmente, sobre la hoja, llevan a menudo una pequeña pieza de tela.

Al igual que los hombres, las mujeres Chácobo tienen el pelo largo, pero lo llevan suelto. Las cejas, el pelo en las axilas y alrededor de los genitales se afeitan con una hierba. En el tabique perforado de la nariz las mujeres usan un trozo de madera o pluma igual a la de los hombres.

Los orejas no se perforan, sin embargo a menudo se perforan los bordes de la nariz. En estos agujeros durante los días de semana colocan trozos de carbón y en ocasiones festivas hermosas plumas. Los pendientes que les regalé, nunca los vi usarlos en las orejas, sin embargo si en su nariz.

Muy a menudo las mujeres tienen correas hechas de corteza de madera y decoradas con semillas de color negro, alrededor de los brazos y piernas, en la parte superior del brazo, por lo general usan joyas hechas de conchas y plumas. En el pelo a veces sujetan las plumas de colores con cera, y también llevan anillos de chonta en los dedos. En ocasiones ceremoniales las mujeres llevan un pectoral de dientes de mono. Sin embargo, este no es tan hermoso como los usados por los hombres, esta decorado con manojos de plumas pequeñas, algunas de ellas son de tucanes.

Las mujeres no son tan apegadas a sus adornos y joyas, ellas siempre están dispuestas a cambiarlas con otras cosas útiles.

Las niñas van siempre desnudas, en cambio los niños usan camisas de corteza. A ambos lados de la "casa comunal" hay dos casas regulares, que son las casas de indios más grandes que he visto durante mis viajes en América del Sur. Son rectangulares, con las puertas en el lado pequeño.

Es muy agradable para vivir en una gran maloka Chácobo. La cual consta de un solo ambiente grande, donde cada familia tiene su habitación y fogón.

Las cestas y bolsas de tela de corteza, donde las mujeres guardan sus pertenencias, cuelgan desde el techo; en el suelo están otras cestas y muchos utensilios de cerámica. La maloka se barre y limpia con frecuencia. Un elemento común a todas las familias es un gran batán, en el que se muele el maíz, donde varias mujeres pueden trabajar a la vez. Yo no he visto este tipo de artefacto en otros pueblos indigenas. 


\section{Nordenskjöld E., 1922. Indianer und Weisse im Nordosten Boliviens}

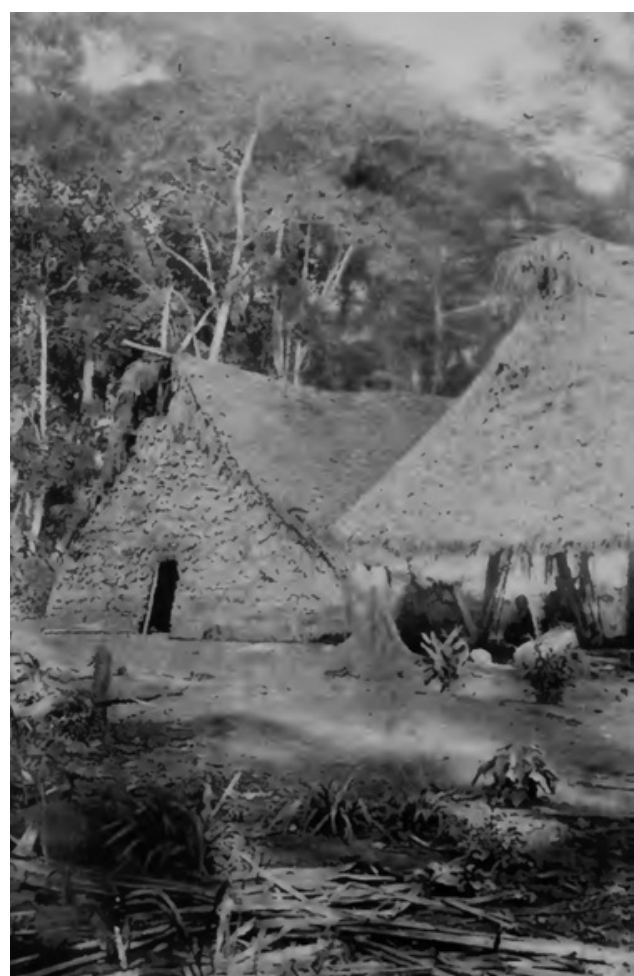

Fig. 6. Viviendas Chácobo, ambas con techo de hojas de motacú, una de ellas tiene paredes con hoja de motacú y mientras que la otra esta al aire libre.
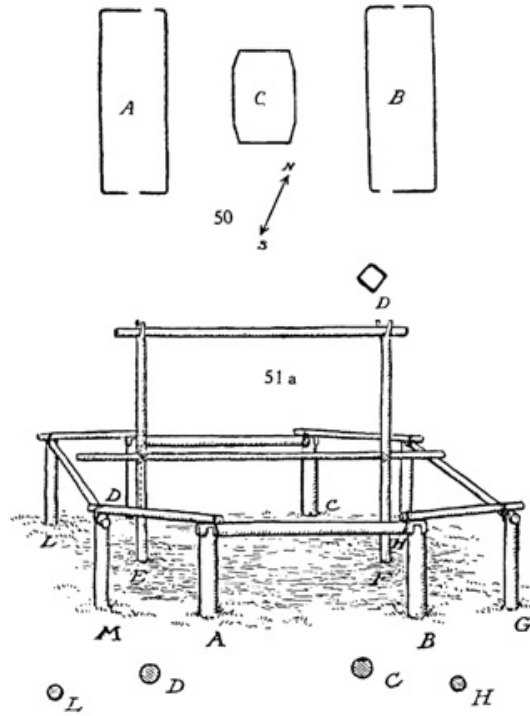

$Q_{E}$

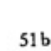

${ }^{\circ} F$

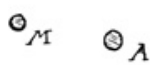

$0_{B}$

- G

Fig. 7. Detalles sobre la contrucción de sus viviviendas, su estructura de madera, y la distribución de sus horcones

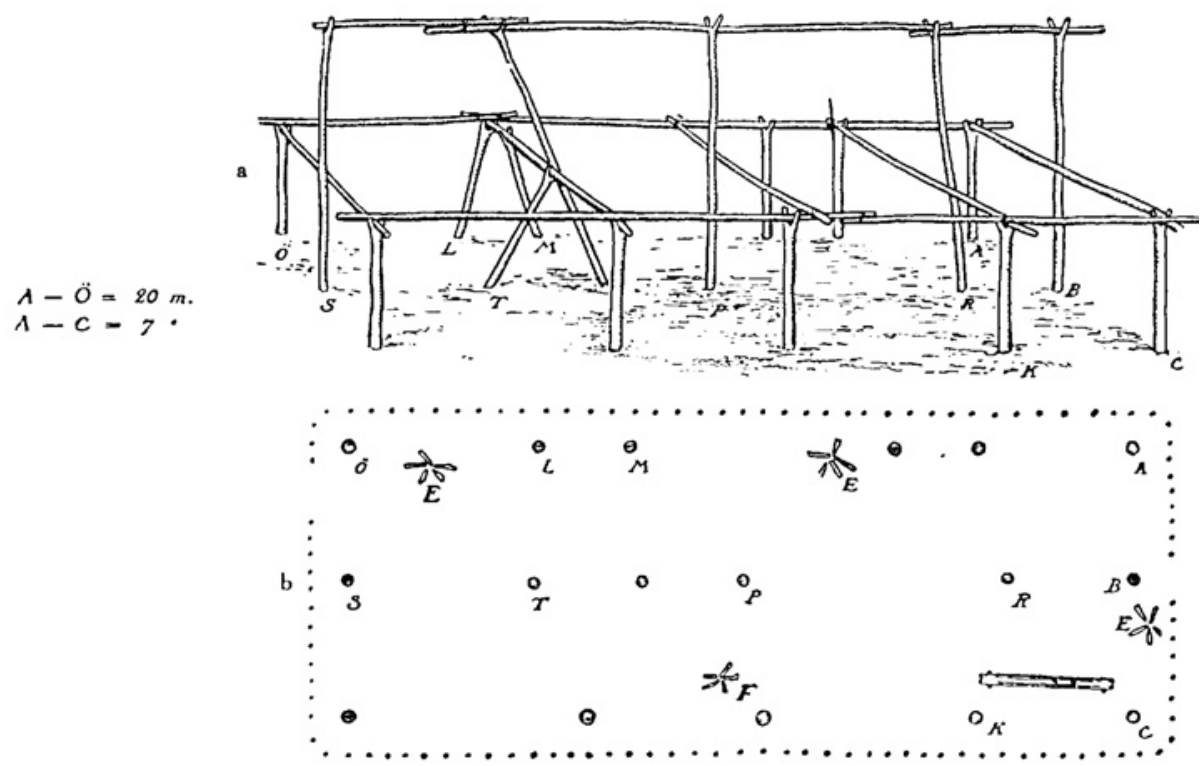

Fig. 8. Detalles sobre la contrucción de sus viviviendas, su estructura de madera, y la distribución de sus horcones 


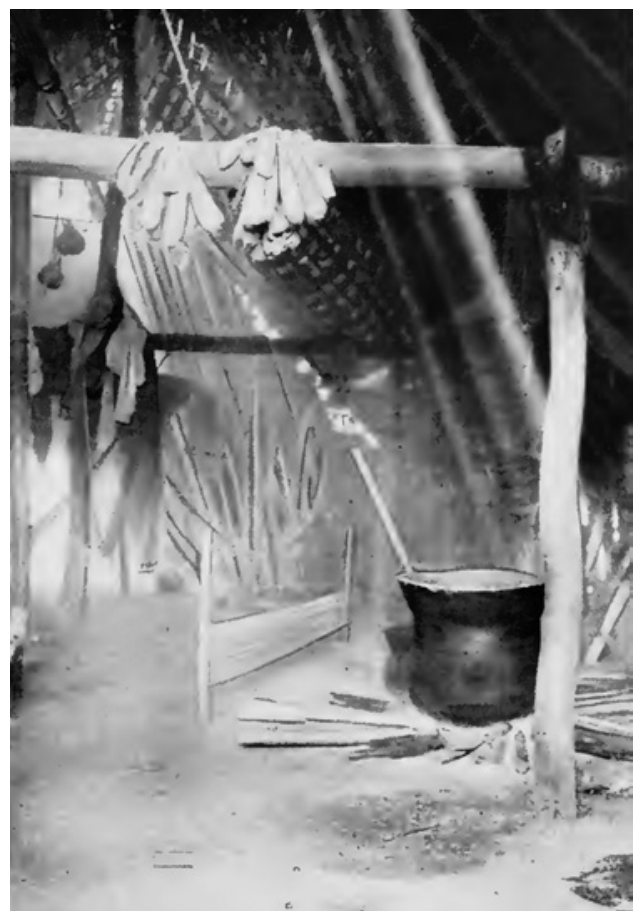

Fig. 9. Fogón donde se prepara la cerveza de yuca, para toda la comunidad.

Hay también un gran fogón donde se cocina la cerveza de yuca y son las mujeres quienes preparan esta bebida para toda la comunidad.

Las casas están techadas con hojas de motacú y una especie de Heliconia. Para moler las raíces de yuca los Chácobo utilizan las raíces espinosas de una palma.

Los Chácobo utilizan las flechas como partidos. Uno mete con el eje de la flecha hecha de chuchio a través de una punta de flecha hecho de bambú, y la coloca debajo de una capa de corteza fina de algodón.

Los Chácobo son agricultores y alrededor de sus chozas tienen plantaciones significativas. Al igual que la mayoría de los otros indigenas siembran diferentes

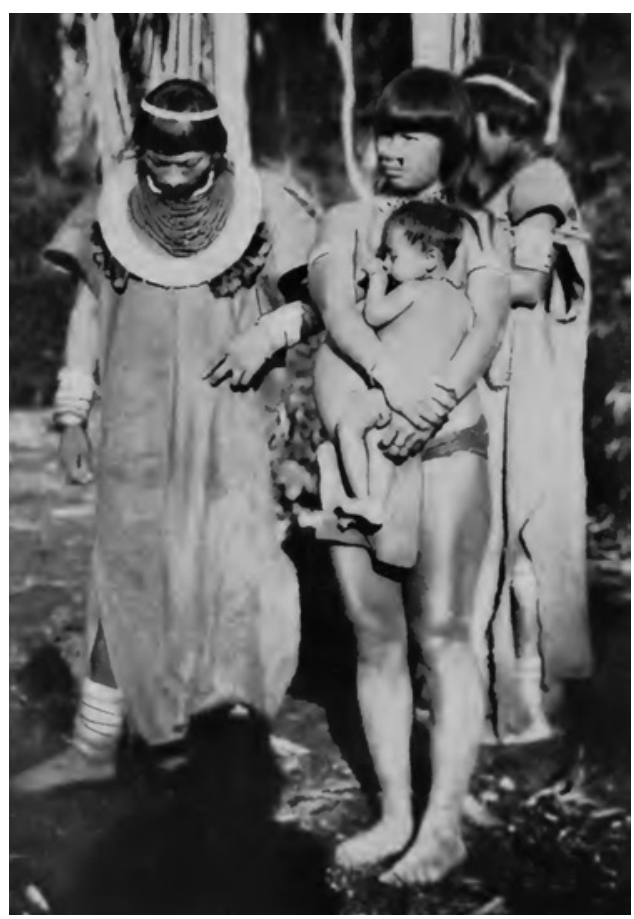

Fig. 10. Familia Chácobo en una actividad social.

cultivos juntos, pero también se ve grandes terrenos con sólo maíz o yuca. Los campos que he visto estaban en el bosque y no en las pampas estaban bien cuidados. Se cultivan las siguientes plantas: caña de azúcar, papaya, plátanos en distintas variedades, batatas, yuca, tabaco, maíz, pimiento, algodón (dos variedades, uno blanco y otro marrón), vaylusa, calabash, caña de flecha (Gynerium saccharoides) para ejes de la flecha. De éstas plantas la yuca, plátanos y maíz son los más importantes. El tabaco se cultiva en pequeñas cantidades $y$ se utiliza exclusivamente para extraer larvas de mosca de la piel, cuando las moscan pican a la gente. Los Chácobo no son fumadores.

La agricultura es la fuente más segura y más importante de alimentos para 
los Chácobo. La opción más natural y La redes para la pesca son desconocidos. saludable sería usar su conocimiento Ellos no saben cómo hacer sogas fuertes. y fuerza para la agricultura y no hacerlos trabajar para los blancos como colectores de caucho.

Los Chácobo también son cazadores y pescadores. Para navegar por los ríos construyeron canoas de corteza. Los Chácobo pescan con flechas y veneno.

Extrañamente, sólo hay dos tipos de flechas, que se usan con el mismo arco y son inusualmente largas.

No creo que los Chacobo sufren de una escasez de alimentos. Sus campos proporcionan buenas cosechas.
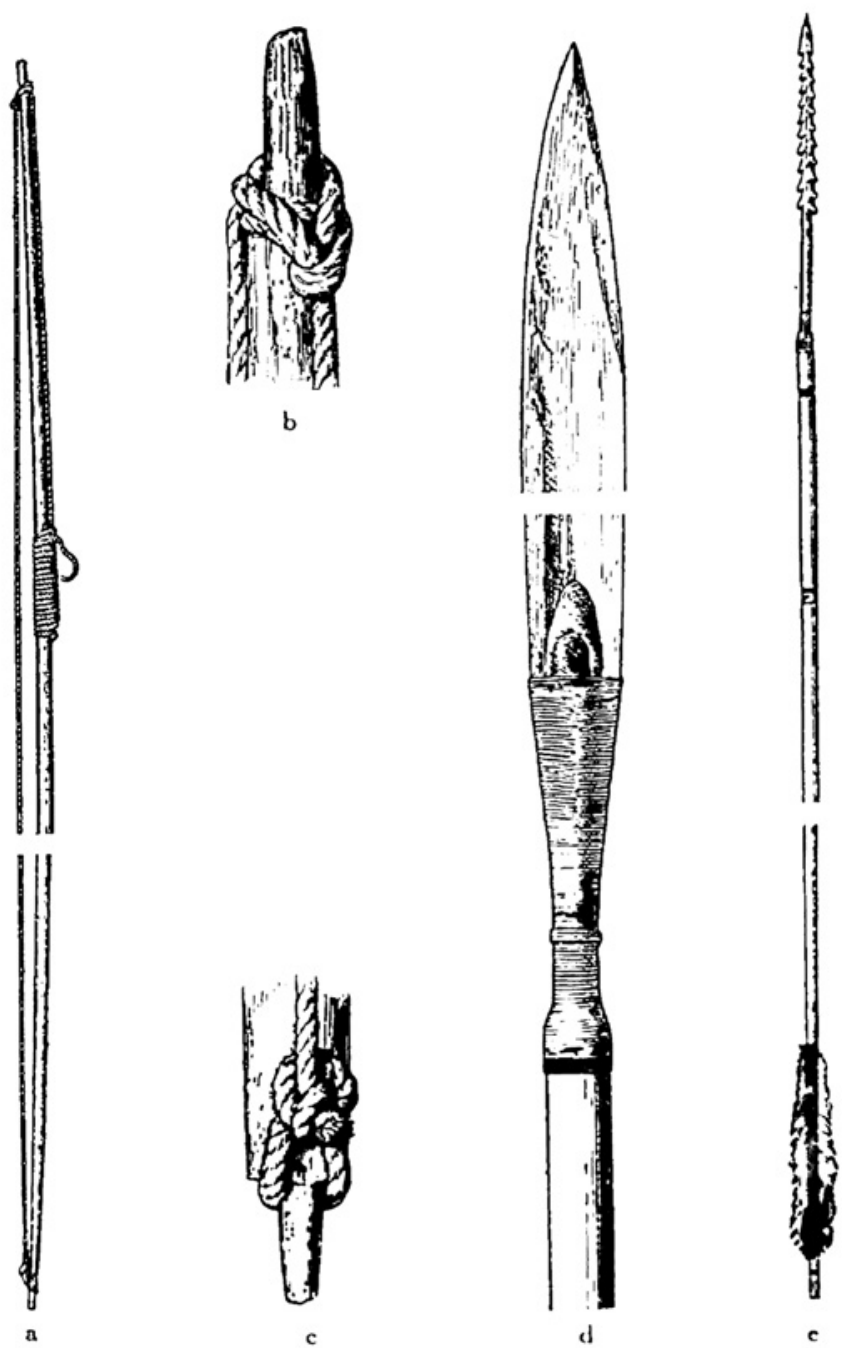

Fig. 9. Arco y flechas Chácobo, con detalles de la forma de anudar la cuerda del arco y forma de los dos tipos de flecha que utilizan para cazar y pescar. 
Las canastas utilizadas por ambos sexos son hechos por ambos. De lo contrario, los hombres tejen cestos.

Los dientes de peces palometa se utilizan como cuchillos. Asimismo las mandíbulas de jabalí se utilizan para pulir arcos. Las plumas de las flechas son quemadas con corteza para darles la forma correcta. El pequeño lazo utilizado para limpiar el algodón se llama "canati" como el arco regular. El hilado se hace con un husillo regular, con la mano como tenedor y el muslo como base.

Sólo vemos pocos niños entre los Chácobo, pensamos que es posible que la población esté disminuyendo, en lugar de aumentar.

No vemos muchos juguetes. Los chicos tienen un arco y una flecha, y conocen el toro.
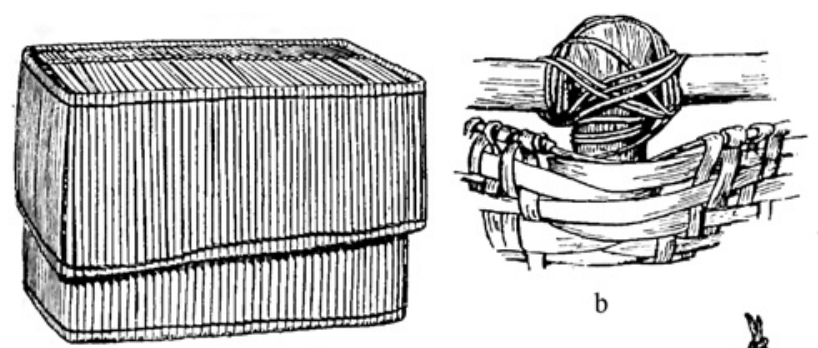

b
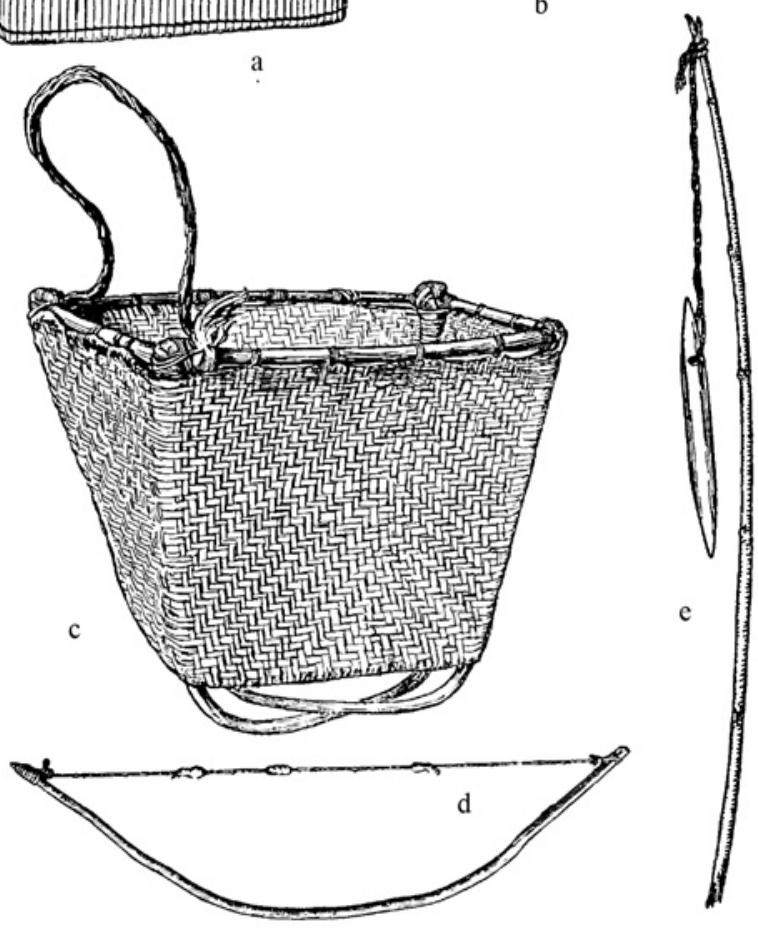

Fig. 10. Utensilios construidos y utilizados por los Chácobo, para su quehacer diario. 
Nordenskjöld E., 1922. Indianer und Weisse im Nordosten Boliviens

Una vez más, nos encontramos con la los Yuracaré, los Chácobo dejan sus costumbre de couvade. Si la mujer da hogares cuando una persona mayor luz, el hombre debe permanecer varios muere. Los muertos son enterrados días en la casa y no puede salir de caza, sentados en la casa, con todas sus joyas de modo que el niño no se enferme. y a continuación, la casa se quema. Ellos Si un Chácobo está enfermo, le curan temen el espíritu de los muertos. Si un generalmente con brocha o soplando. niño muere, lo está enterrado también Es interesante que he visto aquí una en la cabaña, pero la familia sigue bruja mujer. Al igual que todos los indios viviendo en ella. Las mujeres Chácobo creen que la brujería es la causa de la de luto lloran con fuertes gritos y no enfermedad y la muerte. Al igual que llevan joyas, y no se cortan el pelo.

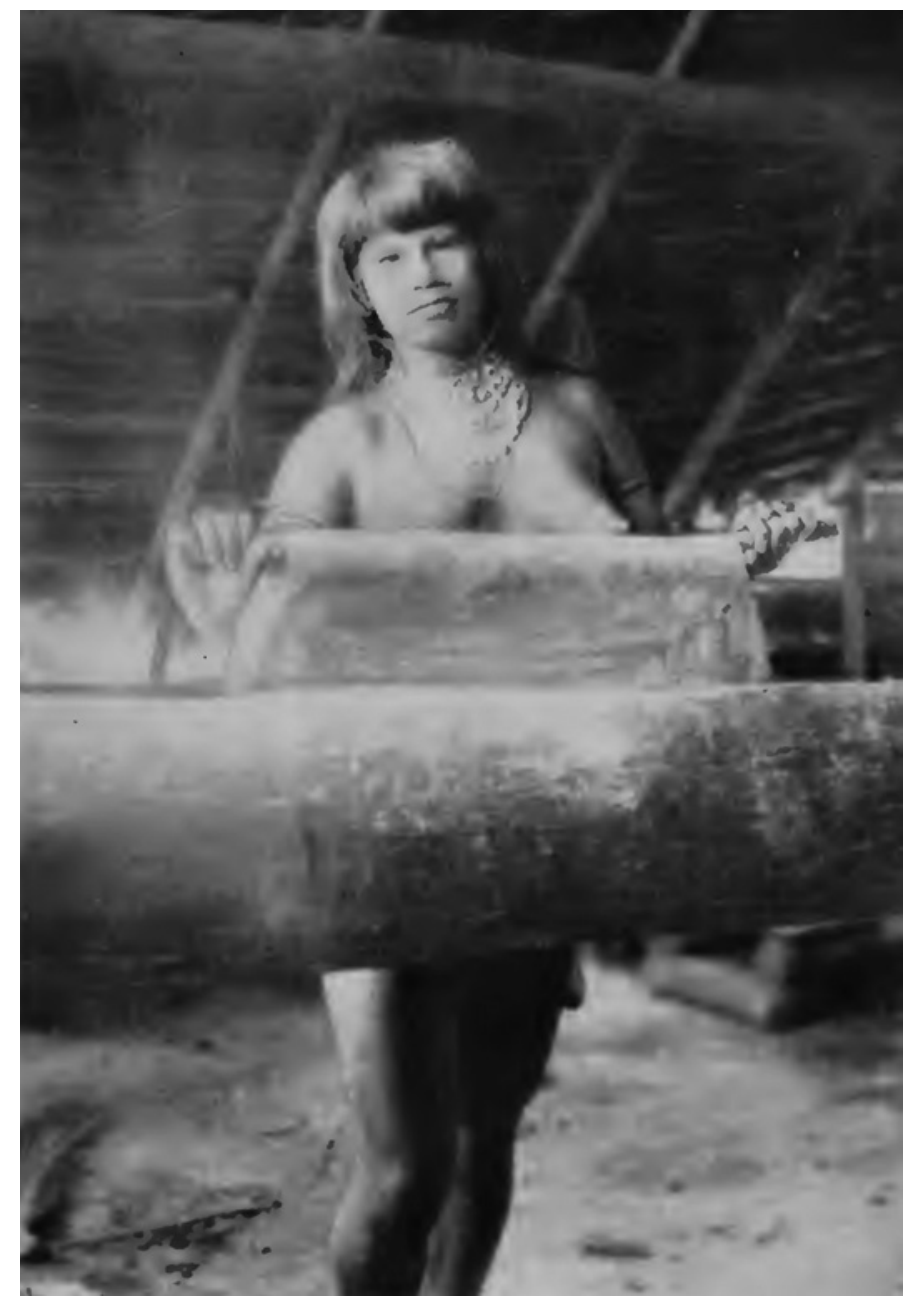

Fig. 11. Mujer Chácobo, moliendo en su batán de madera. 

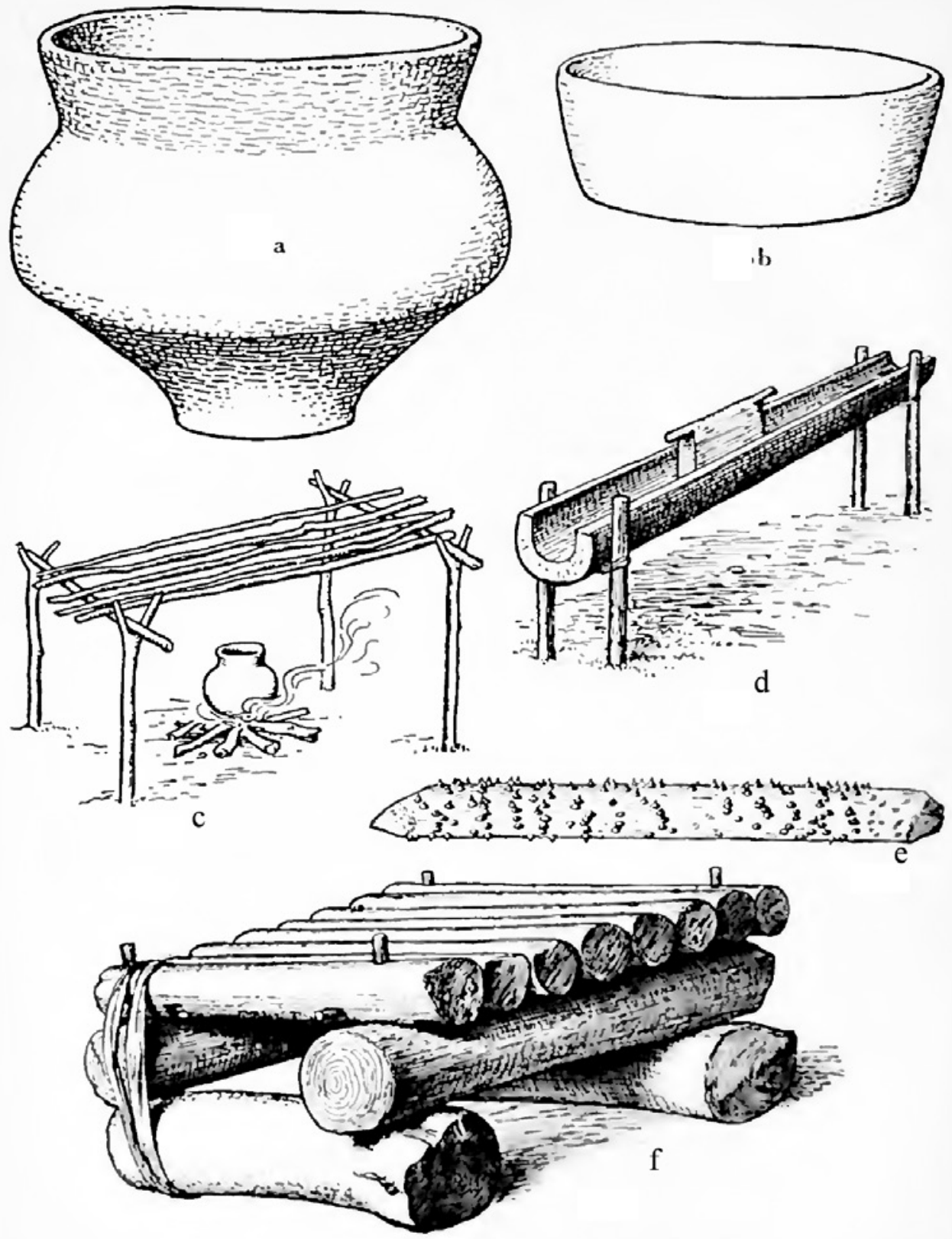

Fig. 12. Utensilios de los Chácobo: (a y b) cerámica utilitaria, (c) fogón, (d) batán, (e) rallador de yuca, (f) asiento de madera. 
Nordenskjöld E., 1922. Indianer und Weisse im Nordosten Boliviens

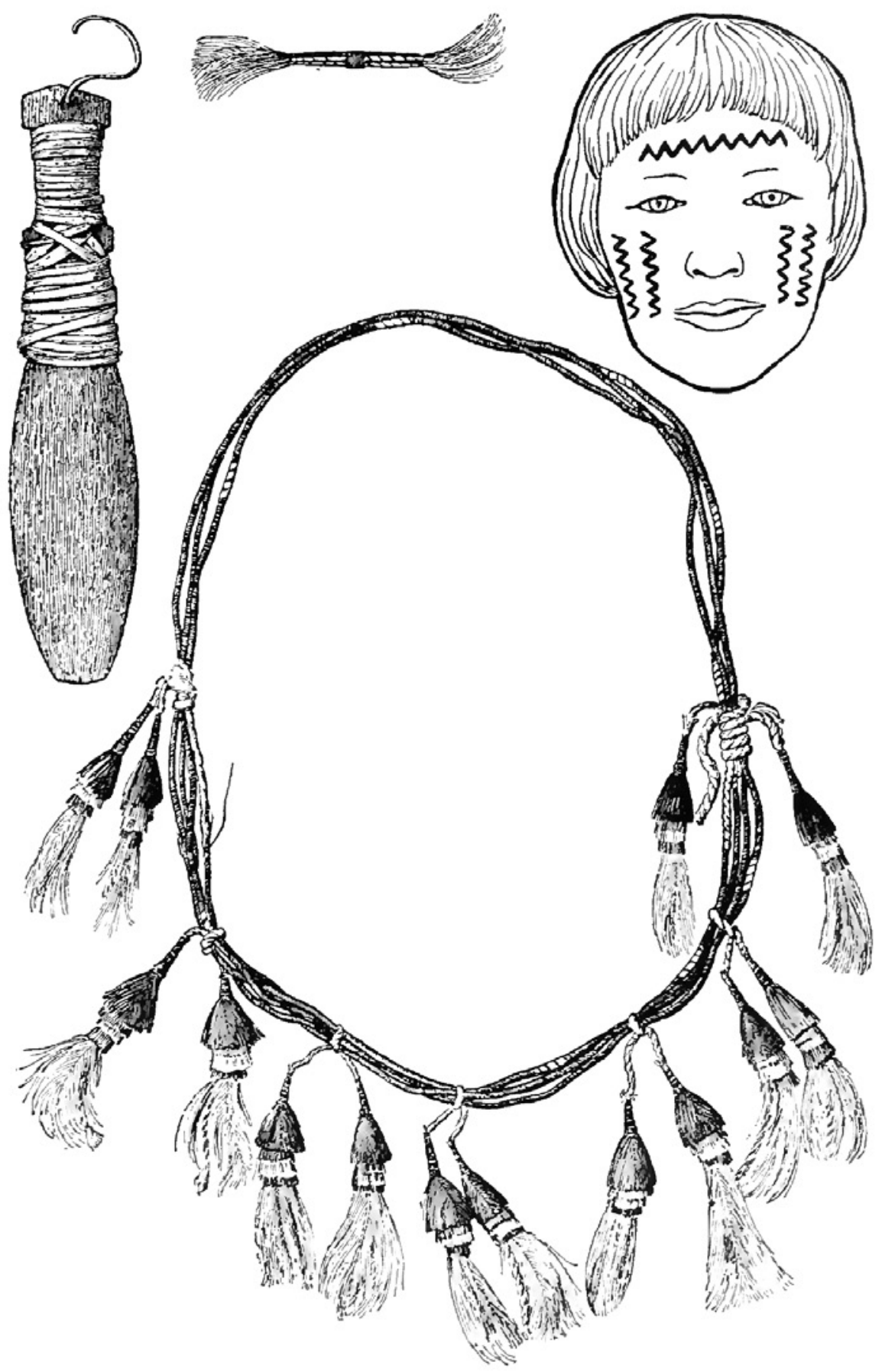




\section{CAPITULO 2 \\ LOS INDIOS CHÁCOBO DEL RIOO BENICITO WANDA HAENKE, 1957}

\section{THE CHACOBO IN BOLIVIA WANDA HAENKE, 1958}

CORRESPONDEN A DOS PUBLICACIONES UNA EN ESPAÑOL $Y$ LA OTRA EN INGLÉS 


\section{INDICE}

Introducción 23

I. LOS CHÁCOBO EN LA ACTUALIDAD 24

1. Su raza, Aspecto físico y mentalidad 24

2. Su hábitat y vivienda 26

3. Número y grupos $\quad 27$

4. La organización de la tribu 30

II. LA CULTURA TOTAL 32

1. Material 32

2. Espiritual 35

III. LA VIDA DIARIA EN LOS GRUPOS SALVAJES, SEGUN OBSERVACIONES PERSONALES 38

IV. EL IDIOMA. CLASIFICACIÓN $\quad 40$

1. El alfabeto $\quad 40$

2. Palabras principales $\quad 40$

3. Vocabulario y observaciones 42

$\begin{array}{ll}\text { BIBLIOGRAFÍA } & 46\end{array}$ 


\section{INTRODUCCIÓN}

1) Dos viajes fracasados. - Soria, un matrimonio desaparecido.

No he tenido suerte con los Chácobo. Quería visitarlos en julio del año 1952 y ya estaba combinando la movilidad, cuando tuve un accidente que por meses me ató a la cama. En enero del año 1953 viajé por el río Mamoré a Navidad, puerto de la estancia Santiago de la Casa Suárez, famosa en el Beni, para conseguir un carretón, que me llevara a Caimanes, en cuya proximidad debían estar los Chácobo. Llegué a Santiago, pero el administrador Enrique Cuéllar me negó rotundamente toda clase de ayuda, a pesar de mis documentos y recomendaciones. Sólo estuvo dispuesto a llevarme a Puerto Siles, puerto oficial, para seguir a donde quisiera.

Tal comportamiento llamó mi atención. Mis averiguaciones dieron por resultado dos cosas que todo me explicaban: $1 .^{\circ}$ Recientemente habían sido asesinados dos Chácobo en Caimanes por un tal Soria, Chácobo civilizado y criado entre los blancos, El mayordomo de aquel establecimiento, Octavio Varioja, se quedó con los hijos de las víctimas.

2. Hacía unos cuatro o cinco años había llegado a Caimanes un pintor austríaco, llamado Chuvatal, con su esposa, para hacer cuadros en óleo de los Chácobo. El hombre, que a la sazón era mayordomo del lugar, llevó dicho matrimonio al río Yata prometiendo de encontrarse allí con los Chácobo. Volvió solo, contando a todo el mundo que los Chácobo habían llegado en sus canoas y llevado a los austríacos, que pidieron que se les busque en el lugar de la partida después de cuatro o cinco días. Los que fueron en busca de ellos no los encontraron y jamás se supo de ellos. Les empleados de la Casa Suárez, muy unidos en este asunto, afirman que los extranjeros fueron asesinados por los Chácobo. La realidad, sin embargo, era distinta. El crimen fué obra de aquel mayordomo que poco tiempo después huyó con el dinero de sus víctimas y fué asesinado por otro igual. Los trastos y objetos del matrimonio aparecieron en venta en Trinidad. Se comprende que a la Casa Suárez no le gustaron que tales rumores llegasen al conocimiento público y eso era la causa de la negativa de $D$. Enrique Cuéllar.

Este segundo fracaso me hizo desistir por un tiempo de la visita a los Chácobo.

Mas al fin de 1953, en noviembre, estimulada por un periodista sueco que quería ver indios, emprendí junto con él un nuevo viaje a los Chácobo; esta vez subiendo el Yata y luego su afluente, el río Benicito.

\section{2) Visitas anteriores a los Chácobo}

El único científico que anteriormente había visitado a los Chácobo era Erland Nordenskiöld, que vió un grupo atrás de Caimanes y describió su visita y sus impresiones en cuatro capítulos de su obra citada en la Bibliografía de este trabajo.

En los últimos años un pintor boliviano sacrificó nueve meses para eternizar en cuadros los lindos y pintorescos Chácobo.

Cardus da solamente una breve mención 
HAENKE, W. 1957. "Los indios Chácobos del río Benicito"

de aquella tribu, como igualmente hace Ramos.

Los Chácobo son, pues, una tribu menos estudiada aún que otras de la familia Pano. Es por tanto urgente estudiarla ante (3) que se incorpore en la llamada civilización de los blancos, que acaba con toda cultura antigua y original y lleva la tribu a la mestización.

\section{LOS CHÁCOBO EN LA ACTUALIDAD}

\section{1) Su raza, aspecto físico y mentalidad}

Rivet divide la familia Pano, geográficamente en tres grupos; el tercero está instalado en las márgenes de los ríos Mamoré, Beni y Madre de Dios. En este grupo se incluyen los Pacaguara, divididos en varias tribus, como loa Kapuiba, Chácobo, Sinabo y Karipuná.

Creo que en los últimos decenios algo se ha cambiado. Nada pude averiguar sobre los Kapuiba y Sinabo y parece que ya no existen. En las márgenes de los ríos Mamoré y Behi ahora no hay tribus de la familia Pano. Los Pacaguara se han mudado y ocupan las costas bolivianas del río Abuna, Sobre el hábitat de los Chácobo a continuación se hablará. Los Karipuna están en Brasil, parte en el alto Yasí-Paraná, parte cerca de Vila Murtinho, si no es que últimamente el S. P. X. los ha llevado al puerto de Riberao. En la región del Madre de Dios todavía debe haber indios de la familia Pañoj aunque una parte se ha trasladado, según informes de personas que estuvieron en aquellas zonas.

La familia Pano pertenece a la segunda capa de pueblos de la Amazonia, según la división de Walter Krickeberg.

Conocí de esta familia, hasta la fecha, únicamente el diminuto grupito de los Karipuna, que vivía en un seringal, cerca de Vila Murtinho. No tengo un recuerdo pormenorizado de ellos, ya que estaban civilizados y nada conservaron de su antigua vida fuera del idioma.

Cuando vi los primeros Chácobo me sorprendió su belleza física. Son muy bien formados. En una pequeña serie de veinticinco adultos que puede medir, el hombre más alto tenía 169 centímetros y el más bajo 157 centímetros, mientras que la mujer más alta medía 158 centímetros y la más baja 136 centímetros. Tanto entre los hombres como entre las mujeres, los diámetros biacromiales y bitrocantéricos eran casi iguales, a veces con muy pequeñas diferencias individuales. Todos eran bien proporcionados y esbeltos, con un hermoso cutis color de cobre y con cabellos negros y lisos. Hombres y mujeres tienen aún el septum perforado y ponen palitos con plumillas rojas dentro, Hay otras deformaciones de las cuales hablaré más adelante.

En su mentalidad son bastante primitivos, sin ambición y sin intereses superiores. A pesar de que varios de ellos ya han tenido contacto con los blancos y que entre ellos vive, desde hace veinte años una mestiza chovina, muy pocos de ellos hablan castellano y los que lo hablan lo hacen bastante mal. Les falta todo sentido artístico y sus habilidades manuales son muy limitadas. Por otro lado, son bastante picaros: roban, mienten y no respetan al huésped, de 
HAENKE, W. 1958. "The Chacobo in Bolivia"
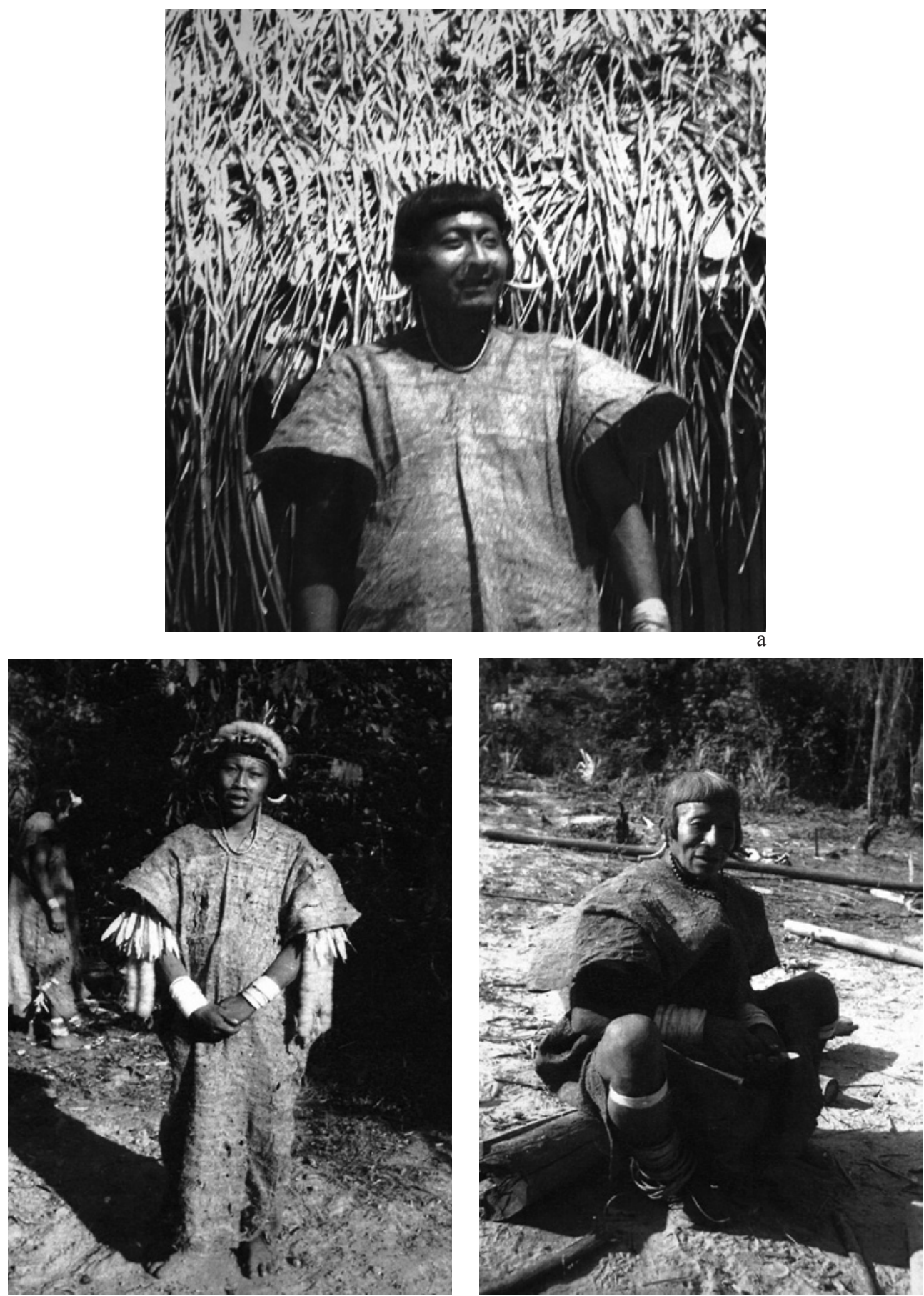

b

c

Fig. 1. (a), (b), (c). Hombres Chácobo donde se puede apreciar su fortaleza, belleza física y contextura muy bien formada. 
cuyo equipaje sacan clandestinamente lo que les agrada. Sacaron de mi bolsa un cinturón nuevo de corteza de bibosi que habíales comprado, y me pusieron en su lugar un cinturón viejo y rasgado. Lo hicieron $\tan$ secretamente que tardé en descubrirlo. Cuando nosotros queríamos salir del grupo de charia, escondieron la canoa declarando que no había canoa y que, por lo tanto, no podían llevarnos a parte alguna. Son alegres, como todos los indios; las niñas son tímidas y encantadoras en su ingenua castidad.

2) Su hábitat y vivienda

Desde tiempos antiguos los Chácobo habitan las regiones de los ríos Yata y

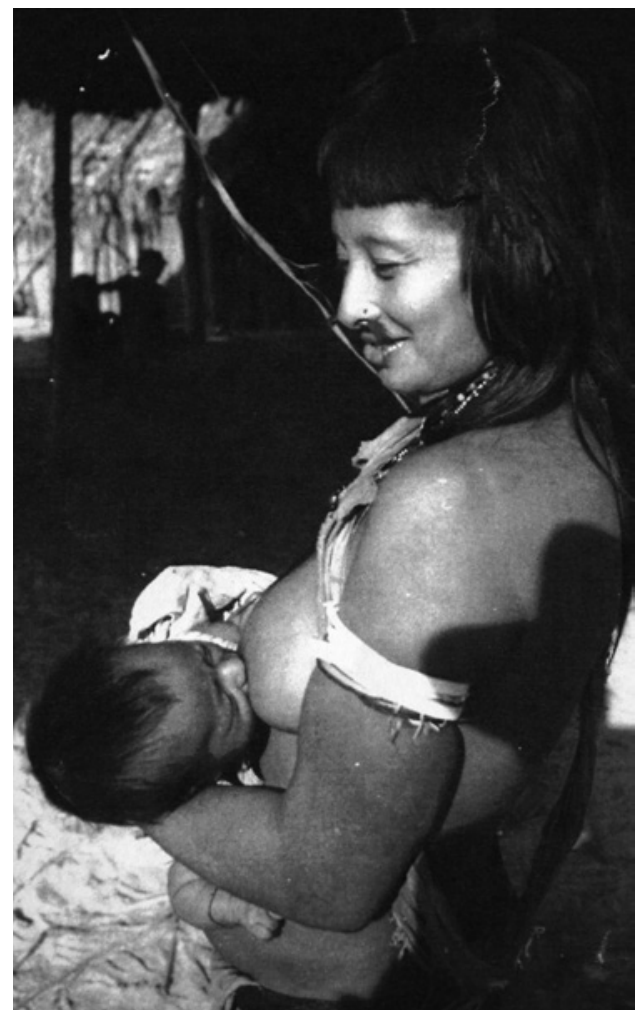

Fig. 2. Madre Chácobo, amamantando a su bebe.
Benicito y las partes vecinas del Beni. Antes había un grupo por Yeneguaya que ya se retiró. Nordenskjöld los visitaba por el sector de Caimanes en el Yata; habla de dos aldeas: Kokoya y Mashishoya. La gente me habló de un puerto, Santa Cruz, arriba de Caimanes, donde supusieron unas quince familias. Pero personas dignas de todo crédito negaron la presencia actual de Chácobos en el Yata. Realmente parece que todos habían emigrado a! Benicito.

Los Chácobo no tienen paradero fijo. Son nómadas en el verdadero sentido de la palabra. Razones del tiempo, de caza y pesca frecuentemente les obligan a realizar traslados; fuera de eso se

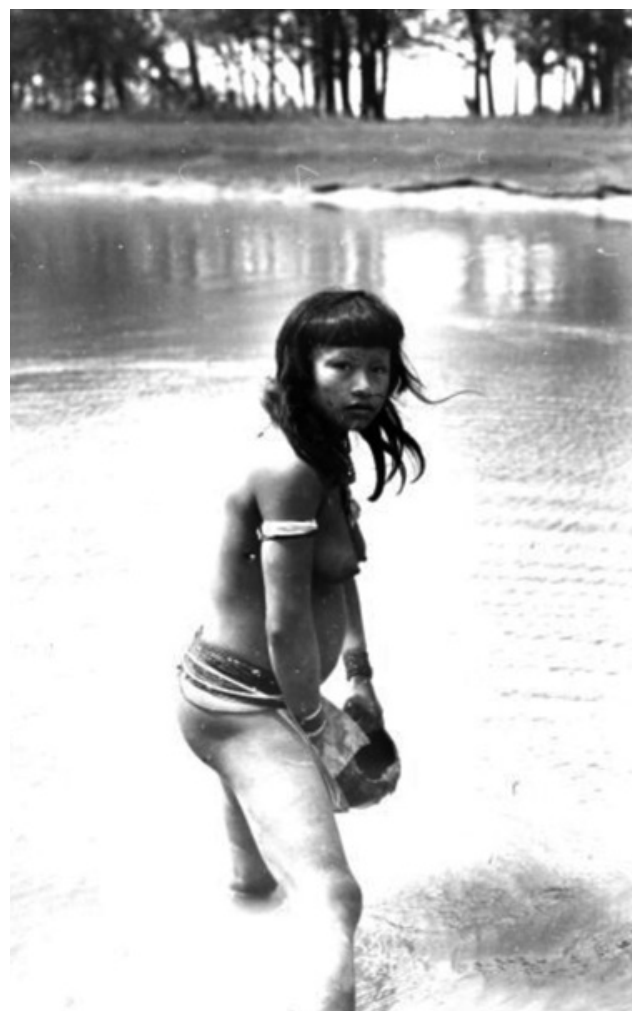

Fig. 3. Las jóvenes Chácobo son muy tímidas. 
mudan en caso de muerte de un adulto o por algún temor o superstición. Últimamente temen al ya mencionado Soria. Parece que este hombre, más hábil e inteligente que los otros, quería hacerse jefe supremo de la tribu. Encontrando resistencia, quedó amenazándolos y la tribu le cobró cierto pánico. Basta que alguien les diga que el tal Soria está por llegar para que se muden a. los desiertos más apartados.

Para llegar al Benicito se debe remontar el Yata, que tiene un puerto llamado Pontón, a la distancia de 36 kilómetros del pueblo de Guayaramerin.

Los Chácobo habitan casas bastante bien hechas y grandes. Son de tres a cuatro metros de largo por dos metros o más de ancho, altas, bien aireadas y cómodas. Algunas tienen paredes de palos; otras solamente un techo de paja que les protege contra las lluvias y Jos rayos solares. En algunas casas duermen, en otras preparan la chicha y sus comidas y tienen ranchos menores que sirven para depósitos de comestibles. Aún ocupan varias familias una casa o "maloca". Recientemente el núcleo indigenal comienza ya a tener casas de una sola familia.

3) Número y grupos

El número total de los Chácobo no alcanza 100 almas. Si antes había más, es difícil de averiguar. Su contacto con los blancos es relativamente moderno. No había persecuciones y parece que hasta ahora se han salvado de graves epidemias.

Hace unos meses que se ha formado un núcleo indigenal del Gobierno de Bolivia para llevar los Chácobo a una vida sed-

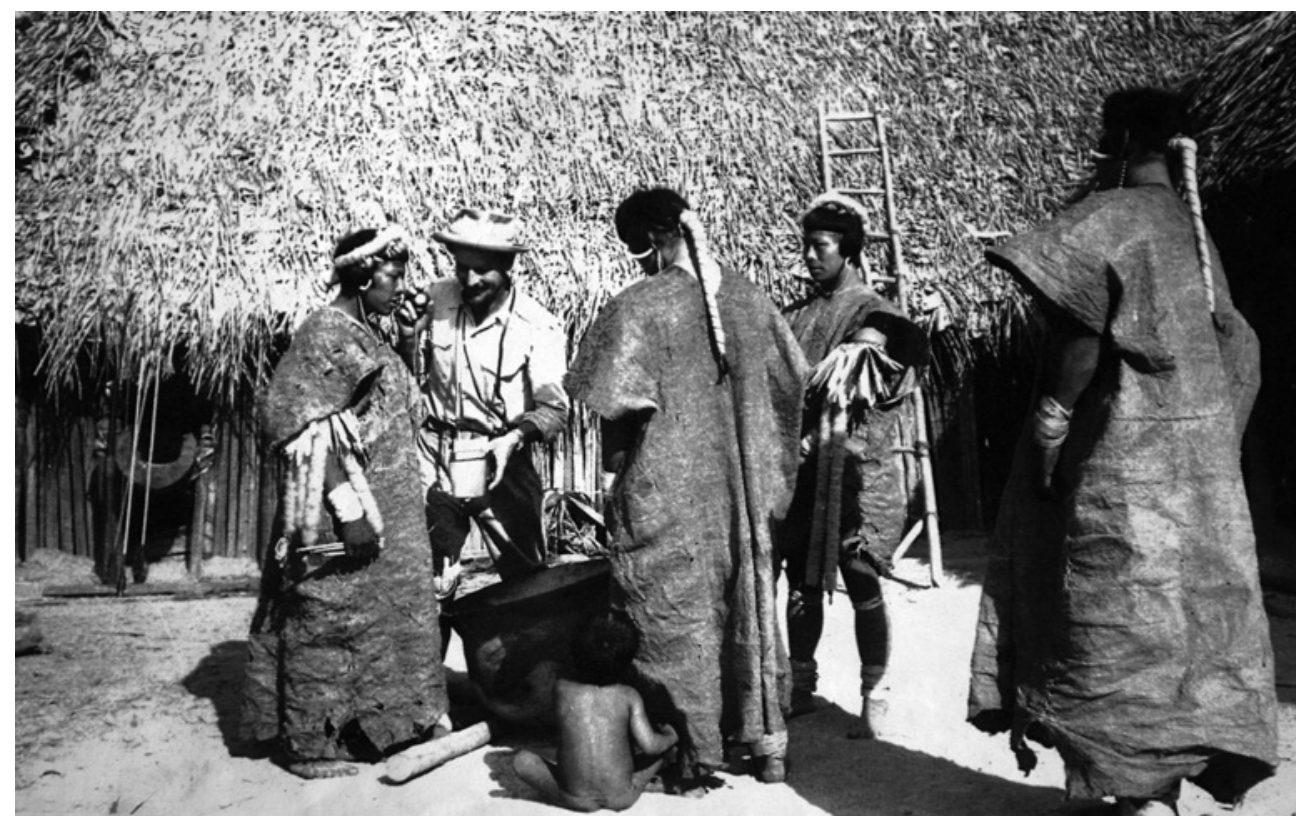

Fig. 4. Los Chácobo hábitan casas bien hechas y grandes. 
entaria e incorporarlos a la civilización. Además me consta la existencia de cinco grupos salvajes.

a) El núcleo indigena Nuflo de Chaves

Lleva dicho nombre en homenaje al actual Ministro de Asuntos Campesinos. El núcleo está situado a unos 15 kilómetros del puerto de Limones, que últimamente también se denomina Puerto Nuflo de Chaves. El director del núcleo es José Martorell, hombre demasiado joven y por lo tanto incapaz para la responsabilidad de tal cargo.

Se han reunido en este núcleo 28 Chácobo, el grupo del supremo cacique Taita Pai.

Entre ellos hay trece adultos; los demás son jovencitos y criaturas. Al grupo de Taita Pai se han agregado tres niños: los hijos de los Chácobo muertos en
Caimanes por Soria. Todavía no hay escuela, aunque se han nombrado ya varios profesores.

En seguida se exigió a los Chácobo que se vistieran, pero se les dieron vestidos viejos y rasgados; así que su aspecto civilizado es menos agradable que el salvaje en las camisas de corteza o en su desnudez adornada. Se cortó el cabello a los hombres y se les enseña a no usar más sus adornos antiguos y no perforarse los lóbulos y el septum.

Es muy probable que en breve se les enseñe a tomar aguardiente, fumar y luego se les llamará "bien civilizados".

El grupo del Taita Pai se adelantó a los otros grupos. La razón parece ser la esposa de dicho jefe, la Mama Tóe en Chácobo, ya que en verdad se llama Hortensia Duran, hija de un blanco

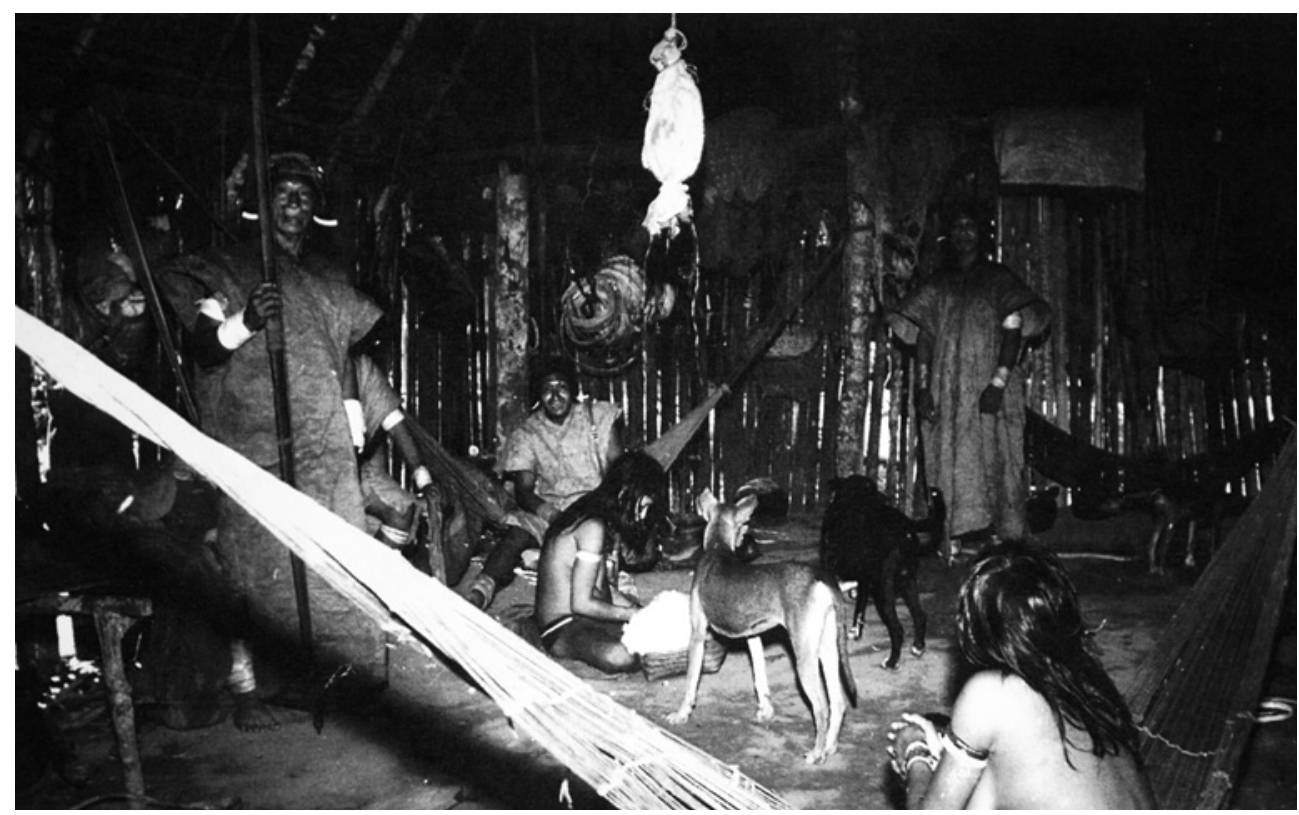

Fig. 5. En algunas casas duermen, en otras preparan la chicha y sus comidas y tienen ranchos menores que sirven para depósitos de comestibles 
con una mestiza chovina, nacida y criada en el pueblo de Santa Ana. La joven Hortensia se casó en su pueblo y acompañó a su esposo a la región de los Chácobo, donde grandes gomales y la cacería de caimanes llamaron la atención de los civilizados. Allí murió su marido y Hortensia quedó sola. Los Chácobo la llevaron consigo y la incorporaron en la tribu, perforándole el septum de la nariz. Más tarde se casó con el primer cacique. Actualmente tiene hijos grandes y nietos y se nota su influencia en éste grupo.

\section{b) Los grupos de María y Maro}

Cruzando el Benicito en la altura de Limones y subiéndolo hora y media a motor o tres horas a remo, se llega al puerta dé María, bien escondido entrelas marañas del bosque. Junto a María vivía entonces el grupo de Maro, al cual también pertenece la familia de Cuya. Había, pues, en el momento de nuestra visita, tres familias con diecisiete almas, entre ellas diez adultos. Sobraron las mujeres.

La Mama Bussi, madre de Maro, era la más vieja y viuda. Luego había otra viuda y dos solteras, jóvenes aún. María es viudo, pero Maro y Cuya son casados; el último tiene dos mujeres. Con estos indios hemos convivido. Sólo María habla un poco castellano.

\section{c) El grupo de Kak}

De lejos vimos el grupo de Kako corriendo por la pampa, una hora arriba de María, Kako vive con su mujer y dos hijos; es el hermano de Taita Pai. Justamente estaba atemorizado por rumores de. una posible llegada de Soria.

\section{d) El grupo de Rhabí}

Lo mismo ocurrió con el grupo de Rhabi, que hasta hace poco estaba cerca del puerto "La Paloma". Por miedo de Soria abandonó su aldea y huyó a la selva. Nadie sabe a dónde se ha ido. Según informes de los vecinos, este grupo se compone de quince personas con ocho adultos. La esposa de Rhabi, la Mama Rosa, es famosa por su inteligencia y habla castellano.

\section{e) El grupo de Tubá}

Teníamos la intención de visitarlo y arribamos al puerto Buen Retiro, cuatro horas arriba de María. Dicho puerto está ocupado por el seringüero Pablo Rivera y pertenece al seringa-lista Juan Calleja. Poco antes de nuestra llegada los Chácobo de Tubá fueron acometidos por una enfermedad que en esta zona se llama asombriila. En consecuencia de este hecho se retiraron a las pampas inundadas, seis leguas del puerto; No encontramos movilidad. Pensaba hacer llamar a los indios, pero mientras tanto, algunos de ellos enfermaron de malaria y uno murió. En seguida se mudaron nuevamente a un palmar.

Yo, también casi me enfermo con malaria, luego la absoluta falta de recursos y la innoble actitud de mi compañero de viaje me obligaron renunciar a mi plan de visitar este grupo y volver a Limones, Chácobo y siringueros me facilitaron información del grupo de Tubá. Según estos relatos, Tubá es el más viejo de la tribu. Su grupo se compone de veinte personas más o menos, entre ellas dos hombres que ya estuvieron en Guayaramerín y hablan castellano, 


\section{4) La organización de la tribu}

Como ya dije, los Chácobo viven en bandas $\mathrm{u}$ hordas nómadas, fijando domicilio temporalmente que abandonan por varias razones. Cada horda tiene su jefe, cuyo nombre lleva. El supremo jefe de toda la tribu en sus hordas dispersas es el ya nombrado Taita Pai. La importancia de los jefes o caciques 110 es muy grande. Parecen tener más bien un cargo representativo. Más respetados y temidos son los hechiceros. María es uno de ellos; Tubá otro. Cierta influencia tienen las mujeres de edad, Las llaman "Mama" título de respeto, como "Taita» para los hombres. Si la mama habla, todos la escuchan y obedecen sus consejos. Mucha importancia en toda la tribu tiene la Mama Tóe; tal vez sea por su superioridad natural.
Los Chácobo respetan y reconocen la propiedad particular. Cada familia tiene sus plantaciones; cada persona sus propios útiles que se queman a. la defunción del propietario. Los grupos se entienden entre ellos por intermedio de mensajeros, que viajan a pie, por tierra, o en canoa, Así también se realizan las mudanzas, Viajando a pie, las mujeres portan el ajuar doméstico, poniéndolo en sus cestos de carga de forma rectangular, que llevan, a la espalda, asegurados con una cinta de corteza de bibosi sobre la frente. Los hombres llevan única1 mente sus armas.

La base de la familia es el matrimonio monógamo o bigamo, que se contrae sin mayores ceremonias. Al casarse se perforan los lóbulos y pone allí los colmillos del capivara. Los hijos se crían con

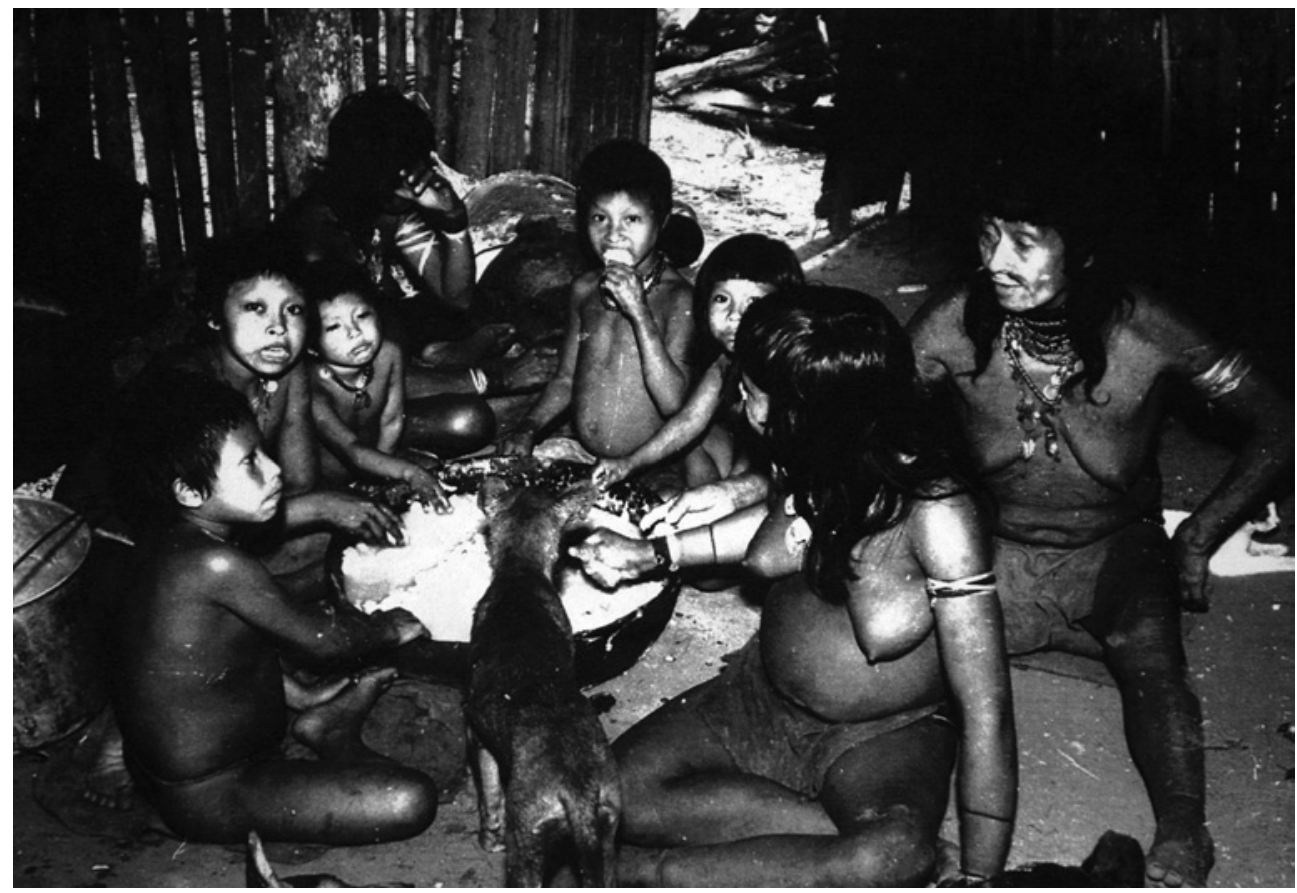

Fig. 6. Los niños Chácobo, se crían muy felices recibiendo el cariño de su familia. 
cariño. Parece que no hay ni había infanticidio de hijos con madre. Pero si ésta muere en el parto o durante la crianza, abandonan al niño de pecho en el monte o lo dejan morir de hambre. Nadie se preocupa de criarlo. El parto ocurre; en la casa; la recién parida se cuida por espacio de dos o tres días. Nada noté de la "couvade" y Tóe negó esta costumbre.

Los casados no son siempre felices. Conozco a Yaco, que se casó con una hija de Taita Pai. La joven esposa, en breve, abandonó al marido, no le dio comida y le negó los derechos conyugales, retirándose Yaco a la casa del director del núcleo.

Disgustos entre los grupos y conflictos internos no son raros. Soria está en conflicto con toda la tribu. Taita Pai y su gente no quieren a María, aunque es cuñado del primero. Le temen por sus brujerías. Por la misma razón Tubá tiene enemigos,

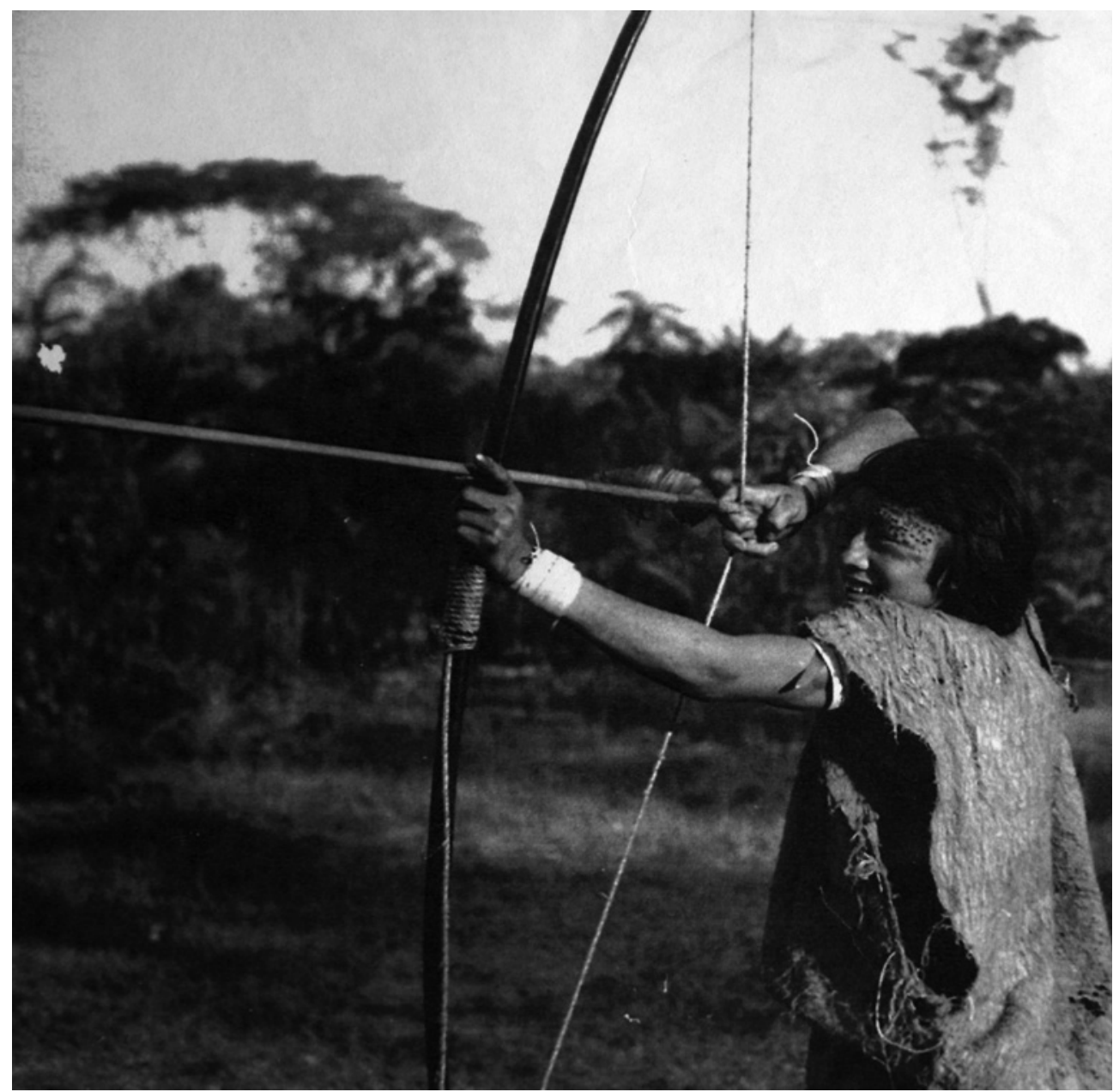

Fig. 7. Los Chácobo son cazadores, pescadores y recolectores por naturaleza, pero también hacen agricultura. 
HAENKE, W. 1957. "Los indios Chácobos del río Benicito"

\section{LA CULTURA TOTAL}

\section{1) Material}

\section{a) Actividades y Alimentación}

Los Chácobo, estando aún en su estado primitivo y en plena libertad fuera del núcleo, se dedican a la caza, pesca, recolección de frutas y raíces y a la agricultura. Los hombres cazan, aún con arcos y flechas bastante largas. La flecha de punta grande de tacuara (bambú) sirve para la caza del tapir o del tigre. Es la flecha de, guerra. Con flechas de punta chica de tecuara se caza el mutum; y aves parecidas en tamaño. Para la otra caza usan la flecha de punta dentada en ambos lados hecha, de chonta.

También la pesca se hace en primer lugar con flechas, que en este caso carecen de plumas y cuya punta consiste en dos clavos de hierro, uno puesto como gancho. Los caños de las flechas son de chuchio (Gynerium saccharoides). Casi siempre son emplumadas con plumas del mutum puestas paralelamente. La atadura se tapa con brea y con urucú. Algunas flechas se adornan arriba de las plumas con tiritas blancas y negras de bejucos del monte.

Los, arcos son planos, ligeramente curvados y en sus terminaciones adelgazados.

Pescan también con veneno, La pesca con anzuelo la aprendieron de .los, blancos. Sus plantaciones son primitivas en medio del monte. Cultivan la mandioca, la banana, la caña de azúcar, a veces la papaya, y siempre el maíz. Del monte traen frutas de palmeras, de las cuales preparan una bebida que en Bolivia se llama "leche de majo"; parece igual al "vino de assai" en Brasil. La chicha la hacen de yuca. La agricultura después del derrumbe y la quema del monte y la recolección de frutas es tarea femenina;

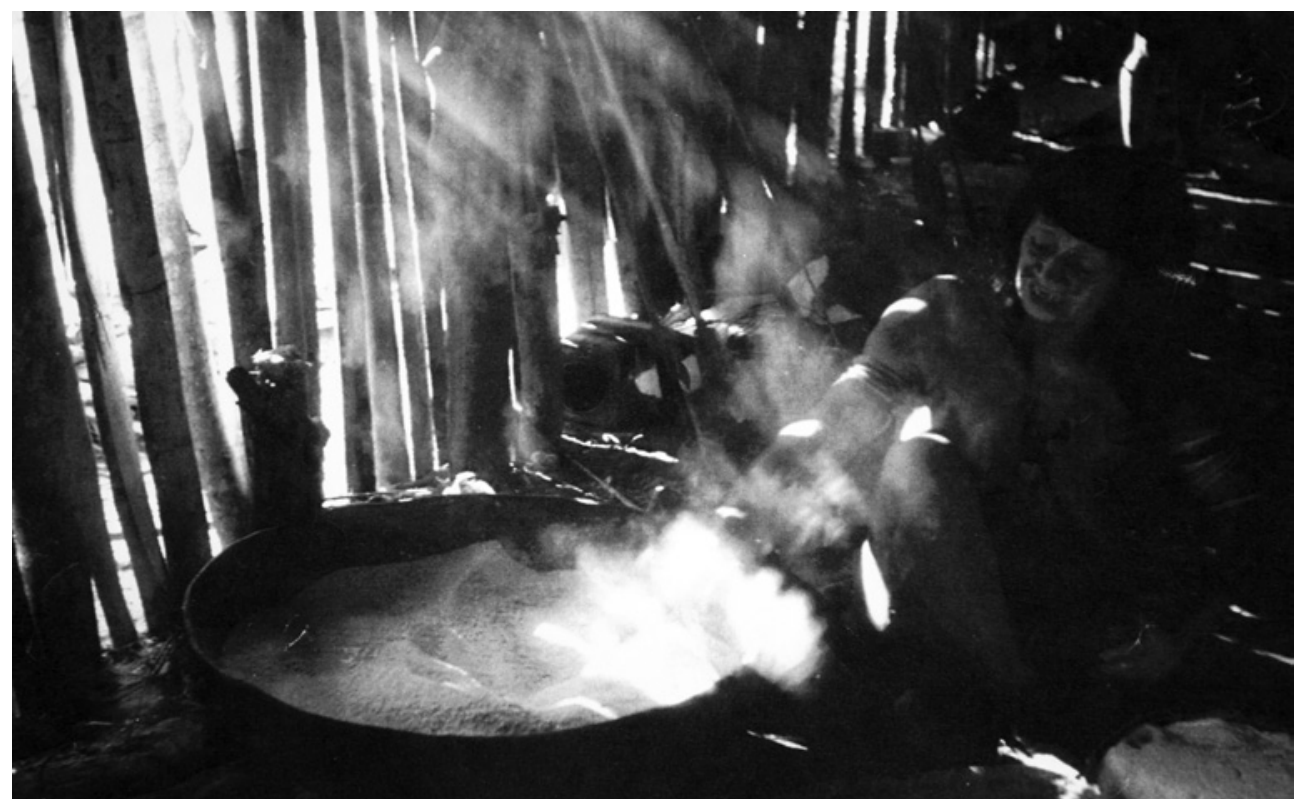

Fig. 8. Mujer Chácobo preparando la chicha a base de yuca. 
así también la preparación de la chicha, de la leche de manjo y de la comida. Recientemente con el contacto de los blancos llegaron a conocer la sal, el azúcar preparado y otros comestibles nuestros.

\section{b) Utensilios}

De los utensilios que Nordenskiöld menciona faltan ya algunos, así como las mazas de danza. Hoy día danzan con una tinaja en la mano. Faltan también los pequeños arcos para limpiar el algodón, que han sido reemplazados por palos de chuchio, con los que lo baten. Tampoco vi suñidores. Las demás cosas domésticas y de uso, descritas por Nordenskiöld, se conservan aún. Como antes, pisan el maíz y la mandioca en sus enormes morteros con pedazos de madera dura o con piedras en forma de hoz. Se sientan en los banquitos hechos de palos cruzados con asientos de cañas gruesas del chuchio. Duermen en sus hamacas de fibra o de algodón y utilizan cántaros y platos toscos de barro sin relieves y sin dibujos, o también calabazas. En ningún objeto se muestra la manifestación del arte. Su cestería es igualmente primitiva, aunque los canastitos con tapa están bastante bien hechos y sirven para guardar cosas pequeñas o plumillas. Con frecuencia se ven bolsas de la corteza de bibosi que reemplazan a los cestos y son más fáciles para confeccionar.

\section{c) Vestidos y adornos}

En estado salvaje, los hombres se visten con largas camisas de la corteza, del árbol bibosi. Esta corteza la machacan

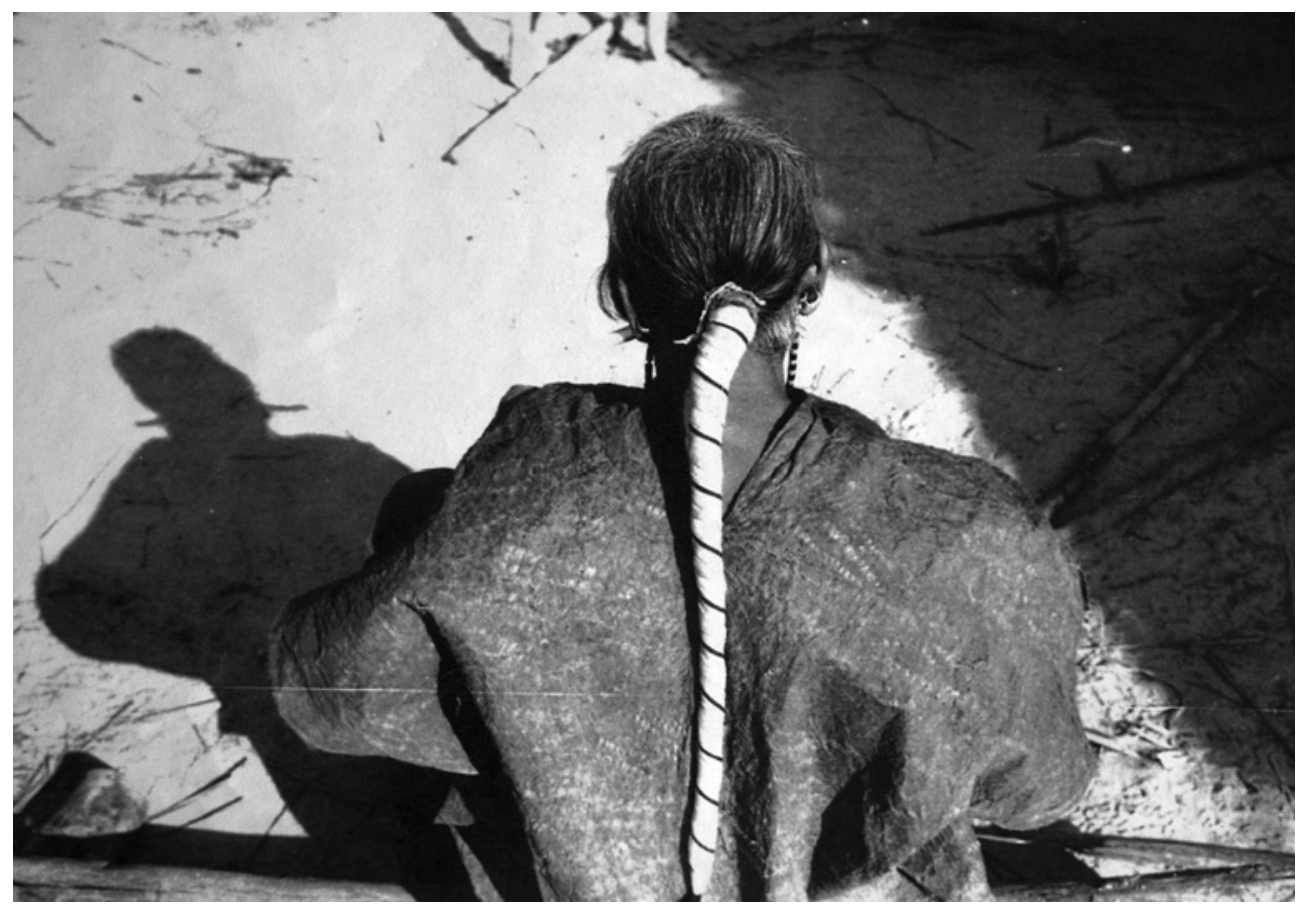

Fig. 9. Los hombres usan una larga trenza, la que adornan y atan con hilos de algodón y de corteza de árbol. 
con un madero para ablandarla y luego se cose con cualquier bejuco o hilo de fibra. Son de color natural; es decir, marrón. También los muchachos usan a veces tales camisas. Las mujeres, en cambio, nunca las usan. Debajo de la camisa el hombre lleva un cinturón, ora de fibras, ora de bejuco, que sirve para atar el pene hacia arriba. Los hombres se distinguen, además, por sus cabellos largos, que tuercen y ponen en una especie de estuche de cintas de algodón, bien tejidas. Así les cuelga el cabello en forma de trenza por el dorso. Encima de la frente se cortan el pelo; en los lóbulos llevan los grandes colmillos del capivara. Les gusta unirlos por collares de un lóbulo al otro, que circundan la parte inferior de la cara. Tienen escasas barbas, pero dejan crecerlas, mientras que afeitan las cejas y el pelo del

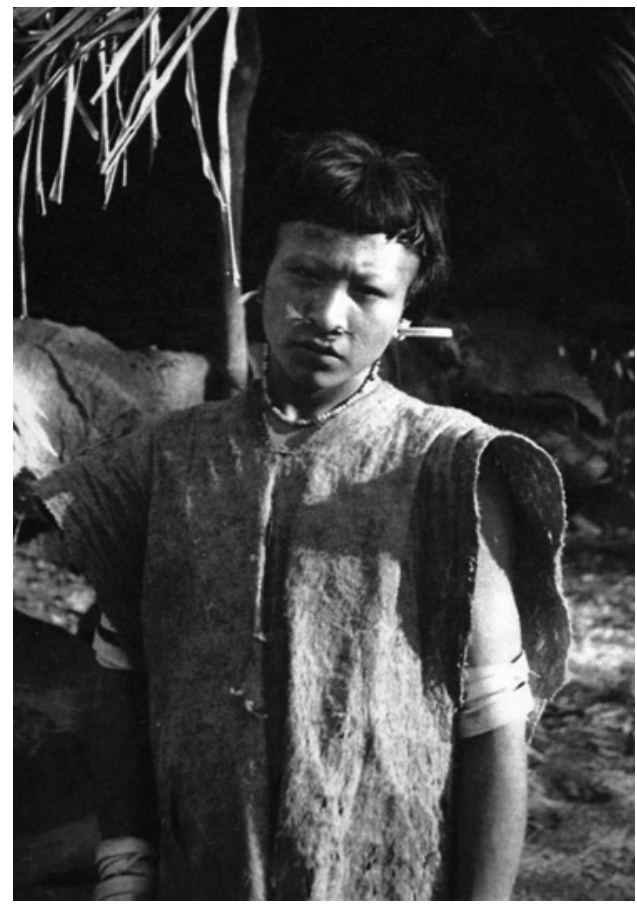

Fig. 10. Los más jóvenes también usan, esta larga camisa fabricada con corteza de árbol. cuerpo. Desgraciadamente no vi más los collares de dientes del mono, de los cuales habla Nordenskiöld. Las mujeres andan desnudas fuera de su cinturón de bejuco negro, frecuentemente matizado con tiritas blancas; encima del pubis se juntan los cabos del cinturón para atarlo sobre el cuerpo. Allí se pone un pedazo rectangular de bibosi, que doblemente tapa las partes púdicas. Estos cinturones son, a veces, muy suntuosos.

Hombres y mujeres usan cintas de bejuco en los brazos, debajo de las rodillas y por les tobillos. A las mujeres les gustan los collares y pulseras de semillas. Es costumbre general perforar el septum de la nariz y poner dentro un palito con plumitas rojas. Tal perforación es obligatoria y constituye algo como marca de la tribu. Parece que los

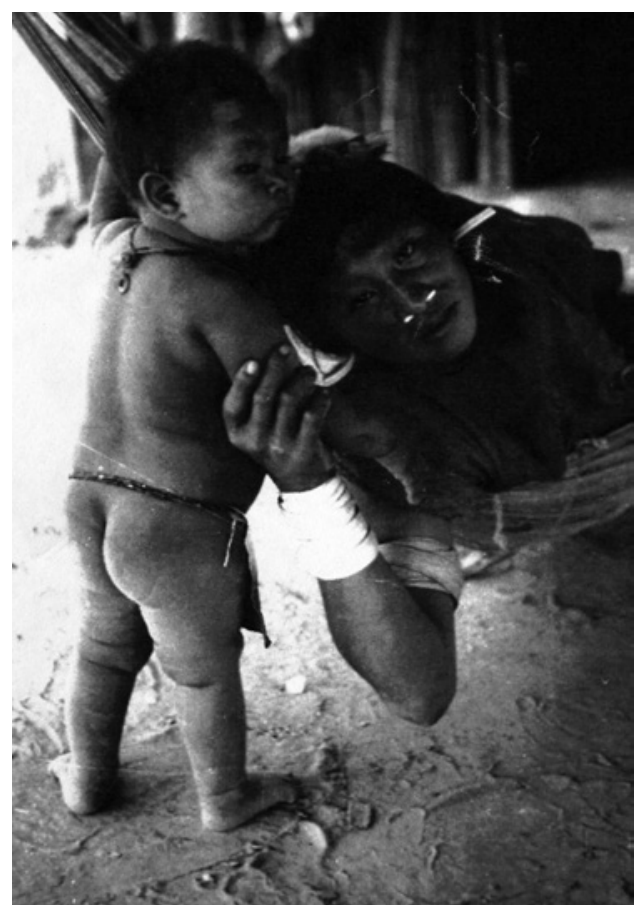

Fig. 11. Es costumbre la perforación de la nariz, para colocar un adorno con plumas de tucán. 
palitos con plumitas tienen también un sentido mágico como defensa contra las enfermedades. Algunas mujeres se agujerean las alas de la nariz y meten finos palitos dentro; esto lo hacen, según su voluntad, para embellecer el rostro. Adornan sus collares con plumillas o se pegan plumillas con cera en los cabellos. Sólo los hombres ponen, en ocasión de fiestas, diademas con plumitas y mechones de plumas chicas en la cabeza; propios de ellos son también los adornos de los brazos con plumas y largas cadenas de plumillas del pato, que en número de tres por cada lado cuelgan hasta los pies. Adornos de plumitas usan también las mujeres en la parte superior de los brazos. También las mujeres se afeitan las cejas y el vello del cuerpo.

Nuevos son los collares de monedas, en moda entre las mujeres del núcleo, y otros collares compuestos de todo: semillas, monedas, botones, cartuchos vacíos, etc. Los anillos de chonta se venden entre los grupos salvajes, pero el grupo del núcleo usa anillos de cobre o de lata. Vi un solo anillo de chonta con un dibujito modesto. De los anillos suelen formar collares para el cuello.

Se pintan raras veces con urucú en la manera como lo hacen los Sirionó: manchando la frente y la cara con manchas irregulares, sin pensar en algún dibujo o figuras geométricas.

En todo se nota la absoluta falta de sentido artístico. No fue posible hacerlos dibujar con lápiz, sobre el papel o con el dedo, en la arena. Nunca se les ve tallar en madera o formar alguna figurita en cera o barro, ni pretenden hacer muñecos o bichitos de corteza, como es común entre otras tribus más elevadas.

\section{2) Espiritual}

\section{a) Religión}

Creencias en seres superiores, en la inmortalidad del alma. Etioc

Parece que los Chácobo representan verdaderamente una tribu sin dios bueno. Creen en un ser maligno, una especie de engañador divino, el Joshin o Joshini, que corresponde al diablo de los cristianos. Joshin vive en los ríos y aparece en los montes; siempre trata de dañar a los humanos y de llevarse las almas de loa difuntos. Creen también los Chácobo en otros varios espíritus malos.

Si un Chácobo muere, el alma sube a su cielo; allí hay una casa grande donde las almas se reúnen. Hermosas selvas ofrecen mucha caza y los ríos están llenos de sabrosos peces. Los Chácobo están solos en este paraíso; no hay dios, ningún "taita" o jefe, ni ha/ blancos. Entre los Chácobo de Taita Pai se oye hablar del Taita Dios, pero esto se debe a la influencia cristiana de la Mama Tóe. Los otros grupos nada saben de un ser en el cielo adonde van las almas para gozar de plena libertad y de abundante comida. Sin embargo, temen la muerte y al espíritu de los difuntos.

Nada saben del origen del mundo y de la Humanidad; ninguna leyenda del diluvio o de otros cataclismos enriquece su mente. Si se les pregunta sobre tales cosas, dicen que no saben que hubo una gran inundación, o interrogados sobre su origen, afirman que siempre había Chácobo por el Yata y Benicito. 
Tampoco hay leyendas sobre los astros. Su ética no es muy elevada; sin embargo, son pacíficos y respetan la vida humana. Las mujeres no viven oprimidas y las niñas se conservan hasta el casamiento, que muy temprano tiene lugar.

\section{b) Culto, fiestas, música}

Lamentan la muerte de uno de ellos, entierran el cadáver adornado y queman la casa y los objetos del difunto. Luego se mudan del lugar. Un año después de la muerte, y en ciertas ocasiones, se repiten las lamentaciones. Fuera de este culto a los difuntos, no tienen ningún otro. No rinden homenaje a ningún ser o astro, ni rezan ni celebran fiestas relacionadas con algo sobrenatural.
Su fiesta principal se hace cuando hay mucha chicha. Entonces baila el hechicero en el extremo de una fila de mujeres alrededor de una enorme tinaja con chicha. Las mujeres se agarran la una a la otra por su cinturón. En otra fila aparte, con los brazos entrelazados, bailan los hombres, tocando sus flautas de pan, y cantando. Luego todos paran y se acercan a la tinaja, de dónde sacan chicha con una calabaza. La toman de un trago y la conservan 5 u 8 minutos en el estómago. Después se ausentan, arrojan la chicha y siguen bailando. Tal procedimiento se repite hasta acabar la chicha. No se emborrachan mucho, porque siempre devuelven la chicha tomada.

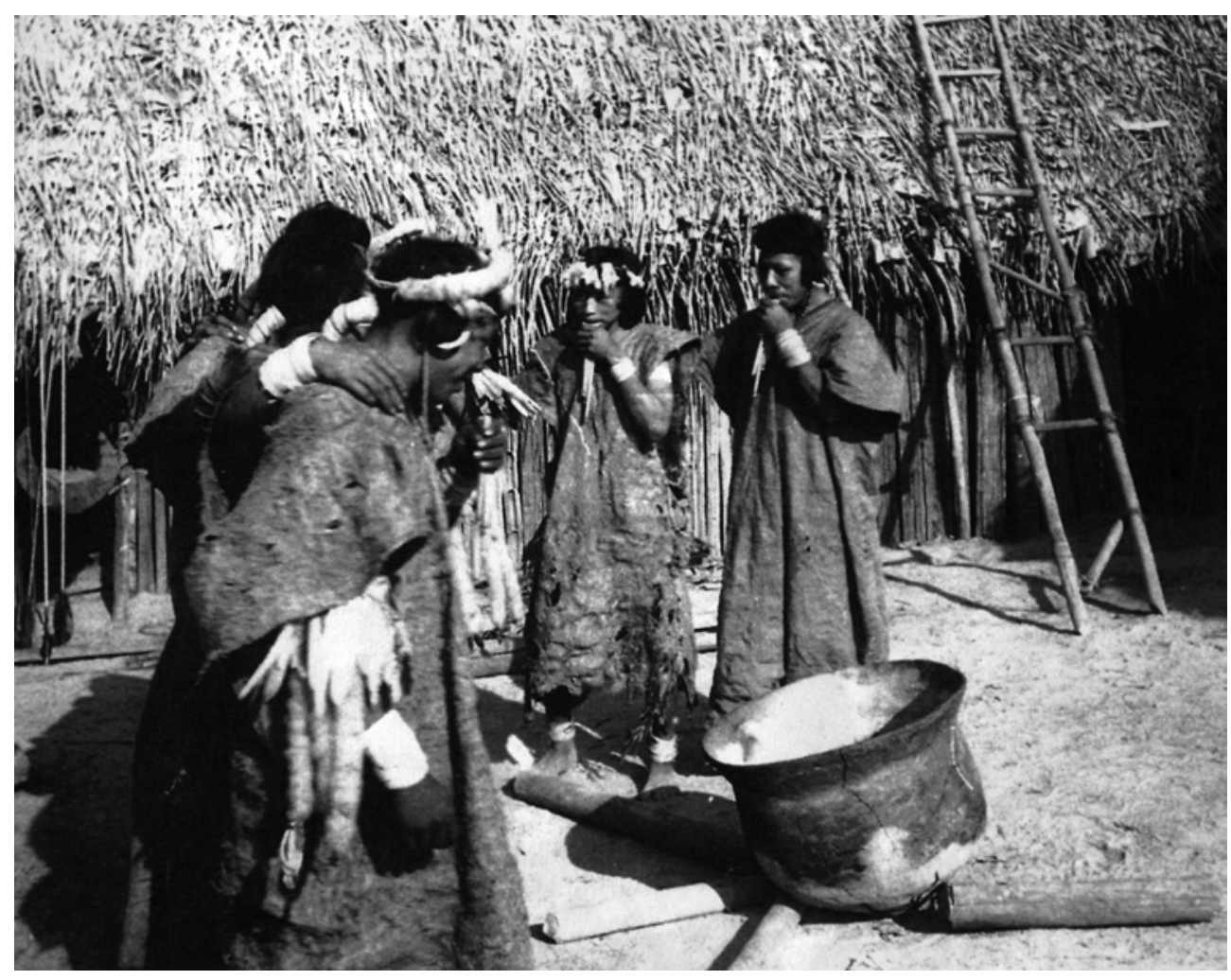

Fig. 12. Durante sus fiestas, beben chicha de manera moderada, pues si toman más de la cuenta la devuelven. 
El único instrumento de música, es la mencionada flauta, que hacen de banbú fino; la tocan mal y sus cantos no impresionan.

\section{c) Hechicería y sus efectos}

Mucha importancia en su vida tiene la magia y la hechicería. Con la magia se relacionan las reglas de la dieta y otras más. Durante la gravidez de una mujer $y$ en los años que hay hijos chicos en la casa, no se deben ni matar, ni comer ciertos animales, así el mono silbador, el hochi pintado, el pato, la perdiz, el paraba, el sucha y toda clase de culebras. Si el padre o la madre matan uno de estos animales, el hijo muere o recibe algún defecto, especialmente manchas, señales o eczemas en la piel. Creencias parecidas se encuentran entre los
Guarayos, aunque esta tribu nada tiene que ver con los Chácobo.

En la opinión de los Chácobo, la muerte es casi siempre producida por hechicería, igualmente) las enfermedades. Los grandes brujos María y Tuba tienen el poder de matar a larga distancia, mandado un viento fuerte o un misterioso pájaro grande, que llevan la muerte. María no niega tener estos poderes y se enorgullece de ellos.

Tubá sabe lo mismo y sabe también transformarse en tigre o en cualquier otro animal, según sus deseos. Tales ideas pueden hacer sospechar algunos vestigios de totemismo. Pero nada de esto se nota en la actualidad. Si antiguamente lo había, casi todos los recuerdos ya se han borrado.

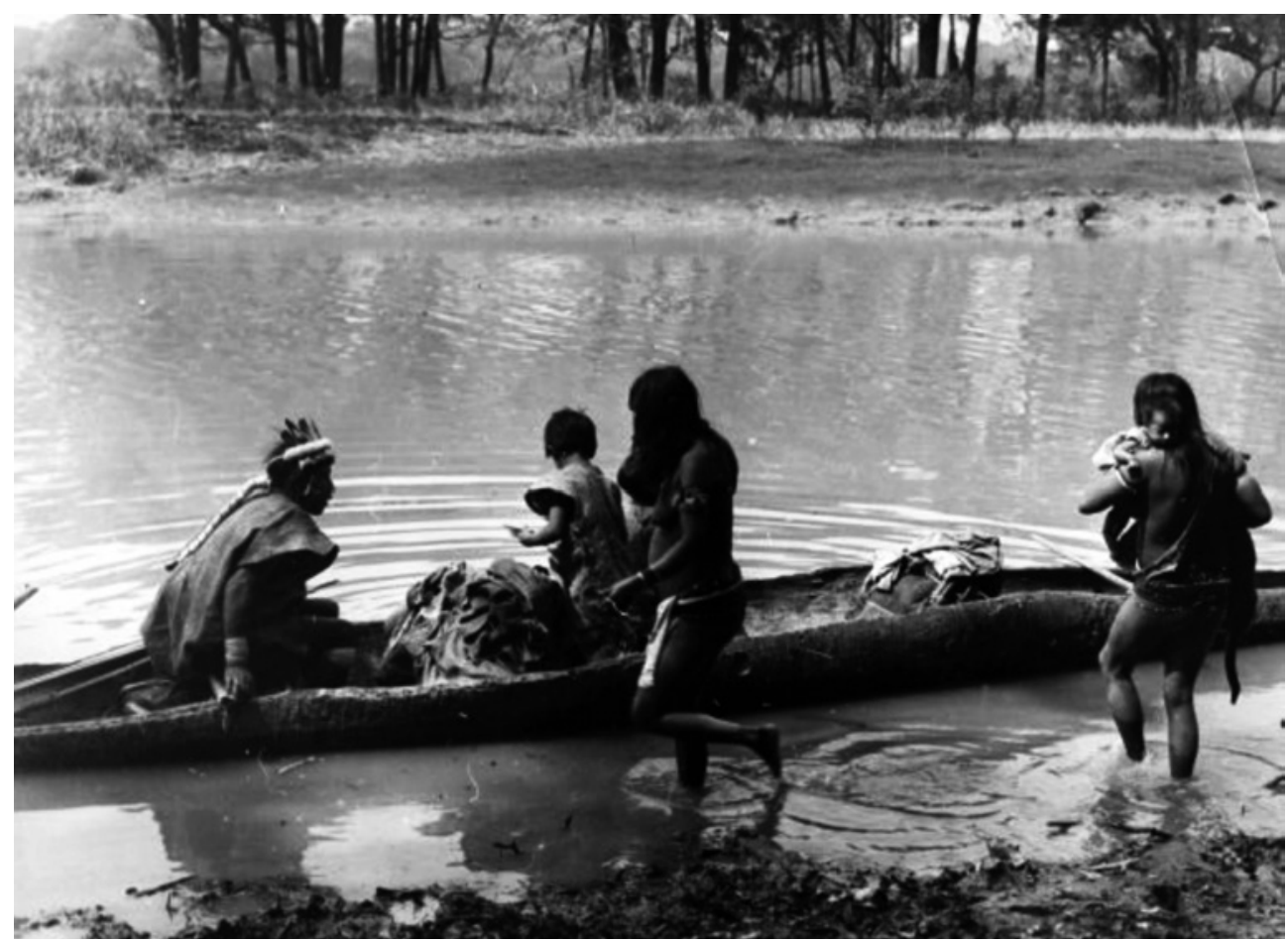

Fig. 13. Las canoas, son muy importantes a la hora de movilizarse de un lugar a otro. 
HAENKE, W. 1957. "Los indios Chácobos del río Benicito"

\section{LA VIDA DIARIA EN LOS GRUPOS SALVAJES, SEGUN OBSERVACIONES PERSONALES}

Antes de amanecer se oyen las voces de los Chácobo, tendidos aún en sus hamacas de fibra de propia confección, o durmiendo en el suelo encima de algún pedazo de corteza de bibosi. Hablan y se ríen hasta que por fin una mujer se levanta, destapa el fuego y lo sopla, poniendo más leña y algunas raíces de mandioca en la brasa para asarlas. Poco a poco, todos se levantan. Los niños chicos lloran, pidiendo el pecho. El joven Cuya juega con sus mujeres y sus hijitos, en plena armonía familiar.

Luego toma arco y flechas y se va al monte para cazar. Máro se dirige al río con su arco y dos flechas sin plumas para acertar el pez en el agua. El último en levantarse es María. Se sienta en un banquito y tuerce una cuerda de arco. Terminado esto, arregla algunos bejucos para nuevos adornos de sus brazos y piernas.

Todos comen yuca asada.

Las mujeres, después, se van a las plantaciones con sus cestos de carga, para traer mandioca, choclos y alguna papaya madura. Dos buscan leña, ya cortada por los hombres, y las jóvenes se dirigen al río para bañarse, y en busca del agua. Más tarde, se reúnen las mujeres y las vemos asar cholas o pisar mandioca en el mortero grande para la preparación de la apreciada chicha.

Una mujer se sienta en el suelo, delante

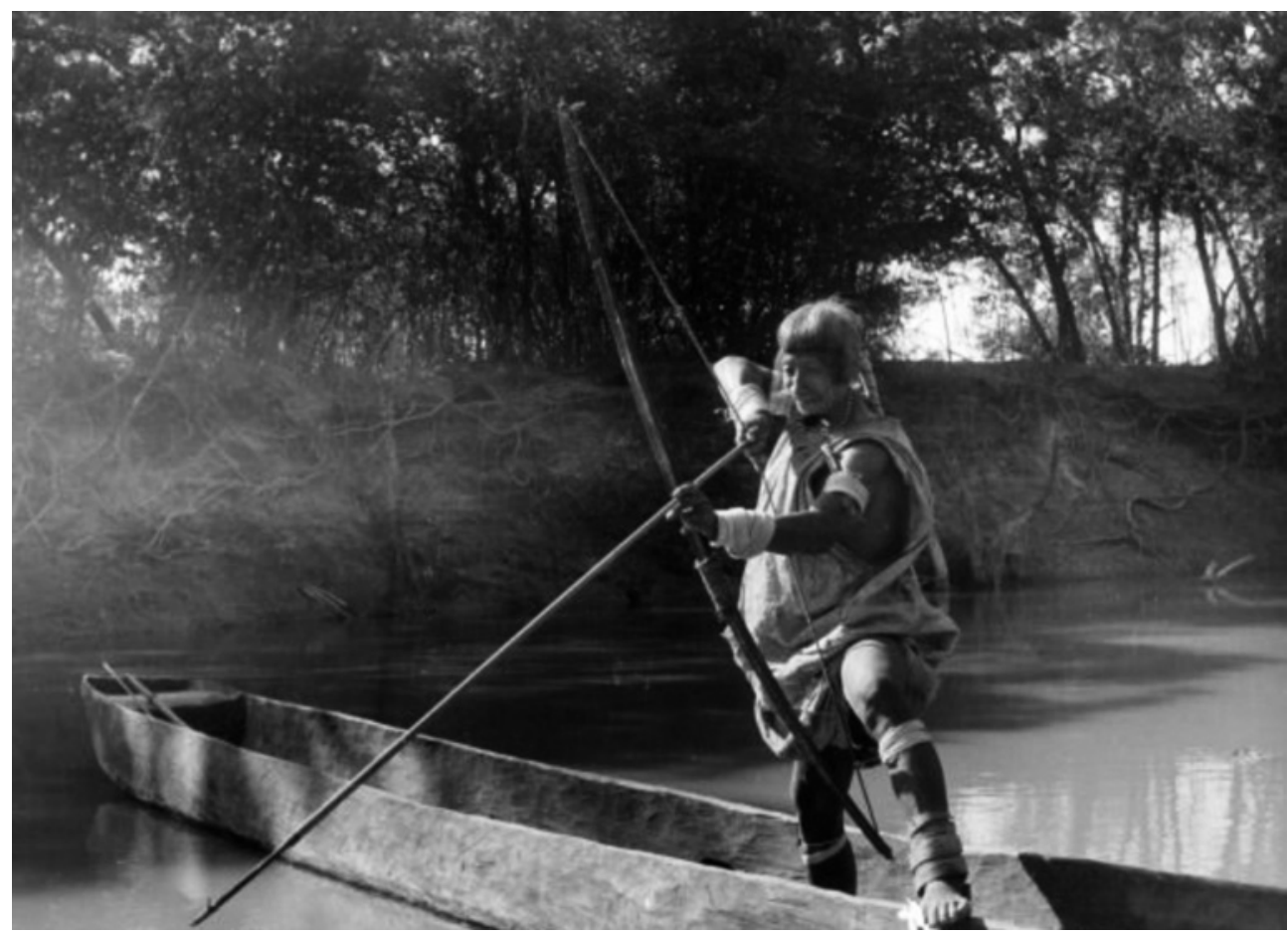

Fig. 14. La pesca con arco y flecha esta dentro de sus actividades cotidianas 
de su telar, y hace una hamaca. El telar es bastante primitivo: dos palos verticales en la tierra, y, entre ellos, dos horizontales; en este rectángulo largo, se tienden las cuerdas, según la largura de la hamaca. La mujer las anuda con cuerdas transversales. Habitualmente lo hace, y la hamaca queda firme y es de larga duración.

Algunas madres juegan con sus hijos y con los animalitos mansos. Así pasan las horas. No hay que imaginarse que trabajan de prisa y sin interrupción. Todo lo hacen con calma y lentitud propia del indio libre, al cual nadie, apura, y que aún no conoce el valor del tiempo. Descansan frecuentemente, charlando y riéndose de las cosas más insignificantes, como es costumbre de las mujeres primitivas. Una que otra se levanta, ora para ir al río, ora para pasear un poco, o ver qué hacen las visitas, y si no habrá ocasión de robar algo. Roban con suma ligereza y habilidad.

En las horas de calor, al mediodía, y en la siesta, la mayor parte de los indios se mecen en sus hamacas en dulce "farniente".

Su diversión son los animales del monte, que crían como compañeros y nunca los matan. Alegremente salta un mono entre la gente, otro está pegado al brazo de un muchacho. A primera vista, notándolos inseparables, uno recuerda el Alter higo, pero nada de eso hay entre los Chácobo. Fácilmente están dispuestos a vender sus animales preferidos. En la aldea de María y, Máro había, luego,

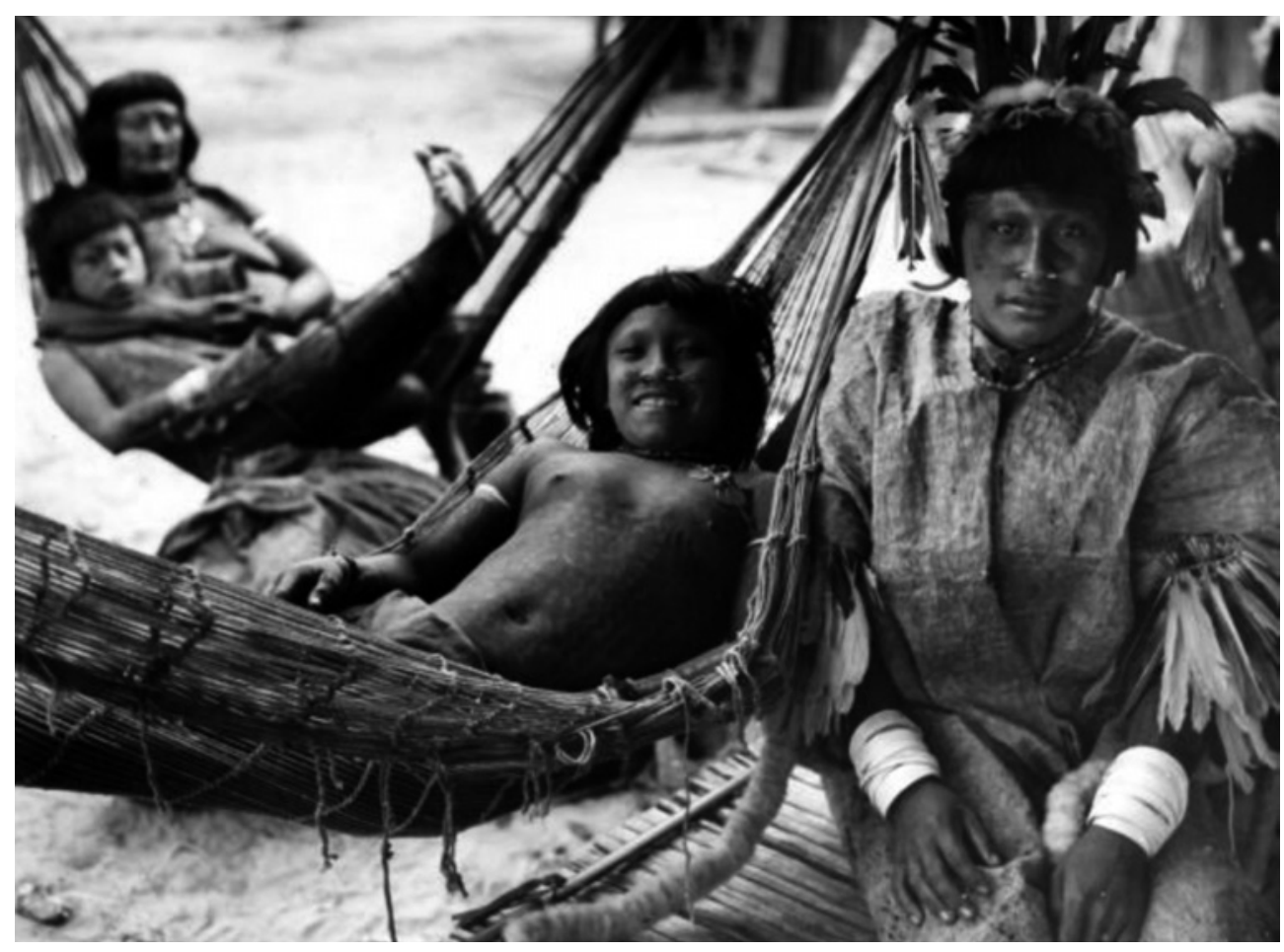

Fig. 14. Con el calor del medio día, todos descansan sin mayor preocupación, tendidos en sus hamacas. 
HAENKE, W. 1957. "Los indios Chácobos del río Benicito"

dos mutúna, un tucán y una especie de cuervo, ni faltaban los loros. En el núcleo solamente había, loros y parabas de todos los colores, bastante vistosos.

Los Chácobo, en estado salvaje, crían pocos animales domésticos; solamente tenían perros. La Muiría Bassi era dueña de un gallo, pero sin gallinas.

De tardecita volvió Maro con un montón de pescados, especialmente tucunaré. Todos entraron en seguida en actividad para preparar la nueva comida. Más tarde vino Cuya, que nada, trajo. No tuvo suerte, a pesar de que del techo cuelgan varios-cráneos de animales silvestres para atraer futuras piezas,

El resto del día se pasa comiendo, y luego todos duermen: bien con el estómago lleno. Ninguna preocupación estorba el sueño sano de aquellos seres en su feliz salvajismo,

\section{EL IDIOMA. CLASIFICACION}

El idioma Chácobo es una lengua del grupo Pano. El grupo-Pano, cómo entidad lingüística individualizada, fue establecido por Raoul de la Grasserie, en 1880 , y aceptado por los más: conocidos americanistas. Según Loukotka (3), el Pano es dividido en lenguas del norte y lenguas del este; a las últimas: pertenece el Karipuna y las dos lenguas bolivianas: Pacaguara y Chácobo,

Sin entrar aquí en comparaciones, discusiones y pormenores, doy el alfabeto de uso y los vocablos de 360 términos: que he podido reunir entre los Chácobo.

\section{1) El alfabeto}

\section{a) Las vocales}

a, clara y abierta.

$e$, nuestra e común.

é, ancha y abierta, como á en alemán.

ó, igual a la ö alemana, por ejemplo, en hören,

$i$, clava.

$y$, oscura...

$y$, oscura y nasal,

$o$, común.

0 , ancha, como en ó limo, en portugués.

u, común

\section{b) Las consonantes}

$a, d, t$, como en castellano

$s, o$, como ch, en castellano,

$f$, I, no se usan.

g, como en alemán,

$h$, bien aspirada, como en guarani, por ejemplo, hetá.

$j$, como en alemán.

$k$, como en alemán, $m, n$, como en castellano

$n n$, sonido duro, como por ejemplo, kenne en alemán.

$r$, como en Portugués

$r h$, en la garganta, muy aspirada

$s$, común, sonido de casa, en castellano.

a, suave, como en polonés, por ejemplo, Sosia,

$b$, más fuerte, como a oh, en alemán.

$a$, como $j$, en castellano

$z$, duro, como en alemán, por ejemplo, Zucher.

$z$, como en checo, por ejemplo,

\section{2) Palabras principales}

Signan los substantivos que denominan grados de parentesco, personas, partes 
del cuerpo y cosas do la naturaleza; luego los pronombres más importantes y los numerales.

\section{Sustantivos}

Grados de parentesco

Madre, kál,

Padre, papá (influencia castellana).

Abuela, caitá.

Hermanos, púi

Hermana, púi-mosko (la segunda parte refleja influencia castellana)

Hijo, hija, waky

Tío, kako

Tía, jajá

Entenado, dzóma

Sobrino, piáka

Cuñado, cái

Esposo, esposa, wuynne

\section{Personas \\ Hombre, xóni \\ Mujer, josa \\ Muchacho, rókawo \\ Muchacha, rótako \\ Niño de pecho, harirhóma-aki \\ Jefe, cacique, cáma \\ Médico, zekemyo-aina \\ Brujo, dzówoka \\ Amigo, compañero, rhábuki}

\section{Partes del cuerpo}

Cabeza, mápo

Cabello, bóo

Frente, cara, bomamá

Nariz, erokyni

Boca, lengua, hánna

Diente, rhyta

Mejilla, támo

Sien, iopamo

Oreja, páuki
Agujero en el lóbulo, páuki-kini

Agujero en el septum, rhúsakikinipystja

Ojo, börro

Cejas, wosko

Párpado, osrhakya

Mentón, köwy

Labios, Kawvei

Bigote, barba, köni

Cuello, této,

Nuca, tesro.

Hombro, pil.

Espalda, káte.

Espinazo, kasasrhán.

Hueso, rhán.

Pecho, sipati.

Senos de la mujer, rhóma,

Leche de la mujer, rhomahönne.

Brazo, pujámo.

Codo, wáspoto.

Mano, raokyne.

Dedo, muchi,

Muñeca, articulación, muorarhan

Vientre, hátuki.

Ombligo, nitro, nóroj,

Estómago, táka.

Corazón, hoitl.

Pulmones, nosaka-aina,

Sangra, himi.

Vena, arteria, pónno.

Piel, cuero, bich.

Nalgas, púiki.

Sexo de hombre, cola, hinna.

Sexo de la mujer, pieso.

Testículos, höwo.

Pierna, kisi.

Rodilla, rhapotó,

Tibia, rhasrarhán.

Pantorrilla, wúimisco

Tobillo, calcañar, hópoto.

Planta del pie, tainápata, 
Dedo del pie, houchi.

Uña, garra, mútysil

Carne, námi

Menstruación, owati

\section{Cosas de la naturaleza}

Sol, wári.

Estrella, wúistima.

Luna, ósre.

Luna creciente, zêkewunakátu

Luna llena, wúathóro.

Luna menguante, wukrshiáma,

Lima nueva, zémo.

Luna tapada, náipaj.

Eclipse de Luna, ôshropiakáina.

Estrella matutina, wúistimaúa.

Cometa, rhénipa,

Vía láctea, awárawái.

Cielo, nubes, relámpago, náipa.

Rocío, niwchi.

Agua, hönne.

Fuego, chlí

Tierra, mái

Río, áni

Lago, hönnepánoj

Laguna, ijáne

Selva, nil

Campo, rawáka

Piedra, maniköuté

Montaña, sierra, sánhro

Arroyo, páo

Viento, wyita

Lluvia, kóro

Trueno, terêáina

Día, wáriáni

Noche, medianoche, wákicha

Mediodía, warimatorôko

\section{Pronombres}

Yo, öa

Tú, mía
El, ella, ya

Nosotros, nowahymiwo

Vosotros, mató

Ellos, ya

Numerales

Uno, wustita

Dos, rhabota

Tres, rhabo-urti

Cuatro, wustima

Mucho, wustima

Poco, rhaborná

Nada, jáma

El primero, miapári

El último, chônno

\section{3) Vocabulario y observaciones}

El idioma Chácobo no es muy rico «en palabras. Ya se dijo que joshím joshin (a veces jushini) significa un ser maligno; pero la misma palabra se usa para designar el alma, espíritu, aire, sombra y también para viento fuerte.

La palabra "rhán" se usa para hueso y combinaciones con hueso, también para tortuga, mientras que el casco de la tortuga se llama "rbánrakáta".

Tales ejemplos se pueden multiplicar Por otro lado, oí nombres diferentes sobre la misma cosa en el núcleo y la aldea de María, Por ejemplo:

Rio Yata en núcleo Carua chava.

Fasi para ambos.

Río Benicito en el núcleo de Sóa.

La formación del substantivo con un pronombre posesivo y el plural son bien simples:

Mi hijo, nowaky (no mi y waky, hijo)

Mi hombro, nopii (no, mi y pii hombro)

Tu hijo, miwary (mi, tu y wary, hijo)

Mi casa, norhobo (no, mi y casa, rhobo)

Pero si se dice mío, es no-una

Una casa, wustita rhóbo (wustita, una y rhobo, casa) 
Muchas casas, wustima rhóbo (wustima, mucho y rhobo, casa)

Extraña es la forma de nuestras cosas, kariké norhóboky

Los sustantivos más interesantes, después de los ya mencionados, son los que denominan objetos, especialmente de uso del indio. Por ejemplo:

Arco, kánati.

Flecha, pía, pié.

Flecha con yunta de tacuara, kovöky.

Flecha con punta de chonta, páka.

Flecha con punta de clavos, bikobí.

Cinturón de mujer, josniwô.

Pedacitos blancos, kóma.

Pulsara, de semillas, kisi.

Cinta para al cabello del hombre, rhápo.

Canasto, kokéta.

Flauta de Pan, pistó.

Cedazo, toati.

Cesto de carga, kákano,

Canoa, nôty.

Remo, wúity.

Anillo de chonta, mokyráty.

Pulsera da bejuco, cimu.

Corona da plumas, cháa.

Cántaro, páyti.

Plato, pétoshte, piterti (según la forma)

Banquito, kénani.

Mortero, rhásrhö.

Mango, piedra de mortero, rhárho.

Cuchillo, mane.

Hacha, poróma,

Cuchara, usti.

Calabaza, rhatána.

Techo, márakati,

Puerta, ventana, kaiti

Huso, íwi

Bolsa de bibosi, sôta

Camisa de bibosi, nósanti

Bibosi, môro
Tinaja para agua, cómo

Adorno del septum, rhósoti

Adorno de las alas de nariz, rhépati

Adorno del lóbulo, ámouo

Hamaca, hisi

Animales

Tigre, gato, kamáuo

Perro, en el núcleo, ináka; aldea de Maúa, waúa.

Anta, ágwara.

Tejón, shisha.

Puerco montés, húnuo.

Marimono, iso,

Mono, shinnô, sinoshóke.

Paraba, kanna.

Paraba rojo, káini.

Pato, monuma,

Gallo, paterybônee.

Gallina, patjárê.

Mutúm, hasini.

Huevo, wáci,

Sucha, púiko.

Sapo, bursko.

Rana, knnapupuma.

Víbora, rúno.

Caimán, kápute.

Pescado, sanino

Raya, iwi

Palometa, máky

Tucunaré, umáka.

Mosca, rhábina.

Mosquito, wii

Hormiga, klíma.

Abeja, wáta.

Avispa, wina.

\section{Plantas}

Maíz, rhuki.

Mandioca, átra. 
HAENKE, W. 1957. "Los indios Chácobos del río Benicito"

Banana, karapúi.

Banana chica, piha.

Papaya, mapájo.

Pasto, wási,

Semilla, auwnêro.

Raíz, hautapún.

Flor, hamhôa.

Fruta, bimi.

Hoja, noipyi.

Madera, káro, kárku.

Urucú, mas'rho.

Ceniza, mis'pu

Algodón, wuásmune

Chorlo, shrhöky.

\section{Substantivos con adjetivos y adverbios}

Mujer, linda, josahía

Feo, joí

Casa vieja, rhóbo josi

Joven, wakybuna

Chico, pistja

Flaco, oo'jo

Con fiebre, ikini

Alto, nyámma

Sano, vivo, rhunna

Blanco, hosrho

Colorado, shinni

Amarillo, wariwo

Malo, káshra

Caliente, ichisa

Desnudo, zowôkónimia

Lindo, hiéhrsni

Viejo, josi

Nuevo, pásra

Casa nueva, rhóbo pásra

Grande, caitarhsni

Ordo, srni

Enfermo, ikikía

Bajo, zánma máxy

Flojo, cykisni
Negro, chöky

Verde, azul, njáwa

Marrón, rhaitychöky

Bueno, sinnahía

Frío, mári

\section{Adverbios:}

Hoy, uéjaky; igual ayer y anteayer

Mañana, uéanno

Cerca, páune

Fuera, kachakatá

Encima de la casa, rhóbomáuaka

Si, hóy

Nunca, jáma

Aquí, neánno

Lejos, ljáma

Encina, máuaka

No, ajamakía

Temprano, wari-ánimo

Verbos, frases, preguntas:

¡Buenos días! ¿Cómo va?, wuosaá, hunimanimia?

¡Hasta luego! Ya no vuelvo, kakiá", hojamachikia

Ha muerto, resoá

Se entierra, maina-ana

Llorar por el muerto, arajia

ivenga!, nö!

Yo paseo (camino), kazykía

Voy a volver, harikaria

Tengo hambre, pashnakía

Quiero tomar agua, hönne akashkia

Quiero tomar chicha, igual (hönne chica)

Dormir, oshraquía

Danzar, pausokía

Cantar, naúarikía

Hacer fiesta, hianakía

Yo me caso, josrabikia (dice el hombre)

Yo me caso, aúwini (dice la mujer)

Soy cochino, kashrhakia-hato

Soy Chácobo, öa chakobo 
Yo hablo Chácobo, channi anakía

Yo hablo castellano, channiana,

húmiraka eshni

Va a morir, náziki

Voy a cortar leña, karo-aikakía

Yo te quiero, minokykía

Yo no te quiero, kajamákia

La lluvia para, anakáke-ué

Llovió fuerte, húnirani-ué

¡ven conmigo!, neahorsúa

Voy contigo, miwutakakía

ivamos juntos!, kátyro hakino

Estoy sola, hámorshrhéa

Se pelean, miniana-aá

Yo lavo ropa, múpakakia raiti

Yo lavo mi casa, múp-akakia bómana

Yo tomo baño, ashikakia

¡Qué mentira!, kiakimía

¡Sabes nadar!, nonoái

No sé, kájamakia

El roba, joúmaki

Yo no robo, joúmajamakía

Asar, chií hauana (de chaúa), imaua (en el núcleo)

Cocinar, hervir, wöteána

Cazar, kokotá

Pescar sanni-atá

Llevar, botá

Acabó, köjáki

Sentarse, saoá

¡Siéntate!, saopáredjöwa!

¡Levántate!, hóydjöwa!

Esta bien, hônima

Subir, inaua

Cortar, miakusáky

Me duele la herida, isini miaháka

No sirve, ánoma

Siempre hago veneno, jônokokía rêati

Este sinvergüenza murió envenenado, kaijamárikin ewarshna réato-aitak
Mañana voy a coser, néaki

kushnarshnarikia

El hochi es para comer, zákaka pihuá

Ahora estoy comiendo, hawaké pikia

Tarde voy a comer, jata piashkía

Ya comí, pikia

No quiero comer, pikashjamashkiai

Como poco, pista pikashkía

¡Ya comiste!, piá?

Este comilón come todo, hünyrapiarshni hatyro-apiá

¡Qué dice el trabajador!, haúni nimia chkisjama?

¡Para qué sirve!, hauni-nina?

¿Por qué hora?, húna arshmiarane?

¿Cuántos hijos tienen?, haute chini miwaky?

¿Dónde está?, myrakía?

¿De dónde viene?, haúni hoaj?

¿A dónde va?, haúini jaê?

¿Cómo te llamas?, hauni hauháne?

Me llamo Foé, haúni toháne Foé

¿Cuándo llegó?, húmina chemicholtá

Hace mucho tiempo, náma chemichoitá 


\section{Conclusión: el porvenir de la tribu}

Una tribu de 80 almas no puede durar mucho tiempo si entra en contacto con gente de fuera. El proceso de la mestización ya ha empezado. Los hijos y nietos de Mama Fóe son mestizos. Tales casos se aumentarán con la civilización de la tribu, que, por lo tanto, se disuelve como tal. En cien años no habrá más Chácobos, puros; habrá mestizos con algo de sangre Chácobo. Su cultura antigua, y por fin su idioma, desaparecerán, conservándose sus recuerdos únicamente en museos y libros científicos.

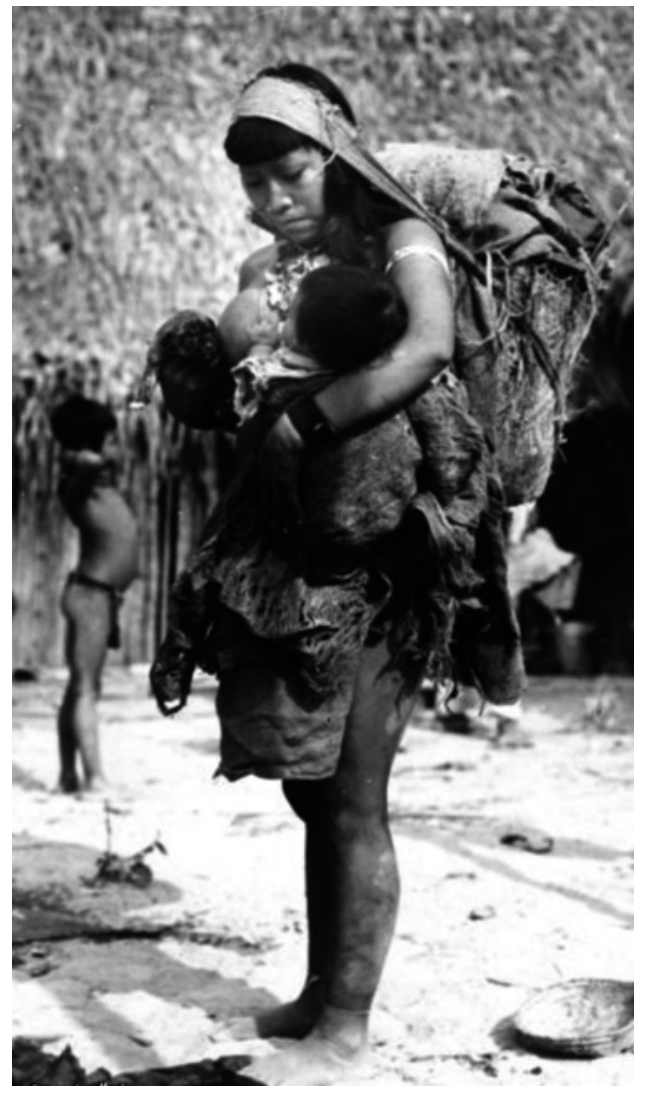

Fig. 15. Una tribu con escasa población tiene un futuro muy incierto.

\section{BIBLIOGRAFÍA}

BAUMANN: Das Tir als Alter Edo imn Afrika, Paidenma, H. 4 B. V. Bamberg. Juni 1952.

CARDUS, FR. José: Las misiones franciscanas entre los infieles de BoliviaBarcelona, 1886.

CRÉQUI MONTFORT, G y RIVET, P.: Linguistique Bilivienne. Les dialectis Pano de Bolivia, Museon Louvain. XIV, 1913.

GRASSERIE, R. DE LA: De la Famille linguistique Pano. Paris, 1889.

HANKE, WANDA; O idioma Karipuna. Documentacâo do Amazonas. Manáus-1951.

HESTERMANN, F.: Die Pano-Sprachen und ihre Beziehunge. XVI Congr.

Int. de Amer. Viena, 1908

Die Schreibweise der PanoVocabularien. "Journ. de la Soc. des Amer”, de Paris. XI, 1914-1919.

KRICKEBERG, WALTER: Etnología de América. México, 1946. Pág. 1993-195.

NORDENSKIÖLD, ERLAND: Indianer und Weirse in Nodostbolivien, Stuttgart, 1933.

RAMOS, ARTHUR: Introducao á Antropología Brasileira, o volumen, 1, série B. As Culturas Náo Europeias. Río de Janeiro, 1943.

RIVET, PAUL: Sur Queques dialects Pano peu comuns. "Journ. de la Soc. des Amer", de Paris N.S. VII, 1910. Pág. 278. 


\section{CAPITULO 3}

\section{COSTUMBRES, HABILIDADES $Y$ CUADRO DE VIDA DE LOS CHÁCOBO MARIAN D. PROST, 1970}

ESTE ES EL TRABAJO ORIGINAL QUE FUE ELABORADO PARA SER PUBLICADO EN BOLIVIA, PERO NUNCA SALIÓ A LA LUZ 
Marian D. Prost, 1970. Costumbres, habilidades y cuadro de vida de los Chácobo

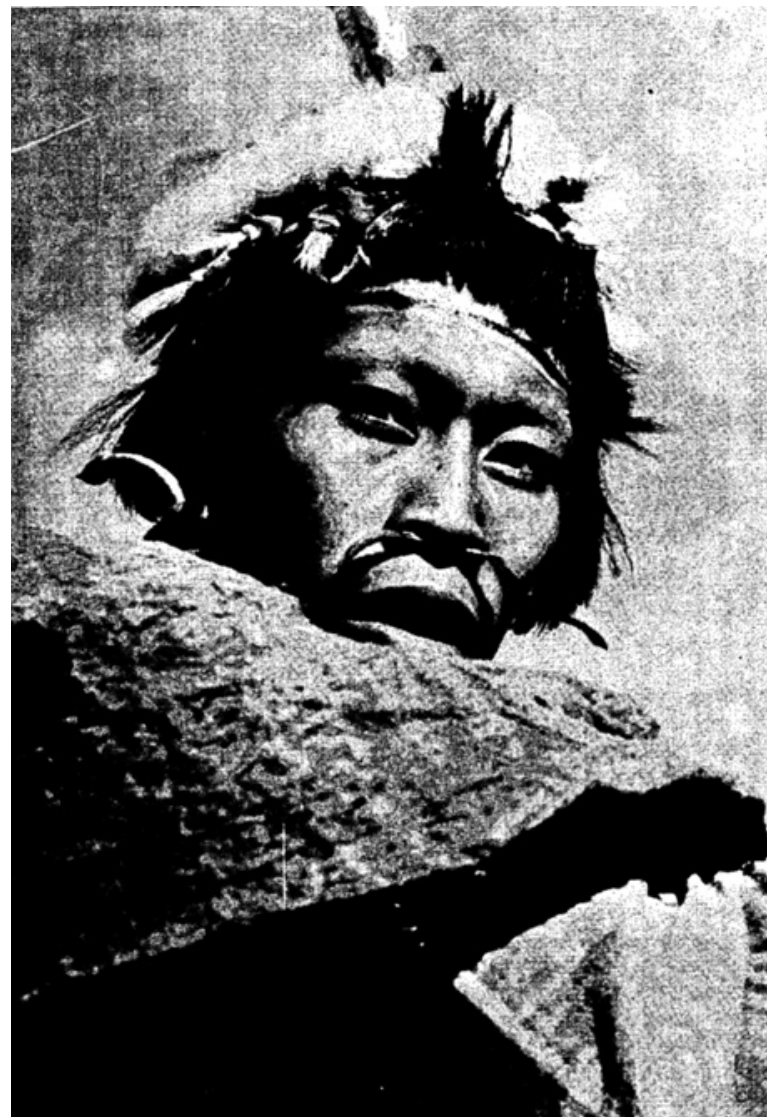

Fig. 1. Hombre Chácobos vestido de manera tradicional

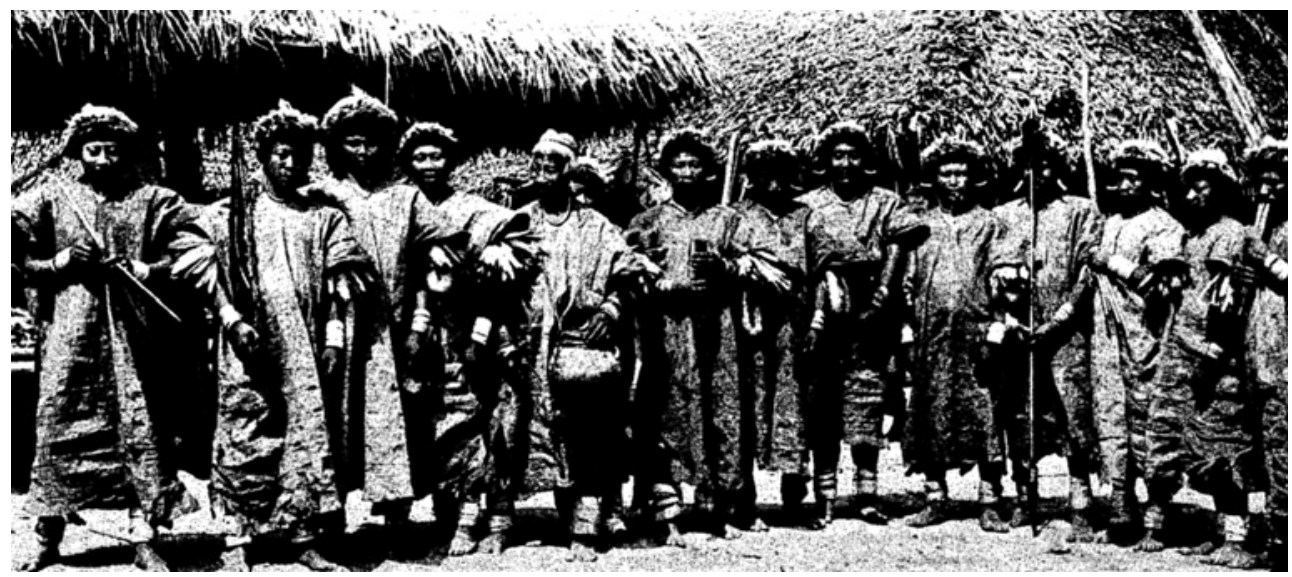

Fig. 2. Grupo de Chácobos en traje de fiesta. Se puede apreciar sus vestidos de corteza, flautas, arcos y flechas. 


\section{INTRODUCCIÓN}

Los Chácobos (Panoan) forman un pequeño grupo, aproximadamente 180 personas, que ahora habitan en la extensión comprendida entre los ríos Yata e Ivón en el departamento del Beni, Bolivia.

Estos datos fueron recogidos bajo el auspicio del Instituto Lingüístico de Verano durante varios viajes a una de las aldeas principales ubicada en el Río Benicito, desde agosto de 1955 hasta agosto de 1964.

Hay actualmente cuatro grupos principales con 45 personas aproximadamente en cada grupo.

En el año 1955 había tres grupos de los Chácobos viviendo por el Río Benicito. En el año 1956, los Chácobos que vivían cerca de Puerto Limones se trasladaron al Río Ivón bajo la guía del gobierno, el cual había formado un núcleo indígena. Otro grupo que vivía más lejos por el Río Benicito cerca de Caimanes, se trasladó varias veces durante los siguientes diez años, por lo general cerca del Río Benicito, pero una vez fueron hasta el Río Geneshuaya. Nosotros vivíamos con un tercer grupo, el cual se quedó diez años en un solo lugar, un poco arriba del Puerto Limones.

Entre los hombres de este grupo fue aumentando el interés para recolectar la goma y empezaron a planear para trasladarse a otra parte. En el año 1964 nosotros quisimos reunir estos tres grupos para ayudarles en un programa social y al mismo tiempo económico. Guiamos a este grupo hasta el Río Ivón, estableciéndolo más o menos a dos horas y media río abajo a pie desde el Núcleo, hasta el Alto Ivón, y entonces en el año 1965 el tercer grupo también se trasladó hasta el Río Ivón, estableciéndose más o menos a dos horas y media río arriba a pie desde el Núcleo, y eligieron el nombre de California para este lugar. 
Marian D. Prost, 1970. Costumbres, habilidades y cuadro de vida de los Chácobo

\section{COSTUMBRES DE LOS Chácobo}

El cuarto grupo permanece todavía en el Río Yata, cuatro horas en lancha a motor desde el Campo Palmar. La única vez que los cuatro grupos se reunieron fue con ocasión de una fiesta en la aldea del Benicito donde nosotros radicamos. Nunca más hasta ahora se han juntado con ese otro cuarto grupo.

Para mayor información leer el apéndice.

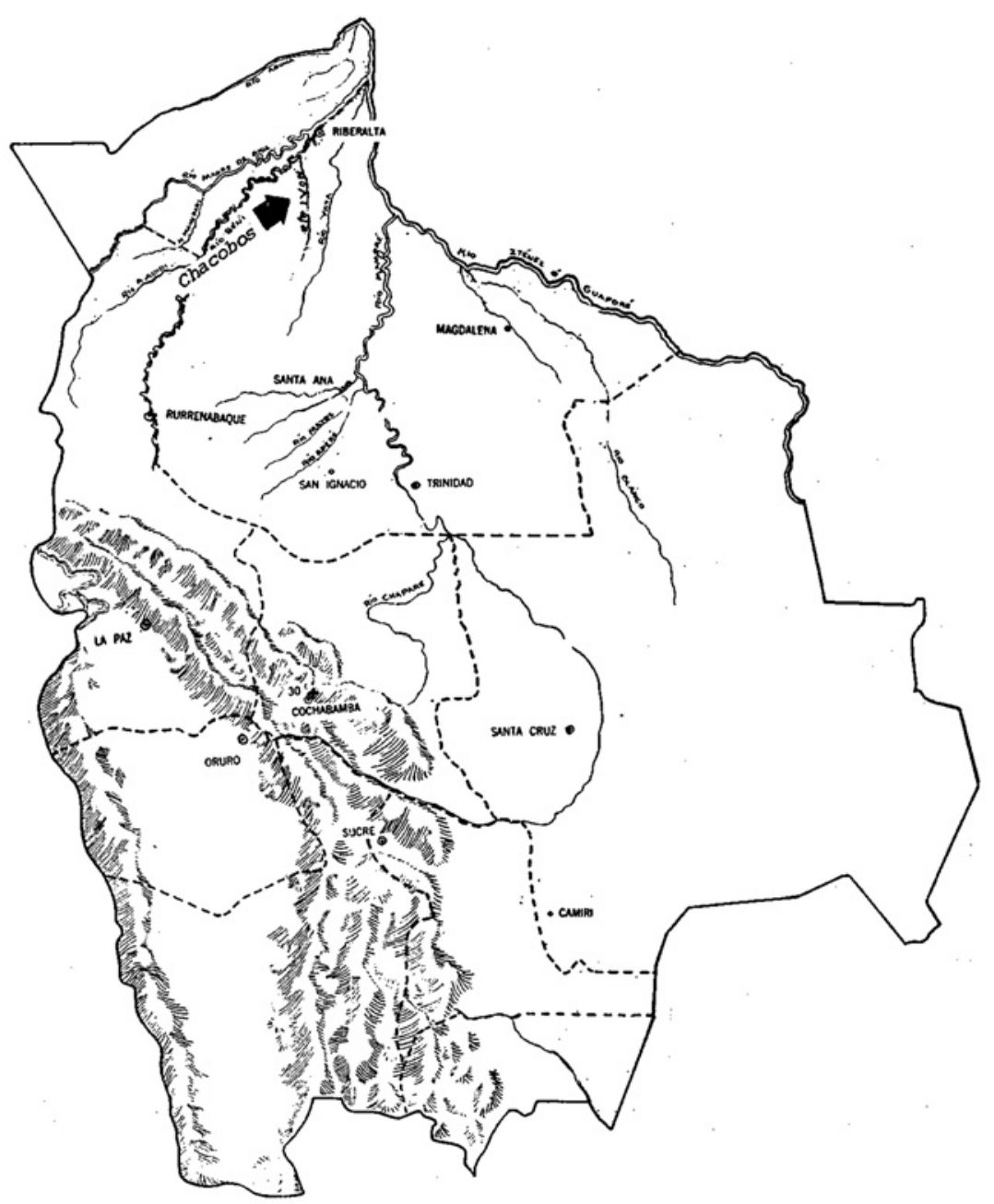

Mapa donde se muestra el territorio Chácobo. 


\section{INDICE}

1. Aldeas y Viviendas de los Chácobos 52

2. Mobiliario $\quad 54$

3. Artefactos: $\quad 56$

Cestería 56

Alfarería $\quad 57$

Armería 58

Taburetes $\quad 59$

Flauta primitiva $\quad 60$

Tintas 60

Trabajos manuales en madera $\quad 60$

Tela de corteza $\quad 60$

Canoas de corteza $\quad 61$

Hilandería 61

4. Vestidos y adornos 63

5. Víveres 68

6. Alimentación: $\quad 71$

Preparación y conservación de los alimentos $\quad 71$

La Fiesta 74

7. Cuadro de la vida humana $\quad 80$

Preñez $\quad 80$

Alumbramiento $\quad 80$

El nombre $\quad 81$

Pubertad $\quad 82$

Matrimonio 83

La Ancianidad $\quad 85$

Enfermedades y Medicinas $\quad 85$

Muerte y Sepelio $\quad 88$

8. Apéndice $\quad 90$

Bibliografía $\quad 92$ 


\section{Aldeas y viviendas}

Los rancheríos o pequeñas aldeas están ubicados en la selva tropical, por lo general a media hora de camino desde la orilla de un río, hacia el interior. Existen aldeas que están situadas en la orilla del Río Ivón, pero estas mismas están demasiado alejadas del tráfico de la gente blanca. Si no está ubicada en la orilla de un río. se halla siempre al lado de algún arroyo. Las aldeas se componen de tres hasta cinco casas, situadas en un claro y no obedecen a regla alguna en su planificación. A veces hay un local especial, para reuniones de hombres, aunque por lo general lo hacen en una casa particular que ha sido construida con una dimensión especial para, este propósito. A veces sucede que una o dos familias viven alejadas de las demás, a distancia de quince a veinte minutos de recorrido a pie.

Las casas de los Chácobos son de forma rectangular, generalmente de más o menos 5 por 9 metros, con techo de palmera. Dos horcones altos sostienen el larguero que descansa sin amarrarse sobre el extremo superior bifurcado. Más o menos a dos metros de los tirantes a los extremos de la casa y paralela con los tirantes, una viga adicional se extiende a todo lo ancho de la casa. Esta viga adicional descansa en los extremos bifurcados de los horcones plantados a unos dos metros de cada lado de la casa, y se amarra con una guía vegetal, o bejuco, al horcón alto, el cual sostiene al larguero. Para sostener al armazón del techo se ponen vigas largas que descansan sobre los cuatro tirantes

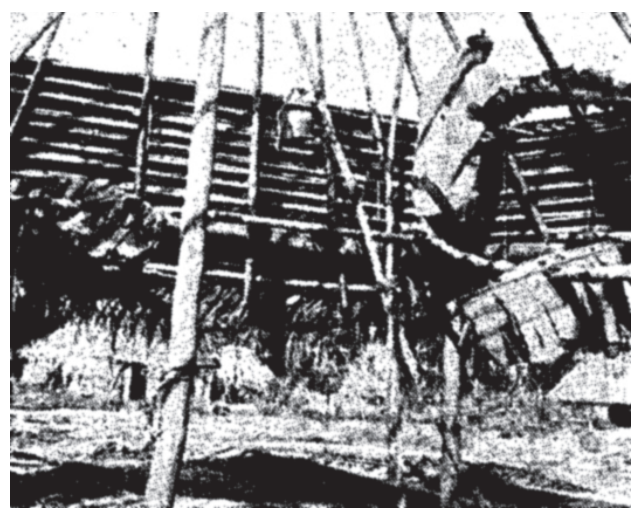

Fig. 3. Casa en construcción

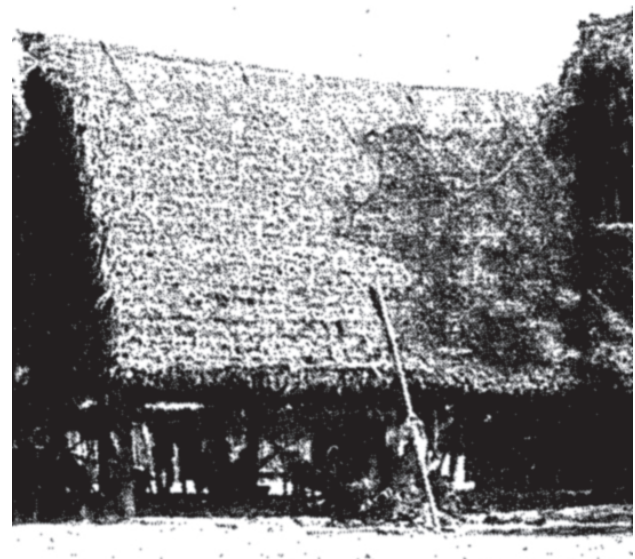

Fig. 4. Casa sin paredes

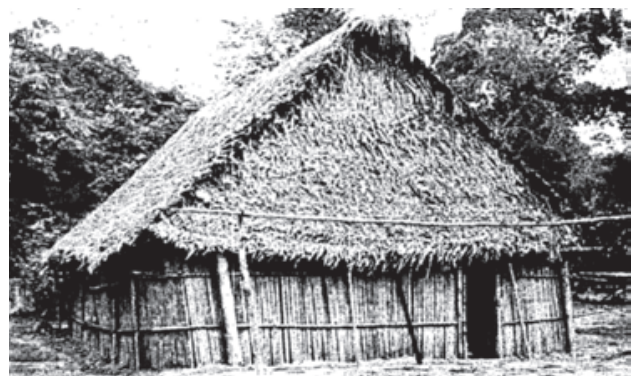

Fig. 5. Algunas casas tienen paredes de corteza 
a los cuales se los amarra lo mismo que a los postes de las esquinas. A veces se plantan más horcones para sostener las vigas.

Las tijeras se colocan a distancia de más o menos 60 centímetros una de la otra y los pares de tijeras se hallan divididos de tal manera que puedan engancharse una con la otra encima del larguero y ser atadas con bejuco. Estas descansan encima del larguero. El techo está hecho de dos clases de hoja de palmera motacucillo, y del patujú que es una hoja ancha parecida a la hoja de plátano. Estas se amarran con guía de bejuco, y de igual manera a las vigas.

Algunas casas carecen de paredes; otras tienen paredes de corteza, y por lo general de mala construcción. Los postes no son de igual altura ni bien verticales, de ahí que el larguero horizontal no queda muy nivelado.

Por lo general sólo reparan los techos si hay urgencia inmediata, par ejemplo, durante una tormenta.

Cada hombre construye su propia vivienda. Si pide ayuda a otro, éste queda comprometido a retribuir idéntico servicio. Las mujeres ayudan en la construcción amarrando las dos clases de hojas, y también los niños, pasando las hojas amarradas a los hombres que las aseguran en las viguetas.

En la construcción de la casa destinada a reunión de varones, toma parte toda la comunidad. Todos los hombres salen juntos a conseguir los materiales necesarios y luego entre todos hacen la construcción.

De igual manera, las mujeres de la comunidad trabajan juntas, amarrando las hojas, en un ambiente de cordialidad y alegría. Últimamente los hombres de nuestra aldea construyeron un local de reunión, dedicado a las reuniones para hombres, en forma octagonal. Es la primera casa fuera de lo común que hemos visto entre los Chácobos.

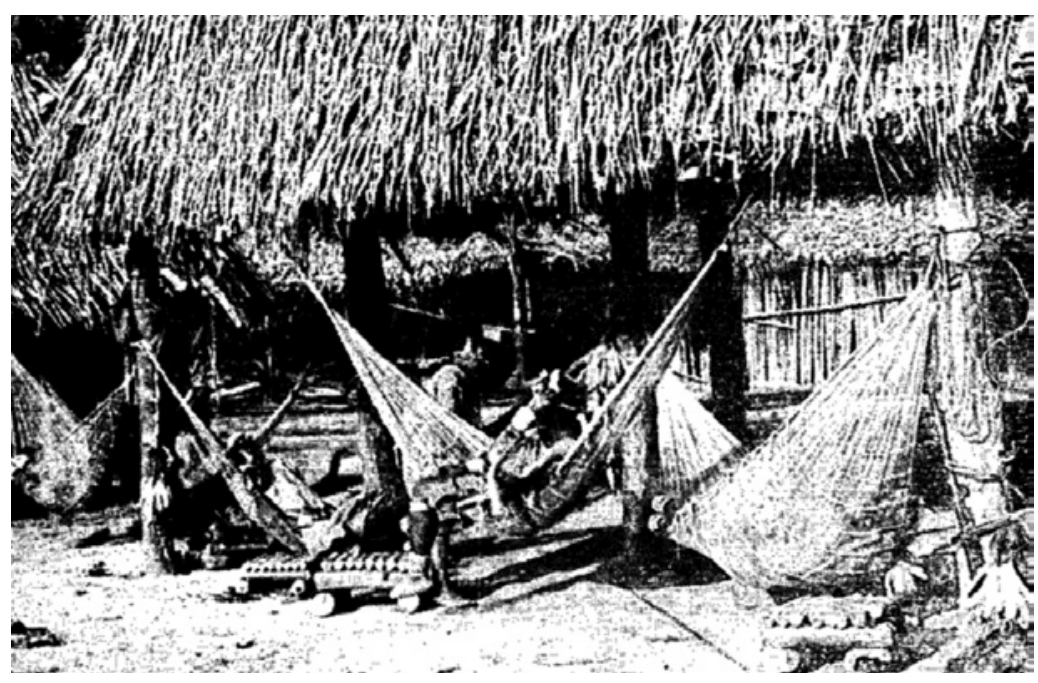

Fig. 6. Entre los enseres de la casa, lo principal es la hamaca 


\section{Mobiliario}

Entre los enseres de casa, la cosa principal es la hamaca. Cada adulto dispone de su hamaca y algunos de los hijos mayores la tienen de tamaño menor. Las camas son hechas de la corteza partida de la palmera pachuba, que se la tiende ya sea sobre el suelo o sobre una plataforma formada por cuatro postes verticales con dos travesaños sobre los cuales está colocada la pachuba. Un vestido viejo confeccionado de corteza o una estera grande, generalmente se pone encima de la plataforma a modo de colchón. Se cuelga un mosquitero encima de la cama. Toda la familia puede dormir en esta cama si no cuentan con otros mosquiteros. Cuando no hay mosquitos, todos duermen en su propia hamaca. Algunos Chácobos tienen frazadas.

Cada mujer tiene un fogón de su propiedad. El fuego queda debajo de una mesa rústica, "chapapa", de palos frescos con una altura de unos
30 centímetros del suelo. Siempre hay fuego ardiendo bajo esta chapapa; haya o no carne sobre ella. El fogón sirve para tostar la harina de yuca, como también para cocer sopas o estofados. A una altura conveniente del fogón, hay un estante para guardar víveres, tales como plátanos, pescado ahumado, carne, y cualquier otra cosa que debe mantenerse seca.

Las enormes ollas de barro en que se prepara y se guarda el refresco hecho a base de yuca o maíz, se hallan guardadas dentro de la casa y cerca del fogón.

Algunas casas tienen un lugar especial para preparar las comidas, pero el fogón está siempre en la casa principal. Esto significa que todo lo relacionado con las comidas, como machacar, moler la yuca, y su manipuleo, y preparar bebidas, etc., se ejecuta en ese lugar que sirve de cocina, pero su cocimiento se hace en el fogón.

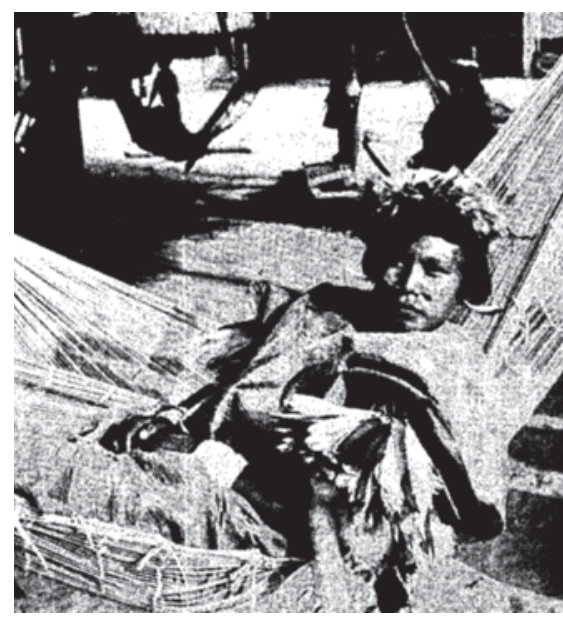

Fig. 7. Cada adulto tiene su propia hamaca

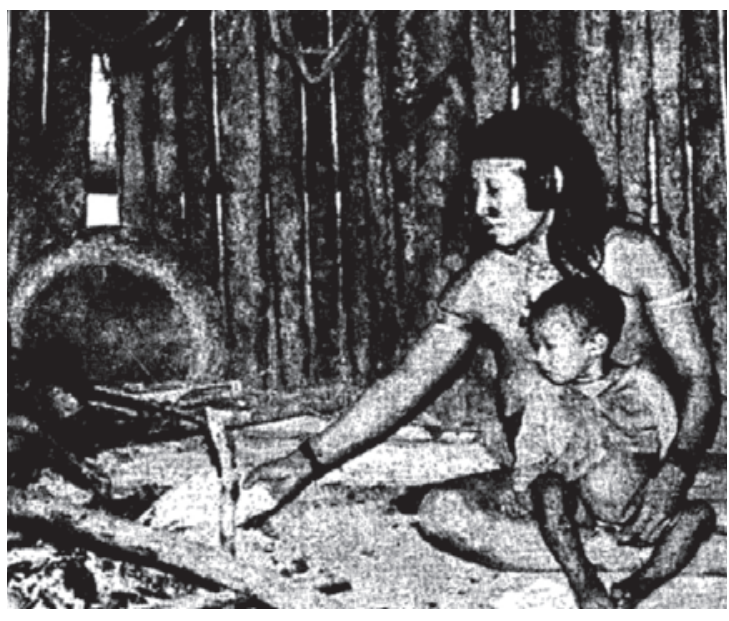

Fig. 8. El fogón bajo la chapapa 
Marian D. Prost, 1970. Costumbres, habilidades y cuadro de vida de los Chácobo

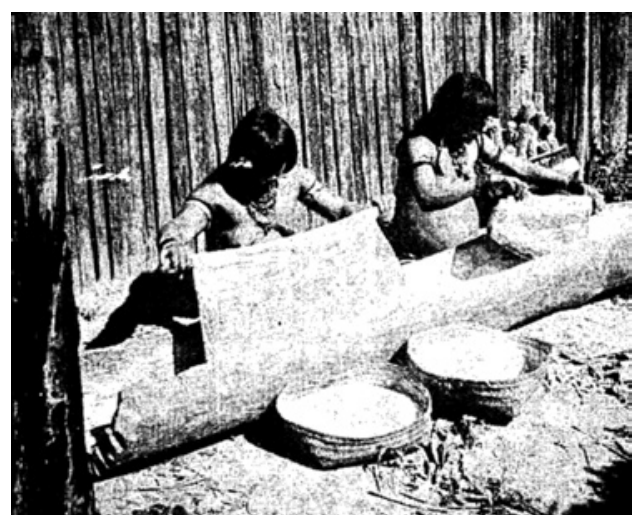

Fig. 9. La batea es de tamaño suficiente para que dos o tres mujeres puedan moler simultáneamente.

La batea consiste en un tronco ahuecado o cavado de unos 3 a 6 metros de largo, sostenida y amarrada de ambos extremos a dos postes verticales, con gruesos bejucos, quedando a la altura de la cintura, más o menos a un metro. Dentro se guarda "la mano" de la batea. Esta es una pieza de madera pesada de unos 60 a $80 \mathrm{~cm}$. de largo, por $40 \mathrm{~cm}$. de alto, con agarradores hechos en la misma madera a los dos extremos. La batea es de tamaño suficiente para que dos o tres mujeres puedan moler simultáneamente. También he visto la batea colocada en el suelo, y a la mujer sentada en el suelo para poder trabajar. A veces sientan a su hijito dentro de la batea mientras muelen. Por lo general se encuentra la batea en uno de los costados exteriores más largo de la casa.

Algunas casas tienen altillos, o plataformas grandes, hechas de corteza partida de la palmera pachuba, colocadas sobre los tirantes de la casa. Este depósito es para almacenar maíz reservado para la siembra, jocos, rollos de corteza, etc.

En los interiores de la casa cuelgan

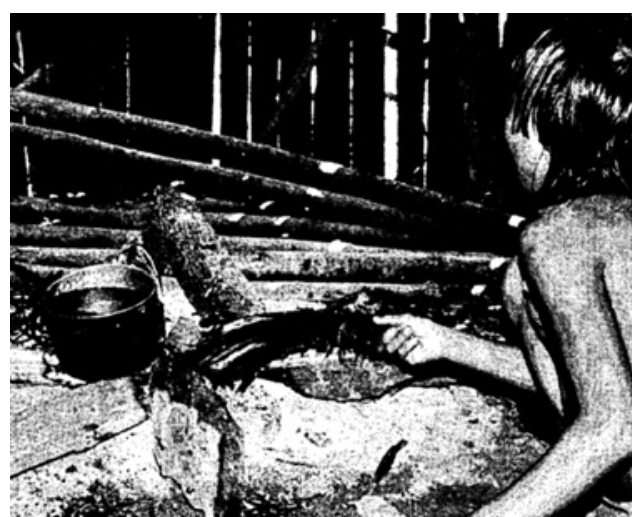

Fig. 10. Los chácobos usan sopladores para el fuego.

canastos, flojamente tejidos, tutumas, cajones, y bolsas para guardar cualquier cosa. Las bolsas en las cuales se guarda la harina de yuca, se las amarra a los postes de la casa al alcance de cualquiera que de paso desee servirse un puñado.

En cada casa hay por lo menos un par de asientos para los hombres. Los hombres también destinan un lugar especial para poner su arco y flechas. Los cuchillos y flechas de repuesto se ensartan entre las hojas del techo.

Para colgar los vestidos de corteza, mosquiteros, frazadas y ropa vieja, los lanzan al azar hacia las vigas de la casa. Cuando caen al suelo, se los recoge rápidamente para lanzarlos otra vez hacia arriba.

Cerca del fogón, o dentro de la cocina guardan los sopladores para el fuego, un colador cuadrado tejido en forma cruzada y los ralladores hechos de la raíz espinuda de la pachuba. Cada familia tiene una choza aparte en la cual guardan la leña y alfarería.

Una escoba bastante práctica, la hacen de la palmera assaí. 


\section{Artefactos}

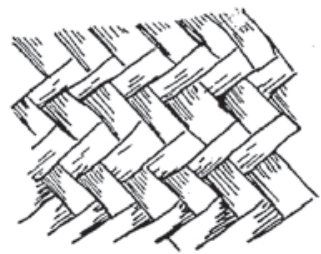

Fig. 11. Tipo de tejido para canastos.

\section{Cestería}

Los canastos hechos por las mujeres, son muy importantes entre los enseres de la casa. Los hombres hacen un solo tipo de canastos, que es flojamente tejido e improvisadamente hecho en el monte para acarrear pescado o frutas a la casa. Las mujeres también saben improvisar en el monte un canasto de forma cónica, hecho de una sola palma, en el cual llevan bayas silvestres. En la casa fabrican otros canastos de mejor clase. El canasto más grande que hacen las mujeres chacobas, es el rectangular, para acarrear, y tiene la boca un poco más ancha que la base.

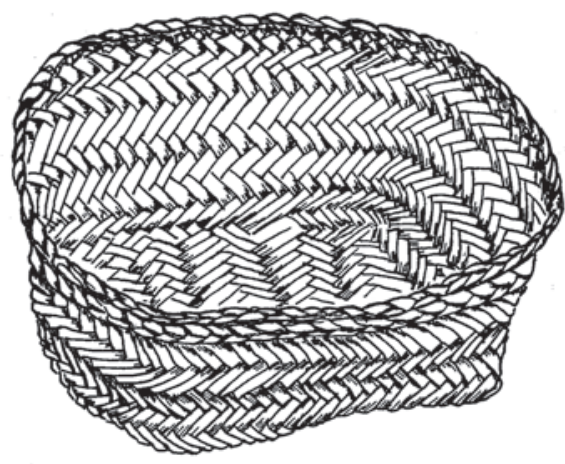

Fig. 12. Canasto rectangular.
Este canasto de acarreo tiene un armazón de bejuco grueso que se llama caca-tao. El fondo y los costados son hechos de un entretejido cruzado, de hebras de la corteza del árbol, cabeza de mono. Una faja de corteza está fijada al canasto para llevarlo. Se coloca en la frente y el canasto descansa sobre la espalda. En dicho canasto llevan cargas pesadas de leña, yuca, maíz y hasta niños.

Otro canasto muy corriente entre ellos es uno muy bien hecho de forma circular y de tejido cruzado, tipo charola. Este tipo de canasto se hace de diversos tamaños, y por eso sirve para muchos

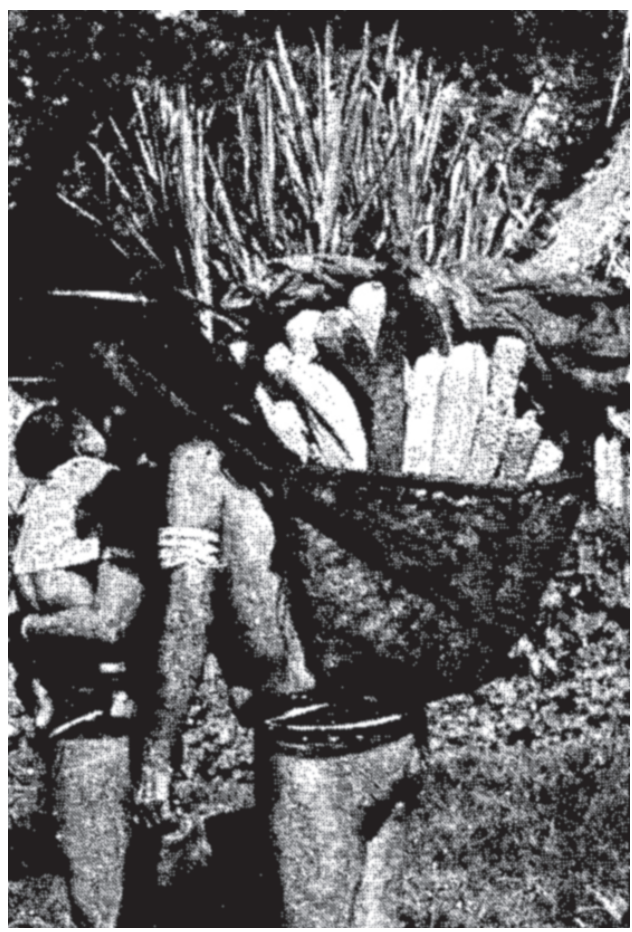

Fig. 13. Canasto de acarreo. 
Marian D. Prost, 1970. Costumbres, habilidades y cuadro de vida de los Chácobo

usos. Los más grandes, de unos 50 $\mathrm{cm}$. o más de diámetro, lo usan para almacenar algodón, harina u otros alimentos secos. Los más pequeños los utilizan como bandejas o platos para las comidas secas. Muchas veces los niños andan con un canastito de estos que contiene harina de yuca tostada para comer durante el día. La misma clase de canasto pero más hondo y con tapa de

\section{Alfarería}

Las mujeres hacen toda la alfarería, utilizando el método de enrollamiento. Para atemperar la arcilla, se le añade ceniza finamente molida y cernida, de una cierta corteza. Entonces la arcilla se amasa bien, aumentándole agua de a poco hasta lograr la consistencia adecuada. Después forman una base plana, y en seguida enrollan tiras de barro alrededor de la base y cada rosca la amoldan y suavizan a mano o con tutuma. Después, la ponen a secar al sol por varios días, y la someten a fuego abierto.

Los distintos objetos de alfarería que elaboran son: las tinajas con boca angosta, tiestos planos, ollas grandes y pequeñas de la misma forma; platos y escudillas para sopa u otros alimentos líquidos. Únicamente las tinajas se barnizan. No se decora ni se pinta pieza alguna de alfarería, y todas tienen forma rudimentaria. La alfarería se guarda en choza aparte. igual profundidad como el canasto, lo emplean para guardar cosas de mayor valor, como hilos, plumas, tijeras y telas.

Otras cosas tejidas son las esteras grandes que usan para camas (en que duermen en el suelo), coladores cuadrados y sopladores de fuego. También hay canastos flojamente tejidos destinados a guardar bagatelas. Estos se cuelgan en cualquier parte de la casa.

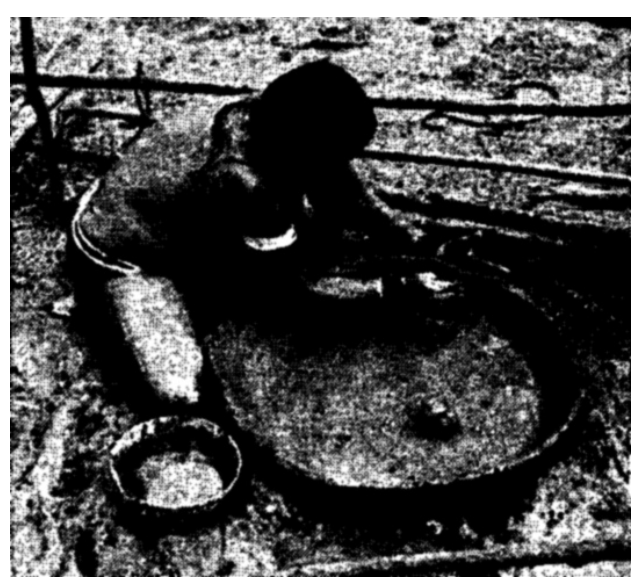

Fig. 14. Una Chácoba haciendo tiestos planos.

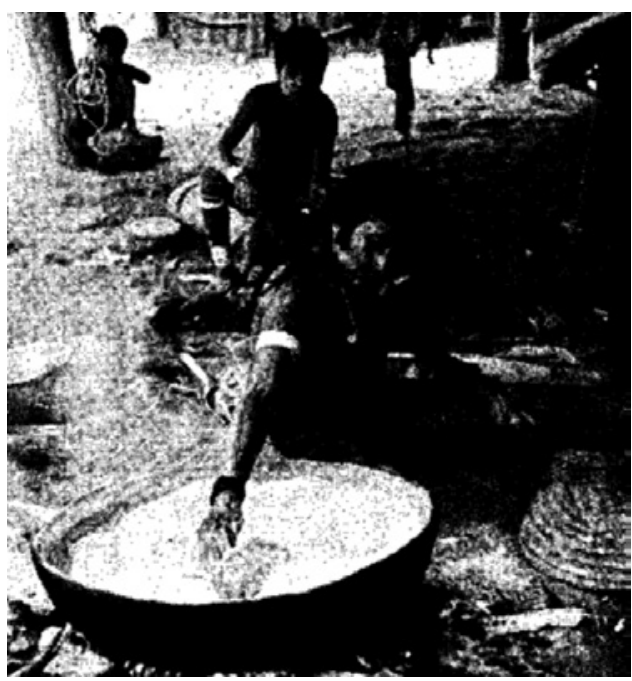

Fig 15. Tostando harina de yuca. 


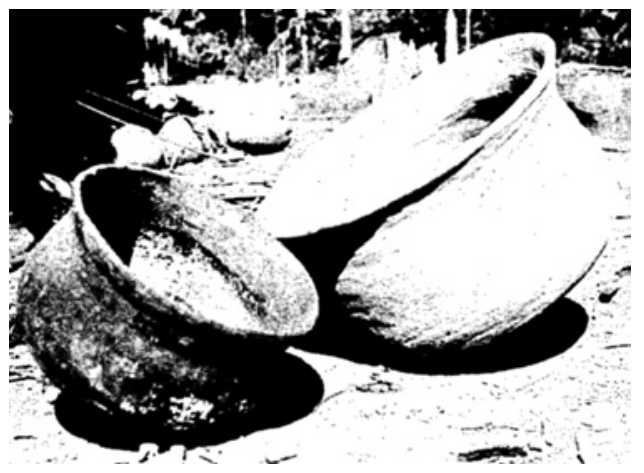

Fig. 16 Los Chácobos fabrican cerámica para uso doméstico. La variedad es pobre: componen recipientes de agua, ollas y fuentes de forma muy peculiar.

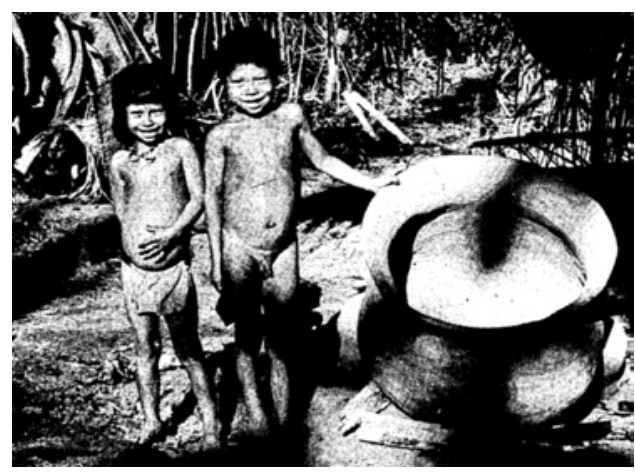

Fig. 17. Algunas de las ollas son gigantes, porque son para uso comunal.

\section{Armería}

El arco y flechas son las únicas armas fabricadas por los hombres Chácobos. El arco lo fabrican de madera dura de la palmera chonta; carece de adornos y lo suavizan con la quijada del chancho del monte, o a veces con cuchillo. También, las cuerdas del arco, las fabrican los hombres, de fibras de corteza. La cuerda se asegura al arco por puntas bifurcadas en sus extremos.

Las flechas las hacen de una especie de caña hueca llamada chuchío, y tienen desde 175 hasta $185 \mathrm{~cm}$. de largo. Las flechas para pescar, no tienen plumas, y la punta casi siempre consiste en un clavo grande bien afilado. Antes no era posible conseguir clavos y usaban huesos de mono. La punta de la flecha para cazar grandes aves y monos la fabrican de madera de chonta, y lleva cinco púas en cada lado. La destinada a aves pequeñas tiene púas en un solo lado. La punta de flecha más usada, se hace de una clase de caña hueca que se llama tacuara. Tiene forma de lanza, y se usa para cazar pécari, jaguar* y otras piezas grandes. No tiene púas, por lo cual se la puede extraer fácilmente del animal y entonces puede servir de nuevo.

Usan también otras dos clases de puntas de flecha: una es para cierta clase de peces y tiene cuatro puntas bifurcadas en el extremo, la otra es más usada por los muchachos para cazar pájaros, la cual en vez de punta tiene una bola de madera. Cada hombre fabrica su propio equipo de caza. Los padres hacen el arco y flechas para sus hijos menores. Los muchachos comienzan a fabricar su propio equipo desde más o menos 13 años arriba.

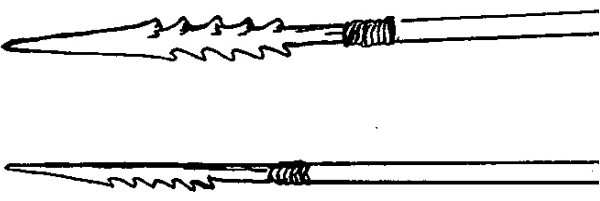

Fig. 18. Detalle de la puntas de lanzas para pescar. 
Fig. 19. (a). Las flechas las hacen de una especie de caña hueca llamada chuchío, y tienen desde 175 hasta $185 \mathrm{~cm}$. de largo.

Fig. 19. (b).Cada hombre fabrica su propio equipo de caza, comenzando desde 13 años..

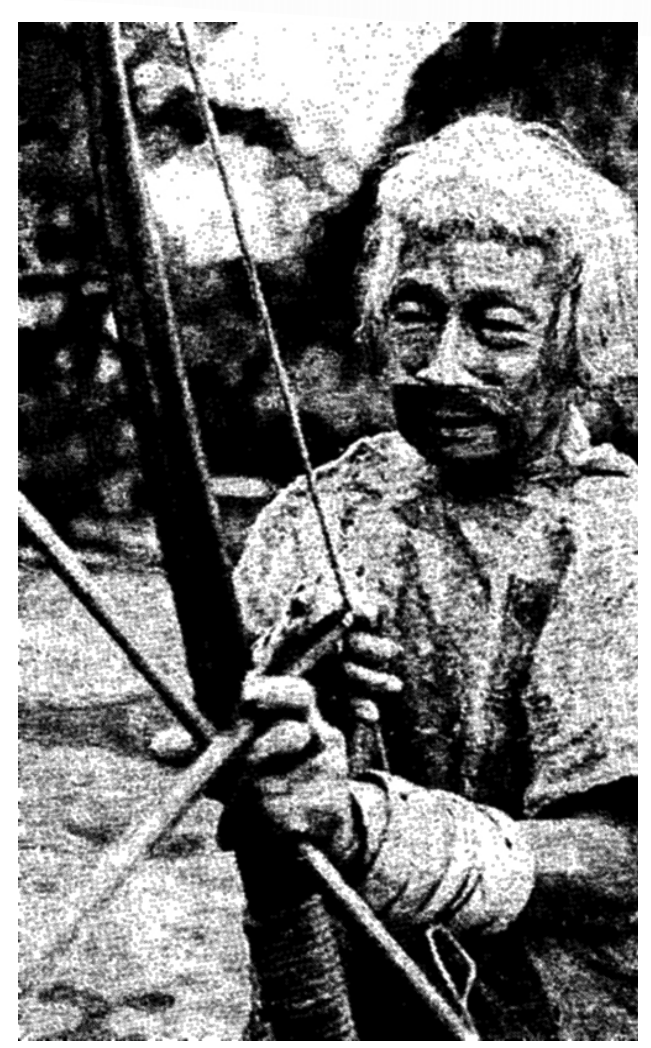

Fig. 20, 21. Hasta hace 5 años atrás, casi todos cazaron con arcos y flechas
Fig. 19. (c). La punta que se ve aquí se usa para cazar pécari, jaguar y otras piezas grandes. Se la puede extraer fácilmente del animal y entonces puede servir después.

\section{Taburetes}

Los hombres también hacen un cómodo taburete. La base se compone de un marco de cuatro troncos de balsa. El asiento es de varas similares al bambú de la palmera "palma real" tejida desdé los extremos perforados de las cañas o varas; y estaquillados al marco del asiento.

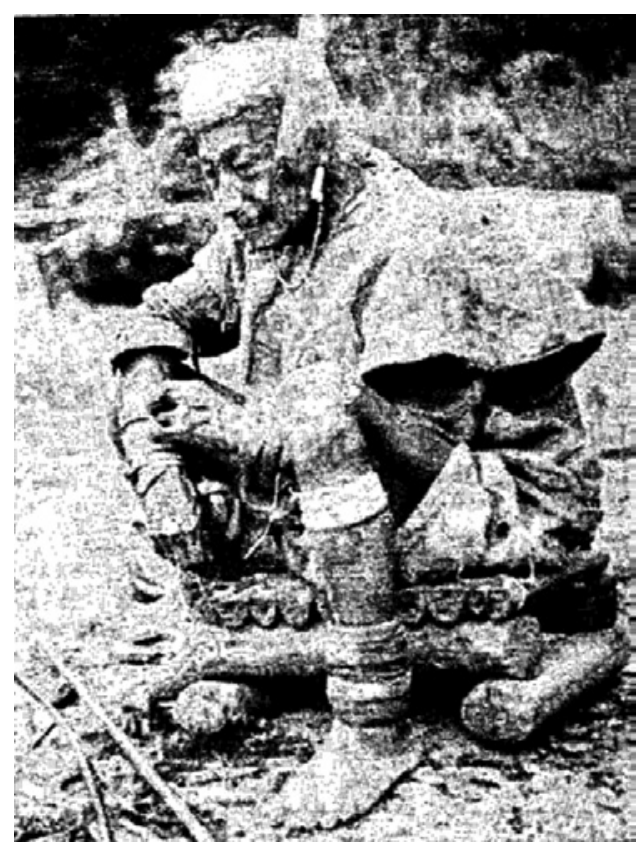




\section{Tintas}

Las mujeres extraen una sustancia del urucú, para el teñido de hilos y para pintar sus cuerpos. Las vainas del urucú las recogen cerca del chaqueado, sacan las semillas, las frotan y las estrujan exprimiéndolas con sus manos. Al jugo una vez colado, se le añade agua, entonces el líquido rojo se hace hervir. Esta mezcla se bate constantemente y cualquier impureza se saca con una cuchara. Cuando está a punto, se retira del fuego y se pone en un sitio a enfriar. Una vez frío, se vierte en un tubo de caña tacuara y se aplica con un palito delgado como un lápiz a lo que se quiere pintar.

Una tinta negra se obtiene de las semillas de la planta conocida en el Beni por el nombre macororó. La tuestan y la muelen y en seguida le añaden manteca. Los hombres llevan en la frente una raya horizontal negra de esta pintura espesa.

Otra tinta se prepara solamente exprimiendo esta fruta. No necesitan cocerla.

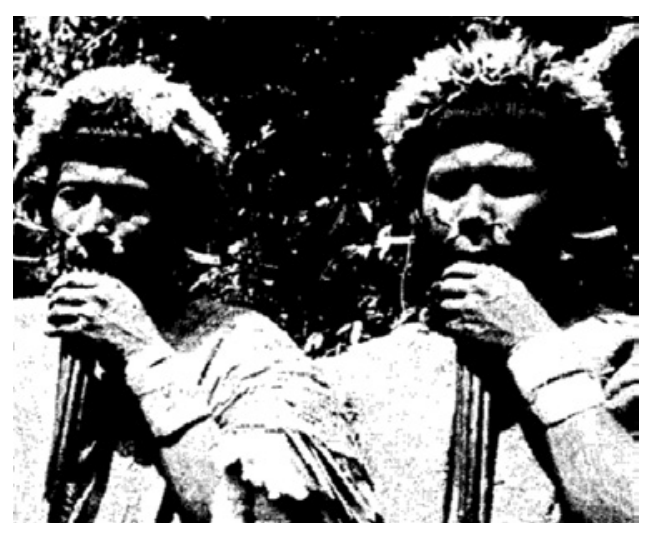

Fig. 22. Tocan sus flautas y bailan en sus fiestas

\section{Flauta Primitiva}

Los hombres fabrican flautas o zampoñas, de tallos de tacarillo. Está formada por cuatro tubos sencillos, abiertos arriba y cerrados abajo, colocados de mayor a menor tamaño, se agarran juntos en la mano para formar el instrumento.

\section{Trabajos manuales en madera}

Un mazo con muescas a ambos lados, se utiliza para golpear y ablandar la corteza de los árboles y esta corteza sirve para confeccionar vestidos para hombres, bolsas, cabestrillos para bebé, etc. Se lo fabrica de madera muy dura. Los hombres hacen estos mazos, como también agujas, husos, canoas de tronco ahuecado, remos, manos de batán, cucharones, tajadores y morteros. Las agujas las usan para amarrar las hojas de los techos.

\section{Tela de Corteza}

Los hombres preparan la tela de corteza, aunque a veces llaman a las mujeres para que les ayuden a golpearla. La corteza se obtiene del árbol bibost en lonjas de más o menos un metro de largo por $30 \mathrm{~cm}$. de ancho. Se la coloca sobre un tronco pulido y se la golpea con el mazo con muescas, mencionado anteriormente.

Entonces la tela se limpia enjuagándola en agua, se exprime, y la tienden al sol. Se utiliza esta tela para vestidos de hombre. La que sobra usan para hacer bolsas, cabestrillos para cargar bebés, bandas para cargar canastos y para trapos. 
Marian D. Prost, 1970. Costumbres, habilidades y cuadro de vida de los Chácobo

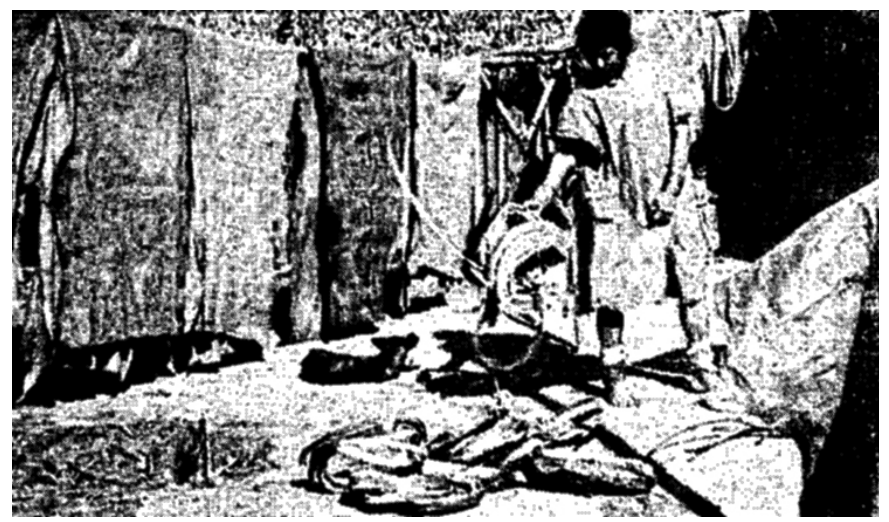

Fig. 23. La tela de corteza, una vez limpia y exprimida, la tienden al sol..

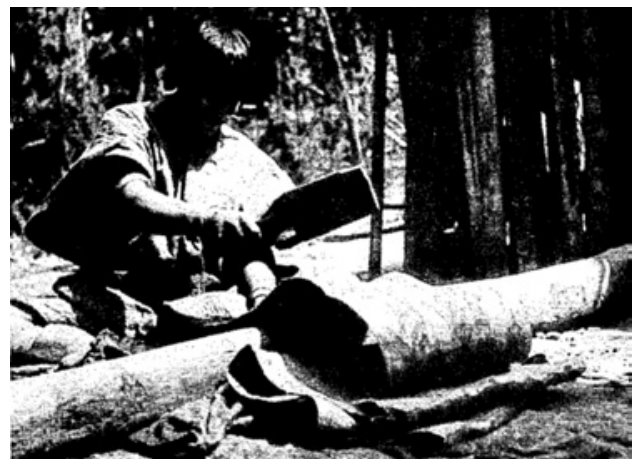

Fig. 24. ..después la golpean con el mazo con muescas, sobre un tronco pulido..

\section{Canoas de Corteza}

Fabrican canoas de la corteza del árbol paquío, y hacen un andamio alrededor del árbol a fin de facilitar el trabajo de los hombres a distintas alturas. Se le extrae una tira angosta de alto a abajo de unos diez centímetros de anchura al árbol, del largo de la canoa que se desea. Entonces, el resto de la corteza, de la cual la canoa se fabricará, se saca golpeándola y sunchándola para desligarla hasta hacerla caer.

Para extender la corteza, se prende fuego y se colocan palos en tres lugares para ayudar a mantener abiertos los

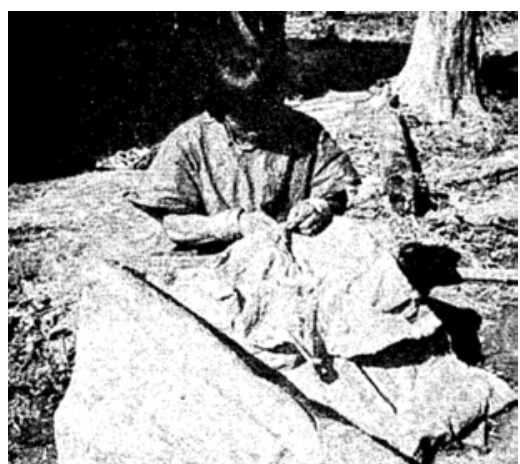

Fig $25 \ldots$ y confeccionan el vestido de hombre.

costados: uno al medio y otros a los extremos. Los extremos se rellenan con barro.

\section{Hilandería}

Las sogas y cuerdas son fabricadas por los hombres, a base de fibras de corteza.

El hilado fino es arte de las mujeres. Ellas usan cuerdas de algodón para las hamacas, decorado de las flechas, y bandas angostas para las coletas de los hombres, para bandas de sus brazos y para usos diarios de la casa. El algodón es traído de los campos y desemillado a mano y cardado con un pequeño arco. Lo hacen con husos de chonta, del 
grosor de un lápiz y más o menos de 40 $\mathrm{cm}$. de largo, con los extremos en punta. A poca distancia de uno de los extremos, hay una bolita de arcilla. Las mujeres se sientan en el suelo para hilar, con la punta del huso dando vueltas sobre un pedazo de madera plana cubierta ligeramente con ceniza. Con la mano izquierda mantienen el copo de algodón a una distancia y tensión adecuada. A veces el huso lo hacen girar sobre el muslo.

Las mujeres fabrican las hamacas con cuerdas delgadas de algodón. Para ello, plantan dos palos firmes en el piso a una distancia apropiada al tamaño de la hamaca que se desea. Las cuerdas de algodón se envuelven alrededor de los palos uniéndolos en hileras de más o menos $1 \mathrm{~cm}$. de distancia. En las hamacas para adultos se deja como unos 20 hilos de trama sueltos, que están a distancia de $10 \circ 12 \mathrm{~cm}$. unos de otros. Estos hilos se amarran juntos a los extremos de la hamaca. Cuando sacan el tejido de los palos, lo pasan a un palito de unos $12 \mathrm{cms}$. En cada extremo del tejido colocan un palito de unos $12 \mathrm{cms}$. y los amarran fuertemente por debajo

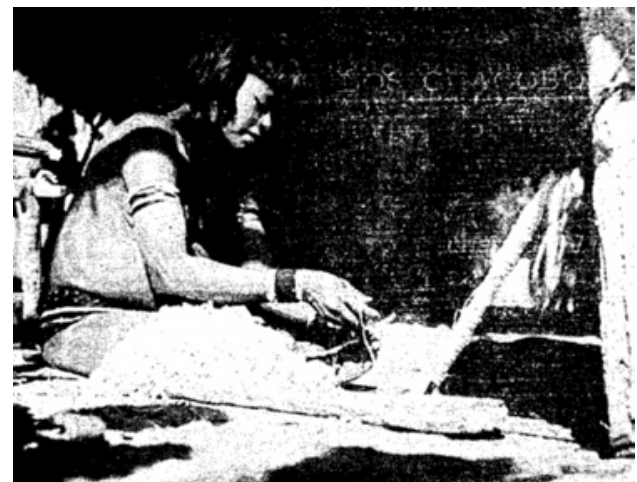

Fig. 27. El hilado fino es el arte de las mujeres. y alrededor de él con hilo de algodón. Estas hamacas son muy resistentes y pueden acomodarse en ella varios miembros de la familia a la vez. Por lo general cada adulto tiene su hamaca, y casi siempre uno o dos niños duermen con él. La familia cultiva la suficiente cantidad de algodón para proveerse de material para una o dos hamacas al año.

La otra obra de tejido, son las bandas para las coletas de los hombres y los adornos para los brazos. Al tejer las bandas para las coletas los hilos de la trama los extienden sobre un marco de madera colocado en forma vertical y los hilos de la trama los pasan con una lanzadera y después son nivelados con un cuchillo sin filo. Usan también hilos comprados, negro, o de otro color. Los entretejen al centro de la trama; el resto de los hilos es de algodón blanco de fabricación casera. Las bandas para los brazos son de $4 \mathrm{~cm}$. de ancho y tienen hilos azules y blancos formando un diseño de esqueleto de arenque. El hilo de algodón lo tiñen para un solo fin: el decorado de las flechas. Un ovillo al año se tiñe en rojo.

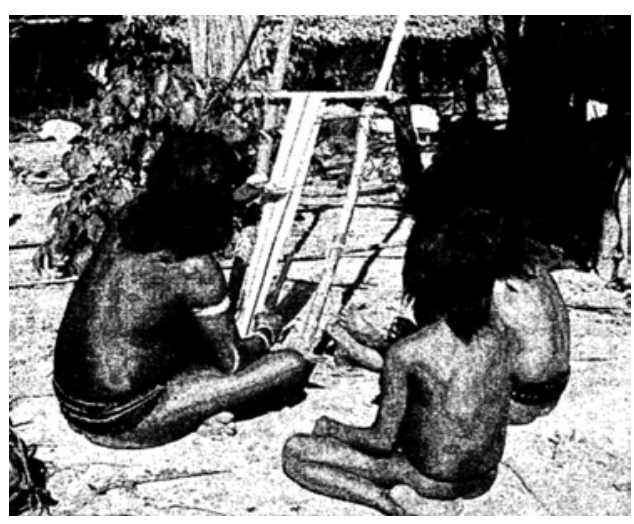

Fig. 28. Mujer Chácoba, tejiendo bandas para coletas de los hombres. 


\section{Vestidos y adornos}

El vestido de las mujeres chacobas consta de un cinturón o faja, y un retazo de tela, fija a unos hilos de algodón para cubrir el pubis. La mujer chacoba nunca puede ser vista sin este retazo de tela, y se considera cosa vergonzosa descubrir el pubis. La faja se hace de hilos de algodón, envueltos en hilos de bejuco negro y delgado que llegan a parecer un collar de cuentas chicas y negras. Esta faja queda como planchada para constituir una tira de 8 a $12 \mathrm{~cm}$. de ancho. Los dos extremos son amarrados con pita de algodón. Esta faja se la pasa alrededor de las caderas, encima de la pita de algodón que sostiene el retazo de tela para el pubis, y se la amarra debajo del retazo.

En la parte de atrás de estos hilos se fija el tallo de la hoja de palmera patujú, y se lo hace pasar adelante, entre las piernas para amarrarlo a los hilos. Cada día las mujeres usan un tallo fresco.

Se ponen tiras de corteza en el brazo y alrededor de las muñecas. Encima de estas tiras de corteza usan brazaletes de cuentas de semillas. Cuando van a visitar otra aldea de Chácobos, o durante las fiestas, las mujeres se ponen una tira en sus brazos con varios ramilletes de plumas fijas. Esta tira está amarrada al pedazo de corteza en la parte superior de los brazos.

Otra cosa importante es el collar de cuentas. La mujer bien vestida es la que tiene varias vueltas de cuentas de colores vivos, y monedas, y chucherías

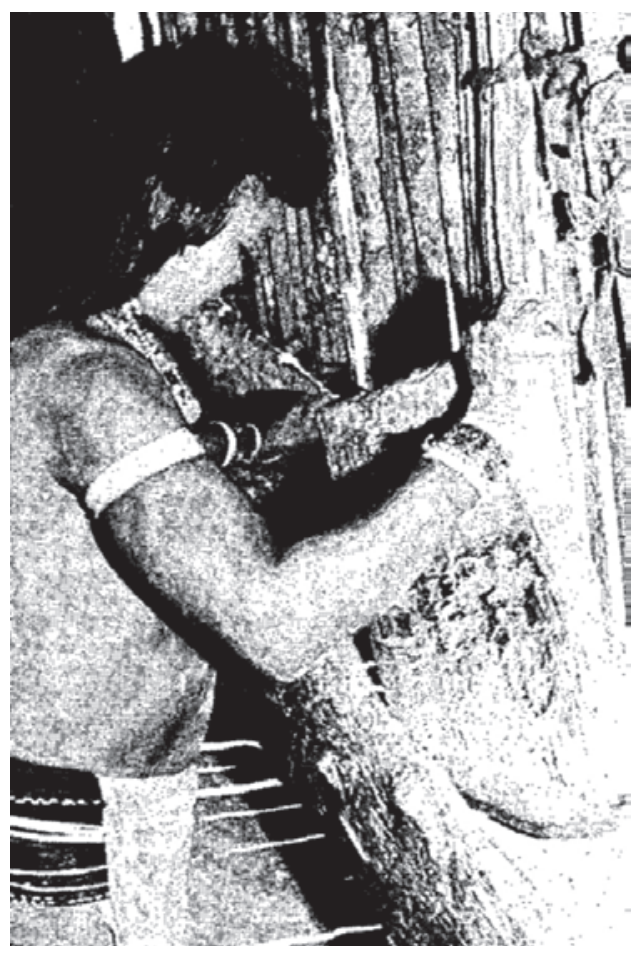

Fig. 29. Mujer Chácoba, preparando el algódon para el tejido

pequeñas. Hace años sólo se ponían cuentas de semilla, pero han ido progresando y ahora han conseguido muchas cuentas y monedas y otros adornos por medio del trueque. Las cuentas indican elegancia y prestigio y cada mujer quiere tener más que las demás para ser superior. Se quitan los collares en los tiempos de luto. Un collar de cuentas o chucherías pequeñas es el primer regalo que recibe la huahua recién nacida y se lo colocan alrededor del cuello y de las muñecas.

También usan las mujeres una tira en la cabeza, en forma circular. Se la hace de 


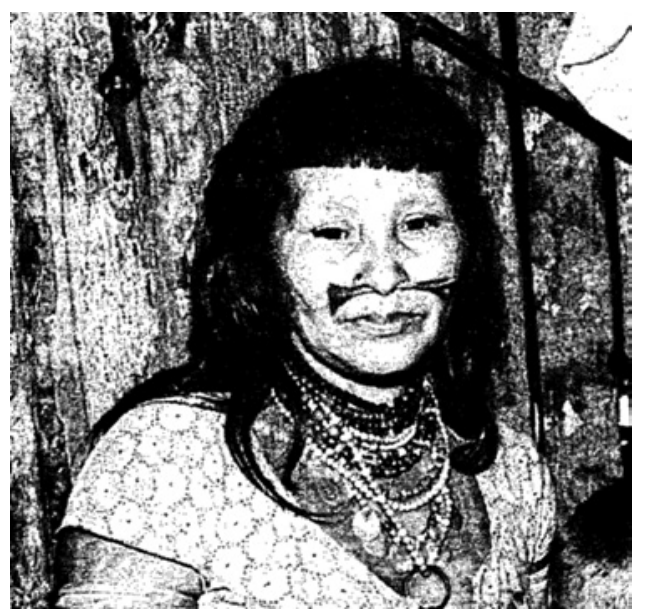

Fig. 30. La mujer bien vestida tiene varias cuentas de coleras vivos.

plumas rojas del tucán, encoladas con cera de abeja a una tela delgada y se la ponen sólo en las fiestas, o cuando visitan otras aldeas de Chácobos. Si la mujer no posee una tira para la cabeza, entonces ella encola algunas de las plumas en su cabello, cerca de la coronilla.

Por lo general las mujeres al pintarse, para las fiestas, usan urucú y genipa, o cuando van a visitar otra aldea. A veces

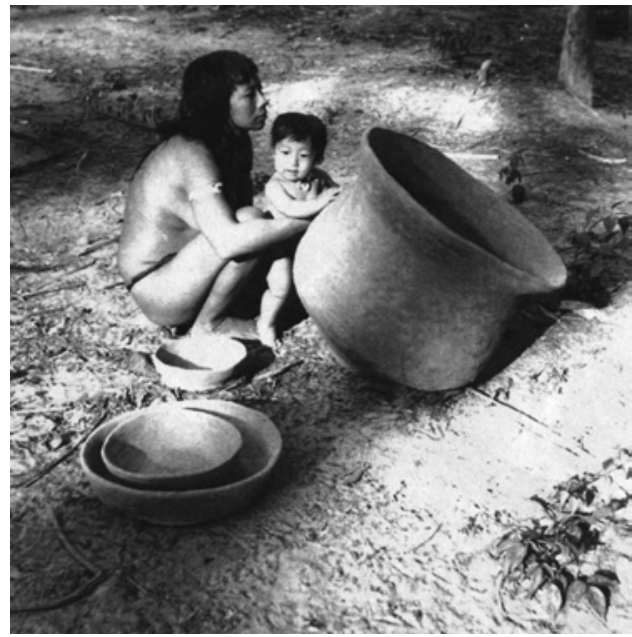

Fig. 31. Mujer con su niño con vestido de diario. se pintan en diseño geométrico con la genipa, y a veces se untan levemente por todas partes. Algunos dicen que lo hacen sólo para adornarse, pero otros afirman que sirve para ahuyentar los insectos, y para prevenir enfermedades.

Las mujeres se perforan el septo nasal en la edad de la pubertad y se insertan un ramillete de plumas rojas del tucán. Muchos años atrás las mujeres también perforaron sus aletas nasales para insertarse una bolita de madera en esas dos pequeñas perforaciones, y así parecían cuentas negras en su nariz. Ahora esa costumbre no existe porque muchas mujeres morían debido sin duda a infección.

Aunque ahora la mayoría de las mujeres chacobas tienen un vestido o dos, rara vez se lo ponen. Mientras están nuevos, los cuidan bien, y se los ponen sólo en las grandes fiestas o durante los surazos. Por fin, cuando ya están viejos, se los da a los niños para que jueguen y ellos los ensucian en el suelo.

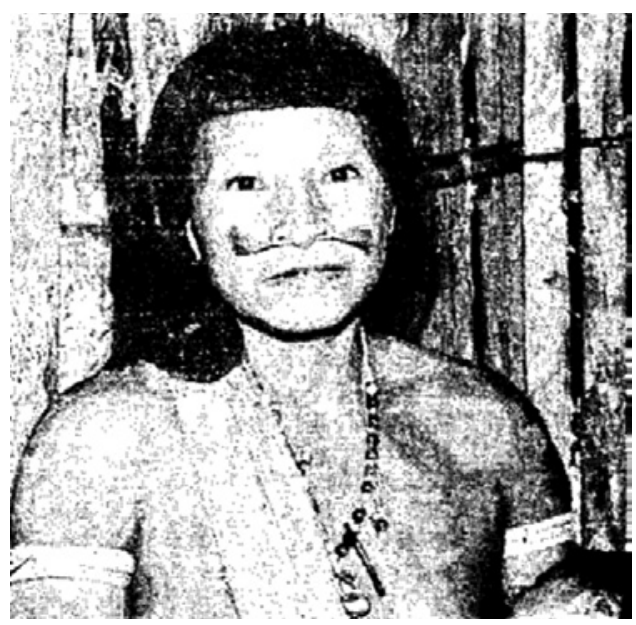

Fig. 32. Mujer mostrando su collar y adornos en sus brazos y nariz. 
Las mujeres usan el cabello de la frente en forma de cerquillo y se lo cortan un poco más abajo de la oreja, y atrás se lo deja caer recto no más. Se peinan una vez al día. Antes siempre hicieron sus peines ellos mismos pero ahora los consiguen de los comerciantes.

Los hombres usan un camisón amplio, como vestido principal, el cual se hace doblando una vez una tira larga de corteza, y haciéndole una abertura para la cabeza. Los costados se cierran con costura de pita de algodón, dejando un hueco holgado para los brazos. Para coser, antes usaban agujas hechas de la palmera chonta, pero ahora usan clavos comerciales bien afilados. El camisón alcanza casi hasta los tobillos. Siempre se lo quitan de noche para dormir .

Usan un cinturón de pita de algodón, debajo del cual meten el pene. Los tobillos los envuelven con tiras largas de corteza como también la parte superior de las pantorrillas, y alrededor de las muñecas y brazos. Las tiras en las muñecas sirven de protección contra la pita del arco.
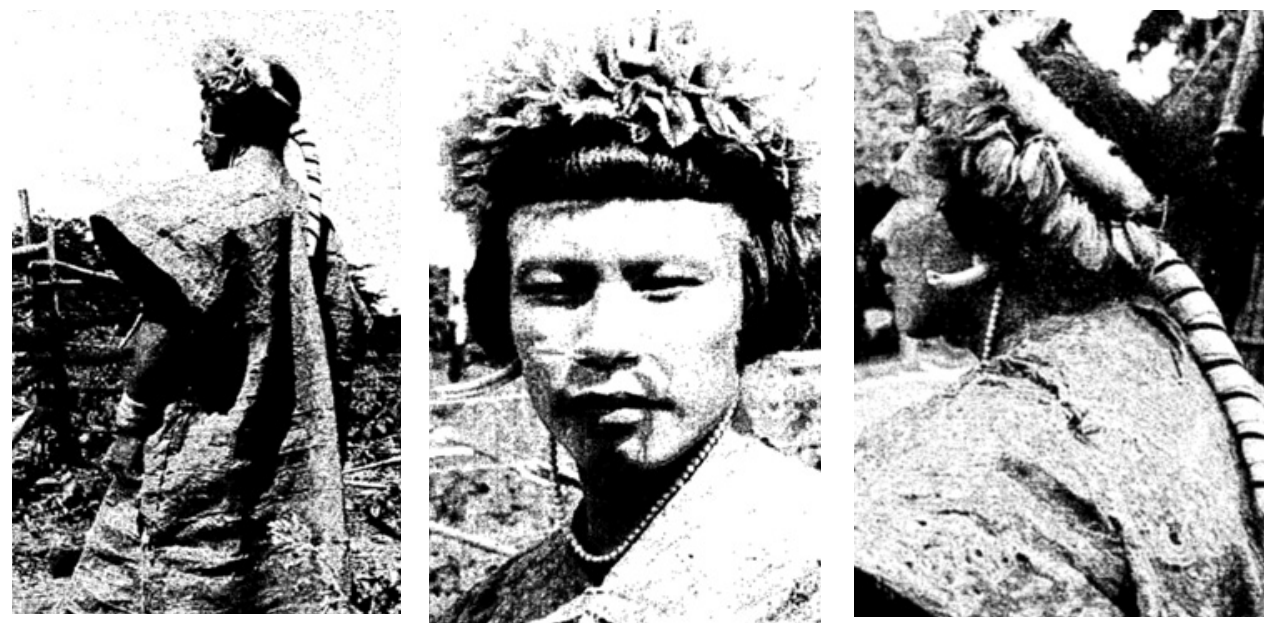

Fig. $32(a, b, c)$. Hombres Chácobo con camisa tradicional y adornos de cabeza y trenza.

En todo tiempo suelen usar un lindo adorno en la cabeza no sólo en las fiestas, sino también en ocasiones ordinarias. Lo hacen de tiras fibrosas cubiertas del plumaje sedoso de los patos de la cual cuelgan borlas de plumas de colores brillantes. Las plumas son las rojas y amarillas del tucán. Puede haber como 100 y hasta 200 borlas en un solo adorno de cabeza. Fijan también pedacitos de espejos rotos, cuentas, y otras chucherías al mismo adorno de cabeza.

Algunos adornos de cabeza incluyen una borla de plumas amarradas a la parte de atrás del adorno, en forma de abanico. La parte principal consta de diez plumas rojas y celestes de la cola del guacamayo. La punta de las dos plumas exteriores se inclinan por el peso de la borla hecha del plumaje sedoso de los patos, de las cuales cuelgan unas cuantas plumas del ave oriol, y delante de las plumas del guacamayo hay un grupo de 12 plumas del oriol; todas estas son amarillas, menos las dos del centro que son negras. Detrás de las plumas del 
guacamayo hay más o menos 30 plumas de la cola de gallina, colocadas cerca de la parte de abajo. Se amarran todas las plumas juntas por la parte del cañón.

De las fajas tejidas y amarradas a los brazos, cuelgan plumas brillantes y amarillas, y también pitas largas cubiertas de un plumón de pato. Cuelgan asimismo de estas fajas de brazo, una variedad de chucherías. Las bandas de cabeza y de brazos, las usan en las fiestas, o al visitar otro grupo de Chácobos, pero muchas veces los hombres las usan en sus casas a modo de ostentación. Cuando no trabajan, les gusta sentarse en el local de reuniones, charlando y adornados de las mismas bandas de cabeza, y de brazo, y de plumas brillantes.

Nos dicen que sus padres hace años se sabían poner en las fiestas grandes collares de cuentas de semillas, que descansaban sobre el pecho. Sólo una vez he visto uno de estos, y pertenecía al padre del hombre que lo llevaba. También, hace mucho tiempo usaron collares de dientes de mono y adornados con plumas de tucán.

El estilo de cabello entre los hombres varía algo del de las mujeres. Los hombres también llevan el cabello en forma de cerquillo en la frente, y los lados son cortados recto por la parte de abajo de las orejas. El cabello largo de atrás lo arrollan en forma de cuerda, y lo envuelven en faja de algodón tejido por las mujeres. Esta banda lleva a lo largo una raya angosta de color oscuro, pintado por el centro. Si el cabello no parece muy largo se le añaden entretejiéndole algunos pelos al cabo de la coleta para que parezca más largo. Estas coletas alcanzan a veces casi hasta el cinturón, y algunas son completamente de cabello propio.

El septo nasal de los hombres es perforado para insertar plumas. Los lóbulos de las orejas se perforan para poder insertar los dientes incisivos del capibara. De cada incisivo cuelga una sarta de cuentas de color celeste brillantes, que alcanza casi hasta la clavícula. Estas se ponen siempre, menos en el tiempo de luto.

Los hombres se pintan la cara más a menudo que las mujeres. Se pintan con macororó, una raya horizontal y gruesa, o unos puntos negros en la frente bajo el cerquillo. El urucú también sirve para pintar la cara y las mejillas y la genipa se usa para pintar los brazos y las piernas de los hombres, por lo general en diseño geométrico.

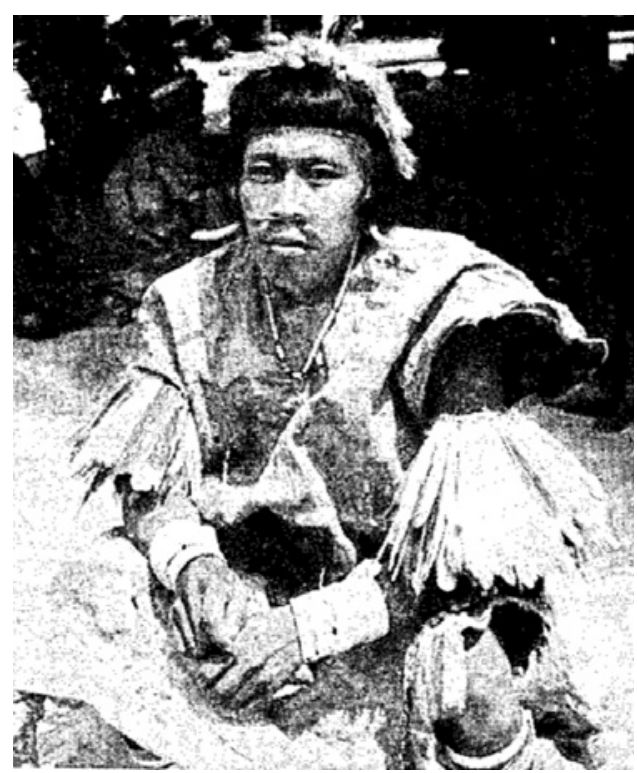

Fig. 33. Cuando no trabajan se sientan y charlan, adornados. 
Los hombres pasan mucho más tiempo que las mujeres en peinarse y lavarse la cara.

Cada mañana, al levantarse, los hombres se peinan, y envuelven su coleta muy aseadamente. Cada hombre posee un espejo, y pasa tiempo cada día mirándose en él. El mismo se recorta su cerquillo a menudo y se pinta cuidadosamente los diseños de la cara. Se afeitan las cejas porque piensan que son inútiles. Se peinan otra vez en la tarde después de bañarse y especialmente si han trabajado fuerte y la coleta se ha deshecho.

Durante la época de mucho calor, se bañan todos los días, y a veces usan jabón. A las huahuas y niños pequeños se los baña salpicándoles y frotándoles con agua tibia de una tutuma. Durante la época de frío, o durante una enfermedad, no se bañan.

Las mujeres se peinan cada día, pero sólo de vez en cuando se pintan la cara y el cuerpo, v.gr. para las fiestas. También afeitan sus cejas y las de sus niños.

Los niños están desnudos, menos en las raras ocasiones cuando pueden conseguir ropa de los blancos.

El cabello de los niños lo llevan muy corto para prevenir picaduras de los piojos que son muy comunes. Todos los Chácobos tienen piojos, por eso se sientan cada día en filas de dos o tres, y se los puede ver sacándose los piojos uno de otro, o, como ellos mismos dicen, "comiendo piojos".

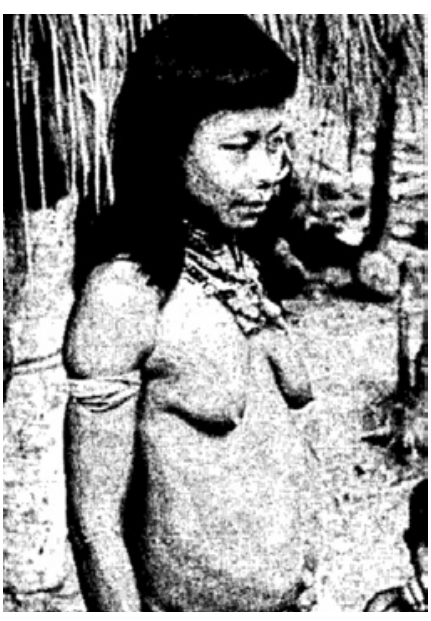

Fig. 34. Las mujeres ne se pintan la cara con frecuencia.

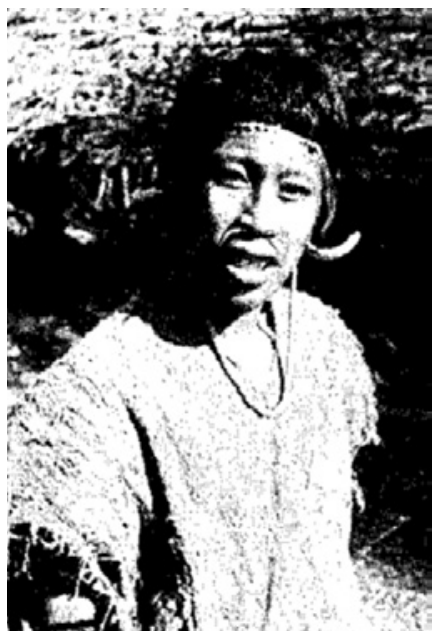

Fig. 35. Los hombres pasan más tiempo que las mujeres para lavarse.

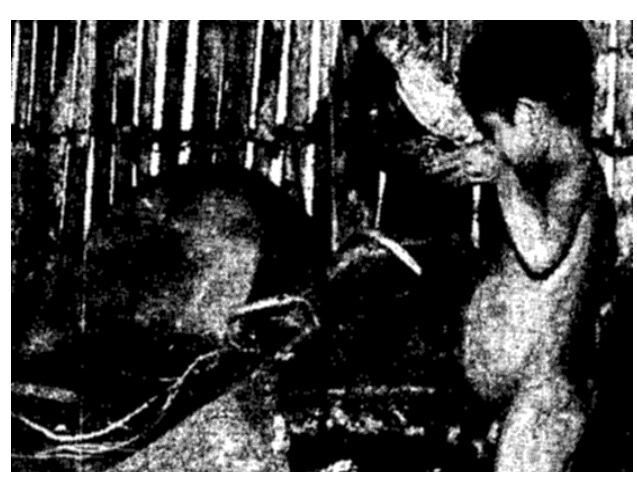

Fig. 36. Los niños disfrutan mucho de bañarse y casi siempre están desnudos.

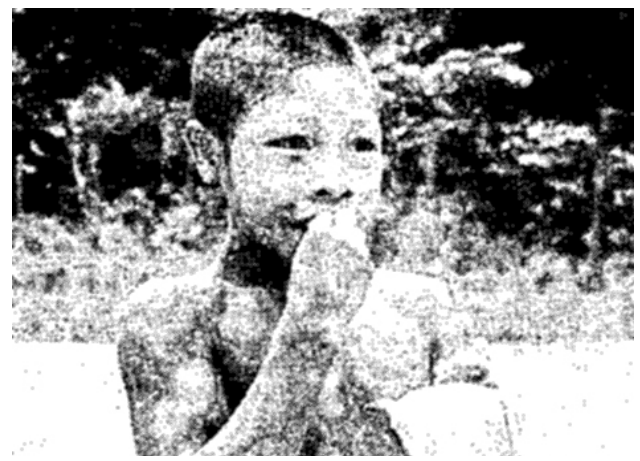

Fig. 37. Los niños llevan cortado el pelo para evitar el contagio de los piojos. 


\section{Víveres}

Los únicos alimentos que los Chácobos cultivan en cantidad son la yuca, el maíz y los plátanos. Lo que más cultivan es la yuca. También siembran camote, arroz, calabaza, pina, papaya y caña de azúcar. Sus claros o chaqueados los limpian con hacha y machete y todo lo dejan secar varias semanas antes de quemarlo. Así queda hasta hacer la siembra.

Siembran la yuca cavando agujeros con machete y mejor si poseen pala. Para sembrar maíz, usan un cuchillo grande de madera. Los hombres preparan el terreno, las mujeres y los niños ayudan a sembrarlo.

Como la yuca es muy abundante, hacen de ella un refresco y también harina tostada. Se la sirve todo el año. Sólo durante la cosecha de maíz hacen refresco de maíz. Les gusta un pudín de plátano, pero no lo hacen a menudo porque no hay abundancia de plátano. Alrededor de las casas siembran papaya, sandía, calabaza, piña, algodón, caña de azúcar y caña para sus flechas. A veces

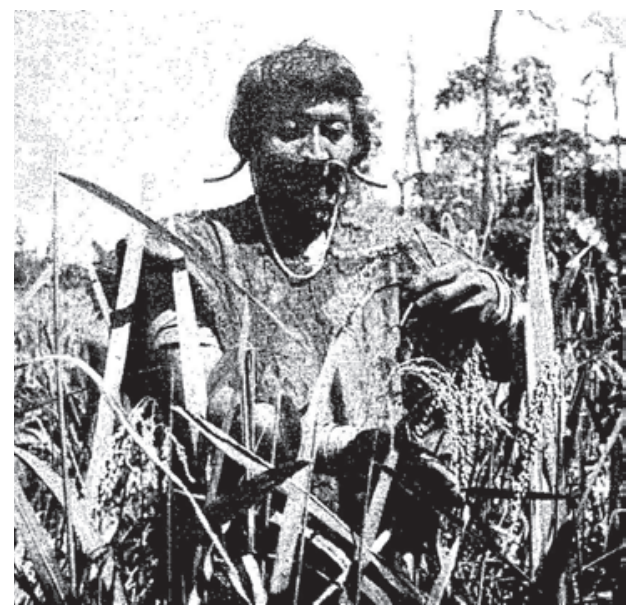

Fig. 38. Los Chácobo son agricultores, siembran yuca, maíz y plátano, principalmente. también siembran un poco de arroz cerca de la aldea.

Fuera de estos alimentos cultivados, los Chácobos usan una cantidad grande de bayas y frutas silvestres. La fruta del árbol motacucillo se tuesta en fuego abierto antes de comerla. Una fruta favorita es el majo, que se parece a las aceitunas maduras. Después de recoger la fruta, se la hace calentar un poco en agua, así la cáscara sale. Adentro queda una capa delgada de carne púrpura <jue se usa en la preparación de un refresco, o la envuelven en harina de yuca y la comen como algo exquisito. También hacen de majo un pudín espeso. Hay una fruta, nui, que se parece mucho a la frambuesa roja, y tiene también sabor semejante. Asimismo recogen chocolate, motacú, pacay y "huevo de perro", como designan una fruta popular entre ellos. Toda la familia toma parte en la recolección de alimentos silvestres, y a veces las mujeres y niños recogen mientras los hombres cazan o están pescando. Recogen de igual modo y a todos les gusta la miel silvestre.

Uno de los productos alimenticios preferidos lo constituyen los peces de los ríos. Los hombres saben pescar solos, o en grupos de 4 o 5 . Durante las fiestas, todos los hombres de la aldea van juntos para cazar o pescar. Por lo general pescan con arco y flecha, pero usan anzuelo y sedal para la palometa, y awaxo, tanto como para el siluro y la raya. Esta pesca es nocturna. Les gusta mucho la raya. No cazan ni comen el caymán. Cuando el río sube se levanta y alcanza hasta la selva, los hombres reman a los lugares donde los pescados 
comen las frutas de algunos árboles. Amarran la canoa y suben a los árboles de donde disparan a los peces. La flecha la recuperan agarrándola con el arco. Durante las altas mareas a los niños y hasta a las mujeres les gusta pescarlas sardinas (los cyprimus phoximos) que es un pez pequeño del río, y que se encuentra a poca profundidad y cerca de la playa. Para esto usan gusanos.

Un día antes, los niños van a la selva y buscan "maco", una nuez con cáscara dura y la abren machacándola. Algunas de las nueces contienen grandes gusanos blancos, que meten en una lata y usan después en la pesca de sardinas. Cuando las sardinas se juntan en cardumen y se acercan en cantidad para comer el gusano, los niños las agarran con las manos. Hasta los hombres pescan sardinas después de pescar todo el día en el río adentro.

Durante el tiempo de altas mareas otra manera de pescar sardinas es a base de los intestinos de los peces más grandes que ya han pescado con las

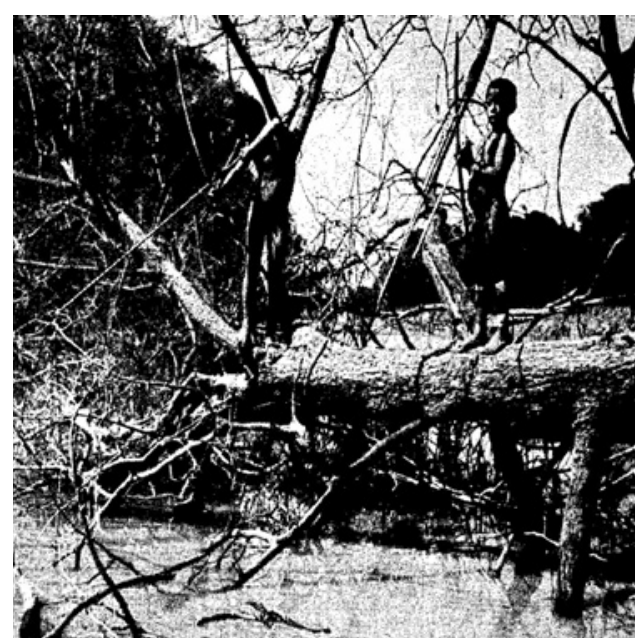

Fig. 39. Los Chácobo desde niños son entrenados para cazar y pescar. flechas, y agarrándoles entre los dedos, los enjuagan en el agua. Entonces las sardinas se acercan para comerlos, y los hombres aprovechan de agarrarlas. Se considera las sardinas un alimento exquisito. Por lo general los niños tienen el privilegio de tostarlas. Durante el tiempo seco, cuando el río es muy bajo, los Chácobos pescan con verbascum, una raíz venenosa. Aplastan la raíz machacándola con palo hasta que sale la fibra, y entonces la tiran al agua. Entonces los peces son anesteciados, y los recogen a mano.

El cazar es tan importante como el pescar, pero parece que pescar es un método más seguro de conseguir algo de comer. Mucho más fácil es traer abundancia de pescado que traer abundancia de carne de una cacería.

Hasta hace cinco o seis años atrás, casi sólo cazaron con arcos y flechas, pero ahora todos usan escopetas y rifles. Los Chácobos cazan una variedad grande de monos, roedores, pécari de labiosblancos y pécari de collar, tapir, venado,

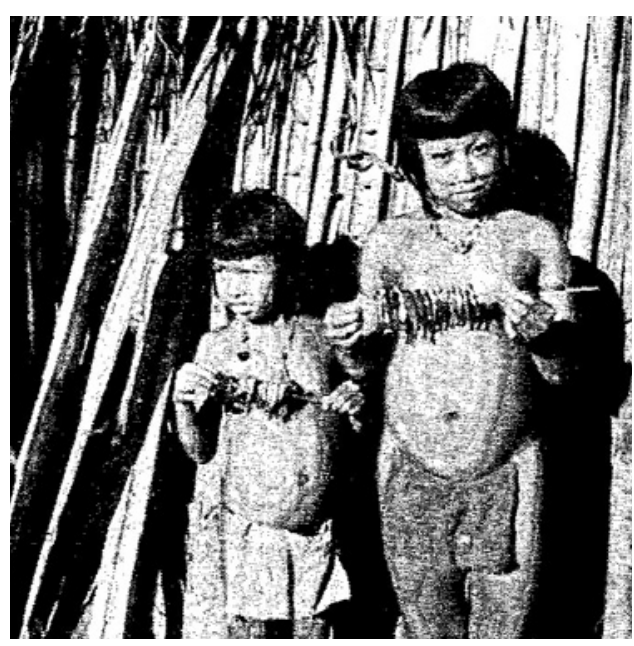

Fig. 40. Se consideran a las sardinas un alimento exquisito y se las comen tostadas. 
ardilla, tortuga y armadillo. Se clasifican los animales como: comestibles y no comestibles. No cazan los animales que no son comestibles, pero estos son pocos. El perezoso, oso hormiguero, mochilera, y un animal que se llama biwino, se les considera no comestibles. La carne de jaguar se la come sólo si no hay otra clase de carne. No se caza el jaguar, pero si el cazador lo ve, lo mata. Últimamente los Chácobos ya saben vender los cueros de jaguar. Ellos cazan toda clase de aves. No sólo ocupan la carne para comer, sino también usan las plumas para adornos. Cazan algunas aves desde puestos escondidos. En la cacería de los monos, los cazadores imitan los silbos de los monos y también usan perros. Muchas veces el pécari o el jaguar ataca a los perros. Una vez los Chácobos escucharon los ladridos de su perro cerca del claro de la selva, a eso de la madrugada. Pensando que un jaguar lo había agarrado, ellos inmediatamente empezaron a buscarlo. Varios hombres, mujeres y niños salieron, determinados a cazar al jaguar y matarlo. Después de media hora de caza, encontraron al animal en lo alto de un árbol. Un Chácobo. disparó con su escopeta, pero por mala puntería, no lo mató, y los otros lo flecharon. Varias flechas fueron necesarias para matarlo. Un Chácobo afiló las flechas cuando fueron sacadas del jaguar, para que sirvieran de nuevo. En seguida los Chácobos lo cortaron para ver si el perro estaba en su estómago. Al abrirlo, vieron la carne fresca y el pelo del perro. Entonces, satisfechos, sacaron algo de la gordura del jaguar, y todos volvieron a la aldea, sin aprovechar la carne del jaguar.
La manteca de cualquier clase es de mucho valor. Cuando vuelve un cazador a la aldea y cuenta de su éxito, la primera cosa que le preguntan es si el animal tenía mucha manteca.

En casi todas las aldeas crían pollos, patos, y chanchos domésticos. No matan las gallinas, pero los huevos los comen o los venden. Las gallinas son queridas, mimadas y acariciadas y por eso no se las puede comer. Cada miembro de la familia tiene sus propias gallinas y mientras tienen más, significa más prestigio entre ellos. Usan perros para cazar. Cada niño tiene su propio perro. Sólo dan de comer a los perros las sobras de su comida, y por eso no comen mucho porque los Chácobos no desperdician casi nada. Si sorprenden a un perro robando comida de una chapapa, lo golpean fuertemente, y a veces lo matan si tiene este vicio. Los perros cuidan bien cuando llegan extraños a la aldea. Cuando un perro tiene éxito con su presa, su dueño recibe más carne que los demás y el perro mismo recibe algo de la carne fresca.

Los Chácobos crían gatos, monos pequeños, periquitos, tortugas pequeñas y pécari tierno como regalones. Cuando encuentran pichones y ratoncitos en su nido, los dan a un niño como juguete. Estos casi siempre mueren dentro de unas horas por tanto manoseo. Crían también, pavos, guacamayo grande, y el tucán, por sus plumas, a estas aves las despluman cada cierto tiempo. Cuando una de estas aves muere, los dueños no la comen, porque era mimada o favorita. 


\section{Alimentación}

La Preparación y Conservación de los Alimentos

La tarea más importante que tiene la mujer en la casa, es la preparación de la comida. Es necesario mantener a mano siempre una olla grande de refresco de yuca o de maíz. Las mujeres se sientan en una estera o sobre un vestido viejo de corteza para pelar la yuca. Después la mondan y cortan en pedazos, tirándola a un canasto grande. Cuando se llena el canasto, lo vacían a una olla grande para cocinar, sin enjuagarla, y la cuecen hasta ablandarla. Entonces la echan a una charola para enfriar. Después que se enfría bastante, las mujeres la mastican'. A veces la mujer invita a sus amigas a ayudarle. Se mete un pedazo de yuca en la boca, y lo mastican algunos minutos, entonces lo escupen en la misma olla grande otra vez. Este procedimiento ocupa dos horas.

La pulpa masticada se la pone en un colador sobre la olla grande, y se echa agua fría encima de la pulpa. Entonces se la exprime con las manos hasta qué la mayor parte haya pasado por el colador. Se llena la olla de agua, y la dejan hasta que se enfríe completamente. El refresco fermenta rápidamente pero por lo general lo toman antes de que fermente mucho. Cuando se hace esta bebida para una fiesta, las mujeres tapan las ollas grandes con hojas de palmera y las dejan unos días hasta que fermente bien. Antes de que fermente la llaman "dulce", y ésta es una bebida popular entre los Chácobos. Casi nunca toman puramente agua, sólo si no hay otro líquido para tomar, por ejemplo cuando hacen viajes largos por la selva.

Durante la cosecha de maíz, también hacen una bebida de maíz. Ellos sacan la cáscara y la semilla con la mano, y la machacan en el mortero. Entonces la cuecen más o menos dos horas hasta que se espese bastante. Las mujeres mastican harina de maíz y la añaden al maíz cocido, junto con agua fría. Se toma esta bebida en uno o dos días, antes de que fermente bien.

La olla grande queda continuamente en el suelo, y pedazos de leña son puestos alrededor de ella en forma de radios de rueda. En cuanto la leña se va quemando y consumiendo, los Chácobos la van empujando más al centro.

La harina de yuca, tostada, constituye la comida principal. Las mujeres la hacen varias veces a la semana. Del chaco traen el canasto lleno de yuca. La mujer se sienta en el suelo sobre una estera, o un vestido viejo, y la mondan. Entonces ella enjuaga la yuca en muy poca agua la cual se ensucia pronto, y la rallan y extienden al sol, encima de hojas de plátanos o encima de vestidos de corteza, para secar por algunas horas. Cuando está seca, la machacan finamente en el mortero, y la ciernen. Entonces está lista para tostar en las vasijas sobre el fogón. Esta harina de yuca se llama dulce.

Se hace una harina fermentada poniendo la yuca recién rallada en ollas grandes, tapándolas con hojas. Se la deja así algunos días, hasta una semana antes de que la pongan al sol para secar, 
y después la tuestan. Comen harina de yuca en cada comida. La usan en sopa o guiso y le añaden carne o fruta silvestre.

Si no hay refresco a mano, añaden harina de yuca a solo agua, y la toman. Cada vez que prepara la mujer harina de yuca, la reparte a cada mujer en la aldea. Manda un plato de la harina a cada una. Yo he visto a varias mujeres hacer harina de yuca al mismo tiempo, cada una en su propia casa, y al terminar, cada una manda a todas las demás, haciendo el cambio una con otra. Siempre llevan harina de yuca con ellos cuando hacen viajes.

También preparan la yuca hervida, o más común, tostada en la cáscara. También hacen un pan en forma plana aplastando la harina bien colada, en una olla casi plana y tuestan un lado hasta que tenga color moreno y entonces lo vuelcan para tostar el otro lado.

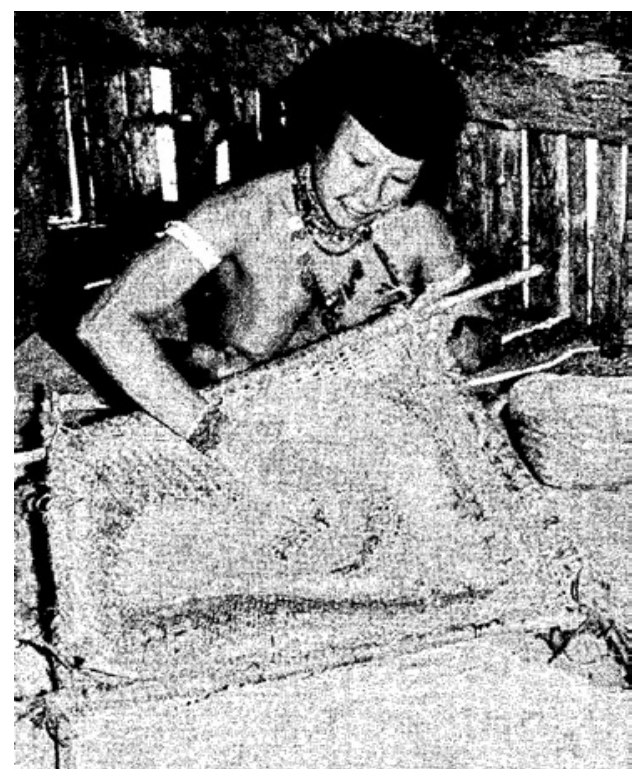

Fig. 41. Preparación de la harina de yuca, por una mujer Chácobo.
Durante la cosecha comen el maíz en varias formas: como bebida, harina tostada, pan plano, tamales, y el maíz tostado en su mazorca.

A los Chácobos les gusta mucho el plátano. Traen a casa una cabeza de plátanos, y los niños son tan ansiosos para comerlos, que no pueden esperar hasta que maduren, y muchas veces los comen antes de que estén buenos. Es lo mismo con las papayas y piñas. Por lo general dan a un chico cualquier cosa que pide.

Muchas veces yo he visto estas frutas abiertas y botadas porque después de abrirlas y probarlas no les fue agradable.

Una manera muy común de preparar la carne o el pescado, es asarlo en la chapapa de palos frescos. Si traen gran cantidad de carne, una porción de ésta la hacen hervir con maíz o yuca rallada para que se vuelva espesa. Para preparar pescado antes de cocinar, lo destripan sin quitarle las escamas. Cuando traen animales de la cacería, la mujer lo parte en el suelo mismo. Si el animal grande es muy peludo la mujer lo corta en pedazos y rápidamente chamusca cada pedazo. Si el animal no es muy grande, ella lo chamusca entero, y después lo raspa con palito. Nunca quitan la piel. Comen todas las partes del animal, y la cabeza es la favorita. A veces los hombres ayudan a las mujeres a cortar los animales grandes.

Las mujeres despluman las aves y las asan en el fogón. Muchas veces se las comen sin que estén bien cocidas, en tal caso la carne está bien golpeada en el mortero después de asar. Después de un 
día entero de pescar al llegar a casa, al hombre le gusta primero comer pescado que ha estado unos pocos minutos encima del fogón. Muchas veces el hombre come pescado así poco cocido, mientras el guiso está cociéndose en la olla grande, y los otros pescados siguen asándose en la chapapa.

Conservan el pescado y la carne, ahumándolo. La mayor parte de toda la carne o pescado la ocupan en las fiestas, lo conservan de esta manera porque mucha de esta carne la preparan una semana antes de comerla. No usan sal como preservativo porque es muy escasa. Sólo usan sal como condimento. Cada persona echa sal a su gusto, en su propio plato, aunque a veces el hombre que es el anfitrión salpica un poco de sal sobre la comida antes de entregar cada plato a los demás. Otras comidas preservadas son el maíz y la yuca. Secan el maíz para sembrar o tostar y la yuca la preservan a la manera de harina tostada.

El primer trabajo que la mujer realiza cada día es cortar y recoger la leña. También las mujeres cargan el agua. Este trabajo lo hacen llevando cántaros en los hombros.

Las comidas las hacen hervir en las ollas más pequeñas, pero del mismo tipo de las que usan en la preparación de las bebidas. No lavan las ollas después de usarlas, sino que las dejan secar y sólo antes de usarlas de nuevo, las limpian con la mano.

No tienen horas fijas para comer, y comen cuando hay comida. La familia come después que el hombre vuelve de la pesca o caza. Si él ha traído buena cantidad de alimentos, entonces también les alcanza para un guiso en la mañana siguiente. Pero durante el día, pueden estar comiendo si hay qué comer. Hay algunos días en que no tienen ni carne ni pescado. En tales casos, ellos se quejan de hambre, aunque tengan frutas silvestres o harina de yuca, porque la única cosa que ellos consideran verdaderamente comida es la carne o el pescado.

Cuando llega el hombre a la casa con un gran canasto de pescado, lo entrega a su esposa, quien lo reparte a cada una de las demás mujeres de la aldea. Por lo general da a cada mujer uno o dos pescados, depende de la cantidad. Siempre dejan lo suficiente para la familia del pescador. Después de la distribución, la esposa prepara una olla grande de guiso de pescado para servir a cada uno de la aldea. Cuando todo está listo, el hombre invita a cada uno por su nombre, a venir y comer con él en el local de reunión. Cada hombre trae su propia harina de yuca y posible- " mente sal y cuchara. El anfitrión pone una fuente grande de este guiso en el suelo, en el centro del local y los hombres se sientan en taburetes y comen con buen apetito. A veces el anfitrión salpica con sal la olla para beneficiar a todos. Ellos comen lentamente y charlan, regocijándose cordialmente. Tan pronto como los hombres son servidos, la esposa del anfitrión reparte una porción de guiso a cada una de las mujeres para que ellas lo coman con sus niños en sus hogares.

Generalmente comen con la mano, porque cada familia no tiene más de dos cucharas. Son muy expertos en comer 
de esta manera, y ni siquiera derraman nada. El resto del pescado traído por el hombre es asado. Si hay algunos hombres que han ido en grupo a pescar, repiten la misma rutina hasta saciarse, sin templanza.

El mismo festín comunal es costumbre hacerlo con ocasión de la matanza de cualquier animal grande.

Si un hombre viene a su hogar con sólo un pájaro o dos, su esposa lo asa rápidamente. La carne es trozada y los hombres son invitados a participar. Generalmente lo comen con harina de yuca. La esposa reparte un puñado de carne a cada mujer, pero si no alcanza, entonces los esposos dividen lo suyo con sus esposas e hijos.

Toda cosa comestible que ellos consiguen en la selva, la reparten también con cada mujer de la aldea. No reparten ni el maíz ni la yuca, porque cada familia tiene su propio chaco. Los plátanos son repartidos pero no de buena voluntad. Algunas mujeres son acusadas de ser mezquinas porque no dan a las demás tanto como ellas quisieran.

\section{Fiestas}

La cosecha es la ocasión para las fiestas. Los alimentos son preparados y comidos de manera distinta durante la fiesta. Cuando un hombre de la aldea decide tener una fiesta, la primera cosa que él hace es ir a invitar personalmente a cada hombre para tomar parte. Posiblemente el anfitrión avisa a los demás con una semana más o menos de anterioridad acerca de la fiesta a fin de que ellos puedan preparar convenientemente su adorno de cabeza, su nuevo vestido de corteza, y sus taburetes.
La primera tarea en la preparación de la comida es cortar la leña. El dueño de la fiesta guía a los hombres hacia la selva para cortar la leña. Cuando ellos han terminado, vuelven a la aldea y avisan a la esposa del dueño de la fiesta que la leña está lista. Ella entonces invita a cada mujer de la aldea para que vayan a traerla. Todas van juntas con sus canastos de acarreo, y generalmente hacen dos o tres viajes. La leña va siendo arrojada y formando un gran montón fuera de la casa donde se prepara la bebida.

Los hombres se alistan para ir a cazar para la fiesta. Ellos van dispuestos por dos o tres días, llevando sus hamacas y la harina de yuca con ellos. Algunas veces no tienen éxito en la cacería, y ellos entonces deciden pescar en estos casos. En una ocasión ellos sólo consiguieron unos diez monos. Antas y pécaris son los preferidos para la fiesta. Las diferentes clases de carne en su totalidad son entregadas a la esposa del dueño de la fiesta. Ella asa la carne en su fogón y algunas veces ella invita a las demás a ayudarle para limpiar y trozar los animales.

Tan pronto como la carne es entregada y mientras se está asando, las mujeres son invitadas por la esposa del anfitrión para ir y traer el maíz y la yuca de su chaco. Ellas salen temprano en la mañana y tan luego como es traído a la aldea, ellas comienzan la preparación de la bebida. Todo se hace en la casa del dueño de la fiesta, y se guarda en ollas grandes, o troncos ahuecados. Un tronco ahuecado se prepara con este propósito por todos los hombres juntos antes de que la leña esté cortada.

Mientras que las últimas ollas de bebida 
están siendo hechas, el anfitrión va con otro hombre a invitar a la aldea vecina. Si hay más de una aldea que invitar, se pide a otros dos hombres que sean sus representantes para invitar a las otras aldeas. Las visitas demoran algunos días en llegar, y si ellos llegan en la tarde al puerto fluvial cercano a la aldea, la fiesta es postergada hasta la mañana siguiente. Durante todo este tiempo, nadie come nada de la carne de la fiesta, y por esto, todos tienen mucha hambre. Cuando la comida va a ser servida, todo está completamente ahumado y bastante seco.

Tan pronto como las visitas han llegado al puerto fluvial, el anfitrión envía al mismo hombre que antes le acompañó, a informar a todos en la aldea que los huéspedes han llegado y decirles que la fiesta puede empezar. El anfitrión duerme con sus huéspedes en la orilla del río. Como ya está dicho, la fiesta generalmente comienza temprano en la mañana. Durante la tarde antes de la fiesta, se barre el local de reunión, se alistan todas las fuentes de barro, y los canastos, y todos están en un estado de euforia y excitación. Generalmente en este tiempo se pintan sus cuerpos. Las mujeres comienzan la música que consiste en tañer el mortero vacío y lo hacen dos mujeres, una a cada lado del mortero. A veces dos parejas de mujeres, y otras veces hasta tres parejas tañen al mismo tiempo. Cada pareja tañe con el mismo ritmo, aunque con ritmo diferente de las otras. Nos parece una forma rara de diversión, cuando toda la semana han estado trabajando de la misma manera para hacer harina de maíz o de yuca en el mortero.
Este ruido rítmico puede ser escuchado por las visitas desde la orilla del río. Generalmente todas las mujeres toman parte en esta música, alegrándose en gran manera y teniendo un tiempo agradable. Esta misma música las mujeres la repiten en la mañana siguiente justo antes que las visitas lleguen a la aldea. Pero no lo hacen más, una vez que la fiesta ha comenzado.

Hay mucho movimiento y desorden en la mañana de la fiesta. La esposa del anfitrión hace hervir grandes pedazos de carne en ollas igualmente grandes, a base de harina de maíz, o de yuca, depende que la fiesta sea la "Fiesta del Maíz" o la "Fiesta de la Yuca". Si la fiesta es la "Fiesta del Maíz", entonces comen harina de maíz, bebida de maíz, tamales de maíz y choclos. Si la fiesta es la "Fiesta de la Yuca", entonces comen yuca preparada de diversas maneras. El guiso está bien cocido y listo para comer tan pronto como las visitas lleguen. Las mujeres barren de nuevo el local de reunión. Todos los hombres se pintan con urucú y llevan sus adornos

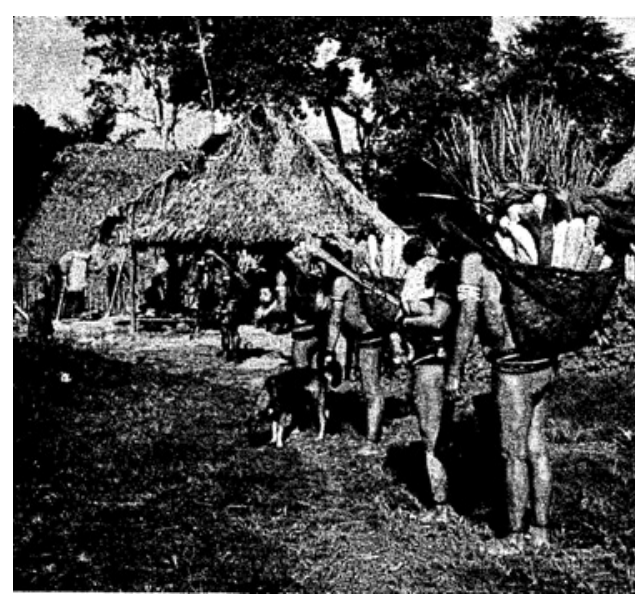

Fig. 42. Anfitrión recibiendo visitas, para iniciar la fiesta. 
de cabeza, brazaletes y otros adornos. Una olla de la bebida fermentada es colocada en el centro del local, con canastos de carne alrededor. Si han sido beneficiados varios pécaris, las cabezas asadas son colocadas alrededor de la olla de bebida. iTodo está listo!

Los hombres de la aldea que los hospeda empiezan a tocar sus flautas, y bailan en el local de reunión. Esto es lo que el anfitrión contempla al llegar a la aldea con sus visitas. El anfitrión camina hacia la aldea. Tan pronto como él entra al local de reunión, los visitantes empiezan a danzar formando una fila hacia la aldea, tocando también sus flautas. Si uno de los hombres visitantes posee un rifle él dispara una vez al aire antes de entrar bailando con sus compañeros a la aldea. Las mujeres con sus niños y con todo lo que poseen amontonado en sus canastos de acarreo caminan detrás de los hombres que danzan. Mientras los hombres visitantes danzan dentro del local de reunión, los hombres de la aldea continúan danzando.

El espectáculo que ofrece en ver a todos estos hombres bailando y tocando sus flautas alrededor de la olla de bebida

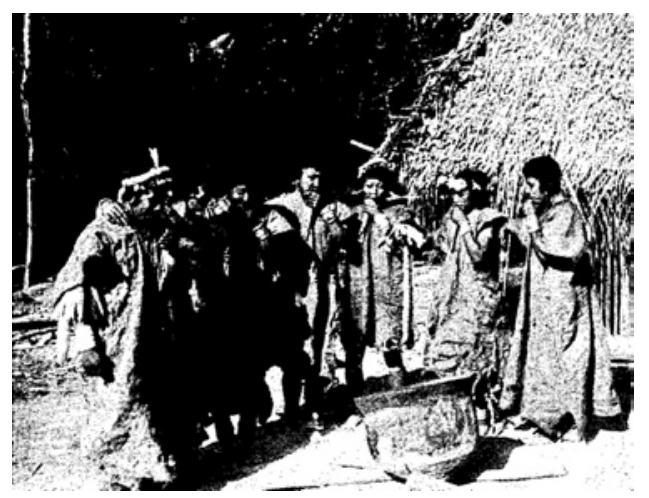

Fig. 42. Hombres Chácobo, tocando la flauta y bailando. colocada al centro de la casa, es de mucho colorido.

Después del tiempo del baile, alrededor de la olla de bebida, ellos cesan. Los hombres de la aldea que invita, saludan a cada una de las visitas, preguntándole si ha llegado. Cada uno responde y hay un período breve de conversación. El anfitrión da a cada una de las visitas un taburete y ellos se sientan. Las mujeres visitantes se sientan entonces alrededor exterior de la casa. La ceremonia siguiente toma lugar:

Al más anciano de los hombres de la aldea, generalmente al curandero, le dan una tutuma llena de pedazos de carne, el cual la pasa a cada uno de los hombres. Los hombres que todavía no llevan aretes con incisivos en sus orejas, solamente tocan la carne; los demás toman un pedazo. Entonces todos los hombres agarran sus flechas y las clavan en el suelo al frente de ellos. El curandero produce un sonido succionando con su boca, y ésta es la señal para que todos comiencen a comer la carne. Entonces el curandero va pasando a todos una tutuma de bebida, en la cual cada hombre mete su dedo. Del mismo modo anterior, los jóvenes sin aretes sólo pasan las manos sobre la tutuma. Al tiempo del mismo sonido, todos los ancianos lamen sus dedos. Nosotros no hemos podido averiguar acerca del significado de esta ceremonia, aunque parece que es una ofrenda a los espíritus malos, porque dicen que si no lo hacen, las mujeres se enferman.

Cuando el anfitrión trae los alimentos, primeramente reparte canastos de harina de yuca a los huéspedes. Los 
hombres se sientan formando círculos, pequeños de cuatro o cinco en cada círculo. El anfitrión entrega una fuente grande de guiso caliente a cada círculo de hombres. Cuando todos los hombres son servidos, la esposa del anfitrión hace lo mismo con las mujeres. Las mujeres huéspedes siempre son atendidas antes que las mujeres de la aldea que invita. En seguida, tutumas llenas de bebida se van entregando a todos los hombres. Estas tutumas siempre son entregadas por los jóvenes (los que todavía no llevan aretes), generalmente uno de cada aldea. De igual manera la esposa del anfitrión entrega una tutuma llena de bebida a cada mujer, quien bebe y da de beber a sus hijos.

Cuando todo esto ha sucedido la olla de bebida ha sido escanciada y está vacía, y es remplazada por una más grande. Esta siempre se procura mantener llena durante toda la fiesta hasta que la bebida se termina. Dos o tres veces más, el primer día de la fiesta se sirve carne y harina de yuca. Después de la primera comida, las mujeres huéspedes comienzan a acomodarse alrededor exterior del local de reunión. Ellas entran al interior del local de reunión solamente para efectuar un canto en forma monótona, alrededor de la olla de bebida con el jefe, y entran también en caso de lluvia. Los hombres visitantes, después de que la fiesta ha comenzado bien, van a la selva para traer un par de palos que colocan como poste en el suelo para las hamacas de sus esposas. Los hombres visitantes duermen en el local de reunión. Después que las mujeres y los niños han soportado el sol unas horas y mirando a los hombres bailar y comer, ellas necesitan protegerse del calor del sol. Cada marido hace un arco de hojas de palma para su esposa, pero si es un flojo o incompetente, ella misma lo hace. Este sirve para señalar el lugar que ocupará durante la fiesta.

Cuando los hombres no están comiendo, están bailando alrededor de la olla de chicha. Generalmente hay dos filas de hombres bailando y tocando flautas. Las flautas se agarran en la mano derecha mientras que con la izquierda agarran el hombro izquierdo de su vecino como abrazándole.

Ellos bailan siguiendo la dirección de los punteros del reloj arrastrando sus pies. Las dos filas de hombres tocan diferentes melodías en las flautas, y una fila baila siguiendo la otra. Mientras ellos hacen esto, el viejo curandero camina lentamente alrededor de la olla de bebida, tocando un tambor con un palo, y cantando en forma monótona. Es casi imposible entender más de una palabra de vez en cuando. Al principio nos dijeron que no había palabras, pero ahora sabemos que estos cantos encierran palabras de profundo significado. Algunas mujeres y niños siguen al viejo, cada una con su mano encima del hombro de su vecino. Ellos no cantan, pero van siguiendo el canto entre dientes y al final de esta canción del curandero, ellos enfatizan en gran manera las últimas notas. Las mujeres alientan a sus niños a tomar parte con ellos en esto. Toda la primera noche bailan y cantan. Hay momentos cuando ellos descansan, pero esto dura poco.

Durante este tiempo y unos pocos días siguientes de la fiesta, hay muy poca charla entre los grupos de mujeres. Las 
mujeres de la aldea que invita se quedan en sus casas, menos cuando van a cantar con el curandero. Las mujeres visitantes se quedan casi todo el tiempo en sus lugares. No hay cambio de saludos entre las mujeres de los dos grupos. La única que habla es la esposa del anfitrión al traer los alimentos 0 bebidas. Finalmente, cuando la fiesta está por terminar, lo cual puede ser después de cuatro o cinco días, las mujeres de la aldea empiezan a salir de sus casas y se sientan alrededor del local de reunión a mirar, y entonces charlan un poco entre ellas.

Después del primer día y primera noche, la fiesta continúa con un tono de más tranquilidad. La mayor parte de la mañana del segundo día la pasan durmiendo porque todos están cansados por el baile de la noche. Algunas veces sirven comida, mientras que la bebida constantemente pasa alrededor para ofrecerse a los hombres. Ellos no pueden rehusar la bebida y tienen que, tomar todo lo que hay en la tutuma. Algunas veces ellos la pasan a sus esposas e hijos en la esperanza que ellos terminen lo que queda. Después de

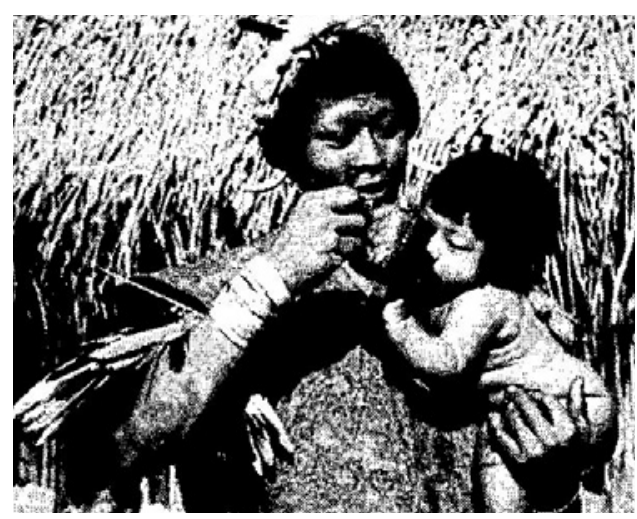

Fig. 43. El hombre Chácobo, muestra mucho cariño por sus hijos. terminar algunas fuentes de esto, ellos no pueden contener más, y entonces salen de la casa, y se meten sus dedos en su boca para producir vómito. Algunos vomitan sin necesidad de meterse los dedos. La gran cantidad de líquido ingerido les hace orinar a menudo, más o menos cada 20 minutos, lo cual hacen en lugares despojados. Los más ancianos son más capaces para beber y no necesitan vomitar tanto. Al contrario, si ellos no vomitan, su borrachera es más acentuada. Los jóvenes procuran estar bailando o tocando las flautas siempre que sea posible para no tener que beber tanto. Los niños de diez a doce años de edad son empujados a entrar y sentarse con los hombres para tomar así como ellos. Generalmente prefieren bailar y tocar sus flautas formando filas aparte. Algunas veces se les permite bailar con los hombres.

De vez en cuando hay algún borracho durante la fiesta, aunque muchas veces no hay borrachera. Todos ellos ríen y gozan por causa de las cosas que el ebrio dice o hace en su borrachera. De repente el hombre se pone violento y quiere pelear. Algunos tienen que agarrarle, y la madre o la esposa se queda a su lado para apaciguarle echándole agua en la cabeza cuando él se pone violento. En pocos minutos más esta violencia pasa, y da lugar a un estado de sopor, y queda sin ánimo, sin fuerzas ni deseos de pelear. Nunca nadie se emborracha antes del último día de la fiesta, y esto sucede porque la bebida está más fermentada. Generalmente la carne se termina mucho antes que la bebida.

La mayoría de las fiestas duran de tres a cinco días; pero cuando se termina la 
chicha, nunca falta que otro hombre de la misma aldea invitante decide que él también quiere dar una fiesta. Entonces él invita no sólo a los hombres de su propio grupo para acompañarle a la cacería, sino también a los hombres del grupo visitante. De igual manera, la esposa del nuevo anfitrión pide a las mujeres de ambos grupos que la ayuden en la preparación. Recién ahora, las mujeres de los dos grupos ya pueden entregarse a la conversación, que es muy lógico entré mujeres.

Si no traen mucha carne para una fiesta, menos bebida se prepara. Cuando la gente de nuestra aldea vuelve de una fiesta de otra aldea, ellos generalmente se quejan y hacen burla de la poca carne y poca bebida que tuvieron. Parece que nunca es suficiente para satisfacer a todos.

Solamente hay un reglamento tabú que hemos descubierto dentro de la fiesta. Cuando las mujeres de la aldea que invita escuchan que las visitas han llegado, les es prohibido caminar por cualquier senda de la selva que les lleva hacia los visitantes, porque si se encuentran con uno de ellos, dicen que estos contraen una maldición y mueren de una clase de enfermedad llamada "manchas de tigre". 


\section{Cuadro de la vida humana}

\section{Preñez}

Parece que los Chácobos no conocen que la menstruación tiene relación con el embarazo. Cuando se les pregunta cómo saben que están embarazadas, ellas dicen que tocándose el estómago. Hay ciertos alimentos tabú para la mujer encinta. Ellas no pueden comer tortuga, porque creen que el niño que va a nacer padecerá de sus testículos hinchados si es varón. Si comen jochi pintado (agouti pecosa), el niño morirá.

Venados, ciertas especies de mono, y otras carnes no se pueden comer. Ellos piensan que algunas frutas de la selva causan enfermedad del hígado y manchas dolorosas al niño cuando la madre encinta las come.

\section{Alumbramiento}

En la selva, el alumbramiento tiene lugar en los claros, o detrás de la casa. La mayoría de las mujeres son atendidas por una amiga que ayuda, o por el mismo marido. Por lo general a los niños de la aldea se les permite contemplar un parto, y todas las madres animan a sus hijas para que observen lo que pasa en este acontecimiento, y ellas a su vez sepan qué hacer cuando les llegue esta ocasión. Los hombres se sientan en el local para charlar hasta que el nacimiento del nuevo hijo es inminente, pero el marido se queda acompañando a su esposa. La madre se sienta en el suelo con las piernas abiertas y los pies cruzados frente a ella. No se pone nada, ni estera ni hojas para recibir al recién nacido. Cuando los dolores se hacen más laboriosos, la mujer que ayuda, se sienta detrás de la madre abrazándola por el abdomen fuertemente y en esto la madre también ayuda a su asistente. Una vez nacida la huahua, el cordón umbilical es amarrado con una pita hechiza de algodón, y cortado con cuchillo o tijeras sin limpiar. La asistente corta el cordón umbilical. Si la placenta no aparece pronto, la madre masajea su abdomen hasta que salga, y una vez que sale, el marido o la ayudante, entierran la placenta. El recién nacido es bañado rociándolo con agua fría de una tutuma. Varias veces durante el primer día se le baña de esta manera.

Al día siguiente la madre trabaja como de costumbre sólo que no corta leña ni hace trabajos pesados. Desde el tercer día ella hace una vida regular y lleva a su nuevo hijo por dondequiera ella va. El nacimiento del hijo no afecta al padre de ninguna manera, excepto por algunos alimentos tabú. El padre puede seguir cazando o pescando pero ni el padre ni la madre puede comer animales ni aves machos hasta que el niño sepa caminar, o en el caso que se enferme y muera.

Un día fui despertada como a las cinco de la mañana por el llanto de un recién nacido. Me vestí, agarré pita y tijeras esterilizadas, y salí. Más o menos a cinco metros de la ventana de nuestro dormitorio, una mujer chacoba había dado a luz detrás de su casa. Entonces ella, su marido, su suegra y todos sus hijos estaban de pie esperándome para 
que yo fuera a cortar el cordón umbilical. Yo había procurado enseñarles a usar un cuchillo o tijeras limpios para este propósito, pero de todas maneras ellos preferían esperarme para que yo lo hiciera, y aprender prácticamente. Cuando estoy en la aldea, siempre me esperan hasta que yo llegue para asistir a las parturientas.

Si una mujer muere durante el parto o poco después, al recién nacido, aunque esté vivo, lo entierran junto con ella. Nunca hemos observado entre ellos el nacimiento de mellizos, aunque un Chácobo me contó que cuando nacen mellizos es costumbre enterrar a uno de ellos, más que esté vivo, porque la madre es incapaz de lactar a ambos.

Nos han contado que una huahua fue enterrada viva, porque no tenía ano, pero otros nos dijeron que el padre lo había hecho porque era niña, y él no la quiso.

Es posible que una mujer pueda lactar a una huahua ajena, pero esto no es lo común. Yo he visto a una mujer amamantar a la huahua de su hermana mientras ésta fue de viaje. Las co-

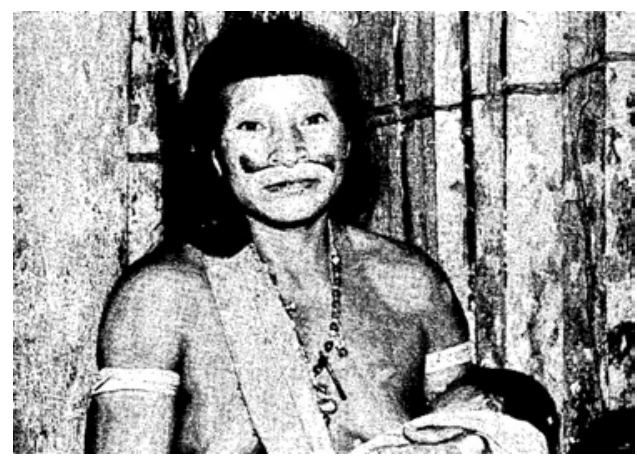

Fig. 44. A veces las mujeres amamantan a huahuas que no son de ellas, pero no con frecuencia. esposas algunas veces hacen también esto. Por el contrario, una huahua murió porque la madre estaba muriendo de tuberculosis y nadie quería alimentar a la huahua.

El niño no es destetado hasta los tres años a menos que nazca el siguiente hermano. Por lo general hay una diferencia de tres a cuatro años entre cada hermano. Se impone la abstinencia a la pareja por dos años después de cada parto. Una madre tuvo un fracaso antes que su primer hijo cumpliera dos años. Ella no admitía la naturaleza de su dolencia, sin embargo todos en la aldea decían que su bebé "cayó." El marido no quería admitir que tuvo relaciones sexuales con ella. Es posible que entré ellos esto sea considerado como un delito.

\section{El nombre}

Inmediatamente al nacimiento sigue el nombre del recién nacido. Los niños llevan el nombre de los abuelos maternos o paternos. Parece que en esto no hay orden de preferencia. Cuando estos nombres ya han sido usados, ponen al niño el nombre del tío

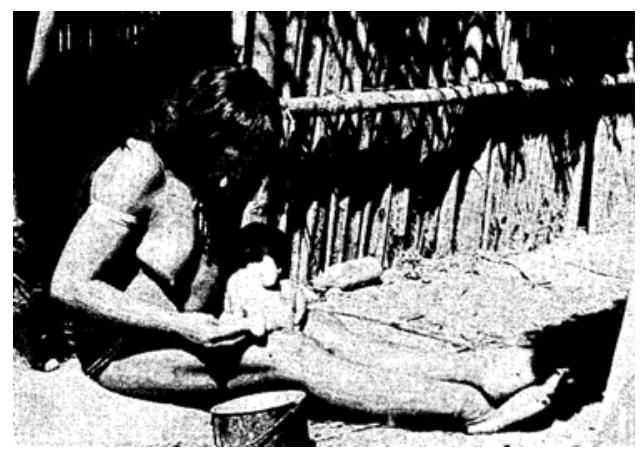

Fig. 45. Mujer Chácobo descansando junto a su hijo. 
o tía. Si un niño muere, es común que el siguiente tome su nombre, si es del mismo sexo. Algunos nombres tienen su sobrenombre. Por ejemplo el nombre Coya tiene sobrenombre Chiba. Los sobrenombres son muy comunes; todos tienen por lo menos uno. Algunos de los Chácobos que han vivido entre gente de habla española, en calidad de esclavos, tienen nombres españoles también, pero nunca lo usan entre ellos.

\section{Pubertad}

La perforación de las narices se lleva a cabo en la edad de la pubertad o antes. Parece más o menos que a los padres les toca decidir el momento cuando se la debe practicar. Los once o doce años de edad parece ser el promedio común. En un caso se la efectuó cuando tuvo lugar la primera menstruación. El niño se sienta en el suelo mientras el hombre perfora el septo nasal con una espina larga de palmera. El niño solloza suavemente por algunos momentos y entonces va a la selva en busca de un palito que inserta en el agujero

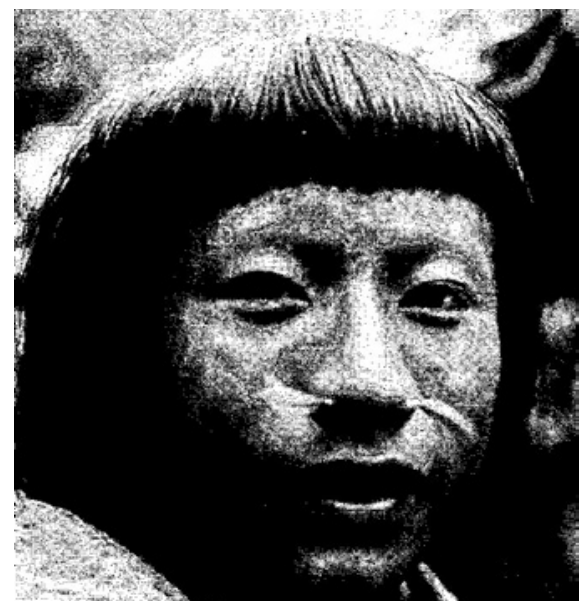

Fig. 46,47. Rostros de hombres Chácobo, con su tradicional corte de cabello y adorno de nariz.

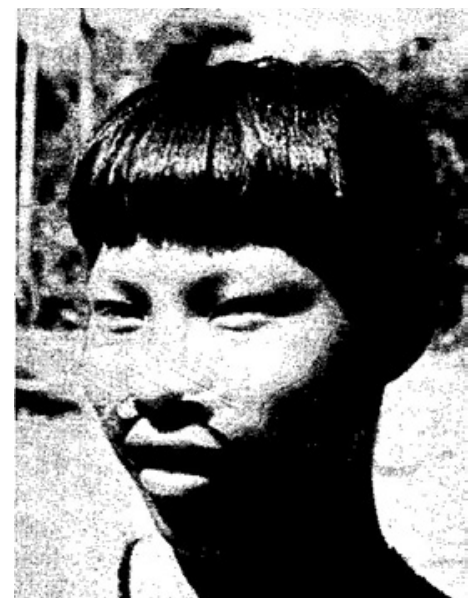

practicado en su nariz. Él tiene que dar vuelta al palito hasta que la herida se cicatrice. El palito impide que el agujero se cierre otra vez. Una vez que la herida está cicatrizada se da al niño un ramillete de plumas de tucán que él insertará en la nariz. No hay-fiesta ni celebración en conexión con este episodio. Otro rito del que fuimos testigos fue con ocasión del período de la primera menstruación. Todos fueron avisados que la chica tuvo su menstruación y todos fueron a la casa para ver la sangre. Fue despojada de sus collares como también de sus adornos alrededor de sus caderas. Su cabello fue cortado al rape, y perforado su septo nasal. Algunos de los hombres se llevaron un manojo de cabello para añadir a sus propias coletas. Su hamaca fue levantada del suelo y preparada a mayor altura en un rincón de la casa. Allí dentro de su hamaca ella tenía que permanecer todo un día. Ni podía comer nada con sangre (prohibida de toda carne y de algunas clases de pescado). Así también no se le permitía beber bebida de yuca en compañía de 
los demás. Sólo podía beber bebida que su madre le ofrecía de una olla aparte. Tampoco había celebración ni festín después de este rito. Cuando su cabello crecía de nuevo hasta los hombros, ella recién podía usar otra vez sus collares y adornos de cadera. Asimismo podía ya usar otra vez su adorno de cabeza. Ella ya estaba en condiciones de madurez sexual.

\section{Matrimonio}

No hay ceremonia o festividad para el matrimonio. Cuando un hombre pretende a una joven por esposa, él pide permiso a su madre de ella o a su tutor. Si el permiso es otorgado, él se muda a la casa de ella. Si un hombre quiere una mujer independizada, solamente le lleva carne para asarla para él. Si ella recibe la carne, entonces él puede considerarse admitido como esposo. Las jovencitas generalmente no se casan antes de los doce a trece años de edad.

La costumbre entre los Chácobos respecto del matrimonio es la preferencia entre primos cruzados. Es decir, que un hombre puede casarse costumbres foráneas, se casó con su prima paralela, a pesar de todo, es decir con la hija del hermano de su padre.

Antes, en un caso similar, un hombre se casó con la hija del hermano de su padre. Cuando los otros hombres se dieron cuenta de este casamiento se irritaron en gran manera. Ellos contaron que ella tenía deseos de ahorcar a su esposo porque lo consideraba como su padre, a causa de su parentesco. Ella sin embargo, no tenía derecho de escoger porque solamente tenía doce años de edad cuando se casó.

La poligamia está permitida y se practica entre ellos. La mayoría de los hombres quisieran tener más de una esposa, pero casi todos tienen solamente una. Cinco hombres tenían dos esposas cada uno. No es bien mirado tener más de dos.

Hemos sido testigos de dos casos de poligamia en nuestra aldea. Un caso fue de dos hermanas con el mismo esposo. Aunque en estas familias abundan los disgustos, discusiones y celos, sin embargo parecen vivir bien. En ambos casos, la segunda esposa causa la mayor con la hija del hermano de su madre, o con la hija de la hermana de su padre. El primocruzado con quien se puede casar, se llama wani, el cual quiere decir esposo o esposa potencial. Le es prohibido a un hombre casarse con la hija de la hermana de su madre, o con la hija del hermano de su padre, las cuales son clasificadas como hermanas. Recientemente un joven, porque conocía las

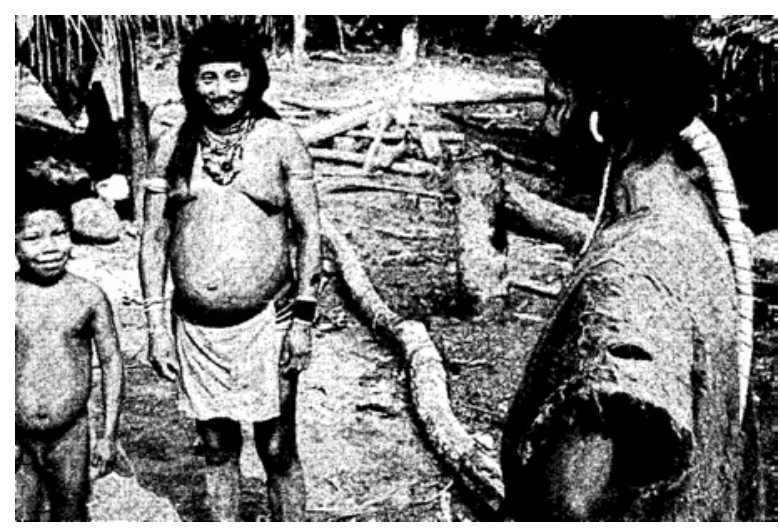

Fig. 48. Una familia Chácobo, en su chaco. 
parte de los disgustos, generalmente no se trata tanto de las relaciones con el marido, sino más bien del trato del marido con sus hijos. Una vez, la segunda esposa amenazó con dejar a su marido y unirse a otro grupo acusándole de no amar a su hijo. Indudablemente había algo de verdad en esta acusación porque hemos visto que éste demostraba cariño a los hijos de la primera esposa, y ningún cariño al hijo de la segunda esposa.

Las co-esposas viven en los rincones opuestos de la casa, y el marido tiene su hamaca en el centro. La primera esposa es casi siempre la preferida. Su marido le trae la carne o el pescado para que ella lo distribuya a la segunda esposa y a los otros en el grupo. La primera esposa también prepara los alimentos que los hombres comen juntos en el local de reunión, y ella sirve también a cada mujer de la aldea. Si el marido trae a la casa un animal más pequeño, lo entrega a ella, y ella da algo solamente a la segunda esposa. El marido generalmente come con la primera esposa.

Durante una fiesta, la primera esposa ocupa un rol más importante que la segunda. Cuando un miembro de la aldea decide dar una fiesta, el invita a todos los otros hombres de la aldea a ir con él a cazar para proveer la carne necesaria para tal ocasión. En el caso que el dueño de la fiesta tiene dos esposas, es la primera quien toma toda la responsabilidad para la preparación de la bebida y de los alimentos. La segunda esposa toma parte en las actividades solamente cuando la primera le invita a hacerlo, es decir, igual que cualquiera otra mujer del grupo. La segunda esposa no tiene un rol importante en las fiestas, mientras que la primera organiza el trabajo de preparar la comida, juntar la leña, llenar las ollas con agua, moler y cocer el maíz o la yuca para la bebida, asar la carne, etc. Toda la carne la asa en su propio rincón de la casa, y en el fogón de su propiedad. Después que la fiesta ha comenzado, ella sirve la comida a todas las mujeres.

No es común que haya entre ellos relaciones extra-maritales, pero una vez, en nuestra aldea, se supo que un hombre tenía relaciones con una joven casada. El marido de la joven acusó al otro delante de toda la aldea, pero él lo negó. Entonces el marido comenzó a castigar a golpes fuertemente a su joven esposa. La madre y la hermana del marido trataron de intervenir para proteger a la joven. Después de castigar a su esposa, él peleó con el presunto adúltero. Solamente las madres de ellos dos pudieron calmarles. Después de todo esto, el marido de la joven fue alejado del resto de los hombres, probablemente a causa de haber golpeado a su esposa. El otro joven siguió en sus actividades como si no hubiera pasado nada, y los demás se comportaron con él de igual modo.

En otra ocasión dos jóvenes solteras pasaron una noche en la selva con dos hombres jóvenes casados de una aldea vecina. Aunque las dos se casaron después con estos jóvenes, los cuales eran sus primos cruzados, fueron castigadas por haber tenido relaciones sexuales antes de casarse.

El divorcio es común entre ellos. Muchos hombres Chácobos cuentan que han 
botado a una o dos esposas. Una vez, una mujer botó a su marido porque él la había castigado. Ella escapó al día siguiente, volviendo a su propia aldea. El no pudo convencerla que volviera con él, aunque le suplicó. Si un hombre se divorcia de su mujer, los hijos menores de cinco años se quedan con la madre, y los de cinco años para arriba, se quedan con el padre. Si vuelve a casarse el hombre, la nueva esposa a veces no quiere criar a los hijos de la primera esposa, y tiene derecho de rechazarlos. En tal caso, los hijos se quedan con la abuela paterna.

\section{La Ancianidad}

La vejez es digna de respeto entre los Chácobos. Ellos piensan que los ancianos tienen poder de hechicería, y a causa de esto, les temen y respetan. Las ancianas también gozan del respeto y consideración y sus hijos y nietos las socorren en sus necesidades.

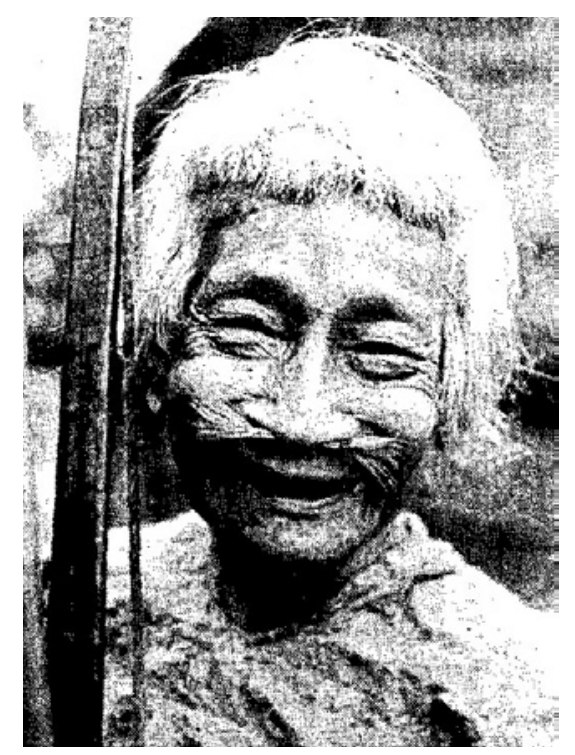

Fig. 48. la vejez es digna de respeto.
Por las tardes se puede ver a un niño sacando las canas o los piojos uno por uno de la cabeza de su abuela. Aunque las viejitas no los acompañan en los viajes largos, por ejemplo, visitando otra aldea, sin embargo ellas son las mujeres más ocupadas de toda la aldea. Sus años de experiencia les dan habilidad para hacer mejores canastos, ollas de barro, hamacas, y otros artefactos, y ellas pasan muchas horas cuidando a sus propios nietos. Si una anciana se enferma y está imposibilitada para recoger su leña las otras mujeres le llevan uno o dos pedazos de su propio montón cada día hasta que se sane.

\section{Enfermedades y Medicinas}

Los Chácobos sufren de paludismo, tuberculosis, disentería, infección de ojos, resfríos y gripes, reumatismo, dolores de dientes y forúnculos. Sabemos de dos casos de epilepsia. Toda enfermedad se atribuye muy rara vez a causas naturales, y por lo general es atribuida a la acción de espíritus malévolos o por haber quebrantado un tabú, o por una maldición impuesta al paciente por el hechicero de otro grupo, o por alguna otra persona.

A menudo los Chácobos usan sus propios remedios al mismo tiempo que remedios modernos que nosotros les hemos proporcionado. El hechicero es llamado para cuidar a los enfermos graves, pero cualquiera puede hacer las veces de practicante con las enfermedades simples de la tribu.

Las huahuas débiles y enfermizas son tratadas por insuflación. Algunas personas, hombres o mujeres de la tribu, 
son autorizadas por el hechicero para practicar este método de insuflar. El que insufla toma la huahua en sus brazos, y echa su aliento sobre ella de largo a bajo en el lado de la espalda, por espacio de más o menos media hora. Generalmente esto lo hacen las mujeres. Dicen que si no soplan, la huahua sufrirá espasmos y su espaldita se quebrará.

Para la diarrea, hacen una bebida mezclando con agua el jugo de la corteza de ciertos bejucos: tsánona, y ponochi. Esta es una bebida muy amarga.

Para tratar las hinchazones usan raspaduras de corteza de bejuco blanco con la cual frotan la parte afectada. La corteza, tanto como las hojas de verbas -cum las usan para estos casos.

Para aliviar dolores en general, usan las hojas de macororó, (un arbusto), colocadas en agua caliente y después las sacan para apretarla contra la parte afectada. Las hojas de urucú sirven asimismo para este propósito.

Para afecciones al pecho, toman la "paja cedrón" a manera de té. Las hojas de limón cocinadas la dan como té para el dolor del estómago. El jugo de un bejuco, boá, se toma también para dolores del estómago.

Aprovechan el tallo del palo cedro cocido y hacen una bebida amarga que usan en el tratamiento del hígado. También la raspadura de un árbol, tararí\} es cocida y hacen una bebida igualmente amarga para la misma enfermedad.

Para las infecciones de los ojos, usan la leche materna, la que exprimen arrojándola con fuerza a los ojos. Un bejuco que crece en el suelo, biro nihi, tiene una savia que se usa también en el tratamiento de los ojos, de igual modo sirven la savia del bejuco kibo xamawa.

Para el dolor de dientes, usan las raíces de una planta pequeña llamada nibosa en Chácobo. Se coloca en la carie dental.

Cuando un gusano mina la piel, el tratamiento es el siguiente: se deja caer la savia de las hojas de cierto árbol, piri, y soplan exprimiendo con los dedos hasta que el gusano sale.

Dolores de cabeza y del estómago curan aprensando el lugar dolorido.

Para heridas, la raspadura de corteza de un árbol grande, wasi canó, y cama, se mete en la herida; también las hojas de la planta rarama se ponen masticadas a la herida.

A los niños flacos se les aplica por todas partes hojas de un árbol, pavo, que han sido remojadas y frotadas en agua. Entonces, las madres soplan sobre ellos. Piensan que este método es bueno para engordarlos.

Usan la sangre del anta para recuperar la salud. Una sola vez hemos visto una ceremonia de baño de sangre, y cuando le preguntamos a un Chácobo de otra aldea, acerca de esto, él pareció ignorar todo. Una noche, poco después de la puesta del sol, uno de los hombres escuchó a un anta en la selva. Dos de ellos salieron y la mataron, volviendo para avisar a los demás que el animal fue muerto. Todos, hombres, mujeres y niños empezaron a prepararse para ir a verlo y ayudar a traer la carne.

En esta ocasión decidimos ir también nosotros, y les ayudamos alumbrándoles la senda con nuestra linterna de gasolina. Después de haber caminado 
como veinte minutos hacia el interior de la selva, encontramos al anta muerta. Para entonces la noche había avanzado y estaba muy oscuro, y empezaron relámpagos y truenos, lo cual daba un aspecto tenebroso a la escena que íbamos a presenciar. Después de narrarnos como habían ultimado al animal, los cazadores se inclinaron para abrir el anta por la barriga. Mientras tanto la sangre había empezado a coagularse. Entonces todos convinieron en insinuar a uno de ellos a quitarse su vestido de corteza y bañarse en la sangre.

Solamente hacía dos meses que nosotros estábamos con ellos, y no comprendimos mucho el alcance de lo que estaba pasando, pero lo que sabíamos era que el hombre estaba enfermo. Este se desvistió, se agachó y con sus manos se bañó prolijamente con la sangre, frotándose la cara, el cabello, y el cuerpo, todo hasta los dedos de los pies. Cuando terminó, una de las mujeres se quitó sus collares y demás adornos, y se baño de igual modo. El marido de esta mujer era quien mató al animal, y él le ayudó a ella a bañarse con la sangre del anta. Nos dijeron que las dos personas que se bañaron en la sangre, estaban enfermos. El hombre que se bañó, padecía de tuberculosis, aunque respecto a la mujer, no estábamos seguros de su enfermedad; posiblemente estaba enferma antes que llegáramos. Tan pronto como terminaron de bañarse, trozaron al animal, y cada uno puso algo en su canasto y todos volvimos a casa. Las dos personas que se bañaron permanecieron así hasta el día siguiente en que se bañaron y limpiaron con agua. Todos comieron la carne del anta.
Los Chácobos tienen mucho miedo a la enfermedad porque el porcentaje de mortalidad es muy alto. Con el miedo a la enfermedad, parece estar relacionado el miedo al agua. A los niños se les prohíbe entrar al agua si hay en la aldea un niño enfermo, o si alguien ha muerto recién. Mas, si no hay enfermedad en la aldea, a los niños les gusta nadar y jugar en el agua cada día. Cuando un niño se está recuperando después de una enfermedad, no se lo baña hasta muchos días después.

En el año 1957 por la primera vez, un Chácobo de nuestra aldea se resfrió. La palabra que ellos usan para resfrío, es natí que quiere decir matón. Habíamos salido de la aldea unos días, y al volver, cada persona estaba padeciendo de un fuerte resfrío. Dentro de una semana, casi todos tenían neumonía, y cuatro de ellos murieron, aunque habíamos repartido muchas píldoras, y puesto muchas inyecciones de antibióticos, Durante esta epidemia, notamos que cada enfermo se preocupaba mucho de sí mismo, y aún los que estaban levemente enfermos ni siquiera han procurado ayudar a los que estaban en condiciones muy graves. Las mujeres que se habían debilitado tanto que no podían andar sin ayuda, no recibieron ninguna ayuda de los parientes que estaban casi sanos. Se sentían todos tan mal que no han recogido leña, ni preparado alimentación, aunque algunos bien podían haberlo hecho. Parecía que todos esperaban la muerte como una cosa inevitable.

Una persona enferma se queda siempre en la hamaca y generalmente tiene un fuego ardiendo debajo de su hamaca. 
Puede uno fácilmente darse cuenta si en una casa hay un enfermo, porque de inmediato advierte el fuego ardiendo debajo de la hamaca.

Una madre tiene siempre una gran preocupación cuando su huahua no quiere mamar. Esta es una señal de enfermedad grave.

Una vez llamaron al hechicero para que observara a una niña enferma del dolor del hombro. El vino de noche, y en medio de la oscuridad él empezó a succionar en su cuello. Esto hizo él por espacio de más o menos veinte minutos y a intervalos él escupió sangre. No había ninguna señal de herida donde él había succionado, y todos los espectadores estaban seguros que la sangre era de la niña.

Cuando una mujer sufrió un aborto involuntario, se llamó al hechicero para verla. Él le dio una taza de agua con sal para que la bebiera. Entonces él escupió en el estómago de ella y lo frotó por largo tiempo. Después descansó brevemente para empezar de nuevo. Todo esto él hizo con el propósito de detener la hemorragia.

\section{Muerte y Sepelio}

La muerte siempre causa mucho temor, reverencia y luto entre los Chácobos. Generalmente esto ocurre mientras el enfermo permanece en su hamaca, pero tratándose de los niños, casi siempre mueren en los brazos de su madre. A la muerte sigue el sepelio que ocurre dentro de las. 24 horas y el lugar indicado es dentro de la casa. Por lo general está enterrado debajo del lugar donde el finado solía dormir. Si una persona de una aldea se muere en otra, la entierran en la selva cerca de la aldea que visitaba. Hubo dos casos de esto en nuestra aldea, los cadáveres fueron sepultados en la antigua aldea que hoy prácticamente es selva, y a unos 60 metros de la actual. A veces un techo pequeño cubre la tumba a modo de protección. El cadáver es colocado en posición fetal, envuelto en un vestido de corteza y revestido de su hamaca. Se practica la sepultura en un agujero de $50 \mathrm{~cm}$. más o menos de profundidad y el cadáver es sepultado acompañado de sus pertenencias más preciosas (collares, adornos de cabeza, faja de brazo, y mosquitero). Una vez cuando se murió una huahua, el padre descendió al agujero primero, cantando a manera de oración, y llorando. Entonces tomó al muertito y lo colocó dentro. Cuando taparon el agujero, la madre con signos de especial ternura aplanó el lugar y lo barrió. Apenas ocurre el deceso toda la familia empieza a llorar y lamentarse en alta voz. Esto sirve de aviso para los demás y pronto llegan casi todos los miembros de la aldea, y se suman a la lamentación que se convierte en un lloro general. La familia continúa llorando por espacio de tres días al mismo tiempo que cumplen con sus labores cotidianas. Después de enterrar al difunto, la familia rompe y deshace las vasijas y destruye totalmente los vestidos y las demás pertenencias del muerto. Hasta las plantas de papaya y algodón que a él pertenecían son cortadas, y a veces hasta matan los animalitos que fueron sus regalones. Los parientes parecen estar muy enojados cuando hacen esta destrucción, probablemente este enojo es hacia los espíritus enemigos que según ellos han causado la muerte.

En cierta ocasión cuando un niño murió, 
el padre puso taburetes encima del sepulcro y los cubrieron con vestidos de corteza. Entonces la familia salió de la casa y durmió fuera de ella, diciendo que ellos querían descubrir en la mañana siguiente las huellas del espíritu impresas en la sepultura. Al siguiente amanecer, ellos no encontraron ninguna de las huellas que esperaban, y volvieron sencillamente a la casa.

En una ocasión una mujer de otra aldea murió al dar a luz y su muerte se atribuyó al hechicero de nuestra aldea. Se supo que uno de los indios de su aldea mataría al hechicero cuando él fuera a presentar su pésame, pero conociendo esta intención, varios hombres de nuestra aldea fueron primero, y al llegar a la casa del finado, apenas al minuto arrojaron sus flechas al suelo y los dos grupos de hombres empezaron a pelear cuerpo a cuerpo. Después de unos momentos, ellos cesaron de pelear y comenzaron a dar vueltas alrededor del sepulcro, cantando y gritando. Y una vez más empezaron a pelear en el mismo estilo. Así de igual modo se detuvieron para recomenzar el canto y los gritos. Entonces todos se sentaron dentro de la casa y se miraron uno a otro con conversación de pocas palabras. Todo eso era hecho a la manera de un rito. Entonces los hombres de nuestra aldea volvieron a sus casas. Algunos días más tarde, el hechicero fue con la mayoría de los hombres de nuestra aldea, con más mi marido, a la casa del finado. El hechicero parecía no tener miedo, pero todos los demás se quedaron atrás y no entraron a la aldea. Ellos estaban listos con sus arcos y flechas preparados para proteger al hechicero en un caso dado. Sin embargo todo terminó en paz, y el hechicero volvió incólume.

De vez en cuando queman la casa después de un funeral, y la levantan en un lugar nuevo. Más parece ésta una costumbre antigua que tiende a desaparecer en nuestra aldea, porque ya van nueve años que no ocurre esto otra vez entre nosotros. Nos han contado que esto sigue sucediendo en otros grupos. Una vez todos los indios abandonaron nuestra aldea por varios meses después de la muerte de dos mujeres. Ellos acamparon en la selva a una distancia de veinte minutos a pie de nuestra aldea.

Las mujeres chacobas durante el luto se despojan de sus cuentas de adorno y no se pintan con urucú. Los hombres se quitan sus aretes y cuentas durante este período de luto que puede durar varios meses.

Inmediatamente después de un deceso, se designan dos hombres para ir a informar a los habitantes de otras aldeas. Si los otros grupos están situados a un día de camino, ellos vienen de inmediato a presentar su pésame. Una vez sucedió que un Chácobo de otra aldea vino a avisar a nuestro grupo acerca de la muerte de una persona. Al escuchar estas noticias, la más anciana del grupo empezó a gritar y cantar en alta voz. Después de más o menos cinco minutos ella de repente dejó de gritar y continuó charlando con la visita. Entonces toda la aldea preparó sus cosas y fueron a presentar su pésame. 


\section{El Instituto Lingüístico de Verano y los Chacobos Quince años de desarrollo de comunidad}

Hace 15 años, cuando el Instituto Lingüístico de Verano llegó a Bolivia, los Chácobos formaban un pequeño grupo nómade, casi desnudos, indios, llevando una vida aislada, escondidos de los civilizados. Viajaron por la selva siempre en grupos; cuatro grupos, en busca de frutas tropicales y nueces, y viviendo especialmente de la pesca y de la caza, usando para ello arcos y flechas. Ubicaron sus campamentos donde no había otra gente, y donde la caza abundaba para sostenerse. Construían sus viviendas a poca distancia de un arroyo. Establecían su campamento, pero si bolivianos ocupaban también estas mismas regiones en busca de nueces o goma, entonces los Chácobos empaquetaban sus cosas y salían en paz de estos lugares, para levantar de nuevo su campamento en otro lugar más aislado. En el año 1955, Gilberto Prost, del Instituto Lingüístico de Verano, efectuó el primer contacto de amistad con los Chácobos, los cuales lo aceptaron a él y a Mariana, su esposa, para convivir con ellos en uno de sus campamentos. Les permitieron construir su casa e inmediatamente Gilberto y Mariana empezaron el trabajo largo y penoso de aprender la lengua chacoba. Sólo uno o dos de ellos hablaban castellano, siendo monolingües la mayoría. El grupo con el cual vivieron los Prost se quedaron en el mismo lugar unos diez años y al cabo de ellos, los hombres Chácobos tuvieron interés en el comercio de la goma e hicieron planes para trasladarse a lugares donde la goma fuera abundante. Durante esos diez años, los otros tres grupos se habían cambiado de sitio varias veces. Gilberto fue a visitar al grupo del Río Alto Ivón, y allí se encontró con un boliviano que les ofreció vender sus intereses, compra que se efectuó casi de inmediato, porque los Prost querían unir a todos los grupos. Por eso, convencieron al grupo con el cual vivían, para trasladarse hasta este otro grupo que habitaba en el Río Alto Ivón. Al año siguiente, un tercer grupo se les reunió en este lugar, y ahora recién Gilberto podía empezar a realizar su sueño, o mejor, su plan para ayudarles en el desarrollo social y económico.

Para que pudieran abandonar su vida nómade, y alcanzar a ser ciudadanos bolivianos productivos, los Prost presentaron al gobierno un mapa de la región donde vivían los Chácobos para solicitar al Supremo Gobierno la cesión legal de estas tierras a estos hombres de Bolivia-los Chácobos. El Presidente de la República lo concedió ampliamente, en el año 1965. Ahora se espera que estos trámites legales lleguen a su más feliz finiquito, y sean legal y oficialmente

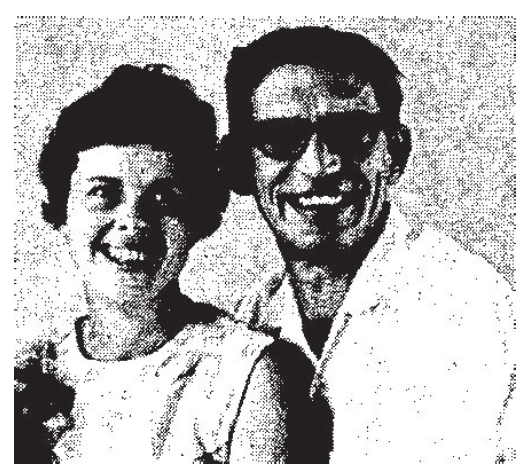

Fig.48. Marian y Gilberto Prost 


\section{Marian D. Prost, 1970. Costumbres, habilidades y cuadro de vida de los Chácobo}

registrados para los ciudadanos Chácobos de Bolivia.

Esta cesión de tierra ha sido la cosa de más importancia en el desarrollo socioeconómico de los Chácobos hasta ahora. Esta es la razón por qué los Chácobos sienten ahora una seguridad que nunca tuvieron antes. Como corolario lógico tienen ahora oportunidad de ganar la vida por medio de la recolección de la goma. Los comerciantes en Riberalta han provisto un buen mercado donde vender la goma, y así los Chácobos han mejorado su manera de vivir. Han abandonado su vida nómade, y ya pueden cultivar productos más adecuados; también poseen rifles con qué cazar, se ponen ropa; tienen mosquiteros, y mantienen una tienda donde pueden adquirir las cosas necesarias para su nueva vida.

Gracias a la ayuda de Gilberto Prost y el programa de Extensión Agronómica del Instituto Lingüístico de Verano, los Chácobos han adquirido algunos ejemplares vacunos de buena raza. $Y$ empiezan también a criar chanchos, gallinas, y patos. Han construido cercos a fin de proteger sus animales para que no salgan lejos y no entren a la pista. Han limpiado varias hectáreas de terreno y han sembrado pasto para proveer forraje para estos animales. La mayoría de las familias chacobas tienen ahora interés en participar en este programa agropecuario como fuente de vida y economía. Recientemente el Sr. Herbert Brussow, agrónomo del ILV, les visitó durante varios días para entrenarlos en el cuidado de sus animales, enseñándoles a colocar vacunas, etc.

Los pilotos del ILV han llevado estos animales en aviones Helio Courier hasta el campamento en el Río Alto Ivón. Asimismo han llevado goma al mercado relacionado con los Chácobos en Riberalta. Aunque este medio de transporte aéreo sea un método un tanto caro, sin embargo, es hasta ahora el único que ofrece ventajas a los lingüistas que no disponen de mucho tiempo, puesto que el objeto principal de ellos es el conocimiento y la práctica del idioma autóctono.

Los Prost han preparado unos 14 textos de alfabetización y lectura en la lengua chacoba, y han procurado enseñarles a leer y escribir. Aunque al principio los Chácobos no tuvieron mayor interés en el aprendizaje de la lectura ni de la escritura, pero ahora sí lo tienen. Algunos Chácobos bilingües asistieron a un curso especial para entrenamiento de maestros bilingües que se llevó a cabo el año pasado en Tumi Chucua, sede del Instituto Lingüístico de Verano en Bolivia. Actualmente contamos con una escuela en donde 35 niños Chácobos se inician en la instrucción en su aldea. $Y$ aún el mismo profesor es un Chácobo que egresó de dicho curso. Otros cinco niños están internados en una escuela boliviana de un pueblo cercano y aprenden a leer y escribir castellano, aritmética, geografía e historia de Bolivia. Al mismo tiempo que se relacionan y hacen amigos con sus congéneres bolivianos. Una consecuencia bienhechora de grandes alcances en la vida de esta gente está sin duda en los principios cristianos que ellos beben juntamente en el aprendizaje y en el contacto con los lingüistas. Gracias al cristianismo, son librados de sus creencias supersticiosas, y de estar subyugados al miedo de los espíritus malos. Los hombres se transforman y son buenos trabajadores y probos en sus costumbres y librados de sus vicios antiguos. Y por ende, su situación económica ha mejorado bastante. En fin, se ha realizado un tremendo cambio en sus vidas durante estos últimos 15 años. 


\section{BIBLIOGRAFÍA}

Haenke, Wanda. "Los Indios Chácobos del Río Benicito," Khana, Año V, Vol. 3-4.26-28, (Octubre-Diciembre 1957). Pp. 39-55.

Prost, Gilbert. "Signalling of Transitive and Intransitive in Chácobo (Pano)," IJAL, Vol. 28, No. 2, Abril de 1962. Pp. 108-118

“Fonemas de la Lengua Chácobo," Notas Lingüísticas de Bolivia, No. 2, La Paz; Publicaciones del Instituto Lingüístico de Verano en colaboración con el Ministerio de Asuntos Campesinos (1960). Pp. 1-13.

"Chácobo," Gramáticas Estructurales de Lenguas Bolivianas", Tomo II. 1965. Riberalta, Bolivia.

Steward, Julián, Ed. Handbook of South American Indians. Bulletin of the Bureau of American Ethnology 143, Bol. 1-6, 1946-1950. 


\section{CAPITULO 4}

\section{CHÁCOBO 1970 : EINE RESTGRUPPE DER SÜDOST-PANO IM ORIENT BOLIVIENS \\ HEINZ KELM,1972}

ESTE ARTICULO ORIGINAL ESTÁ ESCRITO EN ALEMÁN, ESTE CAPÍTULO CONTIENE LA TRADUCCIÓN AL ESPAÑOL DEL MISMO 


\section{INDICE}

El destino histórico de lo Chácobo

Los asentamientos y sus habitantes

Vestimenta y joyas

103

Cultivos tradicionales

Caza

Pesca

Actividades generales de colección

Actividades económicas modernas

La extracción del caucho silvestre

Ganado

Artesanía

Transporte

Condiciones sociales

Cuentos registrados en Alto Ivón (Noviembre de 1970)

La vida de Kako

El origen de las plantas agrícolas

La migración de Nowa Pashawa

Del hombre que perdió a su esposa a una Anta

¿Cómo? Mawokuria ayudó a la gente a recibir canastas

La Lucha contra el hampa

La fiesta de los peces

De Sol y la Luna

De rayo y su hija

Del Viento del Sur

¿Cómo¿ Waita trajo una inundación a un punto muerto

Los que nacieron de las calbazas

La mujer perezoso

Desde el Señor de los Peces

¿Cómo? los animales queían visitar el cielo

¿Cómo? la espesa de la serpiente se casó con jaguar 


\section{Chácobo 1970}

\section{Un grupo residual de los Sudeste Pano en el Oriente de Bolivia}

El Chácobo forman parte de los Sudeste Pano que originalmente poblaron el norte, amazónico de Bolivia con varíos grupos fragmentados con un número relativamente grande. En la actualidad, todavía hay 169 Chácobo y una docena Pacaguara que son los últimos quedan del Sudeste Pano.

\section{El destino histórico de Chácobo}

La mayoría de las fuentes históricas usan el nombre "Pacaguara" tanto como un término genérico y por lo tanto sinónimo de Sudeste Pano, así como para identificar a un grupo en particular esto escribe Cardus escribe: "Los pacaguaras estan esparecidos en una extension de terreno muy grande, pero divididos en pequeños grupos, distantes unos de los otros, los cuales adoptan diferentes nombres, como "Chácobos", "Sinabos", "Capuibos", "Caripunas", etc. Los que se conocen como pacaguaras se encuentran en ambas margenes del río Beni, en ambas margenes de la parte baja del Madre de Dios y en casi todo el territorío comprendido entre el angulo que forman el Beni Madera y el hasta el Purus, en una linea Recta. Tienen lengua propia que varia algo según los grupos. "Con respeto a los Chácobo dice "Estos indios son una fraccion de la tribu pacaguara, y hablan la misma lengua, con alguna diferencia". En el mismo sentido se manifiesta Nordenskjöld que identifi- ca a los Chácobo como una" rama de los Pacaguara.

"El Pacaguara" dice Armentia se habla "por las tribus de Chácobos, Pacaguaras, Caripunas, y por las tribus del Ucayali, donde es conocido con el nombre de lengua Pana que se subdivide en varíos dialectos". Asimismo llama a los grupos que viven en el Arroyo Ivón "Chácobos", luego escribe "Pacaguaras de Ivón". Orbigny viajado por el río Mamoré, en 1832, estima que el número de la Pacaguara llega alrededor de 1000, y se refiere tanto al Pacaguara real cuando menciona que el Río Beni es la una zona de su residencia, así como en la Pacaguara en el sentido más amplio. y por lo tanto, inevitablemente, a la medida que él observa, "El Pacaguara tuvo que pasar tiempo en el misiones de los jesuitas. Se puede suponer que esto representa esfuerzos para incorporarlos en la sociedad dominante, y el hecho es que los jesuitas comenzaron su penetración hacia abajo en el Río Mamoré con el establecimiento de la misión de Exaltación de la Cruz (1704). Durante este período, los vecinos del sur del Pano fueron sometidos por la influencia de los Religiosos. El primer intento a gran escala en la cristianización de los nativos de habla Pano en la región del Río Mamoré, sólo se llevó a cabo en el período colonial tardío. Alentado por la noticia de la 
aparente apertura de la margen izquierda del Río Mamoré por debajo de la confluencia del Iténez Pacaguara. Zamora, gobernador de Mojos, planificó iniciar la misión en un pueblo, que recibió el nombre de "Nuestra Señora del Pilar de Pacaguaras ". Al norte de Exaltación, es decir, más abajo en el río Mamoré, como un baluarte permanente.

Don Francisco Xavier Negrete fue enviado por San Pedro de Moxos como primer sacerdote, para llevar a cabo una expedición de reconocimiento. Salió de San Pedro el 6 Octubre 1795, y parece que los Pacaguara fueron fácilmente persuadidos para vivir juntos en un pueblo cerrado. Con la noticia favorable regresa habiendo convencido a nueve Pacaguaras que deberían formar el núcleo duro, al cual se adicionarian otros después. Negrete salió de San Pedro nuevamente el 19 de septiembre 1796 con 27 canoas, cuya tripulación de 25 hombres procedían de las cinco ciudades de la Gobernación Moxos, en esta vez una epidemia diezmó a los Pacaguara y 220 nativos contactados por Negrete murieron, mientras que otros se retiraron por miedo. Solamente quedaron 29 Pacaguaras y 15 Sinabo, por lo que decidieron retirarse, pues no tenia sentido iniciar un acuerdo con un puñado de personas.

El nombre Chácobo fue mencionado primero por Palacios. Él habla de más de 300 Chácobo, entre los que había también algunos de piel blanca y Gibbon, viajó en 1852 por el Río Mamoré hacia abajo y declaró: "El territorío por el que discurre el río Mamoré, está habitada por una tribu guerrera de los indios, llamado Chácobos, que están en constante lucha con el Cayavabos, de nuestra tripulación"

Habla de que evolucionaron a partir de un balance de la antigua misión de Exaltación en 1868. Leuzinger, en sus notas de viaje por la cuenca Mamoré al pasar por la desembocadura del Río Matucare: "en el campo en la orilla izquierda del Mamoré encima de este punto se encuentra habitada por una tribu amistosa con los blancos, el Chácobos. Ellos miran a los restos de los rebaños salvajes en el campo entre el Mamoré y Beni como de su propiedad. De lo contrarío, se sabe poco acerca de ellos, y parece como si hubieran retrocedido cada vez más hacia el interíor desconocido de las grandes llanuras en los últimos tiempos. Mathews escribió unos diez años después de que el Chácobo tenia dos grupos uno hostil al contacto, y otro parte pacífica con los blancos en Exaltación: "la tribu que infesta el lado derecho o del Brasil se llaman "Siríonos, y los de la izquierda o la banca boliviana son Chácobos" Cardus en sus informes de 1884 habla de contactos pacíficos entre Chácobo y Cayuvava, e indicó que, en vista de la situación desolada de las antiguas misiones jesuíticas de Mojos, los Chácobo prefieren claramente su vida la independiente a la civilización. "Varíos de ellos son mansos, y algunos acostumbran salir todos los años a durante la fiesta Exaltación, en donde 
también suelen proveerse de alguna herramienta... Los Chácobos han sido varias veces convidados para que se hagan cristianos, pero al ver la vida y de los situacion de los mojenos, parece que se les han quitado tales ganas, si alguna vez que las han tenido. No se sabe hasta ahora que los Chácobos hayan hecho daño a nadie, solo se sabe que varíos indios cristianos de Exaltación se han huido del pueblo y escondido entre ellos para vivir de la misma manera". Con respecto a las zonas residenciales de los Chácobo, Cardus señala. "Ellos viven en grupos pequeños, y estan ya tres dias de camino de Exaltación, entre el lago Rogoaguado y el río Mamoré. Parece que algunas de familias Itenes se han establecido tambien en la banda del izquierda Mamoré, entre el pueblo de Exaltación y entre los indios Chácobos y sinabos, tribus de las cuales son enemigos. Los Sinabos son una pequeña fracción de Pacaguaras, y con poca diferencia hablan la lengua de los Chácobos, sus parientes, de quiencs son enemigos, aunque tienen las mismas costumbres.

La orilla norte del lago Rogoaguado y las cabeceras del río Yata junto a sus afluentes forman el centro de la zona habitada por los Chácobo. Aquí fueron visitados por primera vez por un etnólogo. En 1909, Nordenskiöld, que vino por el Río Mamoré y en su resumen dice: "Con los Chácobo llegamos a conocer a una pequeña tribu india más independiente, ellos me han impresionado gratamente, sin embargo, yo no llegué a conocer bien la vida real de estos indios, ya que ellos son desconfiados con los hombres blancos,

$Y$ viven en una zona que está rodeada por todos lados por cercos y no podiamos ver lo que realmente sucedia con ellos, y presenciar así sus actividades diarias, realmente no fuimos bienvenidos es su aldea.

Ya a mediados de los años ochenta del siglo pasado, la explotación de los depósitos de caucho silvestre comenzó no sólo en los grandes ríos Madera, Madre de Dios, Beni, etc, sino también sus tributaríos. La búsqueda de Siringales con gran cantidad de árboles de caucho, requiere una penetración intensiva y la exploración de esta parte de la Hylaea condujo inevitablemente a repetidos contactos con la población indígena local.

El "Terreno Baldío" que estaba sin explotar, y como tal no se ha reconocido legalmente la propiedad de estas tierras. La propiedad viene con el derecho a la existencia de un Siringal. El derecho hereditarío del indígena americano, por realizar dentro del territorío actividades de la siembra, caza y pesca no tenía relevancia alguna. Esto dió que los indios ya sea voluntariamente o forzados tuvieran que ceder sus territoríos. Las consecuencias fueron la pérdida de su base principal de subsistencia, el deteríoro de las condiciones de vida, las enfermedades, etc. El ceder su territorío a la presión externa, generó mayores conflictos sangrientos inter tribales. 
Dominando un espléndido remanso del Río Beni, Tumichucua es una colonia norteamericana muy cómoda fundada por el Instituto Lingüístico de Verano, como un asiento de Bolivia. Aquí hice el intento junto a mi esposa en junio de 1970 para llegar a los Chácobo en Arroyo Ivón, nuestro viaje fue frustrado por dos de los misioneros lingüistas pertenecientes al Instituto. Estos, un capitán Porter y un cierto Arsh, inicialmente alegaron que la poliomielitis espinal estaba muy extendida entre los indios - y la verdad era que no había habido un solo caso de meningitis - el cual mostraran como obstáculo para la visita. Ellos rechazaron nuestras peticiones de un vuelo charter a los Chácobo, la conducta que habría sido en virtud de su licencia era de vuelo comercial, y además el Arroyo Ivón no era navegable. Después de una pérdida considerable de tiempo, fuimos a ver al Director del Instituto, quien fue más más razonable y nos ofreció una visita a los Chácobo en noviembre, lo que dejó sólo diecinueve días de observaciones y encuestas.

No debe dejar de mencionarse que el desafortunado incidente mencionado tuvo poca aprobación de la autoridad boliviana, quienes lamentaron la conducta mostrada por los diferentes miembros del Instituto que nos recibieron con poca hospitalidad.

\section{Los asentamientos y sus habitantes}

Las necesidades de abastecimiento de agua y al mismo tiempo las posibilidades de pesca y transporte son los principales factores que tienen los Chácobo para crear sus asentamientos en las inmediaciones de un curso de agua (HeNe). Y siempre buscan un nivel relativamente alto al punto de la orilla, reduciendo

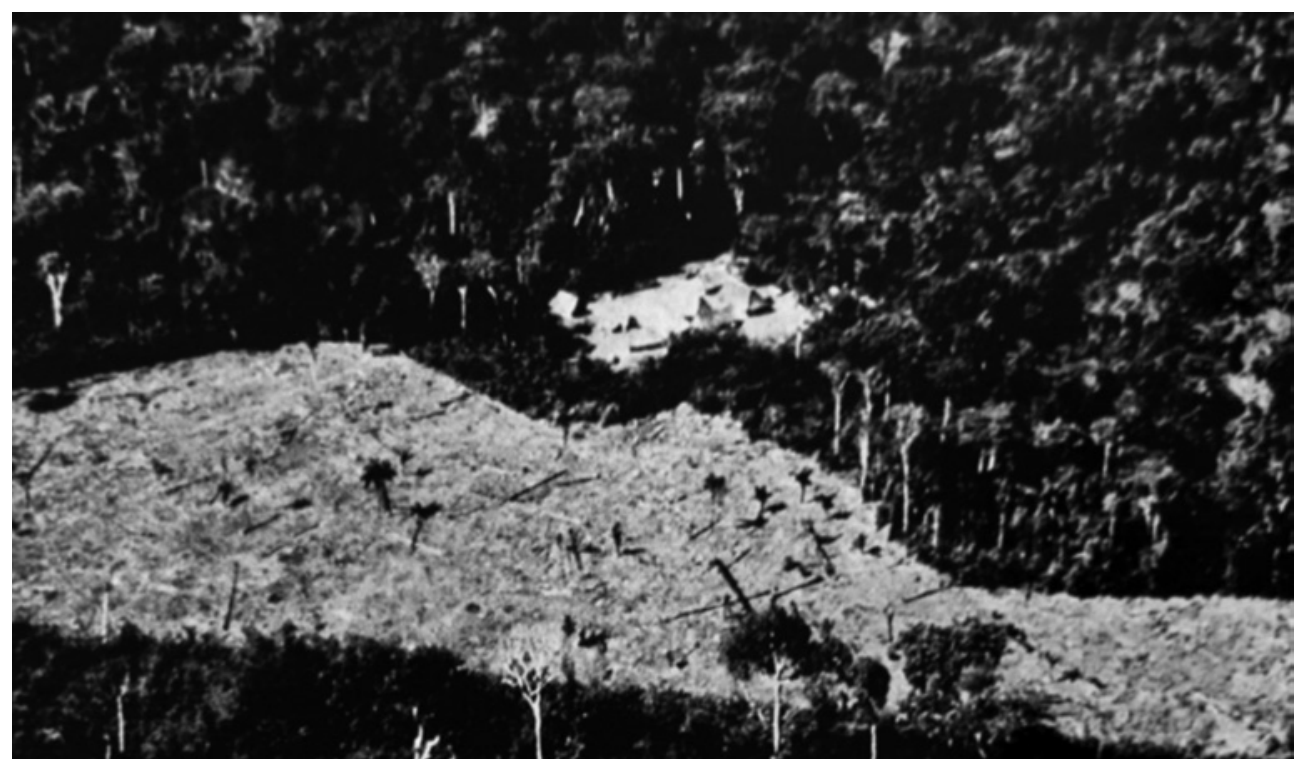

Fig. 1. Asentamiento Chácobo de Alto Ivón 


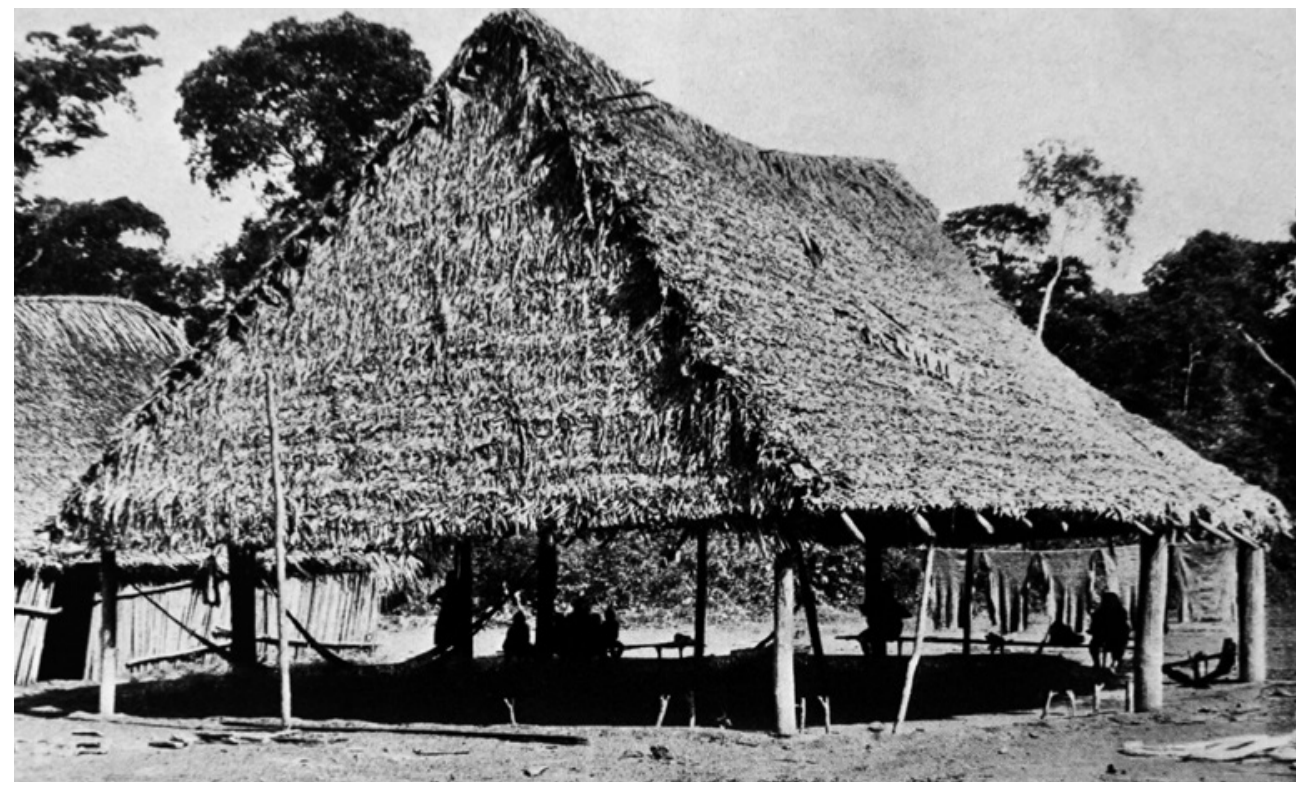

Fig 2. La casa de los hombres, es muy amplia, de forma octogonal y sin paredes y es el centro tradicional del grupo

con ello el riesgo de inundación temporal. Sus viviendas de los Chácobo están siempre en el bosque (ni'i).

Alto Ivón, que, como su nombre indica, se encuentra en la parte superíor de arroyo Ivón es un conjunto de ocho casas que se construyeron juntos a 70 metros de la orilla en un claro despejado. Detrás del borde de tocones quemados, está la selva virgen, con algunos de los árboles de castaña.

En el centro del espacio de vida se eleva casa de los hombres. Edificaciones que Nordenskiöld también las describe que cumplían la misma función. Él llama a estos "casa de reunión", y "casa de beber". El Chácobo distingue muy bien entre la shobo Honi, casa de los hombres, y la shobo yosha, refugio para mujeres.

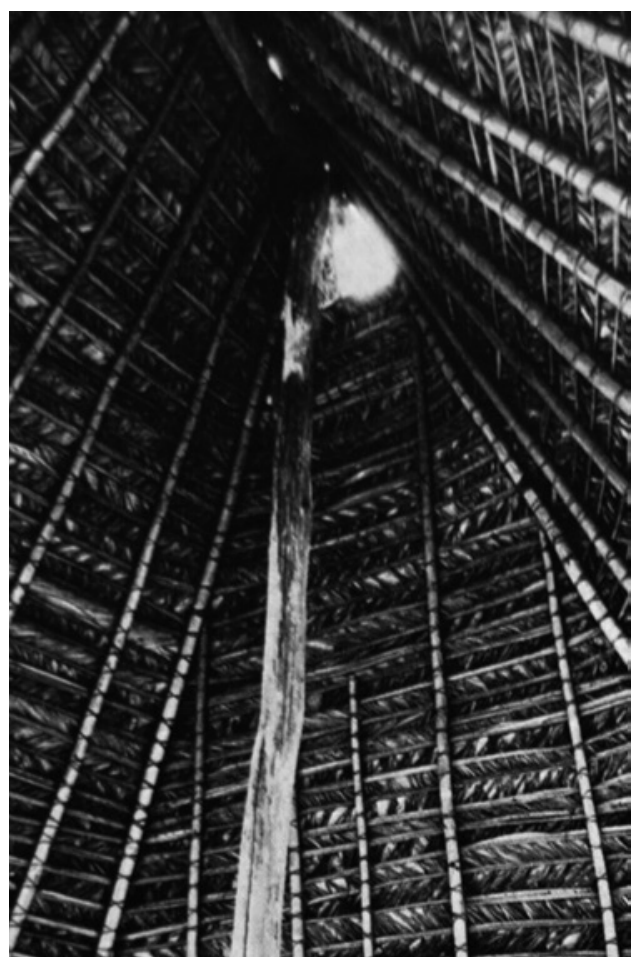

Fig 3. Detalle de la estructura de la casa, vista interior. 
Estructuralmente, las casas de los hombres se caracterizan por una planta octogonal, la falta de paredes y la altura majestuosa. Casa de los hombres de Alto Ivón, está orientada de norte-sur y tiene una altura de seis metros. Es de doce metros de largo y siete metros de ancho, pero la distancia entre los postes de las caras es solo de seis metros. Al igual que las casas de los otros asentamientos de los hombres que sus proporciones son casi igual de tamaño con los mencionados por Nordenskiöld. En la Casa de los hombres los locales tienen el derecho de utilizar dos puestos específicos, entre los que cuelgan su hamaca.

En la línea central de los lados largos, a unos dos metros de distancia de la frontera de los lados estrechos, están colocados dos postes altísimos (hiwame, naniti) en cuyo extremo superíor se forma una horquilla (hiwasheta), donde

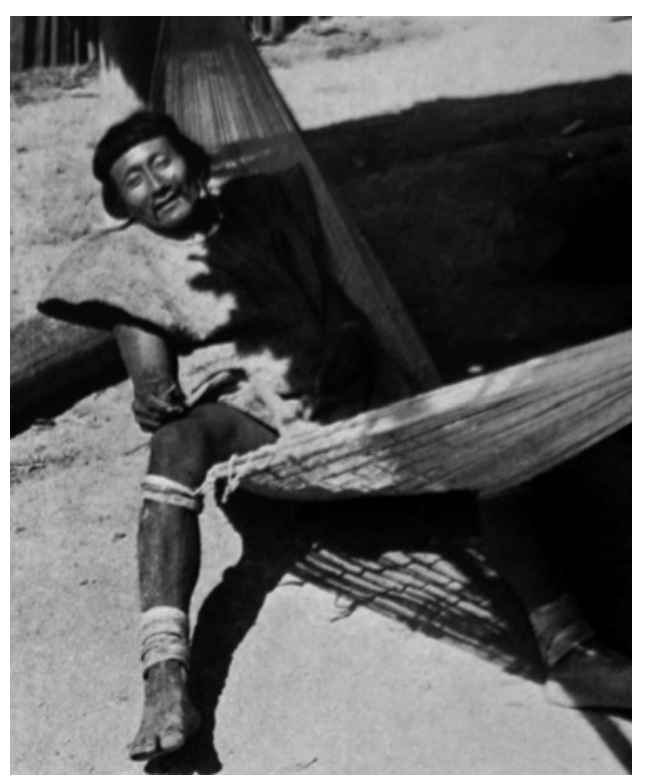

descansa la viga cumbrera (marakati). Las vigas de soporte (pishkend) de la parte central de los lados largos se distinguen por su diámetro considerable. Descansan en particular gruesos postes de dura y pesada Itauba (sinisiti). La cubierta de la madera (mdati) y techo (shepame) se compone de elementos de hojas de palmera motacú y alternativamente de hojas de Heliconia. Por su apego a las correas de los lados longitudinales y estrechas (kano, wepoto), que están conectados en sus extremos inferíores por barras o varillas (shobo Shitao, Weseke) que utilizan agujas hechas de madera de palma (ro'osheti). $Y$ para atar usan el material de fibras de piraquina (shawi) y para unir las vigas estructurales, utilizan lianas fuertes. Después de tres años ya el techo necesita ser renovado, porque se encuentra deteríorado.

Su muebles constan sólo de unos pocos asientos. Actualmente raras veces se hacen. Cuatro bancas de madera de balsa con un asiento de secciones de Tallo de palma (sa'uti), y bancos de uno o dos bloque con el apoyo de las vigas transversales.

Las mujeres entran en casa de los hombres para hacer limpieza y se sientan con sus hijos de vez en cuando en el borde de los bancos mencionados, pero siempre son desalojadas cuando hay visitantes extranjeros, hay discusiones o los hombres de dedican a beber Tschitscha. Aunque hoy en día no se puede saber a certeramente, pero podemos suponer

Fig 4. Los hombres Chácobo, tienen designado su lugar especial para sus hamacas, donde descansan. 
que anteríormente la casa tenía una función cultural muy marcada, pues era usada para celebrar sus fiestas y no solamente para beber Tschitscha. Los instrumentos musicales invariablemente se mantienen bajo el techo de la casa de los hombres. Curíosamente, Hanke no mencionó una Casa de los Hombres, y Prost escribe: "Un espacio que se usa a veces para reuniones especiales" no puede haber ninguna duda de que la Casa de los Hombres es el centro social tradicional del grupo. Construida con cuidado, espaciosa y torres fuertes que satisfacen el orgullo Chácobo y hacen que el sbaita shobo o shobo shobo, la grande, la muy grande casa para hablar.

Los refugios de mujeres, en términos generales, carecen del cuidado puesto en la construcción que siempre se observa en las casas de los hombres, tienen una planta rectangular alargada, están cerradas por todos los lados por las paredes y tienen una altura de cuatro o cuatro y medio metros. Se diferencian en tamaño. Dimensiones de 20 por 7 metros según lo especifica Nordenskiöld, pero estas son ahora muy raras, especialmente en lo que se refiere a la longitud. La principal razón para el cambio es probablemente, el incremento en el número de refugios para mujeres, con una reducción simultánea del espacio cerrado y el número de personas por unidad de vivienda.

En el pueblo visitado por Nordenskiöld había solamente dos refugios para mujeres, habiendo nueve familias nucleares. Hoy en día el modo de construc- ción de la casa es de manera tradicional. Sin embargo, carecen de la antigua práctica de cubrir las paredes exteríores, que como se puede observar en la figura en Nordenskiöld, eran con hojas de Heliconia. Hoy dividen los troncos de palma en listones que se colocan verticalmente, y más o menos unidos, formando las paredes (wenene, a instancia de parte). La apertura de la puerta del kaiti) ha ganado en su alcance, y ahora se coloca en la pared a dos aguas. El interíor de la casa no tiene particiones, pero hay un uso división áreas legalmente definidas de familias o individuos. Las madres duermen con su hijo menor en una hamaca. Los adolescentes en su mayoría tienen su propia, hamaca más pequeña, mientras que los otros niños se apoyan en una cama baja, hecho de Pachiuba (Onipa) madera de palma como un lugar común para dormir (oshati). Plataformas o estanterías, que descansan sobre la estructura horizontal del techo, se utilizan para almacenar las materias primas si no se suspenden en los postes y vigas o como flechas y el machete.

Para los hombres no existe ninguna restricción con respecto a la de entrar en el refugio, pero solo pueden quedarse allí temporalmente y siempre y cuando mantengan previamente sus bienes en casa de los hombres. El equipo indispensable de un refugio para mujeres es el molino de dos piezas. El mango está hecho de madera pesada Almendrillo (Maní), una base fabricada de (Shapi), que tiene una parte inferíor ligeramente curvada. El material para ser molido esta 


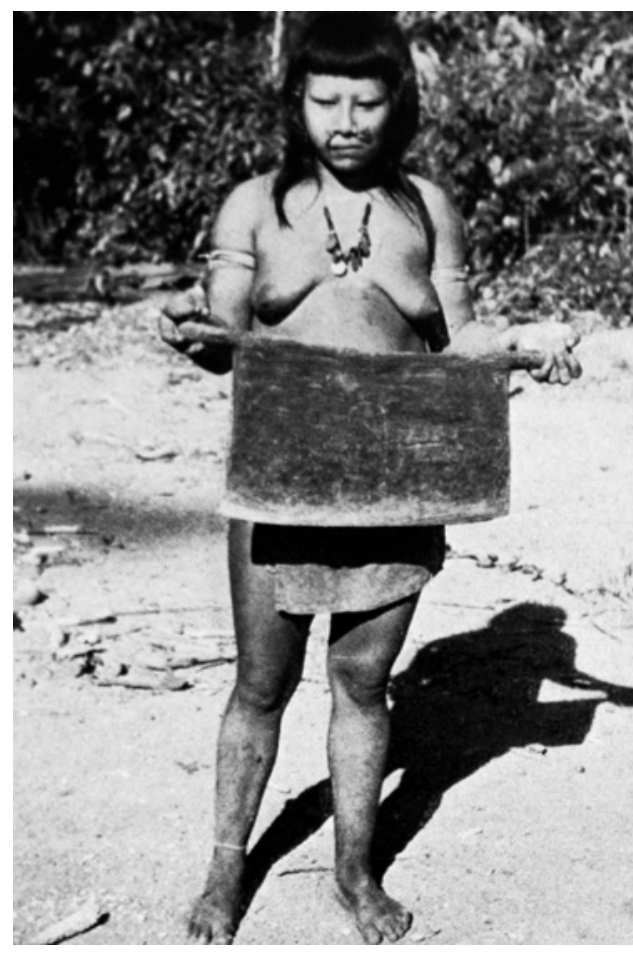

Fig 5. Mujer Chácobo mostrando el mango de madera para moler en el batán.

siempre en una cubeta (Shasho). La base consta de un tronco de árbol partido por la mitad ahuecado longitudinalmente. En la mayoría de los casos, tiene varíos metros de largo y está a unos $80 \mathrm{~cm}$ de altura sobre tacos de madera. Es usado de manera conjunta muchas veces simultáneamente por todas las mujeres de la casa.

En contraste con los otros, el asentamiento de Alto Ivón revela un cierto principio de orden en la posición de las casas, con un total de cinco refugios de mujeres agrupadas en torno a la casa de los hombres centrales, y construidos en ángulo recto con ella y entre sí. La puerta siempre se encuentra al centro del pueblo. El edificio denominado "escue- la", es una estructura alargada, cubierta con hojas de palma, que tiene sólo la mitad de altura, y las paredes son hechas de listones de madera de palma A medio camino entre la casa de los hombres y el Arroyo Ivón está la casa del lingüista -.. Misionero Prost, la cual ha sido construida sobre pilotes, es el único edificio con los tanques que sirven de depósito de agua potable, lo que da lugar a hablar, de una más que extraño estado de cosas. Después de una toda la década bajo el mandato misionero, ninguna familia Chácobo tiene ni un suministro de agua potable, ni letrinas.

En la temporada árida del nivel del agua baja hasta el punto de que el Arroyo Ivón sólo se compone de un par de piscinas de apenas 20 metros de diámetro. Estos estanques se utilizan en Alto Ivón por los seres humanos y animales, el agua para beber y lugar para natación.

A una distancia de una hora a pie de Alto Ivón en dirección del noroeste al oeste en un claro se encuentran tres casas. Yako utiliza dos de las casas como vivienda o lugar de trabajo en relación con la producción de caucho. $Y$ a unos 100 metros de distancia de estos, Buka tiene una base, en el camino a su remota Siringal y ha construido toda una casa solariega. Representa la tercera parte de los tipos de casas encontradas en los Chácobo, que combina la función de la mujer y la casa de los hombres.

El tercero, es el asentamiento más austral Chácobo, al que se puede llegar desde la casa de los hombres del Núcleo en dos horas, lleva el nombre de "Cali- 
fornia" cuenta con seis casas, cada una con orientación diferente y dispuestas al azar.

En Río Yata paseamos por cuatro horas en barco de motor por encima de Campo Palmar, pero no visitamos asentamientos Chácobo por falta de tiempo. Dicen que hay cuatro familias con un total de 16 individuos. Sería interesante saber cuáles son sus condiciones de vida y las razones que les impide trasladarse a Ivón.

En Alto Ivón los lingüistas misioneros tienen una pista de aterrizaje para aviones pequeños.

En noviembre de 1970 en Alto Ivón había 52 habitantes mientras que Núcleo y California habían 58.

\section{Vestimenta y joyas}

Leuzinger escribió sobre su reunión con los indios Caripuna en el Río Madera,
"Ellos tienen casas que estan bien construidas generalmente, de complexión robusta de tamaño medio, con el pelo largo caído y con una trenza larga, llevan insertado pendientes a través del lóbulo de la oreja incisivos curvos del Capibara y tanto hombres y mujeres usan las plumas Tucán en su tabique nasal perforado.

Entre los Chácobo ambos sexos tienen adornos (resetei) en el tabique nasal perforado (eme kini), el cual siempre se compone de tres penachos de plumas rojas de Tucán, cada uno de ellos lleva empalmado con una tira de pluma envuelto de manera que sus extremos hacen forma de cepillo por debajo de las mejillas "el Chácobo de nuestros días llevan los mismos pendientes con dientes de Capibara (dmeno berna, sherta) en el agujero de oreja. (resete kini), mientras que el adorno pecho consiste de bolitas de vidrío (rnoyo), que tienen

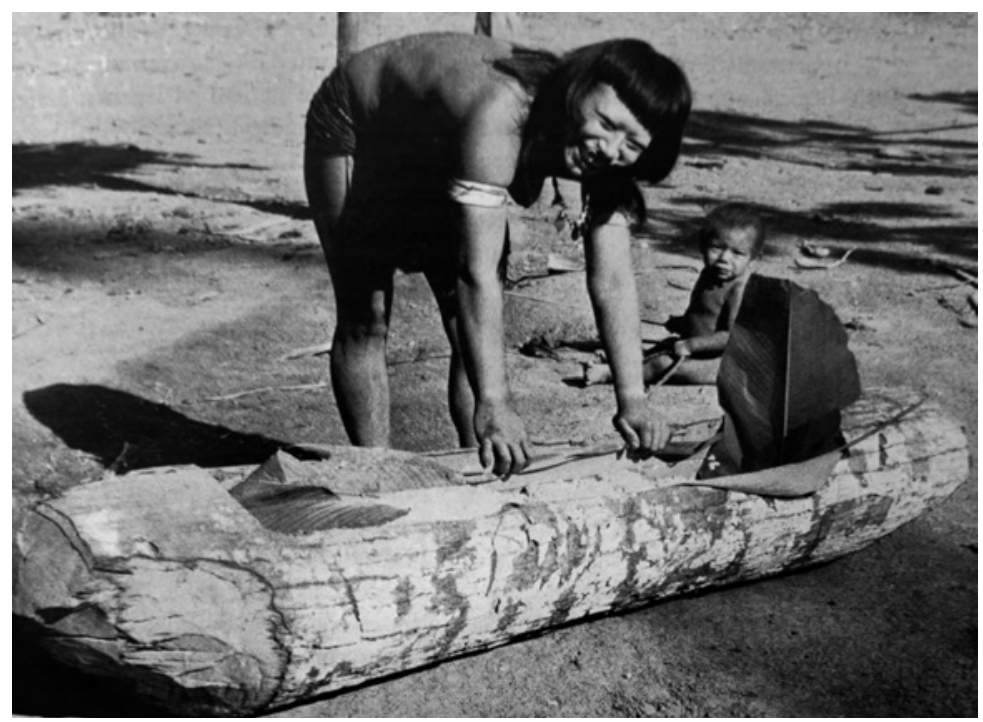

Fig. 6. El material para ser molido esta siempre en una cubeta (Shasho) 


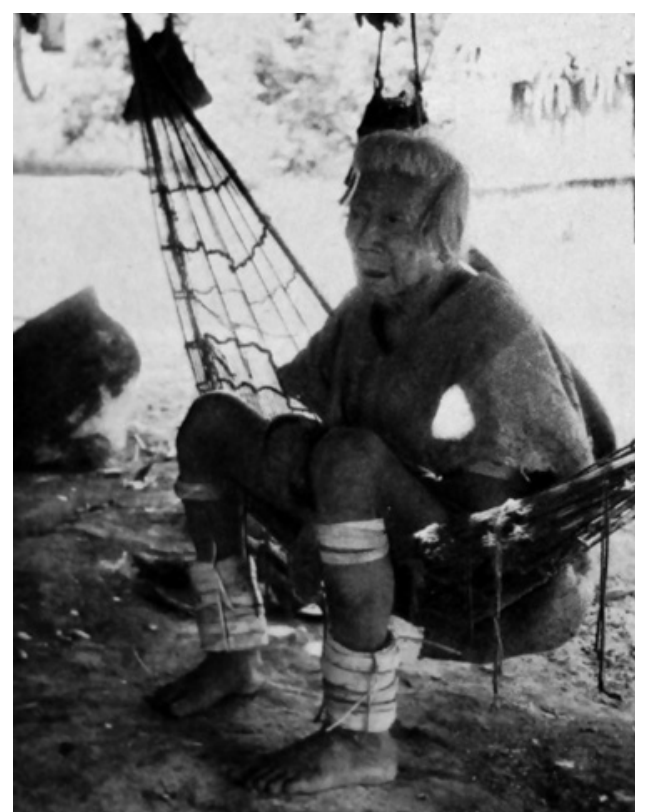

Fig. 7. Los hombres son de complexión robusta de tamaño medio, con el pelo largo caído y con una trenza larga

el tamaño de un guisante y son de color azul claro (nidwa) y estan dispuestos de las hileras de perlas de vidrío, estos son una reminiscencia de los mostrados por Nordenskiöld -. Los cuales tenian dientes de monos capuchinos (sherta shino).

El "Pony" es la tradicional para ambos sexos, que además de la línea del cabello en la parte de la frente y las cejas es eliminado (weshko wa'i, weshko akia). Un procedimiento para el que siempre han utilizado previamente las partes afiladas de la planta ratshi. Sin embargo, las mujeres llevan el pelo casi hasta los hombros, mientras que los hombres se dejan crecer para envolverlo en un cinturón tejido (srapo) a una larga, gruesa trenza (wo'o).

La ropa de los hombres consiste en una relativamente amplia camisa sin mangas de una tela fabricada con una corteza de árbol de color marrón (moro), que cae libremente, sin ser atada a la cintura, llegando hasta la pantorrilla o o hasta el talón. Padre Cardus escribe en 1886, que la mayor parte de los Chácobo suelen ir sin ropa. Probablemente se refiere no solo en la desnudez de la mujer y los niños, sino también en la costumbre de los hombres. Nordenskiöld observó que los hombres renuncian temporalmente a su camiseta y sólo usan un hilo de algodón (siripi) que levanta el pene (hina) desde el escroto (hoho), y lo mantiene presionado contra su abdomen.

Las mujeres adultas llevan un adorno de 10 a $15 \mathrm{~cm}$ de ancho, para cubrir su pelvis (yoshawa sirip). Este consiste en un varíos metros de hilo de algodón y en menor medida las tiras de Macuca, material que recuerda cable negro delgado en caso contrarío las mujeres suelen ir desnudas. Una hoja de Heliconia ubicada sobre la pelvis, entre las piernas van conectados a la banda de hilo, con lo que cubren sus pubis afeitados (Shani). Hoy en día, utilizan un trozo de Pano Europeo. Si Prost escribe: "La mujer Chacoba nunca va al servicio desnuda, pues entiende que es pecado ir sin cubrirse con un retazo de tela, y entiende que es cosa muy vergonsoza de descubrir su pubis. Sin embargo esto no es verdad, el Chácobo sólo se cubren debido a las expectativas de los blancos. Sin duda, la hoja anteríormente se utilizó exclusivamente para cubrir la abertura genital (piasher), es decir, puramente tenían una función protectora. 

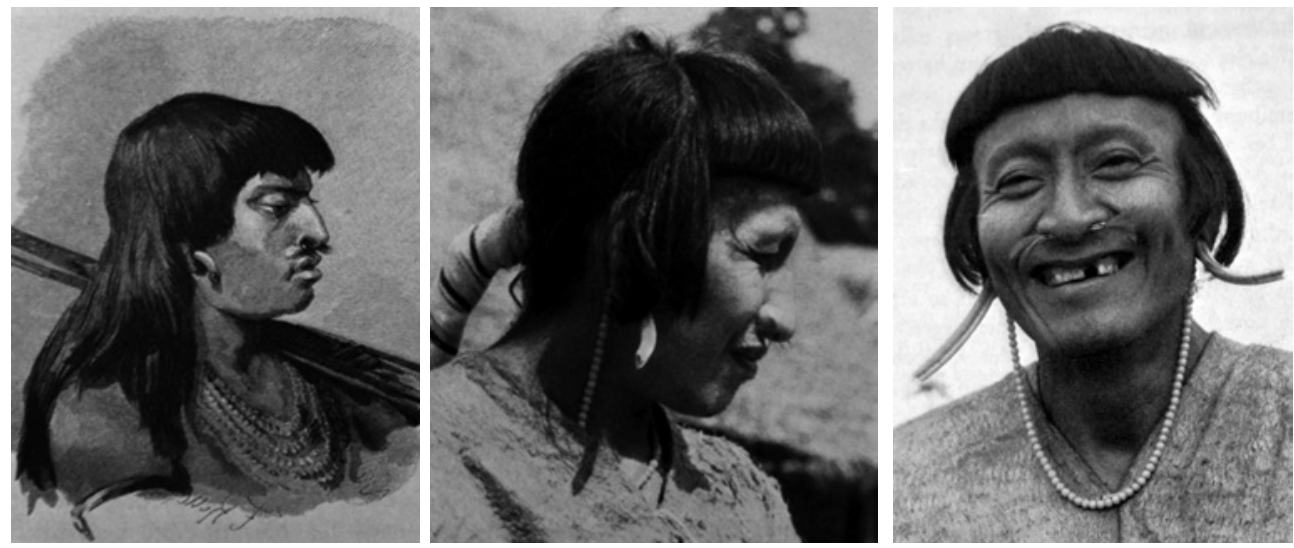

Fig. 8, 9, 10. Rostros de hombres Chácobo, se puede observar en ellos los adornos de nariz y orejas

De una liana muy rara (tshimo) obtienen un material blanquecino, relativamente suave y flexible, con el que hacen tiras que son utilizadas por los hombres como envolver en la parte superíor del brazo, muñeca, pierna (wdntsbttl, mtntthiá, mantkirikato, ránesheti). Las mujeres utilizan pequeño adorno debajo de la rodilla y la muñeca, como arpillera principalmente de pequeño negro, para ello usan semillas de (Shiri Maniwa), y también cuentas de colores de vidrío (inoyo) y ciertos huesos de frutas (Kuei). Todos los días los adornos incluyen collares con las semillas negro, perlas de vidrío, y monedas, así como baratijas tales como llaves y otras de origen europeo.

La perforación y con la inserción de una madera en las fosas nasales, actualmente es hecha por una mujer mayor. Lo que afirmaba Prost que este procedimiento muchas veces conducia a la muerte, es muy cuestionable.

No es necesarío que exista una ocasión especial para que los Chácobo usen sus mejores galas. El tocado de los hombres (tsha'a) es un anillo de tiras de material liana muy bien hecho, con las plumas de patos almizcleros (nunuma). Cada borla (tsha'a wirstita) consiste en plumas de color rojo brillante de la tsoke de tucán, rodeado por tres pequeñas vueltas de plumas formando un cono trunco. A las plumas negras iridiscentes verdosos (seke, naso) le siguen plumas de pato, el rojo (Shini), amarillo (Bosho) o azul (niáwa) del kaimi y loros kana. Esta disposición de negro, amarillo y rojo también es mencionado por Nordenskiöld. De vez en cuando usan la plumas verdes de los loros.

El tocado de las mujeres (matsamiti) consiste en una corona de plumas rojas de Tucán simples. Las borlas de la parte superíor del brazo (potarameti) están hechos de las mismas plumas. El tocado parece no ser muy usado hoy en día.

Los adornos de la parte superíor del brazo para los hombres (washesheti) son muy grandes. Formados por una banda de liana, con hilos de algodón o bandas tejidas y macizos de color am- 

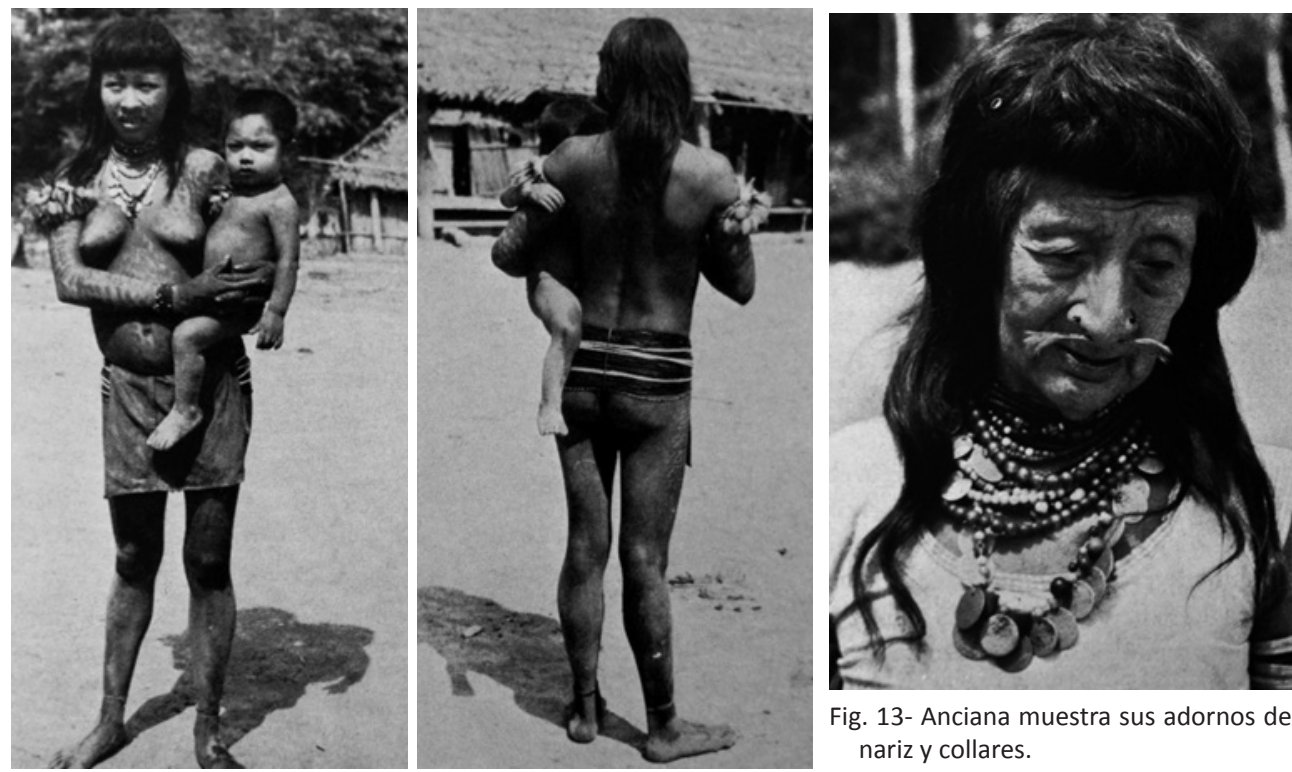

Fig. 13- Anciana muestra sus adornos de nariz y collares.

Fig. 11, 12. Las mujeres adultas llevan una tela de 10 a $15 \mathrm{~cm}$ de ancho, para cubrir su pelvis (yoshawa sirip)

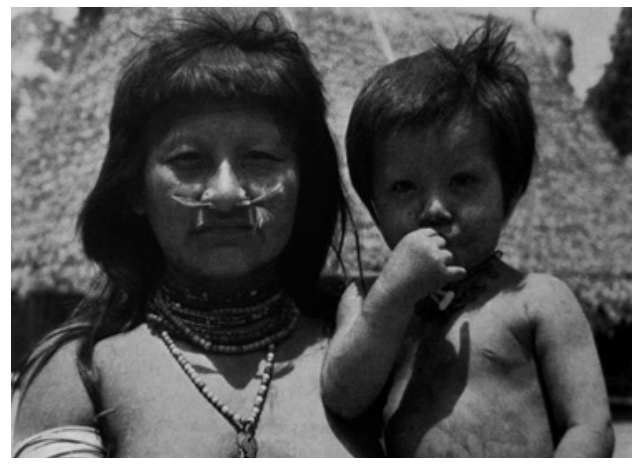

Fig. 14- Madre con su niño en brazos mostrando, sus collares y adorno de nariz.

arillo, para hacerlos les demora mucho tiempo ya que frecuentemente tienen muchos metros de largo. También se le añaden las borlas en la parte de abajo (Shopo) y alas de escarabajos iridiscentes (shana). Para pintar sus cuerpos ambos sexos usan sólo dos colores: Bixa orellana (mashe) para el rojo, y negro o negro azul (seke, Tiso) de Genipa americana (nane). Los tintes se llevan a cabo

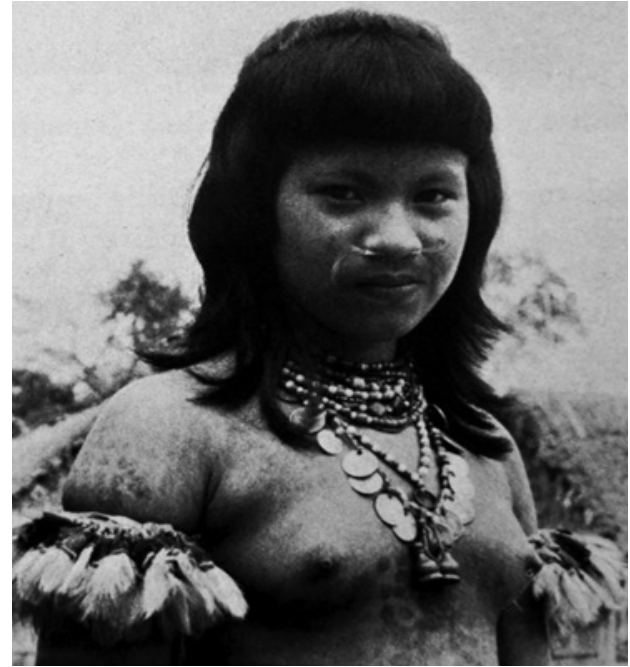

Fig. 15. Adolecente Chácobo, ataviada de sus adornos de cuello y brazos.

en un par de contenedores de bambú de unos $30 \mathrm{~cm}$ de largo (rerwe) cuya tapa (mapoti) está hecho de cáscaras de maíz (shebo Sherki).

Frecuentemente los colores se aplican ampliamente, en caso contrarío los ponen como un punto o patrón, que a 
menudo se extiende casi por todo el cuerpo. En ocasiones, utilizan la cruz y en zigzag. Especialmente son populares las series de puntos en la frente (to'o sa'ána).

A los Chácobo le agrada usar su traje tradicional. $Y$ aunque las mujeres tienen casi todas un vestido hechos de tela, no lo usan con frecuencia porque no les gusta.

La mujeres se visten cuando hay visitantes como nosotros, sin emabargo, luego continuan con su traje tipico. Para los hombres les resulta útil los pantalones cortos, pero éstos sólo son usados para la extracción de caucho crudo. Había muy pocas personas que no se ajustan a la costumbre tribal, ellos se visten como mestizos o indios más aculturados. Estos incluyen a dos profesores, así como un cierto Yako (Carmelo), que se casaron con un Chácobo pero habían vivido varíos años separados de sus parientes. Un caso especial es Kako (Jorge), que le gusta llevar ropa europea, manteniendo su vestido de pelo y joyas faciales.

"Cuando vi por primera vez a un Chácobo", escribe Hanke, "Yo estaba muy emocionado por su aspecto espléndido "A su manera exuberante, añade: "No son voluminosos, más bien de complexión delgada, tienen la cabeza perfectamente moldeada y rasgos regulares, sus cuerpos lisos y sus extremidades proporcionadas -formaban un conjunto singular-mente armonioso- aparentemente una versión del modelo de homo sapiens. Su piel es teñida de color cobre, el pelo negro y liso.

\section{Cultivos tradicionales}

"Los Chácobo que viven lejos de la civilización conservan mejor sus modos primitivos y originales de la vida. Son cazadores, pescadores y recolectores de frutos del bosque y hacen un poco de agricultura muy rudimentaria". Esta opinión de Hankes fue contradictoria. Tal vez sobre la base de una tribu

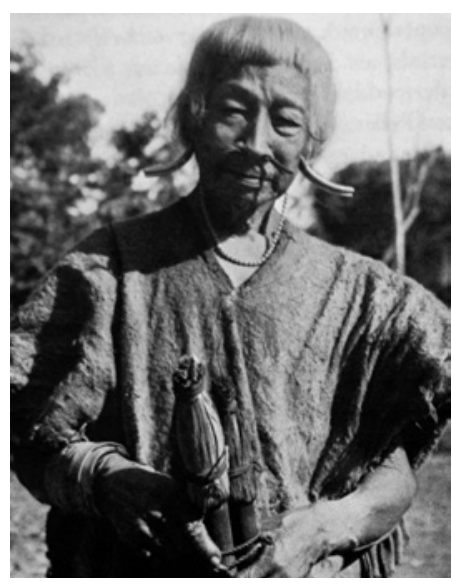

Fig. 16. Su piel es teñida de color cobre, el pelo negro y liso.

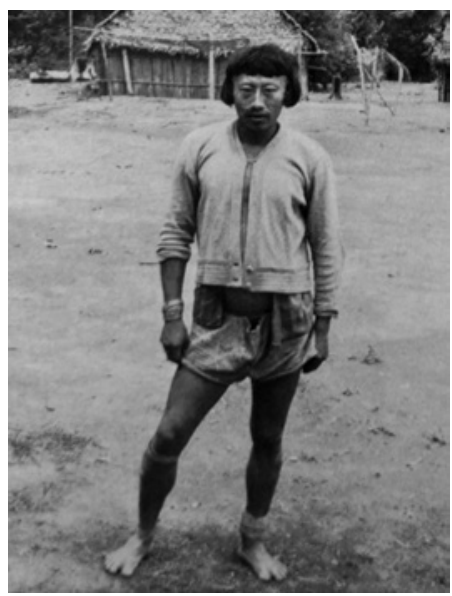

Fig. 17. Kako (Jorge), que le gusta llevar ropa europea.

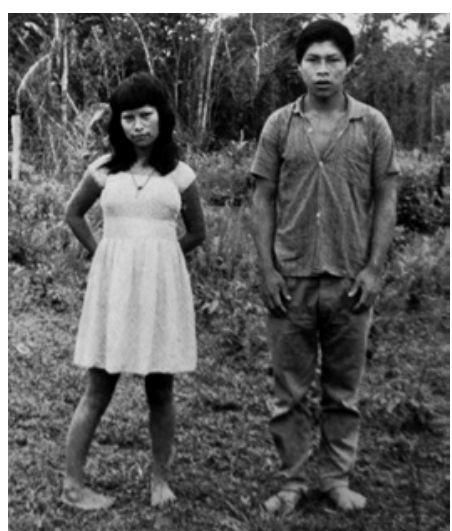

Fig. 18. Los profesores visten a modo occidental. 


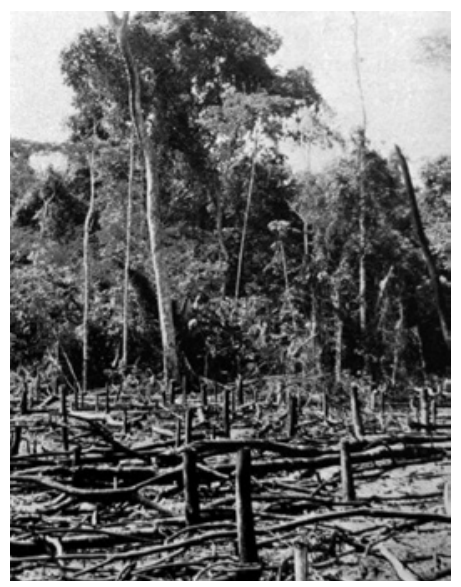

Fig. 19. Chaco listo para la siembra, después de la tala y quema del monte.
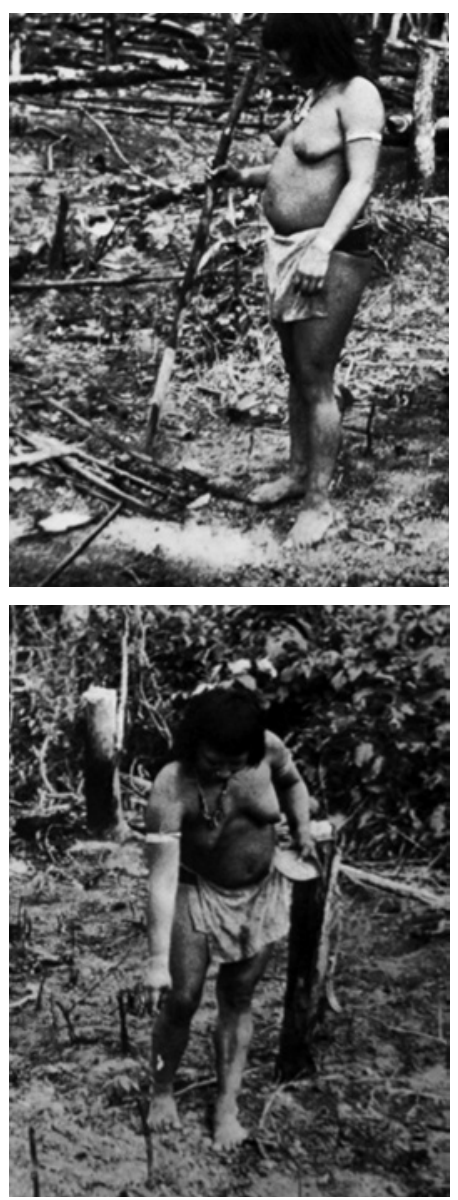

Fig. 20, 21. Mujeres sembrando, usando palos de madera (sersbati). como el siríonó, podría estar justificado, pero para el Chácobo no es verdad. Comparando las diferentes actividades agroalimentarias Chácobo sobre Ivón está claro que el cultivo tiene una importancia decisiva para su sustento. Los Chácobo son principalmente agricultores.

Todo hombre casado tiene un campo privado (wai) de1 - 2 ha. En julio, el Chácobo corta la maleza (hitsaki), seguido por la tala de árboles (hiwi rcraki), y finalmente la quema (mebaki), por lo general en septiembre.

Ambos sexos trabajan en el campo (wanaki). Esto es especialmente cierto para las dos plantas más importantes, la yuca (ATSA), y maíz (sh'erki). Yuca - La tala deberán hacerlo los hombres (Honi ATSA wana aina), y el maíz es sembrado por las mujeres (yosba sh'erki wana aina). Tienen algunas herramientas de hierro como el machete- que ya estaban presentes en el momento de la visita de Nordenskiöld, para la siembra siguen usando palos de madera (sersbati).

Tienen plantas importantes que incluyen diferentes tipos de plátanos (karapue, pi’a), caña de azúcar (shita), las cucurbitáceas Joco, (warame) y Zapallo (shatano), y como plantas bulbosas la papa dulce o camote (kari, Ipomoea batatas), la Valusa (mataka ; Colocasia sp) y Papa del Aire (Puea ; Dioscorea latifolia), Capsicum (yotshi), sandía o Sandia (saniaf) y papaya, así como el comestible Zapallo (Cucurbita moschata), y la calabaza, para vasos y botellas (Lagenaria sp.).

Originalmente no conocían o cultivavan la sandia originalmente. Del mismo modo tienen, la guayaba (wayawá ; Psidium sp.) y Acayu o marañón (cayu ;. Anardium sp). Las plantas no nativas son el arroz (Arosa), naranja (Naraja), y el limón. El maní, se conoce el maitapa, pero no crece en la zona. La piña (Kakama) parece ser una fruta que también se introdució. Finalmente podemos mencionar el algodón, 
Urucu (Bixa), tutuma y tabaco (roma), pero sólo se utiliza para "uso médico" para eliminar el Boro, la larva del moscardón (Dermatobia homini) que ataca al cuerpo humano.

¿Qué criteríos uso Nordenskiold para determinar que el Chácobo eran "agricultores ordenados", no es es muy evidente cuando escribe "Al igual que la mayoría de los otros indios siembran diferentes cultivos al lado del otro, pero también se puede ver más parcelas de tierra solamente con maíz o mandioca. Los campos que he visto estaban en el bosque y no en las Pampas y fueron bastante bien cultivados. "Hoy en día se ofrece esencialmente la misma imagen, excepto por el hecho de que la mayor parte del campo no se siembra con maíz o yuca, pero si con las dos plantas de forma simultánea, es decir, como un cultivo mixto El maíz de rápido crecimiento que ya se puede cosechar en enero, es decir, después de tres o cuatro meses, mientras que el Yuca entra en la etapa de madurez sólo después de nueve meses. Si hoy las parcelas a menudo no se aíslan en el bosque, pero se encadenan entre sí para formar grandes claros, esto es probablemente debido a los esfuerzos del misionero en tener grandes espacios abiertos, que luego pueden ser utilizados como pastizales para introducir el ganado.

Ambos sexos se dedican a la cosecha (tirsakia) de la misma manera. Las mazorcas de Maíz se lían y se mantienen en la casa colgadas. Yuca se cosecha en cantidades apropiadas de acuerdo a sus necesidades. La Yuca es el principal alimento básico y una parte integral de la imagen normal diaria son las mujeres que regresan al pueblo cargadas de tubérculos de yuca y la leña. Y su consumo va desde simplemente asar los tubérculo sin pelar en el fuego del hog-

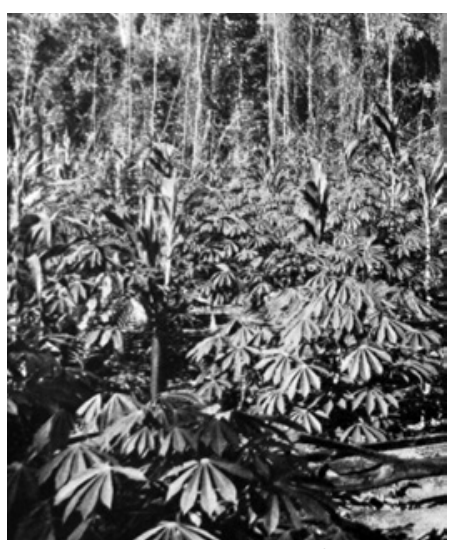

Fig. 22. Campos con sembrío de yuca, bien cultivados.

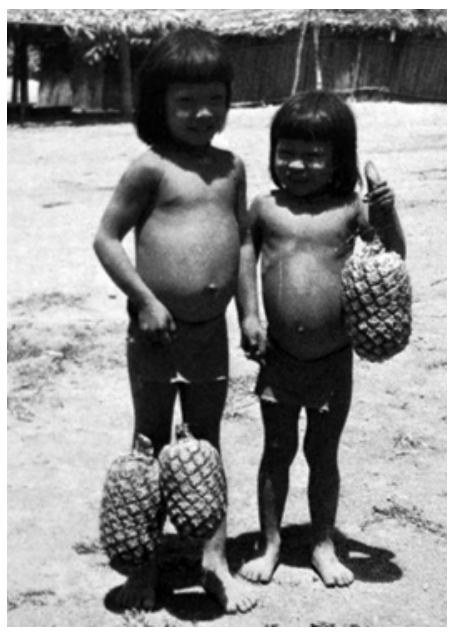

Fig. 23. Niños mostrando grande piñas, cultivadas en sus campos.

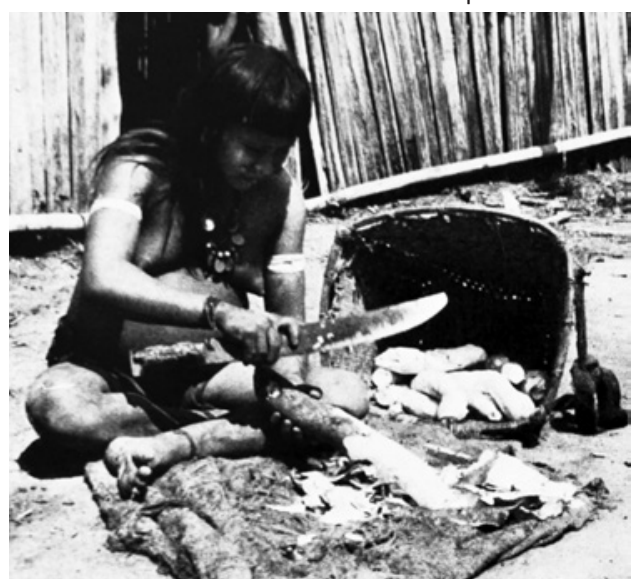

Fig. 24. Mujer pelando yuca con un machete. 


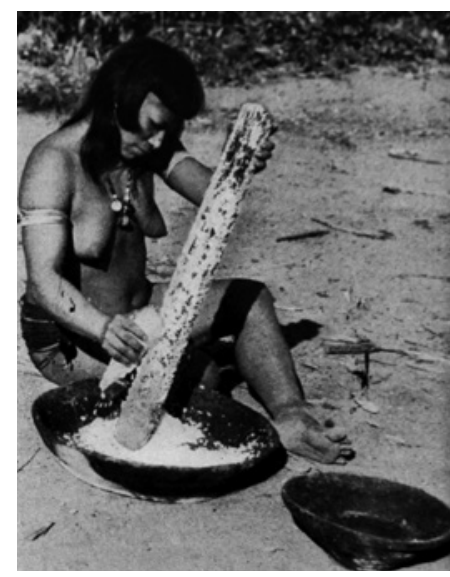

Fig. 25. Raíz espinosa de la palma Pachiubilla utilizado para raspar Yuca (dtsarichiti)

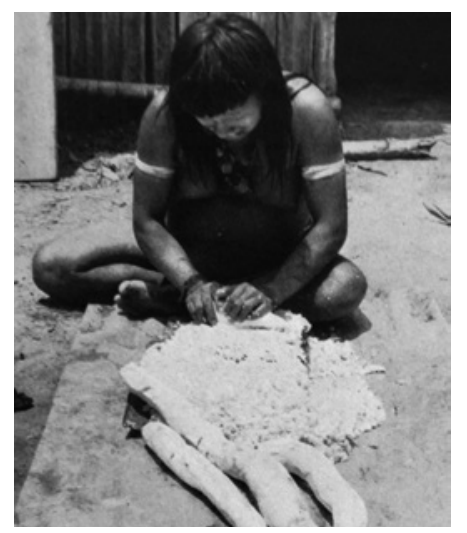

Fig. 26. De vez en cuando uno usan latas perforadas, para raspar yuca.

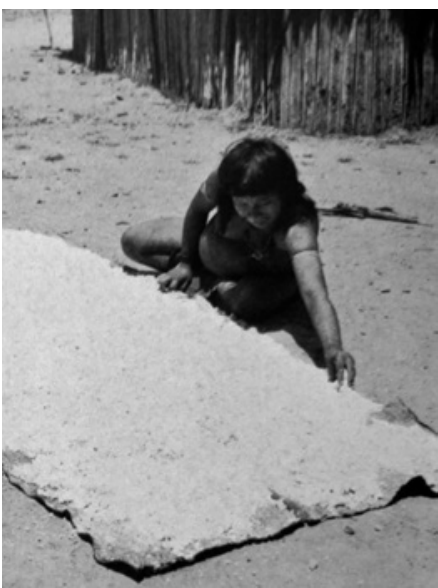

Fig. 27. La yuca es secada al sol en mantas. ar, hasta para preparar una bebida muy fermentada que tiene un largo proceso de producción. Asimismo se tiene la costumbre de producir Chive (harina de yuca), que junto con el Tschitscha débilmente fermentada es el pan de cada día de Chácobo. Para el pelado de los tubérculo utilizan el machete o un cuchillo. Las astillas de bambú utilizados originalmente para este fin ya no están en uso. Sorprendentemente, sin embargo, hay una fuerte tendencia en relación con la raíz espinosa de la palma Pachiubilla utilizado para raspar Yuca (dtsarichiti). Sólo de vez en cuando uno usan latas perforadas para este fin. Lo raspado es fermentados en grandes ollas de barro selladas con hojas por varíos días, luego se extendió en un Pano para ser secado al sol y, por último es hervido en grandes ollas de barro. Chive es también tiene una gran demanda entre la población mestiza. En ocasiones, el Chácobo vender sus excedentes de producción. Dado que no se fermenta, la harina de yuca se percibe como "dulce".

Ciertamente, no es un error suponer que la mayoría de la yuca cosechada se consume en forma de Tschitscha dtsahne "o simplemente h'ene (agua). En este caso, el material de inicio proviene de yucas peladas y cortadas, luego los tubérculos se cocinan sin añadir agua en ollas de barro. Después de enfriar, el proceso de masticación, que puede tardar varias horas o incluso medio día, dependiendo del número de mujeres y niños que participan. ¿Qué parte de la masa total mastica cada unos, es difícil de establecer debido a que todos escupen en el mismo recipiente. Luego se aplasta la masa de Yuca con agua fría contra una malla. El Tschitscha se agita en las grandes ollas de barro utilizando una cuchara de madera en forma de paleta (HeNe rowi ati). Se necesitan varíos días, hasta que la fermentación "ha llegado a su punto", es decir, la bebida ejerce un efecto embriagador. Tal Tschitscha (Shapo h'ene) está reservado para los hombres y por lo general se sirve sólo en las oca- 
siones festivas especiales. Todo Chácobo, independientemente de la edad y el sexo, toma la bebida. Sin embargo lo hacen en grandes cantidades de Tschitscha antes del inicio de la fermentación o antes de la aparición del sabor amargo ( $t$ 'e'i h'ene). Incluso Tschitscha maíz (h'ene sh'erki) permanece bajo la fermentación. La harina obtenida con el batán a partir de los granos (sh'erki w'ero) se hierve con agua en un estado pulposa y luego se mezcla con harina de maíz masticada por las mujeres.

\section{Caza}

La caza tiene que garantizar el necesarío equilibrío en la alimentación, proporcionando la carne (nami). Despues de la agricultura es la caza el componente más importante de las actividades Chácobo tradicionales. Es cierto que la caza una vez estuvo en el primer lugar y en última instancia, sigue en pie, para cada movimiento en el bosque, una visita a la aldea vecina, ir al Chaco, es para la ocasión Chácobo para llevar sus armas. Cualquier oportunidad disponible de forma aleatoria para cazar permite que se olviden de todo lo demás. El método preferido de la caza es acechando. El arco y las flechas son las armas tradicionales cuya longitud corresponde aproximadamente al tamaño de su propietarío, es decir, máximo de $170 \mathrm{~cm}$.

Si Nordenskiöld considera que esto es inusualmente largo, podría explicarse por el hecho de que él compara la longitud de arco y flechas con las de los siríonó, las cuales a menudo tienen más

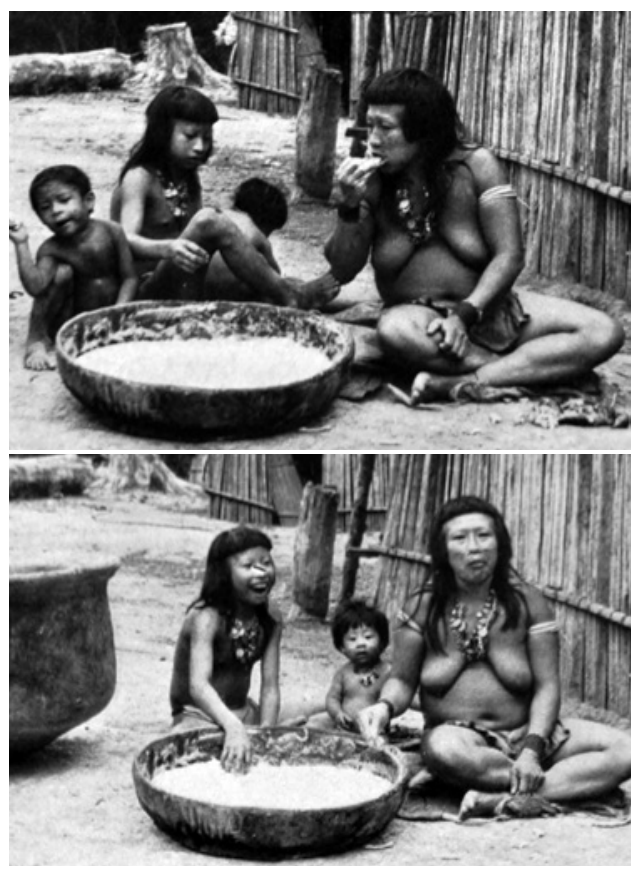

Fig. 28 y 29 , el proceso de masticación de la yuca puede durar varios días.

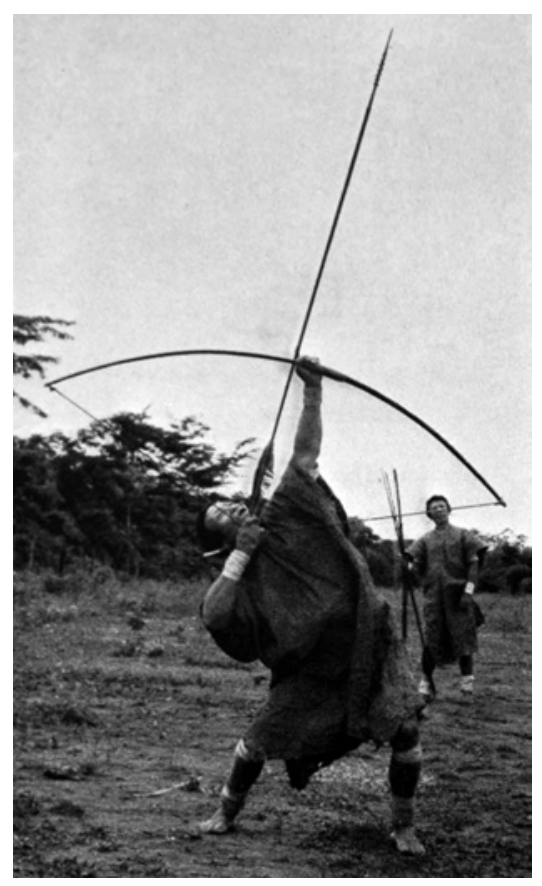

Fig. 30. El arco y flechas, tiene el tamaño de su propietarios aproximadamente $170 \mathrm{~cm}$. 
de tres metros. Por otro lado, la falta de observación puede ser la base de tal afirmación, porque él también aunque parezca mentira, sólo menciona dos diferentes tipos de flechas. En verdad, hay cinco, incluyendo para la pesca. El eje se hace siempre a base de chuchio y hace referencia en la lengua vernácula por su nombre mestizo), (tawa ; Gynerium saccharoides). La punta se hace a partir de madera de palma de chonta, con una serie de púas sólidas (Kereke). Para matar animales más grandes, como Anta (Awara), Taetetu o pecarí de collar (hono ; Tayassu tajacu) y el pecarí de labios blancos o Chancho de tropa (yawa; Tayassu pecari), mueren de preferencia con una punta en forma de lanceta de bambú (paka). La flecha de aves (tiupi) tiene un cono puntiagudo de madera como la punta, cuya base está mirando hacia delante. La punta de la flecha se utiliza para matar a los peces grandes (wikowi) chonta está equipado con una sola lengüeta que recientemente ha sido sustituido por los clavos de hierro. La flecha para la captura de peces pequeños (Notse) tiene cuatro puntas divergentes chonta en forma de embudo.

No importa lo que (pia) flecha de tipo que es, Mutún (hawerpe'i) plumas se utilizan para mantener el equilibrío, y se conectan con las fibras de las hojas resistentes. Lágrima de la palma Chontilla (u'ma). Como la cementación de las plumas a la base del eje porción (woitsho) el Chácobo el zumo de un árbol en particular con cera de abeja purificada, y pintan de rojo el eje con Urucu (Bixa).
El extremo del eje (Shinia) está envuelto con hilo de algodón y tiene un pequeño cono (sishrere) que es siempre de una madera en particular (wekona) la recepción de la ranura de la cuerda del arco. Una peculiaridad de los Chácobo flecha son tres pequeños envoltoríos de color negro, rojo y blanco brillantes -, que consisten en plumas empalmadas. El negro (woitseke) proviene de Chuiivi, para el que utilizan Garza Morena (toto ; espátula rosada) y Manguan (isakd, Euxenura galeata). Hilado de algodón (risisi) se utiliza para la envoltura de la parte frontal de la espiga (sherdnia).

El arco en sí (Kanati) esta completamente sin adornos y tiene una cadena (rsishipi) de las fibras de Ambaibo (wokuno), que acaba en un envoltorío (siripi) alrededor del arco para marcarel lugar para agarrarlo. Los arcos están hechas de la madera de una pequeña palmera chonta (Wanima), que es relativamente pequeña de frutos rojizos, los cuales se pueden disfrutar cocidos. Esto no se parece a la chonta Castillani (Guilielma gasipaes), que es utilizado por los Siríonó y Yuracaré como madera para su arco y que también sus frutos se pueden cocinar.

Cerca de Alto Ivón pude identificar con certeza una chonta como Guilielma gasipaes. El Chácobo llamó esta Panima, pero dijo que no usaban ni la madera ni las nueces de palma. El uso de la madera de otras palmeras no es excepcional, por ejemplo, el uso de la palma Caripuna pachiuba para los arcos. 
El Tapir, el jabalí y el Oso (shra'e) son especialmente valoradas como presas debido a su peso.

Los monos siempre garantizan una alta tasa de éxito, puesto que se encuentran en las familias numerosas, como la manechi o mono aullador (ro'o; Alouatta $\mathrm{sp}$ ), el Marimono o mono araña (iso, Ateles sp.), y el Cuatro Ojos (riro ; Nyctipithecus sp.) y mono Silbador o mono capuchino (shino, Cebus sp.), o incluso a grupos más grandes, tales como mono Ururo (ruka), mono Amarillo (sirmino), mono Blanco (Cebus sp hosho shino.) en grupos aún más grandes.

Otras presas populares también son la capiguara o carpincho (Hydrochoerus dm'eno ; capibara), Jochi Pintado (ano; Coelogenys paca) y Jochi Colorado o agouti (sdkaka ; Dasyproeta aguti). Lo mismo sucede con los armadillos, como Pejichi (panöa, Príodontes giganteus) y Tatii (yawishi ; Dasypus novemeinetus). Cérvidos como el Huaso (Shasho) y Hurina (Shasho koro) también son cazados, pero el venado de las pampas (shashoa) es sólo el tema de historias de caza, ya que evita la espesura del bosque.

Por otro lado los Chácobo rechazan algunas especies. Estos incluyen: El Oso Peresozo (yukama), El zorro (kamashöa), Oso Hormiguero (wiwino; Aardvark sp.), Melero (Wuka ; Eira sp.), La rata (shoyawa), ratón (Shoya,), así como la nutria (Waro bene, ino HeNe ; Lutra sp). Sólo en tiempos de escaces de suministro de carne ellos matan estas especies.

Mientras que el Caimán (kapete ; Caiman niger), el gran Peni - lagarto (sherkepa; Teju tupinambis) son considerados prohibidos, aunque su cola puede ser considerado como un manjar en otros lugares.

Las prohibiciones alimentarias se indican con la fórmula akia (no comer). Antes hacían refugios de hojas de palma (tepasa) para la caza, y la tabladillo fue hecho de madera de chuchio. $Y$ asaban con una rejilla de madera verde (TAPO), la carne era ahumada para su consumo directo o posteríor. La duración gracias al hábito de ahumar es sólo de unos pocos días. Las expediciones de caza, anteríormente a menudo realizadas en relación con la búsqueda de un nuevos espacios de vida, se convirtieron en raras bajo la influencia de los misioneros, que propagó los asentamientos permanentes y el trabajo en los Siringales.

Durante nuestra estancia sólo una vez fue cazado un mono capuchino (Nasua sp ; Shisba), y más frecuentemente se mató a Mazi o ardillas de color marrón rojizo. También trajeron más a menudo Tejón o Coati (kapa ;. Hadrosciurus sp), que viven en los bosques de caucho. Fueron escasos mamíferos más grandes, como el Jabalí, el Oso Bandera y el Chancho de Tropa. Aves como especies de tucán fueron cazados frequentemente, pero los pájaros más grandes, como Hokko Mutunes (Crax sp.), Pico Colorado (Hasene) y Pico Amarillo o Pavichi (Kebu, iwiko) o Pava Campanilla (kuso) y Pava Guaracachi (honokaraka) no los hay. Muy pronto descubrimos que incluso el loro o pájaro cantor más pequeño 

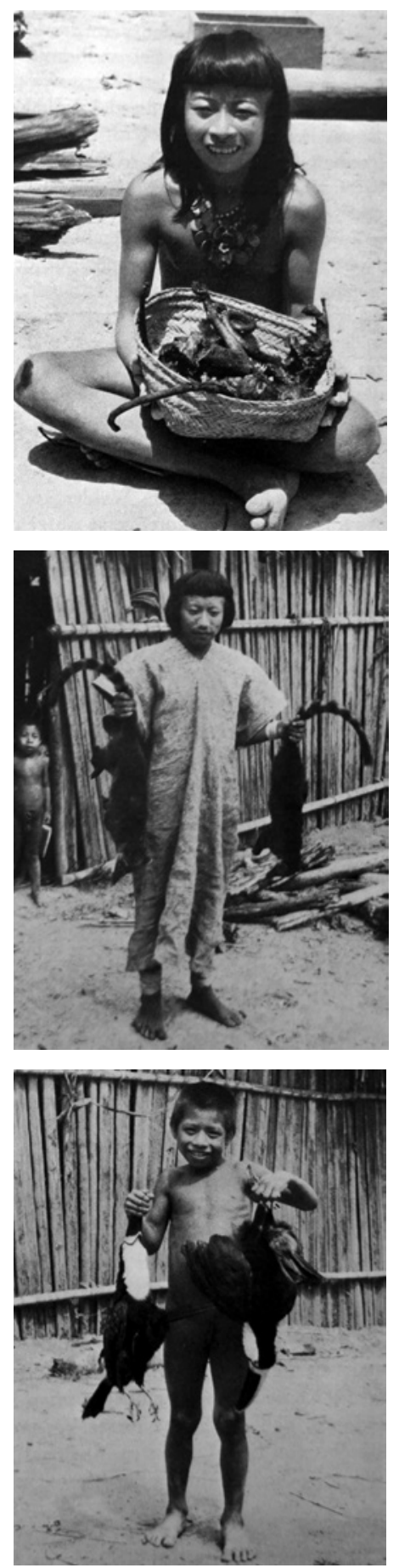

Fig. 31,32,33. La caza, es una actividad básica en la vida de los Chácobos. era una presa muy preferida y fue cazado con un arma de fuego. Aunque, cada macho Chácobo tiene el arco y la flecha, y debe aprender a manejar y fabricarlos ya a una edad temprana, muchos ahora usan con orgullo un rifle o escopeta (tooti). La idea de ayudar al Chácobo con armas de fuego, superíor al arco y flecha, con el fin de facilitar su caza, era bien intencionado, y fue sin duda relacionado con el esfuerzo para darles un incentivo para el trabajo en las siringales. La consecuencia fue que todos Chácobo trataron de comprar un arma de fuego y finalmente lograron hacerlo. No es de extrañar que hoy en día ya de doce años de edad llevan una escopeta en el camino a su campo de Yuca, con la esperanza de sorprender a un Jochi Colorado. El resultado de la utilización continua de un número relativamente grande de rifles y escopetas es inconfundible. En comparación con otras regiones, los bosques de Ivón estan vacíos, y el juego se ha trasladado a un nuevo territorío en otro lugar. El suministro de carne es cada vez más precaria. La solución elegida por el lingüista - misionero para asegurar el abastecimiento de carne, es la introducción de ganado.

\section{Pesca}

El antiguo territorío Chácobo era rico de los remansos de los ríos más grandes y muchos pequeños, arroyos, riachuelos y ríos que desembocan en el Lago Rogo Aguado, uno de los mayores lagos de las tierras bajas de Bolivia, por tanto la pesca jugó siempre un papel importante. Los peces disponibles se encuentran entre las especies más conocidas en el este de Bolivia, por ejemplo, Benton (awasho), Yeyu (nersbini), Surubí (wawino), Palometa (hacer), Boga (sakawiko), Raya (iwi), Sardina (sanibi), Curubina (nersti), Zapato (ipo), Sábalo (bowiritsho), blanquillo (apo), Pirai'ba (yariwd) y Tachaca tapamo). En el agua clara, con buenas condiciones de disparo del Chácobo puede utilizar los dos tipos de flechas mencionados. Formación de bajamar y 
un estanque temporal en época de seca favorece el uso de veneno para peces (asha), extraído de una planta silvestre (Paulinia sp.). Cuando los pozos de agua está casi sin agua, les permite recoger los peces con la mano en el fondo fangoso, una actividad que se hacen a menudo por las mujeres y los niños. El uso de redes y trampas es desconocida. Hoy en día se utilizan anzuelos de pesca de vez en cuando. La existencia de un vocabularío Chácobo para el gancho (Weti) lleva a la conclusión de que o bien la adquirieron hace mucho tiempo, de vez en cuando con anzuelos hechos de fragmentos de huesos, huesos de pescado y espinas, y tenian los hilos de pesca hilo hechos de algodón. El pescado se come principalmente ahumado. Para preservalo se ahuma, con lo cual alargan su período de duración hasta dos dias y medio. Sin embargo, las pozas de poca profundidad del arroyo de Ivón no hay un gran área de pesca que proporcionaría excedentes. Como nos dijeron, hacen expediciones de pesca al comparativamente rico Río Benicito lugar al que requieren de una marcha de dos días.

\section{Actividades Generales de Colección}

Al igual que con todos los grupos de nativos americanos de la zona de tierras bajas de Bolivia, la comida obtenida por el cultivo se complementa con la adición de frutos silvestres recolectados. Las nueces del motacú Palma (sherwini; Atalea) estan disponibles durante todo el año, pero otras frutas como (bimi) y las tuercas (OIE) se producen estacionalmente. A lo largo del Río Ivón (awatishi ; Estoraque sp), Coquino (watawi; Ardisia sp), Paquio (Kurama ; Hymenaea $\mathrm{sp}$ ) y cacao (no'ote) son comunes. Otras plantas no ofrecen mucho más que un regalo para los niños, como el Uvillo (tshakini ; Vallea sp). El uso de frutos de palmera cocidos no parece ser significativo por lo menos, no se observó una vez durante nuestra estancia. Nueces de palma son una de las favoritas, pero el mesocarpio, la única parte carnosa de la pared del fruto (witshi) es débil. Esto se aplica a las nueces del motacú, pero sobre todo Majo (itsama;Oenocarpus $\mathrm{sp)}$ y Marayau (shinishiosho ; Bactris sp). Una excepción es la palma Wanima, que cuenta con gran cantidad de fruta que se pueden cocinar, pero no estoy seguro si esto es Guilielma gasipaes.

Interesantes son las llamadas Manchas, lugares donde varios árboles con gran cantidad de la fruta se puede encontrar. Los árboles individuales en esas localidades son propiedad de individuos particulares. También se recogen tortugas (Prodocnemis sp Shawi ; Testudo tabula$t a$; Nesho.) y sus huevos.

La extracción de la miel de abejas silvestres, que son muy diversas, requiere la tala del árbol refugio. La miel (wato) viene casi siempre de las abejas sin aguijón (Herzegovina, tshara, samuma, heshetewaka etc.). Se usa la cera como un subproducto, pero ha perdido importancia con la disminución de la producción de las flechas y el cultivo de chuchio para fabricar los ejes de las flechas ha 

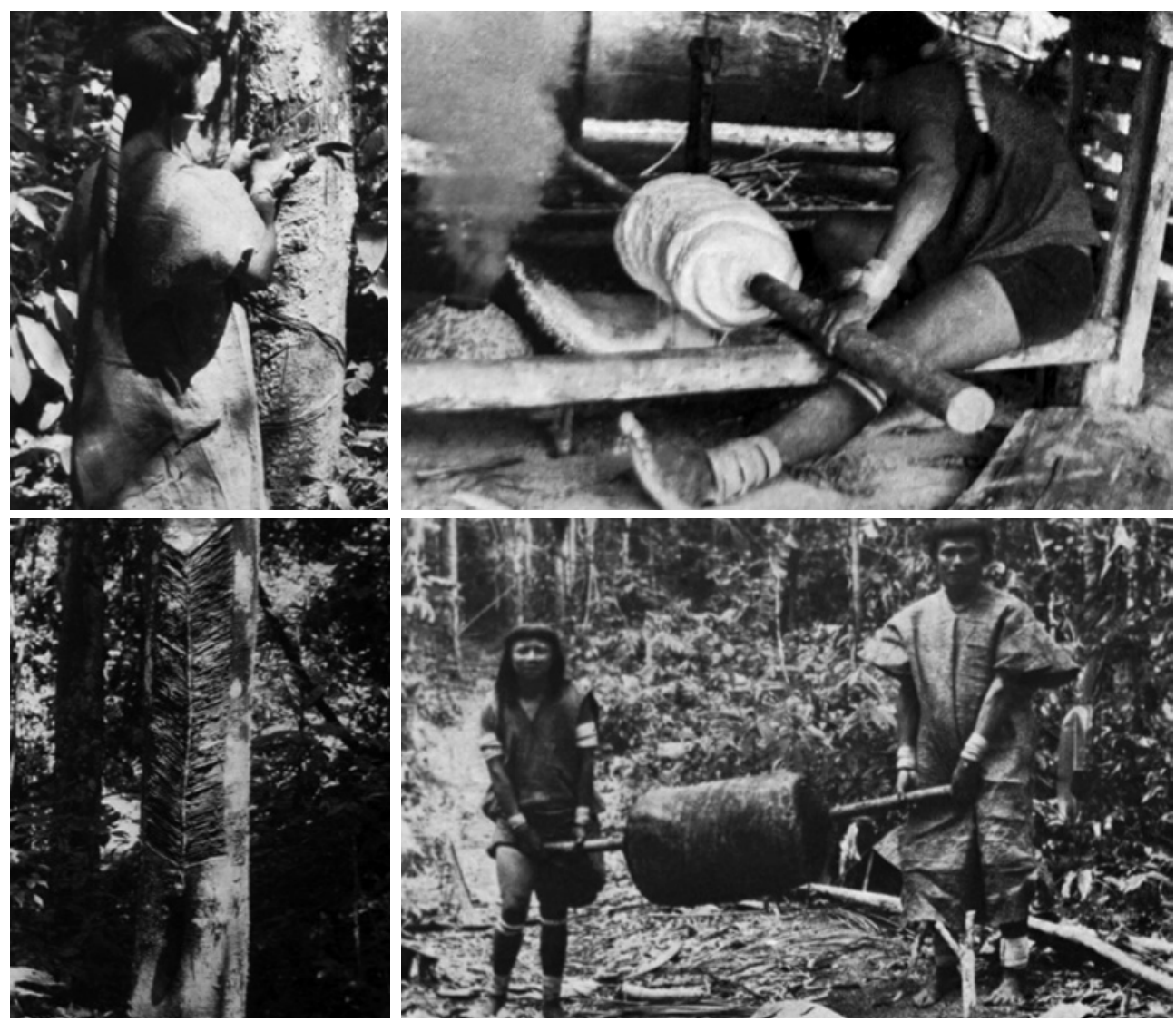

Fig. 34,35,36,37. El Chácobos tiene conocimiento antiguo del karama, como ellos Ilaman al caucho. Acá se puede observar el proceso de extracción del caucho.

sido casi completamente abandonado.

\section{Actividades económicas modernas}

\section{La extracción del caucho silvestre}

Hevea brasiliensis crece sobre todo en tierras relativamente bajas del bosque, estacionalmente inundadas.

Los bosques de este tipo son comunes alrededor de Arroyo Ivón, que ahora está habitada por la mayoría de Chácobo. El Ivón es uno de esos ríos de Bolivia del Noreste que durante mucho tiempo ha sido aprovechado para la extracción del caucho. Antenor Vásquez tenía un cuartel de goma en la confluencia de Ivón y Río Beni en 1886. Después de la Segunda Guerra Mundial Ios lugares de extracción de goma fueron abandonados en muchas regiones. La explotación de las poblaciones silvestres de goma por el Chácobo no se hace de forma colectiva. Más bien, son empresas familiares, ya que cada cabeza de una familia nuclear tiene su propia Siringal. Como regla general, los Siringales tienen dos "estradas", como el colector de caucho llama un cierto número de árboles - soporte de goma (palos), conectadas por un camino. Se 
tiene que dejar en claro que han sido los misioneros lingüistas los que han jugado un rol importante sobre la idea de propiedad privada.

El Chácobo tiene conocimiento antiguo del karama, como ellos lo llaman el caucho, y siempre lo han utilizado para la producción de la tela de los tambores y las bolas (wi'iniwa). Las técnicas de extracción de goma salvajes modernos se sabe que los Chácobo durante mucho tiempo. Una intensificación de la explotación de las poblaciones de Hevea comenzó aparentemente sólo como sugerencia de los lingüistas. El Chácobo esta ahora muy familiarizado con la profesión de Siringuero, y también tienen el equipo necesarío y demás accesoríos utilizados para la producción de caucho. Si él es un Seringuero, el Chácobo generalmente comienza su jornada de trabajo muy temprano, con la llamada "pica" o "colecta ", que es la primera de dos operaciones. Desde su "centro" va al primer árbol de caucho de uno de sus "estradas" corta la corteza y el látex se acumula gradualmente en el "tichela", que se fija expertamente por debajo de la cavidad principal que se extiende verticalmente en la corteza de los árboles. "estrada" que por lo general cuenta con 120 a 150 árboles. el siringuero distinguises árboles con diferentes calidades de goma por el color de la corteza. los ingresos más grande proporciona "siringa rosada". El Chácobo llamar la herramienta caucheros wisbati kara, en contraste con un cuchillo ordinarío (pistia man'e) y Machete (man'e o saipi). Wishakia es el proceso de corte de las incisiones en un árbol. La incisión principal es Wi'ischa ana. El "tichela" es una forma de recipiente de metal afilado cono cono de un octavo o un cuarto de litro de capacidad.

El segundo y último paso es la "salud" del caucho, como se llaman a la coagulación inducida artificialmente del látex. Ella se realiza en la cabaña rectangular, cubierto con hojas de palmera, abierto en dos lados. Procesamiento local de la goma en ponchos de goma y bolsas, que son comunes en otros lugares, a mayor escala, se hace de manera esporádica por los Chácobo, y sólo vimos un par de zapatos. Cada estrada regular tiene 120 a 200 árboles y requiere de tres a cuatro horas para las dos rondas. Aproximadamente dos horas se gastan en calentar la goma. El goma tratada al calor es transportada al mercado por en el avión de los misioneros.

La producción de caucho esta supervisada y dirigida por los misioneros. El ingreso individual se utiliza para comprar ar-

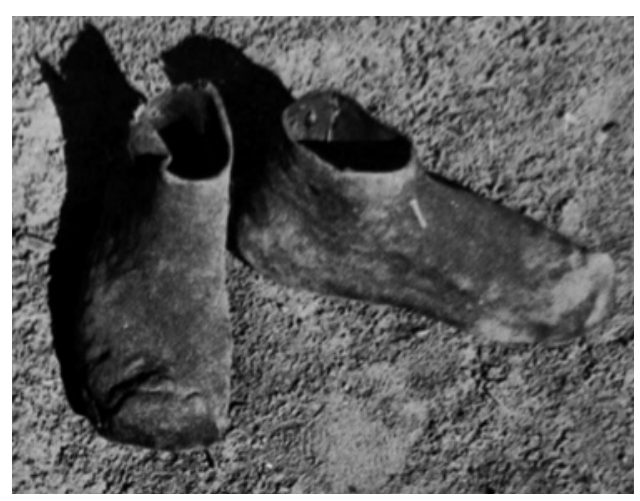

Fig. 38. Zapatos de caucho, son poco comunes. 
mas de fuego y el desarrollo de la ganadería. Sin lugar a dudas la protección de la misión será crucial en el futuro cercano. Es sintomático de la actitud de los mestizos contra los Chácobo que la ausencia temporal del misionero llevó a caucheros que ocupen la estrada Chácobo en el Río Genesuaya.

\section{Ganado}

Al igual que con otros grupos indígenas de la zona, la ganadería originalmente se limita a el perro (inaka), que se utiliza para la caza, pero estos son maltratados. En los últimos tiempos usan a los perros como asistentes de la caza, que es aún más importante cuando uno puede vender las pieles de Jaguar y por lo tanto tiene un mayor interés que antes de utilizar los grupos de perros para el seguimiento de los grandes felinos. Aves de todo tipo, especialmente loros y tucanes, así como mamíferos, como los monos capuchinos se mantienen los bosques..

El pollo (patiari) es sido conocido y a menudo son también tratados como animales de compañía y bien puede suceder que los dejen vivir hasta la ve-

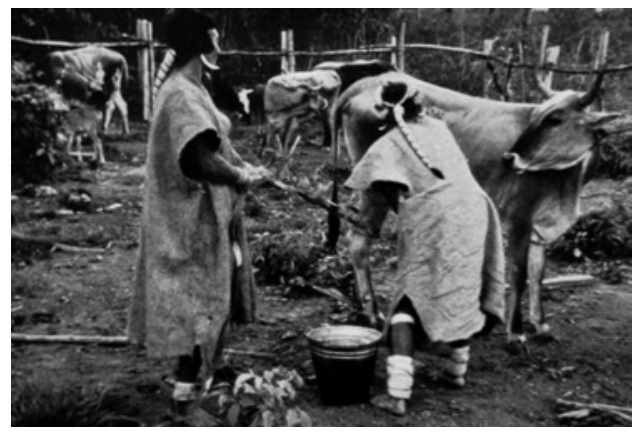

Fig. 39. La crianza de ganado no les gusta, por lo que los resultados que obtienen no son muy alentadores. jez. Los huevos se venden, y los clientes aquí son los miembros de la familia del misionero.

Para abordar el problema de la oferta de carne se ha señalado que la Misión ha introducido ganado bovino y porcino. ¿Qué tan importante el problema de la obtención de la carne es para el Chácobo, es suficiente una observación evidente hecha por Prost : "Hay algunos dias en que no tienen ni carne ni pescado". Ellos comentan que sí se quejan de hambre, aunque Tengan frutas silvestres o harina de yuca, porqué la única cosa que ellos consideran verdaderamente comida es la carne o el pescado". La misión no ha escatimado esfuerzos para dar un buen comienzo a la cría de ganado. Ellos trajeron el ganado por avión. En área relativamente grande se talan y luego son cercadas con alambre y finalmente instruyen al Chácobo en el cuidado de los animales.

Cómo las cosas con el tiempo van a salir no está claro, pero los resultados obtenidos hasta ahora no son alentadores. De diez cabezas de ganado adquiridas originalmente tres han muerto ya. Hay una falta de pastos naturales y artificiales y las garrapatas son un gran problema. Por encima de todo, los propios Chácobo que todavía no disponen de los intereses y la capacitación para la crianza de ganado adecuado. No tienen la práctica en el uso de el lazo, la necesidad para el cultivo de plantas forrajeras, o el lavado de los bovinos para protegerlos contra las garrapatas. Por último, es lamentable que las vacas, aunque no son una 
propiedad colectiva, se mantienen todos en Alto Ivón. Las personas particulares, quienes los hayan adquirido con el producto de la venta de caucho silvestre, están en parte viven en los otros dos asentamientos, y por lo tanto no pueden hacer frente al cuidado del ganado. Se espera de los hombres de Alto Ivón para cuidar el ganado y normalmente, los más antigüos "se ocupan de las vacas" como él mismo describe lo que hace y con la regularidad que tienen que cazar a los animales que escaparon a la selva.

La actitud de los cerdos criados libremente es muy problemático. Ellos están dondequiera en estas áreas, y tienen la idea que el cerdo solamente debe alimentarse de basura orgánica

y las nueces de palma. La experiencia demuestra que los cerdos les encanta cultivos en campos sin cercar y van muy lejos. Nuestra llegada fue razón suficiente para matar a uno de los dos cerdos domésticos existentes de Chácobo Alto Ivón.

\section{Artesanía}

A diferencia por ejemplo de los Yuracaré cuyas esposas hacen la parte principal de este trabajo, la producción de tela de corteza (moro) por el Chácobo es obra de los hombres, probablemente porque sólo ellos usan estas camisas. Las mujeres usan tejidos de corteza vegetal sólo como una banda de apoyo para las cestas y hacer porta bebés (Wake toati) con aproximadamente $15 \mathrm{~cm}$ de ancho y bandas cosidas. Varias especies de Ficus (Shua, isakapoe, pio, mororea, yom'eno), proporcionan la tela, que es naturalmente de color marrón o blanco. El material marrón es preferible porque es más denso y más firme. El requisito previo para la obtención de una pieza adecuada para una camisa de la corteza es que la copa del árbol talado debe tener un tallo sin ramas de longitud y grosor suficiente. Después de golpear la corteza con una madera se desprende la misma del tronco y luego se separa de la capa de la estopa.

La trenza $5 \mathrm{~cm}$ ancha de los hombres tiene siempre una raya negro, y está hecho de algodón. El telar utilizado para su producción (hiwi nima ana) se hace rápidamente de la madera todavía verde y se usa también la corteza de ser necesarío. La mujer (Towu shra ana) se muestra en la Figura 43 está utilizando un cuchillo de origen europeo cuya vanguardia es contundente, en lugar de una espada de madera para tejer.

Los hombres cuando están lejos de las viviendas similares a los siríonó necesitan sólo unos pocos minutos para hacer una canasta (shrapo) a partir de una hoja de palma. Sin embargo, en general, la fabricación de cestas y otros artículos (k'ekokia) es responsabilidad de la mujer. En cada hogar, dos cestas diferentes están presentes siempre en mayor número. Esto es especialmente cierto para las cestas circulares (tsitshama) cuyo diámetro puede ser de más de medio metro, o sólo $15 \mathrm{~cm}$ hace de la hoja inactiva de una palma de chonta (Panima; hrlkowana). Cestas de este tipo se utilizan principalmente para llevar los alimentos, especialmente de carne ahu- 

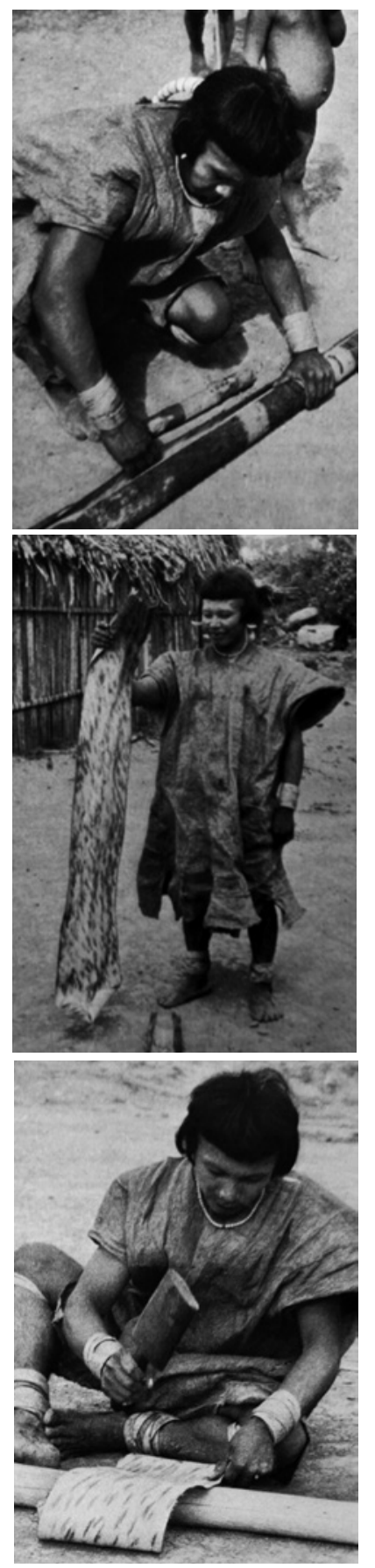

Fig. 40, 41, 42. La fabricación de una camisa de corteza, requiere un conocimiento y destreza especial mada. La columna vertebral de la cesta tiene aproximadamente en forma de pirámide (kakanu) y consta de alrededor de secciones - de una pulgada de espesor de un bejuco (käkatau), formando cuatro escuadras que cruzan desde el lado exteríor a la parte inferíor. Las paredes laterales (kapatd) se hacen de cierta Tiliacee (Apeiba tibourbou Cabeza de Mono). Un artefacto cuadrado construído a partir de una Heliconia (Jichiqui de Patujú), cuya estructura de madera tiene una longitud lateral de $60 \mathrm{~cm}$ como regla general, sirve como un tamiz o colador. Sopladores triangulares (weke weketi) también están hechos de palma. Las inflorescencias, de las especies de palma Onipa (Pachiuba ; Iriartea exorrhiza) y pdnane (Asai = Euterpe edulis) se utilizan como escobas (matsirti). Nordenskiöld, antes citado decía que tenian una caja con tapa rectangular hecho de chuchio, que servía a los hombres para llevar diversos adornos. La existencia de tales artefactos no se puede determinar. Lo mismo se aplica a las grandes esteras tejidas mencionadas por Prost, que como ella escribe, se siven como lugar para dormir en el suelo. En realidad no hemos encontrado a nadie que dormía en el suelo, y el Pano de la corteza y las prendas de tela descartadas fueron utilizados en las plataformas para dormir.

La cerámica está hecha por las mujeres y constan de cuatro vasijas de diferente tipo, sin embargo todas ellas tienen una sección transversal circular. El que se caracteriza por una amplia boca sobresaliente y un fondo más pequeño, esta sirve para la chicha (pae), algunas tienen gran capacidad y llegan a medir casi un metro de altura de casi. Una vasija grande, baja cilíndrica (pitirsbti) sirve o asar Yuca. Las vasijas pequeñas, aproximadamente planas - cónica (Tebo) sirven a varíos propósitos. El cuarto tipo de vasija es una jarra con un bulbo (tshomo), que por lo general sirve como un depósito de agua, y calentar el caucho en bruto (Komeno). Para la preparación de los vasos siempre usan arcilla (mdpuka) desde ciertos puntos de la orilla del arroyo Ivón. Esta es combinado con un material obtenido por molienda 
(teoaki), partículas de carbón y cenizas de la corteza de una madera muy específico llamado m'e'i. No hay ornamentación. Las demás vasijas están hechos de calabazas (Crescentia cujete; Tutuma), kutshupi y shatano (Cucurbita sp; Mate) por ejemplo Tschitscha Abrevaderos o contenedores para semillas.

\section{Transporte}

Los caminos forestales son duros y sinuosos (bai). La única excepción son los caminos de $2 \mathrm{~m}$ de ancho hechos en linea recta entre los asentamientos, hechos por orden de los misioneros lingüistas, de modo que puedan ir de un lugar a otro muy rápido en una motocicleta, que como explica el Chácobo, para proclamar el mensaje de salvación o simplemente para pedir algo. Los puentes se hicieron como estructuras estables en los caminos, mientras que el Chácobo normalmente sólo tiene que utilizar los troncos de árbol como puente. Bajo el título "Transporte" menciona Métraux en la "Guía práctica de los indios de América del Sur", que el Pacaguara y Caripuna utilizan canoas de corteza. Podemos añadir a esto que los Chácobo tiene un tipo similar de embarcaciones. Para la preparación de la canoa (noti) que utilizan la corteza (Sakata) de Kurama (Paquio, Hymenaea sp). Hay paletas sola hoja (la mula), supuestamente hechas de madera de cedro (iTSA).

\section{Condiciones sociales}

Criar a los hijos es parecido a como lo hacen los indios de otros grupos. A la tierna edad, estan siendo custodiados por la madre, el niño está jugando con un arco y flecha. El Chácobo tiene numerosos nombres, en parte como un sinónimo de afiliación, edad, desde recién nacido o niño pequeño (ko b'ena, pistia estela) a las personas mayores (Honi siri, srenih) y la vieja (yosha Yosi, ewati sreni). Todo el mundo tiene su tabique nasal perforado. Una vez que la herida haya cicatrizado, se insertan brillantes plumas rojas.

Sólo cuando está equipado (tak'e resetei), un joven (shina Atsiki) de unos 18 años se puede usar todos los

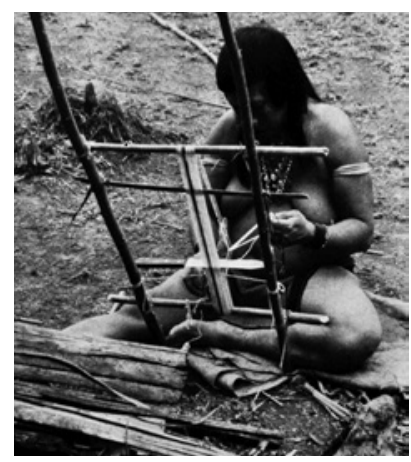

Fig. 43. La mujer está utilizando un cuchillo en lugar de la tradicional madera.

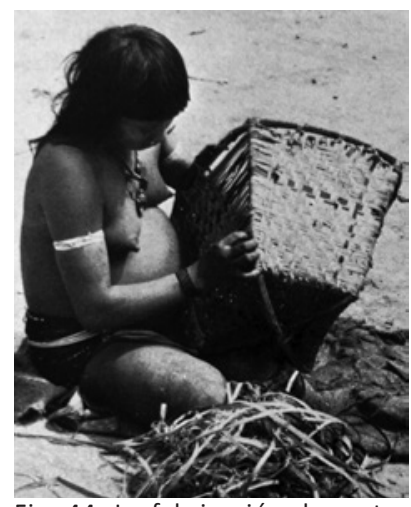

Fig. 44. La fabricación de cestas (tsitshama) y otros artículos (k'ekokia) es responsabilidad de la mujer.

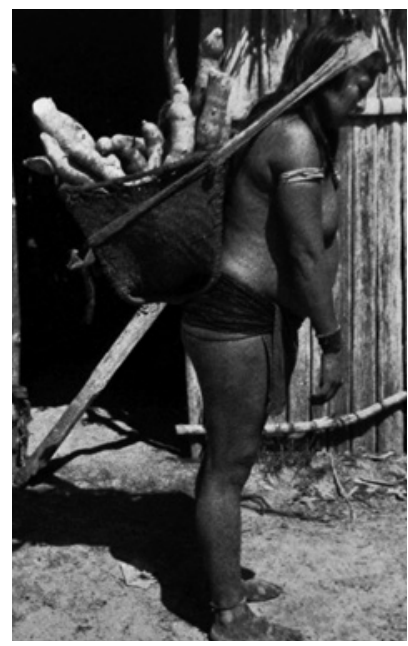

Fig. 45. Mujer llevando yucas en una cesta (tsitshama). 
Heinz Kelm, 1972. Chácobo 1970
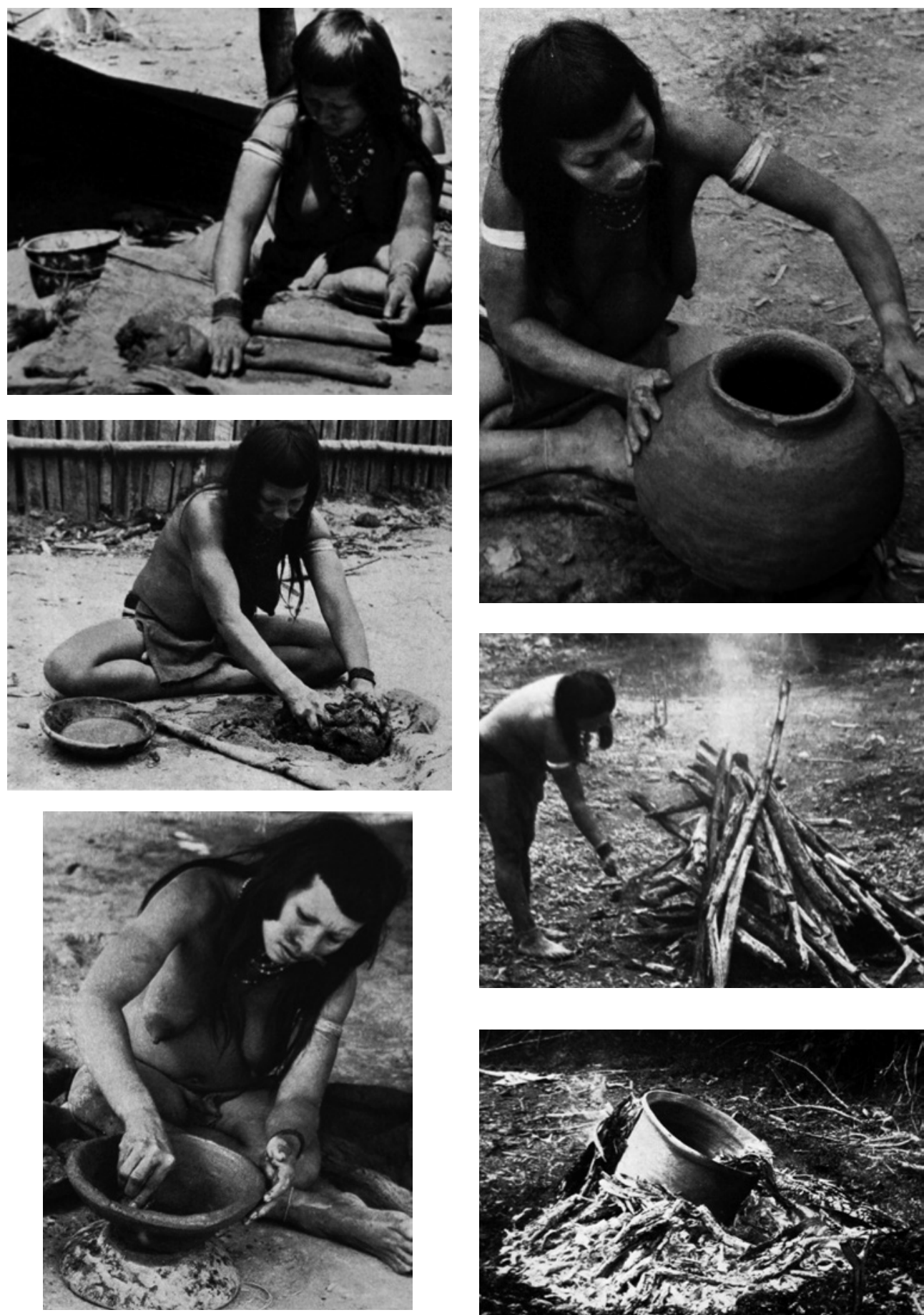

Fig. 46, 47, 48, 49, 50, 51. Proceso de fabricación de la cerámica, desde la preparación de la arcilla, pasando por el moldeado y quemado, su cerámica es para su uso diario. 
adornos de los hombres (am'eyai tak'e) y el cambio de neing soltero (awinuma) para convertirse en casado (awiya) y puede llamarse a sí mismo, después de asumir el papel de padre, un verdadero hombre (Honi Honi ria). Como miembro de pleno derecho de la sociedad, se puede participar a partir de ahora en las deliberaciones en casa de los hombres y la vida ceremonial del grupo. Las niñas reciben sus adornos de la nariz, con ocasión de su primera menstruación.

Los matrimonios se producen sin ningún tipo de ceremonia. El hombre ofrece carne a la cónyuge potencial de su interés. Si éstos son aceptados y devuelve regalos en forma de harina de yuca o Chive (pukakia moto no') el matrimonio se considera cerrado.

No hubo celebración durante nuestra estancia, pero nuestra llegada fue razón suficiente para que los Chácobo que viven lejos lleguen para visitar Alto Ivón. Como se ha observado por otros autores, los visitantes llegaron en fila india. Al entrar las mujeres van detrás de los hombres, y estos magníficamente adornados y de frente sin tener que mirar hacia la izquierda o hacia la derecha, directamente van a casa de los hombres donde son recibidos por los lug- areños, con fórmulas estereotipadas de felicitación. El Tschitscha (Hene Shapo) se encuentra en un gran recipiente de cerámica de la mitad de la Cámara. Antes del disfrute de la Chicha el anciano anfitrión (shina kushi) tiene que coger con el dedo pulgar en un recipiente y dar el ejemplo. El recipiente va pasando por todos en una ronda y todos los hombres siguen el ejemplo del anfitrión, mientras que los jóvenes aún no plenamente iniciados sólo entregan el recipiente. Cada uno coloca por separado con el pulgar en el vaso y todos al mismo tiempo lamen su pulgar, una vez que indica el anciano mayor. Luego se vacía el Tutuma La danza de los hombres (ho - paw'i nibo ana) tiene dos formas. Palma Corto palos de madera (shate), ya que se realizaron anteríormente como un utensilio de la danza, ya no están en uso hoy en día. Las flautas de bambú no son el único instrumento conocido como escribe Nordenskiöld. También se utilizan un tipo de tambor vaso de barro (Komeno), cuya cubierta (mapoti) está hecho de caucho crudo. Se juega con un mazo de madera (awuumati), sentado en frente de la línea de bailarines hombres y da ritmo al canto (nanarikia). En el baile las mujeres (yosbabo pawi ana) ponen sus manos sobre los hombros de sus vecinos.

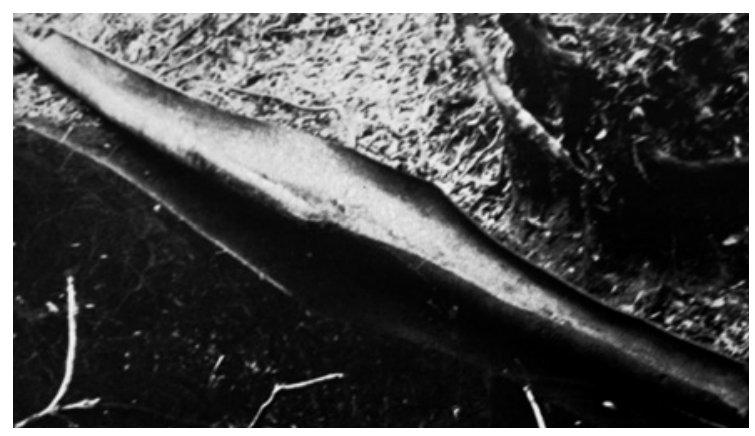

123
Fig. 52. Para la preparación de la canoa (noti) que utilizan la corteza (Sakata) de Kurama. 
Heinz Kelm, 1972. Chácobo 1970

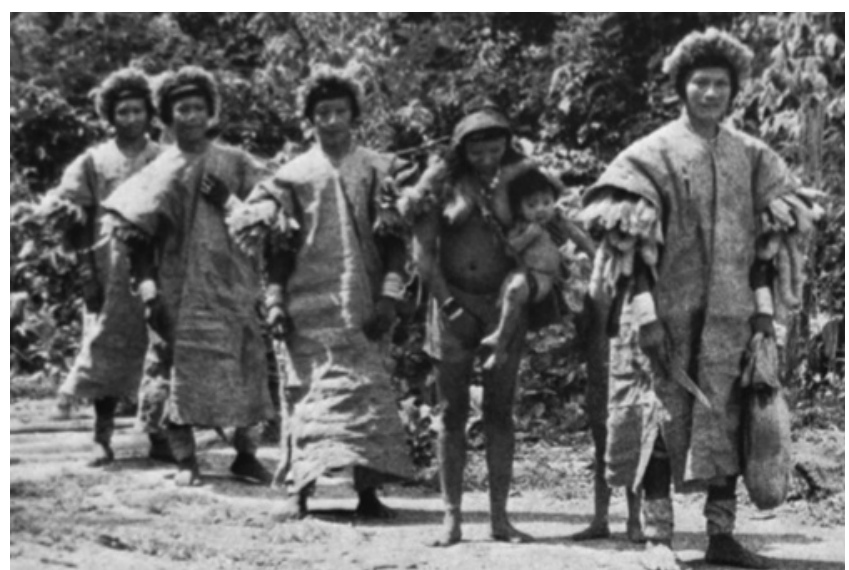

Fig. 53. Chácobo llegando a la celebración de una fiesta.

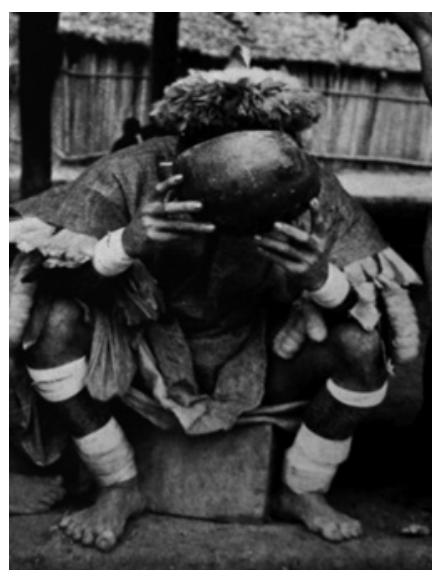

Fig. 52. Anciano Chácobo bebiendo chicha de yuca.

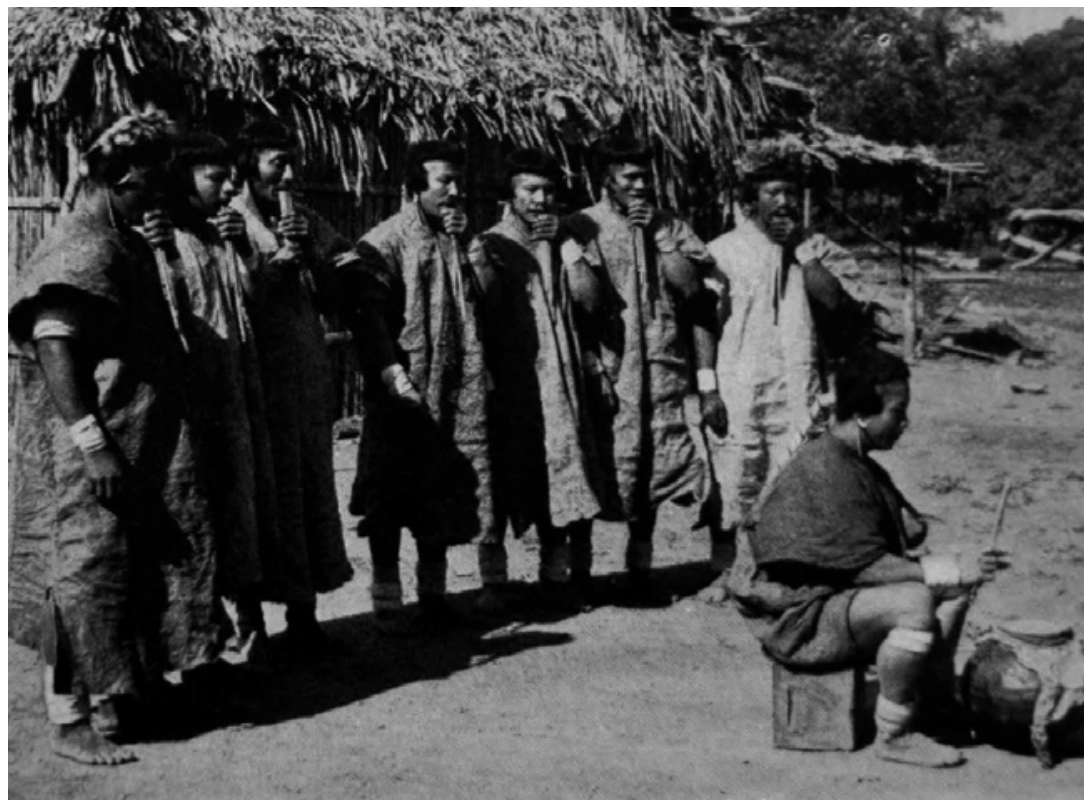

Fig. 52. Chácobo disfrutando de la celebración de una fiesta se observa una línea de bailarines hombres y da ritmo al canto (nanarikia). 


\section{Cuentos registrados en Alto Ivón (Noviembre de 1970)}

\section{La vida de Kako}

Narrado por Carmelo (Yako)

Allí vivía una mujer sola, sin marido. Su marido habia ido al bosque un día, y no regresó, y después de que ella siempre había estado esperando en vano para él, la mujer lo siguió hacia el bosque. Su nombre era Iwa. Ahora ella vagó hacia atrás y adelante a través de la selva, y por la noche dormía solo. Después de un tiempo se quedó embarazada, pero nadie sabía cómo, porque su marido se había ido hace mucho tiempo.

"Dame un juguete", dijo el niño en el cuerpo de su madre. La madre recogió unas hojas y se frotó el vientre con ellos. Asi conversó con el niño. Mientras caminaba por el bosque, llegaron a una encrucijada. Entonces el muchacho dijo a su madre. "Toma el camino de la izquierda, donde las plumas rojas del loro es donde mi padre se fue hacia largo tiempo, pero en el camoino en que el Jaguar (Kamanu) anda verás plumas del loro amarillo. La madre estaba muy confundido por estas palabras de su hijo. "¿Qué camino debo ir" preguntó ella, " el rojo o el amarillo?" En su entusiasmo,siguió el camino equivocado. Después de algún tiempo, llegaron a una choza, en la que estaba sentado una anciana que habló amablemente y dijo :... "Ven a mí". "No, contestó la mujer, yo no puedo parar. Tengo que encontrar a mi marido". "Tu marido no encontrarás aquí", respondió la anciana," caminaba por el otro camino de las plumas de loro rojo." La vieja era, por supuesto, la madre Jaguar. "Oh, hija" le dijo a la joven, "han tomado el camino equivocado.." Entonces la mujer se sentó con la antigua. "Mi hijo regresara pronto," continuó la anciana, "se fue de caza."

El Jaguar ya venía con una Anta (Dwara) en su espalda, pues era un gran cazador. "¿Qué es esta mujer que ha venido aquí", exclamó. Estaba furioso. "Una buena mujer", respondió la madre, "sería la mujer adecuada para que te cases." Pero el Jaguar quería oír nada. Él estaba terriblemente enojado. Después de un rato le dijo a la mujer: "Me podrás scar los piojos en mi piel." "Ten cuidado, hijo mío", dijo el la madre del jaguar, "es una buena mujer. Así que cálmate." Y volviéndose hacia la mujer, ella continuó: "no tires los piojos de mi hijo lejos." Pero Jaguar tenía piojos grandes que estaban cerca de una pulgada de largo, y la mujer no aplastó estos grandes piojos con suficiente atención, y asi todavía estaban con vida cuado se cayó 
al suelo y se arrastró. Jaguar se enojó y golpeó la mujer con su pata de manera que se le rompió el cuello, y cuando murió el Jaguar la arrojó a los pies de su madre. "Aquí, cocina la para mí", dijo el. "Sí, mi hijo", respondió la madre. Jaguar estaba sudando de furia y tiró todas partes de su pelaje. La abuela cortó las extremidades de la mujer y los puso a asar en la Chapapais. Pero cuando abrió el vientre de la mujer, tres hijos salieron fuera, dos niños y una niña. Los chicos fueron llamados Kako y Yana, la chica Mashei'a. La anciana escondió a los niños rápidamente de nuevo en el útero y lo ató cerrada. “¿Dónde puedo esconderles?”, se preguntó. En este instante su mirada se posó sobre un paiti. Le dio la vuelta y puso el útero con los niños debajo. Luego, el jaguar se comió la madre de los niños. Tres días los niños en el útero estaban bajo de la olla de barro. Luego los niños salieron y golpearon con sus nudillos contra la pared de la olla. "Bong !" sonó el tono. La madre Jaguar barrió la cabaña rápidamente y ruidosamente con la escoba, para que su hijo no podía oír lo que estaba ocurriendo bajo la olla de barro. Los niños que ahora habían dejado todo el útero, se quedaron bajo la olla, donde crecieron rápidamente. Después de un día fueron tan grande como si se tratara de niños de un año de edad, y al día siguiente eran tan grandes como niños de tres años. Cuando el Jaguar fue al bosque a cazar, la madre dejó salir a los niños, para que puedan jugar en la casa, y poco antes del regreso del jaguar, se deslizó rápidamente de vuelta a su escondite. Algún día el Jaguar volvió inesperadamente a casa temprano, y los niños ya no podían esconderse a tiempo. Cuando los vió, él se enojó mucho, y con ira, empezó a sudar. "¿De dónde salieron estos niños " exclamó, "estos niños sin madre, ¿qué es lo que quieren ?" "Deja los niños", dijo su madre, "puedan ser tus amigos." "Muy bien", dijo el Jaguar. Los niños crecieron rápido ahora. Kako construyó una pequeña casa para él y sus hermanos, hizo una mesa y un banco, y también pequeños cuencos de barro para todos ellos. Él se cortó una flauta y sopló sobre ella. Cuando Jaguar vio y oyó esto, exclamó: "¿Qué ruido los niños hacen allí. ¿Qué están haciendo?" "Oh, que lo hagan", respondió la Madre Jaguar, ellos sólo juegan." Después de tres días, los niños habían vuelto a ser más grande, y el ruido que hacían era aún más fuerte. "Ya no quiero oír el ruido!!" gritó el Jaguar. Fue hacia los niños y les regañó. “Dejan hacer este ruido", gritó. Los niños se fueron al bosque, donde construyeron una casa más grande y amueblado. Recogieron las frutas de la Chonta que se asan en el fuego y comieron. Kako ahora se sentó de frequencia y tocó la flauta. Esto también escuchó el jaguar, y le gustó mucho. Se fue casa de los niños y escuchó. Bellamente sopló Kako. Pero aún así sabía exactamente que los Jaguares hicieron a su madre. "Debemos pensar en lo que hacemos con el Jaguar", dijo a sus hermanos.

Un día el Jaguar se unió a él y dijo: "Vamos a traer cebolleta por la abuela." Así fueron y trajeron la cebolleta para la madre Jaguar, y cuando ella se agachó comieron y el Jaguar jugó con los niños. Aquí Kako adcendió a una palmera, se 
sentó en la copa del árbol y se balanceó hacia atrás y adelante hasta que la corona se inclinó y le colocó suavemente en la tierra. A medida que el Jaguar vio esto, dijo: Oh, yo también quiero subir y seguir su ejemplo." Se subió. Pero la parte superior de la palma no se rompió, y él se cayó y cayó justo en una estaca puntiaguda que Kako había creado deliberadamente bajo la palmera. Así se murió el Jaguar. "Bien hecho", dijeron los hermanos a Kako. "Ahora lo comeremos." Ellos lo desquartizaron y arrojaron las partes individuales para asar en el Chapapa. Cuando la cabeza estaba caliente, de repente soltó un ojo e hizo un ruido como el disparo de un Shalon (rifle). Entonces la Madre Jaguar llamó: “¿Qué está pasando? Mataron a mi hijo?” "No," respondió el muchacho, "una motacú ha estallado". "Creo que no", gritó la anciana de vuelta "han matado a mi hijo! Ahora voy a tener nada que ver con ustedes." Ella montó en cólera. "Fuera de aquí!" Les gritó: "Yo ya no quiero verles!" Kako se fue paso, mientras que los otros dos estaban todavía allí. En su viaje Kako fue a la casa de un Mutún (Hasene). "¿Qué quieres comer", le preguntó al Mutún. "Nada, respondió el Mutún", y salió de su casa. Al día siguiente sucedió lo mismo. El Mutún estaba comiendo Almendras, y el muchacho lo oyó. “¿Qué tienes”, preguntó: “¿Me puedes decir?" "No tengo nada", respondió el Mutún de nuevo. Después de un rato, el Mutún regresó en secreto a escondidas a la casa. Kako se había fijado y lo siguió en secreto. Entonces vio que el Mutún trayó sus nueces de Brasil, pero él estaba escondiéndose y esperando hasta que el Mutún salió. Se llenó su bolsa con las nueces y luego regresó a su casa. Tan pronto como el Mutún desapareció, Kako salió de su escondite y subió en el árbol de la nuez. Allí se sentó en una rama y comió hasta hartarse. Pero mientras él todavía estaba comiendo, el Mutún regresó. "Oh, este chico malo", le reprendió, "comiste todos mis nueces. "Para castigar Kako se golpeó las manos, y el árbol se disparó rápidamente en el aire, siempre más y más alto, hacia el cielo, con Kako en la punta. Kako miró hacia el suelo y descubrió sus hermanos. "Oh, los pobres," dijo, "sentado allí y no tienen qué comer." Así los tiró Motacú y Asai hacia abajo para que tuvieran algo de comer. Él les arrojó otros alimentos. Despues de unos días el Mutún vino de nuevo para ver el muchacho. Cuando lo vio en el cielo, llamó: "Ves, esto es lo que pasa!" Luego se llevó las manos y el árbol se contrajo, y una segunda, tercera y una cuarta vez que el Mutún se llevó las manos, y cada vez que el árbol se encogió otra pieza. Finalmente, se mantuvo como lo es hoy.

Cuando Kako se sentó en el árbol de la nuez, sus hermanos vinieron y dijeron: “¿Cómo podemos ayudar a usted, que usted puede volver a bajar?" "Hazme un gancho en el que yo me puedo bajar", dijo Kako. Él hizo una muestra y lo lanzó hacia ellos, para que pudieran replicar. Ellos capturaron Caiman (kapete), hicieron un gancho de ella, y lo tiraron a Kako. Pero con eso Kako no podía hacer nada. Luego hicieron un gancho de madera y lo echaron a Kako. Este parecía bien. Así Kako se 
conectó firmemente a una rama de un árbol y luego se bajó lentamente a la tierra. Una vez abajo se abrazó con su hermanos. Hacía calor, y Kako sintió la necesidad de bañarse. Así dejó a sus hermanos y se fue al arroyo y saltó al agua. Pero en este arroyo vivieron pequeños peces que fueron llamados yawaiyawa. "Tapara, Tapara", dijeron. "Ajá", dijo Kako", los frutos que comí fueron tapa. Mientras Kako ahora salpicó en el agua, las olas golpean con fuerza contra el borde de el arroyo y formaron un despeñadero. Eso vio un Torcasa (wisane). Kako incursionó en su parte del arroyo y rebuscó en el agua, por lo que el estrecho arroyo se convirtió en un gran río. "Capturan al Martín Pescador (isafia), Kako gritó a su hermana. "Cuando él me ayuda, lo daré ropa." La hermana se levantó y fue a la casa de Martín Pescador y le dijo al respecto. "Lo intentaré, si puedo," dijo Martin Pescador y pidió a su madre: "tira algo en el agua." Entonces la madre tomó un keñua y lo arrojó al agua. Si tengo éxito con esta jarra para pescar, yo también sería capaz de sacar a Kako", dijo el Martín Pescador. Lo intentó, y lo consiguió. "Ahora puedo también sacar su hermano del agua", dijo. El Martín Pescador ahora voló sobre el río, y el niño regresó por tierra. Finalmente, el Martín Pescador llegó al punto donde estaban los otros pájaros. Kako no podía ver quién realmente eran y comenzó a difundir sus prendas. La Garza recibió un vestido blanco y el Pato negro, y le dio todas las aves que allí se habían reunido las prendas en todos los colores imaginables. Cuando había distribuido todos sus vestidos, les preguntó: “¿Quién realmente me sacó?" "Yo ", dijo el pequeño Martín Pescador, el pequeño hombrecito todavia bastante desnuda que estaba allí en medio de todos los animales magníficamente vestidos. "Oh, y ahora no tengo ni una sola prenda", respondió Kako "¿por qué no lo dijiste antes? Ahora sólo tengo mi bufanda". Así le dio el pañuelo. Enfurecido, el Martín Pescador se fue. Incluso hoy en día es blanco alrededor del cuello, donde se ha atado el pañuelo.

El hermano de Kako no tenía esposa. Sólo había hombres. Así que le dijo Kako "Necesito una esposa". Vamos a ver, dijo Kako, "Te daré una costilla". Kako sacó la costilla, y luego se lo puse debajo de un almendro. Al día siguiente, este estaba convertido ya en una mujer muy bonita. "Oh", exclamó Yatia lleno de alegría, " es una pequeña y hermosa mujer." Así Kako había creado a una mujer para su hermano. La otra gente también querían tener esposas y dijeron: "Pidamos a Kako hacer que más mujeres." Así que se fueron todos a Kako y le pidieron mujeres" Bueno, déjame ver", dijo Kako a uno después del otro. "Qué tipo de mujer te gustaría? Una grande o una pequeña?" A la persona que quiso una mujergrande le sacó una larga costilla y se puso debajo de una vasija de barro, y si alguien quiso una mujer pequeña, Kako tomó una costilla corta. Finalmente, todos los hombres tenían su esposa en el tamaño deseado. Algún tiempo después, la gente quería tener ganado. Kako fue a la Pampa y los llevó el ganado. 


\section{El origen de las plantas agrícolas}

\section{Narrado por Carmelo}

Una anciana tenía una caja con todo tipo de plantas - maíz, yuca y arroz. Las otras personas, sin embargo, no tenían nada. Tenían campos, pero ninguna semilla para sembrar. La anciana, que se llamaba Ashini, les dio semillas y tubérculos, pero no prosperaron en los campos de los seres humanos. "Lo que le da a nosotros no crecs," en el pueblo se decían unos a otros: "queremos ir allí nosotros mismos, y nos traemos semillas de su jardín que crecen en realidad, como el maíz y la yuca." Así que la anciana estaba sentada en su casa y lo molió el trigo, mientras que el loro vigilaba la plantación. En caso de que alguien venga a robar de las plantas, silbaba para informar a la anciana. Había una vez una pareja humana que se reunieron para robar las plantas. El loro silbaba, y la anciana se acercó corriendo. Mientras que las personas se estaban llenando sus cestos con maíz y yuca, la anciana se acercó y les encantó a fin de que ni siquiera podían sentarse. Entonces la anciana puso la pareja humana en cestas y los llevó a su casa. Allí, ella puso una enorme olla en el fuego y arrojó el hombre y la mujer en el interior, ya que ya eran cadáveres y con todas las tripas colgando. Ella los cocinó y luego se los comió. La anciana tenía un solo hijo, que respondía al nombre Wfreka. Este hijo tenía dos niños que nunca podría dejar sin vigilancia, porque si lo hacía, la anciana iba a comerlos inmediatamente. Una vez había ido al bosque a cortar leña y luego la anciana había comido un niño, por lo que la golpeó con su hacha o machete. Pero no pasó nada, porque era duro como la piedra. La anciana se comió mucha, mucha gente, todos los días comía una. "¿Qué vamos a hacer con esta mujer?" La gente preguntaban unos a otros. "Tenemos que encontrar una manera de eliminar de ella." Ellos vinieron con el plan para cavar un hoyo. La casa de la anciana estaba muy limpio. Habia ni un solo grano de maíz. La gente tampoco tenían fuego. Un día, un Grillo se acercó a la casa de la anciana. Cavó un pasaje debajo de la tierra, de modo que la anciana no podía verlo. Ella tenía el maíz apilado cuidadosamente, y si veía un solo grano, lo cogió y se lo puso en la pila. El Grillo ahora estaba bastante cerca a los granos de maíz, pero cada vez que quería agarrar un grano, la anciana llegó con su escoba y lo barrió. Una vez que un grano de maíz cayó al lado del agujero del Grillo. Lo agarró el grano y se escapó con él. La anciana se dio cuenta del robo de inmediato y quería evitar el escape de Grillo. "Hey, uno de mis granos ha sido robado de mí", exclamó. Rápidamente sacó una olla de agua hirviendo y la vació en el agujero de Grillo, pero estaba demasiado lejos y ya no podía ser alcanzado por el agua hirviendo. Con su grano Grillo se arrastró por el bosque y llegó a los campos de los pobres, donde ahora sembró los granos de maíz. Cada día la gente fue a ver. Cuando un hombre pobre día ha entró a su 
jardín, vio las plantas. "Es el maíz creciendo!", exclamó, y trajo todo el pueblo y dijo: "¡Mira! En mi jardín el maíz ha aumentado.Qqueremos proteger las plantas para que no seran derribados por el viento." Dicho y hecho. Después de un rato floreció el maíz y luego crecieron mazorcas con granos blancos, mazorcas con los granos negros, mazorcas con los granos rojos y, por último, en la parte superior, mazorcas con granos amarillos. Así que todas las variedades de maíz crecieron en una sola planta. Las personas cosecharon los granos y los mantenían un lugar seguro. Entonces ellos lo repartían entre ellos y sembraron maíz en todas las plantaciones. Ahora tenían maíz. Pero todavía no tenían fuego. “¿Cómo vamos a comer el maíz? "se preguntaban unos a otros. "¿Qué hacemos para conseguir el fuego?” Ahora había otro animal que robó el fuego. Este fue un Loro (Tui'm), un tipo diferente de loro, que tuvo un pico ancho y largo como un Tucán (tshoke). Un día, la anciana estaba en su hamaca junto al fuego. Siempre lo tuvo ahí con ella, para que nadie pudiera robarlo. Ella también siempre escobo con cuidado las brasas. Pero una vez una pequeña brasa cayó un poco más lejos. Voló el Loro, que yacía cerca de allí a la espera, y de inmediato tomó la brasa con su pico. El pico del ave, sin embargo, que había sido previamente bastante largo, se quemo y ahora es corto Pero la anciana envió agua y la lluvia para apagar el fuego de nuevo pero no lo logró. Ahora les faltaba sólo Yuca. "Vamos a ver," dijo un hombre, "como lo hacemos. Tenemos fuego ahora, pero necesitamos Yuca. Así que vamos a excavar." Así que cavaron una zanja, una larga, larga trinchera, que llegó a la casa de la anciana. Bajo su casa hicieron un hoyo profundo, para que la vieja mujer caiga en ella. Trabajaron hasta las raíces, dejando sólo una capa muy delgada de tierra por encima de la cavidad que hicieron para asegurarse de que la anciana no se dio cuenta de la trampa. A la mañana siguiente se dijeron unos a otros: "Vamos, vamos a ir a ver qué pasa. Cuando la anciana se cae, entonces nos reímos." Así que se pusieron en espera. Pero la anciana no pasó por un largo tiempo sobre el punto fino. Finalmente, por supuesto, ella lo pisó y cayó al suelo.

"HAHAHAHAHAHAHAHAHA!" se rieron las personas. Pero en el mismo momento la anciana se cambió en un Burgos (huro). Ninguno de los que vio allí mantuvo su forma humana. La gente, sin embargo, dijo: "Vamos a ir a su casa y ver si hay algo útil!" Así que todos se fueron el Oso Bandera (shra'e), que también era el hombre, tomó la escoba (matsirti). Pero esta escoba rápidamente creció pegado en su trasero, y desde entonces el Oso Bandera tiene una larga y ancha cola. "Vamos a ver que tiene", exclamó el Mutún, " voy a pintar mi mismo con urucú (mashe)." Así que tomó la Urucu de la anciana. Pero el color no salió despues, y ahora tiene que vivir con un pico rojo y patas de color rojo vivo. "¿Ves lo que yo hago", gritó la Peta (Shawe). "Voy a tomar el tonsille (piártkti)." Ella tomó el tonsille el de la anciana y la puso sobre su espalda. Allí creció pegado y se convirtió en su escudo. 
"Vamos a ver lo que hago", gritó el Tatft. "Sólo voy a tomar esta cesta (shrapo)". Pero la canasta se mantuvo como la casa en la espalda. "Vamos a ver lo que hago", gritó la Raya (iwipm), "voy a llevar conmigo un tamiz (toati)." Ahora el tamiz está creciendo firmemente en la espalda y ha estado allí siempre. La anciana bajo la tierra se convirtió en un Pejichi (panoa), y nunca salió de su agujero de nuevo. Todos los animales que tomaron un objeto de su casa se cambiaron de acuerdo a esas cosas. El Jaguar estaba allí también y se puso una olla de cocina (tshomo). Las personas, sin embargo, que no habían ido a la casa de la anciana mantienen su forma humana. "Ahora, vamos a ir", se dijeron unos a otros: "vamos a coger la Yuca de su jardín. Ahora no puede causar más daño." Así que fueron a su jardín y se metieron toda la Yuca que podían cargar. Desde entonces comen y preparan la chicha de yuca y chive.

\section{La migración de Nowa Pashawa}

narrado por Maro

Una vez la gente tuvo una pelea con los demás. Había varias casas cuyos residentes estaban luchando entre sí. Luego vino un fuego y se quemó a todos, y sólo un hombre se escapó. Éste estaba escondido en la cueva de Tatu. Fue Nowa Pashawa, nuestro antepasado. El fuego se extendió en todas direcciones y también quemó alrededor de la cueva, en la que Nowa Pashawa se había escondido. Después de algún tiempo, el hombre miró fuera de su agujero, y cuando vio que el fuego todavía estaba quemando se arrastró de nuevo bajo tierra. Luego miró de nuevo, y esta vez no pudo ver más llamas. Él salió de su agujero en el suelo y miró a su alrededor. Todo estaba quemado. No había ni una sola persona más. Nowa Pashawa ahora recogió todos los huesos que podía encontrar, y los puso cuidadosamente en un montón. Luego siguió su camino. Llegó a un motacú, y porque tenía miedo de dormir solo sin un arma en el suelo, se subió al árbol para pasar la noche allí. Mientras estaba sentado allí, la Peta vino y lo vio. "Vamos a batirnos contra el árbol," gritó la Peta y sacudió el tronco. El hombre tuvo mucho miedo. "Caerá, caerá!" gritó la Peta, pero no se cayó. Cuando él bajó de la palmera en la mañana, salió para ver si algunas personas habrían sobrevivido al fuego. De pronto, descubrió la Peta y ahora sabía que había estado allí y había hecho el ruido. Luego tomó una estaca y lo puso en el blanco de Peta. Pero después de la Peta estaba muerto, él todavía podía oír el ruido. Luego se fue de nuevo, y después de un tiempo vió un Grillo haciendo ruido. Tomó un palo y golpeó al Grillo en la cabeza. Luego siguió su camino. Caminó y caminó, y de repente se encontró con el Oso Bandera. El hombre llamó a la Chaitén Oso Bandera y lo saludó. "¿Qué estás haciendo, mi nieto?" respondió el Oso Bandera. "Buscando mi madre", dijo el hombre." Oh, tu madre está aquí muy cerca", dijo el 
Oso Bandera." Entonces, por favor guíame hacia ella", preguntó el hombre. "Muy bien", dijo el Oso Bandera. El Oso Bandera iba delante, y ellos marcharon todo el día, y el siguente. Parecía que ya habían recorrido una gran distancia, pero el Oso Bandera siempre iba en zigzag y círculos. Finalmente dijo : "Bueno, mi nieto, ahora queremos dormir, y mañana vamos a ir." Hacía frío. "Voy a ir a buscar el fuego", dijo el Oso Bandera. Se fue y volvió con el Fonfoni. Este es el fuego del Oso Bandera. Puso el Fonfoni bajo Nowa Pashawa. "Cuando quieres encender el fuego me hagas saber", dijo. Pero el hombre decidió no decir nada cuando él trató de encender el fuego, y el Fonfoni se fue volando. “¿Por qué no me lo dijiste ?”, Preguntó el Oso Bandera, "ahora debo ir de nuevo y conseguir fuego. "Otra vez fue y trajo Macua (kuma). Lo puso bajo Nowa Pashawa, y este se acostó con la Macuca. En la mañana siguiente continuaron su camino. Pero el Oso Bandcra fue de nuevo en círculos. Ahora Nowa Pashawa estaba enojado. Tomó un tubérculo de Vaylusa y la tiró sobre sus talones. Se quedo el tuberculo y el Oso Bandera ahore tiene un pie deforme. El Oso Bandera Lloró, y su mujer lloraba. Entonces el Oso Bandera dio la vuelta al hombre trató de matar al hombre. Pero no tuvo éxito, tanto como él se tiró un pedo, el hombre se mantuvo con vida.

Nowa Pashawa continuó su camino. Caminó y caminó, y se encontró con un Mutún. “Hola, papá, ¿̇a dónde vas ?", preguntó el Mutún. Pero Nowa Pashawa tenía aún el temor de Oso Bandera en los huesos, por lo que se escondió debajo de una pila de leña. El Mutún se sentó encima de él. Había estado esperando durante un tiempo el hombre se arrastró cautelosamente entre las ramas, y luego continuó su camino. Caminó y caminó hasta que conoció a Jochi Colorado (takaka). Esto estaba a punto de romper Almendras, llamando al hombre: "Nowa Pashawa, que haces aquí?" "Estoy buscando a mis padres", dijo Nowa Pashawa. "Déjame ver si puedo ayudarte", respondió el Jochi Colorado e invitó al hombre a su casa, donde le ofreció Chicha. "La yuca para este Chicha viene del campo a su madre," dijo. Cuando Nowa Pashawa había bebido, se tumbó en la hamaca para dormir. El Jochi Colorado y su esposa, se sentaron bajo su espalda y prepararon aún más chicha. Para la fermentación ellos masticaron la Yuca. Nowa Pashawa sólo fingió como si estuviera dormido, y los vio allí. "Tiene un sabor muy dulce", dijo el Colorado Jochi", pero todavía le falta un poco." Así que escupió una vez más una gran cantidad de moco en la chicha. Luego lo intentó de nuevo. "Ah, ahora es muy dulce", dijo En la mañana siguiente se ofreció Nowa Pashawa de esta chicha para beber, pero no bebió nada de ella porque se había visto la preparación. Luego Nowa Pashawa y Jochi Colorado comenzaron a caminar juntos. "Si camino delante de ti, usted no puede reirse de mí", dijo el Jochi Colorado. Luego se marchó. Después de un rato llegaron a un árbol que estaba acostado en el camino. A medida que el Jochi Colorado pasó por encima de él, el hombre podía ver sus genitales, y tuvo que reír en voz alta. El Jochi Colorado estaba enojado. "Te lo dije, no te puedes reír de mí", exclamó, "ahora 
averigua cómo encontrar a tu madre." Y desapareció en el bosque. Nowa Pashawa veía ningún camino. A su alrededor sólo había maleza densa, y Nowa Pashawa se extravió. Después de un rato se encontró con el Carpintero (shekere), que fue cortando el tronco de un árbol. El Carpintero conocia Nowa Pashawa y le dijo: "¿A dónde vas, Nowa Pashawa" "Busco a mis padres, mi abuela", dijo Nowa Pashawa. "Usted ya esta muy cerca", dijo el Carpintero. "Si conoces el jardín de mi madre", dijo Nowa Pashawa, "usted no me puede llevar allí?" "Eso lo puedo hacer bien", dijo el Carpintero, "Siempre voy a volar por delante un poco y cortar el tronco de un árbol. Entonces, ¿̇me escuchas y me puedes seguir." El hombre estuvo de acuerdo, por lo que el Carpintero siempre voló un poco más lejos y se estableció por un tiempo en un tronco de árbol y picado para que el hombre pudiera oírle y seguir el ruido. Después de un tiempo llamó el carpintero: "Aquí está el jardín de su madre." Entonces el Carpintero regresó de nuevo a la selva, mientras que el hombre se escondió detrás de una pila de basura la madre todavía estaba de duelo por su hijo, porque ella pensaba que era. muertos. Cuando fue a tirar un poco de basura y vio a su hijo de pie allí, ella pensó que sería espíritu (yosbmi). Ella casi no lo podía reconocer, porque su cuerpo estaba lleno de Boros (sbena), y cubierto con chicha, que había bebido con Jochi Colorado. "Oh, madre", exclamó el hombre, y luego le dijo: "en tres días los muertos que murieron en el incendio se levantarán otra vez. Sólo tiene que hacer un montón de vasijas de cerámica de diferentes tamaños, debido a que muchas personas murieron en el incendio." La madre se puso a trabajar. Después de tres días escucharon la llamada del Sumurucucu (popo), y el hombre dijo: “¿Ves, mamá, ahora los huesos ya están muy cerca." La madre estaba ahora cansado de tener que hacer tanto la cerámica. Pero el Sumurucucu ya voló muy cerca y se sentó en el tejado. Esta fue la señal para la llegada de los muertos, y ya se abrió la puerta y entraron en la casa. Fueron meros esqueletos sin cráneos. A todo que entró pusieron a la vez una olla en la cabeza. Uno tras otro entraron, tomaron una ollay se fueron. Por último, todos tenían de nuevo una cabeza, pero por dos ancianos no había olla. "Mañana vamos a llevar el asunto a fin", dijo Nowa Pashawa. Los dos ancianos esperaban pacientemente. Se casaron, y sus mujeres se fueron y miraron por sus hombres. Cuando finalmente los encontraron querían darles agua para beber. Pero eso no era posible, ya que los dos todavía no tenían cabeza. "Queremos hacer un campamento para pasar la noche y dormimos". Así que prepararon un campamento. Pero los dos viejos no podían dormir porque no tenían cabeza. Entonces las mujeres salieron corriendo y dejaron a sus hombres. Cuando llegaron a su aldea la gente les preguntaba: “¿Dónde están sus hombres? “En este momento dos Sumurucus voló sobre ellos. "Ah, estos son sus hombres! Usted los han dejado y se convirtieron en Sumurucus". Ellos tomaron palos y golpearon a las dos mujeres y las. A partir de entonces no hubo regreso de los muertos. Las personas deben morir y permanecer muerto para siempre. 


\section{Del hombre que perdió a su esposa a una Anta}

\section{Narrado por Carmelo (Yako)}

Un hombre y una mujer vivieron juntos en el bosque. El nombre de la mujer era Waita. El hombre se llamaba Rata y fue el Anta, que caminaba en forma humana. Esta Rata siempre caminó hasta el lugar del pueblo, porque él estaba buscando una mujer con la que podía dormir. Así él secuestró una mujer cuando su marido estaba en el bosque. El pobre hombre buscó a su esposa en todas partes, pero no podía encontrarla por ningún lado. Un año pasó, y el hombre fue en busca de su esposa en el bosque. Entonces vio una casa y la exploró. El Anta estaba fuera, y la mujer estaba allí. El hombre preguntó: “¿Qué estás haciendo aquí? ¿A quién te trajo aquí? "Fue un hombre”, respondió ella. “¿Cómo se le llama?” preguntó el hombre. "Su nombre es Rata." "¿Dónde está ahora?" "Él ha ido al bosque y va a volver por la tarde." “¿Qué podemos hacer para conseguir salir de aquí?”, preguntó el hombre, y subió a la casa y se escondió en el Chapapa bajo el techo para esperar la vuelta de Rata. Rata llegó a casa por la tarde y olía personas. "¿Quién ha venido aquí? ", se preguntó. “¿Quién está aquí?" le preguntó a su esposa. “Nadie”, respondió la mujer. El Anta en realidad nunca se había acostado con la mujer, pero Rata dejó siempre su semen fluyendo hacia abajo sobre sus piernas. Esta vez el hombre observaba desde la parte superior de la Chapapa. Cuando la Anta se fue en la mañana siguiente al bosque para cazar, el hombre se levantó de su Chapapa y se acostó con la mujer. Luego dio a la mujer algo de comer. El hombre permaneció cerca de dos meses en la casa de Anta sin ser notado por él. Estaba escondido en la Chapapa y sólo vino abajo cuando el Anta había ido al bosque a cazar. Después de algún tiempo, por supuesto, Rata olía algoextraño en su casay descubrió en el Chapapa una jarra que estaba llena de orina y entonces el hombre salió de su escondite. En este momento la mujer ya estaba embarazada. El Anta dijo al hombre: "Ven, vamos a ir a buscar Mbi para pintar nuestro hijo cuando entra en el mundo." Juntos fueron al bosque y llegaron a un alto Mbi. "Sube", el Anta dijo al hombre. Pero la mujer había advertido a su marido. "No suba encima del árbol cuando te dice que hay que ir hacia arriba." De modo que el hombre no se suba al árbol como se le pidió Anta. "No, no puedo", respondió el hombre. "Así que, a continuación, voy a empezar", dijo el Anta y subió. Él arrancó el fruto y lo arrojó al suelo. Y la mujer le dijo a su marido: "No capturas los frutos, dañan la mano." En lugar de él, ella empezó a coger la fruta, y dijo "corra!" “, a sumarido, "el quiere matarte." Después ella dijo al Anta: "el hombre ha capturado los frutos." El Anta no podía ver nada de lo alto del árbol. Cuando por fin bajó, miró a su alrededor y preguntó: “¿Dónde está el hombre?" "Él ha huido”, respondió la mujer. Presionó la leche de sus pechos, y comenzó a llover fuertemente, y también 
envió un frío glacial. El hombre, por supuesto, ya estaba muy lejos, y como vino la tormenta ya había encontrado una cueva en el suelo, y podría ocultarse. Cuando pasó la tormenta, el hombre salió de su cueva. El clima era agradable. Así que el hombre se fue. Llegó a un gran lago en el que abundaban los caimanes. Entonces el hombre le dijo a un Caimán en la orilla: "Si usted fuera un hombre podría llevar a míc." El Caimán respondió: "Puedo llevar a usted, sentarse en mi espalda." El hombre se sentó en la espalda del caimán y el caimán nadó con él. A medio camino quería comer el hombre. "Si fueras mi hermano menor, te había matado ya", dijo el Cayman. El hombre se echó a llorar y pidió el Cayman, seguir llevarlo. Un poco más tarde, el Cayman se detuvo de nuevo a comérselo. Pero eran cerca de un árbol en el otro lado. "Quiero sentarme un poco mejor", dijo el hombre con el Cayman, pero en realidad, por supuesto, quería subirse al árbol. Él hizo un gran salto y alcanzó el árbol con arco y flecha. Cuando el Cayman vio que el hombre tenía tierra firme bajo sus pies otra vez, se puso furioso. Pero el hombre siguió su camino. Cuando se fue un rato vio Jotchi Colorado con su esposa en forma humana. El hombre se acercó a ellos, y el Jochi Colorado dijo: "Elai - mi nieto" y los dos dieron el agua hombre para beber y Almendras para comer, y luego se lo llevaron a casa con. Allí le ofrecieron comida y chicha, porque el hombre había llegado muy delgado de caminar mucho en el bosque. Luego se fue a dormir.

Mientras el hombre dormía, los jochis prepararon chicha. En lugar de masticar la yuca usó su moco para fermentar la bebida. "Prueba" él entonces dijo a su mujer. La mujer intentó, pero no la gusto lo suficientemente bueno. "No está listo", dijo. Así que ella tambien escupo vigorosamente y puso una gran cantidad de moco en la Chicha. Luego lo agitó todo. Pero el hombre que estaba acostado en la hamaca, no podía dormir y los miró. Los dos estaban hablando y dijeron: "la Chicha tiene que ser bueno, por lo que podemos ofrecer a nuestro nieto." Por la mañana le presentaron chicha, pero el hombre no quiso beber. "¿Por qué no quieres probar nuestra hermosa chicha?" preguntaronlos dos. Luego le ofrecieron también Yuca. "Este Yuca tuvimos que arrastrar desde muy lejos, viene del campo de tu madre. " "Bueno, entonces, me llevan a mi madre", dijo el hombre. Se fueron y siguieron un camino ancho en el bosque. Después de un rato llegaron a un árbol que se encontraba al otro lado de la ruta, y como el Jochi cruzó el hombre podía ver sus genitales y tuvo que reír. Entonces el Jochi dijo "Vayate solo a su madre," porque estaba enojado. Así que el hombre fue solo, y después de un corto tiempo se había perdido, porque no había camino alguno más en el bosque. El cuerpo del hombre estaba cubierto por todas partes con Boros y erupciónes, porque había estado bebiendo la chicha en la primera noche. Y el hombre se encontró con el Oso Bandera en el bosque. El Oso Bandera le saludó cortésmente y preguntó: “¿A dónde vas?" "Estoy en camino a mi madre", dijo el hombre. "Ya estás muy cerca", aseguró 
el Oso Bandera. Fueron juntos ahora. Cuando ya habían recorrido la mitad del camino, el Oso Bandera estaba cansado y se durmió. El hombre esperó, y cuando el Oso Bandera despertó continuaron su camino. Poco después de caer la noche el Oso Bandera fue a Macuca para pedir a su fuego. El hombre fue destinado a dormir con la Macuca, y se acostó junto al fuego, la Macuca en el medio, el hombre a la izquierda y Oso Bandera de la derecha. Pero cuando el hombre agarró Macuca, se escapó. El Oso Bandera salió y consiguió el menor Fon - Foni y con esto los dos durmieron. En la mañana siguiente continuaron su camino. Oso Bandera anduvo todo el día seguido, pero cuando ya era de noche, estaban en el mismo lugar donde se hubieran quedado antes.

El hombre se enojó. “¿Quieres que no me llevaría bien!" exclamó, y mató al Oso Bandera con un palo. Luego siguió su camino. Una vez más, la noche estaba cayendo. En la oscuridad se encontré con Peta, quien, como el resto de los animales también fue Chacobo. La Peta dormía cerca del hombre, pero no podían verse unos a otros. La mañana siguiente el hombre se levantó en silencio y mató a peta. El siguiente animal que conoció era un grillo. Cuando había caminado un poco más lejos, se encontró con el Carpintero que estaba sentado en un árbol y golpeó contra el tronco de manera que hizo un montón de ruido en el bosque. Cuando vio al hombre, gritó: "Elai, mi nieto, donde vas?" "Oye, abuelo", respondió el hombre, "vago el bosque para encontrar a mi madre." "Oh, tu madre está aquí muy cerca", dijo el Carpintero," te llevaré allí. Pero me tomo mi camino y tú el tuyo. "El Carpintero vuela a través del aire, mientras que el hombre tiene que seguirlo en el suelo del bosque. Carpintero despegó. "Mira," él llamó a aquel hombre: "Voy a noquear en contra los árboles, entonces no te puedes perder el camino."

Así que el hombre siguió el latido del Carpintero. "Cerca de aquí está tu madre", le oyó llamar después de un tiempo. Mientras se acercaba, vio que el plantón de aves en un árbol en el borde de un campo de Yuca. "Este es el campo de su madre:" gritó el Carpintero. "Que encontrarás paz ahora." Y el Carpintero regresó al bosque. El hombre vio una pila de basura en el jardín de su madre. Él se escondió. Después de un rato la madre salió de la casa a arrojar algo de basura, y cuando vio a su hijo exclamó. "Oh, hijo mío" "¿cuánto tiempo ha pasado desde que te he visto!" Apenas lo reconoció porque su cuerpo estaba cubierto por todas partes con Boros. La madre curó a su hijo de sus heridas, para que su piel estaba limpia y suave. Después de tres días llegaron los muertos, todos ellos Chacobo. "Ya ves, madre, ahí están," dijo el hombre. Los muertos se acercaron en gran número y hicieron un ruido fuerte. "Hay muchas más muertes por venir", dijo a los que ya estaban allí. Vamos a ver si mi marido está aquí", dijo la mujer. Ella miró a su alrededor a los recién llegados y descubrió a su marido, pero no tenía cabeza, al igual que todos los demás. Por lo tanto, ella tomó la calabaza para elaboración de la cerveza y la puso 
entre sus hombros como cabeza. Cuando deseaba beber rica chicha se dio cuenta de que no tenía boca, por lo que tuvo que levantar la calabasay poner la chicha directamente hacia el esófago. En ese momento se transformó en un Sumurucucu y salió volando. El otro fallecido y se volvió y desapareció para siempre en el bosque. Desde entonces, ningún muerto jamás ha vuelto a la Tierra.

\section{¿Cómo? Mawokuria ayudó a la gente de recibir canastas}

Narrado por Maro

Un hombre respondía al nombre Mawokuria. Él subió a un tronco de árbol, y con los pies en alto empezó a cortar el árbol. Después de un tiempo se no podía sostener más y se estrelló, y cuando cayó al suelo la cabeza se separó del cuerpo y rodó un poco. Una mujer se acercó y lo miró. El hombre yacía debajo de un árbol con la cabeza fuera. La mujer fue a su casa y le dijo a su madre: "Mawokuri ha caído del árbol. Su cabeza se desprendió i esta ahora en otro lugar." Mawokuria por supuesto, tan pronto como la mujer se había ido, se levantó de nuevo y se puso la cabeza hacia atrás. Ahora subió de nuevo el árbol. Una vez más se estrelló. Una vez más la cabeza se desprendió del cuerpo y rodó un poco. Entonces su padre lo llevó a casa para cocinarlo. Él encendió un gran fuego y puso Mawokuria en una olla grande y la puso sobre el fuego. Pero Mawokuria no se vio afectada por el agua hirviendo, y se mantuvo con vida. Nadó en la superficie del agua, y de vez en cuando, el padre tomó algo de grasa y se lo comió. Tenía un sabor muy delicioso. Luego vino un niño y se miró en el agua hirviendo. "Hey", exclamó, "Mawokuria no está muerto, él todavía está vivo!" "Oh eso no puede ser", respondió el padre,"he estado comiendo su grasa aquí por un tiempo. ¿YYuánto tiempo le cocino ya!" El padre entró a la olla. Entonces este se partió en dos, y el agua hirviendo lo quemó. Mawokuria fue al río a bañarse a fondo. En la orilla se encontró con una Almendra podrida. La abrió y se frotó la pulpa muy gruesa y maloliente en todo su cuerpo de arriba abajo, por lo que emite un hedor terrible. Así que se fue al bosque y se acostó a dormir allí. Cuando dormía una avispa entró, atraído por el olor, y ella tomó un poco del material pútrido con que se había untado. Asi ella voló al Sucha (poikop). El Sucha olía la muestra la avispa le trajo, y inmediatamente decidi comer Mawokuria. En círculos constantes bajó caer sobre Mawokuria. Él Sucha vino con una nueva canasta (Shapo), debido a que el Sucha ya tenía cestas en ese momento. Mawokuria quería robar a la cesta de la Sucha, porque le gustaba tener por sí misma. La Sucha voló hacia abajo y trató de picar los ojos a Mawokuria. Pero cada vez que estaba a punto de recoger Mawokuria estremeció. "Ah, esto es Mawokuria", dijo el Sucha, y lo dejó en libertad. Sin embargo, llegó un segundo Sucha y quiso comer el trasero de Mawokuria. 
"Usted no puede hacer eso", dijo el primer Sucha, "él todavía está vivo." Ya vino un tercer Sucha, que tuvo dos cestas con él, una mala y una buena. Puso estos al lado Mawokuria antes de que intentara picarle los ojos. Cerca del lado de Mawokuria fue la mala cesta que el hombre no quería. Luego vino otro Sucha con dos canastas, y también les puso cerca de Mawokuria. En este momeht el hombre se levantó, cogió rápidamente la canasta del primer buitre y la nueva canasta (tsitsama) de este último y corrió con ella a casa. Allí mostró su presa a su padre, e incluso las mujeres se acercaron y miraron a las cestas. Después aprendieron a tejer cestas, incluso ahora. Mawokuria bajó al río para lavar la carne apestosa. En este momento el Murcielago (katbi) pasó volando. "Hey, ven aquí", Mawokuria llamó a él, "usted puede conseguir estos peces aquí. "El Murciélago bajó hacia abajo sobre el agua y empezó a recoger los peces. Mientras tanto Mawokuria corrió rápidamente a la casa del Murcielago y violó a su esposa. Cuando el Murciélago llegó a casa cargado con los peces, su esposa ya no estaba allí. Estaba muy enfadado. Mientras tanto Mawokuria construyó una casa para él y la esposa del Murcielago. Él la construyó bastante estrecho, sin dejar un solo hueco en las paredes y el techo, y luego vivió con la esposa del Murcielago en esta casa. Después de tres días, el Murcielago fue a buscar a su esposa. Pronto llegó a la nueva casa de Mawokuria y trató de entrar. Pero por lo mucho que él estaba buscando una apertura no pudo encontrar ninguna. Mawokuria vio que el Murcielago flotaba alrededor de la casa, pero se fue a dormir. Después de algún tiempo, el Murcielago había mordido un agujero en el techo, para que pudiera entrar en la casa. Voló directamente hacia el Mawokuria y le mordió un poco de carne del brazo. "Mi esposo ha llegado", dijo la mujer y trató de despertar Mawokuria, pero él seguía durmiendo. A continuación, el Murcielago mordió un pedazo de carne de la pierna. "Mi esposo ha llegado", dijo otra vez la mujer. Mawokuria durmio. A continuación, el Murcielago mordió el tabique nasal, y Mawokuria murió. El Murcielago lo había matado. Ahora llevó a su esposa de vuelta a casa. 


\section{La lucha contra el hampa}

narrado por Maro

Los Maina son como seres humanos pero viven en el subterráneo. Tienen allí abajo todo lo que necesitan, casas, jardines y todo lo demás. Un día un hombre entró solo en el bosque para cazar. Le disparó a un mono que estaba atrapado colgando entre las ramas de un árbol. Así el hombre tenía que subir para llegar al mono. Cuando estaba arriba, uno de estos Maina se acercó. Tenía una flecha como la que nosotros llamamos tiupi, una flecha con una punta redonda. Ahora, mientras el hombre recogió el mono de las ramas en la parte superior del árbol, este Maina miró desde abajo y vio el escroto del hombre.

De inmediato tomó su flecha y disparó contra el escroto. El hombre se cayó del árbol y murió. Otro día dos hermanos fueron a cazar. También mataron a un mono y se quedó atascado en el árbol. Los hermanos discutaron quién debería subir. Uno de ellos tuvo miedo, pero el otro se fue para arriba. Cuando llegó arriba, el Maina que quería sus testículos volvió, y apuntó su flecha al hombre. Este vio el hermano, quien estaba esperando bajo el árbol. Tomó una flecha y golpeó el Maina, pero él no le podía matar, porque su flecha se deslizó de la piel del otro.

Una y otra vez el hermano intentó, pero no tenía éxito, la piel de la Maina era duro como la piedra. Pero entonces el Maina disparó al hombre que estaba en el árbol. Le pegó en el escroto, y el hombre cayó muerto a los pies del Maina. Entonces el Maina tomó una cuerda y atado las extremidades del hombre juntos para que él pudiera subirlo fácil en los hombros y lo podía llevar. El hermano del hombre que había estado observando la cosa, ahora dijo a sí mismo: "Tengo que saber lo que hace con mi hermano", y siguió al Maina. Pasó a través del bosque y luego llegó a su entrada a la tierra que era bien cubierto con hojas y ramas. El Maina arrojó al hombre en el suelo, y luego descubrió la puerta, la abrió y entró en la tierra. Cuando el hermano vio esto, se retiró en silencio y corrió a su pueblo para decir a los demás lo que había observado. “¿Qué vamos a hacer?” el pueblo preguntaban unos a otros. "Tomemos hojas de aji y lo fumigamos".

Luego fueron a sus jardines, y reunieron a todos los Ajies que poseían. Por la noche se fueron a la selva hasta el lugar donde estaba la entrada a la tierra. Abrieron la puerta y encendieron delante un fuerte fuego humeante de las hojas de Aji. Incluso antes del resto de agujeros en el suelo yacían los fuegos humeantes. Entonces flechas salieron disparadas de los agujeros. Los Maina dijeron unos a otros: “¿Qué viene sobre nosotros ¿Por qué debemos constantemente tosar?” Pensaron en una epidemia que se avecinaba. La gente en la superficie de la tierra escucharon la gente de allí abajo toser continuamente pero después de un tiempo cuando era 
tranquilo, dijeron: "Vamos a entrar y mirar. "En primer lugar el hermano del hombre disparado entró. Allí vio cadáveres tirados por todas partes, y finalmente alcanzó una casa del mismo tipo que la tenemos aquí. Bajo una gran olla de barro encontró a una anciana que se había escapado del humo, y él mató a la anciana. Luego continuó y llegó a un jardín. En el borde estaba sentado un anciano que tenía las manos protectoramente delante de su rostro. Él también lo mató. Luego prosiguió. Poco a poco se encontró con algunos Maina más, que habían sobrevivido al humo bajo ollas de barro, y mató a todos. Los otros hombres que habían venido con él mataron a muchos en la tierra. Un joven encontró una chica muy joven escondido debajo de una olla. Dado que aún no se había casado, decidió preservar a la chica y tomarla como su esposa en su pueblo.

Además, el hermano de la joven seguía con vida, y el hombre lo quería como su ayudante y le tomó tambien. Pero este joven Maina se comportó como salvaje. Él atacó y mordió y arañó los Chacobo. Entonces sacaron sus dientes y se fue con los hermanos. El joven Maina era casi tan grande como Carmelito. Llamó a la gente yawa, y le dijo a su hermana: "Este es uno de nuestros cerdos." "¿Yo no soy un cerdo!" gritó el Chacobo: "Yo soy un ser humano!" Pero el Maina continuó llamarlo cerdo. Cuando se reunieron las personas en su camino hacia la aldea el Maina dijo: "Ah, todavía hay más cerdos." Los otros hombres se pusieron enojado, y vencmataron al Maina. Por esto sólo su hermana se quedó y siguió en el pueblo. Las otras personas también querían matar a esta chica, pero el joven se paró frente a ella y gritó: "iNo, no voy a dejar que esto suceda, ella será mi esposa" Así que ahora vivía con él, y poco a poco se acostumbró a las costumbres de los Chacobo. Le tomó mucho tiempo, y sólo después de dos o tres años había aprendido a comer monos y cerdo como nosotros. Las personas en este tiempo no conocían cestas. La Maina podría tejer bandas de trenzas y cestas de tejido, por lo que la joven Maina enseño los Chacobo estas artes.

\section{La fiesta de los peces}

Narrado por Jorge (Kako)

El Pacú (sani noa) tenía una fiesta. Salió del agua hasta los Chácobo para invitar a la gente a su fiesta. Cuando la gente le vio, se maravillaron, diciendo: "¿Quién es ese?" Llegaron el Pacú, el Surubí (waitino), el Platillo (peto), la Palometa (hacer) y la Palometa Real (tukunare) al pueblo, pero no se daron cuenta que el Pacu era extremadamente feo. Ahora invitó a la gente a la fiesta y ellos sigueron a los peces. En las orillas les esperó Sicuri (runua). Esta fue su barco. Se les invitó poner todas sus cosas en ella, se metieron ellos tambien, y se marcharon. En el río había un gran vórtice. Las personas remaban y remaban y remaban pero el vórtice se acercaba 
cada vez más. Finalmente, el barco fue desembolsado en el vórtice. Sólo un hombre fue capaz de saltar en el último minuto y salvarse a la orilla. Cuando las personas llegaron al fondo del río encontraron todo exactamente como antes en la tierra. Fue otro mundo. Cuando los extranjeros llegaron, el perro (inaka) empezó a ladrar. Los peces estaban bailando. Luego vino el Cayman y robaba las mujeres. Así que los Chacobo se casaron con las mujeres de los pesces. Establecieron sus hogares en el fondo del río y se quedaron allí para siempre.

\section{De Sol y la Luna}

Narrado por Maro

Había dos mujeres que vivían en la tierra - Sol (Wari) y Luna (Oshe). Pero no eran hermanas. Un día vieron un árbol de Urucu, y allí tuvieron la alegría del color, subieron y recogieron los frutos. Pero cuando todavía estaban allí, el Señor de la Urucu (mashe ibo) se acercó. Rapido Wari saltó del árbol y se escapó. Antes que Oshe también logró escapar, el hombre ya había subido al árbol y había agarrado Oshe. "Oshe ven", gritó Wari, pero Oshe no vino porque el Señor del Urucu la estrechó. Llevo Oshe a su casa y le presentó a su madre. “¿De dónde sacaste esta mujer?”, preguntó la madre. Luego tomó una pelota y jugó con él, y la pelota le cayó en la cabeza y lo aplastó a una pulpa. Entonces su esposa reunió todos sus huesos y trozos de carne y les puse debajo de un paitiie. Al día siguiente el hombre se unió de nuevo en su forma original, pero era un poco más pequeño que antes. "Asi", gritó a su esposa, "no hay que jugar con él!" Pero él no escuchaba a ella, y otra vez la pelota cayó en su cabeza e hizo papilla fuera de él. Al día siguiente el hombre había recuperado su forma original, pero se había vuelto aún más pequeño. Tan pronto como pudo caminar de nuevo, atacó de nuevo detrás de la pelota y jugó. Una vez más su esposa le advirtió, y otra vez la pelota cayó en la cabeza y lo hizo puré. La mujer recogió como antes todos los huesos y trozos de carne, y puso la pequeña pila debajo del depósito de Chicha, y al día siguiente el hombre había crecido de nuevo a su forma original. Pero se había vuelto aún más pequeño. Y así fue, día tras día, y día tras día el hombre era más pequeño. Cuando él era tan pequeño como un niño recién nacido, la mujer le tiró. Tal el Sucha lo recogió y voló con él a la madre de los pequeños. Él lo había puesto sobre sus hombros y le dijo: "No tengas miedo de mí y de mi comida." Cuando llegó a la casa de la madre, arrojó el pequeño en el montón de basura. La madre, que acaba de regresar de la casa vio el Sucha allí con los residuos, así que decidió a investigar. Descubrió al pequeño y lo reconoció como su hijo, y lo llevó a la casa y se bañó y se preocupaba por él, y rápidamente creció otra vez, y después de unos días estaba de vuelta tan grande como mi hijo Kuya. 


\section{De rayo y su hija}

Narrado por Jorge (Kako)

Un hombre vagaba por el bosque. Allí vio un fuego encendido. "¿Qué podría ser eso", se preguntó. Pero esto era Kanapa con su hija, que era casi tan vieja como Busi. Estos dos fueron por el bosque y cazaban pequeños Sapo (tshaki). Pero el Rayo estaba cazando en el bosque todos los días. Cuando el hombre llegó a esta zona de nuevo otro día, se encontró con la hija sola, su padre estaba muy lejos. El hombre se acostó con la hija del rayo. Luego regresó a su aldea. Al día siguiente, cuando el rayo se fue una vez más a la caza, el hombre volvió a dormir con la chica. Esto se prolongó durante dos meses, y después de este tiempo la chica estaba embarazada. Una vez había dicho al hombre: "Si hay relámpagos y truenos usted no necesita venir, porque no estamos allí" Así el hombre siempre se fue al bosque cuando la tormenta había terminado. Un día, la hija del rayo preguntó el hombre, "¿Tienes esposa?" " No," contestó. Pero mintió. Estaba casado. El cuerpo de su esposa, sin embargo, estaba cubierta por una erupción, por lo la disgustaba. Un día hubo una tormenta de nuevo. El hombre sabía que el relámpago, y su hija estaban en marcha. Esta vez la chica llegó a la aldea del hombre y lo encontró allí con su mujer, que sufría de la erupción. Ella dijo: "me has mentido." ella hizo una vuelta en el lugar y nunca regresó. El hombre se entristeció y lloró, y entonces él decidió seguirla. La muchacha dio luz a un hijo. El hombre vagó durante días por el bosque en busca de su amada, pero por desgracia un día un rayo lo mató.

\section{Del Viento del Sur}

Narrado por Jorge (Kako)

Debe ser que una vez vino un viento frío. Un niño fue a una Camotal y vio a una anciana que estaba allí, asar camote (pua). Esta anciana era el Sur (yotano). El muchacho miró a la mujer. "Que esta haciendo allí? ", se preguntó mientras temblaba de frío. Luego se fue a su casa y le contó a su madre. "Vamos a ir todos," decían unos a otros: "para ver lo que está pasando con esta anciana." Salieron al Camotal, pero sólo pudieron acercarse hasta cierto punto a la antigua debido a todo el frío que irradiaba. Entonces la anciana le dijo al pueblo: "Ven. Te daré un poco de mi vello púbico (Shani). Si usted lo pone en los rastros de animales, puede matar fácilmente a los animales. Los animales no pueden pasar estos pelos. Por lo tanto, son fácilmente cazados." Un niño quería correr hasta la anciana, pero después de unos pasos ya cayó por el frío. Otro puso su moro para llegar a la anciana, pero él también no llegó muy lejos. "Lo intentaré" "Quiero probarlo!" Iloró mucho y se fue corriendo. Pero sin éxito. Finalmente, había un hombre que tenía seis camisas 
de corteza uno sobre otro y también de corteza atada a los pies. Él era el único que lo logró. Todos los demás tuvieron que regresar sin haber logrado su objetivo y el hombre dijo: "quiero probar la cosa ahora en primer lugar, voy a encontrar una ruta de Anta." "Para Anta se necesitan tres pelos porque el Anta es grande", la anciana había dicho. Para una Jochi, sin embargo, solo se necesita un pelo. Así que el hombre puso ahora tres pelos en la pista de un Anta. Él ya no sentía frío, pero el Anta, por supuesto, lo hizo. Entonces el hombre fue en busca de una pista de Jochi, donde dejó un pelo. Tres días después volvió a mirar. Encontró una Anta, que fue congelado por el frío. El hombre tomó el animal que acababa de abrir y comer. A partir de ahora, este hombre siempre cazó con el vello púbico de la mujer antigua, y tenía carne en abundancia.

\section{¿Cómo? Waita trajo una inundación a un punto muerto}

Narrado por Carmelo (Yako)

Hace mucho tiempo aquí era todo agua. Dónde está ahora el bosque sólo había agua, nada más que agua. En ese tiempo vivía una mujer llamada Waita. Como decía la gente, "Waita pueda llevar el agua a caer. Vamos a vestirla espléndidamente y pintarla bien para que el agua tiene su diversión con ella." El Anta, el Jochi, el jJaguar, monos y otros animales fueron a la orilla de la inundación. Los árboles en las orillas fueron arrastrados por las inundaciones, y el agua silbaba. Waita era la novia del agua. Bellamente decorado se puso de pie en la orilla, llevaba hermosos tocados y fue pintado magníficamente a la atención del agua a distraerlo. WI agua que silbaba y corria se acercó, y la gente en la orilla estaban muy asustados. Pero dónde estaba Waita el agua se detuvo. En el resto se hizo cargo de sus bancos y rasgó la gente hacia ella. "Vamos, Waita, bañate ahora! " llamó su madre. Waita entró en el agua, y cuando ella se bañaba, la inundación llegó a un punto muerto. Con todas sus plumas Waita había ido el agua.

\section{Los que nacieron de las calabazas}

Narrado por Jorge (Kako)

Se dice que había un hombre cuya esposa era una casamata de la fruta verde (shatano). Este hombre utilizaba un Mate para caminar, y si él ansiaba puso el Mate en su pene y se acostó con ella. El Mate era la cada vez más grueso y más grueso, y ella creció como un niño. Después de un mes la pareja ya era enorme, pero el hombre seguía caminando y el fruto se hinchó y se hinchó. Cuando el hombre no 
pudo soportarlo más, la colgó en una pared de su casa. Luego cogió otro Mate para dormir con ella. Cuando esto se había vuelto demasiado grande para llevarlo aún, él también lo colgó en una pared de su casa. Entonces él tomó un tercer Mate y un cuarto y así para siempre, hasta que tuvo Mate colgado alrededor de todas las paredes de su casa, con los niños que crecen en todos ellos. Toda la casa estaba llena de esos compañeros. Un día se explotó una fruta y un hombre pequeño se cayó. Al día siguiente estaba reventando de nuevo, y una niña salió. Este hombre también tenía una esposa. Con esta mujer dormía como con los frutos compañeros. La mujer sacó a todos los niños, y después de dos años ya había una gran cantidad de niños en el hogar. El hombre tenía ahora una nueva casa, más grande, especialmente para los niños. Pero el hombre todavía salió con los frutos de Mate. Un día, un mono vio al hombre con la fruta. "¿Qué estás haciendo con esta pareja?" "Con este compañero me duermo, y lo hizó frente al mono. "Pero porque te gusta eso", dijo el mono, "te voy a mostrar cómo lo hacemos nosotros," y él llamó a su esposa, y cuando ella llegó, él la montó y se acostó con ella. El hombre miró. Luego se fue a su casa y hablo con su esposa. "Venga, vamos a ir a buscar leña," dicho. En el bosque, el hombre quería probarlo con su esposa. La depositó en el suelo y se acostó con ella. Este olió la fruta que tenía como compañera, y cuando los dos se volvieron a su casas, a los otros niños, que habían venido de la fruta, lo olieron tambien. Entonces salieron de la casa, y los niños que crecieron en los frutos comenzaron a pudrirse, y el hombre estaba solo con su esposa. Los niños construyeron una nueva casa en el bosque. Un día su madre adoptiva quería visitarlos. Pero cuando los niños se dieron cuenta de su olor, salieron de nuevo y se fueron más lejos en el bosque. Ellos querían saber nada más de la madre. Con el tiempo se alejaron aún más y se convirtieron en el Cayuvava.

\section{La mujer perezoso}

Narrado por Jorge (Kako)

Un hombre estaba casado, pero él no estaba durmiendo con su esposa. Cuando él fue de nuevo al bosque, se encontró con la Perico (yukama) y le pidió que se acostara con él. "Hey, Perico, baja", exclamó. La Perico resucitó entre los árboles, y el hombre se acostó con él. La Perico lo abrazó con fuerza. A partir de entonces, el hombre siempre dormía con la Perico cuando entró al bosque. Con esposa ya no tenía relaciones sexuales. Una dia tomó todas las joyas de su esposa y puso estas cosas en la Perico, y luego se volvió a dormir con él. Después de dos meses, la Perico estaba embarazada. Un día, la mujer fue a visitar a su hermano y él hizo una investigación sobre los tejemanejes de su cuñado. Él lo siguió hasta el bosque y vio cómo él se reunió con la Perico. Ahora lo sabía. Regresó a su casa para recoger a la 
gente y matar al Perico. Pero la Perico tenía sus espías y supo lo que estaba previsto. El hermano luego volvió a entrar en el bosque junto a un compañero para atraer al Perico. Se puso de pie en la parte inferior del tronco y lloró, pero se cubrió la cabeza para que la Perico no pudo reconocerlo. El segundo hombre se quedó oculta. Lentamente, la Perico trepó por el tronco! Ya estaba visiblemente embarazada. El hombre que esperaba en secreto tomó su flecha y disparó al animal, y lo hizo sumergirse en el árbol. Los dos hombres se llevaron las joyas de la Perico para devolverlo a la hermana. Dejaron la Perico muerto allí. Y cuando el hombre llegó, encontró la Perico muerto debajo del árbol, y las hormigas ya se habían apoderado de su cuerpo. El hombre se quejó durante horas, y en la tarde se fue al fin a casa. Desde este había llegado a ser muy ronca y no podía hablar. El cuñado de este hombre le dijo a su hermana: "Cuando tu esposo llega a casa, tienes que hacerle cosquillas. Vamos a escuchar." Cuando la mujer le hizo cosquillas a su marido no podía reír porque era tan ronca. Los otros dos se rieron en su lugar. Mas ytarde este hombre se acostó con su esposa.

\section{Desde el Señor de los Peces}

Narrado por Maro

Un hombre fue a pescar y le pidió al Pato Mosca (pupuma HeNe) si él le traería pescado. Pero primero no recibió pescado porque Pato Mosca estaba cantando. Más tarde vino el Pato Mosca acercándose con su canoa, porque tenía una bonita canoa. Lo acompañaba un gran pez. El Pato Mosca era un buen pescador, por lo que dio el hombre que nunca sacó a sí mismo a los peces. Otro hombre se había escondido en los arbustos y lo vio. Más tarde le preguntó a este hombre. “¿Cómo llegaste a los peces?" El hombre traicionó su secreto cuando estaba borracho, y desde este día el Pato Mosca nunca se le apareció de nuevo, porque el hombre en verdad había hablado acerca de él.

\section{¿Cómo? los animales querían visitar el cielo}

Narrado por Carmelo (Yako)

Vino el Oso Bandera y llamó a la Peta. Los dos querían disparar con el arco y la flecha por una apuesta. El Oso Bandera dijo: "Yo voy primero, luego tu Peta. " Oso Bandera quería alcanzar el cielo, pero no le alcanzó. " Déjame ahora!" llamó Peta. "Pero no creo que yo voy a llegar". Oso Bandera observaba el tiro de Peta, y su flecha alcanzó el cielo y se quedó atascado, y una liana cayó. "Mira allí", dijo la Peta. 
"Eso es justo para subir al cielo." Entonces todos los animales, el Taiteii (konojo), el Anta y todo los demás, dijeron: "Vamos a ascender". Primero subió el Taitetii. Después siguieron el Jaguar, el Anta, y el Jochi. La Peta quería hacer el último en el camino, pero no había más tiempo, por eso se quedó. Ya no había ningún animal en la tierra, todos ellos estaban en el camino al cielo. Pero cuando el Taitetii era casi arriba el Jochi vino y se mordió la liana, de modo que todos los animales cayeron al suelo y se muirieron. Ahora sólo quedaba la Peta, diciendo: "Ya tengo mi casa."

\section{El origen de los monos}

\section{Narrado por Carmelo (Yako)}

La gente tenía una vez no más plantas en sus campos. "¿Qué vamos a comer" las personas preguntaban unos a otros. "Vamos a entrar en el bosque y buscar algo frutos silvestres o quizás Patujú (mani)." Por lo tanto, algunas personas hicieron su camino, y otros se quedaron en casa. Los que habían salido de la aldea no regresaron. Los otros esperaron y esperaron, pero sus familiares no volvieron. "Tal vez deberíamos donde nuestros padres se han ido", dijo un niño. Tres días más tarde salieron y siguieron el rastro, y después de haber caminado un rato, se oyó en el bosque un ruido. "Madre, oh madre, ¿dónde estás?", Gritó el niño. Pero no se podía ver a nadie. En los árboles, sin embargo, estaban en cuclillas monos, porque los padres de los niños se habían convertido en monos. Como ahora los niños se acercaron a ellos, los monos corrían animadamente hacia atrás y adelante. "Oh padre, oh madre", gritaron a los niños y querían atrapar a los monos. Pero los monos escaparon. Una vez más, los niños trataron de atrapar a los monos, y de nuevo, huyeron.

\section{¿Cómo? La esposa de la serpiente se casó con Jaguar}

Narrado por Carmelo (Yako)

Había una mujer que quería saber nada de los hombres. Aunque había muchos hombres que estaban detrás de ella, pero ella no quería tener nada que ver con ellos. Tenía de hecho ya un marido. Fue una Víbora. Solía dormia con ello. "¿Qué podría esta mujer tener contra nosotros?" los hombres le preguntaron uno al otro. "¿Cuál puede ser la razón de que ella no quiere saber nada de nosotros? ¿Con quién le gusta dormir?" El Vibora vivía en un agujero en el piso de la casa de la mujer. La mujer se puse en cuclillas sobre el agujero, y luego el Víbora se acostó con ella. Esto pasó durante muchos años. La madre de la mujer se preguntó: “¿Qué puede 
ser pasando con mi hija?" Esta nunca barrió su casa porque tenía miedo de que pudiera llenar el agujero de la Víbora. Un día tomó su cesto al bosque a buscar leña. La serpiente se quedó solo en su agujero. Luego vino la madre, y cuando vio la tierra tomó una escoba y barrió el suelo. Mientras estaba así ocupado, el Víbora se asomó fuera de su agujero y la observó. Pero ella fue descubierta por la anciana. "Aha," ella dijo, "así estoy suegra de Víbora". Ella fue y preparó una olla grande con agua caliente y lo echó al agujero de la Víbora. Así ella mató a la Víbora. "Vamos a ver lo que estoy haciendo ahora con ella", dijo la madre. Como ejemplo, la madre colgó la Vibora muerto en el marco de la puerta. Su esposa llegó a casa y entró por esa puerta, y algo le tocó la mejilla. Ella levantó la vista vio la Vibora muerto. "Oh no, mi marido está muerto", exclamó. Entonces ella lloró amargamente. Finalmente, ella envolvió la Víbora en un trozo de tela de corteza y lo enterró en la tierra. Entonces salió de su casa y se fue hacia el bosque. Era embarazada y su estómago lleno de pequeñas Víboras. Llorando corrió por el bosque, y como llegó la noche ella dormía solo en el bosque. Cuando despertó, oyó algo silbato. "Oh," dijo ella, "si eso sería un hombre podría traerme carne." Pero fue el Jaguar. Se transformó en un hombre y se acercó en esta mujer. Se fue a dormir con ella, y se la llevó y se acostó con ella en su hamaca. Pero justo cuando estaba empezando a dormir con ella los pequeños Víboras en la vulva de la mujer le mordieron en el pene. Enfadado se levantó de un salto y cuando se había calmado, le dijo a la mujer: "Vamos a ver si puedo sanarte." El Jaguar tenía una bolsa de medicina. Así ató a la mujer en la hamaca, y luego la frotó el vientre con su medicamento. Entonces todos las pequeñas Víboras se arrastraron fuera de su abdomen. Quería matarlos a todos. Mató unas tras otra, numerosos tipos de Víboras. Luego vino la Macuca. El Jaguar aún mató Víboras. “¿Qué estás haciendo?", preguntó el Macuca. "Mato Víboras", respondió el Jaguar. "Déjame intentarlo", dijo el Macuca. "Usted no puede hacer eso", respondió el Jaguar. "Sí, puedo hacerlo." "Bueno, entonces hazlo", dijo el Jaguar. Así de ahora en adelante la Macuca mataba las Víboras. Pero de repente una se escapó. Después de poco tiempo se escapó una segunda y luego una tercera. Cuando por fin la cuarta Vibora escapó, el Jaguar arrancó el cuchillo de la mano de Matuca y le dio una bofetada. Si el Macuca no habría permitido este escape de Víboras, no habría Víboras en el bosque. Después de este tratamiento por el Jaguar el Macuca se fue. Ahora había ninguna Víboras mas. El Jaguar también habia matado los restantes, y cuando había matado a todos el vientre de la mujer estaba vacío. Ahora el Jaguar podía dormir con ella. Después de un tiempo la mujer dio luz a un hijo. Entonces ella quería ir a visitar a su madre, pero el Jaguar dijo: “No, no te vayas todavía, todavía no estás recuperado." Al día siguiente, la mujer comenzó de nuevo, y dijo: "Pero ahora tenemos que ir." "Muy bien, vamos a ir ", respondió el Jaguar. Así hicieron su camino. Jaguar acompañó a su esposa en forma humana. "Oh, mi hija viene con su marido!" exclamó la madre, cuando llegaron. "Ahora mi hija finalmente se casó." De 
inmediato tomó a su nieto en el brazo, y el Jaguar dijo. "Cuidado mujer, deje el niño en el brazo de su madre." Pero la anciana apretó su nieto en sí misma. Entonces esto le mordió la garganta, y la abuela cayó muerta. "Te lo advertí," gritó el Jaguar. Los tres regresaron a su hogare. Pero la anciana tuvo otro hijo. Él dijo: "Yo quiero matar a mi hermano. Él es malo!" Entró en el bosque y mató al Jaguar.

\section{La mujer Paloma}

Narrado por Maro

Hay un pájaro que se llama wisane. Es la Torcasa. Apareció un Torcasa y entró en forma humana. A un hombre parecía ser maravillosamente bonita y de naturaleza agradable. Así que él la tomó y la llevó a su madre. "Te traigo esto", le dijo. Pero la madre trató a la joven mujer mala cada vez que el hombre se fue al bosque a cazar. La joven ya no quería soportarlo, y decidió irse. Cuando el hombre llegó a casa, ella le dijo: "Tu madre no me quiere aquí. Me voy. Cada vez que no estás allí, ella me trata mal. Es por eso no quiero estar aquí." Cuando el hombre salió la próxima vez, su esposa se fue con todos los niños. Entonces el hombre fue a buscarlos. Él la encontró y la trajo de vuelta otra vez. Pero la madre siguió tratando a la mujer gravemente. Entonces la mujer dejó a su marido. Él la siguió de nuevo y la encontró en el bosque. Pero cuando se acercó a su esposa e hijos, ella se levantó como una paloma y se fue volando. El hombre estaba muy triste y lloraba y era enojado con su madre.

\section{¿Cómo? Los cerdos cambiaron de rol}

Narrado por Carmelo (Yako)

Se dice que el Chancho de Tropa (yawa) fue hace mucho tiempo, el Taitetii. Más tarde se intercambiaron entre sí. El Taitetii hizo un gran ruido, que ya se podía oír desde lejos. El Chancho de Tropa, sin embargo, era muy tranquilo. Pero también quería hacer ruido, y gritó al Taitetii: "Ven aquí." Los dos se reunieron e intercambiaron entre sí, y ahora el Chancho de Tropa podría hacer ruido, y le agradó tan bien que nunca se separo de su nuevo papel. 


\section{CAPITULO 5}

\section{LA ETNOBOTÁNICA DE LOS CHÁCOBO \\ BRIAN BOOM, 1987}

EL TRABAJO ORIGINAL ESTÁ ESCRITO EN INGLÉS, ESTE CAPÍTULO CONTIENE LA TRADUCCIÓN AL ESPAÑOL REALIZADA $Y$ PUBLICADA POR BUSSMANN \& PANIAGUA-ZAMBRANA (2011). 

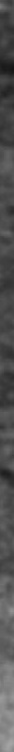

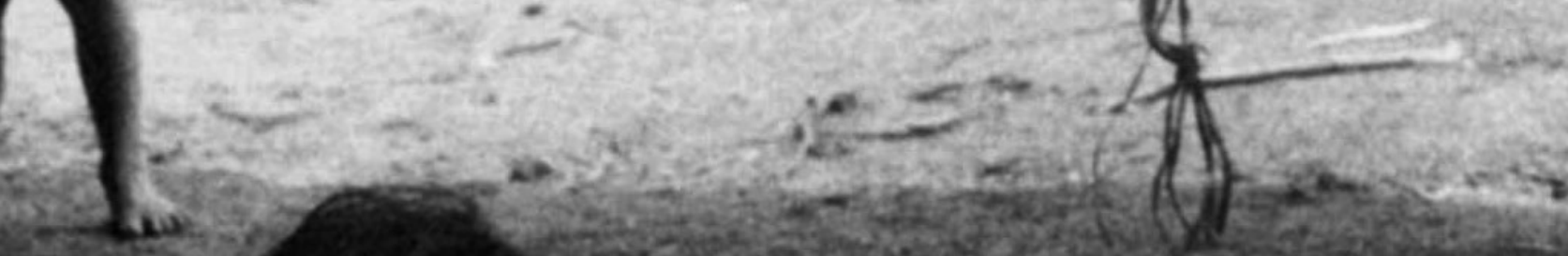

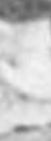

Boom 1987: Mujer Chácobo secando arroz

Lexis
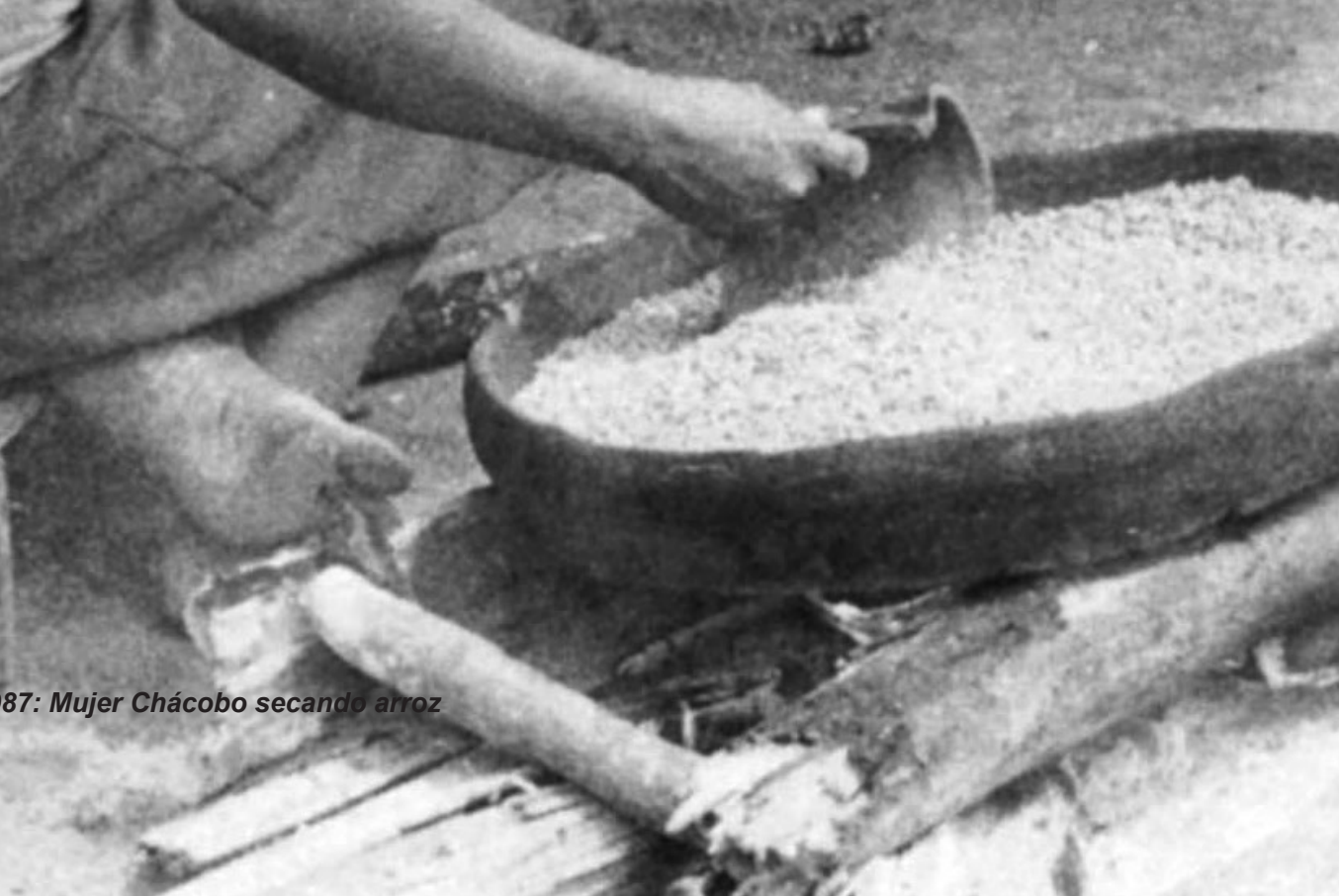

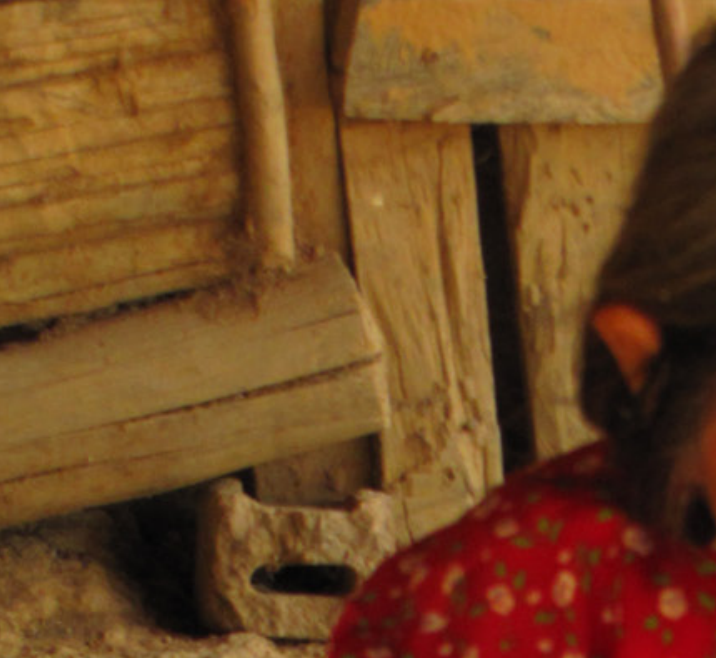

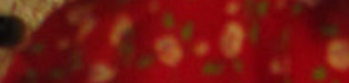

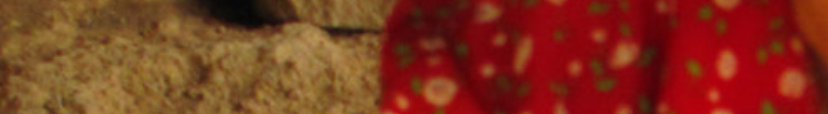

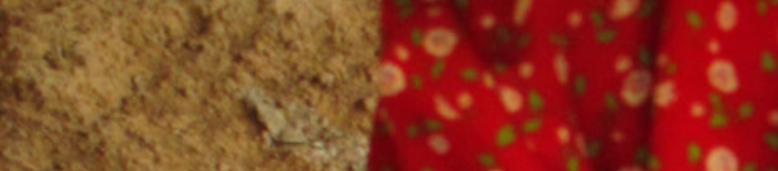

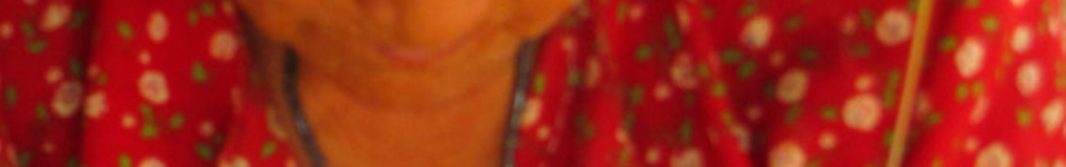

$\mathrm{N} N \mathrm{~N}$

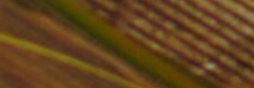

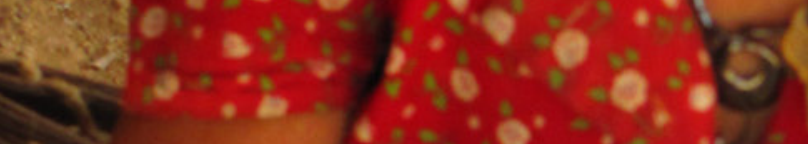

$\left.\mid \begin{array}{ll}0 & 0 \\ 0 & 0 \\ 0 & 0\end{array}\right\}^{0}$

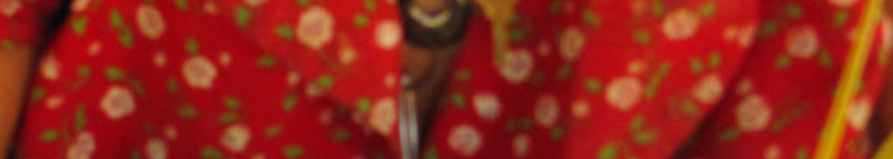

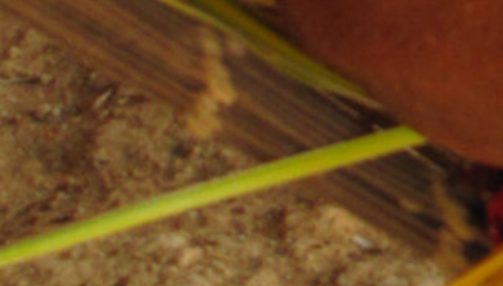

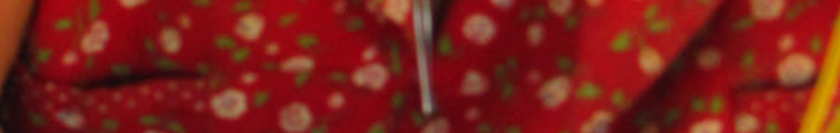



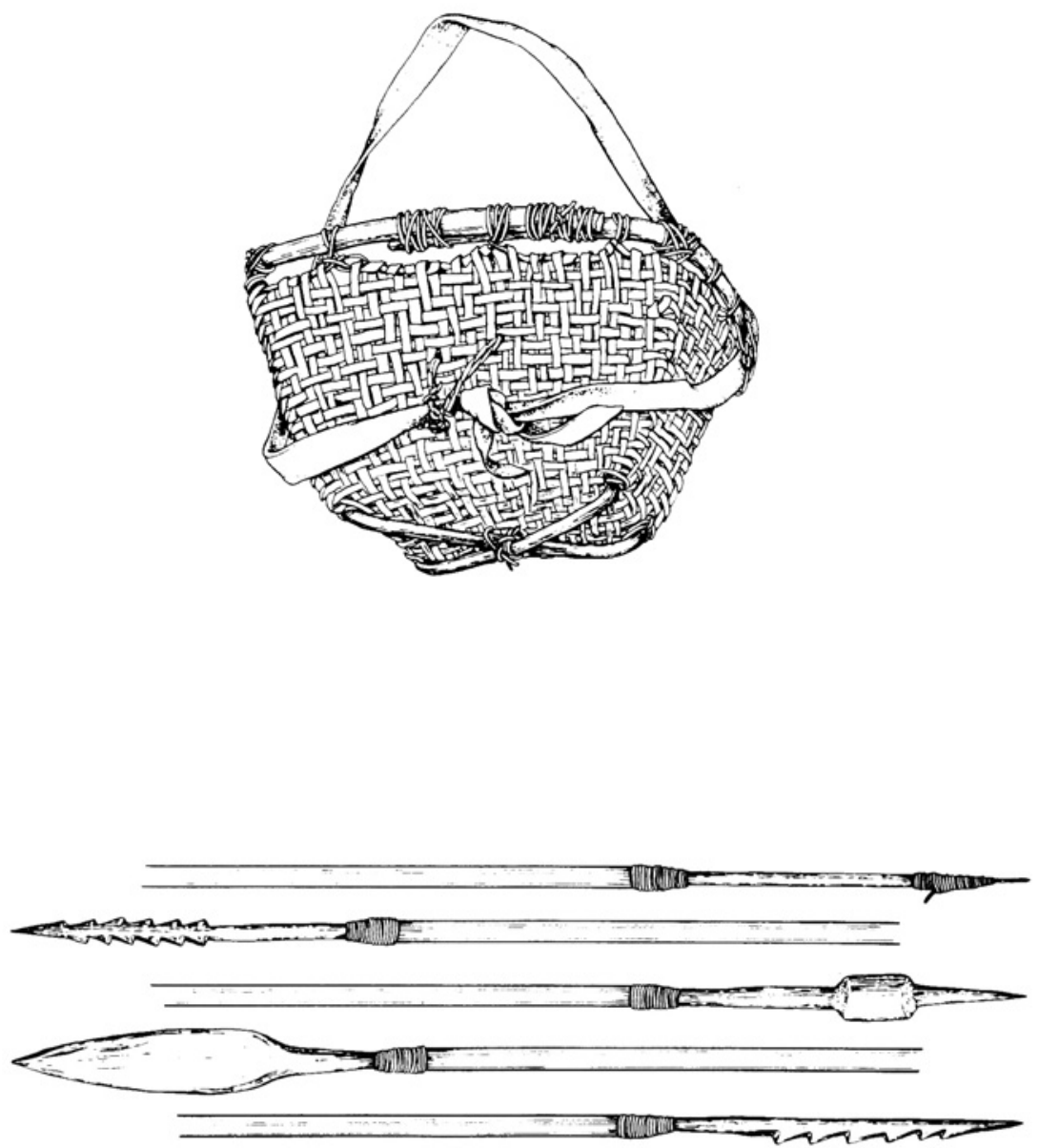


\section{INDICE}

$\begin{array}{ll}\text { Resumen } & 154\end{array}$

$\begin{array}{ll}\text { Introducción } & 155\end{array}$

La Historia de los Chácobo 156

Plantas Útiles de los Chácobo 161

Plantas Conocidas por los Chácobo de Alto Ivón 162

Plantas Comestibles $\quad 214$

Plantas para Leña 216

Plantas para Construcción y Artesanía 217

$\begin{array}{ll}\text { Plantas Medicinales } & 222\end{array}$

Plantas Medicinales de los Chácobo de Alto Ivón 222

$\begin{array}{ll}\text { Plantas Venenosas } & 227\end{array}$

$\begin{array}{ll}\text { Plantas Comercializadas } & 227\end{array}$

$\begin{array}{ll}\text { Otras Plantas } & 227\end{array}$

Importancia del Bosque para la Vida de los Chácobo 228

$\begin{array}{ll}\text { Bibliografía } & 229\end{array}$ 


\section{Resumen}

En 1988 Brian Boom, presentó los resultados de su estudio sobre las plantas utilizadas por los Chácobo en la Amazonía boliviana (Dpto.. Beni), incluyendo información sobre su historia y situación política en ese momento.

El estudio original comprendió cinco meses de colección de plantas y entrevistas etnobotánicas en la comunidad de Alto Ivon, donde se registró un total de 360 especies de plantas vasculares de 221 géneros y 79 familias. De estas, 305 especies de 197 géneros y 75 familias fueron utilizadas por los Chácobo.

Se discutió el uso de las plantas por la cultura Chácobo, rescatando la importancia de los bosques, basados en un inventario etnoecológico de una hectárea cerca de Alto Ivon, indicando que en 1985 se usaron 82\% de las especies de plantas, y el 95\% de los árboles. 


\section{Introducción}

Bolivia tiene una diversidad muy rica de culturas indígenas, con al menos treinta tribus de once familias lingüísticas. Sin embargo, existen pocos estudios detallados sobre el uso de las plantas y los recursos de sus diferentes zonas de vida, además su conocimiento acerca del manejo del bosque han sido ignorado por las autoridades.

A diferencia de Brasil, Bolivia no contó con un servicio de protección de comunidades indígenas, y varias organizaciones extranjeras, especialmente misioneras, trabajaron con poco control en la Amazonía boliviana. El Instituto Lingüístico de Verano (SIL por su nombre en inglés) en particular tuvo un impacto muy fuerte al cambiar la cultura de muchas tribus en Bolivia, incluidos de los Chácobo. EI SIL trabajo con los Chácobo desde 1953 hasta 1980, cuando fue reemplazado por la misión evangélica Suiza establecida en Riberalta, ambas instituciones han originando un proceso permanente de aculturación. Brian Boom condujo el primer estudio etnobotánico de los Chácobo entre 1983-1984, documentando su conocimiento después de casi 30 años del inicio de su cambio cultural. 


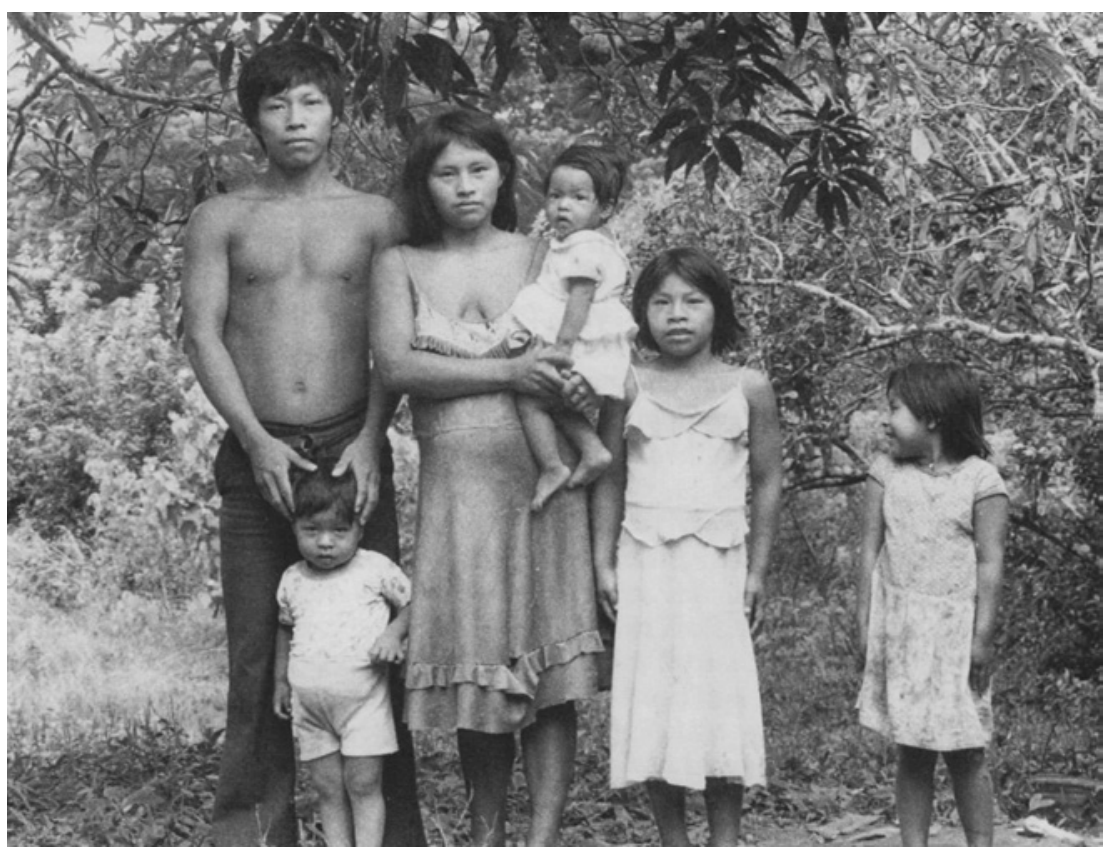

Boom 1987: Una familia Chácobo en Alto Ivon en 1984

\section{LA HISTORIA DE LOS CHÁCOBO}

Los Chácobo pertenecen al grupo lingüístico Panoano que incluye más o menos a doce tribus (Chácobo, Pacahuara, Ese Eja, Matis, Matses, Yaminahua entre otros).

Al fines del año 1890 los Chácobos vivían en grupos pequeños en el noroeste de Bolivia, entre el lago Roguaguado y el río Mamore, al sur de su territorio actual. Desde entonces fueron obligados por tribus más agresivas, a moverse hacia el norte, donde se encontraron amenazados por la influencia de siringueros criollos, los cuales también llevaron enfermedades y epidemias a la tribu. Sin embargo, los Chácobo lograron evitar la mayoría de las amenazantes influencias, mientras otras tribus en la región fueron cazadas como animales para ser esclavizadas para el trabajo de la sinringuería. En 1887 probablemente hubieron dos grupos de Chácobos en la cercanía del río Ivon, una con seis familias, y otra con cuatro. Los primeros misioneros contaron que los Chácobo prefirieron quedarse aislados en lugar de ceder su libertad por la civilización cristiana, viviendo como semi-nomadas y cazadores, cultivando chacos de yuca, maíz y chambur, conociéndose muy poco sobre su idioma y cultura. Solo en 1953 tuvieron un contacto inicial con gente de las misiones de las Nuevas Tribus, y en 1954 el gobierno Boliviano estableció una agencia indígena en Ñuflo de Chávez, a unos $15 \mathrm{Km}$. de la actual ubicación de Puerto Limones, donde vivía un grupo de Chácobos de aproximadamente 28 personas, con 5 grupos semi-nomadas 

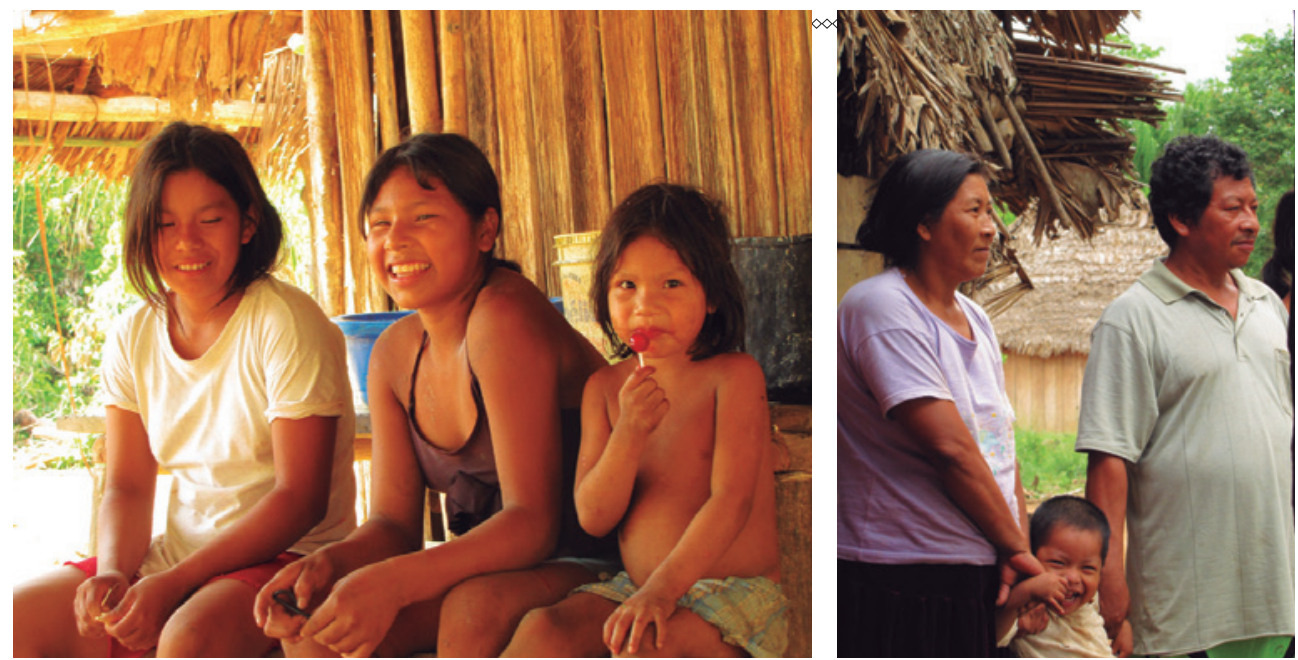

Bussmann \& Paniagua 2010: Familias Chácobo

en los alrededores. En 1955 llegó el misionero lingüista Gilbert Prost bajo del auspicio del Instituto Lingüístico de Verano (SIL). Según Prost hubieron cuatro grupos de Chácobo entre el río Benicito y el río Yata, con más o menos 200 personas. A lo largo del tiempo se formó la comunidad de Núcleo como centro mas permanente de una parte de los Chácobo, mientras los otros grupos de mudaron a los alrededores del río Geneshuaya y Yata.

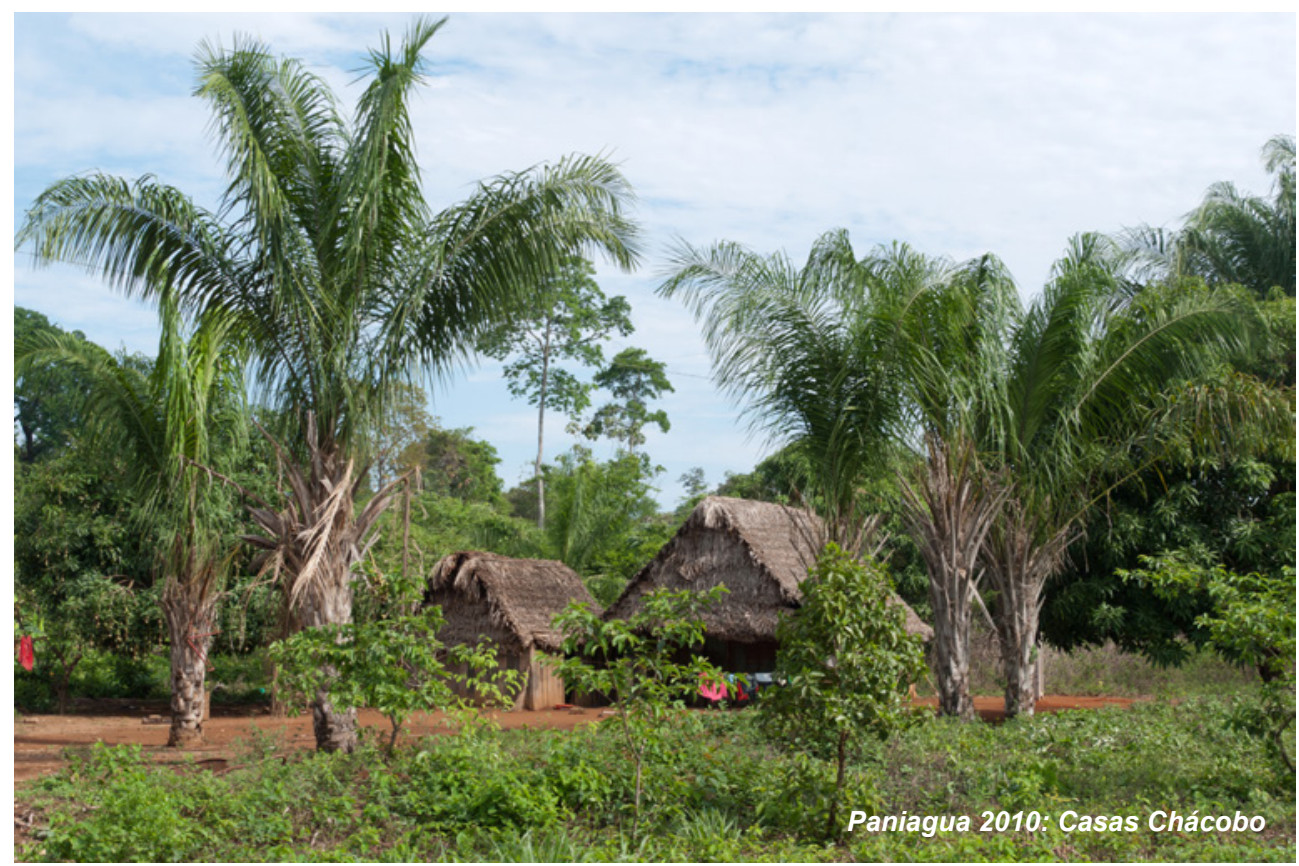


Prost y su esposa continuaron viviendo entre los Chácobo hasta 1980, donde además de traducir el Nuevo Testamento a Chácobo hicieron algunas observaciones sobre sus prácticas culturales y lingüísticas. En 1964 Prost logró comprar un terreno al norte de Núcleo, donde se formó la comunidad de Alto Ivon y los habitantes de Núcleo se mudaron allí. Los Chácobo del río Geneshuaya se mudaron al sur de Núcleo y formaron la comunidad de California. En 1965 finalmente el gobierno boliviano cedió 43.000 hectáreas de terreno a los Chácobo, aunque esta área era menos del $10 \%$ de su territorio original, durante este tiempo la población de California comenzó a moverse hacia Alto Ivon. La influencia de los Prost causó cambios culturales profundos en los Chácobo, incluso el abandono de traje y las danzas tradicionales en 1969. EI SIL cerró sus operaciones en 1980, y la misión evangélica Suiza (SEM) empezó de trabajar en la región, y en este tiempo fue cuando se fundó la escuela de Alto Ivon.

Actualmente la población de los Chácobo esta formada por más de 500 personas, con las comunidades en Alto Ivon como el poblado más grande y Tokyo, Motacuzal, Siete Almendros y otras comunidades mas pequeñas en el río Yata. La comunidad de Alto Ivon cuenta con una pista de aterrizaje y las comunidades que se encuentran en el río Yata cuentan con otra pista, ubicada en la comunidad Paraíso. En la época de lluvias el Arroyo Ivon es navegable, constituyéndose también en una vía de acceso para la comunidad de Alto Ivon.

En época lluviosa el río Benicito, es la única ruta de acceso segura para las comunidades asentadas en su entorno, mientras que las comunidades del río Yata, cuentan para su acceso con una pista de aterrizaje y en época de lluvias, se trasladan de modo seguro por el río del mismo nombre. A la comunidad de Alto Ivon, también se puede ingresar desde la carretera Santa Rosa - Riberalta, esta vía esta habilitada durante todo el año. Las comunidades del río Benicito tienen también un camino que los conecta a Alto Ivon, pero solo es accesible en época seca.

Antiguamente los Chácobo estaban liderados por un Cacique. Actualmente hay dos organizaciones: La Capitanía Grande Chácobo, estrechamente relacionada con los evangelistas, y la Subcentral Chácobo-Pacahuara reconocida por la CIRABO, apoyada por la CPIB y CIDOB. También existe el Distrito Municipal Indígena Chácobo-Pacahuara, dependiente del municipio de Riberalta.

Durante varias décadas la recolección de la goma (Hevea brasiliensis) y la venta del látex fueron una fuente ingresos muy importante para la economía Chácobo. En los últimos años se ha intensificado la explotación de la castaña (Bertholletia excelsa), al haberse instalado en Riberalta una empresa procesadora y comercializadora de este producto (UNAGRO). En 1989 los Chácobo de Alto Ivon organizaron una cooperativa con un almacén de acopio en Riberalta. En cuanto a sus actividades de subsistencia, al margen de la ya señalada, están principalmente la agricultura, la cría de animales domésticos, la caza, pesca y recolección de productos silvestres. 


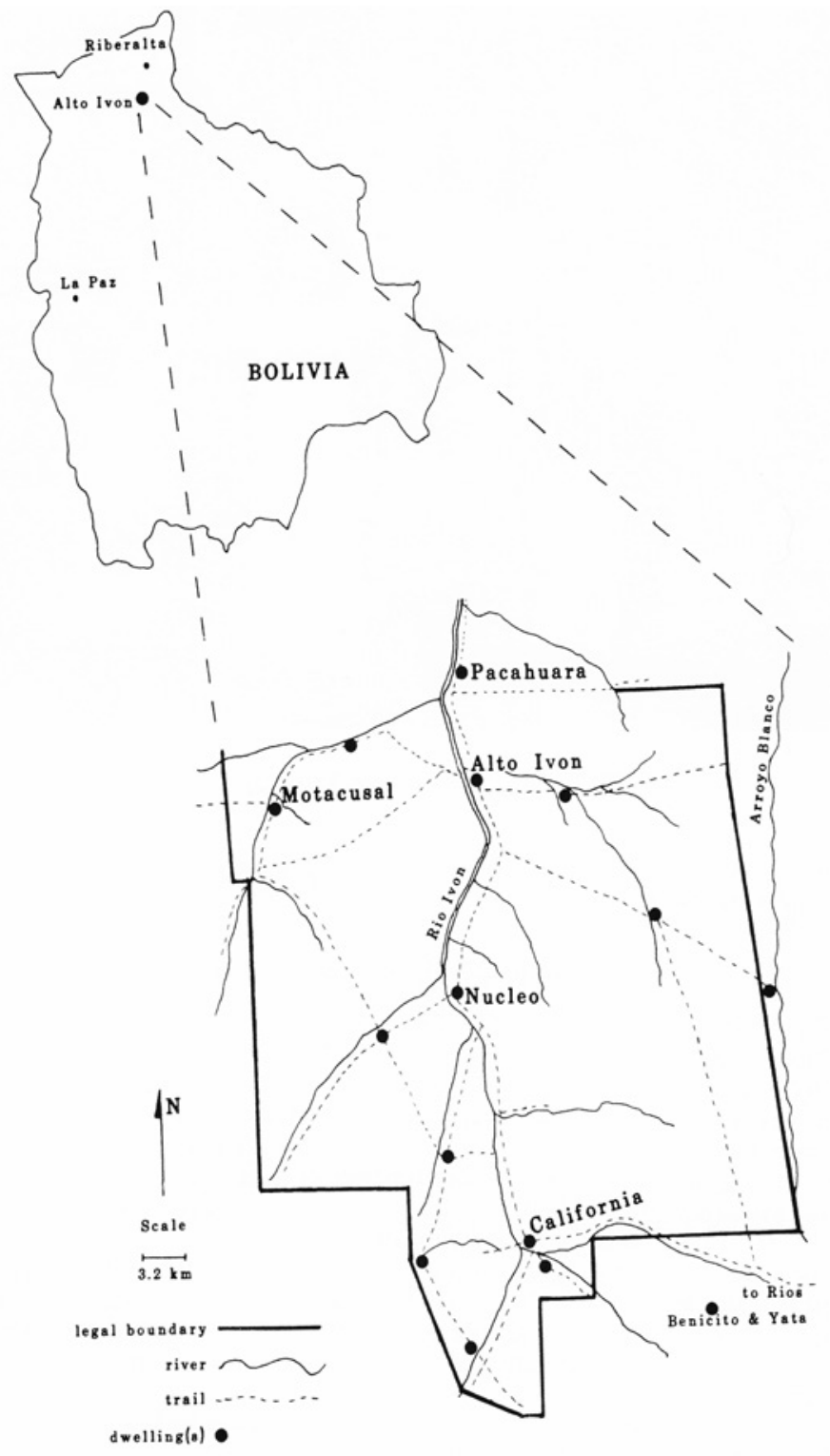

Mapa del territorio de los Chácobo a lo largo del río Ivon en 1985

\section{El territorio Chácobo 1985}

La comunidad de Alto Ivon como centro del territorio Chácobo esta localizada a unos $112 \mathrm{~km}$ al sur de Riberalta, al lado del río Ivon, un tributario del Beni. La elevación del terreno es de unos 200 msnm, y corresponde al bosque lluvioso amazónico de tierra firme. Los árboles de caucho (Hevea brasiliensis) y castaña (Bertholletia excelsa) son abundantes.La temperatura promedio anual es de $26.8{ }^{\circ} \mathrm{C}$ y la precipitación anual promedio de $1.566 \mathrm{~mm}$, basado en observaciones en Riberalta, desde junio hasta noviembre, hay un periodo marcado de sequía. 


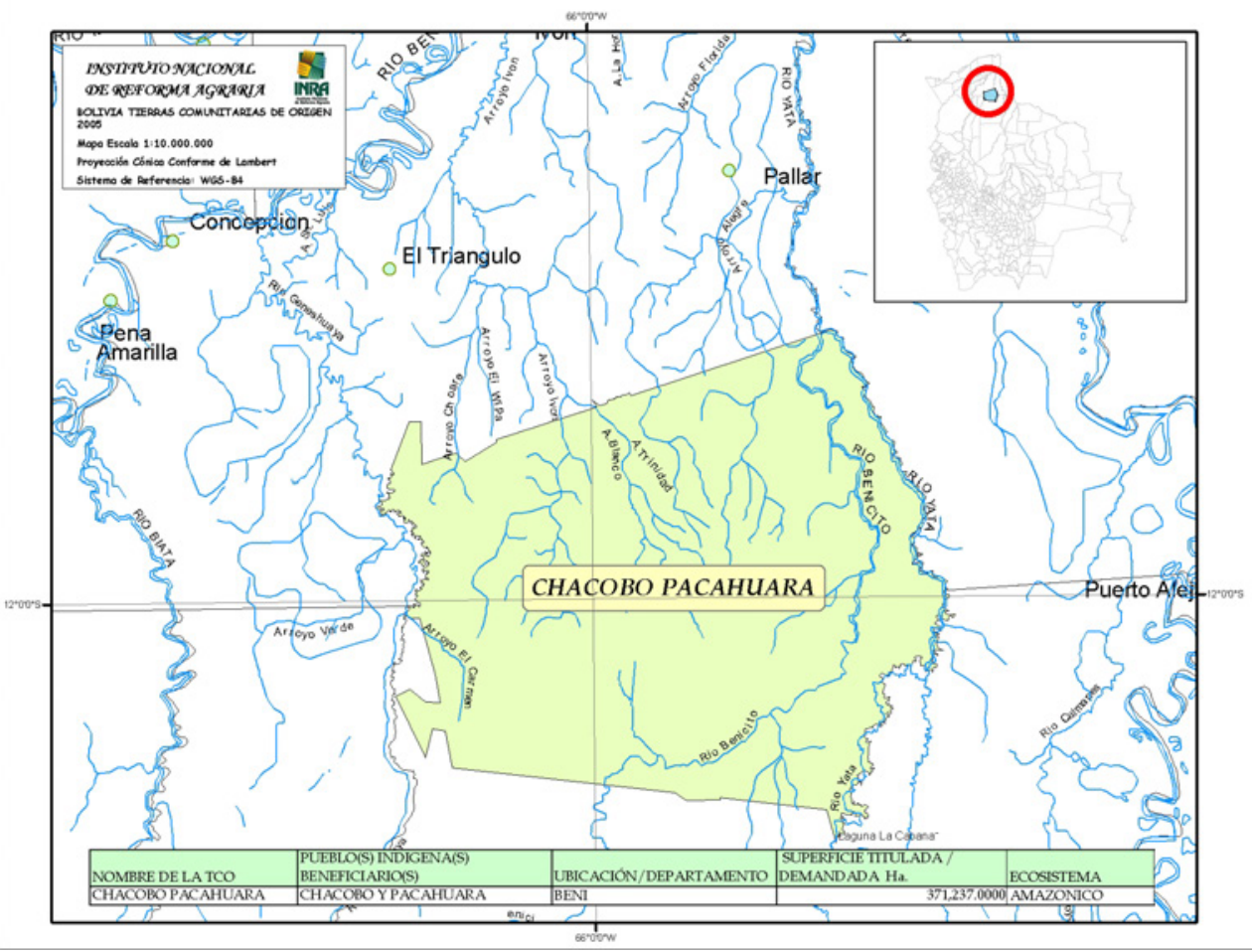

Mapa del territorio de los Chácobo en el 2011

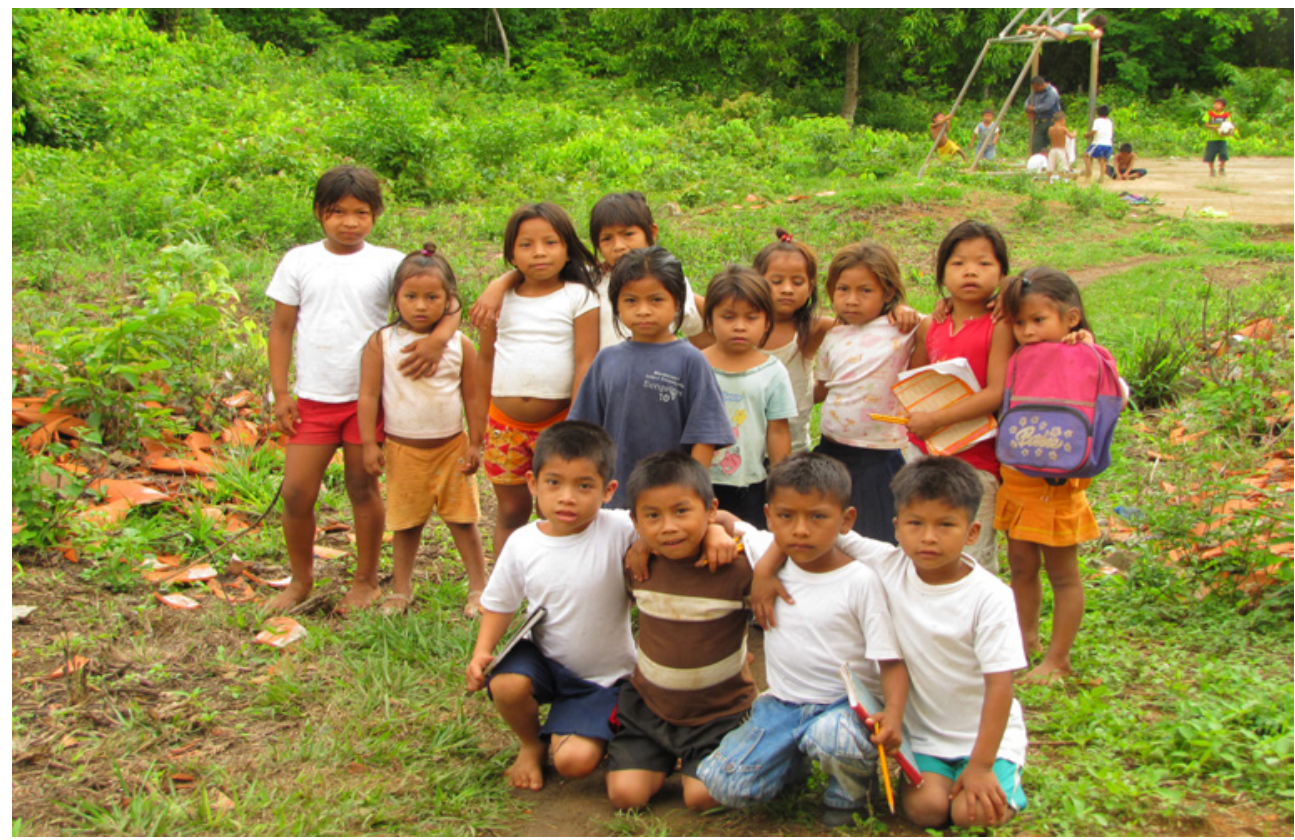




\section{Plantas Útiles de los Chácobo}

Entre noviembre de 1983 y mayo de 1984 Brian Boom, investigador del Jardín Botánico de Nueva York, llevó adelante el primer estudio etnobotánico realizado con los Chácobo.

Boom trabajó identificando las plantas útiles que se encontraban en una parcela de una hectárea de bosque cerca de la comunidad de Alto Ivon. Durante este tiempo condujo entrevistas etnobotánicas y realizó colecciones de campo, con la colaboración de diez informantes Chácobo: Pai Chávez, Caco Soria, Yari Vargas, Tani Chávez, Caco Antelo, Pai Ortíz, María Soria, Caco Ortíz, Pai Davalos y Rabi Ortíz.

Boom encontró 94 especies de árboles mayores a $10 \mathrm{~cm}$ de diámetro, en una parcela de una hectárea de bosque cerca de la comunidad de Alto Ivon, con 649 individuos haciendo una área basal de $21 \mathrm{~m}^{2}$. El bosque estaba dominado por pocas especies como Iryanthera juruensis (Mart.) H. Wendl., Pseudolmedia laevis (R. \& P.) Macbr., Euterpe precatoria Mart. y Socraetea exorrhiza (Mart.) H. Wendl., con las familias Moraceae, Myristicaceae, Arecaceae, Fabacea y Melastomataceas como las mas importantes.

Brian Boom recolectó 360 especies (221 géneros y 79 familias) de plantas en el territorio Chácobo, de cuales 305 eran utilizadas de alguna manera. Estas 305 especies pertenecen a 197 géneros de 75 familias. La información sobre su uso fue organizada en ocho categorías de uso: alimenticio, leña, construcción, artesanal, medicinal, veneno, comercial y misceláneos. Estas categorías fueron propuestas por el investigador, y no necesariamente reflejan las categorías tradicionales de uso. Frecuentemente, aunque no se reportó un uso directo, los informantes indicaron que "se debería tomar en cuenta a la especie para un uso futuro". Es interesante mencionar que ninguna especie se consideró como ornamental. Los Chácobo siembran 27 especies de las que obtienen algún tipo de alimento, y recolectan 75 especies con este mismo fin en el bosque, lo que nos muestra su gran conocimiento como recolectores. 


\section{Plantas conocidas por los Chácobo de Alto Ivon}

A continuación presentamos el listado completo de los las especies de plantas vasculares registrados en Alto Ivon por Brian Boom.

Cada una de las descripciones incluyen: el nombre Chácobo (y su significado en el caso de contar con esta información), nombre en castellano, el nombre científico de la planta, frecuencia (de presencia en la comunidad), habito, hábitat, rango geográfico y la descripción el uso. Un juego completo de las especies se encuentra en el Herbario de Jardín Botánico de Nueva York (NY), y los duplicados en el Herbario Nacional de Bolivia en La Paz (LPB) y otros herbarios.

La traducción de los nombres Chácobo esta basada en un diccionario no publicado de la Misión Evangélica Suiza en colaboración con el Instituto Lingüístico de Verano.

Los árboles encontrados en la parcela de Boom están marcados con un asterisco (*).

\section{PTERIDOPHYTA}

\section{mitaisa}

Adiantopsis radiata (L.) Feé

Helecho terrestre raro en el bosque secundario maduro. Con distribución amplia en el neotrópico. No se utiliza.

mitaisi; xëqui nihi jahehua (xëqui - maíz; nihi - bosque; jahehua - madre).

Adiantum glaucescens $\mathrm{KI}$.

Helecho terrestre común en el bosque secundario maduro. Guayana y la Amazonía. Decocción usada para bañar los niños que tienen fiebre alta.

mitahitsa No se utiliza; xequitaxo (xëqui - maíz); mitaisa

Adiantum lucidum (Cav.) Sw.

Helecho terrestre común en el bosque secundario maduro. Del sur de Panamá a todo América del Sur. Decocción usada para bañar los niños que tienen fiebre alta. Decocción tomada para curar el reumatismo.

xëquihuitaxo (xëqui - maíz); xëquitaxo (xëqui - maíz)

Adianium obliquum Willd.

Helecho terrestre común en el bosque secundario maduro. Común en el neotrópico. Decocción tomada para curar diarrea. Decocción tomada para curar reumatismo.

xequihuitaxo (xëqui - maíz)

Adianium terminatum Kunze ex Miq.

Helecho terrestre común en el bosque secundario maduro. Común en el neotrópico. Decocción tomada para curar la diarrea.

\section{mitaisa}

\section{Adiantum tomentosum $\mathrm{Kl}$.}

Helecho terrestre raro en el bosque secundario maduro. Amazonía. No se utiliza.miiaisa jahëhua (jahehua - madre), No se utiliza; jonotasi 
Asplenium pearcei Baker.

Helecho terrestre raro en el bosque secundario maduro. Endémica del suroeste de la Amazonía. Decocción tomada para curar dolor de estomago.

\section{toriahuitaxo}

Triplophyllum protensa (Afzel. ex Sw.) Holttum

Helecho terrestre común en el bosque secundario maduro. América Central y común en América del Sur. Raspadura del rizoma en decocción fría se toma para curar apendicitis.

toriahuitaxo; jinaristi (jina - línea, cola)

Ctenitis submarginalis (Langsd. \& Fisch.) C. Chr.

Helecho terrestre común en el bosque secundario maduro. Muy extendida en América del Sur tropical hasta el sur de Argentina. Raspadura del rizoma colocar directamente sobre la piel en el lugar del apéndice para aliviar el dolor de la apendicitis. Decocción bebida para aliviar el dolor de cabeza.

Sin nombre Chácobo

Hecisteropteris pumila (Spreng.) J. Sm.

Pequeño helecho epífito común en los bosques secundarios maduros. Amplia distribución en el neotrópico. No se utiliza.

\section{toriahuitaxo}

\section{Lindsaea divaricata $\mathrm{KI}$.}

Helecho terrestre común en bosque secundario avanzando. Amazonía y Planalto brasileño. Raspadura del rizoma hervidas y esta decocción se toma para curar apendicitis.

xëqui jahuehua (xëqui - maíz; jahue-hua - lo que es más grande que ...)

Lindsaea lancea (L.) Brade var. lancea

Helecho terrestre común en bosque secundario avanzando. Común en el neotrópico. En la decocción se bañan los niños hiperactivos.

\section{mitaisa}

\section{Lindsaea portoricensis Desv.}

Helecho terrestre común en bosque secundario maduro. Común en el neotrópico. No se utiliza.

\section{Sin nombre Chácobo}

\section{Lomagramma guianensis (Aubl.) Ching}

Helecho epífito común en bosque secundario avanzando. Las Indias Occidentales y Sudamérica tropical. No se utiliza.

toriahuitaxo No se utiliza

cashimetsisi (cashi -murciélago, mamífero; metsisi - garras)

\section{Lomariopsis prieuriana Feé}

Helecho epífito común en bosque secundario maduro. Neotrópico. Dos gotas de exudado del tronco se mezclan con una pequeña cantidad de agua y esta solución se toma para aliviar el dolor de estómago. 
xëqui jahue (xëqui maíz secundario; jahue - cosa, algo)

Metaxya rostrata (Willd.) Presl

Helecho terrestre común en bosque secundario maduro. Principalmente la Amazonía, se extiende al norte hasta Panamá. No se utiliza.

jihui ratsamica nishi (jihui - árbol; rata -samica - agarrar firmemente para subir; nishi bejuco)

Polypodium bombycinum Maxon

Helecho epífito común en bosque secundario maduro. Común en el norte de América del Sur. Raspadura del rizoma se macera en agua fría y la pasta resultante se coloca directamente sobre la piel, sobre el lugar del apéndice para curar una apendicitis.

jonotasi

Polypodium (Campyloneurum) brevifolium Link

Helecho epífito común en bosque secundario maduro. América Central al sur de la Amazonía. Decocción tomada para curar dolores de estómago.

jonotasi

Polypodium (Phlebodium) decumanum Willd.

Helecho epífito común en bosque secundario maduro. Común en el neotrópico. No se utiliza.

cashimetsisi (cashi - murciélago, mamífero; metsisi - garras)

Microgramma megalophyllum Desv.

Helecho epífito común en bosque secundario maduro. Amazonía. Decocción tomada para aliviar el dolor de estómago.

mitaisa xëqui jahëhua (xëqui - maíz; jahë-hua - madre)

Polypodium sp.

Helecho epífito raro en bosque secundario maduro. No se utiliza.

xëqui jahuehua (xëqui - maíz; jahue-hua - lo que es más grande que ...)

Thelypteris (Goniopteris) abrupta (Desv.) Proctor

Helecho terrestre común en bosque secundario maduro. Amazonía. No se utiliza.

capëtëjiquërëxë (cápete - caimán; ji - cola, la línea; querexe - el tipo de punta de flecha con varios púas)

Trichipteris procera (Willd.) Tryon

Helecho arbóreo común en bosque secundario maduro. Las Indias Occidentales y todo

el norte de América del Sur. Decocción se toma para aliviar el dolor de la apendicitis.

jorojina (jina - cola, la línea) No se utiliza. mitahuisma

Trichomanes pinnatum Hedw.

Helecho terrestre común en bosque secundario maduro. Común en el neotrópico.

Decocción tomado para curar la diarrea. 
jorojina (jina - cola, la línea)

Trichomanes vittaria Poir.

Helecho terrestre común en bosque secundario maduro. Las Guayanas y la Amazonía. Utilizado como un medicamento, pero el informante no especificó cual tipo de enfermedad.

\section{ANACARDIACEAE}

cayo (Castellano: acajú)

Anacardium occidentale $\mathrm{L}$.

Pequeño árbol raro, cultivado en jardines alrededor de las casas. Muy extendida en los trópicos. El pedúnculo carnoso se come.

maca (Castellano: manga)

Mangifera indica L.

Árbol pequeño hasta mediano muy común, cultivado en jardines en los alrededores de las casas. Introducido, nativo de la India. Los frutos del mango son una de las frutas favoritas de los Chácobos. Una decocción de las hojas se toma para aliviar el dolor corporal (reumatismo).

nihibimi (nihi - bosque; bimi - fruta)

Tapirira guianensis Aubl.

Pequeño árbol medio raro sin aletones, en el bosque secundario. Muy ampliamente distribuido en América Central y Sudamérica tropical. Una decocción de la fruta se toma para curar la diarrea y aliviar los problemas estomacales.

xetshitsa (-shi - rojo)

Toxicodendron striatum (R. \& P.) Kuntze

Árbol grande sin aletones, raro en bosque secundario. Común en América Central y Sudamérica. Los troncos se ahuecan para construir canoas.

\section{ANNONACEAE}

ahuaramacha (ahuara - tapir; macha - diente); bimi (-fruta); jeneaxahua (jene - agua; axa para matar con veneno; -hua - fuerte, mucho más)

Annona ambotay Aubl.

Arbusto o pequeño árbol común en bosque secundario. Común en la Amazonía, se extiende hacia el norte en las Guayanas. Frutas comestibles, raspaduras de la corteza se aplican en lesiones de la piel. Decocción de las hojas tomada para curar el dolor de cabeza. Hombres y niños envuelven las ramas jóvenes con fuerza alrededor de sus muñecas para aumentar la fuerza del brazo inferior.

rononosebi (ronoxe - espina; no- estómago; -sebi - unido); ahuaracatoco (ahuara - tapir; catoco - riñón)

Annona hypoglauca Mart.

Arbusto o árbol pequeño en el bosque secundario o cultivadas en los en los jardines 
alrededor de las casas. Principalmente de la Amazonía occidental, pero también en la Amazonía oriental y la cuenca del río Orinoco. Fruta comestible, dicen que tiene propiedades medicinales, pero el informante no fue más específico.

\section{yohisi}

Crematosperma monospermum (Rusby) R. Fr.

Pequeño árbol en el bosque secundario. No se utiliza.

ahuaracato (ahuara - tapir; catoco -c)

Cymbopetalum brasiliense (Vell.) Benth. ex Baill.

Pequeño arbusto en el bosque secundario. Decocción de las hojas tomado para curar reumatismo.

\section{ahuabaca}

Duguetia quitarensis Benth.

Recogido como un árbol joven en viejo bosque secundario. Se conoce de las Guayanas y la Amazonía, la mayoría se encuentran comúnmente en la Amazonía occidental. Tiras de corteza interna utiliza como cuerdas. La madera es utilizada como leña para cocinar.

\section{xahuisi}

Unonopsis guatterioides R. E. Fries

Árbol de tamaño mediano poco frecuente en el bosque secundario. Restringido a la Amazonía boliviana y los Yungas. Frutos comestibles.

\section{xahuisi; xahuisi}

\section{*Guatteria discolor R. E. Fries}

Árbol poco frecuente de tamaño mediano, con aletones, en el bosque secundario. Restringida al suroeste de la Amazonía en Brasil y Bolivia. Decocción de las hojas tomada para provocar el vómito y curar la diarrea. Tiras de corteza se usan para cuerdas.

\section{ahuabaca; ahuabaca; xahui}

* Guatteria hyposericea Diels

Árbol poco frecuente de tamaño mediano en el bosque secundario maduro. Común, pero raramente colectada, Amazonía. Utilizan como cuerdas para el amarre de hojas de palma para techar la casa. La madera es utilizada como leña para cocinar. Tiras de corteza se usa como sogas.

\section{pavo}

*Unonopsis floribunda Diels

Árbol mediano común sin aletones en bosque secundario. No se utiliza.

\section{joisi}

\section{Ephedranthus boliviensis Chatou \& Pirie}

Árbol mediano común sin aletones en bosque secundario. Se conoce en la Amazonía occidental. No se utiliza. 


\section{xahui; xahuiria}

*Xytopia polyantha R.E. Fr.

Árbol común de tamaño mediano en el bosque secundario maduro. Tiras de corteza se usan como sogas. Es la corteza más importante para la fabricación de cuerdas para asegurar el techo en las casas.

tetëmëtoijoni (teteca - grande; meto - señalar con el dedo; joni - hombre); tetemetsisi (tete - grande; metsisi - garras)

Xylopia peruviana R.E. Fr.

Arbusto muy común o pequeño árbol en el bosque secundario. La madera es utilizada como leña para cocinar. Decocción de las hojas tomado para curar problemas de hígado. Frutos dulces se comen.

\section{APOCYNACEAE}

chachama (-cha - en; chama - con mucho poder)

*Aspidosperma megalocarpon Muell. Arg.

Pequeño árbol poco frecuente sin aletones, con tronco acanalado profundamente, en el bosque secundario maduro. Conocido sobre todo de las Guayanas y Venezuela, pero su distribución se extiende a Bolivia amazónica. Una decocción de las raspaduras de la corteza se toma para curar el malestar. Esta misma decocción se aplica a lesiones en la piel para ayudar a la curación.

yoxanameticato (yoxa - mujer; name - encarcelar, matar; -tica-tener sueño)

Fosteronia acouci (Aubl.) A. DC.

Liana poco común en bosques secundarios. Conocido de las Guayanas y la cuenca del Amazonas. Decocción de las hojas ayuda a aliviar el dolor de estómago.

atsa nihi (atsa - yuca; nihi - bosque) No se utiliza; nishi (-bejuco)

Mandevilla bracteosa (Rusby) Woodson

Bejuco común en bosques secundarios y los márgenes de los campos agrícolas. Conocida desde Bolivia hasta la Amazonía peruana. Decocción de las hojas se toma para aliviar el dolor de estómago.

omaca nihiip (maca - tipo de pez; nihi - bosque)

Odontadenia laxiflora (Rusby) Woodson

Bejuco común en pastizales abandonados por el ganado. Restringida al suroeste de la Amazonía. Las hojas estrujadas con las manos, se frotan en puntas de flecha como un veneno para matar a los peces.

pinoreseti (pino - pájaro carpintero; rëseti - plumas colocadas en la perforación del tabique nasal como adorno)

Prestonia coalita (Veil.) Woodson

Bejuco común en pastizales abandonados por el ganado. Generalizado en América del Sur, que se extiende desde Venezuela y el sur de Guayana el Planalto brasileño. No se utiliza. 
bahuaquexti (bahua - un pequeño loro verde)

Tabernaemontana linkii A. DC.

Arbusto muy común en los pastos abandonados. Amazonía. Látex blanco se aplica a las llagas en la piel para ayudar a la curación. Látex blanco se aplica sobre las heridas de las larvas de boro en la piel con el fin de matar las larvas para que puedan ser expulsadas.

quisi; yotabi

Woytkowskia spermatochorda Woodson

Arbusto poco común en los bosques secundarios maduros. Muy rara vez colectado en la Amazonía occidental. Las semillas negras sirven para fabricar collares que se usaban antes como un adorno. Las hojas son hervidas y se coloca sobre las heridas infectadas para reducir la hinchazón.

jihui bepia (jihui - árbol)

*Apocynaceae gen. indet.

Árbol grande poco frecuente, con aletones, en el bosque secundario maduro. Un trozo de tela se empapa en el exudado pegajoso de color blanco, lo que se aplica a los músculos doloridos para aliviar el dolor.

\section{ARACEAE}

maichaca (mai - la tierra, el suelo; chaca - lavar)

Anthurium gracile (Rudge) Lindley

Epífita en bosques secundarios. Una decocción de las hojas y/o de los frutos se toma para curar la apendicitis.

nishishibiri (nishi - bejuco; -shi - rojo; bin - derecha, delgado)

Monstera subpinnata (Schott) Engl.

Epífita en bosques secundarios. No se utiliza.

nihixoni (nihi - bosque); No se utiliza.

Syngonium yurimaguense Engl.

Epífita común en bosques secundarios. Las hojas se aplican directamente a los cuerpos de los niños que no caminan por la debilidad.

\section{mataca}

Xanthosoma striolatum Mart. ex Schott

Hierba cultivada en los campos agrícolas. Los tubérculos con almidón de esta planta suculenta se hierven y se comen como una papa. Esta variedad produce un tubérculo mas largo que una papa.

xeca

Xanthosoma sagittaefolium Schott.

Hierba cultivada en los campos agrícolas. Los tubérculos se hierven y se comen como una papa. Esta variedad produce un tubérculo de $5 \mathrm{~cm}$ de diámetro. 


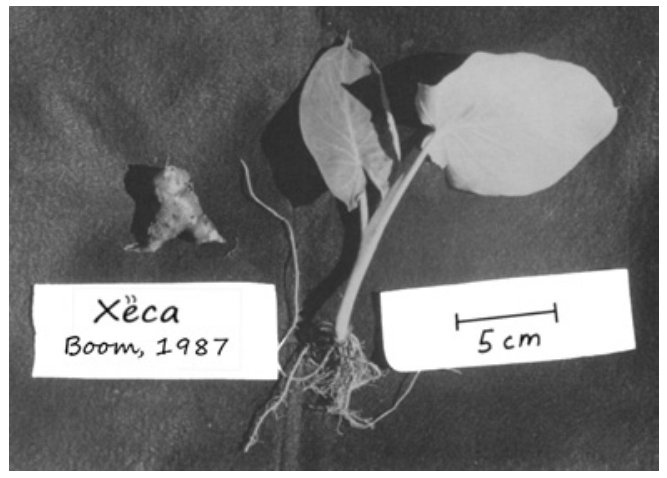

oinihi (oi - rain; nihi - bosque)

Philodendron quinquelobum K. Krause

Epífita en bosques secundarios. No se utiliza.

oibi (oi - lluvia; bi - colectar)

Philodendrum megalophyllum Schott

Epífita en bosques secundarios. Raíces largas aéreas utilizadas como material para tejer cestas.

\section{ARALIACEAE}

nahuabexe ( $n a$ - en el interior; -hua - para realizar o hacer que el tener la calidad de ...)

*Schefflera morototoni (Aubl.) Maquire, Steyerm. \& Frodin

Árbol grande poco frecuente sin aletones, en el bosque secundario maduro. Común en el neotrópico. Una decocción de la raspadura de la corteza se le hace gotear en la oreja para curar dolor de oído.

\section{ARECACEAE}

panima ( - ma - sufijo que significa "no") (Castellano: chonta)

\section{* Astrocaryum aculeatum Meyer}

Palma común en bosques secundarios y con alto grado de alteración.

Los frutos comestibles se obtienen de los bosques a medida que maduran.

Unas larvas de color blanco (maco) se extraen de los frutos y se utiliza como carnada para la pesca.

La dura y negra "madera" del tronco está trabajada para fabricar los arcos de caza (ch: canati), y puntas de flecha, de las cuales cinco variedades reconocidas: quereque, paca, tepi, tahua que - spini y bicobi. Cada una de las flechas es fabricada para cazar o pescar algún tipo de animal en particular. Aunque hoy en día la mayoría de la caza de animales se realiza con rifles calibre 22 , pero la pesca sigue siendo a menudo con arco y flecha, por lo general con el bicobi. El bicobi tiene una inclinación, y presenta unas puntas de acero colocadas en la punta para servir como un garfio. Las puntas de flecha son fabricadas con cera de abejas que recogen de los panales que crecen en los huecos de los troncos de los árboles y las varillas de las flores una gran hierba llamada tahua (Gynerium sagittatum) que se cultivan específicamente para este propósito. 
Las hojas son los materiales más importantes para la cestería. Las pinnas de las hojas son divididas longitudinalmente y se las tejen fabricando diferentes artículos, entre ellos una canasta pequeña de boca ancha, Ilamada shichuma (ch), que es utilizada para guardar arroz; otra canasta también pequeña y con tapa, llamada chichabëcasa (ch), es utilizada para guardar objetos de valor. Tejen también venteadores o abanicos, conocidos como huana huequëti (ch).

Pani (Castellano: chonta loro)

Astrocaryam ulei Burret

Palma poco frecuente, semicultivada en campos agrícolas abandonados y también dispersa por los senderos.

Los frutos son comestibles. La semilla o nuez de sabor a frutas es muy apreciada y se considera tan popular para consumirla como el mango (ch: maca).

xebichoqui (castellano: motacusillo)

* Attalea maripa (Aubl.) Mart.

Palma grande, con un tronco de 8 metros de altura, muy poco frecuente en el bosque secundario maduro.

La espata o bráctea leñosa es el juguete favorito de los niños.

Las hojas son ocasionalmente empleadas para el techado de las casas.

Los frutos son muy apreciados por los Chácobo, que viajan a veces considerables distancias para conseguirlos y comerlos asados al fuego.

xebini (castellano: motacu)

* Attalea phalerata Mart. ex Spreng

Palma con un tronco de $2 \mathrm{~m}$ de altura y $35 \mathrm{~cm}$ de diámetro, muy rara en el bosque secundario maduro.

Los frutos son comestibles y muy apreciados, se consume la pulpa o mesocarpio y también las semillas, se comen crudas.

Las hojas se usan ocasionalmente en la construcción de los techos.

Las hojas son también empleadas como remedio para curar la diarrea, una de las enfermedades mas comunes. Los foliolos se muelen y hierven en agua, esta decocción se toma enfriándola hasta mejorar.

El uso mas importante de las hojas es en el tejido de canastas muy livianas, llamadas Poropachi (ch).

canahuanima (cana - similar a)

Bactris acanthocarpa Mart.

Palma pequeña cómún en bosque secundario maduro.

Remedio para el dolor de estómago, las frutas se hierven en agua y la decocción, una vez enfriada, se toma.

huanima (castellano: chima)

Bactris gasipaes Kunth

Palma semicultivada frecuente en campos agrícolas abandonados y a los largo de los senderos.

Los frutos son comestibles, y también una bebida preparada a partir del jugo extraído 
de los frutos de la palma.

La madera dura y de color negra del tronco es empleada para la fabricación de arcos de caza y puntas de flecha, aunque normalmente utilizan al Panimá (Astrocaryum aculeatum) para este fin.

shinishoxo (Shini - rojo; shoxo - esfera)

Bactris maraja Mart.

Palmera pequeña poco frecuente en el bosque secundario maduro.

Los frutos son comestibles.

panabi (castellano: assai)

Euterpe precatoria Mart.

Palma con un tronco de 13 metros de altura, muy común en el bosque secundario maduro y reciente.

Los frutos se comen después de ablandarlos en agua tibia, también se los usa para preparar una bebida a partir de su jugo a la que se añade azúcar.

El uso mas importante de las hojas es en la construcción de los techos de las casas indiscutiblemente esta es la hoja mas usada por los Chácobo para la construcción de sus techos. Los chácobo construyen sus techos combinando las hojas de Panabi y el Mani (Phenakospermum guyanense).

Las hojas también se utilizan con fines medicinales para aliviar los dolores de pecho, los foliolos son triturados y hervidos, esta decocción fría, se toma, y en algunos casos se emplean también para fabricar escobas improvisadas.

tanane ( - puente)

Geonoma maxima (Spruce.) A.J. Hend. var. chelidoneura

Palmera pequeña, poco frecuente en los bosques secundarios antiguos.

Las hojas se usan para la construcción de los techos de chozas o pequeñas casas.

Los tallos (de aprox. 2,5 $\mathrm{m}$ de largo y $1,5 \mathrm{~cm}$ de espesor) se utiliza a veces como varillas de la flecha cuando la Tahua (Gynerium sagittatum) no está disponible.

itsama (castellano: majo)

* Oenocarpus bataua Mart.

Palma con un tronco de 12 metros de altura, poco frecuente en el bosque secundario maduro.

Los pecíolos robustos de las hojas son atados entre sí para construir las puertas de las casas.

Los frutos aceitosos se comen después de ablandarlos en agua tibia, y se convierten en una bebida mediante a la que se adiciona azúcar.

quëboitsama (quëbo - pava) (castellano: bacaba)

* Oenocarpus mapora Karst.

Palma con un tronco de 8 metros de altura, muy poco frecuente en el bosque secundario maduro.

El jugo extraído de la corteza del tronco se mezcla con agua y bebido para aliviar la fiebre alta. 
Los frutos se comen.

Las hojas se emplean en la construcción de los techos.

onipa (castellano: pachuba)

* Socratea exorrhiza (Mart.) Wendl.

Palma muy común con un tronco de 11 metros de alto, con raíces aéreas largas y espinosas, muy común en el bosque secundario nuevo y antiguo.

Es un remedio utilizado para las fiebres altas, los frutos y/o la raspadura de la corteza se hierven en agua, esta decocción se toma fría.

El uso mas importante de la Onipa esta en la construcción, la madera del tronco se divide en tablas usadas para construir las paredes de las casas, también se usan para las tablillas de las camas y los pisos o plataformas altas.

Otro uso, que ya no se practica mucho es el uso de las raíces espinosas para rallar la yuca, este uso ha sido reemplazado por las laminas de lata (aluminio o metal) con numerosas perforaciones hechas con los clavos.

\section{ARISTOLOCHIACEAE}

carihua (cari - camote; -hua - grande, mucho, pequeño, o tener la calidad de)

Aristolochia odoratissima $\mathrm{L}$.

Bejuco común en bosques secundarios. A lo largo de la región del neotrópico. Decocción de las hojas tomada para curar la diarrea.

\section{ASTERACEAE}

\section{Sin nombre Chácobo}

Mikania psilostachya DC.

Bejuco poco común en bosques secundarios. Suroeste de la Amazonía oriental y laderas de los Andes en Perú y Bolivia. No se utiliza.

carapenihi (carape- plátano; nihi - bosque)

Mikania psilostachya DC.

Bejuco común en claros en el bosque secundario. Conocido de Panamá y en toda América del Sur tropical. No se utiliza.

\section{ororotso}

Porophyllum ruderale (Jacq.) Cass.

Hierba común en pastizales abandonados. Una maleza en todo el neotrópico. Las hojas se aplican directamente sobre las heridas infectadas para reducir la hinchazón.

\section{BIGNONIACEAE}

huëtanihi (huela- sacar agua; nihi - bosque)

Amphilophium paniculatum (L.) Kunth var. paniculatum

Bejuco común en pastizales abandonados. Conocido de toda tropicales de América Central y del Sur. Las hojas se colocan sobre las heridas infectadas para reducir la hinchazón. 
nishiraoxo (nishi - bejuco; raoxo - variedad de yuca)

Arrabidaea platyphylla DC.

Bejuco común en pastos abandonados Se conoce en la Amazonía occidental al Planalto brasileño. Exudado del tallo se mezcla con agua y se toma para curar la diarrea.

cochopi (Castellano - tutuma)

Crescentia cujete L.

Árbol que crece en los en los jardines alrededor de las casas. Ampliamente cultivada en las zonas tropicales de todo el mundo. Frutas se convierten en calabazas que se usan para fabricar recipientes para tomar.

carihua (cari - camote; -hua - grande o pequeño)

Distictelta dasytricha Sandw.

Bejuco poco común en los bosques secundarios maduros. Se conoce en la Amazonía occidental y el Planalto brasileño. No se utiliza.

pitsopi Decocción de las hojas tomado para curar el reumatismo.

*Jacaranda copaia ssp. spectabilis (Mart. ex A. DC.) A.H. Gentry

Árbol común de tamaño mediano en el bosque secundario. Conocido de toda tropicales de América Central y del Sur. No se utiliza.

nishiraoxo (nishi - bejuco; raoxo - variedad de yuca)

Lundia densiflora DC.

escaso en el bosque secundario maduro. Durante la mayor parte del norte de Sudamérica hasta el sur de la Planalto brasileño. Exudado del tallo se mezcla con agua y se toma para curar la diarrea.

xoquerapoto (xogue - tucán; rapoto - rodilla)

Mussatta hyacinthina (Standi.) Sandw.

Bejuco escaso en el bosque secundario maduro. Conocidos de América Central y en toda Guayana y Amazonas. Exudado del tronco se mezcla con agua y se toma para curar la diarrea.

yorosi (yoro - torcido)

Sparattosperma leucanthum (Veil.) K. Schum.

Árbol pequeño común en las afueras del pueblo. La Amazonía occidental de Brasil Planalto, en el sur de Paraguay. Raspaduras de corteza se hierven en agua durante 1-2 horas, el tinte de color marrón que resulta se usa para teñir el hilo de algodón.

nishiraoxo (nishi - bejuco; raoxo - variedad de yuca)

Tanaecium nocturnum (Barb. Rodr.) Bur. \& K. Schum.

Bejuco raro en el bosque secundario maduro. A lo largo de las Guayanas y la Amazonía.

El exudado del tallo se mezcla con agua y luego se toma para curar la diarrea. 
nananihi (nana - tener epilepsia; - bosque)

Pyrostegia dichotoma Miers ex K. Schum.

Bejuco en el bosque secundario maduro, Las hojas son hervidas en agua, la decocción fría se utiliza para bañar a una persona enferma. El tipo de enfermedad no fue especificada por el informante

berochexati (bero - ojo; chexa - curar; ti - sufijo que denota lugar o la función de la acción futura)

Haplolophium rodriguesii A.H. Gentry

Bejuco en el bosque secundario maduro. Los nódulos en las raíces se convierten en chatarra, estas raspaduras se mezclan con agua, se hierven y la decocción fría se hace gotear a los ojos irritados a promover la mejoría.

michisi (michi - gato); mitsisitato

Clytostoma sciuripabulum Bureau \& K. Schum.

Bejuco en el bosque secundario maduro. El bejuco se utiliza como una cuerda para amarrar las estructuras de las casas. Exudado del tallo se mezcla con agua y se toma para curar la diarrea.

\section{BIXACEAE}

maxë (Castellano - urucú, anatto)

Bixa orellana L.

Arbusto muy común en los en los jardines alrededor de las casas. Nativo de los neotrópicos y cultivada en todo. Fuente de anatto. Un tinte de color rojo se extrae de las semillas que se utiliza como colorante para alimentos y pintura corporal. Las semillas también se comen cocidas fritas. Las hojas se usan para aliviar dolores en el cuerpo, presionando contra las zonas afectadas.

\section{BOMBACACEAE}

potasti (potas- destruir; -ti - sufijo que denota la acción futura o la función de un objeto)

*Eriotheca globosa (Aubl.) A. Robyns

Árbol poco común en los bosques secundarios maduros. Muy común en América del Sur. Las fibras de las frutas se hacen girar en el hilo y se utiliza como sería de algodón.

\section{BORAGINACEAE}

\section{pabo}

*Cordia bicolor A. DC.

Árbol raro, de tamaño mediano sin aletones en el bosque secundario maduro. América del Sur tropical. No se utiliza.

bohueliomohuati (bohue - un tipo de pez; homo - acumular; -hua - grande o pequeño; -ti sufijo que indica acción futura o la función de un objeto). No se utiliza.

pabojoni (joni - hombre)

Cordia nodosa Lam.

Arbusto muy común en bosques secundarios. Común a través de América del Sur. Una decocción de las hojas se toma para curar el reumatismo. 
pabo

Cordia ucayaliensis Johnst.

Árbol pequeño común en el campo agrícola abandonada. Amazonía occidental. Tiras de la corteza se utilizan como material para tejer cestas.

carapënishi (carapë - plátano; nishi - bejuco)

Tournefortia paniculata Cham.

Árbol pequeño común en bosques secundarios. Muy común en América del Sur. Tiene uso medicinal, pero el informante no podía ser más específicos.

\section{BROMELIACEAE}

capetejiquerexe (cápete - caimán; ji - una línea; querexe - un tipo de punta de flecha con varias púas)

Aechmea angustifolia Poepp. \& Endl.

Epífita poco común en bosques secundarios. Panamá, al sur de la Amazonía occidental (donde la más común), hasta el sur de Venezuela. Decocción de las hojas se toma para curar el reumatismo.

cacama (Castellano - piña)

Ananas comosus (L.) Merrill

Hierba cultivada en los en los jardines alrededor de las casas y campos agrícolas. Originaria de América del Sur. La piña se come cruda o el jugo se mezcla con azúcar y agua para hacer una bebida.

\section{BURSERACEAE}

toxa

*Crepidospermum goudotianum (Tul.) Tr. P.

Árbol pequeño común, por lo general con aletones, en el bosque secundario maduro. Guayana y la Amazonía. Una decocción de las hojas y la de fruta se toma para aliviar los problemas estomacales. La madera se utilizada como leña para ahumar caucho crudo.

chiabëniti (chi- detrás; - $a$ - pasado; beni- pasar muy cerca de algo; -ti - sufijo que denota la función de un objeto o el tiempo futuro)

Protium subserratum Engl.

Recogido como rebrote solo en el bosque secundario maduro. Amazonía. La madera es utilizada como leña para cocinar.

xanojoxo (joxo - blanco); behisili corihua (beho - lagrimas; isi- dolor; - sufijo que denota la función de un objeto o el tiempo futuro)

Protium unifoliolatum Engl.

Arbusto o pequeño árbol común en bosques secundarios. A lo largo de la Amazonía y el Planalto brasileño. Las frutas rojas dulces se comen. Una pegajosa y aromática savia se extrae de los tallos, lo que se aplica a las infecciones graves para ayudar a la curación. 
xetohitsa (xeto - cera; itsa - cedro)

*Trattinnickia rhoifolia Willd.

Gran árbol sin aletones, común en bosque secundario maduro. Muy extendida en América del Sur. Los troncos son ahuecados para hacer canoas.

\section{CARICACEAE}

mapayo (Castellano - papaya)

\section{Carica papaya $\mathrm{L}$.}

Pequeño árbol común cultivado en los jardines patios y campos agrícolas. Indígenas de la región del neotrópico. Fruta comestible.

\section{CECROPIACEAE}

bocono (boco - para ser digno; -no - después) (Castellano - ambayo)

*Cecropia ficifolia Snethlage

Árbol común de tamaño mediano con pequeños aletones en el bosque secundario. Restringida al suroeste de la Amazonía. Las tiras de la corteza interna se utiliza el cable y la cuerda por la unión y anclaje.

bocobi (boco- para ser digno)

*Cecropia sciadophylla Mart.

Árbol común de tamaño mediano con aletones, en el bosque secundario. Muy extendida en América del Sur. Tiras de la corteza interior se utilizan como cuerda y cuerda para atar y amarre.

quëxquixaquini (qüëxë - pieza; -qui - acción incompleta); xaquitato (xaqui - algo profundo; lato - un árbol suave o un árbol que sigue creciendo)

*Pourouma cecropiaefolia Mart.

Árbol pequeño común con raíces adventicias en los bosques secundarios maduros. Amazonía y la Mata Atlántica Brasileña. Frutos comestibles.

\section{xaquini}

*Pourouma guianensis Aubl.

Árbol pequeño con poca frecuencia raíces adventicias en el bosque secundario. El norte de Sudamérica. Frutos comestibles.

\section{CHRYSOBALANACEAE}

chana jisicato (fisi- quemar; cato - lo que es...); chana; chana jahehua (jahehua - madre); ihuipama (ihui - eje, rayos; -pama - al mismo tiempo, durante, mientras)

*Hirtella lightioides Rusby

Árbol pequeño común sin aletones en el bosque secundario maduro. Restringida al norte y centro de Bolivia. La madera se utilizada como leña para ahumar caucho crudo. Frutos comestibles. 
chana; chana joni (joni - hombre)

Hirtella pilosissima Mart. \& Zuce.

Arbusto común en bosques secundarios. Amazonía occidental. Frutos comestibles, Decocción de las hojas y los frutos se toma para curar el reumatismo.

chana; chanasia

Hirtella racemosa Lam. var. racemosa

Arbusto común en bosques secundarios. De Panamá y Colombia, a través de las Guayanas y la Amazonía hasta el norte de Bolivia. Frutos comestibles.

chanajisicato (jisi - quemar; cato - lo que es)

*Licania britteniana Fritsch

Árboles raros pequeños con aletones, en el bosque secundario maduro. Amazonía occidental. La madera se utilizada como leña para ahumar el caucho crudo.

chana; cascara yobini; mehi

*Licania octandra (Hoffmgg. ex R. \& S.) Kuntz. subsp. pallida (Hook. f.) Prance

Pequeño árbol sin aletones muy frecuente en el bosque secundario maduro. Amazonía occidental y central. Frutos comestibles. Decocción de hojas se toma para curar dolor de estomago. La corteza es pulverizada, mezclada con arcilla, cocida en agua, y la suspensión resultante se usa como cemento para la fabricación de vasos en los hogares.

mëhihua (-hua - grande, pequeño, mucho)

Parinari parilis Macbr.

Árbol poco común en los bosques secundarios maduros. Amazonía occidental, con poca frecuencia colectada. La corteza es pulverizada, mezclada con arcilla, cocida en agua, y la suspensión resultante se usa como cemento para la fabricación de vasos en los hogares.

\section{CLUSIACEAE}

shiquishi (shi- el pecho; quishi - pierna) (Castellano - achachairu)

Rheedia floribunda (Miq.) PI. \& Tr.

Árbol poco común grande con exudado pegajoso amarillo en el bosque secundario maduro Amazonía. Frutos comestibles.

jeni batabi, ocotsimo (oco - toz; tsimos- agarrar firmemente); tiorocorihua (tio - tamaño; -hua - pequeño, grande)

Tovomita schomburgkii PI. \& Tr.

Árbol pequeño común con raíces adventicias y arbotantes en el bosque secundario maduro. Principalmente de las Guayanas y Venezuela, pero el extendiendo al sur de la Amazonía. Frutos comestibles, semi-dulces. La madera se utilizada como leña para ahumar caucho crudo. 


\section{COMBRETACEAE}

nishi moishi (nishi - bejuco; moishi - muy seco); cama (-tigre)

Combretum laxum Jacq.

Bejuco común o árbol, sin aletones, raro en el bosque secundario maduro. Muy común en América Central y del Sur. Según los informantes los frutos se comen, pero esto es dudoso ya que estos frutos son aquenios. Una decocción de rapaduras de la corteza se aplica a heridas para mejorar el saneamiento.

\section{COMMELINACEAE}

manihuashiri (mani - unir; huashi - tacaño; -ri que no saben cuando algo va a suceder)

Commelinopsis glabrata D. R. Hunt

Hierba común en bosques secundarios Amazonía, raramente colectado. Decocción de las hojas y los frutos se toma para curar el reumatismo.

caraina nihi (nihi - bosque)

Dichorisandra hexandra (Aubl.) Standl.

Hierba común en el bosque secundario maduro. Común en América del Sur tropical, se extiende hacia el norte en América Central. Planta para encanto del amor. El informante afirmó que cuando una mujer se niega a los avances de un hombre, el hombre frota las hojas de esta planta en sus manos. Dentro de un mes será capaz de conquistarla.

\section{CONNARACEAE}

jene cochopi (jene - agua; cochopi - tipo de recipiente para líquidos); joxa jaxtahua (joxa blanco; jaxta-hua - mesclar); nishimoisi (nishi - bejuco)

Connarus ruber (P. \& E.) Planchón var. sprucei (Baker) Forero

Arbusto común en bosques secundarios a lo largo de los arroyos. Principalmente de la Amazonía, pero que se extiende hacia el norte en Guayana. No se utiliza.

maxëjoni (maxë- tinte rojo; joni - hombre)

Rourea camptoneura Radlk.

Bejuco común en bosques secundarios a lo largo de los arroyos. Amazonía occidental. La decocción de hojas y los frutos se toma para curar el reumatismo.

\section{CONVOLVULACEAE}

\section{tsisecari, cari hosho}

Ipomoea batatas (L.) Lam.

Bejuco cultivada en los campos agrícolas. Ampliamente cultivada en todo el mundo, probablemente se originó en América del Sur. Dos variedades de papas cultivadas, una con un tubérculo de piel rojiza (tsisecari) y otro con una piel blanquecina (cari hosho).

\section{COSTACEAE}

\section{shico}

Costas scaber R. \& P.

Hierba común de escalada en el bosque secundario. Común en el neotrópico. Las 
raspaduras de la raíz son hervidas en agua, la decocción fría se pone sobre las heridas en la piel para ayudar a la curación.

\section{CUCURBITACEAE}

sania (Castellano - sandia)

Citrullus vulgaris Schrad.

Bejuco cultivada en los en los jardines alrededor de las casas. Originaria de África tropical y del sur. Se come.

cashixopa (cashi - murciélago, mamífero)

Gurania acuminata Cogn.

Bejuco común en bosques secundarios. Amplia distribución en Bolivia y Brasil y el norte de América del Sur. Decocción de las hojas se tome para curar diarrea.

pinoreseti (pino - pájaro carpintero; resell - plumas pasadas por el tabique nasal como adorno)

Gurania robusta Suesseng.

Bejuco poco común en los bosques secundarios maduros. Común en la Amazonía y las Guayanas. No se utiliza.

nainishi (nai - cielo; nishi- bejuco)

Gurania lobata (L) Pruski

Bejuco común en bosques secundarios. Amplia difusión en América del Sur. La decocción de las hojas se toma para curar problemas del hígado.

tsatano (Castellano - mate), xalamo, xatano

Lagenaria siceraria (Molina) Standl.

Cultivado en los en los jardines alrededor de las casas. Probablemente nativa de África tropical y Asia, pero extendida y naturalizada en el neotrópico. Los frutos son divididos longitudinalmente para usarlos como vasos.

\section{CYPERACEAE}

pacaxachi (-cortar)

Diplasia karataefolia L. C. Rich.

Hierba de $1 \mathrm{~m}$ de altura en el bosque secundario. Común desde el sur de América Central y en toda América del Sur. La decocción de las hojas se toma para aliviar el reumatismo.

\section{pacaxachi (-cortar)}

\section{Scleria myriocarpa Kunth}

Hierba de 2 m de altura en el bosque secundario. Amazonía. La decocción de las hojas se toma para aliviar el dolor de estómago.

sico mitsa (-mitsa - posible)

Scleria secans (L.) Urb.

Hierba trepadora en bosque secundario. Indias occidentales y Amazonía. No se utiliza. 


\section{DILLENIACEAE}

pexcanishi (pex - que es; ca - bosque; nishi - bejuco)

Davilla nitida (Vahl) Kubitzki

Bejuco muy común en áreas abiertas de las afueras de la aldea. Común en todo el neotrópico. Las hojas son hervidas y la decocción, una vez enfriada, se toma para aliviar el dolor de estómago.

\section{DIOSCOREACEAE}

pea (Castellano - ñame)

Dioscorea trífida L. f.

Cultivado en los campos agrícolas. Originario del norte de América del Sur y cultivada en todo el trópico. Los tubérculos se hierven y se comen como papas.

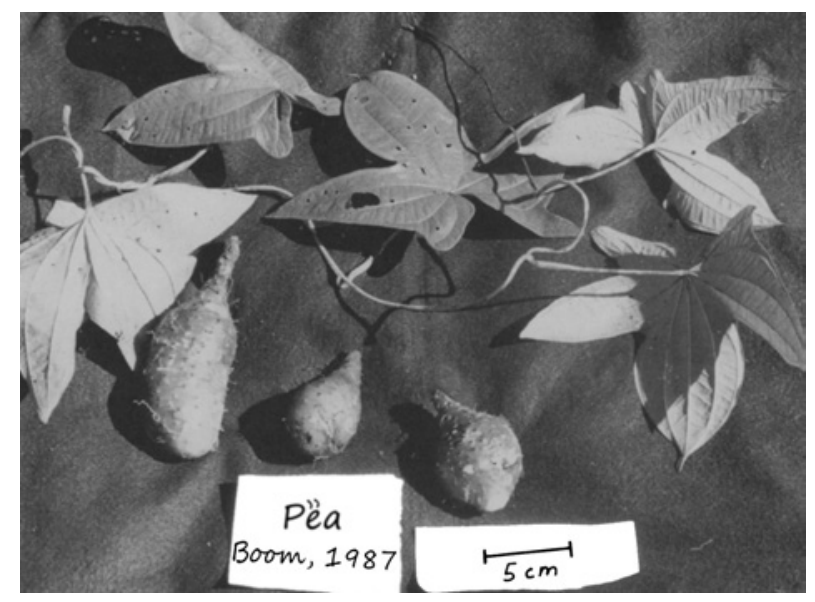

\section{ELAEOCARPACEAE}

jenëtahuatë (jene - agua). No se utiliza. xahuamachi (xahua - tipo de loro)

*Sloanea eichleri K. Schum.

Árbol de tamaño medio con fuertes aletones común en el bosque secundario. Común en las Guayanas y Venezuela, y se extiende hacia el sur en el Planalto brasileño y suroeste en la Amazonía. La madera se utilizada como leña para ahumar el caucho crudo y para cocinar. La especie tiene valor como un medicamento para las infecciones de los ojos, pero el informante no fué específico en su procesamiento.

paxahini, pamaxacaya (pama - tipo de árbol con frutos comestibles; $x a$ - en el interior; -coya - tiene el sentido de "después de haber hecho algo")

*Sloanea laurifolia (Benth.) Benth.

Árbol raro pequeño con raíces aéreas y aletones en el bosque secundario maduro. Venezuela hacia el sur en la Amazonía occidental. La madera es utilizada como leña para cocinar. 


\section{ERYTHROXYLACEAE}

pacachosti (paca - el tipo de punta de flecha para matar la caza mayor).

Erythroxyium squamatum Sw.

Arbusto poco común en bosques secundarios. Las Guayanas y Venezuela se extiende al sur de la selva de la costa atlántica de Brasil, el Planalto, y Amazonía. La madera se utilizada como leña para ahumar el caucho crudo..

\section{EUPHORBIACEAE}

bahuarexa (bahua - loro; rexaqui - nariz)

Acalypha arvensis Poepp.

Hierba de maleza en las afueras del pueblo. De amplia distribución en todo el neotrópico. Las hojas y frutos son aplastados entre los dedos y luego se los huele para ayudar a despejar un resfriado.

hucaxapo; No se utiliza; mamamaxë (mama - tía; maxe - tinte rojo) [4049, 4063]

*Aparisthmium cordatum (Juss.) Baill.

Árbol pequeño común en bosques secundarios. Común en todo el sur trópicos americanos. Decocción de las hojas se toma para aliviar el dolor de estómago.

jihui pohi (jihui - árbol; pohi - heces)

Chaetocarpus echinocarpus (Baill.) Ducke

Árbol pequeño común en bosque secundario. La madera se utilizada como leña para cocinar.

carama jihui (carama - goma; jihui - árbol)

*Hevea brasiliensis Muell. Arg.

Árbol grande común en bosque secundario maduro. Amazonía. El caucho crudo se obtiene de árboles silvestres, ahumado (curado y coagulado) se vende en la ciudad de Riberalta por dinero en efectivo o en intercambio por otros productos y alimentos. La venta de la goma cruda es la única fuente significativa de los ingresos en efectivo para los Chácobo. El caucho es también empleado por los propios Chácobo para fines tales como la fabricación de zapatos, sumergiendo los pies en la goma líquida, y solo se los retira cuando la goma se ha coagulado, teniéndose entonces un zapato de la forma exacta del pie.

piri

Mabea longifolia (Britt.) Pax \& Hoffm.

Arbusto común en bosques secundarios. Tiene valor en la curación de heridas en la piel, pero el informante no pudo ser más específico sobre que tipo de heridas.

atsa; variedades: atsa raoxo, canaqui (Castellano - yuca morada), nasisi, poiquinihua, raoxo (Castellano - yuca blanca), xëbi atsa, xoya atsa

Manihot esculenta Crantz

Arbusto muy común cultivado en los campos agrícolas. Nativa de los neotrópicos, cultivada a lo largo de zonas tropicales del mundo. Los siete variedades de yuca listadas 
arriba son todas dulces y actualmente cultivadas. El término Chácobo general de la yuca es atsa. Este cultivo representa más del $62 \%$ de la tierra dedicada a la agricultura y es el alimento más importante para el Chácobo. Los tubérculos se consumen como verdura, ya sea hervido, frito o al horno, o se convierten en una harina gruesa. A veces, son hervidas, desmenuzadas en esta misma agua, esta mezcla se fermenta con la adición de la saliva y el azúcar para obtener la bebida alcohólica conocida localmente en español como la chicha. Aunque la yuca todavía tuvo mucho papel en la alimentación de loa Chácobo en 2010, fue sembrada mucho menos, y la gran parte de las chacras fue dedicada a arroz.
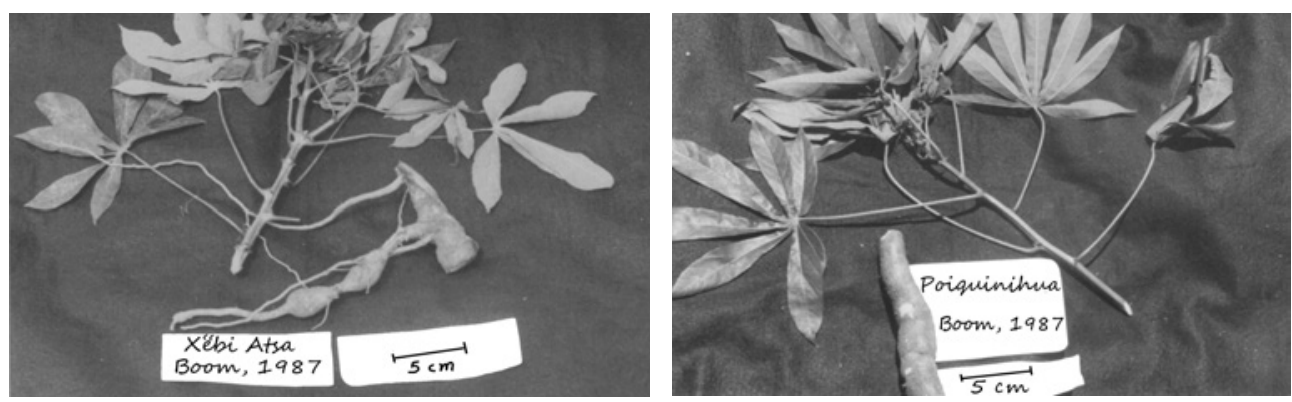

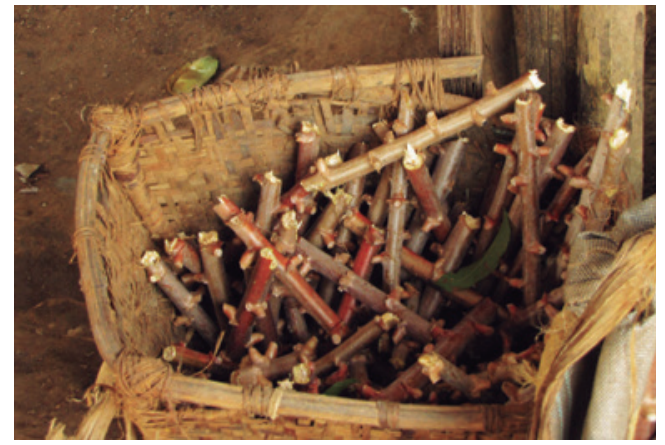

Paniagua, 2010: Yuca lista para sembrar

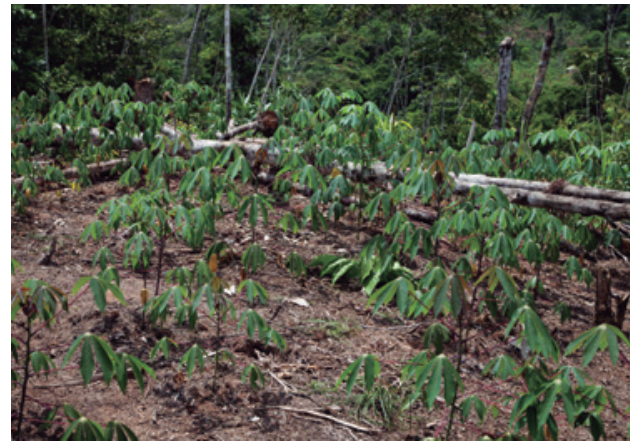

Bussmann, 2010: Chaco de Yuca

chimo (Castellano - bejuco blanco)

\section{Omphalea diandra $\mathrm{L}$.}

Bejuco poco común en los bosques secundarios maduros. Cortes de este bejuco blanco fueron usados antiguamente en las muñecas y los tobillos de los hombres como adornos. Las raspaduras de corteza se frota en una infección de la piel para reducir la hinchazón.

\section{rare}

Ricinus communis $\mathrm{L}$.

Arbusto común, cultivado en jardines y patios, y crece espontáneamente en claros y alrededor de las casas. A lo largo de zonas tropicales del mundo. Las hojas se hierven y se colocan sobre las partes adoloridas del cuerpo para aliviar el dolor.

\section{huicajoxa}

*Alchornea schomburgkii Klotzsch.

Pequeño árbol sin aletones raro en el bosque secundario maduro. Frutos comestibles. 


\section{FABACEAE}

mani (-juntos)

Apuleia molaris Spruce ex Benth.

Árbol de gran tamaño en las afueras del pueblo. Amazonía. Decocción de frutos y hojas se toma para aliviar la fiebre alta.

nishipara (nishi - bejuco; para - nivel); yoxajaxtahua, No se utiliza.

Bauhinia guianensis Aubl.

Bejuco común en las afueras del pueblo, en el matorral. Común en el norte de América del Sur. Utilizado con fines medicinales, pero el informante no pudo precisar su uso.

yoxajaxtahua (yoxa - mujer; jaxta-hua-mezclar, casar)

\section{Bauhinia straussiana Harms}

Bejuco en el bosque secundario. Restringida al suroeste de la Amazonía. No se utiliza. tetateneti (te - cuello; -la - por un período de tiempo; tene - sufrir; -ti - indica que la función de)

\section{*Clathrotropis sp.}

Árbol raro, de tamaño mediano sin aletones con un exudado pegajosa de color rojo como sangre, en el bosque secundario maduro. No se utiliza.

capëhitsa, neapo (Castellano - barbasco blanco)

Derris amazonica Killip

Bejuco frecuente en el bosque secundario. Veneno para los peces, menos efectiva que la axa.

axa (Castellano - verbascum)

Derris floribunda (Benth.) Ducke

Bejuco semi-cultivada en el bosque secundario. Raro en los alrededores de Alto Ivon. El veneno más potente y apreciada para los peces, también es el único veneno que se cultiva. En 2010 el uso de barbasco había sido abandonado ya desde tiempo.

jihui coshi (jihui - árbol; coshi - fuerte, durable.

*Diplotropis purpurea (Rich.) Amsh.

Muy común, árbol de tamaño mediano, sin aletones, en el bosque secundario maduro. Común en la Amazonía y Guayana. La madera se utiliza en la construcción de puentes.

shia, No se utiliza.

*Enterolobium schomburgkii Benth.

Árbol grande, sin aletones, poco frecuente. La madera dura se utiliza en la construcción de las casas.

comma (Castellano -paqu / paqo))

Hymenaea courbaril L.

Árbol común, resinoso en bosques secundarios, pastos antiguos, y también se cultiva en la aldea. A lo largo de neotrópicos. Frutos comestibles; también para hacer una bebida. 
La corteza se utiliza en la construcción de canoas de corteza, y una resina, llamada potasi en Chácobo, se extrae del tronco y se quema como una fuente de luz.

siritësaxenanë (siri - antes o después; tesa - cosechar)

Inga edulis Mart.

Árbol común en pastizales abandonados. Amazonía occidental. Pulpa dulce alrededor de las semillas se come.

\section{xënane}

Inga edulis Mart.

Árbol pequeño común, cultivada en los jardines de las casas. A lo largo de neotrópicos. Pulpa dulce alrededor de las semillas se come.

\section{shipi xënane}

Inga heterophylla Willd.

Árbol poco común en los bosques secundarios maduros. América Central y en toda América del Sur. Pulpa dulce alrededor de las semillas se come.

\section{xënane}

*Inga ruizana G. Don

Árbol pequeño poco frecuente sin aletones en el bosque secundario maduro. Amazonía occidental y el noroeste de América del Sur. Pulpa dulce alrededor de las semillas se come.

huaihuatia xënane (huai - chaco; -hua - grandes, muchos, pequeños; lia - excavar, cortar) (Castellano - pacay)

*Inga sp.

Árbol pequeño poco frecuente sin aletones en el bosque secundario maduro. Amazonía occidental y el noroeste de América del Sur. Pulpa dulce alrededor de las semillas se come.

rayoxënanë, rohoxenanë (who - tipo de mono)

Inga sp.

Recogido sólo como rebrote en el bosque secundario maduro. Pulpa dulce alrededor de las semillas se come.

jimiomaxenanë (jimi - sangre; oma - amigo íntimo)

Inga sp.

Recogido sólo como rebrote en el bosque secundario maduro. Pulpa dulce alrededor de las semillas se come.

isnepa (-espina), No se utiliza.

Machaerium multifoliolatum Ducke

Bejucos espinosas común en el bosque secundario. El sur de Guayana y la Amazonía, Tiene uso medicinal, pero el informante no podría ser más específico. 
isnëpa (-espina)

Poeppigia procera C. Presl

Árbol pequeño común en bosques secundarios. A lo largo de la región del neotrópico. La decocción de las hojas se toma para curar los resfriados.

capanahahuati (capa - ardilla; naha - nido; -hua - tiene la cualidad de; - indica que la función de)

*Pterocarpus sp.

Árbol raro de tamaño mediano con aletones simétricos, exudado pegajoso de color rojo como la sangre, en bosque secundario maduro. No se utiliza.

cano, cano jihui (jihui - árbol)

*Tachigali chrysaloides van der Werff

Árbol grande, común, con aletones en bosque secundario maduro. Amazonía y Guayana. La madera se utiliza como vigas del techo en las casas.

cano pehihua (pehi - pluma, hoja; -hua - grandes, pequeños, mucho)

*Tachigali setifera s. lat. (Benth.) Zarucchi \& Herend.

Árbol común de tamaño mediano, a menudo con aletones, en el bosque secundario maduro. La madera se utiliza como vigas del techo en las casas.

cano

*Tachigali guianensis (Benth.) Zarucchi \& Herend.

Árbol poco frecuente de tamaño mediano con aletones en el bosque secundario maduro. La madera se utiliza en la construcción de las casas.

samomaquexti (samoma - un insecto negro muy grande; queti - para obstruir el paso) xënane

Senna macrophylla var. macrophylla (Kunth) Irwin \& Barneby

Arbusto común en bosques secundarios. Común en el norte de América del Sur. Decocción de las hojas se toma para curar el reumatismo.

cashixopa jahuehua (cashi - murciélago, mamífero; jahue - cosa; -hua - grandes y pequeños, muchos)

Senna macrophylla var. gigantifolia (Britton \& Killip) H.S. Irwin \& Barneby

Arbusto común en bosque secundario. Común en el norte de América del Sur. No se utiliza.

samomaqueti (samoma - un insecto negro muy grande; queti - para obstruir el paso)

Senna obtusifolia (L.) Irwin \& Barneby

Arbusto maleza abundante en la aldea. A lo largo de la región del neotrópico. No se utiliza.

samomaqueti (samoma - un insecto negro muy grande; queti - para obstruir el paso)

Senna silvestris (Veil.) H.S. Irwin \& Barneby

Árbol pequeño común en campos agrícolas abandonados. Hierba muy extendida en América del Sur. No se utiliza. 
jihui pishi (jihui - árbol; pishi - rojo o costilla)

*Vataireopsis speciosa Ducke

Árbol común de tamaño mediano con aletones redondeados, en el bosque secundario maduro. La madera se utilizada como leña para ahumar caucho crudo.

birijore (biri - recto, limpio)

Vigna unguiculata (L.) Walp.

Enredadera, se cultiva en los campos agrícolas. A lo largo de zonas tropicales del mundo. Semillas se comen cuando están disponibles, pero no forman una parte importante de la dieta.

hoxa nihi (nihi - bosque)

Zornia latifolia Sm.

Hierba común en pastizales abandonados. Maleza muy extendida en América del Sur.

No se utiliza.

panaxe

Machaerium madeirense Pittier

Bejuco espinoso común en bosques secundarios maduros. No se utiliza.

nishi para (nishi - bejuco; para - nivel)

Fabaceae gen. indet.

Bejuco espinoso en bosques secundarios maduros. El exudado rojizo del tallo se mezcla con agua y se toma para curar la diarrea.

canapëhicobo (cana - estar del mismo tamaño; pehi - pluma, hoja; -cobo -peludo)

Fabaceae gen. indet.

Colectado como rebrote en el bosque secundario maduro. La madera se utiliza en la construcción de las casas.

\section{FLACOURTIACEAE}

ihuipama (ihui - eje, rayos; pama - al mismo tiempo, durante, mientras), yobiberoxoco (bëro - semilla; xoco - pequeño); chana jisicato (jisi - quemar; cato - lo que es)

*Casearia combaymensis Tul.

Árbol pequeño común en bosque secundario maduro. Frutos comestibles. La decocción de sabor amargo de las raspaduras de la corteza se toma para aliviar el dolor de estómago. La madera se utilizada como leña para ahumar caucho crudo.

\section{cascayobini}

*Casearia javitensis Kunth

Árbol raro pequeño con tronco estriado en el bosque secundario maduro. Común en el norte de América del Sur, se extiende al sur hacia el suroeste de la Amazonía. Una decocción de las virutas de corteza se toma para aliviar el dolor de estómago.

\section{moxoque}

\section{*Casearia mariquitensis Kunth}

Árbol pequeño común en bosques secundarios. Muy extendida en América del Sur 
tropical, que se extiende hacia el sur de Brasil. Decocción de las hojas y/o de los frutos se toma para curar el reumatismo.

chaxohuitaxo (chaxo - venado); comacoro (coma- dar la luz; coro - niebla); iscochai (isco tipo de pájaro)

*Lindackeria paludosa (Benth.) Gilg

Pequeño árbol muy común en bosques secundarios. Ampliamente distribuido en Amazonía. Las hojas tienen uso medicinal, pero el informante no pudo especificar su uso. La madera se usa como leña para ahumar caucho crudo. La madera se utiliza como horcones en la construcción de las casas.

\section{GESNERIACEAE}

chixopa-ati (chixopa - diarrea)

Codonanthe calcarata (Miq.) Hanst.

Arbusto epífito raro en bosques secundarios. Común en el norte de América del Sur. Una decocción de las hojas se toma para provocar el vómito y curar la diarrea.

jasini nihi (jasini - tipo de ave similar a una pava; nihi - bosque)

Gesneriaceae gen. indet.

Liana común en el bosque secundario en el borde del campo de yuca. No se utiliza.

\section{HELICONIACEAE}

tsacahuico (tsaca - herir con un objeto puntiagudo; huico - hueso de la pierna)

\section{Heliconia hirsuta L. f.}

Hierba común en bosques secundarios. De Panamá, al sur por el norte de América del Sur. Decocción de las hojas se toma para curar el reumatismo.

\section{HERNANDIACEAE}

nishichanona (nishi - bejuco); nisitsanona

Sparattanthelium burchellii Rusby

Arbusto o árbol pequeño en el bosque secundario maduro y en las afueras del pueblo. Con poca frecuencia colectada; conocida sólo de Bolivia. Remedio para la diarrea dolores de estomago y para provocar el vómito, las hojas son hervidas, y la decocción, una vez enfriado, se atoma. Esta es una de las plantas medicinales más empleadas.

nishitsanona (nishi - bejuco)

Sparattanthelium amazonicum Mart.

Bejuco o arbolito en el bosque secundario y alrededor de la aldea. Amazonía occidental. Las hojas y/o raspaduras de la corteza se hierven para obtener una decocción que se toma para aliviar el dolor de estómago.

\section{HIPPOCRATEACEAE}

nishi (-bejuco)

Anthodon decussatum R. \& P.

Bejuco común en bosques secundarios. Amazonía occidental. Se utiliza como un 
medicamento para curar problemas de estómago, pero el informante no pudo especificar el procedimiento.

rohonosebi (roho - tipo de mono); nexoquerimate (nexo - tortuga); omacahero (omaca tipo de pez; hero - semilla); quërimati

Cheiloclinium cognatum (Míers) A. C. Smith

Árbol pequeño común (a veces una liana?) En el bosque secundario. Panamá y todo el norte de América Latina. Frutos comestibles.

\section{quërimati}

Tontelea ovalifolia ssp. richardii (Peyr.) Goerts \& Mennega

Liana común en bosque secundarios cerca de los arroyos. Conocida sólo en la Amazonía occidental. Frutas de sabor dulce, comestibles.

\section{LAURACEAE}

comayobini (coma - dar la luz)

*Endlicheria macrophylla (Meissn.) Mez

Árbol raro, de tamaño mediano sin aletones en el bosque secundario maduro. El sur de Guayana venezolana y la Amazonía occidental. Las raspaduras de la corteza se hierven en agua y la decocción, una vez enfriado, se toman para aliviar el dolor de estómago.

vonishi (yo-todo; nishi - bejuco) (Castellano - hitauva)

*Mezilaurus itauba (Meissn.) Taub. ex Mez

Árbol común de tamaño medio del en el bosque secundario sin aletones avanzada. Las Guayanas hasta el centro y la parte occidental de a Amazonía. La madera se utiliza para horcones en las casas.

\section{yobini}

*Nectandra cuspidata Nees. \& Mart.

Árbol pequeño, raro en el bosque secundario. Raspaduras de corteza se hierven en agua y la decocción fría se toma para el dolor de estomago.

\section{cascara yobini}

\section{Ocotea longifoiia Kunth}

Colectado solo como rebrote en el bosque secundario maduro. Amazonía. Las raspaduras de corteza se hierven en agua y la decocción se enfría y toma para el dolor de estómago o dolor en el hígado.

apahuata (Castellano - aguacate)

Persea americana Mill.

Árbol pequeño, común, cultivado en los jardines de las casas. Neotrópico. Frutos comestibles. 


\section{LECYTHIDACEAE}

tapajihui (jihui - árbol) (Castellano - castaña)

Bertholletia excelsa $\mathrm{H}$. \& B.

Árbol grande común en toda la región, por lo general quedan en pie cuando los bosques son cortados. Amazonía. Los Chácobo recolectan los frutos de los que extraen las almedras (semillas). Las almendras de vez en cuando se venden en Riberalta por dinero en efectivo, pero por lo general se negocian con los misioneros por algunos productos y alimentos. Los almendras secas son una parte importante de la dieta y se consumen crudas o tostadas. Además, un aceite se extrae de los frutos que se utiliza para cocinar. Aceite de castaña es considerado por los Chácobo como superior en sabor al aceite de soja disponible en el mercado. En 2010, ninguno de los informantes menciono extraer el aceite de la castaña.

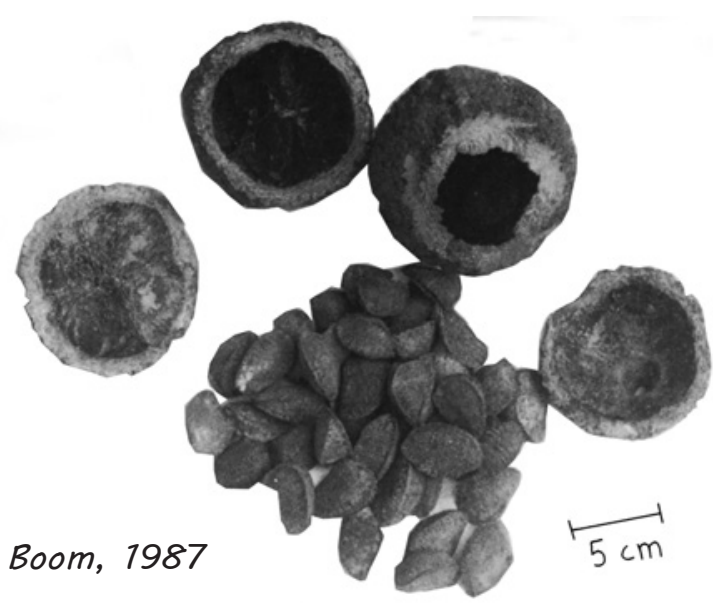

tashi

Couratari guianensis Aubl.

Árbol grande, raro en el bosque secundario maduro. Común en Guayana y Amazonas. Tiras de la corteza de tronco y ramas se entrelazan para formar los lados y el fondo de las cestas de carga.

rohonosobi (roho - tipo de mono)

*Eschweilera parvifolia (Aubl.) Miers

Pequeño árbol sin aletones, poco frecuente en el bosque secundario maduro. Amazonía. Frutos comestibles.

\section{MALPIGHIACEAE}

campe nihi (campe - plátano; nihi -bosque)

Banisieriopsis muricata (Cav.) Cuatr.

Arbusto común en pastizales abandonados. Común en América Central y América del Sur. No se utiliza. 
shoshapo (shapo - hacerse fuerte)

Byrsonima crispa Adr. Juss.

Árbol raro, de tamaño mediano sin aletones en el bosque secundario. Amazonía y la Mata Atlántica Brasileña. Frutos comestibles.

nishi coshi (nishi - bejuco; coshi - fuerte, durable)

Mascagnia benthamiana (Gr.) Anderson

Árbol poco común en los bosques secundarios maduros. Amazonía occidental. Las hojas se remojan en agua fría y luego se colocan sobre las partes del cuerpo para aliviar el dolor.

bero nihi (bero - semilla; nihi - bosque)

Tetrapterys crispa Adr. Juss.

Arbusto común en pastizales viejos. Panamá hacia el sur hasta las Guayanas y en la Amazonía occidental. Los frutos de sabor dulce se consume. El exudado extraído por la maceración de un trozo de la raíz se le pone en los ojos irritados para ayudar a la curación.

cano

Lophopterys occidentalis W.R. Anderson \& C. Cav. Davis.

Arbusto poco común en bosques secundarios. Tiene uso medicinal, pero el informante no pudo precisar su uso.

yahuatao (iyahua - cerdo salvaje; tao - masticar)

Tetrapteris crispa A. Juss.

Liana común en bosques secundarios. Una decocción de las hojas se toma para aliviar el dolor de estómago.

\section{MALVACEAE}

\section{huaxmene}

\section{Gossypium barbadense $\mathrm{L}$.}

Arbusto cultivado en los en los jardines alrededor de las casas. Zonas tropicales de todo el mundo. Fuente de hilo de algodón. En la actualidad, el algodón no se cultiva extensamente ya que la ropa y hamacas se pueden comprar en el mercado de Riberalta con dinero en efectivo obtenidos de la venta de caucho crudo.

\section{MARANTACEAE}

manicoro (mani - unir; coro - niebla); xeco joni (xeco - abrazar; joni - hombre)

Ischnosiphon arouma (Aubl.) Koern.

Hierba común en bosques secundarios. Las Indias Occidentales y todo el norte de América del Sur. manicoro. Decocción de las hojas se toma para curar la diarrea y causar vómitos. El tallo principal se utiliza para fabricar ejes de la flecha cuando la tahua (Gynerium sagittatum) no está disponible. 
xeco (-abrazar)

Ischnosiphon lasicoleus Schum. \& Loess.

Hierba trepadora común en el bosque secundario de la Amazonía occidental. Las tiras de la corteza son extraídas y se usan para tejer una "canasta" para el filtrado de chicha (bebida ligeramente alcohólica hecha de yuca fermentada).

\section{MELASTOMATACEAE}

\section{huicama}

*Bellucia aequiloba Pilger

Árbol raro, de tamaño mediano sin aletones en el bosque secundario maduro. Restringida al suroeste de la Amazonía. Frutos comestibles.

\section{huicama}

*Bellucia grossularioides (L.) Triana

Árbol común de tamaño medio sin aletones en el bosque secundario maduro. A lo largo de la región del neotrópico. Frutos comestibles.

bimi (bimi - fruta)

*Henriettea lasiostylis Pilger

Árbol pequeño común sin aletones en el bosque secundario maduro de la Amazonía, rara vez colectado. No se utiliza.

bimichëxe bimi- fruta; -chëx - curar); hocotsemo

*Miconia affinis DC.

Árbol pequeño común en bosques secundarios. Guayana y la Amazonía. Frutos comestibles. Decocción de las hojas se toma para aliviar el dolor de estómago.

bimichëxe (bimi - fruta; -chëx - curar)

Miconia boomii Wurdack

Árbol pequeño sin aletones, ocasionalmente en el bosque secundario maduro. Localidad del tipo. Frutos comestibles.

bimichëxe (bimi - fruta; -chëx - curar)

*Miconia holosericea (L.) DC.

Árbol pequeño común sin aletones en el bosque secundario maduro. América Central al sur de la Amazonía. Frutos comestibles.

bimichëxe (bimi - fruta; -chëx - curar)

*Miconia klugii Gleason

Árbol raro, de tamaño mediano sin aletones en el bosque secundario maduro. La Amazonía occidental, rara vez colectado. Frutos comestibles.

bimichëxe (bimi - fruta; -chëx - curar)

*Miconia longispicata Triana

Árbol pequeño común sin aletones en el bosque secundario maduro. El norte de Sudamérica, se concentró en la Amazonía. Frutos comestibles. 
bimichëxe (bimi - fruta; -chëx - curar)

Miconia matthaei Naud.

Colectado sólo como rebrote en el bosque secundario maduro. América Central y en toda América del Sur. No se utiliza.

bimichëxe xoco (bimi - fruta; -chëx - curar; xoco - pequeño)

Miconia minutiflora (Bonpl.) DC.

Árbol pequeño común en bosques secundarios. América Central y en toda América del Sur. Los frutos maduros proporcionan un tinte azul que se utiliza para pintar el cuerpo.

bimichëxe (bimi - fruta; -chëx - curar); jihuijoxo (jihui - árbol)

*Miconia myriantha Benth.

Árbol pequeño, raro, con aletones redondeados en el bosque secundario maduro. Norte de Sudamérica. No se utiliza.

\section{hocotsemo}

Miconia nervosa (Smith) Triana

Arbusto común en bosques secundarios. A lo largo de América Central y Sudamérica tropical. Una decocción de las hojas se toma para curar problemas del estómago.

bimichëxe (bimi - fruta; - chëx - curar)

*Miconia poeppigii Triana

Árbol raro de tamaño mediano con aletones en el bosque secundario maduro. América Central y todo el norte de América del Sur. Frutos comestibles.

bimichëxe (bimi - fruta; -chex - curar); huicama

* Miconia punctata (Desv.) Don ex DC.

Árbol pequeño o mediano, común de tamaño sin aletones, en bosque secundario. América Central y Sudamérica tropical Frutos comestibles.

jihui charishi (jihui - árbol)

*Miconia pyrifollia Naud.

Pequeño árbol sin aletones raro en el bosque secundario maduro. Amazonía brasileña a la costa de Planalto y el bosque de la costa atlántica. No se utiliza.

jahuarara; bimichëxe (bimi - fruta; -chëx - curar); shoxapo

*Miconia splendens (Sw.) Griseb.

Árbol pequeño común en bosques secundarios. A lo largo de la región del neotrópico. Frutos comestibles. La especie tiene uso medicinal, pero el informante no pudo ser más específico.

xaba huicama (xaba - sabana, el clima); hocotsemo; jihui moca (jihui - árbol) Miconia tomentosa (Rich.) Don ex DC.

Una decocción de las hojas se toma para aliviar dolores en el pecho. Una decocción de las raspaduras de la corteza es tomada por las mujeres como método anticonceptivo. 
pabojoni (joni - hombre)

Tococa guianensis Aubl.

Arbusto ocasional en el bosque secundario. América Central y el norte de América del Sur. Los frutos semi-dulces se comen. La especie tiene uso medicinal, pero el informante no pudo ser más específico.

bimichëxe (bimi- fruta; -chex - curar)

Tococa subciliata (DC.) Triana

Arbusto ocasional en el bosque secundario. Guayana y la Amazonía. Una decocción de las hojas se toma para aliviar dolores en el pecho.

\section{MELIACEAE}

tetemetsisi (teteca - grande; mëtsisi - garras)

Guarea macrophylla Vahl subsp. tuberculata (Veil.) Pennington

Árbol pequeño común en bosques secundarios. Principalmente de los bosques de Planalto y la costa atlántica de Brasil, pero discontinua en el oeste de la Amazonía (Perú y Bolivia). Decocción de las hojas y de los frutos se toma para curar problemas del hígado.

\section{canohuatsa}

Meliaceae gen. indet.

Colectado sólo como rebrote en el bosque secundario maduro. La madera utilizada en la construcción de las casas.

\section{MENISPERMACEAE}

cashixopame (cashi - murciélago, mamífero; -xo - pelar -pa - medio, pequeño; -me - una reflexiva)

Cissampeios andromorpha DC.

Bejuco en el bosque secundario. Panamá al sur y a lo largo de América del Sur tropical. Las hojas se mastican para aliviar el dolor de muelas.

pexcanishi (nishi - bejuco)

Cissampelos glaberrima St. Hil.

Bejuco en pastizales abandonados. Amazonía occidental y Planalto brasileño. No se utiliza.

\section{MONIMIACEAE}

shishohuitsa (shisho - visitar, pasar por)

Siparuna krukovii A.C. Sm.

Arbusto muy común en bosques secundarios. Común en América del Sur. Dicen que tiene uso medicinal, pero el informante no pudo ser más específico. 


\section{MORACEAE}

teco

*Brosimum acutifolium Huber subsp. obovatum (Ducke) C. C. Berg

Árboles de tamaño medio con fuertes aletones redondeados, común en el bosque secundario maduro. Parte superior de la cuenca amazónica y se extiende al noreste de Guyana. Frutos comestibles.

xetoitsa (xeto - cera; Usa - cedro, el olor humano)

Moraceae indet.

No se utiliza.

teco

Perebea angustifolia (Poepp. \& Endl.) C.C. Berg

Frutos comestibles.

bachirao (bachi - huevo)

*Brosimum guianense (Aubl.) Huber

Árbol poco frecuente de tamaño mediano con aletones redondeadas, empinadas, en el bosque secundario maduro. Distribución discontinua desde el sur de México a Minas Gerais, Brasil, pero la principal zona comprende la Amazonía y Guayana. La madera es utilizada como leña para cocinar.

\section{teco; xanate}

*Brosimum lactescens (S. Moore) C. C. Berg

Árbol muy frecuente de tamaño mediano con fuerte aletones redondeados en el bosque secundario maduro. Extendido desde México hacia el sur hasta Santa Catarina, Brasil. Frutos comestibles.

pío (Castellano - bibosi)

*Brosimum utile (Kunth) Pittier subsp. ovatifolium (Ducke) C. C. Berg

Árbol muy frecuente de tamaño mediano, a veces con empinadas aletones en el bosque secundario maduro. Conocido de la cuenca del Amazonas y la Guayana Francesa. Segmentos del tronco se utiliza como una plataforma de la cama. La corteza interna es una fuente de tejidos de corteza vegetal.

quëototi (quëo - flauta, llame al gallo)

Chlorophora tinctoria (L.) Gaud.

Arbusto espinoso en pastizales abandonados. Común en el neotrópico. El exudado de las hojas machacadas se aplica a los dientes de dolor para aliviar el dolor.

jihui bepia (jihui - árbol)

*Clarisia ilicifolia (Spring.) Lanj. \& Rossb.

Árbol pequeño común en los viejos bosques secundarios. Común en América del Sur. No se utiliza. 
cashipiti (cashi- murciélago, mamífero; pi - costilla, tiras de madera; -ti - indica una acción futura) (Castellano - bibosi)

*Ficus nymphaefolia P. Miller

Árbol raro de gran tamaño con aletones anchas en el bosque secundario maduro. Común en América Central y Sudamérica tropical. Segmentos del tronco se utilizan como plataformas de cama. La corteza interna es una fuente de tejidos de corteza vegetal.

moro; yomëno (yomënona - un tipo de brujería) (Castellano - bibosi)

Ficus obtusifolia Kunth

Árbol poco común en los bosques secundarios maduros. Venezuela hacia el sur en la Amazonía. La corteza interior es la fuente de una tela de color naranja rojizo que se utiliza en la fabricación de prendas de vestir de los hombres y tiras anchas para cargar las cestas. El látex se utiliza para la aplicación sobre las heridas que dejan las larvas de boro (moscardón) que perforan la piel, con el fin de asfixiarlas para que puedan ser expulsadas.

xoa (varios significados: picor, grasa, el Genesuaya - un río al oeste de Alto Ivon donde antiguamente hubieron asentamientos Chácobo)

Ficus radula Willd.

Árbol en las afueras del pueblo. Venezuela y el sur de Guayana en la Amazonía. Corteza interna es una fuente de tela blanca de corteza.

xohua (probablemente una variante de xoa); yomëno (yomënona - un tipo de brujería) Ficus wuiana Rossberg

Árbol pequeño cultivado en el pueblo y que se producen en los alrededores de bosque secundario. Amazonía occidental. Corteza interna es la fuente de una especie de tela blanca.

canapa (un nombre propio en Chácobo, pero también significa "relámpago") (Castellano palo de perro)

*Helicostylis tomentosa (P. \& E.) Rusby

Árbol pequeño o mediano sin aletones en el bosque secundario maduro. El norte de Sudamérica al este de los Andes y en los bosques de la costa atlántica de Brasil, al norte de Río de Janeiro. Frutos comestibles.

coyo moro (coyo - un tipo de hormiga pequeña, vicioso) (Castellano - bibosi) [5053]; camamëquënë (cama - tigre; me-quënë - mano) (Castellano - huevo de perro) [5091]

Perebea mollis (Poepp. \& Endl.) Huber.

Árbol poco común en los bosques secundarios maduros. De la Amazonía a la Guayana Francesa y el noroeste a través de Colombia y el norte de Panamá. Corteza interna es una fuente de tejidos de corteza vegetal. Frutos comestibles.

camamëquënë (cama - tigre; me-quënë - mano)

*Perebea mollis (P. \& E.) Huber

Árbol poco frecuente de tamaño mediano, sin aletones, en el bosque secundario maduro. Más común en la cuenca del Amazonas, en menor medida en las Guayanas. Frutos comestibles. 
pama (Castellano - nui); pamaxaca (xaca - cascara)

*Pseudolmedia laevis (R. \& P.) Macbr.

Árbol de tamaño mediano muy frecuente en el bosque secundario maduro; una de las especies más frecuentes en torno a Alto Ivon. El norte de Sudamérica al este de los Andes. Frutos rojos, comestibles,y de sabor dulce.

pamaxacaya (xaca - corteza; -ya - en este momento); pamaxoco

* Pseudolmedia macrophylla Tree.

Árbol de tamaño mediano muy frecuente en el bosque secundario maduro. Cuenca del Amazonas. Frutos comestibles. El exudado de color crema del tronco se aplica a la piel para aliviar el dolor del reumatismo.

xoquëshëquërë (xoque - tucán; sheque - para extraer un pedazo de algo; re - la emoción de la tristeza)

Sorocea guileminiana Gaudich.

Arbolito en bosque secundario. Amazonía y Planalto brasileño. Dicen que tiene uso medicinal, pero el informante no pudo ser más específicos Frutos sirven de alimento a los tucanes.

xanajoni (joni - hombre); xanajoxo (joxo - blanco)

Sorocea muriculata Miq.

Arbusto en el bosque secundario. El sur de Guayana y en toda la Amazonía. Los frutos de sabor dulce son comidos por la gente y también por los tucanes.

\section{MUSACEAE}

campe (nombre general para el banano, las variedades figuran a continuación); shica carape (Castellano - guineo mota-cusilló), pija tetoya mëxü (Castellano - bellaco), naraxa carape (Castellano - guineo morado), macho (Castellano - guineo macho), sano.

\section{Musa x paradisiaca $\mathrm{L}$.}

Hierba común grande cultivada en los campos agrícolas. Introducido desde el sureste de Asia. Ocho variedades de plátanos en la actualidad se cultivan en la zona del Alto Ivón. Los frutos maduros se comen crudos. Aproximadamente el $12 \%$ de la tierra cultivada por ellos se dedica a los plátanos.

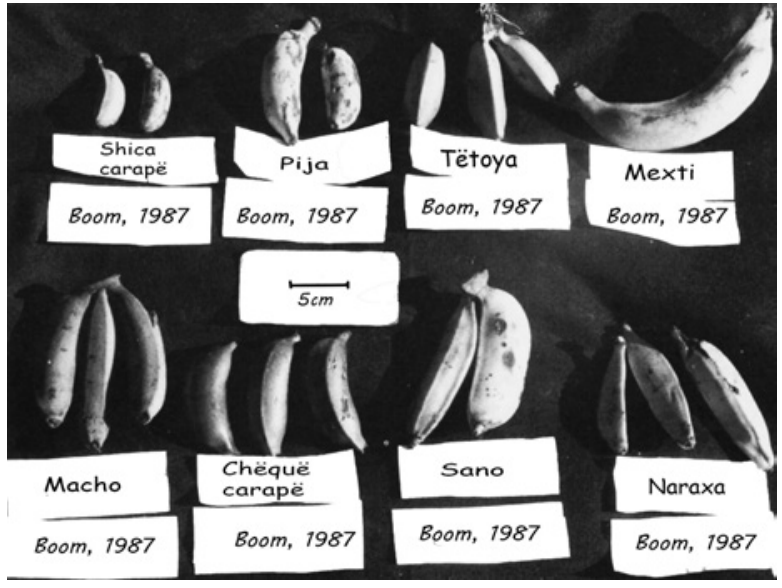




\section{MYRISTICACEAE}

cotibi; xahuisi

*Onychopetalum periquino (Rusby) D.M. Johnson \& N.A. Murray sp.

Árbol común pequeño en sin aletones, en bosque secundario maduro. Frutos comestibles, dulce y grasoso. Decocción de las hojas y los frutos se toma para curar el reumatismo.

bita

*Iryanthera laevis Markgr.

Árbol pequeño común sin aletones, en el bosque secundario maduro. Amazonía. Decocción de las hojas se toma para provocar el vómito.

bita; mëquenebila (mëquëne - mano)

*Iryanthera juruensis Warb.

Pequeño árbol sin aletones, muy común en el bosque secundario maduro, una de las especies más frecuentes en las cercanías de Alto Ivón. Común en la Amazonía y Guayana. Decocción de las hojas se toma para provocar el vómito. La madera se utilizada como leña para ahumar caucho crudo y cocinar.

bita

*Iryanthera tessmannii Markgr.

Árbol pequeño común sin aletones en el bosque secundario maduro. Amazonía occidental, disjunto en Surinam. Decocción de las hojas se toma para curar la diarrea. La madera se utilizada como leña para ahumar caucho crudo.

jenetahuate (jene - agua; tahua - Gynerium sagittatum; te - cuello); No se utiliza. tahuate (tahua - Gynerium sagittatum; te - cuello)

*Virola duckei A. C. Smith

Pequeño árbol poco frecuente, sin aletones, en el bosque secundario maduro. Restringida al suroeste de la Amazonía. Las aves son atraídas por los frutos (arilo de color rosa alrededor de la semilla), los cazadores esperan bajo el árbol para disparar a las aves.

tahuaie (tahua - Gynerium sagittatum; te - cuello)

*Virola flexuosa A. C. Smith

Árbol grande sin aletones, común en el bosque secundario maduro. Amazonía occidental. Las aves son atraídas por los frutos, los cazadores esperan bajo el árbol para disparar a los pájaros.

tahuarëtoshi (tahua - Gynerium sagittatum; retoxi - restringido)

*Virola sebifera Aubl.

Árbol de tamaño medio, sin aletones raro en el bosque secundario maduro. Muy extendida en América del Sur. No se utiliza. 


\section{MYRTACEAE}

bisatamane (tamane - para dar un paso); jënëomacabëro (jënë - agua; omaca - un tipo de pez; hero - semilla)

\section{*Eugenia sp.}

Arbusto o pequeño árbol común en bosques secundarios maduros o cultivadas en los en los jardines alrededor de las casas. Decocción de hojas y/o de la fruta se toma para curar el reumatismo. Los frutos de sabor dulce se consumen.

jihui pohi (jihui - árbol; pohi - heces)

Myrcia mollis (Kunth) DC.

Árbol común, cultivada en los en los jardines alrededor de las casas. Los frutos semidulces se comen. La savia de la raíz se utiliza para aliviar el dolor de muelas.

pin

Myrcia paivae O. Berg

Árbol poco común en la pequeña secundaria. Se usa para curar heridas en la piel, peroel informante no especificó el procedimiento.

jihui bara (jihui - árbol; bara - reflexión)

Myrciaria floribunda (H. West ex Willd.) O. Berg

Arbusto común en pastizales abandonados. Una decocción de las raspaduras de la corteza se toma para provocar el vómito, y para curar el dolor de estómago, problemas hepáticos y diarrea.

chuara-catoco (catoco - riñón)

Psidium guajava L.

Arbusto muy común, cultivada en los en los jardines alrededor de las casas. Ampliamente distribuido en el neotrópico. Las hojas semi-dulces se comen como una ensalada. Los frutos se comen. Una decocción de las hojas se toma para curar la diarrea, se toma tres veces al día hasta que el problema se cura.

omacabëro (omaca - tipo de pez; bëro - semilla)

*Myrtaceae gen. indet.

Árboles raros sin aletones en el bosque secundario maduro. Frutos comestibles, de sabor dulce.

poatë

*Myrtaceae gen. indet.

Árbol poco frecuente con tamaño mediano en el bosque secundario maduro. No se utiliza.

\section{NYCTAGINACEAE}

Neea macrophylla Poepp. \& Endl.

bimichexei (bimi - fruta; chëx - curar)

Neea ovalifolia Spruce ex J. A. Schmidt

Árbol pequeño, raro en el bosque secundario. Común en Guayana, Amazonas, y la costa atlántica bosques de Brasil. Decocción de las frutas y hojas se toma para curar el reumatismo. 
shishoitsa (shisho - visitar, pasar por; itsa - cedro)

Nyctaginaceae gen. indet.

Registrado sólo como arbolito joven en el bosque secundario maduro. Remedio para la fiebre alta o picaduras de insectos; las hojas son hervidas y la decocción, una vez enfriada, se toma para la fiebre o se aplica a las picaduras.

\section{OCHNACEAE}

xahuisi

Ouratea macrobotrys Rusby

Arbusto infrecuente en las afueras del pueblo. Amazonía de Bolivia. Los frutos semidulces se comen. Una decocción de las hojas se toma para curar problemas de hígado.

\section{OLACACEAE}

iscocharisi (isco - tipo de ave; cha - en el centro de; risisi - soga)

Minquartia guianensis Aubl.

La madera es utilizada como leña para ahumar caucho crudo.

\section{ORCHIDACEAE}

cápete jiña (cápete- caimán; jini - pene)

Galeandra boweri Lindl.

Epifita en los bosques secundarios maduros. No se utiliza.

ahuara piti (ahitara - tapir)

Habenaria pratensis Rchb. f.

Hierba terrestre en pastizal abandonado. No se utiliza.

cashimetsisi (cashi - murciélago, mamífero; mëtsisi - garras)

Psygmorchis pusilla (L.) Dodson \& Dressler

Epifitas en ramas de un árbol de limón en un jardín. Común en el neotrópico. No se utiliza.

xoni

Vanilla odorata Presl

Epifita en los bosques secundarios maduros. Amazonía occidental. No se utiliza.

ahuaramacha (ahuara - tapir; macha-diente)

Orchidaceae gen. indet.

Epifita en los bosques secundarios maduros. No se utiliza.

\section{PASSIFLORACEAE}

\section{iscoro}

Passiflora coccinea Aubl.

Bejuco común, maleza en los campos de cultivo y pastos viejos. Común en la Amazonía y Guayana. Frutos comestibles. 


\section{PIPERACEAE}

rononihi (rono - serpiente; nihi - bosque)

Peperomia pellucida (L.) Kunth

Hierba suculenta en el bosque secundario. Trópicos en todo el mundo. Las hojas se machacan en agua fría y la cataplasma así formado se coloca sobre una mordedura de serpiente para ayudar a la curación.

\section{rarama; rarasa}

Piper aleyreanum C. DC.

Arbusto común en bosques secundarios. Conocida sólo en la Amazonía occidental, rara vez colectado. Jugo de las hojas machacadas o de los tallos se aplica a las heridas, como cortes de machete, para ayudar a la curación. Las hojas son también masticadas para aliviar el dolor de muelas.

\section{rarasa}

\section{Piper arboreum Aubl. ssp. arboreum}

Arbusto común en bosques secundarios maduros. A lo largo de la región del neotrópico. Las hojas se muelen y la savia resultante se pone en los cortes para ayudar a la curación.

rarasa; rarahuëtsa (huëtsa - otro)

Piper bartlingianum (Miq.) C. DC.

Arbusto común en bosques secundarios. Amazonía. Exudado de tallos o las hojas muelen se aplican a las heridas para ayudar a la curación.

xëquijahehua (xëqui - maíz; jahehua - algo que es más grande que...); rarasa Piper callosum Ruiz \& Pavón

Hierba rizomatosa en el bosque secundario. Muy extendida en América del Sur tropical, pero principalmente de la Amazonía occidental. Decocción de las hojas y los frutos se toma para aliviar la fiebre. Exudado se aplica a los dientes para aliviar el dolor.

\section{rarasa}

Piper chumboense Yunker

Arbusto en el bosque secundario. Amazonía, raramente colectado. El exudado de las hojas o tallos machucados se aplica a las heridas en la piel para ayudar a la cicatrización.

rarama; rarasa; raramamishni (mishni - pequeño)

Piper consanguineum Kunth

Hierba común en bosques secundarios. Guayana y la Amazonía. Exudado de los tallos se le pone las heridas para ayudar a la curación.

\section{nibosa}

Piper darienense C. DC.

Arbusto frecuente, menos de $1 \mathrm{~m}$ de altura, en el bosque secundario. Panamá hacia el sur hasta Bolivia amazónica. Se utiliza como un medicamento para el dolor de muelas. El exudado del tallo se aplica directamente a las muelas, o mejor aún, un trozo de la raíz se mastica, y una sensación de entumecimiento muy fuerte se siente en aprox. 30 
segundos.

rarasa

Piper hostmannianum (Miq.) C. DC.

Arbusto común en bosques secundarios. Muy extendida en América del Sur. Exudado de tallos o las hojas machacadas se aplica directamente a las heridas para ayudar a la curación.

rarasa

Piper multiplinervium C. DC.

Arbusto en el bosque secundario. El noroeste de Colombia al sur de la Amazonía. El exudado se aplica a los dientes cuando se tiene dolor.

\section{rarama}

Piper nigrispicum C. DC.

Arbusto en el bosque secundario. Amazonía. El exudado se le pone las heridas para ayudar a la curación.

\section{Sin nombre Chácobo}

\section{Piper obliquum Ruiz \& Pavón}

Arbusto en bosques secundarios maduros. Muy extendida en América del Sur. No se utiliza.

\section{POACEAE}

chaxojini (chaxoa - venado)

Andropogon bicornis L.

Hierba común creciendo en manchones en las faldas de la aldea en la zona inundada durante 2-3 meses al año. Común en el neotrópico. Las hojas jóvenes se utilizan como material para tejer cestas.

tahua (Castellano - cuchio)

Gynerium sagittatum (Aubl.) Beauv.

Hierba con tallos de $4 \mathrm{~m}$ de altura, que no se encuentran cerca de Alto Ivón, pero que se cultiva en todo el pueblo de Núcleo. Común en el neotrópico. Es la planta principal utilizada para las flechas, sus tallos huecos son utilizado como ejes de flecha, y solamente se cultiva para este propósito.

\section{bisto}

Lasiacis ligulata Hitchc. \& Chase

Tallos leñosos agrupados hasta a $4 \mathrm{~m}$ de largo, en los campos agrícolas abandonados. A lo largo de los neotrópicos. Tallos utilizadas para hacer flautas.

\section{bisto}

Olyra latifolia L.

Hierba en el bosque secundario. Muy común en el neotrópico. Tallos utilizados para hacer flautas. 
bisto

Paradiolyra micrantha (Kunth) Davidse \& Zuloaga

Hierba con tallos de hasta $2 \mathrm{~m}$ de altura, en el bosque secundario. Muy común en América del Sur. Las hojas son masticadas para aliviar el dolor de muelas.

\section{arosa (Castellano - arroz cruzeño)}

\section{Oryza sativa L.}

Hierba cultivada, introducida. Distribución en todo el mundo, originalmente del sudeste de Asia. El grano se seca y se cocida. El arroz es una de las tres plantas alimenticias más importantes cultivadas. Aproximadamente el $7 \%$ de la tierra cultivada se dedica este producto.

\section{bisto}

Panicum stoloniferum Poir.

Hierbas, enrraiza en nudos, en bosque secundario y a lo largo de orillas de riachuelos en la sombra. A lo largo de la región del neotrópico. Decocción de las hojas se toma para curar el dolor de cabeza.

bisto

Pariana sp.

Hierba en el bosque secundario maduro. Tallos utilizados para hacer flautas. jene arosa (jenë - agua; arosa - arroz); No se utiliza; nihibimi (nihi - bosque; bimi - fruta)

\section{Pharus latifolius L.}

Hierba en el bosque secundario maduro. A lo largo de la región del neotrópico. Decocción de las hojas se toma para curar el dolor de cabeza.

\section{shita (Castellano - caña de azúcar)}

\section{Saccharum officinarum $\mathrm{L}$.}

Hierba cultivada en los jardines alrededor de las casas. Cultiva en todo el neotrópico. Domesticado en Nueva Guinea. Tallos de caña de azúcar son masticadas como un bocadillo. El jugo que se exprime de los tallos se añade a las bebidas para endulzar. La caña de azúcar nunca fue observada en los campos agrícolas, solo se las encuentra en los pequeños jardines cerca de las casas.

\section{huasimapoa; carnario jachocoti}

Streptogyna americana C. E. Hubbard

Hierba, en bosque secundario maduro. Principalmente en la Amazonía. Las hojas se usan para tejer cestas, cuando no hay otro material disponible. Decocción de las hojas se utiliza para bañar a los niños que son débiles.

xëqui (Castellano - maíz)

\section{Zea mays L.}

Hierba cultivada en los campos agrícolas. Cosmopolita, originalmente domesticada en México. El grano se seca y se muele obteniendo en una harina gruesa, por lo general se la almacena en mazorcas. Para comerla se hierven las mazorcas en agua hasta que estén suaves y se consume como alimento, o también se las preparar fermentándolas molidas con agua, para producir una bebida alcohólica, la chica. El maíz es uno de los 
tres cultivos más importantes. Aproximadamente el $18 \%$ de la tierra cultivada en la comunidad se dedica al maíz.

\section{POTALIACEAE}

ahuaramacha (ahuara - tapir; macha - diente)

Potalia resinifera Mart. ssp. resinifera

Arbusto común en bosques secundarios maduros. Común en América del Sur. Frutos comestibles.

\section{POLYGALACEAE}

nihijoa (nihi - bosque; joa - flor)

Polygala acuminata Willd.

Hierba poco frecuente al lado de senderos en el bosque secundario. Amazonía occidental. Decocción de las hojas se toma para aliviar los problemas estomacales.

\section{ROSACEAE}

jihui xoco (jihui - árbol; xoco - pequeño)

Prunus amplifolia Pilger

Árbol pequeño, raro en el bosque secundario maduro. Suroeste de la Amazonía. No se utiliza.

\section{RUBIACEAE}

cat osho (cai - madre; osho - frágil y delgado); nihipëhi (nihi - bosque; pëhi - pluma, hoja); yonishi (yo - todo; nishi - bejuco)

*Amaioua guianensis Aubl.

Árbol pequeño común sin aletones en el bosque secundario maduro. Común en la Amazonía y Guayana. La madera se utilizada como leña para cocinar. Decocción de las hojas se toma para aliviar el dolor de estómago. Troncos se utilizan en la construcción de las casas.

jasini nihi (jasi - entrar; - mucho tiempo ha pasado desde que...; nihi - bosque) bimitsexejoni (bimi - fruta; tseo - entrar al boque; -xe - acción futura; joni - hombre) Bertiera guianensis Aubl.

Arbusto común en bosques secundarios. Común en América Central y Sudamérica tropical. Decocción de las hojas se toma para aliviar los problemas estomacales.

yoshapo (yo - todo; shapo - fuerte); baiahua jihui (bata - miel; hua- grande, pequeño, mucho; jihui - árbol)

*Calycophyllum megistocaulum (K. Krause) C.M. Taylor

Árbol pequeño con tallo suave y corteza de color marrón verdoso, en el bosque secundario maduro. Restringido al suroeste de la Amazonía. Frutos comestibles. Las raspaduras de corteza se secan al sol, se pulverizan, y se mezcla con un poco de agua para formar una pasta que se aplica a las heridas infectadas para ayudar a la curación. 
batahua (bata - miel; hua - grande, pequeño, mucho)

* Capirona decorticans Spruce

Árbol pequeño frecuente con aletones y suave corteza de color marrón verdoso en el bosque secundario maduro. Principalmente de la Amazonía occidental, pero se extiende al norte hacia el sur de Guayana. Una decocción de la raspadura de la corteza se aplicada a las infecciones de la piel para ayudar a sanar. Una decocción de las hojas se utiliza para curar la mordedura de serpiente, esta se toma y se aplica como cataplasma sobre la propia mordedura.

nishiraoxo (nishi - bejuco; raoxo - variedad de yuca)

Courarea hexandra (Jacq.) K. Schum.

Arbusto o liana común en bosques secundarios. Común en todo el neotrópico. Exudado del tallo se mezcla con agua y se toma para curar la diarrea.

bimichëxe (bimi- fruta; chex - curar)

Faramea capillipes Muell. Arg.

Arbusto común en bosques secundarios. Muy común en América del Sur. Tiene uso medicinal, pero el informante no pudo ser más específico. Un tinte azul que se obtiene de los frutos maduros que se utiliza en la pintura corporal.

huicama; maiyochi (mai - suelo, tierra; yochi - pimiento); bimichëxe (bimi - fruta; chex curar); No se utiliza.

Faramea corymbosa Aubl.

Arbusto común en los bosques secundarios. Principalmente de la Amazonía. Frutos comestibles. Las hojas se colocan sobre las heridas en la piel infectada con el fin de reducir la hinchazón.

none (Castellano - bi)

Genipa americana L.

Árbol grande raro en el bosque secundario. Común en el neotrópico. Tinte negro que se extrae de los frutos inmaduros y se utiliza para pintar el cuerpo. Los frutos maduros son comestibles.

maiyochi (mai - suelo, tierra; yochi - pimiento)

Geophila cordifolia Miq.

Hierba rastrera común en bosques secundarios maduros. Guayana y Amazonía. Frutos comestibles.

mai nishi (mai - suelo, tierra; nishi - bejuco)

Geophila repens (L.) I. M. Johnston

Hierba rastrera común en bosques secundarios maduros. Común en el neotrópico. No se utiliza.

ahuaramacha (ahuara - tapir; macha - diente)

Palicourea brachyloba (Muell. Arg.) B. M. Boom

Árbol pequeño raro en el bosque secundario. Amazonía occidental, raramente colectado (Boom, 1985c). Hojas masticadas son utilizadas para aliviar el dolor de muelas. 


\section{xahuisi}

Palicourea grandiflora (Willd ex Roem. \& Schult.) Standl.

Arbusto común en bosques secundarios. Guayana y la Amazonía. Una decocción de las hojas se toma para aliviar la fiebre.

ahuaramacha (ahuara - tapir; macha - diente); bimichëxe (bimi - fruta; chex - curar); No se utiliza.

*Palicourea grandifolia (Willd. ex R. \& P.) Standl.

Árbol pequeño común en bosques secundarios. Guayana y la Amazonía. Hojas y/o tallos masticadas son reportados como útiles aliviando el dolor de muelas.

bisatamane (bi - colectar tamane - dar un paso)

Palicourea quadrifolia (Rudge) DC.

Árbol pequeño poco común en bosques secundarios. Amazonía. Parece que tienen uso medicinal, pero el informante no pudo ser más específico.

yotabi (yo - todo)

Psychotria deflexa DC.

Arbusto común en bosques secundarios. Común en el neotrópico. Las frutas maduras proporcionan un tinte azul que se utiliza para pintar el cuerpo.

bimichëxe (bimi - fruta; chex - curar); bohuehomohuati (bohue - tipo de pez:-hua- grande, pequeño, mucho; -ft - acción futura o la ubicación de un objeto)

Psychotria iodotricha Muell. Arg.

Arbusto muy común en bosques secundarios. Guayana y la Amazonía. No se utiliza

\section{Sin nombre Chácobo}

Psychotria sphaerocephala Muell. Arg.

No se utiliza.

ahuaranihi (ahitara - tapir; nihi - bosque)

Psychotria lupulina Benth. f.

Arbusto frecuente en el bosque secundario. Amazonía y Guayana. Una decocción de las hojas se toma como una cura para la diarrea y para provocar el vómito.

bimichëxe (bimi- fruta; chex - curar); taxabahueti (ta - por un tiempo, después; xa - en el interior; bahue - limpiar; ti - tiempo futuro o localización)

Psychotria prunifolia (Kunth) Steyerm.

Arbusto común en bosques secundarios. Principalmente en el oeste de la Amazonía y el Planalto brasileño. Una decocción de las hojas se toma para aliviar la fiebre. Las hojas son hervidas y se colocan sobre una herida infectada, dicen que ayuda a expulsar la pus mas rápidamente.

bimichëxe (bimi - fruta; chex - curar)

Psychotria poeppigiana Muell. Arg.

Arbusto común en el bosque secundario, a través del Neotrópico. Exudado del tallo se aplica directamente a los ojos para curar la infección. 
huaranihi (nihi - bosque); jotabi; No se utiliza.

Psychotria racemosa (Aubl.) Willd.

Arbusto muy común en bosques secundarios. América Central y Sudamérica tropical. Con uso medicinal, pero el informante no pudo ser más específico.

xohuaxëni (xëni - muy)

Psychotria trichophora Muell. Arg.

Arbusto común en bosques secundarios. Con uso medicinal, pero el informante no pudo ser más específico.

jënë nane (jënë - agua; nane - Genipa americana)

Simira hydrantha (Standi.) Steyerm.

Árbol poco común en bosques secundarios. Amazonía occidental. Lo frutos son una fuente de tinte negro usado para pintarse el cuerpo.

\section{cacatao}

Uncaria guianensis (Aubl.) Gmel.

Liana común en bosques secundarios. América del Sur tropical. Exudado Tallo se mezcla con agua y se toma para curar la diarrea. El tallo es el material más importante empleado para hacer el marco de las canastas carga (cacano).

\section{RUTACEAE}

rimo (Castellano - limón)

Citrus aurantifolia (Christm.) Swingle

Árbol pequeño común, cultivada en los jardines de las casas. Probablemente originario de la India o el sudeste asiático; ampliamente cultivada. El fruto se utiliza para hacer una bebida refrescante mediante la adición de azúcar al jugo. Una decocción de las hojas se prepara y se toma, como un té para curar el dolor de estómago.

toronja (Castellano - toronja, pomelo)

Citrus paradisi $\mathrm{Ma}$

Árbol pequeño común, cultivada en los jardines de las casas. Probablemente de origen antillano, un híbrido, con amplia distribución. El jugo jomelo se consume como una bebida y también se lo come.

\section{boxcaisini}

\section{Galipea trifoliata Aubl.}

Arbusto común en pastizales abandonados por el ganado. Común en Guayana y Amazonas. El agua producto de la decocción de las hojas sirve para aliviar el dolor de cabeza, se debe lavar la cabeza con esta agua.

\section{nahuabexë; paxahini}

\section{Metrodorea fiavida Krause}

Arbusto o pequeño árbol común en pastizales abandonados y bosques secundarios. Común en la Amazonía. Una decocción de las hojas se toma para aliviar los problemas del hígado. La madera se utilizada como leña para ahumar caucho crudo. 
coroquisi (coro armadillo pequeño de las sabanas, niebla o neblina; quisi - las pequeñas semillas negras unidas para hacer collares)

Xanthoxylum rhoifolium Lam.

Arbusto espinoso común en pastos abandonos. América del Sur templada, se extiende hacia el norte en la Amazonía y el Planalto brasileño. No se utiliza.

\section{SAPINDACEAE}

shoshapo (shapo - Fuerte)

Paullinia sp.

Arbusto común en bosques secundarios maduros. Frutos comestibles.

nishi bepiya (nishi - bejuco)

Serjania altissima (Poepp.) Radkl.

Bejuco común en pastizales abandonados ganado. Amazonía occidental. No se utiliza.

axacoro, carahina nihi (nihi - bosque)

Serjania lethalis A. St. Hill.

Liana común en bosques secundarios. Amazonía occidental, con poca frecuencia colectada. Veneno para pesca. Trozos de la liana se golpean con el fin de liberar un exudado transparente y pegajoso, el trozo golpeado se agitaba en el agua de los arroyos pequeños o calas en el río durante la estación seca, con el fin de envenenar a los peces.

carinaxa; axa; capehitsa (Castellano - barbasco blanco)

Serjania pyramidata Radkl.

Liana común en bosques secundarios. Amazonía, Bolivia, infrecuente colectado. Veneno para pesca. Usado como Serjania tenuifolia; pero el exudado de S. trirostris es blanco.

xabajihui (xaba - sabana, - árbol)

*Toulicia patentinervis Radkl.

Árbol común de tamaño medio sin aletones en el bosque secundario maduro. No se utiliza.

\section{SAPOTACEAE}

toroquerhina (-hua - grande, pequeño, mucho); tiorocoriba (tio - tamaño); xaxojihui (xaxo - tronco para la molienda del maíz; jihui - árbol)

*Micropholis guyanensis (A. DC.) Pierre

Árbol grande, común, con aletones en bosque secundario maduro. Guayana y la Amazonía. Una decocción de las hojas se toma para curar el reumatismo Fruto comestibles de sabor dulce. Mortero para moler el grano está tallado del tronco.

\section{queo}

Pouteria caimito (R. \& P.) Radlk.

Árbol poco común en los bosques secundarios maduros. Común en Guayana y Amazonas. Frutos comestibles de sabor dulce. 
yahe (Castellano - lúcuma); tioroquërihua xoco (tio - tamaño; -hua - grande, pequeño, muchos; xoco - pequeño) [5108;] batabi (Castellano - coquino)

Pouteria macrophylla (Lam.) Eyma

Árbol en el bosque secundario. También se cultiva en los en los jardines alrededor de las casas. Amazonía, que se extiende de norte a Guyana Francesa. Frutos comestibles.

\section{quispi}

Chrysophyllum sparsiflorum Klotsch. ex. Miq.

Árbol pequeño poco común en bosque secundario. La madera se utilizada como leña para ahumar caucho crudo.

\section{SIMAROUBACEAE}

tararí (tara - tronco seco, sin ramas; ri - rápido, que no saben cuando algo va a ocurrir, también)

\section{Simaba sp.}

Poco común, recogido como un árbol joven en el bosque secundario maduro. Virutas de corteza se hierve, y la cocción, una vez enfriado, se toma para provocar el vómito y curar la diarrea y dolor de estómago.

\section{SMILACACEAE}

nishi (-bejuco); patiarijomoxa (patiaríhen; jo - pies; moxa - espina)

Smilax poeppigii Kunth

Bejuco común en bosques secundarios. Amazonía occidental. Se dice que las hojas y los frutos tienen un uso medicinal, pero los informantes no pudieron ser más específicos.

\section{SOLANACEAE}

nishi (- bejuco); No se utiliza; yahuatahua (-iyahua - cerdo salvaje; tahua - Gynerium sagittatum)

Cestrum strigillatum R. \& P.

Arbusto enredadero común en los bosques secundarios y el margen del pueblo. Suroeste de la Amazonía, que se extiende hacia el sur en Paraguay y Argentina. Una decocción de las hojas se toma para curar problemas de hígado.

Sin nombre Chácobo; No se utiliza; shia

Solanum proteanthum Bohs

Arbustos raros en el bosque secundario. Una decocción de las hojas se toma para curar problemas de hígado.

bimitsexejoni (bimi - fruta; tseo- entrar al bosque; xe - tiempo futuro; joni - hombre) Lycianthes glandulosa (Ruiz. \& Pav.) Bitter.

Arbusto poco común en bosques secundarios. Amazonía del Perú y Bolivia. Las hojas y los frutos tienen uso medicinal, pero el informante no pudo ser más específico. 
yobini (yo - todos)

Solanum placitum C.V. Morton

Maleza en los campos agrícolas. Bolivia y Perú, principalmente en las laderas de los Andes. Raspaduras de corteza se mezcla con agua y la pasta resultante se aplica a lesiones en la piel para ayudar a la curación.

\section{popatoa}

Solanum mammosum $\mathrm{L}$.

Arbusto común en las áreas de residuos alrededor de las viviendas. Hierba muy común. No se utiliza; se dice que semillas son venenosas.

cashixopa (cashi - murciélago, mamífero)

Solanum pensile Sendtn.

Bejuco poco común en bosques secundarios. Común en América del Sur. Una decocción de las hojas se toma para curar problemas de hígado.

\section{STAPHYLEACEAE}

toxa

Stapylea occidentalis Sw.

Árbol pequeño, raro en el bosque secundario. Centroamérica en el noroeste de América del Sur, disjunto en la Amazonía boliviana. Una decocción de las hojas se toma para aliviar la fiebre.

jihuijoxo (jihui - árbol; joxo - blanco)

Turpinia occidentalis ssp. brevifolia Croat

No se utiliza.

\section{STERCULIACEAE}

nihi popotahua (nihi - bosque; popo - papaya; tahua - Gynerium sagittatum)

Byttneria catalpifolia Jacq.

Liana común en bosques secundarios y perturbados. Común en las regiones tropicales de América Central y del Sur. No se utiliza.

xaquini (Castellano - ambaivillo)

Herrania sp.

Árbol en el bosque secundario maduro. Frutos comestibles.

nohote (Castellano - chocolate)

*Theobroma speciosum Willd. ex Spreng.

Árbol pequeño común en bosques secundarios maduros y en el cultivo en los en los jardines alrededor de las casas. Común en la Amazonía y Guayana. Pulpa dulce de la fruta madura se come cruda. También se dice que las hojas tienen uso medicinal, pero el informante no pudo ser más específico. 


\section{STRELITZIACEAE}

mani (- para unir) (Castellano - pa-tujú); manixoco (mani - para unir; xoco - pequeño); No se utiliza; xapanati (Castellano - patuhucito)

Phenakospermum guyanense (L. C. Rich.) Endl. ex Miq.

Hierba grande muy común en los bosques secundarios maduros. A lo largo de Guayana y la Amazonía. Las hojas grandes de esta planta son los principales materiales utilizados para la paja del techo de las casas. Algunos techos están completamente cubiertas con esta especie, pero más comúnmente se la utiliza junto con las hojas de cualquiera de las varias especies de palmas. La hojas jóvenes se usaban como un taparrabos para las mujeres.

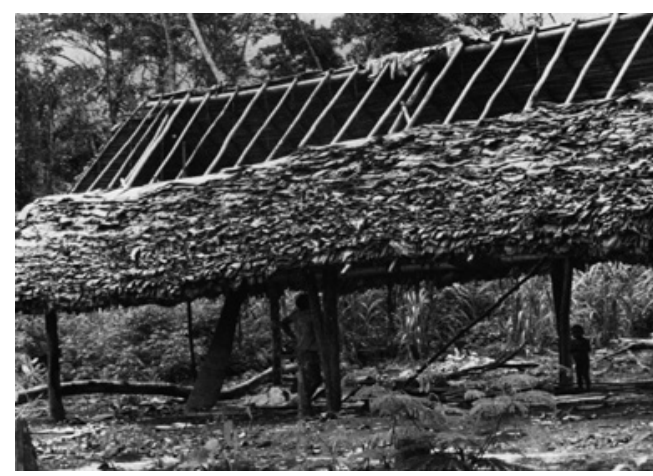

Boom 1987: Techo de Patuju

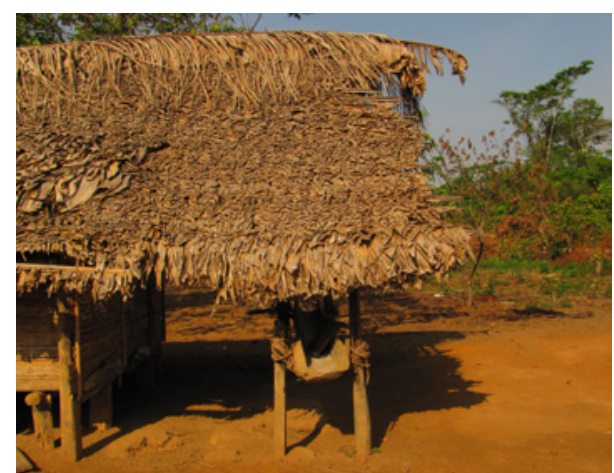

Paniagua 2010: Techo de Patujú

\section{TILIACEAE}

moxoque (Castellano - cabeza del mono, balsa); No se utiliza

*Apeiba echinata Gaertn.

Árbol pequeño común sin aletones en el bosque secundario maduro y también en el pueblo, pero al parecer no cultivado. Guayana y la Amazonía. Tronco se utilizaba antiguamente para hacer taburetes bajos sentado. Las tiras de la corteza interna se utilizan para tejer canastas, cuando no hay otro material disponible.

\section{moxoque; paro}

Apeiba tibourbou Aubl.

Árbol común de tamaño mediano en bosques secundarios y pastos antiguos márgenes. A lo largo de la región del neotrópico. Tronco se utilizaba antiguamente para hacer taburetes bajos para sentarse. Tiras de la corteza interior se utilizan como cuerdas. Las hojas y fragmentos de corteza se añaden al cauchi crudo, para que el líquido espese. Las hojas se hierven y se colocan en las partes del cuerpo de los niños que son débiles o delgados, e para hacerlos más fuertes.

huaxmenehua (huaxmene - algodón; -hua - grande, pequeño, mucho)

* Lucheopsis schultesii Cuatr.

Árbol raro de tamaño mediano, sin aletones, en el bosque secundario maduro. Amazonía occidental. No se utiliza. 


\section{TRIGONIACEAE}

cashishopa (cashi - murciélago, mamífero)

Trigonia killipii Macbr.

Bejuco poco común en la vegetación secundaria cerca de la aldea. Restringida al suroeste de la Amazonía. No se utiliza.

\section{TURNERACEAE}

matsoti (-escoba)

\section{Turnera sp.}

Subarbusto, maleza muy común en el pueblo. Un puñado de ramas frondosas es atado a un palo para formar una escoba rústica.

\section{ULMACEAE}

yahuatao (iyahua - cerdo salvaje; lao - masticar)

Celtis morifolia Planch.

Liana espinosa, raro en el bosque secundario maduro. Con uso medicinal, pero el informante no pudo ser más específico.

jis-si tao (jis - mirar; tao - masticar)

Celtis pubescens Spreng

Frutos comestibles.

\section{merabi}

Trema micrantha (L.) Blume

Árbol pequeño común en bosques secundarios. Común en el neotrópico. Decocción de las hojas se aplicada a lesiones en la piel para curarlas.

\section{VERBENACEAE}

bimichëxe (bimi - baya; chex- curar); nishi (-bejuco); No se utiliza.; jihui joxo (jihui - árbol; joxo - blanco); nisbiraoxo (nishi - bejuco; raoxo - variedad de yuca)

\section{Aegiphila boliviana Mold.}

Arbusto o liana común en bosques secundarios endémicas de Bolivia, desde Santa Cruz hacia el norte de Pando y Beni. Una decocción de las hojas se toma para curar el reumatismo. Exudado del tallo se recoge en un recipiente, se mezcla con agua, y se toma para curar la diarrea.

bahuarexa (bahua - un pequeño loro verde)

Lantana cujabensis Schau.

Arbusto común en pastizales abandonados de ganado. Hierba muy extendida en América del Sur. Las hojas son aplastadas entre los dedos y luego se huele para ayudar a curar un resfriado. 
urn (Castellano - uva)

Lantana trifolia L.

Arbusto común en las afueras del pueblo. Malezas común en todo el neotrópico. Las frutas dulces se comen.

camano-nihi (carnario - tigre; nihi - bosque)

Stachytarpheta cayennensis (L. C. Rich.) Vahl

Hierba de maleza en pastizales abandonados del ganado. Maleza agresiva común en toda América del Sur tropical, al norte de Panamá y las Antillas. Una decocción de las hojas se toma para aliviar los problemas estomacales.

\section{VIOLACEAE}

\section{mairao; mairo}

Leonia cymosa Mart.

Árbol pequeño raro en el bosque secundario maduro. La madera es utilizada como leña para ahumar caucho crudo y cocinar.

roquëxëquërë; No se utiliza; cai-osho (cai - madre; osho - flaco)

Rinoreocarpus ulei (Melchior) Ducke

Árbol pequeño raro en el bosque secundario. Amazonía occidental. Una decocción de las hojas y los frutos se toma para aliviar el dolor de estómago.

\section{VISCACEAE}

carape nihi chahitabo (carapë - plátano; nihi - bosque; chahita - grande, abuelo)

Phoradendron racemosum (Aubl.) Krug \& Urban

Parásito frecuente en los bosque secundario maduro. en las Antillas y Sudamérica tropical. No se utiliza.

\section{VITACEAE}

nainishi (nai - cielo; nishi - bejuco)

Cissus erosa Rich.

Enredadera muy común en bosques secundarios y en las afueras del pueblo. A lo largo de la región del neotrópico. Dicen de que tiene uso medicinal, pero el informante no pudo ser más específico. Los tallos y las hojas se añaden a al caucho cruda y líquido para que espese.

carabocoati (cara - goma; -bo - plural; -co - mucho; -ti - futuro)

Cissus sicyoides $\mathrm{H}$.

Bejuco común en el margen de los pastos viejos. A lo largo de la región del neotrópico. Los tallos y las hojas se añaden al caucho crudo y líquidos para que espese. 


\section{VOCHYSIACEAE}

omacabero (omaca - un tipo de pez; hero - semilla)

Qualea acuminata Spruce ex Warming

Árbol raro pequeño a lo largo de los arroyos en el bosque secundario. Ampliamente distribuido en Guayana, Amazonas, y el Planalto brasileño. Frutos comestibles, de sabor dulce.

jihui sama (jihui - árbol); omacabero (omaca - un tipo de pez; bero - semilla)

*Qualea paraensis Ducke

Árbol poco común con grandes aletones redondeados en bosque secundario maduro. Amazonía. Frutos comestibles.

sipame; jihui coshi (jihui - árbol; coshi - fuerte, duro); cano

*Vochysia vismiifolia Spruce ex Warming

Gran árbol común en bosques secundarios maduros. Guayana y Amazonía. Frutos comestibles, sabor semi-dulce. Frutos comestibles. Dicen que también se los usa para curar la piel irritada, pero el informante no pudo describir el procedimiento. La madera muy durable se utiliza en la construcción de puentes.

\section{ZINGIBERACEAE}

manihuashiri (mani - unir; -hua - pequeños, muchos, grande)

Renealmia breviscapa P. \& E.

Hierba común en bosques secundarios. Amazonía, principalmente la porción occidental. Una decocción de las hojas se toma para curar la diarrea.

\section{huacosa}

\section{FAMILIA NO DETERMINADA}

Árbol poco común en los bosques secundarios maduros. No se utiliza. 


\section{Plantas comestibles}

De todas las especies registradas como útiles para los Chácobo entre 1983 y 1984, 102 especies era utilizadas como fuente de alimento.

Las 27 especies comestibles que eran sembradas crecían en pequeños jardines cerca de las casas, las especies mas comunes fueron el mango (Mangifera indica, Anacardiaceae), aguacate (Persea americana, Lauraceae), papaya (Carica papaya, Caricaceae) y limón (Citrus aurantifolia, Rutaceae). En en el trabajo realizado en el 2010 se encontraron solamente mango y naranja (Citrus sinensis, Rutaceae). Las especies menos comunes en los jardines fueron Annona hypoleuca (Annonaceae), Inga edulis (Fabaceae), Pouteria macrophylla (Sapotaceae) y el cacao silvestre (Theobroma speciosum, Sterculiaceae), que ha sido semi-domesticado.

Los arbustos como Psidium guayava, Myrica sp. y Eugenia sp., todos Myrtaceae, también fueron comunes en los años 80. Otra planta comúnmente cultiva en los jardines era Bixa orellana (Bixaceae), de la que usaban las semillas para dar color a sus alimentos, también cultivaron melón (Citrullus vulgaris, Cucurbitaceae) y caña de azúcar (Saccharum officinarum, Poaceae). En 2010 solo se encontraron muy pocos individuos de estas especies, y la caña se siembra en los chacos.

Los especies alimenticias mas importantes fueron sembradas en los chacos (=campos de cultivo, huai en Chácobo) localizados a $1 \mathrm{~km}$ de la comunidad.

En los 1980's la yuca (Manihot esculenta, Euphorbiaceae) era claramente el alimento mas importante para los Chácobo, y se sembraron hasta siete variedades abarcando casi el $62 \%$ de todo el terreno cultivado en la comunidad. La yuca podía cosecharse a partir de mayo. El maíz (Zea mays, sembrado en $18 \%$ del terreno) y el arroz de tierras altas (Oryza sativa, sembrado en $7 \%$ del terreno), ambas Poaceae, se sembraron alternadamente con la yuca, y ambas se podian cosechar a partir de enero o febrero. El arroz se secaba en el campo en vasijas de barro sobre fuego. En el 2010 el arroz se había convertido en el alimento principal, dejando a la yuca y maíz con un rol mas secundario, reflejando claramente un cambio en la dieta de los Chácobo, y también mostrando la influencia del mercado, porque una gran parte de la cosecha del arroz se vende. La forma de cosechar y secar el arroz también cambio. Ahora se cosecha la planta completa y se almacena en galpones, sin secar los granos en el campo.

Otro cultivo importante eran los cambures o plátanos y bananos (Musa x paradisiaca, Musaceae), sembrados en los jardines y los chacos, sin tener lugar especial en el $12 \%$ del terreno, pero con una importancia evidente dentro los alimentos que consumían. Boom encontró ocho variedades locales de cambures, todas dulces y comestibles como frutos. En el 2010 observamos que el plátano no tiene mayor importancia, y solo se encontró como cultivo secundario en los alrededores de las casas, solamente la variedad comercial, 
mientras las variedades tradicionales habían desaparecido, indicando una pérdida profunda de recursos filogenéticos tradicionales.

Además de estas especies importantes, también se cultivaba piña (Ananas comosus, Bromeliaceae), frejol (Vigna unguculata, Fabaceae), ñame (Dioscorea trífida, Dioscoreaceae), waylusa (Xanthosoma sp., Araceae), batata (Ipomoea batatus, Convolvulaceae) y calabaza (Lagenaria siceraria, Cucurbitaceae) esta última para su uso en la fabricación de recipientes. Todas estas plantas todavía se registraron en 2010.

Los chacos áun eran temporales, un chaco solo era utilizado para un año de producción. En el 2010, encontramos que el uso de los chacos se extendían por aproximadamente por tres años, el primero con la siembra de arroz, a la que le seguía la de maíz, y finalmente la de yuca. Los hombres son los responsables de limpiar el chaco, que normalmente tienen mas o menos una hectárea. Actualmente el arroz se siembra con sembradoras manuales adquiridas en el mercado, mientras el xëtsati (una pala de madera) todavía de veces sirve para sembrar maíz y yuca.

En los 1980's con frecuencia se sembraba la Huanimá (Bactris gasipaes, Arecaceae) en los chacos abandonados para cosechar sus frutos. En el 2010 la palma, era muy escasa y solamente fue encontrada en los alrededores de los pueblos, en el bosque, solo existen algunas plantas, las que quedaron de las que fueron sembradas antes, actualmente ya no se la siembra.

La especie de planta comestible mas importante del bosque es sin duda la castaña (Berthollettia excelsa, Lecythidaceae). Actualmente aun la gente la come cruda o asada, y pero la mayor parte de la población la recolecta solo para la venta, constituyendo una de sus principales fuentes de ingresos. La producción de aceite de las semillas de castaña reportada por Boom en los 80's, no fue reportada en el 2010. La cosecha de la castaña se realiza entre enero y marzo, cuando casi toda la población se muda a los bosques cercanos del río Benicito donde se encuentran la mayor cantidad de árboles de castaña. De esta manera hoy día se puede de nuevo observar un sistema semi-nómada entre los Chácobo, en el que muchas familias tienen casas u hogares en el centro poblado de Alto Ivon, pero también cerca de los chacos nuevos (por ejemplo en la comunidad de Tokyo), y cerca de las áreas de mayor concentración de castaña (a orillas del río). La otra especie comestible de Lecythidaceae encontrada por Boom fue la Eschweilera parviflora.

Por lo menos 9 especies de las Moraceae, la familia mas importante en los bosques del territorio Chácobo, fueron fuente de algún tipo de alimento en los 1980s: Brosimum acutifolium, Helicostylis tomentosa, Perebea guianensis, Perebea mollis, Perebea macrophylla, Sorocea guilleminiana y Sorocea muriculata. Las dos especies de Pseudolmenia (P. laevis y P. macrophylla), fueron las mas comunes y una importante fuente de frutos del bosque.

Porouma cecropifolia y Porouma guianensis de las Cecropiaceae, y las Melastomataceae 
Bellucia aequiloba, Bellucia grossularioides, Toccoa guianensis, asi como varias especies de Miconia, Hirtella lightioides, Hirtella racemosa y Licania octandra (Chrysobalanaceae), Rheedia floribunda y Tovomita schomburgkii (Clusiaceae) también se comieron. Los frutos del genero Inga (xënanë) de las Fabaceae remplazaban al mango como el fruto de mayor consumo en la época de lluvias.

Otros frutos comestibles fueron los del cotibi (Onychopetalum periquino, Myristicaceae) que se consumían durante la época de lluvias, de las Hippocrateaceae (Cheiloclinum cognatum, Tontelea fluminenis), Vochysiaceae (Qualea acuminata, Qualea paraensis, Vochysia vismiifolia), Annonaceae (Annona ambotay, Xylopia sp. y Guatteria buchtenii) y la familia de café (Rubiaceae, Genipa americana, Geophila cordiifolia y Faramea corymbosa). Las lianas Tetrapteris crispa, Byrsonima crispa, Pouteria caimito y Micropholis guyanensis de la familia Malpighiaceae también fueron usado como comida, y otras plantas silvestres de interés menor incluyeron Combretum laxum (Combretaceae), Ouratea macrobotrys (Ochnaceae), Passiflora coccinea (Passifloraceae), Potalia amara (Potaliaceae) y Paullinia sp. (Sapindaceae).

Sin embargo, pese a esta diversidad la familia silvestre con mayor importancia como fuente de alimento (frutos), fueron las palmeras (Arecaceae). Bactris maraja solo tenía una importancia limitada, pero Astrocaryum ulei, Astrocaryum aculeatum, Euterpe precatoria, Oenocarpus bataua, Attalea maripa, Oenocarpus mapora y Attalea phalerata fueron recolectadas y consumidas con mayor frecuencia.

Aunque la contribución en cuanto a su contenido calórico en la alimentación, no era abundante, las plantas que aprovechaban y recolectaban de bosque, constituyeron una fuente importante de vitaminas y minerales para los Chácobo.

\section{Plantas para leña}

La investigación de Boom mostró que los Chácobo usaron 22 especies como fuente de leña, incluido su uso para curar el caucho crudo (látex de Hevea brasiliensis). Se mostró que el conocimiento tradicional de las propiedades de ciertas maderas era bastante profundo.

Para curar goma se necesita un humo denso y ácido, y como para este propósito se usaron de manera especial diez especies de árboles: Unonopsis floribunda (Annonaceae), Crepidospermum goudotianum (Burseraceae), Maytenus sp. (Celastraceae), Hirtella lightioides y Licania britteniana (Chrysobalanaceae), Tovomita schomburgkii (Clusiaceae), Erythroxylum squamatum (Euphorbiaceae), Lindenackeria paludosa (Flacourtiaceae), Vataireopsis speciosa (Fabaceae) y Metrodorea flavida (Rutaceae).

Para cocinar obviamente no servirá una especie con mucho humo, y entonces los Chácobo usaron maderas diferentes con mejores calidades de combustión. Las especies mas deseables fueron Duguetia quitarensis, Guatteria hyposericea y Xylopia sp. (Annonaceae), Protium subserratum (Burseraceae), Sloanea stipitata (Elaeocarpaceae), Casearia combaymensis 
(Flacourtiaceae), Brosimum guianense (Moraceae) y Amaiuoa guianensis (Rubiaceae).

Leonia cymosa (Violaceae), Sloanea eichleri (Elaeocarpaceae), Casearia combayensis (Flacourtiaceae), Iryanthera juruense e Iryanthera tessmannii (Myristicaceae) fueron usados para ahumar goma y cocinar, porque todas, especialmente las dos últimas, eran muy abundantes.

\section{Plantas para construcción y artesanía}

En en los 80's se registraron 68 especies de plantas importantes para su uso en la construcción, principalmente en la construcción de las casas y plantas empleadas en la fabricación de artesanías .

Para los postes en las esquinas de las casas (horcones), fueron usadas las maderas mas duras como Enterolobium schomburgkii y Sclerolobium sp. (Fabaceae), Amaioua guianensis (Rubiaceae), Lindackeria paludosa (Flacourtiaceae) y Mezilaurus itauba (Lauraceae).

Los techos eran principalmente construidos con hojas de Phenacospermum guyanense (Streliziaceae), pero frecuentemente estas hojas eran mezcladas con hojas de palmeras, especialmente de Euterpe precatoria, Attalea maripa, Oenocarpus mapora y Attalea phalerata. Geonoma máxima var. chelidoneura servía para techar estructuras pequeñas.

Para sujetar las hojas sobre el armazón del techo se usaba la fibra obtenida de la corteza de Cecropia ficifolia, Cecropia sciadophylla (Cecropiaceae), Duguetia quitarensis, Guatteria discolor, Guatteria hyposericea y Xylopia sp. (Annonaceae) y Apeiba tibourbou (Tiliaceae).

En esta época las casas no tenían paredes, aunque se observó el uso de paredes con los troncos de Socratea exorrhiza (Arecaceae) que eran cortados en tablas que se colocaban de forma vertical, y en algunos casos las ranuras eran rellanadas con barro. Con los peciolos largos y resistentes de Oenocarpus bataua (Arecaceae) se construían las puertas de las casas. No existieron muchos muebles. Las camas eran plataformas construidas con los troncos de Brosimum utile, Ficus nympheaifolia (Euphorbiaceae) y Socratea exorrhiza (Arecaceae). La madera liviana de Apeiba echinata y Apeiba tibourbou (Tiliaceae) era utilizada para hacer sillas. Para la fabricación de las hamacas se uso la fibra de algodón (Gossypium barbadense, Malvaceae), que en ese tiempo era comprada en el mercado de Riberalta. Actualmente muchos de los Chácobo cultivan si propio algodón, que cosechan e hilan para tejer sus hamacas. Las escobas eran fabricadas con hojas de Euterpe precatoria (Arecaceae) o con un puñado de Turnera sp. La bractea peduncular de Attalea maripa (Arecaceae) frecuentemente sirvió como juguete de niños, y las raíces grandes de Socratea exorrhiza (Arecaceae) fueron usadas como ralladores de yuca, aunque ya en los 1980 s habían sido reemplazadas por ralladores fabricados de lata. 


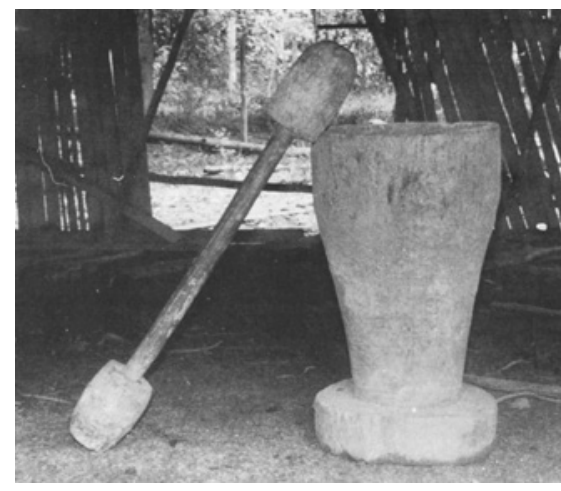

Boom 1987: Tacu

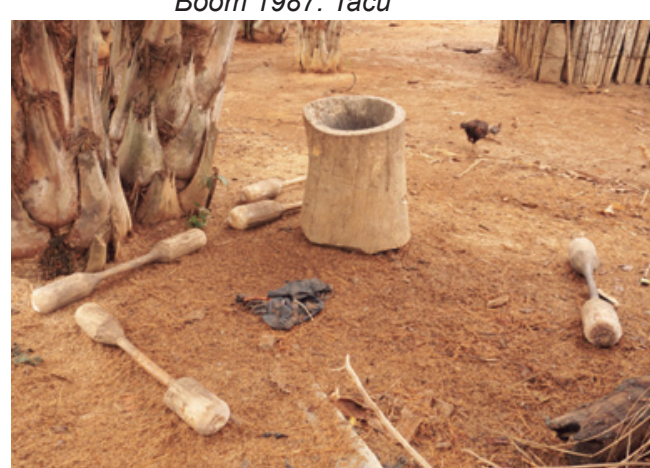

Paniagua 2010: Tacu

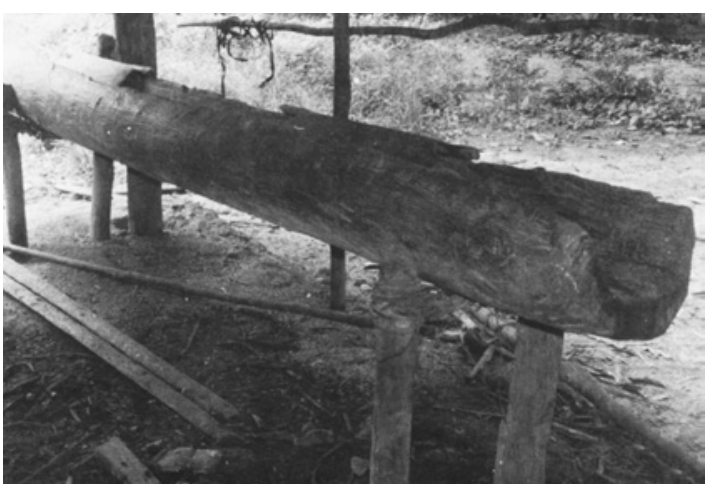

Boom 1987: Batán

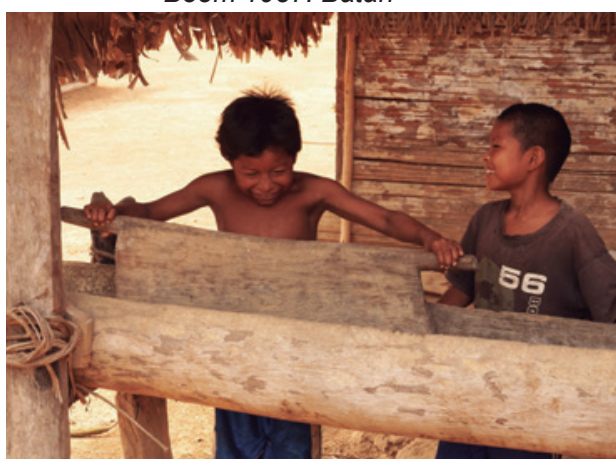

Paniagua 2010: Batán

Los morteros o tacus eran fabricados de Micropholis guianensis (Sapotaceae), y los recipientes y vasijas de los frutos de Crescentia cujete (Bignoniaceae) y Lagenaria siciaria (Cucurbitaceae). Para sellar las bateas que fabricaban de madera se usaba un extracto de los troncos de Licania octandra o Parinari excelsa (Chrysobalanaceae). Pese que los Chácobo aun fabricaban sus propios utensilios de cocina, Boom ya encontró que en muchos casos usaban bastantes ollas de aluminio y artefactos que compraban en Riberalta.

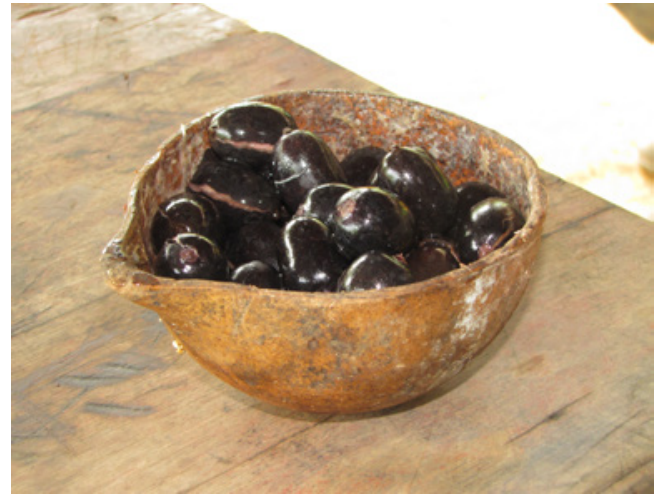

Paniagua 2010: Vasija de los frutos de Crescentia cujete
Como instrumentos musicales se usaron las flautas (bisto) fabricadas con los tallos de Lasiacis ligulata, Olyra latifolia y Parinaria sp. (Poaceae), las cuales eran originalmente usadas en ceremonias, pero en los 80 's solo fueron usadas como juguete por niños.

Muchas especies fueron usadas para fabricar cestas o canastas. Las mas grandes (cacano) requerían bastante trabajo. Las cuerdas de amarre con las que se fabricaban estas canastas venían de la corteza interior de Couratari guianensis (Lecythidaceae), 
para el armazón se usaba Uncaria guianensis (Rubiaceae) y la correa que se coloca en la frente de la persona era de la corteza interior de Ficus obtusifolia (Moraceae). Actualmente, aun se fabrican y usan estas canastas, usando las mismas especies descritas por Boom.

Un pequeño abanico, huana huëquëti se fabricaba con fibras de Astrocaryum aculeatum (Arecaceae). El poropachi, otra canasta liviana de carga, era tejida de las hojas tiernas de Attalea phalerata (Arecaceae). También se fabricaban canastas de otras fibras, aunque su uso era menos común; se usaban las hojas de Andropogon bicornis y Streptogyna americana (Poaceae), el interior de la corteza de Apeiba echinata (Tiliaceae) y Cordia ucayalensis (Boraginaceae). También se usaron las raíces adventicias de una especie de palmera (no identificada) y los delgados troncos de Ischnosiphon lasioceoleus (Marantaceae) para fabricar una cesta usada para escurrir el agua de la masa de yuca.

La ropa original (tatë) de los chácobo era fabricada de la corteza de varias especies de Moraceae, especialmente Brosimum utile, Perebea guianensis, Ficus nymphaefolia, Ficus obtusifolia, Ficus radula y Ficus wulana. Las mujeres usaron un taparrabo hecho de hojas jóvenes de Phenacospermum guyanense (Strelitziaceae), amarrado con una cuerda (yoshnibo) hecho de hongos negros. Los hombres usaron bandas blancas como ornamento en sus tobillos, cuales fueron fabricadas de Omphalea diandra (Euphorbiaceae), que también se usaban en las muñecas. Las semillas negras con las que fabricaban los collares venían de Woytkowskia spermatochora (Apocynaceae), un arbusto bastante raro. Los hilos y sogas para costura de la ropa eran fabrcados de las fibras de Eriotheca globosa (Bombacaceae).

Un gran numero de plantas sirvió para preparar tintes para pintar el cuerpo y teñir. Con la corteza de Sparattosperma leucanthum (Bignoniaceae) producian un tinte de color marrón empleado para teñir hilos, las semillas de Bixa orellana (Bixaceae) servían para obtener un rojo intenso, Miconia minutiflora (Melastomataceae), Faramea capillipes y Psychotria deflexa (Rubiaceae) proporcionaba un tinte azul. Los tintes de color negro eran producidos de los frutos de Genipa americana y Simiria hadrantha (Rubiaceae).

El caucho de Hevea brasiliensis (Euphorbiaceae) fue usado para fabricar zapatos sumergiendo los pies en el caucho liquido, y después secando los zapatos al sol.

Vochysia vismifolia (Vochysiaceae) y Diplotropis purpurea (Fabaceae) fueron los árboles preferidos para construir puentes por poseer una madera muy dura y persistente. Para la fabricación de las canoas se usaron los troncos de Toxicodendron striatum (Anacardiaceae), Trattnickia peruviana (Burseraceae), aunque a veces también construían botes de corteza de Hymenea courbaril (Fabaceae). Las resinas de las mismas especies sirvieron para iluminación.

Un uso muy importante fue la fabricación de materiales de caza y pesca que originalmente fueron arcos y flechas. Para su fabricación en general se uso la madera de Astrocaryum aculeatum y Bactris gasipaes (Arecaceae) para los arcos y puntas de flechas. Los mangos de 
BООМ ВМ. 1987, Etnobotánica de los Chácobo (Beni, Bolivia)

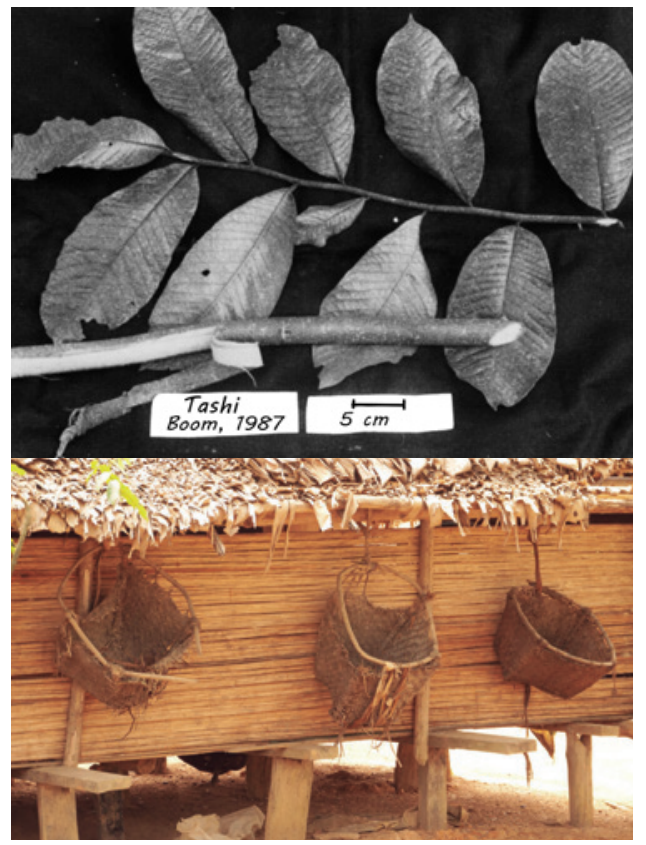

Paniagua 2010: Tashi
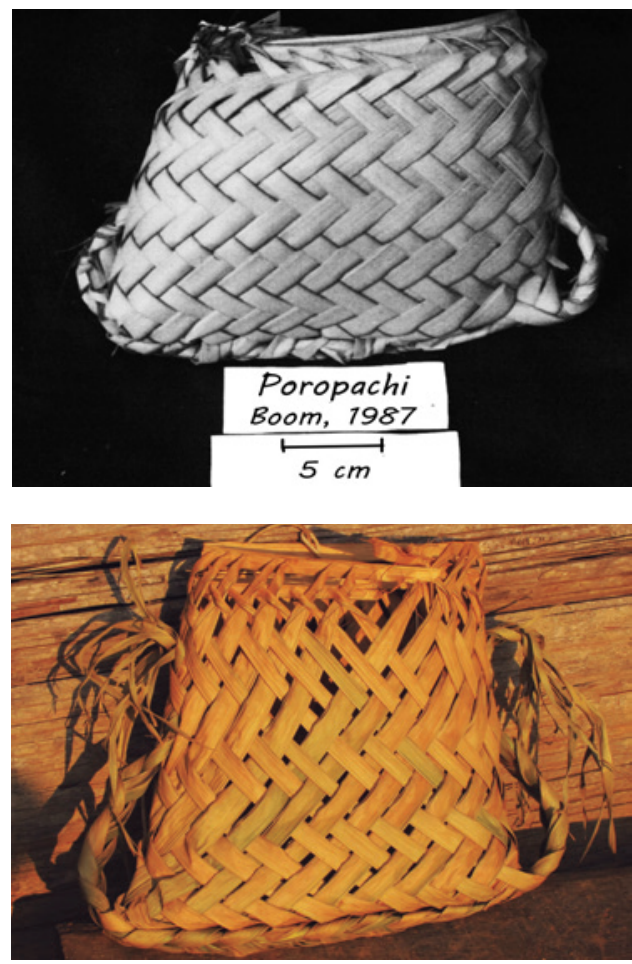

Paniagua 2010: Poropachi

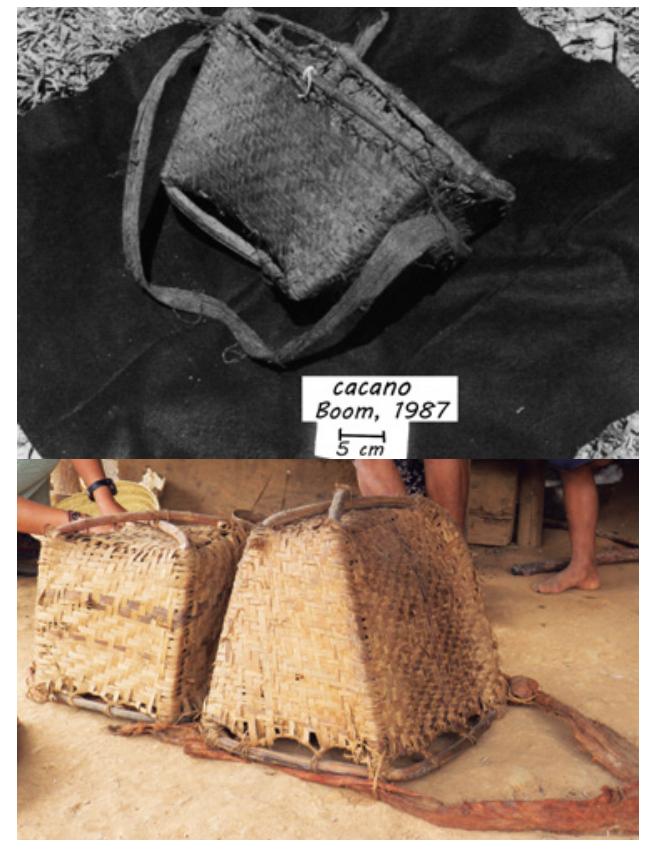

Paniagua 2010: Cacano
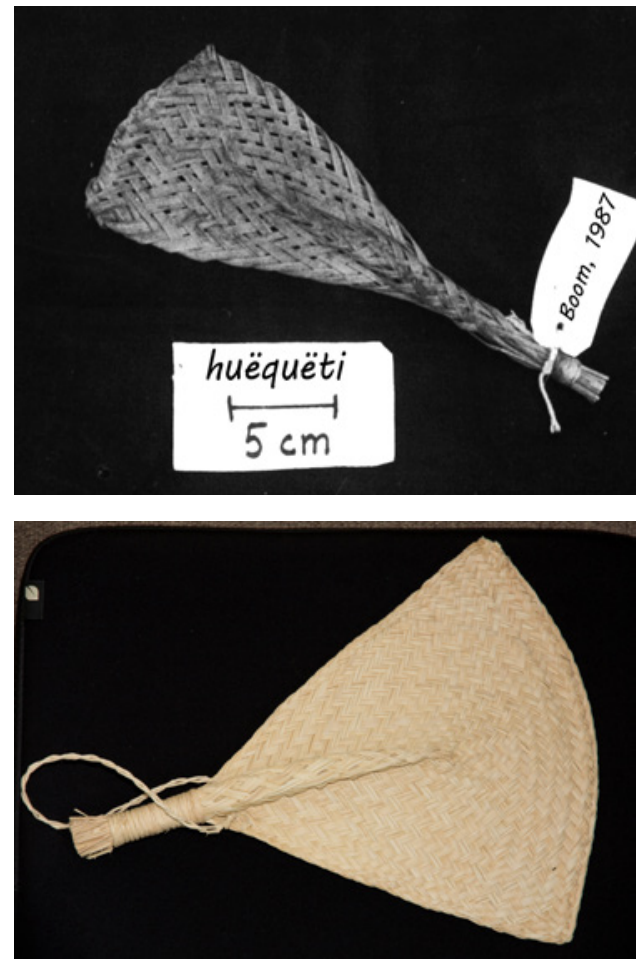

Paniagua 2010: huëquëti fabricado con hojas de Astrocaryum aculeatum 
las flechas eran fabricados de los tallos de las flores de la Caña brava (Gynerium sagittatum, Poaceae), y cuando esta no estuviera disponible usaban los tallos de Geonoma maxima var. chelidonura (Arecaceae) o Ischnosiphon arouma (Marantaceae). Boom registró cinco tipos de flechas muy distintas diseñadas para cazar para diferentes tipos de animales: tëpi, quërëquë (para aves de tierra), tohua quëspini, paca (para animales grandes) y bicobi (para peces). En el 2010 se usaron solo rifles (shalon de calibre 22 y escopetas del calibre 20) para la caza, y solo el bicobi se usa todavía para la pesca, los otros tipos de flechas ya desaparecieron completamente, solo los mas ancianos cuentan que habían muchos tipos de flechas.

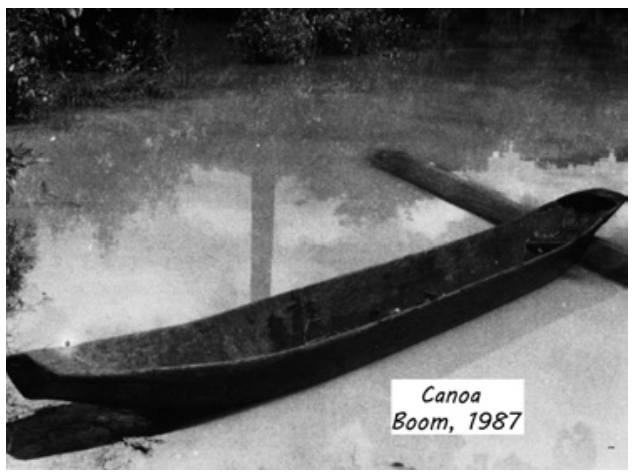

Canoa usada por los Chácobo

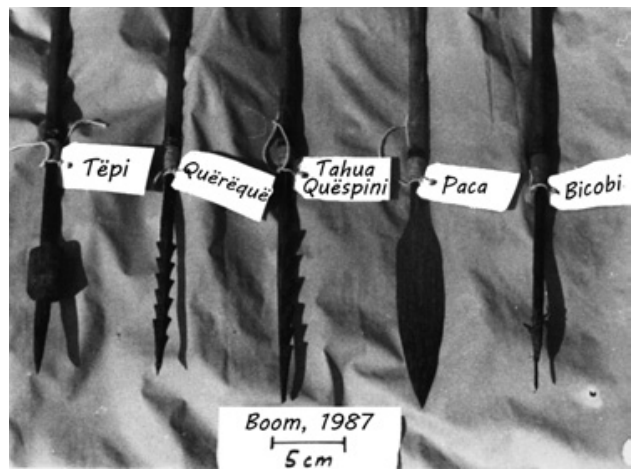

Tipos de flechas usadas por los Chácobo

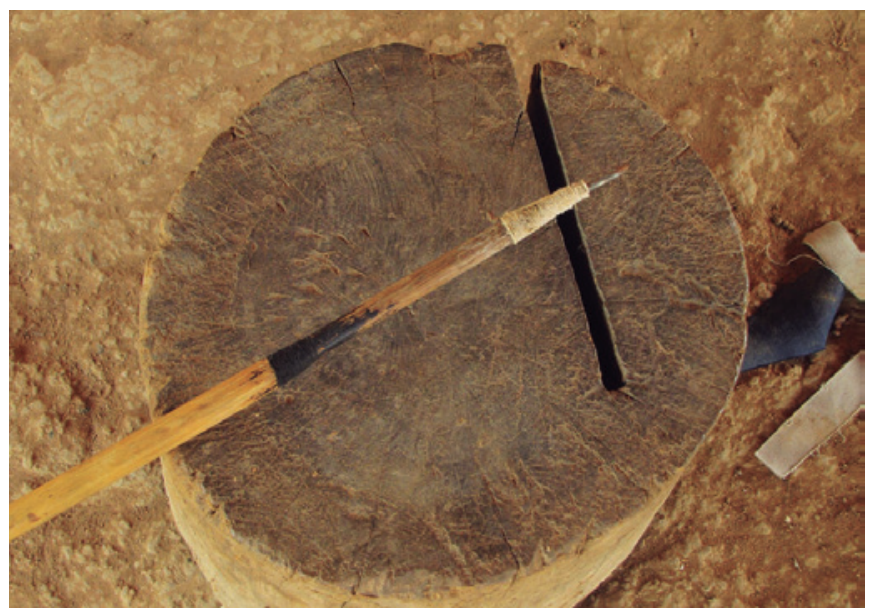

Paniagua 2010: Bicobi, el unico tipo de flecha que se mantiene en uso 


\section{Plantas medicinales}

Una gran diversidad de plantas del bosque eran usadas por los Chácobo con fines medicinales. Los informantes de Boom mencionaron 174 especies, pero no indicaron exactamente como se usaban cada una de ellas. En general se describió el uso de una cocción hervida de hojas, cortezas o frutos para curar enfermedades del cuerpo. A veces se indicó la aplicación del recurso (hoja, corteza, latex, resinas, frutos) directo en la región del cuerpo que fue afectada, en particular en casos cuando se usaba látex u otros extractos de plantas. Sin embargo, Boom no encontró un verdadero curandero entre los Chácobo con el "espacio" que pudiera corroborar o complementar la información obtenida con los informantes. El conocimiento de plantas medicinales estaba particularmente vivo solamente entre los informantes mas viejos que entrevistó, un indicativo de que el conocimiento de medicina tradicional ya estaba en proceso de perderse. Como así la documentación y diseminación de este conocimiento entre la población presente pueda ser de mayor importancia.

\section{Plantas medicinales de los Chácobo de Alto Ivon}

\section{APENDICITIS}

PTERIDOPHYTA: toriahuitaxo - Ctenitis protensa, toriahuitaxo, jinaristi - C. submar-ginalis, toriahuitaxo - Lindsaea divaricata, jihui ratsamica nishi - Polypodium bombycinum, capëtëjiquërëxë - Trichipteris procera. ARACEAE: Anthurium gracile.

\section{CONTRACEPTIVO PARA MUJERES}

MELASTOMATACEAE: xaba huicama, hocotsemo, jihui moca - Miconia tomentosa

\section{DIARREA}

PTERIDOPHYTA: xëquitaxo - Adiantum obliquum, mitahuisma - Trichomanes pinnatum. ANACARDIACEAE: nihibimi -Tapiria guianensis. ANNONACEAE: xahuisi - Guatteria discolor. ARECACEAE : xebini - Attalea phalerata. ARISTOLOCHIACEAE: carihua -Aristolochia odoratissima. BIGNONIACEAE: nishiraoxo - Arrabidea platyphylla, nishiraoxo - Lundia densiflora, xoquerapoto - Mussatia hyacinthina, nishiraoxo - Tanaecium nocturnum, michisi, mitsisitato -Clytostoma sciuripabulum. CUCURBITACEAE: cashixopa - Guarania acuminata. FABACEAE: nishi para - Genero no determinado. GESNERIACEAE: chixopaatiCodonanthe calcarata. HERNANDIACEAE: nishichanona, nisitsanona - Sparattanthelium burchllii. MARANTACEAE: manicoro, xeco joni - Ischnosiphon arouma, MYRISTICACEAE: bita - Iryanthera tessmannii. MYRTACEAE: jihui bara - Myrciaria floribunda, chuaracatoco - Psidium guajava. RUBIACEAE: nishiraoxo - Courarea hexandra, ahuaranihi - 
Psychotria lupulina, cacatao - Uncaria guianensis. SIMAROUBACEAE: cacatao - Simaba sp. VERBENACEAE: bimichëxe, jihui joxo, nisbiraoxo - Aegiphila boliviana. ZINGIBERACEAE: manihuashiri - Renealmia breviscapa.

\section{DOLOR DE CABEZA}

PTERIDOPHYTA: toriahuitaxo, jinaristi - Ctenitis submarginalis. ANNONACEAE: ANNONACEAE

ahuaramacha, bimi - Annona ambotay. POACEAE: bisto - Panicum stoloniferum, nihibimi Pharus latifolius. RUTACEAE: boxcaisini - Galipea trifoliata.

\section{DOLOR DE DIENTES}

MENISPERMACEAE: cashixopame - Cissampelos andromorpha. MORACEAE: quëototi - Chlorophora tinctoria. MYRTACEAE: Myrcia sp. PIPERACEAE: rarama, rarasa - Piper aleyreanum, xëquijahehua, rarasa - P. callosum, nibosa - P. darienense, rarasa - $P$. multiplinervium. POACEAE: bisto - Paradiolyra micrantha. RUBIACEAE: ahuaramacha Palicourea brachyloba, ahuaramacha, bimichëxe - P. grandifolia.

\section{DOLOR DE ESTOMAGO}

PTERIDOPHYTA: jonotasi - Asplenium pearcei, cashimetsisi - Lomariopsis japurensis, cashimetsisi - Microgramma megalophyllum, jonotasi - Polypodium brevifolium. ANACARDIACEAE: nihibimi - Tapiria guianensis. APOCYNACEAE: yoxanameticato Fosteronia acouci, nishi - Mandevilla bracteosa. ARECACEAE: canahuanima-Bactris humilis. BURSERACEAE: toxa - Crepidospermum goudotiana. CHRYSOBALANACEAE: chana, cascara yobini, mehi - Licania octandra. CYPARECEAE: pacaxachi - Scleria myriocarpa. DILLENIACEAE: pexcanishi - Davilla nitida. EUPHORBIACEAE: mamamaxë - Aparisthmium cordatum. FLACOURTIACEAE: ihuipama, yobiberoxoco, chana jisicato - Casearia combaymensis, cascayobini - C. javitensis. HIPPOCRATEACEAE: nishi - Anthodon decussatum. LAURACEAE: comayobini - Endlicheria macrophylla, yobini - Nectandra cuspidata, cascara yobini - Ocotea longifolia. MALPIGHIACEAE: yahuatao - Tetrapteris crispa. MELASTOMATACEAE: bimichëxe, hocotsemo - Miconia affinis, hocotsemo - M. nervosa. MYRTACEAE: jihui bara - Myrciaria floribunda. POLYGALACEAE: nihijoa - Polygala acuminata. RUBIACEAE: osho, nihipëhi, yonishi - Amaioua guianensis, jasini nihi, bimitsexejoni - Bertiera guianensis. RUTACEAE: rimo - Citrus aurantifolia. SIMAROUBACEAE: tararí - Simaba sp. VERBENACEAE: camanonihi - Stachytarpheta cayennensis. VIOLACEAE: caiosho - Rinoreocarpus ulei. 
BOOM ВM. 1987, Etnobotánica de los Chácobo (Beni, Bolivia)

\section{DOLOR DE OÍDOS}

ARALIACEAE: nahuabexe - Schefflera morototoni.

\section{DOLOR DE PECHO}

MELASTOMATACEAE: xaba huicama, hocotsemo, jihui moca - Miconia tomentosa, bimichëxe - Tococa subciliata. ARECACEAE: panabi - Euterpe precatoria.

\section{FIEBRE}

PTERIDOPHYTA: mitaisi - Adiantum glaucescens, A. lucidum. ARECACEA: quëboitsama - Oenocarpus mapora, onipa - Socratea exorrhiza. FABACEAE: mani - Apuleia molaris. PIPERACEAE: xëquijahehua, rarasa - Piper caliosum. RUBIACEAE: xahuisi - Palicourea grandiflora, bimichëxe, taxabahueti - Psychotria prunifolia. STAPHYLEACEAE: toxa - Stapylea occidentalis.

\section{GRIPE}

EURPHORBIACEAE: bahuarexa - Acalypha arvensis. FABACEAE: isnëpa - Poeppigia procera. VERBENACEAE: bahuarexa - Lantana cujabensis.

\section{HEPATITIS}

ANNONACEAE: tetëmëtoijoni, tetemetsisi - Xylopia peruviana. CUCURBITACEAE: nainishi - Gurania lobata. LAURACEAE: Ocotea longifolia. MELIACEAE: tetemetsisi - Guarea macrophylla, MYRTACEAE: jihui bara - Myrciaria floribunda. OCHNACEAE: xahuisi - Ouratea macrobotrys. RUTACEAE: nahuabexë, paxahini - Metrodorea flavida. SOLANACEAE: yahuatahua - Cestrum strigillatum, shia - Solanum proteanthum, cashixopa - Solanum pensile.

\section{HIPERACTIVIDAD}

PTERIDOPHYTA: xëqui jahuehua - Lindsaea lancea.

\section{INFECCIÓN DE OJOS}

BIGNONIACEAE: berochexati - Haplolophium rodriguesii. ELAEOCARPACEAE: xahuamachi Sloanea eichleri. MALPIGHIAICEAE: bero nihi - Tetrapterys crispa. RUBIACEAE: bimichëxe - Psychotria poeppigiana

\section{INFECCIONES DE PIEL}

ANNONACEAE: ahuaramacha, bimi - Annona ambotay. APOCYNACEAE: chachama - Aspidosperma magalocarpon, bahuaquexti - Tabernaemontana linkii, quisi, yotabi 
-Woytkowskia spermatochoida. ASTERACEAE: ororotso - Porophyllum rudeale. BIGNONIACEAE: huëtanihi - Amphilophlum paniculatum. BURSERACEAE: xanojoxo, behisili corihua - Protium unifoliatum. COSTACEAE: shico - Costus scaber. EUPHORBIACEAE: piri Mabea longifolia, chimo - Omphalea diandra. MYRTACEAE: pin - Myrcia paivae. PIPERACEAE: rarama, rarasa - Piper aleyreanum, rarasa - P. arboreum, rarasa, rarahuëtsa - P. bartlingianum, rarama - P. nigrispicum. RUBIACEAE: yoshapo, baiahua jihui - Calycophyllum acreanum, batahua - Capirona decorticans, huicama, maiyochi - Faramea corymbosa, bimichëxe, taxabahueti - Psychotria prunifolia. SOLANACEAE: yobini - Solanum placitum. ULMACEAE: merabi - Trema micrantha. VOCHYSIACEAE: sipame, jihui coshi - Vochysia vismiifolia.

MALESTAR

APOCYNACEAE: chachama - Aspidosperma megalocarpon.

\section{BORO (MOSCARDÓN)}

APOCYNACEAE: bahuaquexti - Tabernaemontana linkii. MORACEAE: moro, yomëno - Ficus obtusifolia

\section{NIÑOS FRÁGILES}

ARACEAE: nihixoni - Syngonium yurimaguense. POACEAE: huasimapoa, carnario jachocoti - Streptogyna americana. TILIACEAE: moxoque, paro - Apeiba tibourbou.

\section{PICADURA DE INSECTOS}

NYCTAGINACEAE: shishoitsa - Genero no determinado.

\section{PICADURA DE VÍBORA}

PIPERACEAE: - rononihi - Peperomia pelluida. RUBIACEAE: batahua - Capirona decorticans.

\section{REUMATISMO}

PTERIDOPHYTA: mitaisi - Adiantum lucidum, xëquitaxo - A. obliquum.

ANACARDIACEAE: maca - Mangifera indica, ANNONACEAE: ahuaracato - Cymbopetalum brasiliense. APOCYNACEAE: jihui bepia - Genero no determinado. BIGNONIACEAE: pitsopi Jacaranda copaia. BIXACEAE: maxë - Bixa orellana. BORAGINACEAE: pabojoni - Cordia nodosa. BROMELIACEAE: capetejiquerexe - Aechmea angustifolia. CHRYSOBALANACEAE: chana, chana joni - Hirtella pilosissima. COMMELINACEAE: manihuashiri - Commelinopsis glabrata. CONNARACEAE: maxëjoni - Rourea camptoneura. CYPERACEAE: pacaxachi - Diplasia karataefolia. EUPHORBIACEAE: rare - Ricinus communis. FABACEAE: samomaquexti - 
BOOM BM. 1987, Etnobotánica de los Chácobo (Beni, Bolivia)

Senna macrophylla. FLACOURTIACEAE: moxoque - Casearia mariquitensis. HELICONIACEAE: tsacahuico - Heliconia hirsuta. MALPGHIACEAE: nishi coshi - Mascagnia benthamiana. MORACEAE: pamaxacaya, pamaxoco - Pseudolmedia macrophylla. MYRISTICACEAE: cotibi, xahuisi - Onychopetalum periquino. MYRTACEAE: bisatamane, jënëomacabëro Eugenia sp. NYCTAGINACEAE: bimichexei - Neea ovalifolia, shishoitsa - otra de genero no determinado. SAPOTACEAE: toroquerhina, tiorocoriba, xaxojihui - Micropholis guyanensis. VERBENACEAE: bimichëxe, jihui joxo, nisbiraoxo - Aegiphila boliviana.

\section{VóMITO}

ANNONACEAE: ahuaramacha, bimi, jeneaxahua - Guatteria discolor. GESNERIACEAE: chixopa-ati - Codonanthe calcarata. HERNANDIACEAE: nishichanona, nisitsanona Sparattanthelium burchellii. MARANTACEAE: manicoro, xeco joni - Ischnosiphon arouma. MYRISTICACEAE: bita - Iryanthera laevis, bita, mëquenebila - I. juruensis. MYRTACEAE: jihui bara-Myrciaria floribunda. RUBIACEAE: ahuaranihi - Psychotria lupulina. SIMAROUBACEAE: tararí - Simaba sp.

\section{ENFERMEDADES NO ESPECIFICADAS}

PTERIDOPHYTA: jorojina - Trichomanes vittaria. ANNONACEAE: rononosebi, ahuaracatoco Annona hypoglauca. BIGNONIACEAE: nananihi - Pyrostegia dichotoma. BORAGINACEAE: carapënishi - Tournefortia paniculata. FABACEAE: nishipara - Bauhinia guianensis, isnepa - Machaerium multifoliolatum. FLACOURTIACEAE: chaxohuitaxo, comacoro, iscochai - Lindackeria paludosa. MALPIGHIACEAE: cano - Lophopterys occidentalis. MELASTOMATACEAE: jahuarara, bimichëxe, shoxapo - Miconia splendens, pabojoni - Tococa guianensis. MONIMIACEAE: shishohuitsa - Siparuna krukovii. MORACEAE: xoquëshëquërë Sorocea guilemiiana. RUBIACEAE: bimichëxe - Faramea capilipes, ahuaramacha - Palicourea quadrifolia, huaranihi - Psychotria racemosa. SMILACACEAE: nishi, patiarijomoxa - Smilax poeppingii. SOLANACEAE: bimitsexejoni - Lycianthes glandulosa, STERCULIACEAE: nohote Theobroma speciosum. ULMACEAE: yahuatao - Celtis morifolia. VITACEAE: nainishi - Cissus erosa. 


\section{Plantas venenosas}

Las cinco especies de plantas venenosas identificadas eran usadas en la pesca debido a su toxicidad. El látex de Odontadenia laxiflora (Apocynaceae) fue aplicado en puntas de flechas para atrapar peces en aguas profundas. Derris floribunda (Fabaceae) fue hasta cultivada para la pesca, mientras que Derris amazónica, Serjania lethalis y Serjania pyramidalis (Sapindaceae) eran recolectados solamente en el bosque. De estas 4 especies se maceran los tallos molidos en agua poco profunda durante la temporada seca para sofocar los peces, cuales se colecto cuando vinieron al superficie. En el 2010 practicamente se ha descartado el uso de veneno procedente de plantas para la pesca.

\section{Plantas comercializadas}

Las plantas mas importantes para vender en los 1980s fueron la castaña (Bertholletia excelsa, Lecythidaceae), que se vendía por 2.500 Bolivianos por kilo (US\$ 2,50 en 1983) en el mercado de Riberalta, y cara jihui (goma, Hevea brasiliensis, Euphorbiaceae), que costaba 1.400 bolivianos por kilo (US\$1,40 en 1983). El negocio de goma fue la fuente mas importante de ingresos para los Chácobo en esta época.

En el 2010 la comercialización de algunos de estos productos ha cambiado drásticamente. La goma ya no tiene ninguna importancia como fuente de ingresos, solo se la usa tradicionalmente para fabricar algunos utensilios de uso domésticos. Sin embargo, la castaña sigue siendo el producto de venta mas importante, los Chácobo vende la castaña a compradores en las mismas comunidades, y este dinero es su principal fuente de ingresos anual.

El arroz, que en los 80's no tenia importancia económica, ahora es el segundo producto comercial mas importante generando ingresos en las comunidades Chácobo.

Basada en la comercialización de estos dos productos, la comunidad ha creado una organización que compra tanto la castaña como el arroz a todos los miembros de la comunidad, pagándoles en efectivo, y encargándose luego de comercializar estos productos en las ciudades próximas.

Un producto que recientemente esta siendo aprovechado con fines comerciales es el palmito (Euterpe precatoria, Arecaceae), que es recolectado caminando cada vez distancias mas largas y vendido a contratistas que ingresan a las comunidades para comprar grandes cantidades que entregan a las fabricas enlatadoras de las Guayaramerín y Riberalta (las dos ciudades cercanas mas grandes).

\section{Otras plantas}

Un gran numero de plantas reportadas como útiles no fueron incluidas en las categorías de uso empleadas por Boom, por ejemplo Annona ambotay (Annonaceae) que se amarran en 
las muñecas de los niños para incrementar su fuerza; los tallos, corteza y hojas de Apeiba tibourbou (Tiliaceae), Cissus rosea y Cissus sicyoides (Vitaceae) que eran añadidos a al caucho crudo para espesarlo, y Dichorisandra hexandra (Commelinaceae) que era considerada como planta mágica para el amor.

\section{La importancia del bosque para la vida Chácobo}

Brian Boom hizo el inventario completo de todos los árboles mayores a $10 \mathrm{~cm}$ diámetro a la altura de pecho en una parcela de $10 \times 1.000 \mathrm{~m}$ cerca de Alto Ivon. Encontró 649 individuos de 94 especies de árboles. El 82\% de las especies, o 95\% de los árboles tuvieron algún uso por parte de los Chácobo, que significa que el bosque hasta en esta época tuvo una importancia muy alta para el pueblo, y que el conocimiento de la diversidad fue tremendamente alto. La única especie comercialmente usada fue Hevea brasiliensis (goma, Euphorbiaceae), aunque la castaña (Bertholletia excelsa, Lecythidaceae) creció muy cerca pero fuera de la parcela. De los árboles encontrados 14 especies con 163 individuos sirvieron como leña, 33 especies con 264 individuos tuvieron frutos comestibles, 23 (225 individuos) estaban útil para construcción e artesanía, y 23 especies con 271 individuos tuvieron propiedades medicinales. 


\section{BIBLIOGRAFIA}

BOOM, B.M. 1985a. Amazonían Indians and the bosque environment, Nature 314:324

BOOM, B.M. 1985b. Advocacy botany for the neotropics. Garden 9(3): 24-28; 32

BOOM, B.M. 1985d. A new combination in Palicourea (Rubiaceae: Psychotrieae) with ethnobotani-cal notes from Amazonían Bolivia. Brittonla 37:209-210

BOOM, B.M. 1985c. Ethnopteridology of the Chácobo Indians in Amazonían Bolivia. Amer. Fern Jour. 75(1): 19-21

BOOM, B.M. 1986a. A bosque inventory in Amazonían Bolivia Blotroplca 18:287-294

BOOM, B.M. 1986b. The Chácobo Indians and their palms. Principes 30:63-70

BOOM, B.M. 1987. Ethnobotany of the Chácobo Indians, Beni, Bolivia. Adv. Econ. Bot. 4:1-68

CARDUS, J. 1886. Las misiones Franciscanas entre los infieles de Bolivia: descripción del estado de ellas en 1883 y 1884 con una noticia sobre los caminos y tribus salvajes. Barcelona.

CARNEIRO, R.L. 1978. The knowledge and use of rain bosque trees by the Kuikuru Indians of Central Brazil. En: R.I. Ford, ed. The Nature and Status of Ethnobotany, Ann Arbor: University of Michigan. Press.

DAVIS, E.W. 1983. The Ethnobotany of chamairo; Mussatla hyacinthina. Jour, of Ethnopharmacology 9:225-236.

HAENKE, W. 1985. The Chácobo in Bolivia. Ethnos 23:100-125.

HOLMBERG, A.R. 1950. Nomads of the long bow. Washington: Smithsonian Institution,

KELM, H. 1972. Chácobo 1970; Eine Restgruppe der Sudost-Pano em Oriente Bolivíens. Tribus 21: 129-246.

KENSINGER, K.M. s.d. Panoan linguistic, folkloristlc and ethnographic research. Unpublished manuscript.

LEVI-STRAUSS, C. 1950. The use of wild plants in tropical South America. En: J.H, Steward, ed. Handbook of South American Indians 6:465-486.

LEWIN, R, 1984. Parks: how big is big enough? Science 225:611-612.

MASON, J.A. 1950. The languages of South American Indians. En: J.H. Steward, ed. Handbook of South American Indians 6:157-318.

MAY, R.M. 1984. Prehistory of Amazonían Indians. Nature 312:19-20

METRAUX, A. 1948. The Southeastern Panoan tribes. En: J.H. Steward, ed. Handbook of South American Indians 3:449-452.

NORDENSKiOLD, E. 1923. Indianer und Weisse in Nordostbotivien. Stuttgart.

OBLITAS POBLETE, E. 1969. Plantas medicinales de Bolivia; farmacopea. Callawaya. Cochabam-ba: Editorial Los Amigos del Libro.

OPORTO, L. 1981. Catálogo: materiales del instituto Lingüítico de Verano sobre grupos ëtnicos de Bolivia: 1955-1980. La Paz: Centro de Documentación Antropológica.

PROST, G. 1960, Fonemas de la lengua Chácobo. Notas lingüísticas de Bolivia, No. 2. Cochabamba: Instituto Lingüístico de Verano.

PROST, G, 1962. Signalling of transitive and intransitive in Chácobo (Paño). International Journal of American Linguistics 28:108-118. 
воОМ вМ. 1987, Etnobotánica de los Chácobo (Beni, Bolivia)

PROST, G. 1965. Chácobo, En: Gramáticas estructurales de lenguas bolivianas 2:1-13. Rlberalta: Instituto Lingüístico de Verano.

PROST, M D. 1970. Costumbres, habilidades y cuadro de la vida humana entre los Chácobo. Riberana: Instituto Lingüístico de Verano.

RIESTER, J. 1975. Indians of eastern Bolivia: aspects oí their present situation. International Work Group for Indigenous Affairs (IWGIA) Document 3:43-49.

SUMMER INSTITUTE OF LINGUISTICS, s.d. 25 años de servicio al pueblo Boliviano.

TOR RICO P., B. 1971. Indígenas en el corazón de Amërica. La Paz; Los Amigos del Libro.

UNZUETA Q,. 0.1975. Mapa Ecológico de Bolivia. Memoria explicativa. La Paz: Ministerio de Asuntos Campesinos y Agropecuarios

VICKERS, W.T. 1977. External models and native adaptations; missionaries and tropical bosque Indians in Ecuador. Trabajo no publicado presentado al 76 Annual Meeting of the American Anthropological Association, Houston, Texas (1 de diciembre de 1977).

VICKERS, W.T. \& T. PLOWMAN. 1984. Useful plants of the Siona and Secoya Indians of Eastern Ecuador. Fleldiana, Bot. New Series, No. 15:1-61 


\section{CAPITULO 6}

\section{USO DE LAS PLANTAS POR LOS CHÁCOBOS (ALTO IVÓN, BENI, BOLIVIA) \\ SYLVIE BERGERON, 1998}

ESTE CORRESPONDE AL TRABAJO ORIGINAL, EL INFORME FINAL, DEL PROYECTO DE INVESTIGACIÓN 


\section{Contenido}

Prólogo 233

Agradecimientos $\quad 234$

RESUMEN 236

Introducción 238

La importancia de los conocimientos tradicionales

para el desarrollo sostenible de Bolivia 238

El papel de la etnobiología en la valoración de los conocimientos tradicionales $\quad 239$

Descripción del área de estudio $\quad 240$

Los Chácobos: Aspectos históricos y socio-económicos $\quad 240$

Aspectos metodológicos $\quad 246$

Los estudios florísticos y etnobotánicos $\quad 247$

Estructura de "El uso de las plantas por los Chácobos" 251

Capítulo 1:

La Diversidad Florística del Bosque de Tierra Firme de Alto-Ivón 253

Altura y estratos del bosque 253

Distribución de los diámetros de los árboles y palmas de la parcela $\quad 253$

Riqueza específica del Bosque de Tierra Firme en Alto Ivón 254

Abundancia de las especies $\quad 255$

El índice de valor de importancia (IVI) 261

\section{Capítulo 2:}

La Clasificación de las Plantas por los Chácobos 265

Principios básicos de la clasificación etnobiológica 265

Característica de la clasificación botánica de los Chácobos 267

$\begin{array}{ll}\text { Los ambientes y las formas de vida } & 267\end{array}$

Los diferentes grupos de plantas $\quad 268$

Nomenclatura y significación de los nombres de las plantas 292

Nomenclatura de los nombres Chácobos 292

\section{Capítulo 3:}

El uso de las plantas por los Chácobos 294

El uso general de las plantas por los Chácobos 296

Al nivel de todos los ambientes $\quad 301$

Los diferentes tipos de plantas utilizadas (tipos biológicos) 301

Al nivel de cada uno de los ambientes 302

Las plantas utilizadas por los Chácobos según su categoría de uso 309

Plantas utilizadas para la caza y la pesca 309

Plantas comestibles $\quad 311$

Plantas utilizadas en la construcción 313

Plantas que sirven para la leña y/o astillas $\quad 315$

Plantas medicinales $\quad 316$

Plantas que tienen otros usos 328

Plantas que tienen varios usos (multi-uso) 331

\section{Capítulo 4}

Guía Popular de las Plantas Chácobo 338

Conclusión $\quad 377$

La clasificación de las plantas por los Chácobos $\quad 379$

El uso de las plantas por los Chácobos 381

Bibliografía $\quad 384$ 


\section{Prólogo}

"El uso de las plantas por los Chácobos (Alto Ivon, Beni, Bolivia)" es parte de un proceso de intercambios entre las culturas tradicional y occidental, donde se trata de valorizar los conocimientos que tienen las etnias indígenas a cerca de las plantas, sus usos, y los sistemas de clasificación tradicional.

Para ilustrarla importancia de los conocimientos indígenas en nuestra sociedad, se ha considerado el caso particular del uso de las plantas por los Chácobos, (etnia amazónica boliviana de la provincia Vaca Diez, departamento del Beni), restringiendo el estudio a la comunidad de Alto-Ivón, donde vive la mayoría de los indígenas pertenecientes a esta etnia.

"El uso de las plantas por los Chácobos (Alto Ivon, Beni, Bolivia)" constituye una síntesis de diversos trabajos de investigación. Por otra parte, es el resultado de un estudio realizado durante más de seis meses a lo largo de dos años, en el cual los comunarios Chácobos han expresado, con toda confianza y generosidad, sus conocimientos a cerca de su entorno vegetal.

Lo mencionado anteriormente implica que los Chácobos disponen de la información mencionada a lo largo del libro, la misma que queda como propiedad intelectual exclusiva de ellos. En otros términos, cualquier tipo de investigación que podría ser realizada a partir del presente estudio, debería involucrar directamente a los comunarios, respondiendo a sus deseos y necesidades, y asimismo, beneficiar a toda la comunidad.

Más allá de los resultados expresados en este libro, se intenta recalcar la importancia que tiene la sabiduría indígena en el mundo actual, especialmente, en el desarrollo sostenible de los bosques tropicales y la preservación de la entidad indígena. Estas metas podrán lograrse a través del acercamiento de dos escuelas distintas de conocimientos, o sea a través de intercambios de conocimientos, experiencias y tecnologías entre la cultura occidental y la cultura tradicional. 


\section{Agradecimientos}

Este libro no hubiera podido existir sin la colaboración diaria y continua de los comunarios de Alto Ivon quienes me brindaron su amistad y apoyo durante todo el periodo de estudio. Quiero expresarles mis profundos agradecimientos y reconocimientos por su colaboración y su paciencia. Siempre les recuerdo y de donde sea, me acuerdo de los momentos que hemos compartido juntos en su comunidad, y que en la vida de un investigador, no pueden nunca olvidarse.

Quiero expresar mis agradecimientos especiales a los comunarios Barí Ortiz, Jeri Ortiz, Cana Soria, Caco Ortiz, por su apoyo, confianza, paciencia y dedicación, día tras día, en el estudio etnobotánico y la sistematización de sus tan valiosos conocimientos. A ellos, muchas gracias por los momentos de alegría compartidos, aún a veces, en las condiciones difíciles que representaron, los estudios de campo.

Agradezco a Rabí Ortiz quien nos permitió realizar este estudio y quién se encargó de la coordinación del trabajo de campo a lo largo de los seis meses pasados en Alto-Ivón.

Por último, agradezco a todos los comunarios (hombres, mujeres y niños), quienes me brindaron su amistad y su confianza durante mi estadía en la comunidad.

De la misma manera agradezco al antropólogo Philippe Erikson, a su esposa Heléne, por su colaboración a lo largo de la realización del estudio, y por su amistad que va más allá del estudio de campo.

Agradezco a la Misión Evangélica Suiza de Riberalta, por haberme apoyado en la parte logística a, a lo largo de las salidas de campo.

Por otro lado, este estudio no hubiera podido realizarse sin el apoyo logístico y económico del Instituto Francés de Estudios Andinos
(IFEA) y quiero agradecer especialmente a su coordinador Christian Demuizon quién me brindó su apoyo a lo largo de los dos años de cooperación con esta institución.

Quiero agradecer especialmente a Michel Sauvain del "Instituí Frangais de Recherche Scientifíque pourle Développement en Coopération " (ORSTOM), y Mireille Hontebeyrie (Instituto Pasteur), quienes me acogieron en el Instituto de Biología de Altura (IBBA) de La Paz, y me brindaron su amistad, confianza, durante todo el estudio, y más allá de mi estadía en esta institución. Gracias a Michel Sauvain pude realizar este estudio, me colaboró día tras día en todas las fases del trabajo tanto de gabinete como de campo.

Un agradecimiento especial al Instituí Frangais de Recherche Scientifíque pour le Développement en Coopération " (ORSTOM) y particularmente a Christian Moretti por su apoyo seguido tanto en Bolivia como desde Francia en la realización de este trabajo.

La identifícación botánica pudo realizarse gracias al Herbario Nacional de Bolivia de La Paz (HNLPB). Agradezco especialmente a Stephan Beck, por su apoyo, sus consejos y su dedicación en la revisión de más de ocho cientas muestras vegetales. Quiero agradecer a Emilia García por haberme facilitado el acceso al herbario durante mi estadía en Bolivia, a Tim Killeen, Rosy Michel, Mónica Moraes, Luis Rea, Lurdes Vargas, y Ester Estensoro por su colaboración en las identifícaciones botánicas. Agradezco a los demás miembros del herbario quienes me brindaron su amistad, y gracias a quienes las plantas han podido ser montadas y sistematizadas en el herbario. 
Expreso mis sinceros agradecimientos a Geneviéve Bourdy (ORSTOM), por su participación en la revisión y corrección de la versión definitiva del libro así como por el seguimiento a las identificaciones botánicas. De igual manera, agradezco a Eric Deharo (ORSTOM) y a Alberto Gimenez (Instituto de Investigación Farmacobioquímicas, IIFB) por el seguimiento que han dado a las muestras farmaco-bioquímicas.

Sin el apoyo del Fondo Nacional de Medio Ambiente (FONAMA), no hubiera existido el capítulo de la guía popular de las plantas de los Chácobos y por ello expreso mis agradecimientos a esta identidad.

Quiero agradecer a las instituciones auspiciadores que han podido hacer posible la edición de este libro. Expreso mis sinceros agradecimientos a CIDDEBENI, particularmente a la responsable de la Unidad de Investigación y Planificación, Zulema Lehm, y a su director Carlos Navia, quienes me han brindado su apoyo y confianza a lo largo de los tres años pasados en la institución. Gracias a ellos por haberme permitido adquirir los conocimientos y la experiencia que hoy tengo respecto a la problemática indígena. Agradezco a OXFAM-América y CIDDEBENI por su apoyo en la elaboración de este libro.

Finalmente, a todas las personas $y / 0$ instituciones que de una u otra manera quienes han participado a la ejecución de este trabajo. 


\section{RESUMEN}

"El uso de las plantas por los Chácobos (comunidad de Alto Ivon, Vaca Diez, Beni, Bolivia)" constituye una síntesis de diversos trabajos, enmarcados en proyectos de investigación financiados por el Instituto Francés de Estudios Andinos (IFEA), el Fondo Nacional para el Medio Ambiente (FONAMA), y OXFAM América (a través del Centro de Investigación y Documentación para el Desarrollo del Beni, CIDDEBENI). Más allá del contenido de este libro, se intenta recalcar la importancia que tiene la sabiduría indígena en el desarrollo sostenible de los bosques tropicales y la preservación de la entidad indígena.

El trabajo de investigación, llevado a cabo entre los años 1992 y 1994, con una permanencia de 6 meses en el campo a lo largo de 1992-1993 permitió: conocer la diversidad florística de la formación vegetal de mayor importancia para los Chácobos (el bosque de tierra firme); Conocer el sistema tradicional de clasificación de las plantas; Conocer el uso de las plantas en cada formación vegetal existente en el área de Alto - Ivon; Elaborar una guía popular de cincuenta plantas utilizadas por los Chácobo.

Asimismo, se estimó la diversidad florística del bosque de tierra firme de Alto - Ivon, a través de una muestra de una hectárea (parcela permanente) en la cual se numeraron, recolectaron e identificaron todos los árboles, bejucos y palmas con diámetro igual o superior a $10 \mathrm{~cm}$. Por otra parte, se realizaron colectas generales en diversas formaciones vegetales tales como bosque de tierra firme, bosque ribereño, barbechos o (bosque secundario) de diferentes edades así como sabana húmeda (pampa). A partir de la información recogida en el campo y la identificación botánica de las muestras vegetales, se seleccionaron 50 plantas en base a varios criterios como frecuencia, abundancia, uso, identificación botánica completa de las plantas, las mismas fueron descritas en detalle en una guía de uso de las plantas de los Chácobo.

"El uso de las plantas por los Chácobos" está conformado por 4 grandes capítulos, además de la introducción y conclusión:

La introducción en la cual se presentan conceptos de la etnobotánica enmarcada en el desarrollo sostenible, el área de Alto Ivon, con su población y sus diversos ambientes, y los aspectos metodológicos.

- El capítulo 1 presenta los resultados sobre la diversidad florística del bosque de tierra firme de Alto - Ivon.

- El capítulo 2 describe el sistema de clasificación de las plantas de los Chácobos tomando como referencia los trabajos de Berlín Brent (1972).

- El capítulo 3 presenta de manera cuantitativa y cualitativa el uso de las plantas por los Chácobos, según diversas categorías de uso definidas arbitrariamente.

- El capítulo 4 hace una descripción detallada de 50 plantas seleccionadas con sus caracteres

morfológicos, hábitat, grado de abundancia, usos y modos de utilización.

Por último, se destacan en la conclusión los resultados más importantes, y se hacen unas recomendaciones específicas a los 3 primeros capítulos.

Como principales resultados, podemos mencionar lo siguiente:

- El bosque de Alto-Ivón es un bosque no muy alto. La riqueza específica es bastante elevada (123 especies/ha) sin ser tan importante como en otras áreas amazónicas. El área basal ( $\pm 27 \mathrm{~m} 2 /$ hectárea) es poco elevado, explicándose en parte por la gran abundancia de la herbaceae Phenakospermum guianensis. Los Moraceae, Myristicaceae, Palmae, Caesalpiniaceae y Papilionaceae son las 5 familias más importantes del bosque de Alto-Ivón. Las 8 especies realmente características de la comunidad vegetal representan el $36 \%$ del VI total: Pseudolmedia laevis, Iryanthera juruensis, Socratea exorrhiza, Perebea aff. acutifolium, 


\section{Bergeron S., 1998. Uso de las plantas por los Chácobos (Alto Ivón, Beni, Bolivia)}

Pseudolmedia macrophylla, Micropholis guyanensis, Horda sp., Helicostylis tomentosa.

- De las 530 plantas abarcadas en el capítulo 2 , solamente seis eran desconocidas por los Chácobo, y se han distinguido claramente 70 grupos de plantas:

- La clasificación tradicional puede basarse en criterios morfológicos, (47 grupos responden a este sistema). Las plantas están agrupadas por tener semejanzas por ejemplo, en la forma del árbol, hierba o bejuco, en la forma de las hojas o de las frutas. Este tipo de clasificación se encontró mayormente en el caso de los árboles y en segundo lugar, para las hierbas. Dentro este mismo modelo de clasificación, se han distinguido tres formas posibles de distribución, la tercera encontrándose más frecuentemente. También, la clasificación puede basarse en otros tipos de criterios ( 23 grupos de plantas), como el uso mismo de las plantas, o una característica especial de la planta (madera dura, corteza amarga, entre otras características).

- El análisis, aunque superficial, de los nombres Chácobo ha demostrado una gran variabilidad respecto a la nomenclatura de los nombres. Muchas veces, para un mismo grupo, los nombres de las plantas tienen una raíz común. Ocurre también que para plantas del mismo grupo, los nombres no tienen una raíz común. Por otro lado, una misma planta puede ser nombrada de diferentes maneras.

- En cuanto a la significación de los nombres Chácobo, el nombre de la planta puede ser su nombre propio sin poder ser traducido en castellano. También puede basarse en función de sus características morfológicas, en su uso, en una semejanza o en una relación que existe entre la planta y un animal.

- Sobre un universo de 472 diferentes plantas distinguidas por los Chácobos, y recolectadas para muestras botánicas, el $68 \%$ tiene uso, y de estas plantas, el $15 \%$ se utiliza para varios fines (multi-uso). Los Chácobos aprovechan todos los ambientes, probablemente con mayor o menor intensidad. Por lo general, todos los tipos biológicos (árboles, arbustos, bejucos, y hierbas) se utilizan. Los árboles y arbustos entran en todas las categorías de uso, salvo, respectivamente, caza y pesca, y construcción. Por otro lado, los bejucos y palmas también tienen un uso diversificado (sirven para varios fines), mientras que las hierbas son más utilizadas para caza y pesca así como, medicina.

- Las plantas medicinales son las que más se encontraron, luego aparecen las plantas comestibles, plantas que sirven para construcción, pesca, leña y astillas, las otras plantas siendo utilizadas en proporciones menores para otros fines. Por otro lado, muchas de las plantas registradas pueden tener varios usos, siendo el uso comestible y medicinal, más común. Los Chácobos se sirven de las plantas medicinales para luchar contra los parásitos, los problemas de estómago, vómitos, diarreas, así como los problemas de cicatrización de la piel o inflamaciones debidas a picaduras de insectos. El modo de preparación consiste en 2 formas principales dependiendo de la enfermedad: decocción de la corteza, o en aplicación directa sobre la piel a través de las cenizas o exudado de corteza.

- Por otro lado, se destacan en este estudio, las plantas que sirven para pescar o cazar, que pueden ser "barbascos" (método frecuentemente utilizado para la pesca) o que tienen una acción "indirecta", considerándose como plantas "mágicas".

Por último cabe mencionar que los Chácobos, a través de un contacto diario con la selva amazónica, han acumulado conocimientos que se han transmitido de generación a generación a través del paso de los siglos. Esos conocimientos representan un saber general al nivel familiar y al nivel de la comunidad. 


\section{Introducción}

\section{La importancia de los conocimientos tradicionales para el desarrollo sostenible de Bolivia}

Por sus aspectos geográficos, climáticos, y ecológicos muy especiales, Bolivia se caracteriza por una amplia gama de formaciones vegetales, y una diversidad biológica muy grande. Se estima la riqueza florística de este país entre 18000 y 20 000 especies (Solomon, 1989, citado por Moraes y Beck, 1992: 87), lo que representa aproximadamente el $21 \%$ de la flora neotropical. Por otro lado, debido a que la cultura occidental no ha sido totalmente asimilada, Bolivia mantiene sus fuertes raíces tradicionales quedándose como uno los países sudamericanos con mayor población indígena.

Asimismo, el Beni constituye uno de los nueve departamentos del país, donde se concentra mayor diversidad biológica y cultural. En esos hábitats tan diversos, viven poblaciones indígenas de origen y familia lingüística diversas. A lo largo de los siglos, esas poblaciones han venido acumulando conocimientos y experiencias transmitidos de generación a generación, los mismos que les han permitido vivir de manera armónica con su entorno, utilizando por ejemplo las plantas como recursos principales (Bergeron, 1995: 1). Sin embargo, por los programas y acciones de desarrollo aplicados en el país, basados principalmente en la extracción y explotación de los recursos naturales, y no siempre apropiados a los contextos regional y nacional, las etnias indígenas se ven enfrentadas cada día más, a problemas múltiples que tienen repercusiones al nivel ambiental, como social y cultural. Asimismo, los cambios que se producen al nivel de los sue- los, recursos hídricos y biológicos, vienen induciendo una degradación del medio ambiente y por lo tanto, una pérdida de la diversidad biológica. Paralelamente, las poblaciones indígenas tienen que enfrentarse al éxodo rural, a los procesos de marginalización y de aculturación, a los daños que afectan su economía de subsistencia, y que les hacen depender del mercado y de la competición; al mismo tiempo se ven desamparadas frente a nuevas enfermedades, las cuales son provocadas por la aparición o al aumento de insectos vectores (Kroeger, et al. 1982:225).

Reflexionando un poco más sobre esos aspectos, nos enfrentamos a que cada día más, la sabiduría indígena se está extinguiendo, paralelamente, especies de plantas y animales están desapareciendo, y con aquello, todo un patrimonio genético, indispensable para la sobrevivencia de la humanidad.

Afortunadamente, después de varios años, se intenta llegar a una toma de conciencia en cuanto a la protección de los bosques tropicales, la conservación de la biodiversidad (UICN et al., 1980,1991), así como al reconocimiento a los derechos de los pueblos indígenas.

Asimismo, si se quiere preservar la identidad indígena, los conocimientos tradicionales, así como, conservar los recursos naturales y por lo tanto, la biodiversidad, es imprescindible involucrar tanto a la cultura tradicional como a la cultura occidental en el proceso de desarrollo sostenible, el cual podrá lograrse en parte, a través de inter- 
cambios de conocimientos, experiencias y tecnologías entre ambas culturas. Una de las primeras etapas necesarias para lograr el acercamiento de esas dos escuelas de sabiduría, radica en el conocimiento y en la comprensión del saber inherente a cada una de ellas, respecto a la naturaleza que la rodea.

\section{El papel de la etnobiología en la valoración de los conocimientos tradicionales}

Existen varias disciplinas cuyos campos de acción enfocan a los conocimientos de las sociedades tradicionales y las relaciones Hombre-Naturaleza. Entre ellas, se encuentra la etnobiología que, como lo indica su nombre, “...combina intuición, conocimientos y conceptos de dos disciplinas que son la antropología y la biología. Del mismo modo, tiene campos de acción muy amplios ya que se refiere a las relaciones que existen entre plantas y/o animales y las sociedades humanas presentes o pasadas..." (Brent, 1992: 4).

A lo largo de la historia, la etnobiología tuvo varias corrientes, los cuales son expuestos por Brent (1992: 4-5) de la manera siguiente:

"La etnobiología remonta a finales del siglo XVIII en Estados Unidos y hasta la primera mitad del siglo XIX, se definía como "la utilización de las plantas y animales por la gente primitiva" (Harshburger, 1896).

Luego, el etnógrafo Harrington (1947), en sus estudios sobre las plantas, dio más énfasis al concepto económico cuando afirmó: "una pequeña parte del estudio etnobotánico consiste en la determinación de los nombres nativos de las plantas y de los sistemas de clasificación, la otra parte del estudio, más importante, consiste en la determinación de los usos de las plantas a manera de conocer la cultura de la gente por un lado y por el otro lado las plantas alimenticias y medicinales. Los resul- tados de estos estudios eran, por lo general, listas de uso".

Las respuestas a las preguntas respecto a cómo los seres humanos van y perciben las plantas y animales y cuáles son las relaciones entre el Hombre y su entorno, vinieron esencialmente de la antropología y psicología. Estos aspectos fueron claramente definidos por Conklin (1954) en su tesis doctoral y a partir de esta investigación, los aspectos más utilitarios y más económicos de la etnobiología fueron considerados como secundarios".

Luego, la etnobiología fue ampliamente desarrollada por Strauss (1966) y por Brent (1972, 1976a, 1973, 1978a, 1992), cuyos estudios trataron principalmente, de definir los sistemas de clasificación de las sociedades tradicionales:

"Efectivamente, la naturaleza no es percibida
como una continuidad uniforme sino como una
serie de discontinuidades cuyas estructuras y
cuyos contenidos son vistos por todos los seres
humanos de la misma manera. Sin embargo,
por los valores culturales y experiencias inher-
entes a cada sociedad, y por el hecho de que
el ser humano tiene la "necesidad intelectual"
de clasificar la naturaleza (Lévi Strauss, 1966),
las sociedades, que sean occidentales como
tradicionales (sociedades amazónicas, centro
americanas o asiáticas), tienen su propia con-
cepción de la naturaleza. Han desarrollado a
lo largo de los siglos, sistemas de clasificación
de las plantas y animales así como sistemas de
uso y de manejo del medio ambiente sobre la
base de sus propios valores culturales y expe-
riencias. Esos sistemas de clasificación de las
plantas o de los animales pueden ser generales
o más complejos, dependiendo de los posibles
parámetros de percepción y organización de la
naturaleza" (Brent 1992: 9). Hoy en día, los etnobiólogos reconocen la importancia, tanto de los conceptos económicos como, de las relaciones Hombre-Naturaleza y sistemas de clasificación de las plantas y animales. Ciertos estudios darán más énfasis al uso de las plantas desde el punto de vista económico, otros 
se enfocarán más en la concepción que tienen los seres humanos de su entorno vegetal o/y de los animales.

Asimismo, para resumir el papel de la etnobiología en las sociedades, esta ciencia permite contestar varias preguntas básicas y fundamentales para el desarrollo de cualquiera sociedad:

- ¿Cómo las sociedades conciben su entorno?,

- ¿Cuáles son los sistemas de clasificación utilizados por las sociedades respecto a la naturaleza, por ejemplo a los animales y plantas?,

- ¿Cómo las sociedades utilizan sus recursos naturales? (Brent, 1992: 8).

\section{Descripción del área de estudio}

Para ilustrar la importancia que tiene la etnobiología en el desarrollo sostenible, se consideró el caso particular de la comunidad Chácobos de Alto-Ivón (Provincia Vaca Diez, departamento Benin, Bolivia).

La etnia Chácobos, de familia lingüística Paño, merecía toda nuestra atención ya que se trata de una población indígena poco conocida, pero que se encuentra ecológica-, social, y culturalmente amenazada, debido a los procesos de deforestación existentes en esta región amazónica, y por la proximidad de la comunidad de Alto-Ivón, a la ciudad de Riberalta.

También, el área de estudio era de interés por ubicarse en una de las regiones amazónicas muy poco conocidas desde el punto de vista de la investigación botánica (Moraes, Beck, 1992).

\section{Los Chácobos: Aspectos históricos y socio-económicos}

A través de una recopilación bibliográfica realizada por Boom (1989), y a partir de otras fuentes bibliográficas como Montaño (1987), o Nordenskiold (1911; 1923) quién describió la vida cotidiana y las costumbres de los Chácobos 3 , se puede entender mejor la historia de este pueblo indígena, el cual desde tiempos históricos, ha sido bajo la influencia de presiones exteriores:

"La familia Pano a la cual pertenecen los Chácobos, fue conocida tanto desde el punto de vista lingüístico como del etnográfico, a partir de mediados del siglo XVII, principalmente por los misioneros españoles que ingresaron a la Amazonia por los derroteros del Perú. Las reducciones de estas tribus empezaron en 1802, encaradas por el franciscano Fr. Antonio Serra. Desde entonces se mencionan las agrupaciones de los Pacawaras, Capuibo, Sinabo y Chácobos. En los años 18861887, los franciscanos Fr. Nicolás Armentia (1887) y Fr. José Cardús (1886), describieron las costumbres y lenguas de estas etnias" (Montano, 1987: 1).

"De las tribus Pano existentes en la Amazonia, los Chácobos son los menos conocidos. Hasta la década de los años 50's, habían vivido fuera de la economía boliviana, en áreas aisladas sobre pequeños ríos, evitando sucesivamente los contactos externos cuando se sentían amenazados por presiones externas (Haenke, 1958). Al final del último siglo, vivían en pequeños grupos en la Amazonia del Este, dispersados entre los ríos Lago Rogoaguado y Mamoré, pero tuvieron que ir más al norte por la presión de los grupos Tacanas. Luego, a consecuencia del auge del caucho y por las epidemias, el número de grupos y de indígenas Chácobos vino reduciéndose. Según Métraux (1948), existían en 1887, dos grupos de Chácobos sobre el río Ivón, uno de seis familias, el otro de cuatro.

Haenke (1958) visitó a los Chácobos del río Benicito cuando las organizaciones religiosas y gubernamentales empezaban a tener cierto interés en la etnia. En 1953, la misión de Nuevas Tribus tuvo contacto con un pequeño grupo de Chácobos, y en 1954, al establecer 


\section{Bergeron S., 1998. Uso de las plantas por los Chácobos (Alto Ivón, Beni, Bolivia)}

la agencia indígena Nuflo de Chaves en el territorio Chácobo, el gobierno boliviano se relacionó directamente con la etnia e incitó a unas veinte-ocho personas a vivir en aquel lugar.

En 1955, el misionero Gilbert Prost y su esposa Mirian, del Instituto Lingüístico de Verano (SIL), tuvieron contacto con la etnia. En aquella época, existían cuatro grupos de Chácobos, tres a lo largo del río Benicito y uno a lo largo del rio Yata. La población total era de 135 personas, pero sin incluir la población del Yata y los grupos aislados.

En 1956, el gobierno boliviano trasladó al primer grupo que vivía cerca de Puerto Limones, a una nueva comunidad llamada "Núcleo" sobre el río Ivón. Un segundo grupo vivía sobre el río Benicito. Este grupo había migrado varias veces a lo largo de diez años, pero siempre en el área del mismo río. El tercer grupo se ubicaba arriba de Puerto Limones y el cuarto grupo vivía a lo largo del río Yata.

Los Prost se quedaron la mayoría del tiempo con el tercer grupo de Chácobos. Al ver que tenían interés en la recolección y venta del caucho (Hevea brasiliensis), planes fueron hechos para encontrar un lugar donde el caucho era más abundante. Al ir al río Ivón, en 1964, el misionero compró tierras para los Chácobos. Asimismo, los Prost y el tercer grupo de Chácobos se trasladaron de Puerto Limones al río Ivón, instalándose en un lugar que Ilamaron "Alto-Ivón"4. En 1965, el grupo de los Chácobos que vivía a lo largo del río Geneshuaya fue desplazado a "California", sobre el río Ivon a dos horas y media a pie de "Núcleo".

Prost, con deseo de conseguir para los Chácobos de Núcleo, California y Alto-Ivón, un área legalmente reconocido, hizo una propuesta al gobierno que les otorgó en 1965, un área de 43 000 ha., incluyendo los tres ceñiros. Durante los años siguientes, algunas familias Chácobos se fueron de esos lugares. Hoy en día Alto-Ivón y Núcleo quedan los centros más grandes. Un grupo sigue viviendo en el río Yata, a cuatro horas en motor del Campo Palmar.

Los Prost vivieron con los Chácobos hasta 1980, lo que resultó en la traducción en Chácobo del Nuevo testamento y varios himnos (Prost, 1960; 1965; 1970). El mismo año, el SIL fue reemplazado por la Misión Evangélica Suiza, con base en Riberalta, la misma que sigue manteniendo contactos constantes con los Chácobos".

(Boom, 1989: 79-80).

La Misión Evangélica Suiza formó a uno? profesores, un enfermero, un radioelectricista y pastores. La comunidad de Alto-Ivón comprende actualmente una escuela con dos cursos básicos y un curso intermedio, los dos primeros son en Chácobo y el último, bilingüe.

Actualmente, según el censo indígena Rural de Tierras Bajas Oriente, Chaco, y Amazonia. (SAE et al., 1994), la población total de los Chácobos5, es de 759 personas, distribuida en 404 hombres (o sea el 53.2\%), y 355 mujeres (o sea $46.8 \%$ ).

Aunque no se posee datos de la historia de la población Chácobo, y tampoco, tasas de mortalidad y natalidad, podemos hacer unos comentarios acerca de la distribución de la población según la edad y sexo (ver Tabla 1), ilustrada en el Gráfico 1:

La población Chácobo es muy joven ya que el $50.6 \%$ de la población total tiene menos de 15 años, y aproximadamente el $70 \%$ de los Chácobos son menores de 25 años. El Gráfico 1 muestra que entre 0 y 4 años, los hombres son más numerosos que las mujeres (107 hombres contra 68 mujeres), mientras que entre 5 y 9 años, la proporción de mujeres y de hombres es casi similar (60 hombres contra 63 mujeres). Este fenómeno puede explicarse por el hecho de que, si bien nacen más hombres que mujeres, es probable que la mortalidad infantil de los varones sea mayor, y muchos de ellos no lleguen a los cinco años. Por otra parte, se observa que entre 10-14 años, el número de varones es 
Bergeron S., 1998. Uso de las plantas por los Chácobos (Alto Ivón, Beni, Bolivia)

superior al número de mujeres, mientras que la situación es inversa entre 15 y 19 años. Lamentablemente, la carencia de datos no permite explicar este fenómeno. Solamente se puede formular al nivel de hipótesis que entre 15 y 19 años, los varones se van de la comunidad como fuerza de trabajo, así como por el servicio militar. En las clases de edad mayor, no se observan tanta diferencia entre el número de varones y de mujeres, excepto entre 45 y 49 años, donde el número de hombres es el doble.

También, la Tabla 1 muestra que el índice de masculinidad $(\mathrm{IM})^{6}$ respecto a la población total, es de 113.8 hombres por 100 mujeres. Este índice es muy variable según la clase de edad, en particular en los

Tabla 1: Distribución de la población Chácobos por edad y sexo

\begin{tabular}{|c|c|c|c|c|c|c|c|}
\hline \multirow[t]{2}{*}{ Rangos } & \multicolumn{2}{|c|}{ Hombres } & \multicolumn{2}{|c|}{ Mujeres } & \multicolumn{2}{|c|}{ Total } & \multirow{2}{*}{$\begin{array}{c}\mid \mathrm{M} \| \\
157.4\end{array}$} \\
\hline & No & $\%$ & No & $\%$ & No & $\%$ & \\
\hline $0-4$ & 107 & 14.1 & 68 & 9.0 & 175 & 23.1 & \\
\hline $5-9$ & 60 & 7.9 & 63 & 8.3 & 123 & 16.2 & 95.2 \\
\hline $10-14$ & 54 & 7.1 & 32 & 4.2 & 86 & 11.3 & 168.8 \\
\hline $15-19$ & 26 & 3.4 & 48 & 6.3 & 74 & 9.7 & 54.2 \\
\hline $20-24$ & 38 & 5.0 & 35 & 4.6 & 73 & 9.6 & 108.6 \\
\hline $25-29$ & 27 & 3.6 & 33 & 4.3 & 60 & 7.9 & 81.8 \\
\hline $30-34$ & 29 & 3.8 & 22 & 2.9 & 51 & 6.7 & 131.8 \\
\hline 35-39 & 16 & 2.1 & 22 & 2.9 & 38 & 5.0 & 72.7 \\
\hline $40-44$ & 10 & 1.3 & 10 & 1.3 & 20 & 2.6 & 100.0 \\
\hline $45-49$ & 16 & 2.1 & 8 & 1.1 & 24 & 3.2 & 200.0 \\
\hline $50-54$ & 3 & 0.4 & 4 & 0.5 & 7 & 0.9 & 75.0 \\
\hline 55-59 & 3 & 0.4 & 3 & 0.4 & 6 & 0.8 & 100.0 \\
\hline $60-64$ & 7 & 0.9 & 2 & 0.3 & 9 & 1.2 & 350.0 \\
\hline $65-69$ & 1 & 0.1 & 2 & 0.3 & 3 & 0.4 & 50.0 \\
\hline $70-74$ & 2 & 0.3 & 1 & 0.1 & 3 & 0.4 & 200.0 \\
\hline $75-79$ & 1 & 0.1 & 1 & 0.1 & 2 & 0.3 & 100.0 \\
\hline $80-84$ & 3 & 0.4 & 1 & 0.1 & 4 & 0.5 & 300.0 \\
\hline $85-89$ & 1 & 0.1 & 0 & 0.0 & 1 & 0.1 & \\
\hline $90-94$ & 0 & 0.0 & 0 & 0.0 & 0 & 0.0 & \\
\hline 95-99 & 0 & 0.0 & 0 & 0.0 & 0 & 0.0 & \\
\hline Totales & 404 & 53.2 & 355 & 46.8 & 759 & 100.0 & 113.8 \\
\hline
\end{tabular}

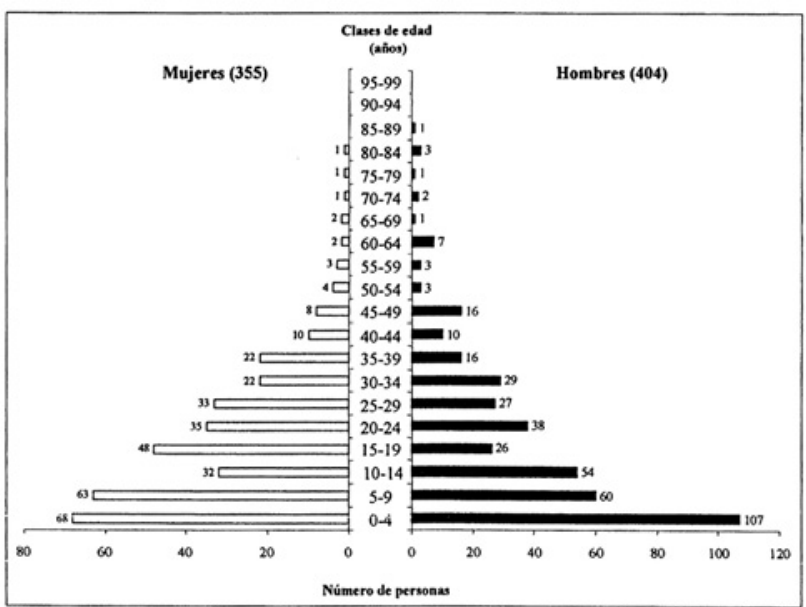

Gráfico 1: Población total de la etnia Chácobos (Fuente: INE, 1994) 
rangos de edad fértil (entre 15 y 44 años). En efecto, hay mucho más mujeres que hombres entre 15-19 y 25-29 y 35-39 años, mientras que es el contrario entre 20-24 años y 30-34 años, lo que podría plantear un problema al nivel de la perpetuación de la población Chácobo. El índice de masculinidad tiende a aumentar en las clases de mayor edad (60-64, 70-74, 80-84 años). Aquello sugiere que la esperanza de vida de los hombres es mayor a la de las mujeres en esos rangos de edad.

En cuanto a la población de Alto-Ivón y según la misma fuente (INE, 1996), existen 293 habitantes (151 hombres o sea el $51.5 \%$ y 142 mujeres o sea el $48.5 \%$ ), distribuidos en 52 viviendas.

Los Chácobos practican la agricultura bajo el sistema tradicional de roza-tumbaquema, actividad realizada durante los meses secos de agosto, septiembre y octubre. Por lo general, los chacos, de tamaño promedio de una hectárea, se ubican en las cercanías de la comunidad, a una distancia de aproximadamente media hora caminando. Cultivan principalmente arroz, maíz, plátano y yuca, los mismos sólo alcanzan para el consumo. Generalmente, siembran la yuca y el maíz en septiembre, y el arroz en noviembre. También siembran, en menor proporción, algodón, piña, hualusa, entre otras plantas.

El intervalo de uso más común de los chacos fluctúa entre 3 y 5 años. Pasado este lapso, se inicia la apertura de uno nuevo para el cultivo intensivo. Los antiguos chacos siguen siendo utilizados para la cosecha de los plátanos y algunas palmas (Boom, 1987).

(6) Indice de masculinidad: Número de hombres por 100 mujeres.
La recolección constituye una actividad tan importante como la actividad agrícola. Los principales recursos económicos de los Chácobos provienen del comercio del caucho o goma (Hevea brasiliensis, Euphorbiaceae) cosechado entre abril y agosto, y de la castaña (Bertholletia excelsa, Lecythidaceae) recolectada desde fines de noviembre hasta febrero.

Los Chácobos están organizados en cooperativa y pueden comprar los productos básicos tales como aceite, azúcar, harina, en cambio de la venta de la goma y de la castaña.

Se puede decir que la caza y la pesca no son actividades tan importantes como la agricultura y la recolección de castaña y goma y otros productos alimenticios del bosque, por lo que pocos animales se encuentran a proximidad de la comunidad, (sino a dos a tres días de viaje). Y también porque el río Ivón (principal río del área) desaparece casi completamente en época seca (agosto-octubre). Entre los animales cazados se encuentran los monos, jochis, taitetú, tatú y guaso mientras que las especies más importantes que se pescan son el ventón, yayú y tucumaré (SAE et. al, 1994).

\section{El área de Alto-Ivón: Condiciones ecológicas}

Alto-Ivón se ubica en el departamento del Beni, provincia Vaca Diez. Tiene como coordenadas geográficas: $11^{\circ} 45^{\prime} \mathrm{S}$, $66^{\circ} 02^{\prime} 0$, y una altura de $200 \mathrm{~m}$ sobre el nivel del mar (s.n.m.) (ver el mapa esquemático, Ilustración 1).

El área de estudio se caracteriza por un clima caliente y húmedo y es considerado como clima tropical de carácter estacional (Holdridge, 1979). Las estaciones climáti- 


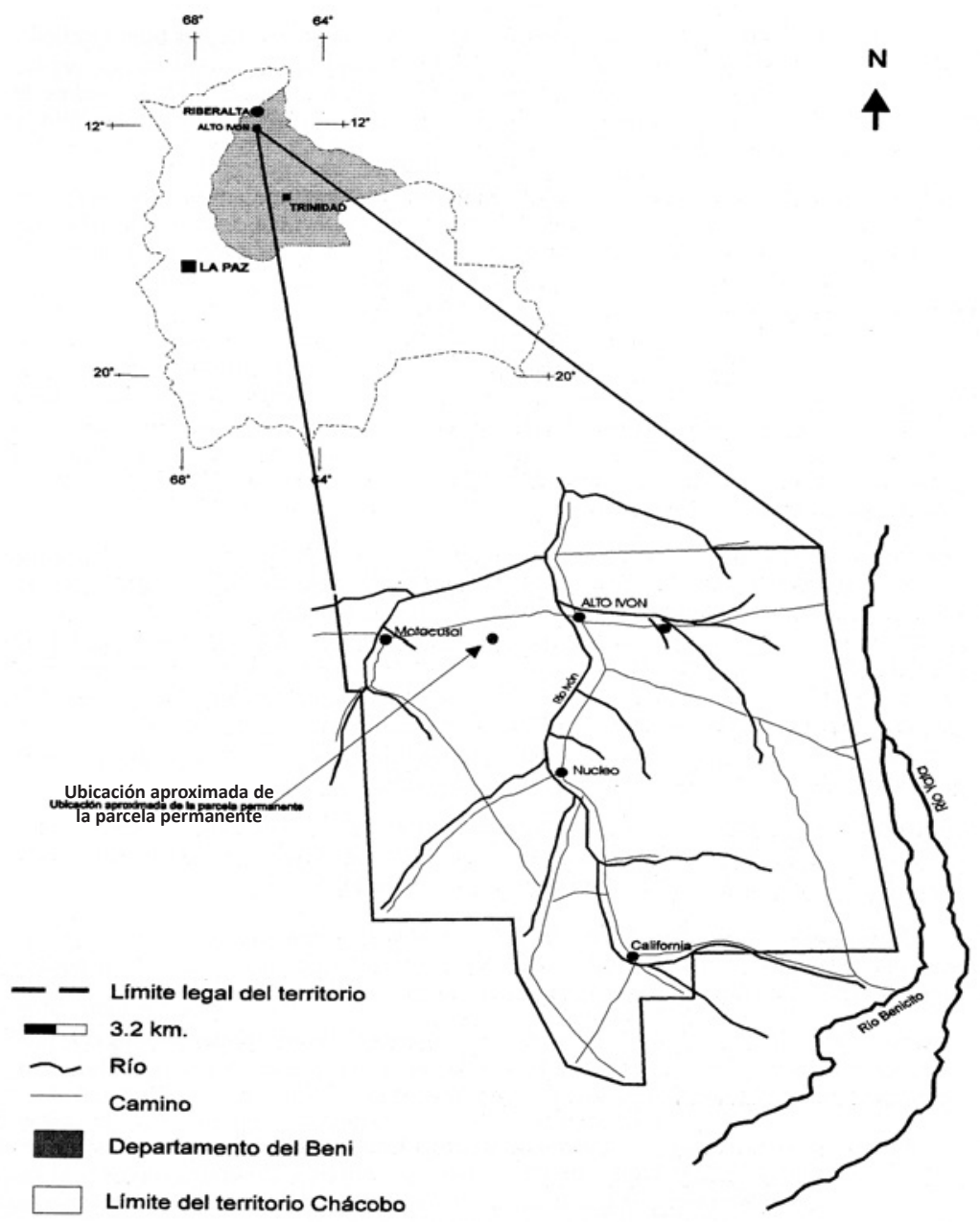

Ilustración 1: Mapa de Ubicación de Alto-Ivón (Fuente Boom, 1987)

cas de Guayaramerín y Riberalta indican una temperatura promedia anual entre 25 y $27^{\circ} \mathrm{C}$. Durante la época seca y particularmente en julio-agosto, soplan los "Surrazos", vientos fríos del sur (subantárticos) que implican una leve disminución de las temperaturas.

La precipitación promedia anual no es muy elevada, variando entre $1500 \mathrm{~mm}$ y $1800 \mathrm{~mm}$, con dos a tres meses secos La estación de lluvia se extiende desde diciembre hasta mayo con precipitaciones máximas de diciembre a febrero. La estación seca dura desde junio-julio hasta septiembre-octubre.

Las informaciones sobre el déficit hídrico difieren bastante según las fuentes bibliográficas. Según ciertas fuentes como el Atlas de Bolivia (1989), no existe déficit hídrico ya que las precipitaciones son siempre superiores a la evapotranspiración potencial ETP, la cual es de 
$1256 \mathrm{~mm}$. Por lo contrario, según otras fuentes, existe un déficit hídrico de julio a septiembre (De Morales, 1990).

La información referida a la formación vegetal asociada a este tipo de clima (o sea el tipo de vegetación dominante), es también bastante contradictoria según las fuentes bibliográficas consultadas y los sistemas de clasificación empleados por cada autor. En efecto, aunque basados en la clasificación internacional del Unesco (1973), estos sistemas pueden ser muy complejos por no utilizar los mismos criterios de clasificación. Esos últimos puedenser detipofisionómicoy/oflorístico (Lara, 1983; Hueck, 1978), o climático (MACA, 1975; Ellenberg, 1981; Beck, 1988) entre otros criterios. Por lo tanto, según la clasificación de Ribera (1992), basada en las clasificaciones tradicionales anteriores, pero más orientada hacia actividades de conservación y desarrollo de las áreas naturales del país, el bosque de Alto-Ivón hace parte de la gran región geográfica Pandina -Amazónica y está considerado como "bosque húmedo amazónico" (siempreverde estacional con elementos de la Hylea).

Asimismo, gran parte de la vegetación del área de Alto - Ivon corresponde a un bosque de tierra firme (comúnmente llamado "monte" alto). Se encuentran también grandes superficies de sabanas arboladas ("pampa") que se inundan anualmente durante 3-5 meses. Esas sabanas han sido poco estudiadas comparativamente con las sabanas de la región central del Beni (Pampas de Moxos). En un estudio realizado en el oeste del río Beni, Haase (1990), (citado por Ribera, 1992), relaciona la estructura y composición de estas sabanas con las que existen en el norte de Sudamérica
(Guyana, Venezuela), indicando poca similitud con las pampas de Moxos. En zonas de relieve se encuentran islas de bosque húmedo de tierra firme que no se inundan en tiempo de lluvia.

Describiendo un poco más los tipos de vegetación del área de Alto-Ivón, se encontraron cuatro tipos de ambientes o formaciones vegetales, la última siendo formación típicamente antrópica (es decir donde hay o hubo intervención del Hombre).

* Bosque húmedo amazónico de tierra firme o Bosque húmedo amazónico llamado localmente "monte alto". Según Ribera (1992), este bosque corresponde a un bosque siempreverde estacional con elementos de la Hylea.

*Sabanas arboladas ("pampa"). Esas sabanas se ubican al sur-oeste del pueblo de Alto-Ivón. Son inundadas en época de lluvias. En las áreas de relieve (zonas más elevadas), se encuentran presentan islas de bosque de tierra firme.

*Bosque ribereño inundado estacionalmente. Este bosque se representa como franjas angostas a lo largo del río Ivon y de los arroyos secundarios. En época lluviosa, el río puede subir hasta $8 \mathrm{~m}$ mientras que en época seca, el río tiende a desaparecer, dejando áreas de agua estancada ("charcos") en zonas de depresiones.

* Vegetación secundaria (o "barbechos"). Esta vegetación se debe a la presencia de asentamientos y a los frecuentes chaqueos de la población local.

En cuánto a los tipos de suelos que se encuentranenlazona de Alto-Ivón, lasáreas de bosque presentan suelos ferralíticos 
(Ferric Acrisols) según la clasificación de la FAO (1970). Se caracterizan por un perfil $A B C$, de color amarillo oscuro, de textura de tipo limo-arenosa en superficie y sabioarcillosa o limo-arcillosa en profundidad. Esos suelos son ácidos y pobres. Los suelos de la sabana son medianamente a bien desarrollados según el micro-relieve, de textura limo-arcillosa en superficie, y arcillosa en profundidad (De Morales, 1990).

\section{Aspectos metodológicos}

El "uso de las plantas por los Chácobos" constituye una etapa final de diversos trabajos de investigación, los mismos se han llevado gracias a la colaboración de varias instituciones científicas y financieras:

La idea inicial de la investigación era acercarse al sistema de clasificación que tienen los Chácobos de Alto-Ivón, respecto a su entorno vegetal y a las plantas. Por otra parte, se trataba de conocer el propio uso de las plantas, y finalmente, tener una idea de la diversidad florística de la formación vegetal frecuentemente utilizada por los indígenas. Asimismo, se complementaban los trabajos anteriores realizados por Boom (1985a, 1985b, 1986a, 1986b, 1987, 1989), y gracias a los cuales se había empezado a conocer la vegetación de Alto-Ivón, así como el uso de las plantas por los indígenas. En este sentido, entre 1992 y 1994, se ejecutó el proyecto: "Aproximación preliminar a la clasificación botánica Chácobo" (Bergeron, 1992) que fue financiado por el Instituto Francés de Estudios Andinos (IFEA), y en el cual colaboró el antropólogo P. Erikson. Por otro lado, con el fin de iniciar estudios biológicos sobre algunas plantas con propiedades medicinales, participaron también para la parte logística del estudio, el departamento de farmacognosia del Instituto Boliviano de Biología de Altura (IBBA), en La Paz, $y$ el "Institut Fran^ais de Recherche Scientifíque pour le Développement en Coopération" (ORSTOM).

Al terminar los estudios de campo en Alto-Ivón, se ejecutó de 1993 a 1996, el proyecto: "Propuesta de conservación ambiental a través de la valoración etnobotánica y etnofarmacológica en Bolivia" (HNLPB et al. 1993), con el fin de consolidar los conocimientos tradicionales y conocer los potenciales farmacobioquímicos de las plantas utilizadas por los Chácobos. Este proyecto fue auspiciado por el Fondo Nacional para el medio Ambiente (FONAMA). Además de las instituciones citadas anteriormente para el primer proyecto, participaron el Herbario Nacional de La Paz para el montaje de las plantas, el Instituto de Investigaciones Farmaco-Bioquímicas (IIFB) y el Instituto de Investigaciones Químicas (IIQ) de la Paz para los análisis farmaco-químicos de las muestras vegetales. A través de este proyecto, fue elaborada, a principio de 1996, una versión preliminar de una guía popular de las plantas utilizadas por los Chácobos (Bergeron, 1996).

Por último, a manera de compilar los resultados florísticos y etnobotánicos de Alto-Ivón así como la guía popular de las plantas utilizadas por los Chácobos, se redactó durante el periodo 1996-1997, "El uso de las plantas por los Chácobos", con el apoyo del Centro de Investigación y Documentación para el Desarrollo del Beni (CIDDEBENI), auspiciado por OXFAM - América. Asimismo, se actualizaron las identificaciones botánicas y los resultados de los inventarios florísticos y etnobotánicos, los mismos que fueron 
Tabla 2: Cronograma de las salidas de campo (Alto-Ivón, 1992 - 1993)

\begin{tabular}{|c|c|}
\hline FECHA & ACTIVIDAD \\
\hline Junio de 92 & $\begin{array}{l}\text { - Reconocimiento general de los diversos ambientes y de las } \\
\text { plantas } \\
\text { - Ubicación y delimitación de la parcela permanente en bosque de } \\
\text { tierra firme. Colectas en bosque de tierra firme } \\
\text { - Colectas en bosque húmedo y sabana para los estudios } \\
\text { etnobotánicos y fito- químicos }\end{array}$ \\
\hline Agosto de 92 & $\begin{array}{l}\text { - Inventario florístico en la parcela permanente } \\
\text { - Colectas en bosque húmedo y sabana para los estudios } \\
\text { etnobotánicos y fotoquímicos }\end{array}$ \\
\hline $\begin{array}{l}\text { Noviembre de } \\
\quad 92\end{array}$ & $\begin{array}{l}\text { - Estudio de la vegetación de río y de los barbechos } \\
\text { - Recolección de muestras fitoquímicas }\end{array}$ \\
\hline Febrero de 93 & $\begin{array}{l}\text { - Estudio sobre la clasificación Chácobos } \\
\text { - Complementación de los datos etnobotánicos } \\
\text { - Complementación de las colectas de material botánico y } \\
\text { fitoquímico en todas las formaciones vegetales }\end{array}$ \\
\hline Octubre & $\begin{array}{l}\text { - Recolección de muestras fitoquímicas que habían demostrado } \\
\text { cierta actividad antiparasitaria, con una misión de la ORSTOM y el } \\
\text { IIFB }\end{array}$ \\
\hline
\end{tabular}

complementados a través de información secundaria.

\section{Los estudios florísticos y etnobotánicos}

Para la realización los estudios florísticos y etnobotánicos se realizaron entre 1992 y 1993, varias salidas de campo, con una duración de aproximadamente un mes y medio (referirse a la Tabla 2).

Durante las salidas de campo, se aplicaron dos tipos de metodología, la primera utilizada para conocer la diversidad del bosque de tierra firme o "monte" alto, y la segunda, más relacionada al estudio etnobotánico propio, es decir al uso de las plantas y al sistema de clasificación tradicional. En las dos metodologías participaron de manera permanente pero en forma rotativa, tres comunarios Chácobos (Bari y Jeri Ortiz, y Cana Soria), y de manera puntual, Caco Ortiz. Por otra parte, al volver del campo con las muestras botánicas, se revisaron con algunos comunarios, los nombres y uso de las plantas.

\section{La diversidad florística del bosque de tierra firme de Alto-Ivón}

La UNESCO (1973) define la diversidad florística o específica, como: "la manera de repartición de las especies entre los individuos presentes en el área de estudio". Si tomamos el ejemplo del bosque, conocer la diversidad florística del bosque, es conocer qué y cuántas diferentes clases de plantas se encuentran en el bosque, y cómo se distribuyen en este ambiente. Por ejemplo, mediante el estudio de la diversidad florística del bosque, se puede saber si los árboles de una misma clase se encuentran en manchas, o de manera aislada en el bosque.

Asimismo, se hizo un inventario florístico considerando una parcela permanente delimitada en el bosque de tierra firme. Este tipo de muestreo es generalmente utilizado para estudios a largo plazo (por 
ejemplo monitoreo o seguimiento a la biología de las plantas), y también, en los estudios etnobotánicos a corto plazo, para los cuales se necesita estimar la diversidad florística del bosque, así como inventariar las especies utilizadas por la población local.

La ubicación de la parcela fue seleccionada en base a un mapa IGM con escala de 1: 50 000, considerando un área de bosque homogéneo ${ }^{(7)}$. El tamaño elegido de la parcela fue de una hectárea, tamaño considerado como medida estándar para los bosques tropicales (Martin, 1995: 156), y sabiendo que en un estudio anterior a lo nuestro, Boom (1986a) había considerado este tamaño como representativo del bosque, a través del método área-especie ${ }^{(8)}$.

Asimismo se ubicó una parcela permanente en el bosque de tierra firme a aproximadamente $4 \mathrm{kms}$. al suroeste de Alto-Ivón ${ }^{(9)}$. La parcela tenía 1000 $\mathrm{m}$ de largo por $10 \mathrm{~m}$ de ancho, con una orientación de $65^{\circ} \mathrm{NO}$ y $155^{\circ} \mathrm{NE}$. La ventaja de este tipo de transecto, mucho más largo que ancho, llamado "belt transect" o transecto cinturón" (Martin, 1995: 157), es que permite abarcar varios micro-hábitats del bosque, así como varias especies características de esos micro-hábitats.

Para cada uno de los individuos marcados, se anotaron la altura, el diámetro, la posición del árbol en la parcela, los criterios morfológicos (es decir cómo eran el tronco, las hojas, la corteza), el nombre Chácobo, el nombre español cuando se conocía, y el uso de la planta. Todos los individuos fueron colectados para muestras de herbario, excepto cuando se repetían de manera evidente, como Onipa (Socratea exorhizza), Batahua (Capirona decorticans). Cada planta numerada fue recolectada en cuatro ejemplares. Las muestras fueron prensadas, secadas y conservadas en el campo para su posterior identificación en el herbario de la Paz y otros herbarios nacionales e internacionales.

El Gráfico 2 en la página siguiente permite entender mejor la relación entre el grosor del árbol y su diámetro.

A lo largo de 1992 y 1993, y a mediados de 1994 se identificaron las muestras vegetales en el Herbario Nacional de La Paz (HNPLB), a través de comparaciones con muestras de referencia, y por otro lado, utilizando claves y libros de referencia tales como los trabajos de Killeen et al. (1993) y Gentry (1993) entre otras obras. Paralelamente, se creó una base de datos (en los programas de Pro-file Maker y Microsoft Access) para las etiquetas de herbario adjuntas a cada muestra vegetal. Actualmente, la identificación botánica de las muestras sigue siendo revisada y actualizada por especialistas nacionales e internacionales.

Simultáneamente a la clasificación e identificación de las muestras, se analizaron e interpretaron los datos florísticos recolectados en el campo. Para analizar la diversidad florística del bosque, se utilizan generalmente índices, tales como los de Simpson, Shannon, ShannonWiener (Krebs, 1989). La utilización de

\footnotetext{
Homogéneo: la parcela tenía que representar lo más posible el conjunto del bosque.

8 Método área-especie: Método empleado para conocer la superficie mínima de muestreo. Se va contando las nuevas especies que aparecen a medida que se va aumentado la superficie. Cuando no parecen nuevas especies, se tiene la superficie mínima de muestreo.

9 Según los comunarios de Alto-Ivón, este lugar "nunca" había sido sometido a chaqueos.
} 


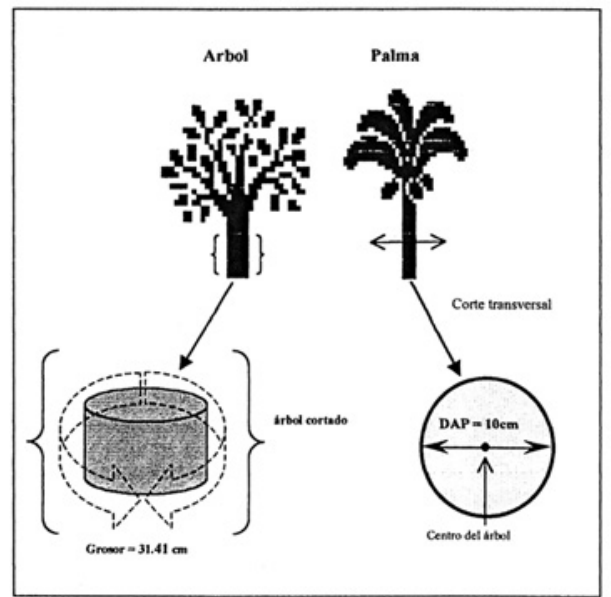

Gráfico 2: Relación entre el diámetro y el "grosor" de un árbol

estos índices varía en función al número y tamaño de parcelas inventariadas, objetivos del estudio entre otros criterios. En el caso de la parcela permanente de Alto-Ivón, considerada como pequeña muestra, hemos utilizado el Índice de Valor de Importancia (IVI) muy frecuentemente empleado para este tipo de muestreo. Asimismo, se analizaron los datos de diversidad florística en el programa Excel 5 y 7.

\section{El uso de las plantas por los Chácobos y su sistema tradicional de clasificación}

La metodología utilizada para este estudio fue basada en colectas generales en los diversos ambientes de Alto-Ivón, así como, en entrevistas semi-estructuradas y/o conversaciones de tipo informal con los colaboradores indígenas y los comunarios (hombres, mujeres):

Se hicieron varios recorridos con los colaboradores indígenas en el bosque de tierra firme, la sabana ("pampa"), el bosque ribereño y la vegetación secundaria es decir los "barbechos" de 5,10 , y 20-25 años. Para cada tipo de ambiente y en varias oportunidades, se recolectó la mayor parte de las plantas que se encontraban en el lugar, cualquier fuese su tipo biológico (árbol, hierba, bejuco, arbusto), o su uso. Asimismo, en el mismo día, o en los siguientes, se repitieron las colectas hasta tener por lo menos cinco veces la misma planta repetida en el mismo tipo de ambiente con el mismo colaborador. Por otra parte, a partir de las recolecciones realizadas en los diferentes recorridos, se obtuvieron varias listas de plantas. Esas últimas fueron discutidas entre los colaboradores indígenas a manera de complementarlas con nuevas especies por recolectarse en los siguientes recorridos.

De igual manera que para el estudio florístico, pero sin marcar las plantas, se consideraron para cada una de ellas, la altura, las características morfológicas (corteza o "cáscara", madera, hojas entre otras), el nombre Chácobo, el nombre español cuando se conocía, el uso de la planta y el modo de preparación en el caso de las plantas medicinales. Las áreas de cultivo no fueron consideradas en esta investigación, por haber sido ampliamente estudiadas por Boom (1989), algunos años atrás.

Por lo tanto, a medida que se iba familiarizándose con los nombres y usos de las plantas, se empezó a estudiar las relaciones de parentesco que podían existir entre las diferentes plantas. Este estudio fue llevado a cabo de manera informal durante los diferentes recorridos, y de manera intensiva durante el último mes de campo. Participaron en esta fase, los cuatro colaboradores indígenas así como algunos comunarios, (de manera separada al principio y luego conjunta 
para verificar la información en los casos donde existían problemas).

De igual forma que para los estudios florísticos, las muestras recolectadas fueron identificadas en el herbario Nacional de La Paz, y los datos recopilados y procesados en Excel 5 y 7.

\section{Recolección de muestras fitobioquimicas}

Paralelamente a los estudios botánicos y etnobotánicos, recolecciones de material vegetal fueron realizadas para los estudios fitoquímicos. El objetivo de los estudios fitoquímicos realizados por el Instituto Boliviano de Biología de Altura (IBBA) y el Instituto de Investigaciones Farmaco-Bioquímicas (11FB) de la Paz, era encontrar plantas que demostraban cierta actividad biológica (en particular para el paludismo, la leishmaniasis llamada también "espundia" o lepra blanca y enfermedad de Chagas), o con propiedades antibacterianas y antifungícidas.

Asimismo, se recolectaron muestras de las plantas utilizadas el paludismo, fiebre, dolores de estómago, problemas del hígado, disentería, diarrea, y también, las plantas usadas para las heridas infectadas de la piel (con nombre local de "caracha"), "espundia", cortaduras, picaduras de víboras, insectos. Según la parte utilizada (corteza, raíces o hojas), se colectaron de $200 \mathrm{~g}$ hasta $500 \mathrm{~g}$ de material seco. Las muestras fueron primeramente secadas al sol, y luego, en la hornilla de gas, simultáneamente con las muestras vegetales. Las muestras fitoquímicas fueron ubicadas en bolsas de tela, y conservadas en grandes bolsas plásticas para su posterior análisis en el Instituto Boliviano de Biología de Altura (IBBA) y en el Instituto de Investigaciones FarmacoBioquímicas (IIFB) de La Paz.

\section{La guía popular de las plantas utilizadas} por los Chácobos

A partir de la información botánica y etnobotánica recopilada en AltoIvón, se elaboró la guía de las plantas utilizadas por los comunarios de AltoIvón. Por el gran número de muestras recolectadas en los diferentes ambientes (más de 900 muestras correspondientes a aproximadamente 360 especies botánicas), se tuvo que seleccionar unas cincuenta plantas para la guía popular. Cabe mencionar que este capítulo fue elaborado a través de un proyecto ejecutado después de los estudios de campo en Alto-Ivón, por lo que no se pudo seleccionar las plantas con los comunarios Chácobos, y tampoco, sacar fotos de las plantas en su medio natural.

Para seleccionar las plantas descritas en esta guía, se ha intentado tomar en cuenta las diversas categorías de uso (referirse al capítulo 3), considerando las especies siguientes:

* Las especies que son o han sido (por ejemplo, las especies utilizadas para la elaboración de vestimenta) usualmente utilizadas por los Chácobos.

* En el caso de las plantas del bosque de tierra firme, las especies más frecuentes o abundantes del bosque. Se presentarán sin embargo en algunos casos, plantas que a pesar de no ser muy abundante en el bosque, son bastante utilizadas por los Chácobos.

Por otra parte, cabe mencionar que la noción de usualmente y bastante utilizado es cualitativa. También debido a que la metodología empleada no nos permitía saber cuál era el uso más importante para los comunarios, se presentaron las cincuenta plantas Chácobo, por orden alfabético. 
Para cada planta descrita, se consideraron:

* Su nombre Chácobo,

* Su nombre botánico cuando la planta tiene una identificación

* La descripción de la planta incluyendo:

- Su nombre español cuando se sabía,

- Descripción del género botánico y su distribución, en los Trópicos

- Distribución de la planta en Alto - Ivon y abundancia en la parcela permanente.

- Características de los árboles que fueron recolectados

- Significación de la planta (es decir que se mencionó lo que significaba el nombre Chácobo cuando éste tenía un significado en castellano).

* El o los usos de la planta

\section{Estructura de "El uso de las plantas por los Chácobos"}

"El uso de las plantas por los Chácobos" presenta varios capítulos articulados entre sí, y cuya finalidad es acercarse a las relaciones que existen entre la población Chácobos de Alto-Ivón y su entorno vegetal, así como destacar la importancia de los conocimientos tradicionales para la conservación de la biodiversidad y preservación de la identidad indígena:

* El primer capítulo presenta la diversidad florística del bosque de tierra firme, formación vegetal muy utilizada por los Chácobos. En este capítulo, se presentan los resultados obtenidos en base al inventario florístico realizado en la parcela permanente del bosque de tierra firme de Alto-Ivón. Se describe el bosque en sus aspectos generales (los diferentes estratos del bosque y la estructura de los árboles y palmas, o sea la altura y el "grosor" que pueden tener los árboles y árboles). En segundo lugar, se presenta la diversidad del bosque incluyendo la riqueza específica, abundancia, frecuencia y dominancia de las especies y asimismo las especies más representativas de la parcela de bosque de tierra firme de Alto-Ivón.

* El segundo capítulo trata exclusivamente del sistema de clasificación tradicional de las plantas por los Chácobos.

* En primer lugar, se presentan unos conceptos generales de los sistemas de clasificación tradicional según Brent (1992). Luego, se ven las relaciones de parentesco que tienen las plantas entre ellas. En este caso, se trata solamente de aproximarse al sistema de clasificación tradicional de las plantas de los Chácobos ya que este sistema es el reflejo de los conocimientos tradicionales de una pequeña parte de la población de Alto-Ivón, y por otro lado, no abarca a los demás lugares de residencia de los Chácobos como Núcleo, California o la región del Yata. Por otro lado, llegar a un conocimiento profundizado del sistema de clasificación tradicional de los Chácobos requiere estudiar y manejar perfectamente la lingüística Chácobo, lo que no permitió la corta duración del estudio.

* El tercer capítulo trata del uso de las plantas por los Chácobos.

Se hace previamente una categorización arbitraria de los usos, por ejemplo, uso medicinal, alimenticio, entre otros usos. Luego se analiza a un nivel general cuántas especies (valor expresado en porcentaje) entran en cada categoría de 
Bergeron S., 1998. Uso de las plantas por los Chácobos (Alto Ivón, Beni, Bolivia)

uso, y también, el número de especies utilizadas según el ambiente considerado (bosque de tierra firme, sabana, bosque ribereño, barbechos). En este caso, por la misma metodología utilizada, no se comparará de manera cuantitativa, el uso de las plantas según los diferentes ambientes. Solamente podremos ilustrar de manera cuantitativa, el uso de las plantas inventariadas en la parcela permanente. Por otro lado, se consideran a un nivel detallado y para cada tipo de uso, las diferentes especies que se han recolectado en los diferentes ambientes de Alto-Ivón.

* En el cuarto y último capítulo (guía popular), se describen con más detalle unas 50 plantas utilizadas por los Chácobos. Cada planta está ilustrada por una foto de muestra de herbario.

* Por último, como conclusión de este trabajo, se hace una síntesis de los resultados mencionados a lo largo del libro, así como recomendaciones generales y específicas para futuros estudios.

Por último, cabe mencionar que en todo el libro, se ha intentado utilizar un lenguaje bastante simple, sin por lo tanto, perder el rigor científico del estudio. Por consiguiente, se podrá observar que al presentar los resultados, los términos científicos están a menudo complementados por su significación expresada de una manera más común y más accesible para los comunarios. El mismo caso se presentará en algunas oportunidades para sentencias enteras.

Por otro lado, se observarán que la mayoría de las tablas mencionadas a lo largo de este libro, en las cuales aparecen los nombres Chácobos y científicos, son acompañadas por un número de muestra de herbario, correspondientes a las recolecciones de material vegetal. Aquello tiene por objetivo a mediano y largo plazo, actualizar de manera más eficiente, y rigurosa, las determinaciones botánicas.

También, se podrá observar que en este libro, existen muy pocos nombres de plantas en castellano, debido a que esos últimos, no son casi utilizados por los comunarios. Asimismo, todos los nombres de las plantas están en Chácobo y se encuentran subrayados a lo largo del texto (excepto en las tablas). 


\section{Capítulo 1:}

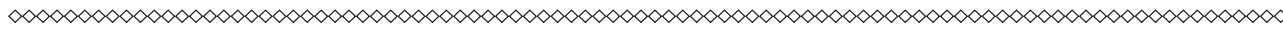

\section{La Diversidad Florística del Bosque de Tierra Firme de Alto-Ivón}

\section{Aspectos generales del bosque}

\section{Altura y estratos del bosque}

El bosque de tierra firme de Alto-Ivón, localmente llamado "monte alto", está representado por árboles no muy altos. En efecto, el dosel (o sea la mayoría de los árboles que se ven desde un avión), tiene una altura entre 15 y $20 \mathrm{~m}$, y los emergentes (es decir los árboles que sobresalen, como la castaña), miden entre 25 y 30m. Por esta razón, la luz penetra fácilmente al interior del bosque, y por consiguiente el sotobosque (las plantas que existen dentro del bosque) es bastante denso o tupido.

Asimismo, los árboles y palmas se distribuyen en cuatro grupos según su altura, entre otros términos, se definen cuatro estratos en el bosque (Tabla 3 )

\section{Distribución de los diámetros de los árboles y palmas de la parcela}

Según Rollet (1974) citado por (Unesco, 1976), la distribución de los diámetros de los árboles y palmas (todas especies confundidas) en diferentes clases, se llama la "estructura total" del bosque. La misma constituye un método simple y eficiente para ver si el bosque se regenera normalmente y si no es perturbado ${ }^{10}$.

Para conocer la estructura total del bosque de tierra firme de Alto-Ivón, tomando el caso particular de la parcela permanente de una hectárea, se establecieron clases de diámetro de 10 en $10 \mathrm{~cm}$ y se contaron los árboles y palmas inventariados que pertenecían a cada clase. Por ejemplo la clase de diámetro $10-20 \mathrm{~cm}$ incluye todos los árboles y palmas que tienen un diámetro de $10 \mathrm{~cm}$ incluido hasta $20 \mathrm{~cm}$ no incluido, o sea un "grosor" entre $31.4 \mathrm{~cm}$ y $62.8 \mathrm{~cm}$. Asimismo, se obtuvo el Gráfico 3 representando el número de árboles y palmas en función de las diferentes clases de diámetro. Este gráfico muestra que el número de árboles y palmas disminuye con el aumento de las clases de diámetro, o sea que existen mucho más árboles y palmas con pequeño diámetro. Aquello significa que el aporte continuo de individuos jóvenes asegura la regeneración de las especies del bosque y por consiguiente su mantenimiento.

Tabla 3: Grupos de árboles según la altura

\begin{tabular}{|c|l|}
\hline GRUPO & \multicolumn{1}{c|}{ ARBOLES } \\
\hline 1 & $\begin{array}{l}\text { Los emergentes: Arboles muy altos que sobresalen del bosque y cuya altura es de } \\
25 \text { a } 30 \mathrm{~m}\end{array}$ \\
\hline 2 & $\begin{array}{l}\text { El dosel: La mayoría de los árboles y/o palmas que tienen una altura entre } 15 \mathrm{y} \\
20 \mathrm{~m}\end{array}$ \\
\hline 3 & Árboles o arbolitos que tienen una altura entre 8 y $15 \mathrm{~m}$ \\
\hline 4 & Arbustos, pequeñas plantas, hierbas que están por debajo de los $8 \mathrm{~m}$ \\
\hline
\end{tabular}

\footnotetext{
10 Se entiende por perturbación cualquier intervención humana que implica modificaciones de la cobertura vegetal (Lleras, 1994; 340), entendiendo la cobertura vegetal como el conjunto de la vegetación.
} 


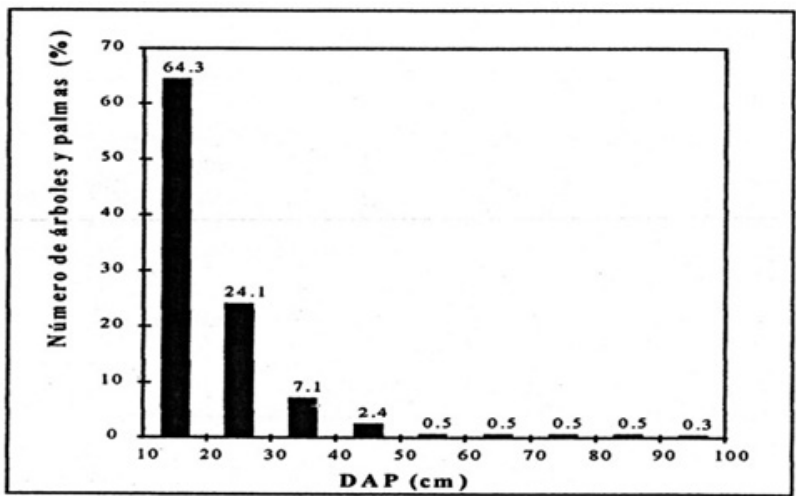

Gráfico 3: Distribución de los diámetros en la parcela del bosque de tierra firme de Alto-Ivón

Las especies que presentaron mayor diámetro o "grosor" se presentan en la Tabla 4.

Tabla 4: Arboles de mayor diámetro o mayor "grosor"

\begin{tabular}{|c|c|c|c|c|}
\hline $\begin{array}{l}\text { Diámetro } \\
\text { (m) }\end{array}$ & $\begin{array}{l}\text { "Grosor" } \\
\text { (m) }\end{array}$ & $\begin{array}{l}\text { Nombre } \\
\text { Chácobos }\end{array}$ & Nombre Científico & $\begin{array}{c}\text { Número de } \\
\text { herbario }\end{array}$ \\
\hline $0.9-1$ & $2.8-3.2$ & $\begin{array}{l}\text { Canopëixoco } \\
\text { Mani } \\
\text { Yomëno }\end{array}$ & $\begin{array}{l}\text { Sclerolobium aff. rugosum } \\
\text { Apuleia leiocarpa } \\
\text { Ficus gomelleira }\end{array}$ & $\begin{array}{c}471 \\
54 \\
147\end{array}$ \\
\hline $0.9-1$ & $2.8-3.2$ & $\begin{array}{l}\text { Canopëixoco } \\
\text { Mani } \\
\text { Yomëno }\end{array}$ & $\begin{array}{l}\text { Sclerolobium aff. rugosum } \\
\text { Apuleia leiocarpa } \\
\text { Ficus gomelleira }\end{array}$ & $\begin{array}{c}471 \\
54 \\
147 \\
\end{array}$ \\
\hline $0.8-0.9$ & $2.5-2.8$ & $\begin{array}{l}\text { Tapa } \\
\text { Mani }\end{array}$ & $\begin{array}{l}\text { Bertholletia excelsa } \\
\text { Apuleia leiocarpa }\end{array}$ & $\begin{array}{l}229 \\
241\end{array}$ \\
\hline $0.7-0.8$ & $2.2-2.5$ & $\begin{array}{l}\text { Jihuipisi } \\
\text { Nihipëpëcho } \\
\text { Mani }\end{array}$ & $\begin{array}{l}\text { Vataireopsis speciosa, } \\
\text { Qualea paraensis } \\
\text { Apuleia leiocarpa }\end{array}$ & $\begin{array}{l}457 \\
164 \\
807\end{array}$ \\
\hline
\end{tabular}

\section{Diversidad Especifica del Bosque de Tierra Firme de Alto-Ivón}

En el presente capítulo, se menciona las especies encontradas en el bosque de tierra firme de Alto-Ivón, con sus respectivos valores de frecuencia, abundancia, dominancia absoluta y relativa, así como el Índice de Valor de Importancia IVI.

\section{Riqueza específica}

La riqueza específica corresponde al número de especies (o al número de diferentes clases de plantas) que se encuentran en un área considerada, y en nuestro caso, en la parcela permanente de una hectárea, en el bosque de tierra firme.

De las plantas inventariadas y numeradas en la parcela permanente del "monte" alto de Alto-Ivón, se han encontrado un total de 123 especies (es decir 123 distintas clases de plantas) distribuidas en: 
$>112$ especies de árboles (o 112 diferentes clases de árboles),

$>5$ especies de palmas ( 5 diferentes clases de palmas),

$>6$ especies de bejucos ( 6 diferentes clases de bejucos).

Asimismo, el bosque de Alto-lvón es bastante rico en especies (123 especies/ ha) o sea, tiene bastantes clases distintas de plantas. Por lo tanto, no es tan rico como en otras áreas amazónicas como Colombia (Bergeron, 1992), Perú (Gentry, 1983) y Brasil (Prance, 1976; Balee 1993) donde se encontraron mayor número de especies en bosques de tierra firme (ver Tabla 5).

El coeficiente de mezcla CM que corresponde al número total de especies sobre el número total de individuos, es de aproximadamente $1 / 5 \quad(123 / 635)$. Concretamente, eso significa que una especie está representada por aproximadamente 5 individuos en la hectárea inventariada.

Por otro lado, las familias más diversificadas, o sea las familias que son representadas por numerosas especies, corresponden a los Moraceae (con 16 especies), Papilionaceae (11 especies); Chrysobalanaceae (7 especies);
Palmae, Burseraceae, Caesalpiniaceae y Flacourtiaceae (respectivamente 5 especies en cada familia).

\section{Abundancia de las especies}

La abundancia también llamada "densidad" corresponde al número de individuos que pertenecen a una clase de planta (o especie) en la parcela inventariada y se expresa en abundancia absoluta o abundancia relativa:

$>$ Abundancia absoluta (Aba) de una especie i corresponde al número total de individuos perteneciente a esta especie en la parcela inventariada. Por ejemplo se ha contado más de 50 Onipa (Socratea exorrhiza) en la parcela.

- Abundancia relativa (Abr) de una especie i se calcula a partir de Aba y se expresa en porcentaje:

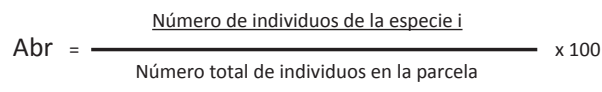

Asimismo, en la parcela del bosque de Alto-Ivón, se registraron un total 635 individuos de los cuales:

568 árboles (o sea el $89.5 \%$ de las plantas que han sido inventariadas en la parcela, son árboles)

Tabla 5: Diversidad específica de bosques de tierra firme en otras áreas amazónicas

\begin{tabular}{|c|c|c|c|c|c|c|}
\hline Área & $\begin{array}{c}\text { Alto-Ivón, } \\
\text { Bolivia } \\
\text { (Bergeron } \\
\text {, 1997) }\end{array}$ & $\begin{array}{c}\text { Alto-Ivón } \\
\text { Bolivia } \\
\text { (Boom, } \\
\text { 1986a) }\end{array}$ & $\begin{array}{c}\text { Araracuara } \\
\text { Colombia } \\
\text { (Bergeron, } \\
\text { 1992) }\end{array}$ & $\begin{array}{c}\text { Brasil } \\
\text { (Prance, } \\
\text { 1976) }\end{array}$ & $\begin{array}{c}\text { Perú } \\
\text { (Gentry, } \\
\text { 1983) }\end{array}$ & $\begin{array}{c}\text { Alto } \\
\text { Turiacu } \\
\text { Brasil } \\
\text { (Balee, } \\
\text { 1993) }\end{array}$ \\
\hline $\begin{array}{c}\text { Número de } \\
\text { especies } \\
\text { por } \\
\text { hectárea }\end{array}$ & 123 & 94 & 255 & $\begin{array}{c}180 \text { sin } \\
\text { considerar } \\
\text { las palmas }\end{array}$ & 300 & $\begin{array}{c}\text { promedio } \\
\text { de } 135 \\
\text { incluyendo } \\
\text { bejucos }\end{array}$ \\
\hline
\end{tabular}

${ }^{11}$ Salvo el caso de Alto- Turiacu (Balee, 1993) los inventarios florísticos no han considerado los bejucos. 
61 palmas (el 9.6\% de las plantas que han sido inventariadas en la parcela son palmas)

> 6 bejucos (el $0.9 \%$ de las plantas que han sido inventariadas en la parcela son bejucos)

Comparando con otros trabajos realizados en regiones distintas de Amazonia, observamos que las palmas arborescentes (es decir que tienen tronco) del bosque de tierra firme de Alto Ivon son no solamente diversificadas (cinco diferentes clases de palmas), pero también abundantes. Por ejemplo, los inventarios florísticos realizados en otras áreas amazónicas y sobre una hectárea, han demostrado que las palmas representaban: 3\% del total de las plantas inventariadas en una hectárea de bosque de tierra firme en Colombia (Bergeron, 1992), 6.5\% en Alto Turiafu-Brasil (Balee, 1993), y según Kahn (1983), 8\% en Amazonia oriental, 4.5\% en
Amazonia central, y $6.5 \%$ en Amazonia occidental.

En último, hay que mencionar que Phenakospermum guianensis (Mani en Chácobo), especie no considerada en este inventario por ser una hierba, es bastante abundante y ocupa áreas de más de $50 \mathrm{~m} 2$ en la misma parcela.

Las 15 especies más abundantes al nivel de la hectárea muestreada, representan aproximadamente el $62 \%$ de la abundancia relativa total (ver Tabla 6): Pseudolmedia laevis (Pamaxoco) es de lejos la especie más abundante (21.1\%). Luego siguen Iryanthera juruensis (Mëquënobita y Yorabita) y Socratea exorrhiza (Onipa) con una abundancia relativa respectiva de 6.9 y $5.5 \%$. Las demás especies indicadas en la Tabla 6 hacen también parte de las especies más abundantes inventariadas en la parcela, pero no lo son tanto como las primeras.

Tabla 6: Las 15 especies más abundantes de la parcela

\begin{tabular}{|l|l|c|l|}
\hline \multicolumn{1}{|c|}{ Nombre Chácobos } & \multicolumn{1}{|c|}{ Nombre científico } & $\begin{array}{c}\text { Abundancia } \\
\text { relativa Abr } \\
(\%)\end{array}$ & \multicolumn{1}{|c|}{ Número de herbario } \\
\hline Pamaxoco & Pseudolmedia laevis & 21.1 & $\begin{array}{l}19,21,85,438,438,93,113,119,84,439, \\
440,453,934,450 \mathrm{bis}\end{array}$ \\
\hline Mëquënobita y Yorabita & Iryanthera juruensis & 6.9 & $86,91,96,221,451$ \\
\hline Onipa & Socratea exorrhiza & 5.5 & 100,535 \\
\hline Shiuë & Rinoreocarpus ulei & 3.6 & $25,29,88,102,111,456,465,901$ \\
\hline Pananë & Euterpe precatoria & 3.3 & 101,281 \\
\hline Teco & Perebea aff. acutifolium & 3.0 & $\begin{array}{l}16,53,106,115,130,155,156,244,454, \\
459\end{array}$ \\
\hline Canapa & Helicostylis tomentosa & 2.5 & $120,121,149,150,180,220,509,533$ \\
\hline Pamaxoco & $\begin{array}{l}\text { Pseudolmedia } \\
\text { macrophylla }\end{array}$ & 2.4 & $\begin{array}{l}19,21,84,85,93,113,119,198,205,438, \\
439,440,453,478,511\end{array}$ \\
\hline Nohotë & Theobroma speciosum & 2.4 & $34,134,135$ \\
\hline Batahua & Capirona decorlicans & 2.2 & 4,171 \\
\hline Isonaraja & Hortia sp. & 2.2 & $14,122,240,835$ \\
\hline Yorabita y Mequënobita & Iryanthera laevis & 2.0 & $27,114,144,223,727$ \\
\hline Tioroquërihua & Micropholis guyanensis & 2.0 & $17,34,168,173,231,246$ \\
\hline Caiosho & Amaioua guianensis & 1.6 & $30,146,169,251,442,450,458,616$ \\
\hline Paxaini & Metrodorea flavida & 1.6 & $\begin{array}{l}24,31,92,145,211,476,477,479,485,493, \\
913,\end{array}$ \\
\hline & & 62.4 & \\
\hline & & & \\
\hline & & & \\
\hline
\end{tabular}


Frecuencia de las especies

La frecuencia se utiliza para medir la regularidad de la distribución de una especie en el bosque, o de manera más concreta, permite saber si una especie se distribuye en forma de "manchas" en el bosque, o de manera aislada. Por ejemplo, los árboles de la especie Pamaxoco (Pseudolmedia laevis) están agrupados entre ellos, mientras que los árboles de la especie Carama (Hevea brasiliensis), o de la especie Tapa (Bertholletia excelsa) se encuentran más bien aislados unos de los otros.

La frecuencia puede expresarse en frecuencia absoluta $o$ en frecuencia relativa.

$>$ La frecuencia absoluta (Fra) y corresponde al número de sub-parcelas que contienen las diferentes especies de la parcela. En nuestro caso, el área de estudio corresponde al hectárea y la sub-unidad, a una superficie de $50 \mathrm{~m} \times 10 \mathrm{~m}(500 \mathrm{~m} 2)$ o sea, el hectárea comprende 20 sub-unidades. Por ejemplo se ha encontrado Onipa (Socratea exorrhiza) en las 20 subparcelas y para calcular su frecuencia absoluta se lo cuenta solamente una vez en cada sub-parcela. Por consiguiente su frecuencia (absoluta) es de 20.
$>$ La frecuencia relativa $(\mathrm{Fr})$ de una especie i expresada en porcentaje corresponde a:

$\operatorname{Pr}=\frac{\text { Frecuencia absoluta de la especie } i}{\text { Suma de las Fra de todas las especies presentes en la parcela }} \times 100$

Tomando el ejemplo anterior donde la frecuencia absoluta de Onipa era de 20, su frecuencia relativa es de $(20 \times 100) / 380$, o sea $4.2 \%$, donde 380 corresponde a la suma de las Fra de todas las especies presentes en la parcela.

Por otra parte, con el fin de tener una idea más concreta de la distribución general de las especies en el bosque, se atribuye a cada una, una clase de frecuencia según el método de Raunkier (citado por PRORADAM, 1986) (ver Tabla 7).

Estas clases se obtienen a partir de las frecuencias absolutas consideradas en porcentaje. Por ejemplo, si la frecuencia absoluta de una especie es de 2 , esta misma frecuencia transformada en porcentaje es de $10 \%$ ((2/20)x100); 20 representando el número de sub-unidades y 100 , la transformación en porcentaje. Según la Tabla 7, la especie pertenece a la clase I y por lo tanto, es escasa. Asimismo, se contabiliza todas las especies que pertenecen a cada clase y este número se transforma en

Tabla 7: Repartición de las especies del bosque de tierra firme de Alto-Ivón en clases de frecuencias (frecuencias absolutas expresadas en porcentajes)

\begin{tabular}{|c|c|c|c|c|}
\hline $\begin{array}{c}\text { Clases de } \\
\text { frecuencia }\end{array}$ & $\begin{array}{c}\text { Frecuencia } \\
\text { Absoluta } \\
(\%)\end{array}$ & $\begin{array}{c}\text { Número de } \\
\text { especies (valor } \\
\text { absoluta) } \\
\boldsymbol{h}\end{array}$ & $\begin{array}{c}\text { Número de } \\
\text { especies } \\
(\%)\end{array}$ & Clasificación de la especie \\
\hline I & $0-20$ & 101 & 82.1 & Escasa \\
\hline II & $21-40$ & 10 & 8.1 & Ocasional \\
\hline III & $41-60$ & 9 & 7.3 & Frecuente \\
\hline IV & $61-80$ & 1 & 0.8 & $\begin{array}{c}\text { Abundante o frecuencia } \\
\text { elevada }\end{array}$ \\
\hline V & $81-100$ & 2 & 1.6 & $\begin{array}{c}\text { Muy abundante o } \\
\text { frecuencia muy elevada }\end{array}$ \\
\hline TOTAL & & $\mathbf{1 2 3}$ & $\mathbf{1 0 0}$ & \\
\hline
\end{tabular}


porcentaje. Por ejemplo si encontramos que 101 especies pertenecen a la clase I, significa que el $82.1 \%(101 / 123 \times 100)$ del total de las especies (123) de la parcela pertenecen a la clase I.

Por lo tanto, la Tabla 7 expresa concretamente lo que observa el campo: la mayoría de las especies o sea el 82.1\% (101 especies) son escasas y pertenecen a la clase I, las demás son ocasionales $(8.1 \%$ o sea 10 especies), o frecuentes $(7.3 \%$ o sea 9 especies). Muy pocas especies pertenecen a las clases de frecuencia elevada $(0.8 \%$ o sea, una especie), o muy elevada (1.6\% o sea, dos especies). Aquello significa que la composición florística del bosque, cambia considerablemente de un sitio al otro y a poca distancia. Sin embargo, algunas especies abundantes o muy abundantes tienen una distribución regular en toda la hectárea inventariada, y generalmente en el bosque de Alto-Ivón. En otros términos, a medida que uno va recorriendo el bosque, los árboles que se encuentran a poca distancia son muy diferentes, pero ciertas especies como Pseudolmedia laevis (Pamaxoco), o Socratea exorrhiza (Onipa), son muy abundantes y se encuentran en cualquier lugar del bosque.

A un nivel más detallado, las especies más frecuentes de la parcela del bosque de tierra firme de Alto-Ivón se presentan en la Tabla 8.

Tabla 8: Las 15 especies más frecuentes de la parcela

\begin{tabular}{|l|l|c|l|}
\hline Nombre Chácobos & \multicolumn{1}{|c|}{ Nombre científico } & $\begin{array}{c}\text { Frecuencia } \\
\text { relativa Fr (\%) }\end{array}$ & \multicolumn{1}{|c|}{ Número de Herbario } \\
\hline Pamaxoco & Pseudolmedia laevis & 5.0 & $\begin{array}{l}9,84,93,113,119,439, \\
440,453,450 \mathrm{bis}\end{array}$ \\
\hline $\begin{array}{l}\text { Mëquënobita y } \\
\text { Yorabita }\end{array}$ & Iryanthera juruensis & 5.0 & $\begin{array}{l}26,86,91,96,110,118, \\
221,451\end{array}$ \\
\hline Onipa & Socratea exorrhiza & 4.2 & 100,535 \\
\hline Pananë & Euterpe precatoria & 3.2 & 101,281 \\
\hline Teco & Perebea aff. acutifolium & 3.2 & $\begin{array}{l}16,53,106,115,130, \\
155,156,244,454,459\end{array}$ \\
\hline Isonaraja & Hortia (sp.) & 2.9 & $14,122,240,835$ \\
\hline Tioroquërihua & Micropholis guyanensis & 2.9 & $17,34,168,173,231,246$ \\
\hline Shiuë & Rinoreocarpus ulei & 2.6 & $\begin{array}{l}25,29,88,102,111, \\
456,465,901\end{array}$ \\
\hline Canapa & Helicostylis tomentosa & 2.6 & $\begin{array}{l}120,121,149,150,180, \\
220,509,533\end{array}$ \\
\hline Batahua & Capirona decorlicans & 2.6 & 4,171 \\
\hline Nohotë & Theobroma speciosum & 2.4 & $34,134,135$ \\
\hline $\begin{array}{l}\text { Yorabita y } \\
\text { Mëquënobita }\end{array}$ & Iryanthera laevis & 2.4 & $27,114,144,223,727$ \\
\hline Caiosho & Amaioua guianensis & 2.1 & $\begin{array}{l}30,146,169,251,442, \\
450,458,616\end{array}$ \\
\hline Pamaxoco & Pseudolmedia macrophylla & 1.8 & $\begin{array}{l}19,21,84,85,93,113, \\
119,198,205,438,439 \\
440,453,478,511\end{array}$ \\
\hline Bisatamanëjoni & Qualea paraensis & 1.8 & $181,226,482,527,531$ \\
\hline & Total: & & \\
\hline & & & \\
\hline
\end{tabular}


Estas 15 especies representan aproximadamente el $45 \%$ de la frecuencia relativa total. Pseudolmedia laevis (Pamaxoco) y Iryanthera juruensis (Mequënobita y Yorabita) con una frecuencia relativa de $5 \%$, así como Socratea exorrhiza (Onipa), con una frecuencia relativa de $4.2 \%$, son las especies más frecuentes de la parcela. Les siguen de cerca Euterpe precatoria (Pananë) y Perebea aff. aculifolium (Tëco), con $3.2 \%$. Las demás especies más frecuentes mencionadas en la Tabla 8 cuya frecuencia relativa varía entre 1.8 y $3.2 \%$, son las mismas que las especies más abundantes, con excepción de Qualea paraensis (Bisatamanejoni).

Asimismo, si se consideran simultáneamente los valores de abundancia (ver Tabla 6) y de frecuencia (ver Tabla 8) de las 15 especies más abundantes y/o más frecuentes, se puede definir tres categorías:

Las especies tan frecuentes como abundantes: Theobroma speciosum (Nohotë), Helicostylis tomentosa (Canapa), Euterpe precatoria (Panane), ya que los valores de abundancia y frecuencia relativa son similares para cada una de esas especies.

$>$ Las especies que tienden a distribuirse en el bosque en grupos mono específicos o sea en forma de manchas ya que su abundancia es más elevada que su frecuencia: Esto se aplica especialmente en la especie Pseudolmedia laevis (Pamaxoco), y con menor intensidad para Iryanthera juruensis (Mëquënobita y Yorabita), Socratea exorrhiza (Oruga), Rinoreocarpus ulei (Shiuë), Pseudolmedia macrophylla (Pamaxoco). Metrodorea flavida (Paxaini).

> Las especies que no son tan abundantes pero que tienen una distribución regular en el bosque. Esas especies se encuentran comúnmente en el bosque ya que su abundancia es menos elevada que su frecuencia: Amaioua guianensis (Caiosho), Capirona decorticans (Batahua), Iryanthera laevis (Mëquënobita y Yorabita), Micropholis guyanensis (Tioroquërihua), Perebea aff. acutifolium (Tëco), Hortia sp. (Isonaraja). Qualea paraensis (Bisatamanëjoni). Asimismo, esas especies se distribuyen de manera aislada en el bosque pero se encuentran regularmente.

\section{Dominancia}

La dominancia indica la superficie ocupada por una especie en el bosque, es decir cuánto espacio ocupa la planta en la parcela. Por ejemplo, Bertholletia excelsa (Tapa) y otros árboles como Apuleia leiocarpa (Mani), Sclerolobium aff. rugosum (Canopëixoco), Ficus gomelleira (Yomëno), a pesar de no ser muy numerosos en el bosque, ocuparán mucho espacio en el bosque por tener gran volumen.

Asimismo, se distingue la dominancia absoluta y la dominancia relativa:

> La dominancia absoluta $\mathrm{Da}$, de una especie corresponde a la suma de las áreas basales de los individuos que pertenecen a esta especie. Por otro lado, el área basal $A B$, de un individuo, equivale a $(/ 4) \times(D A P)^{2}$ según la fórmula de Müeller Dombois y Ellenberg (1974).

$>$ La dominancia relativa $\mathrm{Dr}$ de la especie expresada en porcentaje, corresponde a :

\footnotetext{
$\mathrm{Dr}=\frac{\text { Área basal de la especie }}{\text { Total de las áreas basales en la parcela considerada }} \times 100$
}

E1 área basal obtenido al nivel de la hectárea, es decir la suma de todas las áreas basales de las diferentes especies de la parcela, es de aproximadamente $27 \mathrm{~m}^{2}$. Comparando el área basal de la parcela inventariada en el bosque de 
Alto-Ivón, con áreas basales de diferentes bosques amazónicos, el valor encontrado para la parcela de estudio, es inferior a los valores generalmente encontrados en los bosques tropicales (promedio de $32 \mathrm{~m}^{2} /$ ha, según Dawkins, 1958 citado por la Universidad de Medellin, 1986). Por ejemplo, se encontraron valores de $30 \mathrm{~m}^{2}$ en Araracuara-Colombia (Bergeron, 1992), $29.4 \mathrm{~m}^{2}$ en Alto Turiafu-Brasil (Balée, 1993), $35 \mathrm{~m}^{2}$ en Perú (Gentry, 1988). Esto puede explicarse por la gran abundancia de la hierba Phenakospermum guianensis (Mani) que ocupa varias áreas de $50 \mathrm{~m}^{2}$ en la hectárea inventariado, impidiendo de esta manera, la implementación de especies leñosas.

El área basal promedio por individuo es de aproximadamente $426 \mathrm{~cm}^{2}$. Aunque el área basal promedio por individuo varía según las regiones, queda inferior al promedio de los valores encontrados en el resto de la Amazonia: $\pm 453 \mathrm{cni}^{2}$ (Bergeron, 1992) y $443 \mathrm{~cm}^{2}$ (Universidad de Medellin, 1986) en Colombia, $519 \mathrm{~cm}^{2}$ (Mori et a/.citado par Boom, 1986) y 592.7 (Balée, 1993) en Brasil. En Alto-Ivón, este valor poco elevado podría explicarse por la gran abundancia de las palmas y de las especies tales como Theobroma speciosum (Nohotë), Rinoreocarpus ulei (Shiuë), Amaioua guianensis (Caiosho) representadas por árboles de altura y diámetro pequeños.

También, aquello corrobora el estudio de la estructura de los diámetros (ver Gráfico 3 ), en el sentido de que la mayoría de los árboles del bosque de Alto-Ivón se caracteriza por un diámetro pequeño (inferior a $30 \mathrm{~cm}$ ). Los árboles con gran diámetro son poco abundantes, solamente 14 de ellos tienen un diámetro superior a $50 \mathrm{~cm}$.

Las 15 especies características por su dominancia representan aproximadamente el 64\% del área basal total (ver Tabla 9). Encontramos de nuevo, las mismas especies que anteriormente (especies más frecuentes y/o más abundantes) como Pseudolmedia laevis (Pamaxoco), Iryan- thera juruensis (Mëquënobita y Yorabita), Perebea aff. acutifolium (Teco), Micropholis guyanensis (Tioroquërihua), Helicostylis tomentosa (Canapa), Hortia sp. (Isonaraia), Socratea exorrhiza (Onipa), Pseudolmedia macrophylla (Pamaxacaya), entre otras especies. Por otro lado, aparecieron nuevas especies poco abundantes y frecuentes pero bien dominantes, tales como Apuleia leiocarpa (Mani), Sclerolobium aff. rugosum (Canopëixoco), Ficus gomelleira (Yomëno), Vataireopsis speciosa (Jihuipisi), Bertholletia excelsa (Tapa).

Asimismo, si se compara las 15 especies caracterizadas por su abundancia y por su dominancia, se pueden distinguir tres grupos de especies:

Las especies abundantes y dominantes: Pseudolmedia laevis y $P$. macrophylla (Pamaxoco). Iryanthera juruensis (Mëquënobita y Yorabita), Socratea exorrhiza (Onipa), Helicostylis tomentosa (Canapa), Micropholis guyanensis (Tioroquërihua), Perebea aff. acutifolium (Tëco). Hortia sp. (Isonaraja). El hecho de que esas especies se caracterizan por su abundancia y dominancia significa que no solamente los individuos son abundantes pero también que su diámetro es suficientemente grande para tener una dominancia elevada.

Las especies abundantes pero no dominantes: Amaioua guianensis (Caiosho), Capirona decorticans (Batahua), Eulerpe precatoria (Panane), Iryanthera laevis (Yorabita), Rinoreocarpus ulei (Shiue), Theobroma speciosum (Nohote). Aunque abundantes, esas especies están representadas por individuos con diámetro demasiado pequeño para tener una dominancia elevada.

Las especies dominantes pero no
abundantes: Apuleia leiocarpa
(Mani), Sclerolobium aff. rugosum
(anopëixoco), Ficus gomelleira


Tabla 9: Las 15 especies más dominantes de la parcela

\begin{tabular}{|c|c|c|c|}
\hline $\begin{array}{l}\text { Nombre } \\
\text { Chácobo }\end{array}$ & Nombre científico & $\begin{array}{l}\text { Dominancia } \\
\text { relativa Dr } \\
\text { (\%) }\end{array}$ & $\begin{array}{l}\text { Número de colecta de } \\
\text { herbario }\end{array}$ \\
\hline Pamaxoco & Pseudolmedia laevis & 14.8 & $\begin{array}{l}9,84,93,113,119,439 \\
440,453,450 \text { bis }\end{array}$ \\
\hline Mani & Apuleia leiocarpa & 8.3 & $54,233,241,765,807$ \\
\hline Canopëixoco & Sclerolobium aff rugosum & 6.8 & $\begin{array}{l}49,157,224,445,471, \\
508,472 \text { bis }\end{array}$ \\
\hline $\begin{array}{l}\text { Mëquënobita y } \\
\text { Yorabita }\end{array}$ & Iryanthera juruensis & 6.0 & $\begin{array}{l}26,86,91,96,110,118, \\
221,451\end{array}$ \\
\hline Bisatamanejoni & Qualea paraensis & 3.8 & $181,226,482,527,531$ \\
\hline Yomëno & Ficus gomelleira & 3.2 & 147,206 \\
\hline Jihuipisi & Vataireopsis speciosa & 2.9 & $201,457,472,532,534$ \\
\hline Tëco & Perebea aff. acutifolium & 2.9 & $\begin{array}{l}16,53,106,115,130,155, \\
156,244,454,459\end{array}$ \\
\hline Tioroquërihua & Micropholis guyanensis & 2.7 & $17,34,168,173,231,246$ \\
\hline Tapa & Bertholletia excelsa & 2.6 & 229 \\
\hline Isonaraja & Hortia sp. & 2.5 & $14,122,240,835$ \\
\hline Onipa & Socratea exorrhiza & 1.9 & 100,535 \\
\hline Pamaxoco & Pseudolmedia macrophylla & 1.9 & $\begin{array}{l}19,21,84,85,93,113 \\
119,198,205,438,439 \\
440,453,478,511\end{array}$ \\
\hline Pamaxoco & Pseudolmedia macrophylla & 1.9 & $\begin{array}{l}19,21,84,85,93,113, \\
119,198,205,438,439, \\
440,453,478,511\end{array}$ \\
\hline Itsa & Cedrela fissilis & 1.8 & $177,228,483,498,618$ \\
\hline \multirow[t]{2}{*}{ Canapa } & Helicostylis tomentosa & 1.6 & $\begin{array}{l}120,121,149,150,180, \\
220,509,533\end{array}$ \\
\hline & Total: & 63.7 & \\
\hline
\end{tabular}

(Yomëno), Vataireopsis speciosa (Jihuipisi), Bertholletia excelsa (Tapa), Cedrela fissilis (Itsa). Aunque poco abundantes esas especies son generalmente representadas por emergentes lo que implica su dominancia característica.

Como síntesis, la Tabla 10 resume las 15 especies quienes son características por su abundancia (ver Tabla 6), frecuencia (ver Tabla 8) y/o dominancia (ver Tabla 9) elevada:

\section{El índice de valor de importancia (IVI)}

El cálculo de Índice de Valor de Importancia (IVI) permite ver no solamente cuáles son las especies predominantes o más "características" de la parcela estudiada, sino también conocer las especies más escasas, que no fueron mencionadas en los estudios de frecuencia, abundancia y dominancia. EI IVI corresponde a la suma de la frecuencia, abundancia y dominancia relativa (expresadas en porcentajes) 
Tabla 10: Resumen de las 15 especies características por su abundancia, frecuencia, y/o dominancia elevada

\begin{tabular}{|c|c|c|c|c|c|}
\hline \multicolumn{2}{|c|}{$\begin{array}{c}\text { Especies características por tres } \\
\text { parámetros (abundancia, } \\
\text { frecuencia, dominancia) }\end{array}$} & \multicolumn{2}{|c|}{$\begin{array}{c}\text { Especies características por dos } \\
\text { de los tres parámetros (en } \\
\text { general, abundancia y } \\
\text { frecuencia) }\end{array}$} & \multicolumn{2}{|c|}{$\begin{array}{c}\text { Especies características por uno } \\
\text { de los tres parámetros (en } \\
\text { general, dominancia) }\end{array}$} \\
\hline $\begin{array}{l}\text { Nombre } \\
\text { Chácobos }\end{array}$ & $\begin{array}{l}\text { Nombre } \\
\text { científico }\end{array}$ & $\begin{array}{l}\text { Nombre } \\
\text { Chácobos }\end{array}$ & $\begin{array}{l}\text { Nombre } \\
\text { científico }\end{array}$ & $\begin{array}{l}\text { Nombre } \\
\text { Chácobos }\end{array}$ & $\begin{array}{l}\text { Nombre } \\
\text { científico }\end{array}$ \\
\hline Pamaxoco & $\begin{array}{l}\text { Pseudolmedia } \\
\text { laevis }\end{array}$ & Shiuë & $\begin{array}{l}\text { Rinoreocarpus } \\
\text { ulei }\end{array}$ & Maní & $\begin{array}{l}\text { Apuleia } \\
\text { leiocalyx }\end{array}$ \\
\hline $\begin{array}{l}\text { Mëquënobita y } \\
\text { Yorabita }\end{array}$ & $\begin{array}{l}\text { Iryanthera } \\
\text { juruensis }\end{array}$ & Pananë & $\begin{array}{l}\text { Euterpe } \\
\text { precatoria }\end{array}$ & Canopëixoco & $\begin{array}{l}\text { Sclerolobium } \\
\text { aff. rugosum }\end{array}$ \\
\hline Onipa & $\begin{array}{l}\text { Socratea } \\
\text { exorrhiza }\end{array}$ & Nohotë & $\begin{array}{l}\text { Theobroma } \\
\text { speciosum }\end{array}$ & Yomëno & $\begin{array}{l}\text { Ficus } \\
\text { gomelleira }\end{array}$ \\
\hline Tëco & $\begin{array}{l}\text { Perebea aff. } \\
\text { acutifolium }\end{array}$ & Batahua & $\begin{array}{l}\text { Capirona } \\
\text { decorticans }\end{array}$ & Jihuipisi & $\begin{array}{l}\text { Vataireopsis } \\
\text { speciosa }\end{array}$ \\
\hline Canapa & $\begin{array}{l}\text { Helicostylis } \\
\text { tomentosa }\end{array}$ & $\begin{array}{l}\text { Yorabita, } \\
\text { Mëquënobita }\end{array}$ & $\begin{array}{l}\text { Iryanthera } \\
\text { laevis }\end{array}$ & Tapa & $\begin{array}{l}\text { Bertholletia } \\
\text { excelsa }\end{array}$ \\
\hline Pamaxoco & $\begin{array}{l}\text { Pseudolmedia } \\
\text { macrophylla }\end{array}$ & Caiosho & $\begin{array}{l}\text { Amaioua } \\
\text { guianensis }\end{array}$ & Itsa & Cedrela fissilis \\
\hline Isonaraja & Hortia sp. & $\begin{array}{l}\text { Bisata- } \\
\text { manëjoni }\end{array}$ & $\begin{array}{l}\text { Oualea } \\
\text { paraensis }\end{array}$ & Paxaini & $\begin{array}{l}\text { Metrodorea } \\
\text { flavida }\end{array}$ \\
\hline Tioroquërihua & $\begin{array}{l}\text { Micropholis } \\
\text { guyanensis }\end{array}$ & & & & \\
\hline
\end{tabular}

de una especie, multiplicada por 100. Prácticamente en cuánto más el IVI de una especie es importante, más esta última es predominante. Por ejemplo en el caso de monocultivo el IVI es de 300.

Generalmente se clasifican las especies en cuatro grupos según el valor del IVI (Proradam, 1979) y dependiendo de los valores encontradas en el inventario florístico:

$>$ Grupo I: Especies muy predominantes: el IVI es $>7$

$>$ Grupo II: Especies predominantes: $7<|\mathrm{V}|<4$

$>$ Grupo III: Especies medianamente predominantes: $4<|\mathrm{V}|<1.5$

$>$ Grupo IV: Especies nopredominantes:

$$
1.5<\text { IVI }
$$

Sin embargo, es importante considerar que una especie poco abundante $y / o$ poco frecuente pero con gran dominancia relativa, tendrá un IVI grande y por lo tanto no es una especie realmente predominante en la parcela. En este sentido, para clasificar las especies en diferentes grupos de IVI, hemos considerado no solamente el valor de dicho Índice para cada especie, sino también los parámetros de frecuencia, abundancia y dominancia considerados separadamente como criterio de clasificación, es decir tomado en cuenta la Tabla 10:

> Grupo I: Especies muy predominantes: esas especies tienen un IVI muy generalmente $\geq 7$ pero deben representativas por los parámetros de abundancia, frecuencia y dominancia.

Grupo II: Especies predominantes: deben ser representativas por 2 de los 3 parámetros y generalmente el IVI tiene valores entre 4 y 7.

Grupo III: Especies medianamente 
Bergeron S., 1998. Uso de las plantas por los Chácobos (Alto Ivón, Beni, Bolivia)

predominantes: deben ser representativas por 1 de los 3 parámetros generalmente tienen un IVI entre 1.5 y 4

$>$ Grupo IV: Especies no predominantes cuyo IVI es inferior a 1.5 y no son representativas por ninguno de los tres parámetros.

La clasificación de las especies en diferentes grupos permitió llegar a la Tabla 11.

Las ocho especies muy predominantes (grupo I) o sea el $6.6 \%$ del total de las especies son realmente "características" de la parcela, en el sentido de ser a la vez, muy abundantes, frecuentes y dominantes. Esas especies representan el $35.8 \%$ del IVI total. Las siete especies predominantes (grupo II) o sea el $5.8 \%$ del total de las especies alcanzan el $14.4 \%$ del IVI total. Esas especies son también bastante representativas de la parcela ya que se caracterizan por tener una abundancia y una frecuencia bastante elevadas (entre 2 y $3 \%$ ).Las treinta especies del grupo III (representando el $24.4 \%$ del total de las especies) son medianamente predominantes y no son tan representativas como las especies anteriores. Este grupo incluye especies características por uno de los 3 parámetros, en general la dominancia. Citaremos por ejemplo Cedrela fissilis (Itsa),
Apuleia leiocarpa (Mani), Qualea paraensis (Bisatamanëjoni), Ficus gomelleira (Yomëno), Vataireopsis speciosa (Jihuipisi). Berthollelia excelsa (Tapa), Sclerolobium aff. rugosum (Canopëixoco). Por otro lado este grupo III incluye especies cuya abundancia, frecuencia o dominancia es relativamente poco elevada sin ser por lo tanto despreciable $(\leq 0,5 \%)$.

En conclusión, podemos decir que los grupos I y II y más secundariamente el grupo III representando el $36.6 \%$ del total de las especies y alcanzando el $82.2 \%$ del IVI total (incluyendo los grupos I, II, III) representan bien la hectárea de vegetación estudiada y más generalmente el bosque de tierra firme de Alto-Ivón. Concretamente cualquier sea el sitio de estudio, se encontrarán estas especies en más o menos abundancia, frecuencia y dominancia pero de una forma constante. Por el contrario, el grupo IV, mayoritario por la cantidad de especies $(63.4 \%$ del total de las especies), y alcanzando solamente el $19 \%$ del IVI total, incluye especies mucho más aleatorias cuya abundancia, frecuencia o dominancia es muy poco elevada, aún despreciable y que no se encontrarán siempre en el bosque, cualquier sea el área de estudio. 
Bergeron S., 1998. Uso de las plantas por los Chácobos (Alto Ivón, Beni, Bolivia)

Tabla 11: Repartición de las especies en diferentes grupos de los IVI

\begin{tabular}{|c|c|c|c|c|c|c|}
\hline Grupos & Nombre Chácobo & Especies & Nb sp. & $\%$ & IVI & $\%$ \\
\hline Grupo I & $\begin{array}{l}\text { Pamaxoco } \\
\text { Mëquënobita y } \\
\text { Yorabita } \\
\text { Onipa } \\
\text { Teco } \\
\text { Tioroquërihua } \\
\text { Isonaraja Canapa } \\
\text { Pamaxoco }\end{array}$ & $\begin{array}{l}\text { Pseudolmedia laevis } \\
\text { Iryanthera juruensis } \\
\text { Socratea exorrhiza } \\
\text { Perebea aff acutifolium } \\
\text { Micropholis guyanensis } \\
\text { Hortia sp. } \\
\text { Helicostylis tomentosa } \\
\text { Pseudolmedia macrophylla } \\
\text { TOTAL }\end{array}$ & 8 & 6.5 & $\begin{array}{c}40.9 \\
17.9 \\
\\
11.7 \\
9.0 \\
7.6 \\
7.6 \\
6.8 \\
6.1 \\
107.6\end{array}$ & 35.8 \\
\hline Grupo 11 & $\begin{array}{l}\text { Pananë } \\
\text { Shiuë } \\
\text { Bisatamanëjoni } \\
\text { Batahua } \\
\text { Nohotë } \\
\text { Yorabita y } \\
\text { Mëquënobita } \\
\text { Caiosho }\end{array}$ & $\begin{array}{l}\text { Euterpe precatoria } \\
\text { Rinoreocarpus ulei } \\
\text { Qualea paraensis } \\
\text { Capirona decorlicans } \\
\text { Theobroma speciosum } \\
\text { Iryanthera laevis } \\
\text { Amaioua guianensis } \\
\text { TOTAL }\end{array}$ & & & $\begin{array}{l}7.7 \\
7.5 \\
7.1 \\
5.9 \\
5.5 \\
5.2 \\
4.3 \\
43.1\end{array}$ & \\
\hline & & TOTAL & 7 & 5.7 & 43.1 & 14.4 \\
\hline Grupo IH & & $\begin{array}{l}\text { Especies cuyo } 15 \leq \mid \mathrm{VI}<4 \circ \\
\text { características por } 1 \text { de los } 3 \\
\text { parámetros }\end{array}$ & 30 & 24.4 & 93.0 & 31.0 \\
\hline Grupo IV & & Especies con $\mathbf{I V I} \leq \mathbf{1 . 5}$ & 78 & 63.4 & 56.5 & 18.8 \\
\hline
\end{tabular}




\section{Capítulo 2:}

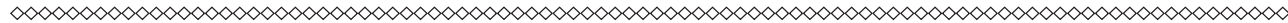

\section{La Clasificación de las Plantas por los Chácobos}

El presente capítulo tiene como objetivo presentar las principales características del sistema de clasificación de las plantas por los Chácobos. Por una parte, se trata simplemente de ver cómo los Chácobos agrupan las plantas entre ellas y por qué. Por otro lado, con el fin de iniciar el intercambio entre la cultura tradicional y la cultura occidental, se trata de acercarse a la estructura de la clasificación botánica Chácobo, considerando como modelo de referencia, el modelo de la clasificación etnobiologíca descrito por Brent (1992) (referirse a los principios básicos de la clasificación etnobiológica p.38).

Por lo tanto, este capítulo no constituye un estudio etnobiológico propio en el cual se analizaría en detalle la estructura de la clasificación y la nomenclatura de los nombres de plantas, considerados en este caso, desde una perspectiva puramente lingüística. Más bien, se destacan los conocimientos que tiene una pequeña parte de la población Chácobo respecto a la organización de su entorno vegetal. Esto permitirá dar unas pautas para futuros estudios puramente etnobiológicos, y en los cuales la lingüística jugará un papel fundamental. Sin embargo, al final del capítulo, mencionaremos algunas ideas sobre la nomenclatura y significación de los nombres Chácobos, las mismas que merecen ser profundizadas con estudios puramente lingüísticos.
Por otra parte, aunque aparezcan nombres científicos, tampoco se trata de hacer una comparación entre el sistema de clasificación tradicional y el sistema de clasificación occidental (sistema de Linné). Este último sistema solamente aporta al estudio, dando unas pautas para el intercambio de conocimientos entre las dos culturas; al mismo tiempo, puede servir de referencia para lectores más especializados en el tema de la botánica. Cabe mencionar que en las diferentes tablas mencionadas a lo largo de este capítulo, ciertas de las casillas aparecen en blanco, porque no se tiene información respecto a los nombres Chácobos, o porque la planta no ha sido identificada botánicamente.

Por último, cabe mencionar que el estudio sobre la clasificación y el uso de las plantas por los Chácobos no abarcó las plantas cultivadas, por las diversas razones mencionadas en la introducción. Sin embargo, aparecerán en el sistema de clasificación tradicional, algunos nombres de plantas cultivadas, ya que, si bien los comunarios de Alto-Ivón diferencian perfectamente las plantas domésticas de las silvestres, pueden agrupar esas distintas plantas en los mismos grupos.

\section{Principios básicos de la clasificación etnobiológica}

Para entender mejor la estructura de la clasificación tradicional de los Chácobos 
mencionaremos a continuación unos principios y definiciones de la clasificación etnobiológica según Brent (1992). Estos principios son válidos en el caso de una clasificación basada sobre las afinidades morfológicas de las plantas, es decir que estas plantas están agrupadas según sus similitudes (hojas, tronco, frutas). En efecto, existen otros tipos de clasificación donde las plantas se agrupan según sus usos, u otras características (Balée, 1994: 157):

Respecto a los sistemas de clasificación podemos destacar lo siguiente:

En los sistemas de clasificación etnobotánicos, el reconocimiento conceptual será dado a una parte de la flora y fauna existente, la cual comprende las especies que más se distinguen y sobresalen en el hábitat local.

Los sistemas de clasificación etnobotánicos se basan en primera instancia en las afinidades que pueden tener las plantas entre ellas, independientemente de la significación cultural actual o potencial de esos grupos de plantas.

Los sistemas de clasificación son conceptualmente organizados bajo una estructura jerárquica.

Los grupos ("taxa") reconocidos se distribuyen en cuatro a seis rangos o categorías, mutuamente exclusivos. Esos rangos son: el reino, la forma de vida, la categoría intermediaria, genérica, específica y varietal.

Los grupos de la categoría forma de vida son poco numerosos, pero amplios como árboles, bejucos, hierbas, y abarcan la mayoría de los rangos inferiores.

Los grupos de la categoría intermediaría, agrupan generalmente pocos grupos de la categoría genérica. No se perciben en los sistemas de clasificación y tampoco son nombrados.

Los grupos de la categoría o rango genérico son los más numerosos en cualquier sistema etnobiológico, son los más sobresalientes, y más fáciles de percibir e identificar. En un sistema tradicional puede haber de 500 a 600 taxas genéricas. Por otra parte, el $80 \%$ de esas taxas genéricas son monotípicas es decir que no incluyen categorías inferiores como taxa específica o varietal.

Los grupos de la categoría específica subdividen los grupos de la categoría genérica pero son menos numerosos que esos últimos.

Los grupos de la categoría de variedades existen muy rara vez en los sistemas de clasificación etnobiológica y subdividen los grupos de la categoría específica".

(Brent, 1992: 23-33; Martin, 1995: 215)

Encuantoalanálisis propio (nomenclatura) de los nombres de las plantas, aunque existan reglas lingüísticas diferentes, existen ciertas similitudes respecto a la forma en que las personas nombran a las plantas. Asimismo, existen dos tipos de nombres, el nombre o "lexeme" primario y el nombre secundario.

Un nombre primario corresponde a una 
Bergeron S., 1998. Uso de las plantas por los Chácobos (Alto Ivón, Beni, Bolivia)

unidad semántica que significa una sola expresión, es generalmente un nombre único o simple pero a veces puede ser complejo si está definido por varios constituyentes. En el caso de un nombre primario complejo, puede ser productivo si lleva el nombre de la categoría superior, o no productivo si no lleva este último nombre. Por ejemplo el nombre Chácobo Pama, considerado como categoría genérica, es un nombre primario simple. También puede llamarse Pamajihui (árbol de Parna) el cual es un nombre primario productivo: lleva el nombre de Pama así como la categoría superior o forma de vida Jihui (árbol).

Un nombre secundario lleva el nombre primario además de otro nombre más específico. Por ejemplo Pamaxoco es una especie de Pama. Asimismo, volviendo a las diferentes categorías mencionadas anteriormente, el reino y la clase intermediaria generalmente no llevan nombres. La forma de vida y la categoría genérica incluyen nombres primarios mientras que las categorías específicas y de variedad incluyen nombres secundarios (Brent, 1992: 34; Martin, 1995: 215-216).

\section{Características de la clasificación botánica Chácobos}

\section{Los ambientes y las formas de vida}

De manera general, si bien no existe un nombre específico para el mundo de las plantas (o reino vegetal), los Chácobos distinguen claramente los diferentes tipos de ambientes que les rodean, la mayoría de ellos tiene un nombre definido (referirse al Gráfico 4):

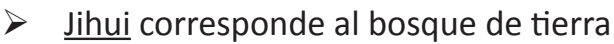
firme o "monte alto". Jihui significa también árbol.

> Jéné, significa agua, y corresponde al bosque ribereño.

> Xaba corresponde a la sabana o pampa.

$>$ Por último, si bien los Chácobos distinguen los barbechos del bosque de tierra firme o "monte alto" o de los otros tipos de ambientes, esos últimos no tienen nombre en particular.

Por otro lado, al nivel de los diferentes tipos de plantas (formas de vida), los Chácobos distinguen principalmente cuatro formas de vida:

$>$ Jihui designa al árbol.

$>\quad$ Nishi designa al bejuco.

Nihi designa a la hierba. Cabe mencionar que dentro los Nihi existe un grupo específico para los bambúes (Bisto). 


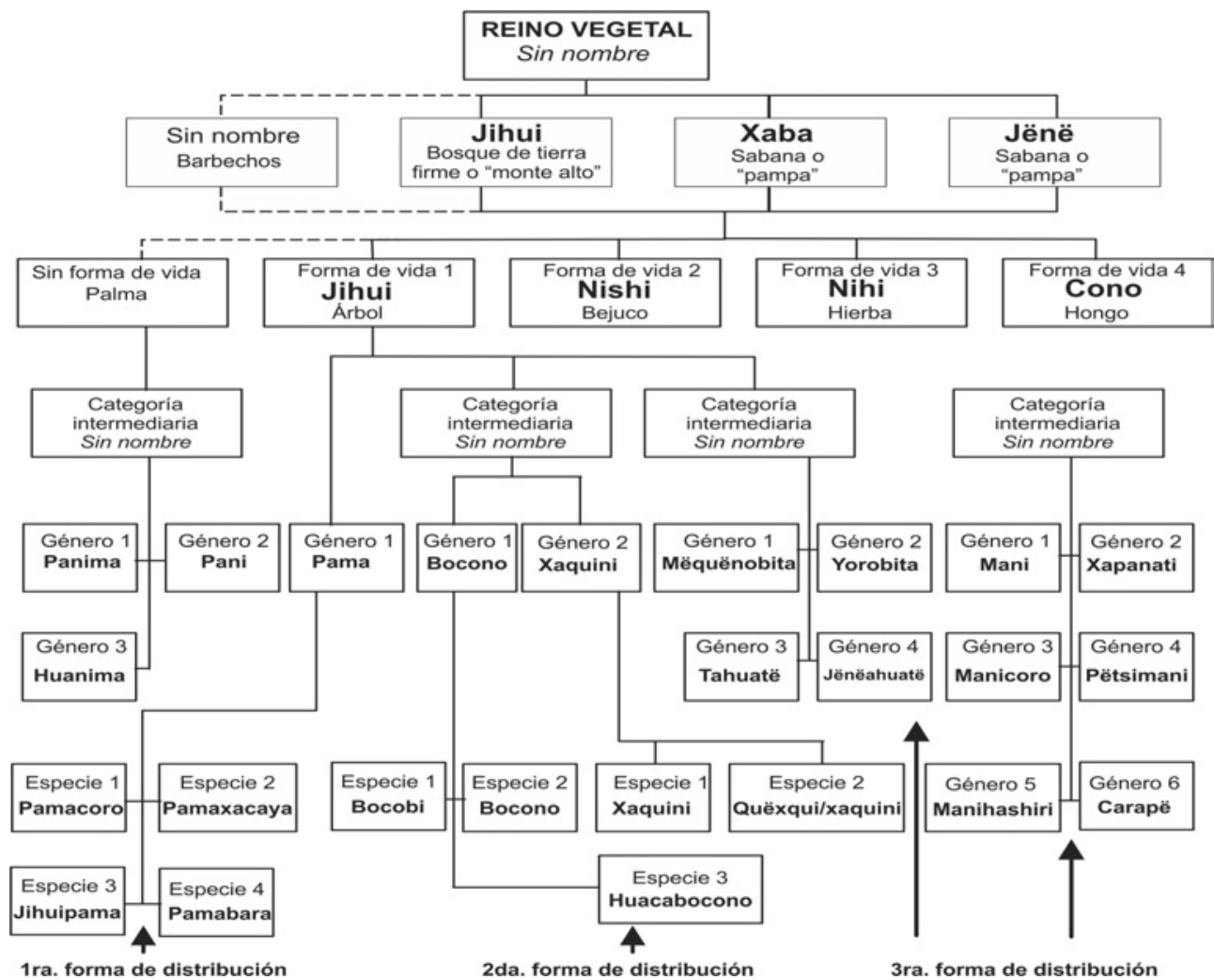

Gráfico 4: Estructura de la clasificación de las plantas Chácobos, basada en el sistema de clasificación de Brent (1992)

$>$ Cono designa el hongo, aunque que este tipo de plantas no fue estudiado en detalle.

Las palmas y los arbustos no tienen nombre específico y pueden ser considerados como Jihui cuando son leñosos, o como Nihi (hierba) cuando no tienen madera. De la misma forma, los helechos son considerados como hierba. Assimismo, si nos referimos al sistema de clasificación de Brent (1992) (ver Gráfico $4)$, vemos que dentro del reino vegetal, existe la categoría medio ambiente, que arbitrariamente, podría llamarse la categoría "subreino". Por otro lado, la categoría forma de vida (tipo de planta) está representada por pocos grupos (árbol, bejuco, hongo, hierba).

\section{Los diferentes grupos de plantas}

De aproximadamente $\mathbf{5 3 0}$ diferentes plantas diferenciadas por los Chácobos y abarcadas en este estudio, 472 fueron recolectadas. Ese número de plantas no incluye las plantas repetidas ${ }^{13}$, correspondiendo a aproximadamente a 361 especies botánicas.

De aquellas recolectadas, solamente seis no pudieron ser identificadas por los Chácobos, lo que refleja un alto conocimiento de las plantas, por los comunarios de Alto-Ivón.

${ }^{13}$ Con estas últimas, se alcanzó a un número total de muestras recolectadas de 953 
Entre las 530 plantas distinguidas por los Chácobos (recolectadas y/o no recolectadas), aparecieron 70 grupos claramente definidos por los indígenas y más específicamente, 43 grupos de árboles, 4 grupos de palmas, 8 grupos de bejucos y 15 grupos de hierbas. Por otro lado, algunas plantas, como Nahuabexë (Didymopnax morototoni), Bahuaquëxti (Tabernaemoniana sp.), Pitsopi (Jacaranda copaia), no entran en esos grupos ya que no tienen relación con otras plantas, o a veces pueden tienen relación con plantas que no existen en Alto-Ivón sino en otros lugares como la región del Yata. Asimismo, analizando más en detalle los 70 grupos definidos por los Chácobos, y basándose en los principios de etnobiología de Brent (1992), podemos ver que:

Las plantas están agrupadas entre ellas según sus afinidades morfológicas, o sea, por ser parecidas (forma del árbol, hojas, frutas). Esos grupos de plantas entran en el modelo de clasificación de Brent (1992) y por otro lado, existen variaciones dentro de este modelo (ver Gráfico 4).

Las plantas están agrupadas no porque se parecen, sino porque tienen un uso similar o una característica especial en común. Asimismo, para los Chácobos este uso común o esta característica muy peculiar (por ejemplo, madera dura, ausencia de madera, corteza amarga) es más importante que las semejanzas que podrían tener las plantas en- tre ellas. En este caso, los grupos de plantas que responden a este tipo de clasificación, no entran en el sistema de clasificación de Brent (1992).

\section{Las plantas están agrupadas según sus afinidades morfológicas}

Dentro de las plantas agrupadas según sus características morfológicas y que responden al modelo de Brent (1992), se presentan tres formas de distribución.

\section{Primera forma de distribución de las plantas}

Esta forma de distribución de las plantas, se dirige a los grupos de plantas para los cuales, después de la forma de vida, siguen directamente las categorías genéricas y específicas respectivamente denominadas, o sea que no existe una categoría intermediaria (no denominada):

Este caso se presentó solamente para 4 grupos de árboles (sobre un total de 43 grupos de árboles), no se presentó para las hierbas, tampoco para los bejucos y palmas (referirse al Gráfico 4).

Asimismo, en la Tabla 12 se mencionan los diversos grupos de plantas diferenciados por los Chácobos y para los cuales no existe categoría intermediaria. Se presentan también las características principales de estos grupos y las diferencias más sobresalientes que existen entre cada tipo de planta ("categoría específica"). 
Bergeron S., 1998. Uso de las plantas por los Chácobos (Alto Ivón, Beni, Bolivia)

Tabla 12: Grupos de plantas para los cuales no existe categoría intermediaria pero existen categorías genéricas y específicas

\section{Gupo Pama:}

Pama es el nombre propio de estos tipos de árboles, no tiene traducción en castellano. El grupo Pama está representado por árboles con leche, mismos tipos de árboles, frutas, hojas

\begin{tabular}{|c|c|c|c|c|}
\hline $\begin{array}{l}\text { Nombre } \\
\text { Chácobo }\end{array}$ & Características & Género y especie & Familia & No de colección \\
\hline Pamaxacaya & $\begin{array}{l}\text { Frutas y hojas } \\
\text { grandes }\end{array}$ & $\begin{array}{l}\text { Pseudolmedia cf murure y } \\
\text { Pseudolmedia laevis }\end{array}$ & Moraceae & $\begin{array}{l}478,511,624,943, \\
20\end{array}$ \\
\hline Pamacoro & $\begin{array}{l}\text { Frutas y hojas sin } \\
\text { pelos }\end{array}$ & $\begin{array}{l}\text { Pseudolmedia } \\
\text { macrophylla y } \\
\text { Pseudolmedia laevis }\end{array}$ & Moraceae & $625,629,840$ \\
\hline Pamabara & $\begin{array}{l}\text { Frutas y hojas con } \\
\text { pelos }\end{array}$ & Pseudolmedia cf murure & Moraceae & 198 \\
\hline Pamaxoco & $\begin{array}{l}\text { Frutas y hojas } \\
\text { pequeñas }\end{array}$ & $\begin{array}{l}\text { Pseudolmedia laevis y } \\
\text { Pseudolmedia } \\
\text { macrophylla }\end{array}$ & Moraceae & $\begin{array}{l}9,84,93,113, \\
119,439,440, \\
453,450 \text { bis } \\
19,21,85,205,438\end{array}$ \\
\hline Jihuipama & $\begin{array}{l}\text { Pama del bosque } \\
\text { ribereño }\end{array}$ & Pseudolmedia laevigata & Moraceae & 867,1006 \\
\hline
\end{tabular}

\section{Grupo Xanatë:}

Xanatë es nombre propio del árbol, no tiene traducción en castellano.

Arboles con leche, mismos tipos de árboles, de corteza varían por sus frutas.

Arboles presentados por el tamaño descendente de las frutas.

\begin{tabular}{|c|c|c|c|c|}
\hline Nombre Chácobo & Características & Género y especie & Familia & $\begin{array}{l}\text { No de } \\
\text { colección }\end{array}$ \\
\hline Xanatëchëquë & $\begin{array}{l}\text { Arbol de Xanatë con } \\
\text { frutos negros }\end{array}$ & Brosimum lactenses & Moraceae & $234,235,760$ \\
\hline Xanajoxo & $\begin{array}{l}\text { Arbol de Xanatë con } \\
\text { frutos blancos. } \\
\text { "Joxo" significa } \\
\text { blanco }\end{array}$ & Sorocea muriculata & Moraceae & $\begin{array}{l}94,270,699, \\
762\end{array}$ \\
\hline Tëco & & Perebea aff. acutifolium & Moraceae & $\begin{array}{l}16,53,106, \\
115,130,155, \\
156,244,454, \\
459\end{array}$ \\
\hline Xëquibëroxanatë & & No recolectado & & \\
\hline Bachirao & $\begin{array}{l}\text { La fruta es parecida } \\
\text { a un huevo ("bachi") }\end{array}$ & Brosimum guianense & Moraceae & $\begin{array}{l}209,245,407, \\
553,619,623, \\
839\end{array}$ \\
\hline Bërobishi & & No recolectado & & \\
\hline
\end{tabular}




\section{Grupo Cano:}

Cano es nombre propio del árbol, no tiene traducción en castellano.

Mismos árboles, corteza, hojas. Presentados por el tamaño descendente de los árboles.

\begin{tabular}{|c|c|c|c|c|}
\hline $\begin{array}{l}\text { Nombre } \\
\text { Chácobo }\end{array}$ & Características & Género y especie & Familia & $\begin{array}{c}\text { No de } \\
\text { colección }\end{array}$ \\
\hline Canopëihua & $\begin{array}{l}\text { Cano es el nombre del } \\
\text { árbol. } \\
\text { "Pehihua": Grandes } \\
\text { hojas }\end{array}$ & $\begin{array}{l}\text { Sclerolobium aff. } \\
\text { chrysophyllum }\end{array}$ & Caesalpiniaceae & 460,502 \\
\hline Canopëixoco & $\begin{array}{l}\text { "Pëixoco: Hojas } \\
\text { pequeñas. } \\
\text { La madera más pesada } \\
\text { que Canopéhihua }\end{array}$ & Sclerolobium sp. & Caesalpiniaceae & $\begin{array}{l}49,157,224, \\
445,471, \\
508,472 \text { bis }\end{array}$ \\
\hline Muasicano & $\begin{array}{l}\text { "Huasi": Hierba. Este } \\
\text { Cano vive cerca a la } \\
\text { Pampa }\end{array}$ & $\begin{array}{l}\text { Sclerolobium aff. } \\
\text { raülkoferi }\end{array}$ & Caesalpiniaceae & 374 \\
\hline $\begin{array}{l}\text { Xabahua- } \\
\text { sicano }\end{array}$ & Cano de la pampa. & $\begin{array}{l}\text { Sclerolobium aff. } \\
\text { guianense }\end{array}$ & Caesalpiniaceae & 381,591 \\
\hline
\end{tabular}

\section{Grupo Xenanë:}

Xenanë viene de "Xëna": guzano, porque los guzanos comen las hojas de los árboles. Arboles parecidos con el mismo tipo de corteza, hojas y frutas (comestibles). Presentados por el tamaño descendente de los árboles.

\begin{tabular}{|c|c|c|c|c|}
\hline Nombre Chácobo & Características & Género y especie & Familia & $\begin{array}{l}\text { No de } \\
\text { colección }\end{array}$ \\
\hline Ahuapixënanë & $\begin{array}{l}\text { Las frutas están comidos } \\
\text { por la anta ("Ahua") }\end{array}$ & Inga cf. fagifolia & Mimosaceae & 766,906 \\
\hline Huaihuatixënanë & $\begin{array}{l}\text { El árbol fructifica en la } \\
\text { misma época de la } \\
\text { apertura de los chacos". } \\
\text { Viene de ("Huai": chaco) }\end{array}$ & Inga sp. & Mimosaceae & 308 \\
\hline Rispixënanë & $\begin{array}{l}\text { Frutas alargados y } \\
\text { fibrosos como la soga } \\
\text { ("Rispi": soga) }\end{array}$ & Inga sp. & Mimosaceae & $311,659,1001$ \\
\hline $\begin{array}{l}\text { Jimihomaxënanë o } \\
\text { Jimixënane }\end{array}$ & $\begin{array}{l}\text { Las frutas son rojos como } \\
\text { la sangre ("Jimi": sangre) }\end{array}$ & Inga sp. & Mimosaceae & 372 \\
\hline Yaroxënanë & $\begin{array}{l}\text { Las frutas son medio } \\
\text { torcidos ("Yaro": medio } \\
\text { torcido) }\end{array}$ & Inga sp. & Mimosaceae & 306 \\
\hline Rohoxënanë & $\begin{array}{l}\text { Un tipo de mono ("Roho") } \\
\text { vive en el árbol }\end{array}$ & Inga sp. & Mimosaceae & 666.894 \\
\hline Shipixënanë & $\begin{array}{l}\text { Hojas pequeñas ("Shipi": } \\
\text { pequeño) }\end{array}$ & Inga heterophylla & Mimosaceae & 309 \\
\hline Tsacoxënanë & & $\begin{array}{l}\text { Pithecellobium } \\
\text { cauliflorum }\end{array}$ & Mimosaceae & 890,1004 \\
\hline
\end{tabular}


Los nombres de las categorías genéricas como Pama, Xanaté, Cano, Xénané pueden definirse como nombres simples, es decir están conformados por un sólo nombre. En efecto, cuando se refieren a los árboles de los grupos Pama, Xanaté, Cano. Xénané, los Chácobos sobreentienden los nombres de Pamajihui, Xanatéiihui. Canojihui y Xénanéiihui, y no mencionan la palabra Jihui. Por otro lado, las especies que entran en esos diferentes grupos de árboles, tampoco llevan el nombre de la forma de vida Jihui.

La mayoría de las veces, existe dentro de las categorías especies, una raiz común que corresponde al nombre genérico, por ejemplo Pamaxoco. Pamaxacaya, pertenecen al grupo Pama, o Canopeihua y Canopeixoco pertenecen al grupo Cano. Sin embargo puede existir el caso en que la especie no lleva el nombre de la categoría genérica. Por ejemplo, Teco, Bachirao, Bérobishi pertenecen al grupo Xanaté sin llevar este nombre.

\section{Segunda forma de distribución de las plantas}

Este caso solamente se presentó para dos grupos de árboles (el primer grupo que abarca a Bocono y Xaquini. el segundo abarcando a Caxcono y Quisi). Cómo lo indica el Gráfico 4, y a la diferencia de la primera forma de distribución de las plantas, existe, después de la forma de vida, una categoría intermediaria no nombrada, que se subdivide en categorías genéricas, que a su vez, se subdividen en categorías específicas. Asimismo, se presentan en la Tabla 13, los dos grupos de árboles (presentados por el tamaño descendente de los árboles) que se caracterizan por esta forma de distribución, con las principales características de las plantas.

Tabla 13: Grupos de plantas para los cuales existe categoría intermediaria y existen categorías genéricas y específicas

\section{Grupos Bocono y Xaquini:}

Los nombres Bocono y Xaquini no tienen traducción en castellano. Se trata de un grupo considerado como único (categoría intermediaria) en el cual habría dos subgrupos (Bocono y Xaquini) como categorías genéricas. También este caso es un poco especial ya que no se trata de un grupo que incluye solamente árboles, sino también está incluido el Coyoboconishi (Ficusparaensis), bejuco del bosque ribereño (referirse al Gráfico 4).

\begin{tabular}{|c|c|c|c|c|}
\hline $\begin{array}{l}\text { Nombre } \\
\text { Chácobo }\end{array}$ & Características & $\begin{array}{l}\text { Género y } \\
\text { especie }\end{array}$ & Familia & $\begin{array}{l}\text { No de } \\
\text { colección }\end{array}$ \\
\hline \multicolumn{5}{|c|}{ Bocono } \\
\hline Bocobi & Arbol delgado y grande & $\begin{array}{l}\text { Cecropia } \\
\text { sciadophylla }\end{array}$ & Moraceae & $208,219,249$ \\
\hline Bocono & Arbol más pequeño & Pourouma sp. & Moraceae & $57,202,489$ \\
\hline Huacabocono & & Cecropia ficifolia & Moraceae & 302,753 \\
\hline $\begin{array}{l}\text { Coyomoro o } \\
\text { Coyoboco-nishi }\end{array}$ & $\begin{array}{l}\text { Bejuco cuya corteza es casi } \\
\text { idéntica a Bocono }\end{array}$ & Ficus paraensis & Moraceae & 722 \\
\hline \multicolumn{5}{|c|}{ Xaquini } \\
\hline Xaquini & & $\begin{array}{l}\text { Pourouma } \\
\text { cecropiifolia }\end{array}$ & Moraceae & $\begin{array}{l}56,186,248 \\
346,523\end{array}$ \\
\hline Quexqui-xaquini & $\begin{array}{l}\text { "Quexqui: Árbol cuyas } \\
\text { frutas son pequeñas y } \\
\text { hojas rugosas }\end{array}$ & $\begin{array}{l}\text { Pourouma } \\
\text { guianensis }\end{array}$ & Moraceae & $418,448,464$ \\
\hline
\end{tabular}




\section{Grupos Caxcono y Quisi:}

Caxcono y Quisi son los nombres de esos árboles.

Los árboles pertenecientes a este grupo se caracterizan por presentar un tronco con espinas. Los árboles tienen la misma apariencia, solamente varían por las hojas.

Los Caxcono se encuentran tanto en el bosque de tierra firme como en los barbechos mientras que los Quisi predominan en los barbechos.

\begin{tabular}{|c|c|c|c|c|}
\hline $\begin{array}{l}\text { Nombre } \\
\text { Chácobo }\end{array}$ & Características & Género y especie & Familia & No de colección \\
\hline \multicolumn{5}{|c|}{ Caxcono } \\
\hline Caxcochëquë & $\begin{array}{l}\text { Corteza negra ) } \\
\text { ("Cheque") }\end{array}$ & $\begin{array}{l}\text { Pithecellobium sp. } \\
\text { o Albizia sp. }\end{array}$ & Mimosaceae & 858,915 \\
\hline $\begin{array}{l}\text { Caxcojoxo } \\
\text { Caxcono }\end{array}$ & $\begin{array}{l}\text { Corteza blanca ("joxo": } \\
\text { blanco). Además cuando } \\
\text { el árbol se muere, los } \\
\text { hongos aparecen sobre el } \\
\text { árbol ("Cono". Hongo) }\end{array}$ & $\begin{array}{l}\text { Parapiptadenia } \\
\text { excelsa }\end{array}$ & Mimosaceae & $\begin{array}{l}109,196,237, \\
530\end{array}$ \\
\hline $\begin{array}{l}\text { Sipiricaxcono o } \\
\text { Caxcopisi }\end{array}$ & $\begin{array}{l}\text { Mal olor de la corteza } \\
\text { ("Pisi": podrido) }\end{array}$ & $\begin{array}{l}\text { cf. Piptadenia } \\
\text { buchtienii }\end{array}$ & Mimosaceae & $\begin{array}{l}18,108,190, \\
260,461,514, \\
829\end{array}$ \\
\hline \multicolumn{5}{|c|}{ Quisi } \\
\hline Coroquisi & $\begin{array}{l}\text { La corteza es similar a la } \\
\text { piel de tatú ("Coro": tatú) }\end{array}$ & $\begin{array}{l}\text { Zanlhophyllum } \\
\text { rhoifolium }\end{array}$ & Rutaceae & $422,653,810$ \\
\hline Quisi & & & Papilionaceae & 850 \\
\hline
\end{tabular}

El gráfico 5 muestra la forma de distribución del grupo Caxono - Quisi

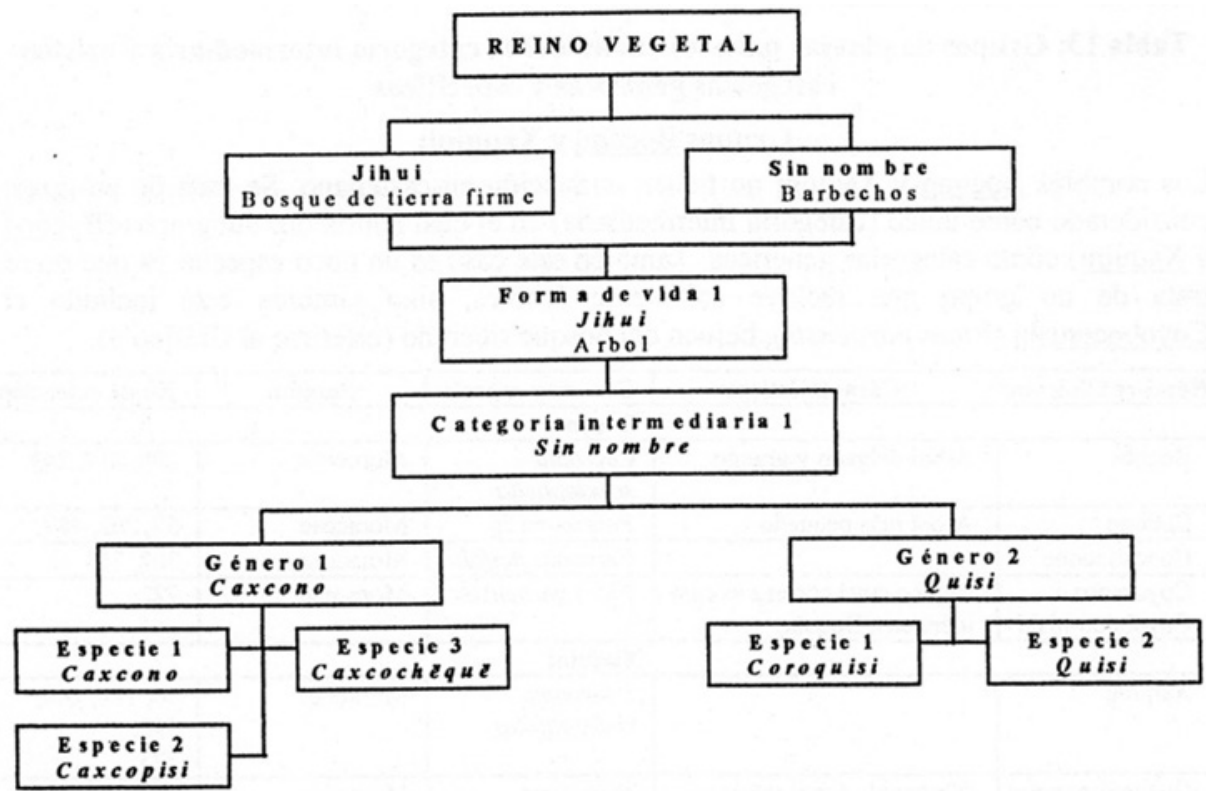

Gráfico 5: El grupo Caxono-Quisi según el modelo de clasificación de Brent (1992) 


\section{Tercera forma de distribución de las plantas}

Esta forma de distribución ha sido observada para la mayoría de los árboles (28 grupos sobre un total de 43 grupos), 2 grupos de palmas (sobre un total de 4), 9 grupos de hierbas (sobre un total de 15) y solamente 2 grupos de bejucos (sobre un total de 8).

Esta forma de distribución es parecida a la anterior ya que existe después de la forma de vida, una categoría intermediaria que abarca a varios géneros, pero en este caso no existen categorías específicas (referirse al Gráfico 4, 3era forma de distribución). Se presentan en la Tabla 14, los grupos de árboles, hierbas y bejucos que responden a este tipo de distribución de plantas.

Tabla 14: Grupos de plantas para los cuales existe categoría intermediaria y genéricas pero las categorías específicas son ausentes

\begin{tabular}{|c|c|c|c|c|}
\hline Nombre Chácobo & Características & Genero y especie & \multicolumn{2}{|c|}{ Familia No de colección } \\
\hline \multicolumn{5}{|c|}{$\begin{array}{l}\text { GRUPO } 1 \\
\text { En este grupo, los árboles (Bita) son similares (corteza, resina, frutas). Las frutas (rojas) son comidas por los } \\
\text { pájaros }\end{array}$} \\
\hline Mëquënobita & $\begin{array}{l}\text { Frutas sobre las ramas } \\
\text { ("Mëquënë" } \quad \text { significa } \\
\text { brazo) }\end{array}$ & $\begin{array}{l}\text { Iryanthera juruensis o } \\
\text { Iryanthera laevis }\end{array}$ & Myristicaceae & $\begin{array}{l}96,118 \\
221,451 \\
27,727\end{array}$ \\
\hline Yorabita & $\begin{array}{l}\text { Frutas sobre el tronco } \\
\text { ("Yora": tronco) }\end{array}$ & $\begin{array}{l}\text { Iryanthera juruensis o } \\
\text { Iryanthera laevis }\end{array}$ & Myristicaceae & $\begin{array}{l}86,91 \\
110,114 \\
144,223\end{array}$ \\
\hline Tahuatë & $\begin{array}{l}\text { "Tahua": una cierta } \\
\text { hierba, ya que la hoja } \\
\text { de Tahuatë es tan } \\
\text { delgada como este } \\
\text { hierba. Árbol grande y } \\
\text { recto }\end{array}$ & Virola flexuosa & Myristicaceae & $\begin{array}{l}48,83 \\
132,143 \\
475\end{array}$ \\
\hline Jenetahuatë & $\begin{array}{l}\text { Árbol parecido al } \\
\text { tahuatë pero es del } \\
\text { bosque ribereño }\end{array}$ & Virola aff. elongata & Myristicaceae & 709,1005 \\
\hline \multicolumn{5}{|c|}{ GRUPO 2} \\
\hline Xëtohitsa & $\begin{array}{l}\text { Xëtohitsa vinen de } \\
\text { "Xëto" que significa } \\
\text { brea, porque el árbol } \\
\text { tiene resina }\end{array}$ & Trattinnickia rhoifolia & Burseraceae & $\begin{array}{l}10,151 \\
878\end{array}$ \\
\hline Corihua & $\begin{array}{l}\text { Corihua es el nombre } \\
\text { propio del árbol }\end{array}$ & $\begin{array}{l}\text { Trattinnickia lawrencei } \\
\text { var bolivianum }\end{array}$ & Burseraceae & 521,826 \\
\hline Bëisiticorihua & $\begin{array}{l}\text { Bëisiticorihua viene de } \\
\text { "Bëisiti": espejo, } \\
\text { corihua porque la } \\
\text { corteza tiene placas } \\
\text { como espejos. Resina } \\
\text { de buena calidad para } \\
\text { la elaboración de las } \\
\text { flechas }\end{array}$ & $\begin{array}{l}\text { Protium cf. sagotianum o } \\
\text { Protium unifoliatum }\end{array}$ & Burseraceae & $\begin{array}{l}162,250 \\
45,673 \\
718,847\end{array}$ \\
\hline
\end{tabular}


Bergeron S., 1998. Uso de las plantas por los Chácobos (Alto Ivón, Beni, Bolivia)

Tabla 14 (continuación): Grupos de plantas para los cuales existe categoría intermediaria y existen categorías genéricas pero las categorías específicas son ausentes

\begin{tabular}{|c|c|c|c|c|}
\hline Nombre Chácobo & Características & Género y especie & Familia & $\begin{array}{l}\text { No de } \\
\text { colección }\end{array}$ \\
\hline $\begin{array}{l}\text { Xababëisiti-corihua o } \\
\text { Xabachaca- } \\
\text { bëisiticorihua o }\end{array}$ & $\begin{array}{l}\text { Resina de buena calidad } \\
\text { para la elaboración de } \\
\text { las flechas }\end{array}$ & $\begin{array}{l}\text { Tetragastris o } \\
\text { Dacryodes }\end{array}$ & Burseraceae & 587 \\
\hline Jenëbëisiti-corihua & Corihua del río & $\begin{array}{l}\text { Protium } \\
\text { unifolioliatum }\end{array}$ & Burseraceae & 822 \\
\hline Toxa & $\begin{array}{l}\text { Nombre propio del } \\
\text { árbol }\end{array}$ & $\begin{array}{l}\text { Crepidospermun } \\
\text { goudotianum }\end{array}$ & Burseraceae & 50,851 \\
\hline Bishatë & $\begin{array}{l}\text { Bishatë viene de } \\
\text { "Bisha": guzanos, que } \\
\text { viven en el árbol }\end{array}$ & $\begin{array}{l}\text { Protium } \\
\text { subserratum }\end{array}$ & Burseraceae & 159,700 \\
\hline Xababishatë & Bishatë de la pampa & $\begin{array}{l}\text { Protium } \\
\text { subserratum }\end{array}$ & Burseraceae & 561 \\
\hline \multicolumn{5}{|c|}{ GRUPO 3} \\
\hline \multicolumn{5}{|c|}{ Corteza o "cáscara" parecidas, color del tronco y forma de los árboles similares, pero hojas y frutas diferentes } \\
\hline Jihuijoxo & $\begin{array}{l}\text { "Joxo": blanco. La } \\
\text { corteza es blanca }\end{array}$ & Qualea paraensis & Vochysiaceae & 82,183 \\
\hline $\begin{array}{l}\text { Xabajihuixoco } \\
\text { Ilamado también } \\
\text { Xabajihuijoxo }\end{array}$ & & $\begin{array}{l}\text { Qualea multiflora } \\
\text { ssp. pubescens }\end{array}$ & Vochysiaceae & 63 \\
\hline Bisatamanëjoni & $\begin{array}{l}\text { "Bisatamanë": nombre } \\
\text { propio del árbol y } \\
\text { "Joni": falso, porque es } \\
\text { el Bisatamanë ordinario }\end{array}$ & Qualea paraensis & Vochysiaceae & $\begin{array}{l}181,226 \\
482,527 \\
531\end{array}$ \\
\hline Bisatamanë & & Qualea sp. & Vochysiaceae & $\begin{array}{l}409,515, \\
517\end{array}$ \\
\hline Nihipëpëcho & $\begin{array}{l}\text { Nombre propio del } \\
\text { árbol }\end{array}$ & Qualea paraensis & Vochysiaceae & $\begin{array}{l}164,449, \\
944\end{array}$ \\
\hline Xabapepëcho & Pëpëcho de la pampa & $\begin{array}{l}\text { Erythroxylum } \\
\text { campestre o } \\
\text { Roupala montana }\end{array}$ & $\begin{array}{l}\text { Erythroxylaceae } \\
\text { Proteaceae }\end{array}$ & 604,69 \\
\hline \multicolumn{5}{|c|}{ GRUPO 4} \\
\hline Shia & Corteza amarga & & Mimosaceae & 58,204 \\
\hline $\begin{array}{l}\text { Ahuarari o también } \\
\text { Jihuijoxo }\end{array}$ & & & Papilionaceae & 241 \\
\hline Jihuirashia & $\begin{array}{l}\text { Jihuirashia viene de } \\
\text { "Shia": amarillo, por el } \\
\text { tronco amarillo }\end{array}$ & & Mimosaceae & 696,849 \\
\hline Mani & $\begin{array}{l}\text { Nombre propio del } \\
\text { árbol }\end{array}$ & Apuleia molaris & Papilionaceae & $\begin{array}{l}54, \\
233,241 \\
765,807 \\
\end{array}$ \\
\hline Canamashia & & & Papilionaceae? & $\begin{array}{l}59,194 \\
197,473 \\
941\end{array}$ \\
\hline Matsaquiti & $\begin{array}{l}\text { Nombre propio del } \\
\text { árbol }\end{array}$ & Poeppigia procera & Caesalpiniaceae & 218 \\
\hline
\end{tabular}


Bergeron S., 1998. Uso de las plantas por los Chácobos (Alto Ivón, Beni, Bolivia)

Tabla 14 (continuación): Grupos de plantas para los cuales existe categoría intermediaria y existen categorías genéricas pero las categorías específicas son ausentes

\begin{tabular}{|c|c|c|c|c|}
\hline Nombre Chácobo & Características & Género y especie & Familia & $\begin{array}{l}\text { No de } \\
\text { colección }\end{array}$ \\
\hline Tëtëmabaspa & $\begin{array}{l}\text { Tëtëmabaspa viene de } \\
\text { "Tëtë": el pájaro chubi y } \\
\text { de "mabaspa": cresta } \\
\text { porque la corteza es tan } \\
\text { delgada que las uñas } \\
\text { del chubi }\end{array}$ & & Mimosaceae & 369 \\
\hline Jënëtëtëmabaspa & Tëtëmabaspa del río & Inga sp. & Mimosaceae & 889 \\
\hline \multicolumn{5}{|c|}{ GRUPO 5} \\
\hline Itsama & Nombre propio & Jessenia batana & Palmae & $\begin{array}{l}\text { No } \\
\text { recolectado }\end{array}$ \\
\hline Quëboitsama & $\begin{array}{l}\text { "Quëbo": pava, por las } \\
\text { frutas comidas por la } \\
\text { pava? }\end{array}$ & Oenocarpus mapora & Palmae & $\begin{array}{l}\text { No } \\
\text { recolectado }\end{array}$ \\
\hline Xoquëitsama & $\begin{array}{l}\text { "Xoquë": Tucán, por las } \\
\text { frutas comidos por el } \\
\text { tucán }\end{array}$ & & Palmae & $\begin{array}{l}\text { No } \\
\text { recolectado }\end{array}$ \\
\hline \multicolumn{5}{|c|}{ GRUPO 6} \\
\hline Yobini & $\begin{array}{l}\text { Nombre propio del } \\
\text { árbol }\end{array}$ & $\begin{array}{l}\text { Nectandra cuspidata } \\
\text { o } \\
\text { Ocotea sp. }\end{array}$ & Lauraceae & $\begin{array}{l}217,528, \\
468\end{array}$ \\
\hline Jënëyobini & Yobini del río & Ocotea sp. & Lauraceae & 827 \\
\hline Xabayobini & Yobini de la pampa & Heisteria nitida & Lauraceae & 433 \\
\hline Nahuami & & & & 806 \\
\hline Cascarayobini & & Ouratea macrobotrys & Ochnaceae & $\begin{array}{l}47,210 \\
227,351 \\
621\end{array}$ \\
\hline $\begin{array}{l}\text { Xanëyobini o } \\
\text { Xaxohati }\end{array}$ & $\begin{array}{l}\text { "Xaxo": batán, Árbol } \\
\text { para hacer el batán } \\
\text { Corteza gruesa }\end{array}$ & & Flacourtiaceae & 55 \\
\hline \multicolumn{5}{|c|}{$\begin{array}{l}\text { Grupo } 7 \\
\text { Color de la corteza ("cáscara"), hojas, árboles similares. Para Omacabero, Xabaomacabéro, Jéneomacabero, } \\
\text { Jihuisama, la corteza cambia, pero las hojas son parecidas a los demás árboles. }\end{array}$} \\
\hline $\begin{array}{l}\text { Chanahua o } \\
\text { Chanahahëhua o } \\
\text { Morochesti o } \\
\text { Chanajoni o Chana }\end{array}$ & $\begin{array}{l}\text { "Chana": un cierto tipo } \\
\text { de insecto, que come } \\
\text { las hojas }\end{array}$ & Hirtella pilosissima & Chrysobalanaceae & $\begin{array}{l}182,212, \\
399,503 \\
723,836 \\
883\end{array}$ \\
\hline Pacachësti & & Licania intrapetiolaris & Chrysobalanaceae & 175,862 \\
\hline Chana & $\begin{array}{l}\text { Planta pequeña } \\
\text { (arbusto) del } \\
\text { sotobosque }\end{array}$ & $\begin{array}{l}\text { Hirtella racemosa var. } \\
\text { racemosa }\end{array}$ & Chrysobalanaceae & 541,685 \\
\hline
\end{tabular}


Bergeron S., 1998. Uso de las plantas por los Chácobos (Alto Ivón, Beni, Bolivia)

Tabla 14 (continuación): Grupos de plantas para los cuales existe categoría intermediaria y existen categorías genéricas pero las categorías específicas son ausentes

\begin{tabular}{|c|c|c|c|c|}
\hline Nombre Chácobo & Características & Género y especie & Familia & $\begin{array}{l}\text { No de } \\
\text { colección }\end{array}$ \\
\hline Omacabëro & $\begin{array}{l}\text { "Omaca": Tucunarë (pez) y } \\
\text { "Bëro": Ojo. Las frutas } \\
\text { parecen al ojo del pez }\end{array}$ & & Myrtaceae & 60,167 \\
\hline Xabaomacabëro & Omacabëro de la pampa & Eugenia sp. & Myrtaceae & 391,601 \\
\hline Jënëomacabëro & Omacabëro del río & Eugenia uniflora & Myrtaceae & 733,824 \\
\hline Jihuisama o Tsamiti & Corteza más negra & Mouriri sp. 1 & Melastomataceae & 546,892 \\
\hline Quëo & & Pouteria caimito & Sapotaceae & $\begin{array}{l}254,408, \\
549\end{array}$ \\
\hline Rohonosëbi & $\begin{array}{l}\text { "Roho": un cierto tipo de } \\
\text { mono que vive en este } \\
\text { árbol }\end{array}$ & $\begin{array}{l}\text { Cheiloclinium } \\
\text { cognatum }\end{array}$ & Hippocrataceae & $\begin{array}{l}44,170 \\
207,455\end{array}$ \\
\hline Huaniquesa & & Abuta grandifolia & Menispermaceae & 338 \\
\hline \multicolumn{5}{|c|}{ GRUPO 8} \\
\hline \multicolumn{5}{|c|}{ Color, forma de tronco, hojas similares. } \\
\hline Huicama & Nombre propio del árbol & $\begin{array}{l}\text { Bellucia aequiloba y } \\
\text { Bellucia } \\
\text { grossulariodes }\end{array}$ & Melastomataceae & 506,257 \\
\hline Xabahuicama & Huicama de la pampa & Bellucia acutata & Melastomataceae & 402, 614bis \\
\hline \multicolumn{5}{|c|}{ GRUPO 9} \\
\hline Mehi & & Licania sp. & Chrysobalanaceae & 174 \\
\hline Mëhihua & & Couepia cf. paraensis & Chrysobalanaceae & 708 \\
\hline Huápamo & $\begin{array}{l}\text { "Huapa": área inundada } \\
\text { donde vive el árbol. } \\
\text { Huápamo es un poco } \\
\text { diferente de los demás } \\
\text { árboles, porque tiene } \\
\text { leche }\end{array}$ & Maquira coriáceo & Moraceae & 691 \\
\hline \multicolumn{5}{|c|}{$\begin{array}{c}\text { GRUPO } 10 \\
\text { Arboles (tronco, corteza, hojas) parecidos. Las frutas de la mayoría de esos árboles tienen algodón }\end{array}$} \\
\hline Bepasti & & Myrcia aff. mollis & Myrtaceae & $\begin{array}{l}112,617, \\
649\end{array}$ \\
\hline Potasti & Nombre propio & & Bombacaceae & $\begin{array}{l}447,466, \\
520\end{array}$ \\
\hline Poatë & $\begin{array}{l}\text { "Poa": tubérculo, porque } \\
\text { el tronco del árbol le } \\
\text { parece, por su corteza } \\
\text { muy espesa }\end{array}$ & Turpinia occidentalis & Staphylacaceae & 752 \\
\hline Nahuabexë & Frutas pequeñas & $\begin{array}{l}\text { Dydimopanax } \\
\text { morototoni }\end{array}$ & Araliaceae & 105,658 \\
\hline \multicolumn{5}{|c|}{ GRUPO 11} \\
\hline Corama & Nombre propio & Hymenea courbaril & Caesalpiniaceae & 379 \\
\hline Xabacorama & Corama de la pampa & Hymenea courbaril & Caesalpiniaceae & 79 \\
\hline
\end{tabular}


Bergeron S., 1998. Uso de las plantas por los Chácobos (Alto Ivón, Beni, Bolivia)

Tabla 14 (continuación): Grupos de plantas para los cuales existe categoría intermediaria y existen categorías genéricas pero las categorías específicas son ausentes

\begin{tabular}{|c|c|c|c|c|}
\hline Nombre Chácobo & Características & Género y especie & Familia & $\begin{array}{c}\text { No de } \\
\text { colección }\end{array}$ \\
\hline \multicolumn{5}{|c|}{ GRUPO 12} \\
\hline \multicolumn{5}{|l|}{ Hierbas parecidas } \\
\hline Bahuarëxa & $\begin{array}{l}\text { "Bahua": loro porque } \\
\text { las frutas son comidas } \\
\text { por el loro. }\end{array}$ & & Verbenaceae & 341 \\
\hline Bahuarëxajoni & $\begin{array}{l}\text { Bahuarëxa ordinario } \\
\text { (joni) }\end{array}$ & & & $\begin{array}{l}\text { No } \\
\text { recolectado }\end{array}$ \\
\hline \multicolumn{5}{|c|}{$\begin{array}{l}\text { GRUPO } 13 \\
\text { Hierbas parecidas por sus hojas, olor. No tienen madera y además la presencia de estas hierbas indica que la } \\
\text { tierra es buena para hacer chacos }\end{array}$} \\
\hline Raramá & & Piper hispidum & Piperaceae & $497,746,748$ \\
\hline Rarasa & & $\begin{array}{l}\text { Piper hispidum o } \\
\text { Piper } \\
\text { hosthmannianum }\end{array}$ & Piperaceae & 323,669747 \\
\hline Nihibosa o Nibosa & $\begin{array}{l}\text { "Ni": de pie, porque la } \\
\text { planta es recta }\end{array}$ & Piper darienense & Piperaceae & $277,667,694$ \\
\hline Rarasajoni & Rarasa ordinario & Piper divaricatum & Piperaceae & 295 \\
\hline Xëquihahëhua & & Piper callosum & Piperaceae & 638 \\
\hline $\begin{array}{l}\text { Xëquihua o } \\
\text { Xëquihuajoni }\end{array}$ & & $\begin{array}{l}\text { Pipero } \\
\text { hosthmannianum }\end{array}$ & Piperaceae & 276 \\
\hline Shibiri & & Zingiber officinale & Zingiberaceae & 838,874 \\
\hline \multicolumn{5}{|c|}{ GRUPO 14} \\
\hline Pabo & $\begin{array}{l}\text { Nombre propio Corteza } \\
\text { fibrosa y gruesa }\end{array}$ & $\begin{array}{l}\text { Cordia sp. } 1 \text { o Cordia } \\
\text { ucayaliensis }\end{array}$ & Boraginaceae & $\begin{array}{l}\text { 488, 179; } \\
242,474,490\end{array}$ \\
\hline $\begin{array}{l}\text { Nihimaxë o Maxejoni } \\
\text { o Rohomaxë }\end{array}$ & $\begin{array}{l}\text { "Maxë": Urucu. Las } \\
\text { frutas son parecidas a } \\
\text { las del urucú }\end{array}$ & Luheopsis sp.1 & Tiliaceae & 348 \\
\hline $\begin{array}{lr}\text { Nihimoxoquë } & \text { o } \\
\text { Moxoquëjoni o Jihui } \\
\text { moxoquë }\end{array}$ & $\begin{array}{l}\text { Nombre propio del } \\
\text { árbol. } \\
\text { Corteza gruesa. Frutas } \\
\text { grandes con espinas }\end{array}$ & Apeiba echinata & Tiliaceae & 116 \\
\hline Moxoquë & $\begin{array}{l}\text { Árbol de los barbechos. } \\
\text { Corteza gruesa. Frutas } \\
\text { grandes con espinas. } \\
\text { Hojas grandes }\end{array}$ & Apeiba tibourbou & Tiliaceae & 380 \\
\hline Paro & Corteza más delgada & $\begin{array}{l}\text { Cordia bicolor } \\
\text { Alchornea sp. } \\
\text { Triumfetta } \\
\text { altheoides }\end{array}$ & Boraginaceae & $\begin{array}{l}193,855743 \\
845\end{array}$ \\
\hline Canaboi & & & & $\begin{array}{l}\text { No } \\
\text { recolectado }\end{array}$ \\
\hline Maxë & $\begin{array}{l}\text { Bien parecido a } \\
\text { Nihimaxë }\end{array}$ & Bixa orellana & Bixaceae & $\begin{array}{l}\text { No } \\
\text { recolectado }\end{array}$ \\
\hline
\end{tabular}


Bergeron S., 1998. Uso de las plantas por los Chácobos (Alto Ivón, Beni, Bolivia)

Tabla 14 (continuación): Grupos de plantas para los cuales existe categoría intermediaria y existen categorías genéricas pero las categorías especificas son ausentes

\begin{tabular}{|c|c|c|c|c|}
\hline Nombre Chácobo & Características & Género y especie & Familia & $\begin{array}{c}\text { No de } \\
\text { colección }\end{array}$ \\
\hline Shishipa & & & & $\begin{array}{l}\text { No } \\
\text { recolectado }\end{array}$ \\
\hline \multicolumn{5}{|c|}{ GRUPO 15} \\
\hline Batajihui & Corteza muy delgada & & Simaroubaceae & 42,444 \\
\hline Jihuipisi & $\begin{array}{l}\text { "pisi": Mal olor cuando } \\
\text { se muere al árbol. } \\
\text { Corteza más gruesa }\end{array}$ & $\begin{array}{l}\text { Vataireopsis } \\
\text { speciosa }\end{array}$ & Papilionaceae & $\begin{array}{l}201,457, \\
472,532, \\
534\end{array}$ \\
\hline \multicolumn{5}{|c|}{ GRUPO 16} \\
\hline Metëque & $\begin{array}{l}\text { "Mëtëquë": Nudo, } \\
\text { porque la planta } \\
\text { presenta nudos (rama) }\end{array}$ & Qualea sp. & Vochysiaceae & 76,789 \\
\hline Xabamëtëquë & Mëtëquë de la pampa & & & $\begin{array}{l}\text { No } \\
\text { recolectado }\end{array}$ \\
\hline \multicolumn{5}{|c|}{ GRUPO 17} \\
\hline Tapa & Nombre propio & Bertholletia excelsa & Lecythidaceae & 229 \\
\hline Taparisti & & Micropholis sp. & Sapotaceae & 117 \\
\hline Xabatapaho & & & & $67,81,800$ \\
\hline Cama & & & & 759 \\
\hline \multicolumn{5}{|c|}{ GRUPO 18} \\
\hline Quispi & $\begin{array}{l}\text { Nombre propio. } \\
\text { Grandes hojas }\end{array}$ & $\begin{array}{l}\text { Casearia } \\
\text { gossypiosperma }\end{array}$ & Flacourtiaceae & 95,264 \\
\hline Xoquëpaiti & $\begin{array}{l}\text { Xoquë: "Tucán". } \\
\text { Pequeñas hojas }\end{array}$ & & & $\begin{array}{l}\text { No } \\
\text { recolectado }\end{array}$ \\
\hline \multicolumn{5}{|c|}{$\begin{array}{l}\text { GRUPO } 19 \\
\text { rboles (tronc }\end{array}$} \\
\hline Xahuamachi & Hojas grandes & $\begin{array}{l}\text { Sloanea guianensis } \\
\text { Sloanea cf. eichleri } \\
\text { Sloanea gracilis }\end{array}$ & Elaeocarpaceae & $\begin{array}{l}141,189, \\
214,463, \\
518,931484\end{array}$ \\
\hline Cahinihamaraxa & & & & $\begin{array}{l}\text { No } \\
\text { recolectado }\end{array}$ \\
\hline Xahuamachijoni & $\begin{array}{l}\text { Xahuamachi ordinario. } \\
\text { Hojas pequeñas }\end{array}$ & Clathrotropis sp. & Papilionaceae & 882 \\
\hline \multicolumn{5}{|c|}{ GRUPO 20} \\
\hline Tioroquërihua & $\begin{array}{l}\text { Nombre propio Árbol } \\
\text { con leche }\end{array}$ & $\begin{array}{l}\text { Micropholis } \\
\text { guianensis }\end{array}$ & Sapotaceae & $\begin{array}{l}17,34,168, \\
173,231, \\
246\end{array}$ \\
\hline Jënëtioroquërihua & Tioroquërihua del rio & Panopsis rubescens & Proteaceae & 834 \\
\hline Jënebatabi & $\begin{array}{l}\text { Batabi del río Árbol con } \\
\text { leche }\end{array}$ & Pouteria sp. & Sapotaceae & 833 \\
\hline
\end{tabular}


Bergeron S., 1998. Uso de las plantas por los Chácobos (Alto Ivón, Beni, Bolivia)

Tabla 14 (continuación): Grupos de plantas para los cuales existe categoría intermediaria y existen categorías genéricas pero las categorías específicas son

Ausentes

\begin{tabular}{|l|l|l|l|l|}
\hline \multicolumn{1}{|c|}{ Nombre Chácobo } & \multicolumn{1}{|c|}{ Características } & Género y especie & Familia & $\begin{array}{c}\text { No de } \\
\text { colección }\end{array}$ \\
\hline Batabi & Nombre propio & Pouteria nemorosa & Sapotaceae & 909 \\
\hline \multicolumn{2}{|c}{ GRUPO 21 }
\end{tabular}

Las hojas de los árboles son parecidas pero los árboles pueden ser diferentes (por ejemplo, algunos tienen leche otros no tienen leche).

\begin{tabular}{|c|c|c|c|c|}
\hline Jënëcarajoni & & $\begin{array}{l}\text { Tabebuia } \\
\text { impetiginosa }\end{array}$ & Bignoniaceae & 540 \\
\hline Jënëcarama & & Caryocar dentatum & Caryocaraceae & 895 \\
\hline Jihuicarama & $\begin{array}{l}\text { Árbol que vive cerca a } \\
\text { la Pampa, no tiene } \\
\text { mucha leche y la } \\
\text { madera es muy dura. }\end{array}$ & & & $\begin{array}{l}\text { No } \\
\text { recolectad } \\
\text { o }\end{array}$ \\
\hline Carama & & Hevea brasiliensis & Euphorbiaceae & 268 \\
\hline
\end{tabular}

Esos árboles tienen hojas parecidas aunque pueden ser diferentes por el tronco, la corteza.

\begin{tabular}{|l|l|l|l|l|}
\hline Cocahuarahuara & $\begin{array}{l}\text { Erythroxylum cf. } \\
\text { macrophylltim }\end{array}$ & Erythroxylaceae & 547 \\
\hline Xabacoca & $\begin{array}{l}\text { Erythroxylum } \\
\text { campestre }\end{array}$ & Erythroxylaceae & 432,739 \\
\hline
\end{tabular}

GRUPO 23

Esas plantas agrupadas en el mismo grupo pueden ser árboles o hierbas pero tienen las hojas parecidas.

\begin{tabular}{|l|l|l|l|l|}
\hline Chaxoromë & $\begin{array}{l}\text { "Chaxo": ciervo y } \\
\text { "Romë": Tábaco El } \\
\text { tronco parece a la pata } \\
\text { del ciervo y la hoja } \\
\text { huele a tabaco }\end{array}$ & Miconia buba!i na & Melastomataceae & 529 \\
\hline $\begin{array}{l}\text { Xabachaca- } \\
\text { chaxoromë }\end{array}$ & $\begin{array}{l}\text { Chaxoromë de la } \\
\text { pampa }\end{array}$ & Vochysia aff. Rufa & Vochysiaceae & 424 \\
\hline Romë (tábaco) & & Solana nicotiana & Solanaceae & $\begin{array}{l}\text { No } \\
\text { recolectad } \\
\text { o }\end{array}$ \\
\hline
\end{tabular}

GRUPO 24

Esas plantas agrupadas en el mismo grupo pueden ser árboles o hierbas pero tienen las hojas parecidas.

\begin{tabular}{|l|l|l|l|l|}
\hline Isonaraja & $\begin{array}{l}\text { "Iso": Marimono y } \\
\text { "naraja": naranja. El } \\
\text { marimono come las } \\
\text { frutas }\end{array}$ & Hortia sp. & Rutaceae & $\begin{array}{l}14,122, \\
240,835\end{array}$ \\
\hline Jihuibepiya hoja larga & "Bëpiya": leche & Ecclinusa lanceolata & Sapotaceae & $\begin{array}{l}51, \\
133,230, \\
859\end{array}$ \\
\hline Ahuaramacha & $\begin{array}{l}\text { "Ahua": anta. Las frutas } \\
\text { son comidas por la anta }\end{array}$ & Polalia amara & Loganiaceae & 262,805 \\
\hline
\end{tabular}

GRUPO 25

Esas plantas son hierbas, y están agrupadas por tener el mismo tipo de hojas.

\begin{tabular}{|l|l|l|l|l|}
\hline Mani & Patujú & $\begin{array}{l}\text { Phenakospermum } \\
\text { guyanensis }\end{array}$ & Strelitziaceae & $\begin{array}{l}\text { No } \\
\text { recolectad } \\
\text { o }\end{array}$ \\
\hline Xapanati & & & & 337 \\
\hline
\end{tabular}


Bergeron S., 1998. Uso de las plantas por los Chácobos (Alto Ivón, Beni, Bolivia)

Tabla 14 (continuación): Grupos de plantas para los cuales existe categoría intermediaria y existen categorías genéricas pero las categorías específicas son ausentes

\begin{tabular}{|l|l|l|l|l|}
\hline \multicolumn{1}{|c|}{ Nombre Chácobo } & \multicolumn{1}{|c|}{ Características } & Género y especie & \multicolumn{1}{c|}{ Familia } & \multicolumn{1}{c|}{$\begin{array}{c}\text { No de } \\
\text { colección }\end{array}$} \\
\hline Manicoro & & & & No recolectado \\
\hline Pëtsimani & & & & No recolectado \\
\hline Manihuashiri & & & Strelitziaceae & 651 \\
\hline Carapënihi & & & Musaceae & $\begin{array}{l}\text { No } \\
\text { recolectados }\end{array}$ \\
\hline Carapë & $\begin{array}{l}\text { Plátanos y guineos } \\
\text { Plantas cultivadas }\end{array}$ & & & \\
\hline
\end{tabular}

Esas plantas son hierbas, y están agrupadas por tener el mismo tipo de hojas.

\begin{tabular}{|l|l|l|l|l|}
\hline Xoni & $\begin{array}{c}\text { "Xoni": Tipo de taropé, } \\
\text { ya que la hoja es similar }\end{array}$ & & Pterydophytae & 636 \\
\hline Nihichacaxoni & & & & No recolectado \\
\hline
\end{tabular}

\section{GRUPO 27}

Esas plantas son hierbas, y están agrupadas por tener el mismo tipo de hojas ("cortaderas").

\begin{tabular}{|l|l|l|l|l|}
\hline Camanojachocoti & $\begin{array}{l}\text { "Camano": jaguar, } \\
\text { "jachocoti"; limpiarse } \\
\text { los dientes. Ya que el } \\
\text { jaguar come esta hierba }\end{array}$ & & No recolectado \\
\hline Pacachachi & & Diplazia karataefolia & Cyperaceae & 920 \\
\hline Chachi & & & & No recolectado \\
\hline Sicomitsa & $\begin{array}{l}\text { "Sico": hoja con tres } \\
\text { ángulos }\end{array}$ & & & 337 bis \\
\hline
\end{tabular}

GRUPO 28

Esas plantas tienen las hojas parecidas y tienen raices en forma de papa (tubérculos)

\begin{tabular}{|l|l|l|l|l|}
\hline Mataca & & & & No recolectado \\
\hline Tsaramataca & & & & 648 \\
\hline Xëqua & & & & No recolectado \\
\hline Sëco & & & No recolectado \\
\hline Esas hierbas tienen raices con papa (tubérculos) & $\begin{array}{l}\text { GRUPO 29 } \\
\text { Carihua } \\
\text { la raiz es parecida al } \\
\text { camote Hierba }\end{array}$ & & Malvaceae ? & 328 \\
\hline Cari & $\begin{array}{l}\text { Planta cultivada } \\
\text { Tsisocari }\end{array}$ & & & \\
\hline
\end{tabular}


Bergeron S., 1998. Uso de las plantas por los Chácobos (Alto Ivón, Beni, Bolivia)

Tabla 14 (continuación): Grupos de plantas para los cuales existe categoría intermediaria y existen categorías genéricas pero las categorías específicas son ausentes

\begin{tabular}{|c|c|c|c|c|}
\hline Nombre Chácobo & Características & Género y especie & Familia & $\begin{array}{l}\text { No de } \\
\text { colección }\end{array}$ \\
\hline Pënacari & Planta cultivada & & & $\begin{array}{l}\text { No } \\
\text { recolectad } \\
0\end{array}$ \\
\hline Cashishopa & $\begin{array}{l}\text { Bejuco herbaceae } \\
\text { "Cashi": murciélago y } \\
\text { "Shopa": pequeña liana. } \\
\text { Las frutas son comidas } \\
\text { por el murciélago. }\end{array}$ & Cissus erosa & Vitaceae & 653bis \\
\hline \multicolumn{5}{|c|}{ GRUPO 30} \\
\hline \multicolumn{5}{|c|}{ Arboles acanalados, la corteza se deshace por láminas ("se desquama") } \\
\hline Caiosho & $\begin{array}{l}\text { "Cai": madre, "Osho". el } \\
\text { árbol } \\
\text { El árbol es tan flaco } \\
\text { como una persona } \\
\text { anciana. }\end{array}$ & Amaouia guianensis & Rubiaceae & $\begin{array}{l}30 \\
146,169 \\
251,442 \\
450,458 \\
616\end{array}$ \\
\hline Chaxohuitaxo & $\begin{array}{l}\text { "Chaxo": venado } \\
\text { "Huitaxo"; el árbol. El } \\
\text { tronco parece a la pata } \\
\text { del animal. }\end{array}$ & & Sapindaceae & 123 \\
\hline Iscochaishi & $\begin{array}{l}\text { "Isco": el tojo (pájaro) } \\
\text { Las frutas son comidas } \\
\text { por este animal }\end{array}$ & Cupania cinerea & Sapindaceae & 335,924 \\
\hline Jihuibara & $\begin{array}{l}\text { Hojas diferentes de los } \\
\text { demás árboles }\end{array}$ & Myrcia sp.? & Melastomataceae & 41,776 \\
\hline \multicolumn{5}{|c|}{ GRUPO 31} \\
\hline \multicolumn{5}{|c|}{ Arboles parecidos solamente por la corteza del tronco. } \\
\hline Paxaini & $\begin{array}{l}\text { "Paxa": crudo, e "Hini"; } \\
\text { el árbol } \\
\text { La madera se domora } \\
\text { mucho para secar }\end{array}$ & Metrodorea flavida & Rutaceae & $\begin{array}{l}24,31,92 \\
145,211 \\
476,477 \\
479,485 \\
493,913\end{array}$ \\
\hline Shiué & Nombre propio & Rinoreocarpus ulei & Violaceae & $\begin{array}{l}25,29,88 \\
102,111 \\
456,465 \\
901\end{array}$ \\
\hline \multicolumn{5}{|c|}{ GRUPO32 } \\
\hline \multicolumn{5}{|c|}{ Plantas (árboles o bejucos) que tienen leche muy blanca, pero cuyas hojas pueden ser diferentes. } \\
\hline Xoquëxëquërë & $\begin{array}{l}\text { "Xoquë": Tucán, } \\
\text { "Xëquërë": otro párajo. } \\
\text { los dos viven en el árbol }\end{array}$ & Sorocea guilleminia & Moraceae & 46,192 \\
\hline Jihuibëpiya & $\begin{array}{l}\text { "Bëpiya": leche. Arbol } \\
\text { con leche }\end{array}$ & Ecclinusa lanceolata & Sapotaceae & $\begin{array}{l}51,133 \\
230,859\end{array}$ \\
\hline Nishibëpiya & $\begin{array}{l}\text { "Bëpiya": leche. Bejuco } \\
\text { con leche }\end{array}$ & & & 355,551 \\
\hline \multicolumn{5}{|c|}{ GRUPO 33} \\
\hline Huákibi & Nombre propio & Jacaratia digitata & Caricaceae & 43,140 \\
\hline
\end{tabular}


Bergeron S., 1998. Uso de las plantas por los Chácobos (Alto Ivón, Beni, Bolivia)

Tabla 14 (continuación): Grupos de plantas para los cuales existe categoría intermediaria y existen categorías genéricas pero las categorías específicas son ausentes

\begin{tabular}{|c|c|c|c|c|}
\hline Nombre Chácobo & Características & Género y especie & Familia & No de colección \\
\hline Mapayo & & Carica papaya & Caricaceae & No recolectado \\
\hline \multicolumn{5}{|c|}{ GRUPO 34} \\
\hline Panima & $\begin{array}{l}\text { Nombre propio Palma } \\
\text { con tronco }\end{array}$ & $\begin{array}{l}\text { Astrocaryum } \\
\text { aculeatum }\end{array}$ & Palmae & No recolectado \\
\hline Pañi & Palma con tronco & $\begin{array}{l}\text { Astrocaryum } \\
\text { huicungo }\end{array}$ & Palmae & No recolectado \\
\hline Huanima & Palma con tronco & Bactris gasipaes & Palmae & No recolectado \\
\hline Shinibi o Shinipa & Palma sin tronco & & Palmae & No recolectado \\
\hline Shinijoxo & Palma sin tronco & Bactris montícola & Palmae & No recolectado \\
\hline Paniboxcata & Palma sin tronco & & Palmae & 282 \\
\hline \multicolumn{5}{|c|}{ GRUPO 35} \\
\hline Yahuaxé & $\begin{array}{l}\text { "Yahu": Tropero. Los } \\
\text { ganchos son parecidos } \\
\text { a los dientes del animal }\end{array}$ & Smilax sp. & Smilacaceae & 367 \\
\hline Patiarijomoxa & $\begin{array}{l}\text { "Patiari": gancho del } \\
\text { gallo, y "Jomoxo": } \\
\text { espina. } \\
\text { Bejuco con espinas } \\
\text { iguales a los ganchos } \\
\text { del gallo }\end{array}$ & Smilax sp. & Smilacaceae & $\begin{array}{l}329,610,666, \\
756,812\end{array}$ \\
\hline \multicolumn{5}{|c|}{ GRUPO 36} \\
\hline Nishipayo & & & & No recolectado \\
\hline Nahinishi & & Gurania sp. & Cucurbitaceae & 654 \\
\hline \multicolumn{5}{|c|}{ GRUPO 37} \\
\hline Xëco & $\begin{array}{l}\text { "Xëco": Maíz. La planta } \\
\text { crece recto como el } \\
\text { maíz }\end{array}$ & & Marantaceae & 278,674 \\
\hline Jënëxëco & "Xëco" del río & & Marantaceae & 716 \\
\hline Boshishi & Nombre propio & Costus cf. arabicus & Zingiberaceae & $316,698,817$ \\
\hline \multicolumn{5}{|c|}{ GRUPO 38} \\
\hline Shoshapo & $\begin{array}{l}\text { Frutas amarillas } \\
\text { comestibles parecidas a } \\
\text { un diente }\end{array}$ & & & No recolectado \\
\hline Xabachaca-shoshapo & & $\begin{array}{l}\text { Byrsonima } \\
\text { crassifolia }\end{array}$ & Malpighiaceae & 571 \\
\hline
\end{tabular}


Bergeron S., 1998. Uso de las plantas por los Chácobos (Alto Ivón, Beni, Bolivia)

Tabla 14 (continuación): Grupos de plantas para los cuales existe categoría intermediaria y existen categorías genéricas pero las categorías específicas son ausentes

\begin{tabular}{|l|l|l|l|l|}
\hline \multicolumn{1}{|c|}{ Nombre Chácobo } & \multicolumn{1}{|c|}{ Características } & Género y especie & \multicolumn{1}{c|}{ Familia } & $\begin{array}{c}\text { No de } \\
\text { colección }\end{array}$ \\
\hline Jënëshoshapo & Shoshapo del río & & $\begin{array}{l}\text { No } \\
\text { recolectado }\end{array}$ \\
\hline Xëchi & Frutas medio rojas & Byrsonima crispa & Malpighiaceae & 872 \\
\hline Xabaxëchi & Frutas verdes & $\begin{array}{l}\text { Byrsonima } \\
\text { chrysophylla }\end{array}$ & Malpighiaceae & 396 \\
\hline Nahuëshi & $\begin{array}{l}\text { Frutas más pequeñas } \\
\text { muy dulces }\end{array}$ & $\begin{array}{l}\text { Ocotea aff. } \\
\text { diospyrifolia }\end{array}$ & Lauraceae & 764 \\
\hline
\end{tabular}

GRUPO 39

Grupo de bejucos y árboles que pueden ser diferentes (diferentes hojas y madera) pero cuyas frutas son parecidas a la chirimoya.

\begin{tabular}{|l|l|l|l|l|}
\hline Rononopa & Bejuco & Almona ambotay & Annonaceae & $\begin{array}{l}581,679 . \\
853\end{array}$ \\
\hline Rononopajoni & Bejuco & & & $\begin{array}{l}\text { No } \\
\text { recolectado }\end{array}$ \\
\hline Jënërononopa & Bejuco & Almona hypoglauca & Annonaceae & 888 \\
\hline Jihuirononopa & Árbol & Prunus amplifolia & Rosaceae & $\begin{array}{l}154,628, \\
854\end{array}$ \\
\hline
\end{tabular}

GRUPO 40

Estas hierbas son agrupadas por tener frutas parecidas.

\begin{tabular}{|l|l|l|l|l|}
\hline Ahuatishi & $\begin{array}{l}\text { Hierba grande muy } \\
\text { escasa }\end{array}$ & & $\begin{array}{l}\text { No } \\
\text { recolectado }\end{array}$ \\
\hline Yahë & & $\begin{array}{l}\text { Pouteria } \\
\text { macrophylla }\end{array}$ & Sapotaceae & 650,773 \\
\hline \multicolumn{5}{|c|}{ GRUPO 41 } \\
Plantas cuyas frutas se parten en dos aunque pueden ser árboles, hierbas. & $\begin{array}{l}\text { No } \\
\text { recolectado }\end{array}$ \\
\hline Jënëcochopi & & & $\begin{array}{l}682,825, \\
1009\end{array}$ \\
\hline Sipamë & & Hymenea sp. & Caesalpiniaceae & $\begin{array}{l}\text { No } \\
\text { recolectado }\end{array}$ \\
\hline Cochopi & & Crescentia cujute & Bignoniaceae &
\end{tabular}

\section{Las plantas no están agrupadas por sus semejanzas morfológicas sino por otros caracteres}

Existen bastante grupos de plantas que no responden al modelo de la clasificación de Brent, ya que se agrupan según otros criterios de clasificación.

Ciertas plantas son consideradas en un mismo grupo porque tienen el mismo uso (medicinal, construcción, vestidos en el pasado, "barbasco" o plantas ictiotóxicas, plantas que llevan suerte para cazar o pescar). 
Bergeron S., 1998. Uso de las plantas por los Chácobos (Alto Ivón, Beni, Bolivia)

> Otras plantas están agrupadas por tener un carácter especial en común, por ejemplo, corteza o "cáscara" amarga, madera muy dura, pelos de las hojas irritantes, plantas donde se encuentran hormigas.

Asimismo, este tipo de clasificación se aplica especialmente para los bejucos ( 7 grupos de bejucos sobre 8). También se aplica a dos grupos (sobre cuatro) de palmas y de 6 grupos de hierbas (sobre 15). (ver Tabla 15)

Solamente dos grupos de plantas llevan un nombre más general (el grupo de los árboles

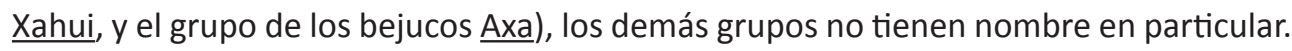

Tabla 15: Grupos de plantas que no responden al modelo de clasificación etnobotánica de Brent (1992)

\begin{tabular}{|c|c|c|c|c|}
\hline Nombre Chácobo & Características & Género y especie & Familia & $\begin{array}{l}\text { No de } \\
\text { colección }\end{array}$ \\
\hline \multicolumn{5}{|c|}{$\begin{array}{l}\text { GRUPO 1: XAHUI } \\
\text { árboles o bejucos, y la corteza sirve para hacer cuerdas de amarre ("panchos"). } \\
\text { decreciente de la cuerda }\end{array}$} \\
\hline Xahui & $\begin{array}{l}\text { Nombre propio Buen } \\
\text { pancho }\end{array}$ & Xylopia cf. peruana & Annonaceae & $\begin{array}{l}158,199 \\
443,695\end{array}$ \\
\hline Xahuipëixoco & $\begin{array}{l}\text { Nombre propio. Hoas } \\
\text { pequeños. } \\
\text { Buen"pancho" }\end{array}$ & Xylopia cf. peruana & Annonaceae & 898 \\
\hline Ahuabaca & $\begin{array}{l}\text { Ahuabaca viene de } \\
\text { "Ahua": anta, porque } \\
\text { las hojas y frutas son } \\
\text { comidas por el animal. } \\
\text { Buen"pancho" }\end{array}$ & $\begin{array}{l}\text { Guatteria aff. } \\
\text { schomburgkiana } \\
\text { Guatteria cf. } \\
\text { boliviana }\end{array}$ & Annonaceae & $\begin{array}{l}15,32,910 \\
301\end{array}$ \\
\hline Huapaxahui & $\begin{array}{l}\text { "Huapana": área } \\
\text { inundada. Xahui de las } \\
\text { áreas inundadades } \\
\text { Buen"pancho" }\end{array}$ & $\begin{array}{l}\text { Aff. Bocageopsis } \\
\text { multiflora }\end{array}$ & Annonaceae & 866 \\
\hline Xahuisi & "Pancho" más ordinario & $\begin{array}{l}\text { Guatteria boliviana } \\
\text { Guatteria discolor } \\
\text { Duguetia císpixiana } \\
\text { Annonaceae no } \\
\text { identificado }\end{array}$ & Annonaceae & $\begin{array}{l}929 \\
921728 \\
507\end{array}$ \\
\hline Cótibi & $\begin{array}{l}\text { Nombre propio } \\
\text { "Pancho" más ordinario }\end{array}$ & $\begin{array}{l}\text { Unonopsis } \\
\text { floribunda }\end{array}$ & Annonaceae & $\begin{array}{l}103,136 \\
139,195 \\
200,730 \\
928\end{array}$ \\
\hline Capëtërobo & "Pancho" más ordinario & Annona hypoglauca & Annonaceae & 542 \\
\hline \multicolumn{5}{|c|}{$\begin{array}{c}\text { GRUPO } \mathbf{2} \\
\text { Arboles antiguamente utilizados para hacer los vestidos (árboles con leche; }\end{array}$} \\
\hline Yomëno & $\begin{array}{l}\text { Nombre propio Vestido } \\
\text { de color marrón }\end{array}$ & Ficus gomelleira & Moraceae & 147,206 \\
\hline
\end{tabular}


Bergeron S., 1998. Uso de las plantas por los Chácobos (Alto Ivón, Beni, Bolivia)

Tabla 15 (continuación): Grupos de plantas que no responden al modelo de clasificación etnobotánica de Brent (1992)

\begin{tabular}{|c|c|c|c|c|}
\hline Nombre Chácobo & Características & Género y especie & Familia & $\begin{array}{l}\text { No de } \\
\text { colección }\end{array}$ \\
\hline Mororia & $\begin{array}{l}\text { "Moro": Vestidos de los } \\
\text { antiguos. } \\
\text { Vestido de color blanco }\end{array}$ & No recolectado & Moraceae & \\
\hline Xoa & $\begin{array}{l}\text { "Xoa": Escocer, porque } \\
\text { la leche es irritante. } \\
\text { Vestido de color blanco }\end{array}$ & $\begin{array}{l}\text { Ficus cf. maxima } \\
\text { Ficus cf. schultesii }\end{array}$ & Moraceae & 521002 \\
\hline Isacapoi & & Ficus spenophylla & Moraceae & 864 \\
\hline Pió & Vestido de color marrón & Brosimum utile & Moraceae & $\begin{array}{l}61,172,325 \\
441,841 \\
881\end{array}$ \\
\hline Piobi & Es más ordinario & & & $\begin{array}{c}\text { No } \\
\text { recolectado }\end{array}$ \\
\hline Piochao & Es más ordinario & Clarísia racemosa & Moraceae & 406,842 \\
\hline \multicolumn{5}{|c|}{ GRUPO 3} \\
\hline \multicolumn{5}{|c|}{ Arboles cuya madera se utiliza para orcones } \\
\hline Shixaxë & $\begin{array}{l}\text { "Shisha": Coati, porque } \\
\text { el animal vive en este } \\
\text { árbol }\end{array}$ & Licania sp. & $\begin{array}{l}\text { Papilionaceae } \\
\text { Chrysobalanaceae }\end{array}$ & 256516 \\
\hline Yonishi & & Gustavia hexapetala & Lecythidaceae & $\begin{array}{l}247,615 \\
877\end{array}$ \\
\hline Xabayonishi & & & & 71 \\
\hline \multicolumn{5}{|c|}{ GRUPO 4} \\
\hline \multicolumn{5}{|c|}{ Árboles que sirven para hacer flechas } \\
\hline Bëcona & & $\begin{array}{l}\text { Erísma cf. } \\
\text { uncinatum }\end{array}$ & Vochysiaceae & 310 \\
\hline Tsamiti & & Mouriri sp. & Melastomataceae & 546,892 \\
\hline \multicolumn{5}{|c|}{ GRUPO 5} \\
\hline \multicolumn{5}{|c|}{ Árboles que sirven para curar la toz } \\
\hline Ocotsémo & $\begin{array}{l}\text { "Oco": Toz, "Semo": } \\
\text { nube, porque el árbol } \\
\text { sirve para la toz y la } \\
\text { corteza raspada es } \\
\text { negra como un nube. }\end{array}$ & Miconia sp. & $\begin{array}{l}\text { Melastomataceae } \\
\text { Myrtaceae }\end{array}$ & 376911,925 \\
\hline Jënëocotsëmo & Ocotsémo del río & Quima florida & Quiinaceae & 826 \\
\hline \multicolumn{5}{|c|}{$\begin{array}{l}\text { GRUPO 6: GRUPO DE LOS AXA } \\
\text { Esos bejucos sirven para matar o adormecer los peces ("barbascos"), los } 5 \text { primeros son "barbascos"de calidad, } \\
\text { los demás son más ordinarios. }\end{array}$} \\
\hline Axa o Axaria & $\begin{array}{l}\text { "Axa": Barbasco y "Ra": } \\
\text { bueno, porque Axaria } \\
\text { es el mejor barbasco }\end{array}$ & Derris sp. & Papilionaceae & 582,960 \\
\hline Capëhitsa & $\begin{array}{l}\text { "Cëpëtë": Lagarto, } \\
\text { porque el bejuco } \\
\text { parece por su color a la } \\
\text { piel del lagarto }\end{array}$ & Derris amazónica & Papilionaceae & $\begin{array}{l}259,364 \\
645,689 \\
880\end{array}$ \\
\hline
\end{tabular}


Bergeron S., 1998. Uso de las plantas por los Chácobos (Alto Ivón, Beni, Bolivia)

Tabla 15 (continuación): Grupos de plantas que no responden al modelo de clasificación etnobotánica de Brent (1992)

\begin{tabular}{|c|c|c|c|c|}
\hline Nombre Chácobo & Características & Género y especie & Familia & $\begin{array}{l}\text { No de } \\
\text { colección }\end{array}$ \\
\hline Axacoro & $\begin{array}{l}\text { "Axa": Barbasco, } \\
\text { "Coro": Rasguño, } \\
\text { porque la corteza } \\
\text { parece rasguñada }\end{array}$ & Patilinia sp. & Sapindaceae & $\begin{array}{l}359,690, \\
947\end{array}$ \\
\hline Carahinahaxa & $\begin{array}{l}\text { "Carahina": Blanco, } \\
\text { "Axa": Barbasco. } \\
\text { Barbasco utilizado por } \\
\text { los Blancos }\end{array}$ & Serjania sp. & Sapindaceae & 326,362 \\
\hline Jënëhaxahua & $\begin{array}{l}\text { "Jënë": Agua "Axa": } \\
\text { Barbasco Barbasco del } \\
\text { agua }\end{array}$ & Derris sp. & Papilionaceae & $\begin{array}{l}545,664 \\
688,823 \\
946\end{array}$ \\
\hline Iscoro & $\begin{array}{l}\text { "Isco": Tojo, porque la } \\
\text { flor del bejuco tiene el } \\
\text { color de la cola del } \\
\text { pájaro }\end{array}$ & Passiflora coccínea & Passifloraceae & 314 \\
\hline Nishiquëspë & $\begin{array}{l}\text { "Nishi": bejuco; } \\
\text { "Quëspé": aplanado El } \\
\text { bejuco es aplanado }\end{array}$ & & Bignoniaceae & 336 \\
\hline Pacábocoxo & $\begin{array}{l}\text { También sirve para el } \\
\text { empeine }\end{array}$ & & & $\begin{array}{l}\text { No } \\
\text { recolectado }\end{array}$ \\
\hline \multicolumn{5}{|c|}{$\begin{array}{cc}\text { GRUPO } 7 \\
\text { Esos bejucos tienen frutas comestibles (frutas amarillas y dulces) }\end{array}$} \\
\hline Ahuaxtëpoco & $\begin{array}{l}\text { "Ahuaxo": bentón } \\
\text { "Tëpoco": frutas. Las } \\
\text { frutas de este bejuco } \\
\text { son comidas por este } \\
\text { pez }\end{array}$ & Salada aff. gigantea & Hippocrataceae & $\begin{array}{l}360,420 \\
938\end{array}$ \\
\hline Quërimati & & Tontalea sp. & Hippocrataceae & 832 \\
\hline Nëxoquërimati & $\begin{array}{l}\text { "Nëxo": Tortuga de } \\
\text { agua, "Quërimati": } \\
\text { nombre del bejuco. Las } \\
\text { frutas del bejuco tiene } \\
\text { escamas como la } \\
\text { tortuga }\end{array}$ & Salada sp. & Hippocrataceae & $\begin{array}{l}736,865 \\
1008\end{array}$ \\
\hline $\begin{array}{l}\text { Xabachaca- } \\
\text { nexoquërimati }\end{array}$ & $\begin{array}{l}\text { Nëxoquërimati de la } \\
\text { pampa }\end{array}$ & & & $\begin{array}{l}\text { No } \\
\text { recolectado }\end{array}$ \\
\hline Xabachaca-taporachi & & & & $\begin{array}{l}\text { No } \\
\text { recolectado }\end{array}$ \\
\hline \multicolumn{5}{|c|}{$\begin{array}{c}\text { GRUPO } 8 \\
\text { Esos bejucos (menos es último) sirven para la diarrea. Presentados por eficiencia decreciente. }\end{array}$} \\
\hline Ponochi & $\begin{array}{l}\text { "Pono": vena La resina } \\
\text { del bejuco es roja como } \\
\text { la sangre }\end{array}$ & & Malphigiaceae? & $\begin{array}{l}7 \\
632\end{array}$ \\
\hline Nishiratëquënëhua & $\begin{array}{l}\text { "Nishi": bejuco } \\
\text { "Tëquënëhua": Canilla } \\
\text { larga, porque el bejuco } \\
\text { tiene nudos alejados } \\
\text { entre ellos. }\end{array}$ & $\begin{array}{l}\text { Tanecium jaroba } \\
\text { Arrabidea } \mathrm{sp} .\end{array}$ & Bignoniaceae & $\begin{array}{l}627 \\
757\end{array}$ \\
\hline
\end{tabular}


Bergeron S., 1998. Uso de las plantas por los Chácobos (Alto Ivón, Beni, Bolivia)

Tabla 15 (continuación): Grupos de plantas que no responden al modelo de clasificación etnobotánica de Brent (1992)

\begin{tabular}{|c|c|c|c|c|}
\hline Nombre Chácobo & Características & Género y especie & Familia & $\begin{array}{l}\text { No de } \\
\text { colección }\end{array}$ \\
\hline Nishiraoxo & & Arrabidea sp. & Bignoniaceae & $\begin{array}{l}207,307, \\
631\end{array}$ \\
\hline Nishitsanona & $\begin{array}{l}\text { "Nishi": bejuco } \\
\text { "Tsanona": corteza } \\
\text { negra; porque la } \\
\text { corteza del bejuco es } \\
\text { negra. }\end{array}$ & $\begin{array}{l}\text { Sparaitanthelium } \\
\text { amazonum spp. } \\
\text { Amazonum }\end{array}$ & Hernandiaceae & 365,819 \\
\hline Quëboxamahua & $\begin{array}{l}\text { "Quëbo": Pava } \\
\text { "Xamahua": Matriz } \\
\text { Bejuco tan blanco como } \\
\text { la matriz de la pava }\end{array}$ & Derris $s p$ & Papilionaceae & 682 \\
\hline Cacataho & & Uncaria guianensis & Rubiaceae & 291,646 \\
\hline Isistaho & & Celtis sp. & Ulmaceae & 366 \\
\hline Nishipara & $\begin{array}{l}\text { "Nishi": bejuco; "Para": } \\
\text { aplanado } \\
\text { El bejuco es aplanado }\end{array}$ & Bauhinia guianensis & Caesalpiniaceae & $\begin{array}{l}261,354, \\
869\end{array}$ \\
\hline
\end{tabular}

Esos bejucos (menos el último) sirven para los dolores de cabeza. Además son parecidos.

\begin{tabular}{|l|l|l|l|l|}
\hline Huacamatiapi & Nombre propio & & & 304 \\
\hline Nëxatarati & & & $\begin{array}{l}\text { No } \\
\text { recolectado }\end{array}$ \\
\hline Nananihi & & $\begin{array}{l}\text { Pithecoctenium cf. } \\
\text { crucigerum }\end{array}$ & Bignoniaceae & 643 \\
\hline Jënënëxatarati & Connarus ruber & Connaraceae & 896 \\
\hline \multicolumn{4}{|c|}{ GRUPO 10 }
\end{tabular}

Esos bejucos sirven para el empeine. Además son parecidos.

\begin{tabular}{|c|c|c|c|c|}
\hline Isnëpa & & Mimosa sp. ? & Mimosaceae & 357,820 \\
\hline Masneisnëpa & & & Mimosaceae & 857 \\
\hline \multirow{2}{*}{\multicolumn{5}{|c|}{ en para techar las casas }} \\
\hline & & & & \\
\hline Pane & Nombre propio & Geonoma juruana & Palmae & $\begin{array}{l}\text { No } \\
\text { recolectado }\end{array}$ \\
\hline Panane & Nombre propio Asai & Euterpe precatoria & Palmae & 101,281 \\
\hline Xëbichoqui & Motacusillo & $\begin{array}{l}\text { Maximiliana maripa } \\
\text { o } \\
\text { Syagrus maximiliana }\end{array}$ & Palmae & 23352 \\
\hline Xëbini & Motacú & Scheleea princeps & Palmae & $\begin{array}{l}\text { No } \\
\text { recolectado }\end{array}$ \\
\hline Onipa & $\begin{array}{l}\text { Nombre propio } \\
\text { Pachiuba }\end{array}$ & Socratea exorrhiza & 'Palmae & 535 \\
\hline \multicolumn{5}{|c|}{ GRUPO 12} \\
\hline Bomë & & & Palmae & $\begin{array}{l}\text { No } \\
\text { recolectado }\end{array}$ \\
\hline Huanahua & & & Palmae & $\begin{array}{l}\text { No } \\
\text { recolectado }\end{array}$ \\
\hline
\end{tabular}


Bergeron S., 1998. Uso de las plantas por los Chácobos (Alto Ivón, Beni, Bolivia)

Tabla 15 (continuación): Grupos de plantas que no responden al modelo de clasificación etnobotánica de Brent (1992)

\begin{tabular}{|c|c|c|c|c|}
\hline Nombre Chácobo & Características & Género y especie & Familia & $\begin{array}{l}\text { No de } \\
\text { colección }\end{array}$ \\
\hline Canahuanima & & Bactris humilis & Palmae & $\begin{array}{l}\text { No } \\
\text { recolectado }\end{array}$ \\
\hline \multicolumn{5}{|c|}{ GRUPO 13: GRUPO BISTO } \\
\hline \multicolumn{5}{|c|}{ Hierbas que sirven para hacer las flautas (sampoñas) } \\
\hline \multicolumn{5}{|l|}{ Rëhuë } \\
\hline Camabisto & $\begin{array}{l}\text { "Camano": jaguar } \\
\text { "Bisto": Sampoña } \\
\text { porque la hierba es } \\
\text { manchada como el } \\
\text { jaguar }\end{array}$ & Olyra sp. & Poaceae & 284 \\
\hline Bistobara & & & & $\begin{array}{l}\text { No } \\
\text { recolectado }\end{array}$ \\
\hline Bistocoxoa & & & & $\begin{array}{l}\text { No } \\
\text { recolectado }\end{array}$ \\
\hline Bistocoxi & $\begin{array}{l}\text { "Bisto": Sampoña } \\
\text { "Coxi": Duro, Hierba } \\
\text { dura }\end{array}$ & & Poaceae & 287 \\
\hline Bistoratëquëxoco & $\begin{array}{l}\text { "Bisto": Sampoña } \\
\text { "Ratëquë": rodilla } \\
\text { "Xoco": pequeño } \\
\text { Sampoña con nudos } \\
\text { pequeños }\end{array}$ & & Graminae & 315 \\
\hline Jihuibisto & $\begin{array}{l}\text { "Bisto": Sampoña } \\
\text { "Jihui": Arbol porque } \\
\text { este bisto es más } \\
\text { grande que los demás }\end{array}$ & & & 324,641 \\
\hline \multicolumn{5}{|c|}{ Hierbas que sirven para el mal de ojo. } \\
\hline Yoquiria & Nombre propio & & & $\begin{array}{l}\text { No } \\
\text { recolectado }\end{array}$ \\
\hline Toromoca & Nombre propio & & & $\begin{array}{l}\text { No } \\
\text { recolectado }\end{array}$ \\
\hline \multicolumn{5}{|l|}{ 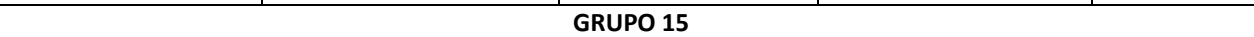 } \\
\hline Jononihi & $\begin{array}{l}\text { "Joño": Taitetú "Nihi"; } \\
\text { Hierba Hierba para } \\
\text { cazar el taitetú }\end{array}$ & & & 305 \\
\hline Jonopaxpi & & $\begin{array}{l}\text { Campyloneurum sp. } \\
\text { Asplenium cf. } \\
\text { stuebelianum }\end{array}$ & Pterydophytae & 279344 \\
\hline Jonoshia & $\begin{array}{l}\text { "Joño": Taitetú "Shia": } \\
\text { amargo Planta amarga } \\
\text { como el animal }\end{array}$ & Piper sp. & Piperaceae & $299,662,801$ \\
\hline Jonotapo & & $\begin{array}{l}\text { Brunfelsia } \\
\text { grandiflora }\end{array}$ & Solanaceae & 837 \\
\hline
\end{tabular}


Bergeron S., 1998. Uso de las plantas por los Chácobos (Alto Ivón, Beni, Bolivia)

Tabla 15 (continuación): Grupos de plantas que no responden al modelo de clasificación etnobotánica de Brent (1992)

\begin{tabular}{|c|c|c|c|c|}
\hline Nombre Chácobo & Características & Género y especie & Familia & $\begin{array}{l}\text { No de } \\
\text { colección }\end{array}$ \\
\hline Jonotasi & & & & $\begin{array}{l}\text { No } \\
\text { recolectado }\end{array}$ \\
\hline \multicolumn{5}{|c|}{ GRUPO 16} \\
\hline \multicolumn{5}{|c|}{ Hierbas que llevan suerte para pescar } \\
\hline Ahuaxonihi & $\begin{array}{l}\text { "Ahuaxo": Bentón } \\
\text { "Nihi": Hierba Hierba } \\
\text { para pescar el bentón }\end{array}$ & & & 349 \\
\hline Omacanihi & $\begin{array}{l}\text { "Omaca": Tucunaré } \\
\text { "Nihi": Hierba Hierba } \\
\text { para pescar el Tucunaré }\end{array}$ & & & 400 \\
\hline Mainohini & $\begin{array}{l}\text { "Mainoa": Serepapa } \\
\text { "Nihi": Hierba Hierba } \\
\text { para pescar el Serepapa }\end{array}$ & & & 425 \\
\hline \multirow[t]{2}{*}{ Paxamainonihi } & $\begin{array}{l}\text { "Mainoa": Serepapa } \\
\text { "Nihi": Hierba }\end{array}$ & & & 312 \\
\hline & $\begin{array}{l}\text { Hierba para pescar el } \\
\text { Serepapa }\end{array}$ & & & \\
\hline Bahuinonihi & & & & 427 \\
\hline \multicolumn{5}{|c|}{ GRUPO 17} \\
\hline Chachama & Nombre propio & Aspidosperma sp. & Apocynaceae & 37,161 \\
\hline Jihuimoca & $\begin{array}{l}\text { "Moca": Amargo Arbol } \\
\text { con corteza amarga }\end{array}$ & $\begin{array}{l}\text { Psychotria sp. o } \\
\text { Geissospermum } \\
\text { laeve }\end{array}$ & Rubiaceae & $\begin{array}{l}33,188,236 \\
272,519,703 \\
768\end{array}$ \\
\hline Nihitarari & & $\begin{array}{l}\text { Bowdichia } \\
\text { virgilioides }\end{array}$ & $\begin{array}{l}\text { Papilionaceae } \\
\text { Simaroubaceae? }\end{array}$ & $\begin{array}{l}74 \\
932,951,956\end{array}$ \\
\hline Poicorëbixpi & & $\begin{array}{l}\text { Aspidosperma } \\
\text { macrocarpon }\end{array}$ & Apocynaceae & 861 \\
\hline \multicolumn{5}{|c|}{ GRUPO 18} \\
\hline Jihuicoshi & $\begin{array}{l}\text { "Coshi" o "Coxi": duro } \\
\text { "Jihui": árbol Arbol duro }\end{array}$ & Diplotropis purpurea & $\begin{array}{l}\text { Papilionaceae } \\
\text { Vochysiaceae }\end{array}$ & 469548 \\
\hline Jënëjihuicoshi & Jihuicoshi del río & & & $\begin{array}{l}\text { No } \\
\text { recolectado }\end{array}$ \\
\hline Jihuicharishi & & $\begin{array}{l}\text { Toulicia } \\
\text { patentinervis }\end{array}$ & Sapindaceae & $\begin{array}{l}11,40,90,137, \\
160\end{array}$ \\
\hline Jihuiracharishi & & $\begin{array}{l}\text { Chaetocarpus } \\
\text { echinocarpus } \\
\text { Miconia cf. } \\
\text { molybdea }\end{array}$ & $\begin{array}{l}\text { Flacourtiaceae } \\
\text { Melastomataceae }\end{array}$ & 12,526492 \\
\hline Jihuimoishi & & Guatteria sp. & Annonaceae & 421 \\
\hline
\end{tabular}


Bergeron S., 1998. Uso de las plantas por los Chácobos (Alto Ivón, Beni, Bolivia)

Tabla 15 (continuación): Grupos de plantas que no responden al modelo de clasificación etnobotánica de Brent (1992)

\begin{tabular}{|c|c|c|c|c|}
\hline Nombre Chácobo & Características & Género y especie & Familia & No de colección \\
\hline \multicolumn{5}{|c|}{ GRUPO 19} \\
\hline \multicolumn{5}{|c|}{ Arboles muy duros que la hacha no puede tumbar. } \\
\hline Boexëni & $\begin{array}{l}\text { "Boé": Yaturama "Xeni": } \\
\text { que tiene aceite, porque } \\
\text { las hojas tienen aceite } \\
\text { como el pez }\end{array}$ & $\begin{array}{l}\text { Platymiscium cf. } \\
\text { fragrans }\end{array}$ & Papilionaceae & $\begin{array}{l}123,176,481 \\
505,693\end{array}$ \\
\hline Nisho & Nombre propio & $\begin{array}{l}\text { Tabebuia } \\
\text { serratifolia }\end{array}$ & Bignoniaceae & $39,89,626$ \\
\hline Xabanisho & Nisho de la pampa & Qualea sp. & Vochysiaceae & 570 \\
\hline \multicolumn{5}{|c|}{ GRUPO 20} \\
\hline \multicolumn{5}{|c|}{ Bejucos cuya madera es muy dura. } \\
\hline Nishicoshi & $\begin{array}{l}\text { "Nishi": Bejuco "Coxi": } \\
\text { duro bejuco duro }\end{array}$ & & & 363,415 \\
\hline Nishimoishi & & & & No recolectado \\
\hline \multirow{2}{*}{\multicolumn{5}{|c|}{ GRUPO 21}} \\
\hline & & & & \\
\hline Kátsisi & & Celtis schipii & Ulmaceae & $38,504,510,512$ \\
\hline Yahuataho & & Cupinia sp. & Sapindaceae & 740 \\
\hline Mërabi & & & & No recolectado \\
\hline \multirow{2}{*}{\multicolumn{5}{|c|}{ GRUPO 22}} \\
\hline & & & & \\
\hline Capëtëina & $\begin{array}{l}\text { "Cápete": lagarto porque } \\
\text { la planta parece a la cola } \\
\text { del animal }\end{array}$ & & & 368 \\
\hline Isisanihi & & & & No recolectado \\
\hline Coyobi & & & & No recolectado \\
\hline Coyonishi & & & & No recolectado \\
\hline Mitaisi & & & & $294,644,804$ \\
\hline \multicolumn{5}{|c|}{ GRUPO 23} \\
\hline Hierbas que tienen $\mathrm{p}$ & s irritantes para la piel. & & & \\
\hline Chihihua & & Cordia nodosa & Boraginaceae & 285 \\
\hline Coyonihi & & & & No recolectado \\
\hline Chirënihi & $\begin{array}{l}\text { "Chirë": Un cierto tipo de } \\
\text { ave porque las frurtas son } \\
\text { comidad por este ave }\end{array}$ & Mikania sp. & Asteraceae & 303 \\
\hline
\end{tabular}


Tabla 15 (continuación): Grupos de plantas que no responden al modelo de clasificación etnobotánica de Brent (1992)

\begin{tabular}{|l|l|l|l|l|}
\hline \multicolumn{1}{|c|}{ Nombre Chácobo } & \multicolumn{1}{|c|}{ Características } & Género y especie & \multicolumn{1}{|c|}{ Familia } & $\begin{array}{c}\text { No de } \\
\text { colección }\end{array}$ \\
\hline Nishixoa & & $\begin{array}{l}\text { Dioscorea sp. } \\
\text { Cissampelos } \\
\text { glaberrima }\end{array}$ & $\begin{array}{l}\text { Dioscoreaceae } \\
\text { Menispermaceae }\end{array}$ & $\begin{array}{l}661 \\
902\end{array}$ \\
\hline Camanopaoqui & $\begin{array}{l}\text { "Camano": Jaguar y } \\
\text { "Paoqui": Oreja } \\
\text { ¿porque las hojas son } \\
\text { parecidas a las del } \\
\text { jaguar? }\end{array}$ & $\begin{array}{l}\text { poeppigiana } \\
\text { var. poeppigiana } \\
\text { Hibiscus sp. }\end{array}$ & Rubiaceae & 296, \\
\hline
\end{tabular}

\section{Nomenclatura y significación de los nombres de las plantas}

Por último, y a pesar de que nuestro estudio no tiene el objetivo de profundizar la lingüística Chácobo, queríamos mencionar alguna información relacionada a la nomenclatura y la significación de los nombres de las plantas Chácobos.

\section{Nomenclatura de los nombres Chácobos}

Si analizamos los nombres de las plantas Chácobos, podemos destacar lo siguiente:

- Muchas veces, para un mismo grupo, los nombres de las plantas tienen una raiz común, por ejemplo, Yorabita y Mëquënobita tienen la raiz común Bita (grupo 1 de la Tabla 14), o también Bëhisiticorihua, Xababëisiticorihua y Jënëbëisiticorihua tiene Corihua en común (grupo 2 de la Tabla 14), Cari, Carihua, Tsisocari, tienen Cari en común (grupo 29 de la Tabla 14); $\underline{\mathrm{Ji}-}$ huirononopa, Jënërononopa, Rononopajihui, tienen Rononopa en común (grupo 39 de la Tabla 14), Jonoshia, Jonopaxpi, Jonotapo tienen Joño en común (grupo 15 de la Tabla 15).

- Ocurre también que las plantas que pertenecen al mismo grupo, no tienen una raiz común, por ejemplo,
Capehitsa del grupo Axa (ver Tabla 15); Shixaxe del grupo 3 de la Tabla 15, Xoa e Isacapoi, Yomeño del grupo 2 de la Tabla 15, Ahuabaca del grupo de los Xahui (grupo 1 de la Tabla 15), entre otros ejemplos.

- Cabe mencionar por otra parte, que una planta puede ser nombrada de diferentes maneras por ejemplo, la planta Chana se llama también Morochësti, Chanahaëhua, Chanahua, Xaxohati también se llama Xanëyobini. Por otro lado, los nombres de las plantas que se encuentran en la sabana, llevan muchas veces de manera indiferente el nombre de Xaba 0 Xabachaca.

- $\quad$ Respecto a las formas de vida (Jihui, Nihi, Nishi), por lo general los nombres de los árboles no llevan jihui. Para las hierbas y los bejucos, es variable: a veces la planta lleva el nombre de nihi (por ejemplo Chirënihi, Isisanihi, Ahuaxonihi. Omacanihi), y a veces no llevan ese nombre aunque la planta sea una hierba (Jonotapo, Jonoshia, Yoquiria, Toromoca, Rëhuë). Lo mismo ocurre para los bejucos, ciertos de ellos llevan el nombre de Nishi (Nishicoshi, Nishimoi- 
shi, Nishiraoxo. Nishitsanona, Nishiratëquënëya, Nishiquëspë), mientras que otros no llevan este nombre (Isnëpa, Masnësnëpa, Huacamatiapi, Nexatarati, Capëhitsa, Jenëaxahua).

- Por último, si bien el nombre del bosque alto no está incluido en los nombres de las plantas, el nombre del bosque ribereño y de la sabana siempre están incluidos ${ }^{(14)}$. Asimismo, podemos reconocer ciertos tipos de ambientes en el cual se encuentran las plantas ya que esas últimas llevan el nombre de Jënë cuando se encuentran en el bosque y de Xaba o Xabachaca cuando se encuentran en la pampa.

\section{Significación de los nombres Chácobos}

Existen también, muchas variaciones respecto a la significación de los nombres Chácobos:

- El nombre de la planta no tiene traducción en castellano, es su nombre propio (Batahua, Bisatamanë, Bocono, Corama, Mani, Onipa, Potasti entre otras plantas).

- El nombre de la planta refleja las características morfológicas u otro carácter de la planta: bejuco aplanado (Nishipara o Nishiquëspë), madera dura (Jihuicoxi o Nishicoxi), corteza, árbol o bejuco blanco (Jihuijoxo), o con leche (Jihuibëpiya o Nishibëpiya), planta recta (Nihjbosa), hojas o frutas pequeñas (Pamaxoco, Canopëixoco), hojas o frutas grandes (Canopëixoco, Canopehihua), planta amarga (Shia, Jihuimoca), entre otros ejemplos.

- El nombre de la planta puede basarse en su propio uso (Axaria, Ocotsëmo, Carahinaaxa, Mahinohanihi, Morochësti, Omacanihi), o en la calidad misma de la planta para un uso particular: por ejemplo, Mororia, Axaria, son de buena calidad, mientras que las plantas que llevan "Joni" ("falso", "ordinario") no son de tan buena calidad como Xahuamachi ioni, Moxoquëjoni, Bimichëchejoni.

- Es interesante ver que muchas veces, el nombre Chácobo se refiere a la semejanza que existe entre la planta y un animal (Ahuaramaeha, Boexëni, Camabisto. Camamëquënë, Capëhitsa, Capëtëjina, Cashimëtsisi, Iscoro, Jonoshia, Omacabëro, Tëtëmabaspa, entre otros ejemplos), y a veces, existe una semejanza entre la planta y el hombre (Caiosho, Mëquënobita, Yorabita, Nishiratëquënëhua. Ponochi).

- Por otro lado, el nombre de la planta está a menudo relacionado con el habitat de un animal o su alimentación, por ejemplo hojas o frutas de la planta comidas por el animal (Shishaxe, Quëboitsama, Rohonosëbi, Samomaquëti, Xahuamachi, entre otras plantas).

\footnotetext{
${ }^{14}$ Solamente, se encontró que Jihuipama, (el “Pama”) del bosque ribereño, no llevaba Jënë.
} 


\section{El uso de las plantas por los Chácobos}

El presente capítulo pretende profundizar los conocimientos que tienen los Chácobos sobre las plantas, enfocando el estudio desde una perspectiva más "económica ${ }^{15 "}$ o sea, considerando el propio uso de las plantas. Entre otros términos: ¿Para qué sirven las plantas encontradas en los diferentes ambientes de Alto-Ivón y cómo son utilizadas?

Asimismo, a partir del universo de plantas considerado en este estudio (472 plantas $\left.^{16}\right)$, y tomando en cuenta las actividades diarias de los Chácobos, se han agrupado las plantas según las diferentes categorías de uso mencionadas a continuación por orden alfabético:

- $\quad$ Plantas utilizadas para la caza y pesca: se refiere a las plantas localmente llamadas "barbascos" (plantas ictiotóxicas), y a las plantas que llevan suerte para cazar o pescar, o ver mejor las presas $^{17}$.

- Plantas comestibles o con fines alimenticias: se refiere a las plantas que sirven para comer, (la gran mayoría de esas plantas tienen frutas comestibles).

- Plantas utilizadas para la construcción: se refiere a las plantas utilizadas para construir las casas. Varias partes de la plantas, como las hojas, madera, corteza pueden ser utilizadas. También están incluidos los bejucos en esta categoría ya que sirven a amarrar las vigas, horcones, tijeras entre otros tipos de maderas.

- Plantas utilizadas para la leña y/o fumar la goma ("astillas"): la madera de esas plantas sirve para cocinar (leña), o presenta buenas características $^{18}$ para transformar la leche del caucho o Carama (Hevea brasiliensis), en goma.

- Plantas medicinales: Plantas utilizadas para curar una enfermedad, aliviar el dolor entre otros ejemplos.

- Plantas utilizadas para otros fines. Por ser poco numerosas, se han agrupado en esta categoría las plantas que sirven para la fabricación de utensilios domésticos, flautas, o sirven para pintar cerámica entre otros usos. También se encuentran las plantas comercializadas como el caucho (Hevea brasiliensis ${ }^{19}$ ). Por otro lado, hemos incluido en esta categoría, las plantas que si bien ya no se utilizan actualmente, servían antes para la elaboración de los vestidos o adornos.

\footnotetext{
${ }^{15}$ Referirse a la introducción: “ El papel de la etnobiología en la valoración de los conocimientos tradicionales”.

${ }^{16}$ El universo de 472 plantas corresponde a las que fueron identificadas por los Chácobo y las recolectadas, para muestras de herbario, en los diferentes ambientes circundantes al pueblo de Alto- Ivón (bosques, "barbechos" y sabana)

${ }^{17}$ Estas últimas plantas, que llevan suerte para pescar, cazar han sido definidas por Balée (1994) como plantas "mágicas". Debido a que no hemos profundizado los conocimientos sobre esas plantas, solamente las hemos considerado en un sentido más práctico, o sea, tomando en cuenta la actividad misma de la pesca y caza.

18 Las plantas cuya madera libera mucho humo y bastante calo, son utilizadas en la transformación de goma. Asimismo. sirven localmente de "astillas".

19 La castaña (Bertholettia excelsa) es también comercializada, pero como tiene otro uso, se encuentra en la categoría de multi-uso.
} 
- Por otro lado, se ha añadido una categoría de plantas con uso múltiple o multi-uso, refiriéndose a plantas que pueden tener varios usos (plantas consideradas sin orden de preferencia o de prioridad de uso).

Debido a que un nombre Chácobo puede incluir varias especies científicas y viceversa, y que los nombres científicos pueden cambiar a medida de la actualización de las identificaciones botánicas, la interpretación de los datos fue realizada en base a los nombres nativos ${ }^{20}$. De esta manera, los nombres científicos mencionados en este capítulo, (complementados por su número de recolección), servirán solamente de referencia. Sin embargo, a manera de tener una relación entre el estudio de la diversidad florística (referirse al Capítulo 1) y el uso de las especies inventariadas en la parcela permanente, la interpretación de los datos se hará en este caso particular, en función a las especies botánicas. Cabe recordar que se encontraron 123 especies botánicas en la parcela, las cuales corresponden a 112 diferentes nombres Chácobos.

Asimismo, la primera parte de este capítulo presentará los aspectos generales con relación al uso de las plantas. En este caso, se tratará de ver ¿Cuántas plantas son utilizadas, y qué clase de uso tienen?. Cabe mencionar que por la misma metodología empleada ${ }^{21}$, no se pudo comparar la utilización de las plantas según los diferentes tipos de ambientes (bosque de tierra firme y ribereño, barbechos, sabana), y por lo tanto, se hizo el análisis considerando cada uno de ellos de manera separada. Solamente el caso particular de la parcela del bosque de tierra firme nos permitirá tener una idea más cuantificada del uso de las plantas forestales en un área determinada.

En la segunda parte de este capítulo, se hará una descripción cualitativa del uso de las plantas, consideradas por categoría de uso. En ningún caso, los usos están descritos por orden de importancia en la vida diaria de los Chácobos, sino por orden alfabético.

Por otra parte, se observarán también las plantas que no son utilizadas por los Chácobos, (considerando siempre un universo de 472 plantas). En efecto, a pesar de no ser de gran importancia para los fines de este estudio, la información podrá ser comparada con posibles estudios que se realizarán en la mismo área, o en otros lugares, donde también existen estas plantas, las mismas que pueden ser utilizadas por otras etnias indígenas.

${ }^{20}$ En este caso, hablaremos también de especies de plantas cuando se tratan de diferentes plantas distinguidas por los Chácobos. Cuando se trata de especies distinguidas desde el punto de vista botánico, hablaremos de especies científicas o botánicas.

${ }^{21}$ A parte del bosque de tierra firme donde se consideró una muestra de una hectárea. los demás ambientes no han sido muestreados, y la información ha sido obtenida a partir de recolectas generales. 


\section{El uso general de las plantas por los Chácobos}

\section{Plantas utilizadas, no utilizadas y plantas con varios usos}

Considerando todos los tipos de ambientes y el universo de 472 plantas diferenciadas por los Chácobos ${ }^{22}$, se observa que 317 plantas (o sea, el $68 \%$ de este universo vegetal) se utilizan. De estas 319 plantas, 48 (15\%) tienen varios usos (ver Tabla 16 y Gráfico $6 \mathrm{a}, \mathrm{b})$.

Cabe recordar que según Boom (1989: $82)$, el $84.7 \%$ de las especies botánicas registradas (sobre un total de 360 y correspondiendo a 197 géneros y 75 familias botánicas), tenía uso.

Considerando cada uno de los diferentes tipos de ambientes estudiados:

- En el bosque de tierra firme, el $81 \%$
(183) de las plantas se utiliza, y de esas plantas, el $20 \%$ (36) tiene varios usos (ver Tabla 16 y Gráfico 6 c, d).

- En los barbechos, el 41\% (39 especies) de las plantas se utiliza, y de esas plantas, el $3 \%$ ( 1 especie) tiene varios usos (ver Tabla 16 y Gráfico 6 e, f).

- En el bosque ribereño, el 58\% (32) de las plantas es utilizado, y de esas plantas, el $16 \%$ (5) tiene varios usos (ver Tabla 16 y Gráfico 6 g, h).

- En la sabana, el 66\% (65) de las plantas es utilizado, y de esas plantas, el $9 \%$ (6) tiene varios usos (ver Tabla 16 y Gráfico 6 i, j).

Tabla 16: Las plantas utilizadas y no utilizadas en todos los ambientes y por tipo de ambiente

\begin{tabular}{|c|c|c|c|c|c|c|c|c|c|c|}
\hline \multirow{2}{*}{$\begin{array}{c}\text { Uso general } \\
\text { de las } \\
\text { Plantas }\end{array}$} & \multicolumn{2}{|c|}{$\begin{array}{c}\text { Todos los tipos } \\
\text { de } \\
\text { ambientes }\end{array}$} & \multicolumn{2}{|c|}{$\begin{array}{l}\text { Bosque de tierra } \\
\text { firme }\end{array}$} & \multicolumn{2}{|c|}{ Barbechos } & \multicolumn{2}{|c|}{$\begin{array}{l}\text { Bosque } \\
\text { ribereño }\end{array}$} & \multicolumn{2}{|c|}{ Sabana } \\
\hline & $\begin{array}{c}\text { No de } \\
\text { especies }\end{array}$ & $\%$ & $\begin{array}{c}\text { No de } \\
\text { especies }\end{array}$ & $\%$ & $\begin{array}{c}\text { No de } \\
\text { especies }\end{array}$ & $\%$ & $\begin{array}{c}\text { No de } \\
\text { especies }\end{array}$ & $\%$ & $\begin{array}{c}\text { No de } \\
\text { especies }\end{array}$ & $\%$ \\
\hline $\begin{array}{l}\text { Especies } \\
\text { utilizadas: }\end{array}$ & 317 & 68 & 183 & 81 & 39 & 41 & 32 & 58 & 65 & 66 \\
\hline (Un solo uso) & 269 & 85 & 147 & 80 & 38 & 97 & 27 & 84 & 59 & 91 \\
\hline (Varios usos) & 48 & 15 & 36 & 20 & 1 & 3 & 5 & 15 & 6 & 9 \\
\hline $\begin{array}{l}\text { Especies no } \\
\text { utilizadas }\end{array}$ & 153 & 32 & 42 & 19 & 55 & 59 & 22 & 42 & 34 & 34 \\
\hline Total & 472 & & 225 & & 94 & & 54 & & 99 & \\
\hline
\end{tabular}

22 Debido a que existan plantas comunes entre los diferentes tipos de ambientes, el número de especies encontradas para todos los ambientes (472), no corresponde a la suma de las especies encontradas en cada ambiente ( o sea $233+94+54+99$ ). Por otro laso, los porcentajes del número de especies que tienen un o varios usos ha sido calculados para cada tipo de ambiente, a partir de las especies utilizadas solamente. 


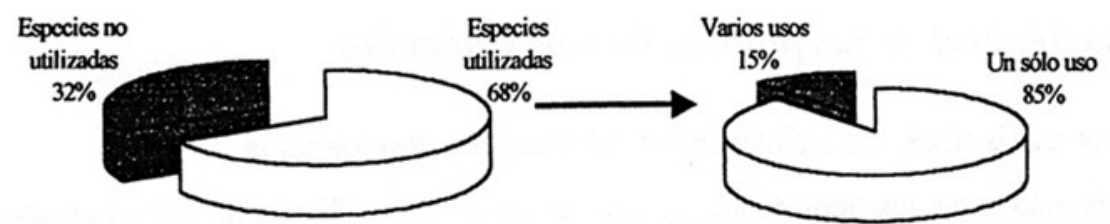

(a) Plantas utilizadas y no utilizadas en todos los diferentes ambientes (considerando un universo de 472 plantas diferentes)

(b) Plantas utilizadas en todos los diferentes ambientes

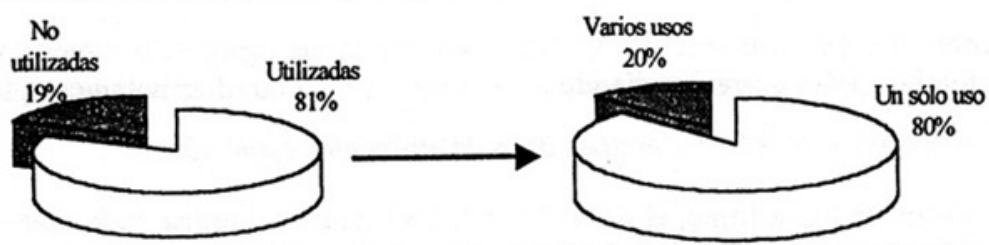

(c) Plantas utilizadas y no utilizadas en el bosque de tierra firme

(d) Plantas utilizadas en el bosque de tierra firme (considerando un toniverso de 225 plantas diferentes) (considerando un universo de 183 plantas utilizadas)

No utilizadas $59 \%$

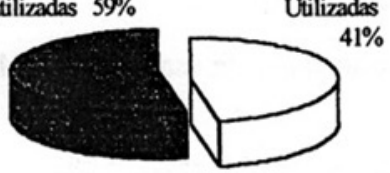

(e) Plantas utilizadas y no utilizadas en los barbochos (considerando in universo de 94 plantas diferentes)

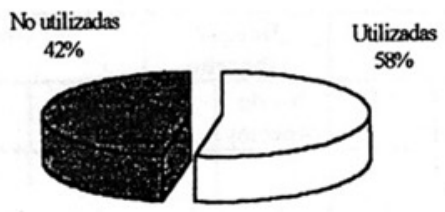

(g) Plantas utilizadas y no utilizadas en el bosque riberetio (considerando un teniverso de 54 plantas diferentes)

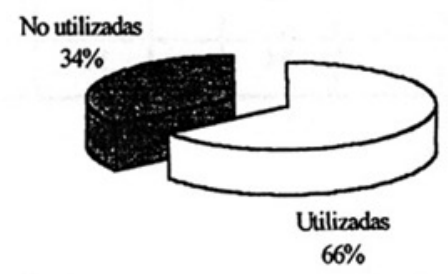

(i) Plantas utilizadas y no utilizadas en la sabana (considerando un tunherso de 99 plantas diferentes)
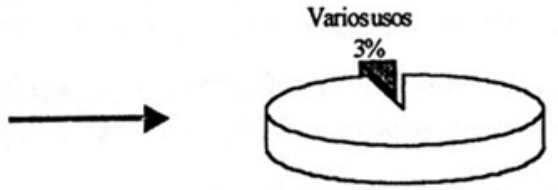

Un sólo uso $97 \%$

(f) Plantas utilizadas en los barbechos (considerando un universo de 39 plantas utilizadas)

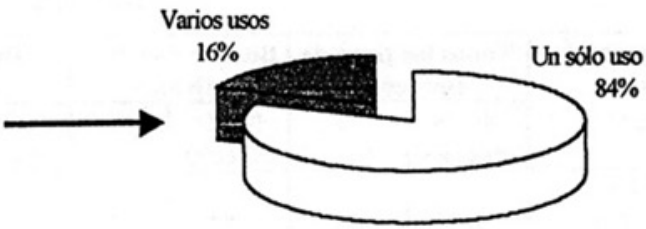

(h) Plantas utilizadas en el bosque ribereño (considerando un universo de 32 plantas utilizadas)

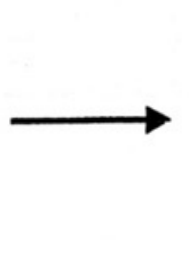
(considerando un universo de 65 plantas utilizadas)

Gráfico 6: Las plantas utilizadas y no utilizadas en los diferentes tipos de ambientes 
Bergeron S., 1998. Uso de las plantas por los Chácobos (Alto Ivón, Beni, Bolivia)

Por lo general, de las 48 plantas han encontrado 22 plantas comestibles encontradas con varios usos, la mayoría, y medicinales). También se encuentran (67\%, o sea 32 plantas sobre 48), son a menudo plantas medicinales $\mathrm{y} / \mathrm{o}$ comestibles y muchas veces tienen al maderables, que tienen otros usos como mismo tiempo un uso medicinal, (se caza y pesca, leña y/o astillas (ver Tabla 17 y Gráfico 7).

Tabla 17: Las formas de utilización de las plantas que tienen varios usos

\begin{tabular}{|l|c|c|}
\hline \multicolumn{1}{|c|}{ Tipo de uso } & $\begin{array}{c}\text { No de } \\
\text { especies }\end{array}$ & $\%$ \\
\hline Comestible; Construcción & 3 & 6 \\
\hline Comestible; Leña y/o astillas & 4 & 8 \\
\hline Comestible; Medicinal & 22 & 46 \\
\hline Comestible; Otros & 2 & 4 \\
\hline Comestible; Otros; Medicinal & 1 & 2 \\
\hline Construcción; Leña y/o Astillas & 1 & 2 \\
\hline Construcción; Leña y/o Astillas; Otros & 1 & 2 \\
\hline Construcción; Otros & 3 & 6 \\
\hline Leña y/o Astillas; Otros & 4 & 8 \\
\hline Medicinal; Leña y/o Astillas; & 1 & 2 \\
\hline Medicinal; Caza y/o Pesca & 3 & 6 \\
\hline Medicinal; Construcción & 2 & 4 \\
\hline Medicinal; Otros & 1 & 2 \\
\hline Total & $\mathbf{4 8}$ & \\
\hline
\end{tabular}

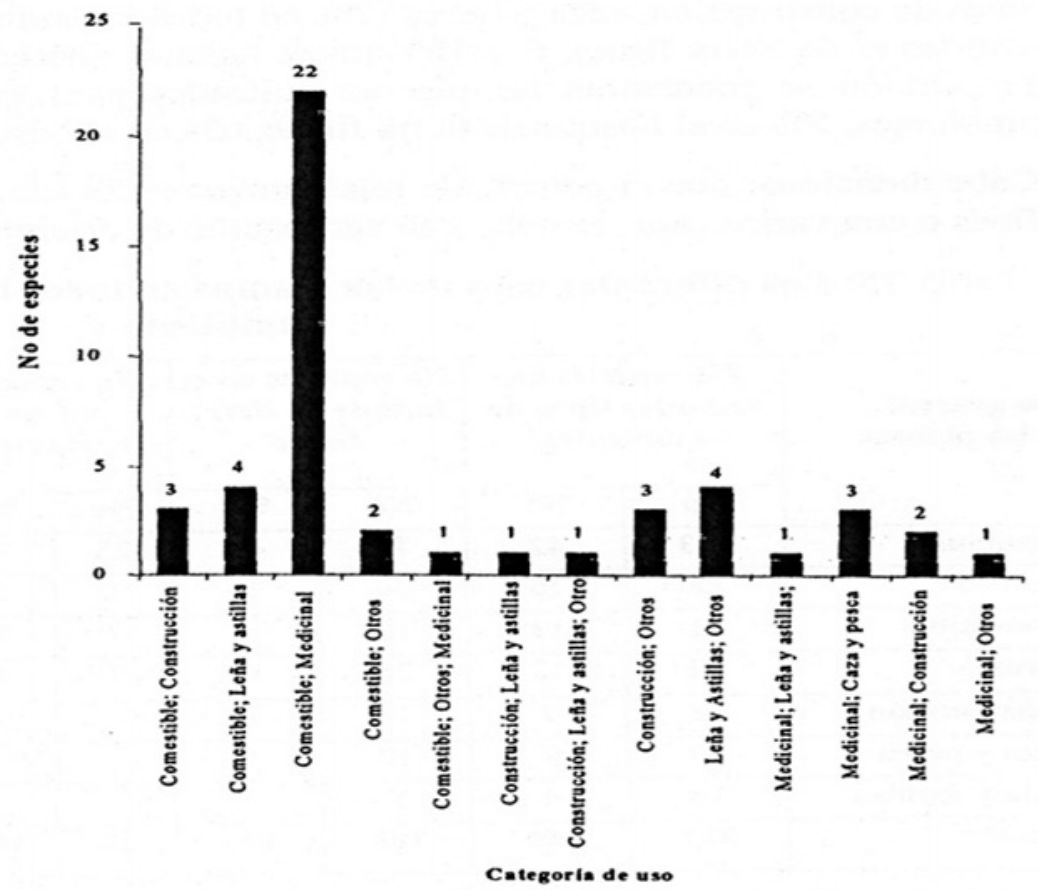

Gráfico 7: Las formas de utilización de las plantas que tienen varios usos 


\section{Las diferentes categorías de uso de las plantas}

Si consideramos los diferentes tipos de uso de las plantas (referirse a la Tabla 18 y el Gráfico 8), vemos que tanto al nivel de todos los ambientes, como en cada uno de ellos, el uso medicinal predomina, (el $42 \%$ de las especies tiene un uso medicinal en todos los ambientes, $40 \%$ en el bosque de tierra firme, $71 \%$ en los barbechos, $26 \%$ en el bosque ribereño y $35 \%$ en la sabana). Luego, con excepción del bosque de tierra firme, las plantas están por lo general más utilizadas con fines alimenticias, (en todos los ambientes, el $13 \%$ de las especies son comestibles, $18 \%$ en los barbechos, y respectivamente $23 \%$ en el bosque ribereño y en la sabana). Por último, salvo en los barbechos, las plantas son utilizadas con fines de construcción, caza y pesca ( $7 \%$ en todos los ambientes, respectivamente 8 y $5 \%$ en el bosque de tierra firme, 6 y $13 \%$ en el bosque ribereño y $9 \%$ en la sabana). En menor proporción se encuentran las plantas utilizadas para leña y/o astillas ( $4 \%$ en todos los ambientes, $5 \%$ en el bosque de tierra firme, $6 \%$ en el bosque ribereño y $5 \%$ en la sabana).

Cabe mencionar que el porcentaje relativamente elevado de las plantas utilizadas con otros fines o con varios usos, se debe a la agrupación de diferentes usos.

Tabla 18: Los diferentes usos de las plantas en todos los ambientes y por cada tipo de ambiente

\begin{tabular}{|c|c|c|c|c|c|c|c|c|c|c|}
\hline \multirow[t]{2}{*}{$\begin{array}{l}\text { Uso general de } \\
\text { las plantas }\end{array}$} & \multicolumn{2}{|c|}{$\begin{array}{l}\text { No especies en } \\
\text { todos los tipos } \\
\text { de ambientes }\end{array}$} & \multicolumn{2}{|c|}{$\begin{array}{l}\text { No especies en } \\
\text { el bosque de } \\
\text { tierra firme }\end{array}$} & \multicolumn{2}{|c|}{$\begin{array}{c}\text { No especies } \\
\text { en los } \\
\text { barbechos }\end{array}$} & \multicolumn{2}{|c|}{$\begin{array}{c}\text { No especies En } \\
\text { el bosque } \\
\text { ribereño }\end{array}$} & \multicolumn{2}{|c|}{$\begin{array}{c}\text { No especies en } \\
\text { la sabana }\end{array}$} \\
\hline & No & $\%^{*}$ & No & $\% *$ & No & $\% *$ & No & $\%^{*}$ & No & $\% *$ \\
\hline Medicinal & 133 & 42 & 74 & 40 & 28 & 71 & 8 & 26 & 23 & 35 \\
\hline Multiuso & 48 & 15 & 36 & 20 & 1 & 3 & 5 & 16 & 6 & 9 \\
\hline Comestible & 41 & 13 & 12 & 7 & 7 & 18 & 7 & 23 & 15 & 23 \\
\hline Otros & 39 & 12 & 28 & 15 & 3 & 8 & 4 & 10 & 6 & 9 \\
\hline Construcción & 22 & 7 & 14 & 8 & - & - & 2 & 6 & 6 & 9 \\
\hline Caza y pesca & 20 & 7 & 10 & 5 & - & - & 4 & 13 & 6 & 9 \\
\hline Leña y astillas & 14 & 4 & 9 & 5 & - & - & 2 & 6 & 3 & 5 \\
\hline Total** & 317 & 100 & 183 & 100 & 39 & 100 & 32 & 100 & 65 & 100 \\
\hline
\end{tabular}

* Los porcentajes han sido calculados a partir del total de las plantas encontradas en cada lugar.

** Los totales corresponden a la suma de las plantas utilizadas en todos los tipos de ambientes y en cada uno de ellos. En efecto se han descartado las plantas no utilizadas. 

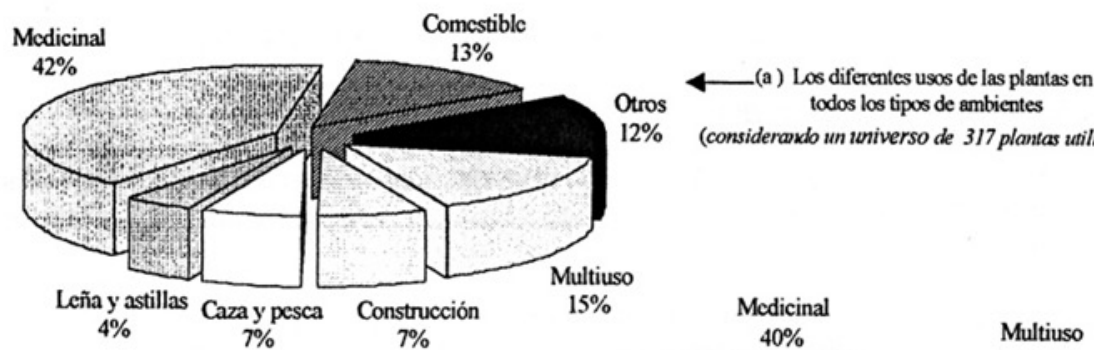

(considerando un universo de 317 plantas utilizadas)

(b) Los diferentes usos de las plantas en el bosque de tierra firme

(considerando un universo de 183 plantas utilizadas)

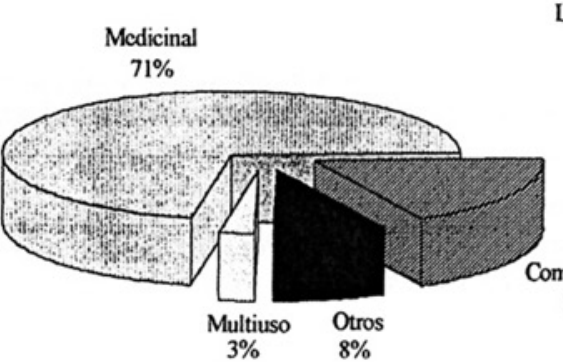
Lcria y astillas
$5 \%$
Construcción
$8 \%$
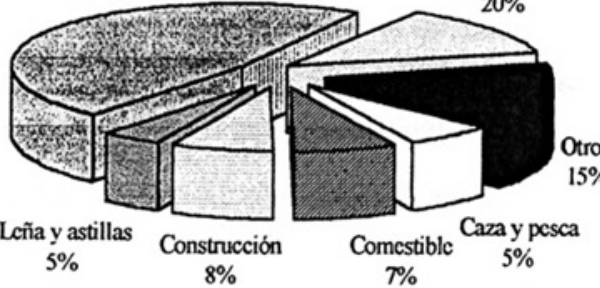

(c) Los diferentes usos de las plantas en los barbechos (considerando un universo de 38 plantas utilizadas)

(d) Los diferentes usos de las plantas en el bosque ribereño (considerando un universo de 31 plantas utilizadas)

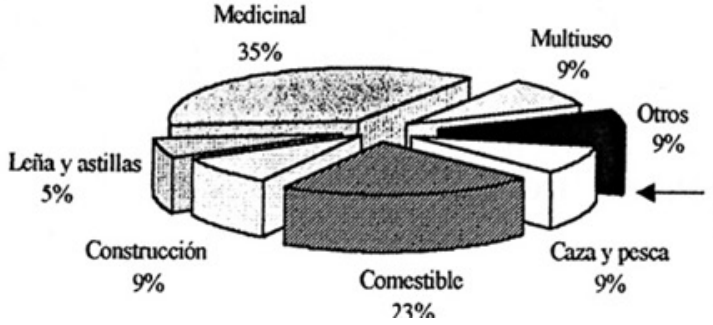

(c) Los diferentes usos de las plantas en la sabana (considerando un universo de 65 plantas utilizadas)

Gráfico 8: Los diferentes usos de las plantas en todos y en cada uno de los ambientes 


\section{Los diferentes tipos de plantas utilizadas (tipos biológicos)}

\section{Al nivel de todos los ambientes}

La Tabla 19 y el Gráfico 9 indican al nivel de todos los ambientes, el número de árboles, arbustos, bejucos, helechos, hierbas, y palmas utilizados para fines distintas, o simplemente no utilizadas:

- Los árboles son por lo general más utilizados, (en comparación a los demás tipos biológicos), para fines alimenticios, construcción, medicinal, leña y/o astillas u otros usos. Por lo contrario, pocos árboles se utilizan para la pesca y caza.

- Igualmente, los arbustos, son bastante utilizados para varios fines (comestible, caza y pesca, multi-uso, u otros usos) salvo en la construcción.
- Los bejucos y las palmas tienen también un uso diversificado, o sea que salvo la leña y astillas, tienen varios usos.

- Las hierbas son esencialmente utilizadas para la caza y pesca (en este caso, plantas que llevan suerte). Sin embargo, pueden tener un uso medicinal $u$ otros usos (por ejemplo las frutas que sirven de tinta).

- Por último, considerando las plantas que no son utilizadas, el $20 \%$ $(46 / 225 * 100)$ de las especies de árboles y el $37 \%$ de los arbustos no se utilizan. Por otra parte, una gran parte de especies de bejucos $\left(46 \%{ }^{23}\right)$ y el $66 \%$ de las especies de hierbas tampoco se utilizan.

Tabla 19: Los diferentes tipos de plantas utilizadas en todos los ambientes

\begin{tabular}{|l|c|c|c|c|c|c|c|c|c|c|c|c|c|c|}
\hline $\begin{array}{c}\text { Tipo } \\
\text { biológico/ Uso en } \\
\text { todos los } \\
\text { ambientes }\end{array}$ & $\begin{array}{c}\text { No de } \\
\text { árboles }\end{array}$ & $\%$ & $\begin{array}{c}\text { No de } \\
\text { arbustos }\end{array}$ & $\%$ & $\begin{array}{c}\text { No de } \\
\text { bejucos }\end{array}$ & $\%$ & $\begin{array}{c}\text { Node } \\
\text { helechos }\end{array}$ & $\%$ & $\begin{array}{c}\text { No de } \\
\text { hierbas }\end{array}$ & $\%$ & $\begin{array}{c}\text { No de } \\
\text { palmas }\end{array}$ & $\%$ & Totales & $\%$ \\
\hline Caza y pesca & 1 & 0.4 & 6 & 6 & 6 & 9 & 2 & 40 & 5 & 8 & - & & 20 & 4 \\
\hline Comestible & 24 & 10 & 10 & 11 & 6 & 9 & - & & - & & 1 & 17 & 41 & 9 \\
\hline Construcción & 19 & 8 & - & & 3 & 4 & - & & - & & - & & 22 & 5 \\
\hline Leña y astillas & 12 & 5 & 2 & 2 & & 0 & - & & - & & - & & 14 & 3 \\
\hline Medicinal & 87 & 37 & 20 & 21 & 14 & 20 & 2 & 40 & 10 & 16 & - & & 132 & 28 \\
\hline Multiuso & 32 & 14 & 8 & 8 & 3 & 4 & - & & - & & 5 & 83 & 49 & 10 \\
\hline Otros & 15 & 6 & 14 & 15 & 5 & 7 & 1 & 20 & 6 & 10 & - & & 41 & 9 \\
\hline No utilizado & 46 & 19 & 35 & 37 & 32 & 46 & - & & 40 & 66 & - & & 153 & 32 \\
\hline Totales & 236 & 100 & 95 & 100 & 69 & 100 & 5 & 100 & 61 & 100 & 6 & 100 & 472 & 100 \\
\hline
\end{tabular}

\footnotetext{
${ }^{23}$ La gran mayoría de esos bejucos no tienen madera ( bejucos "herbáceas").
} 


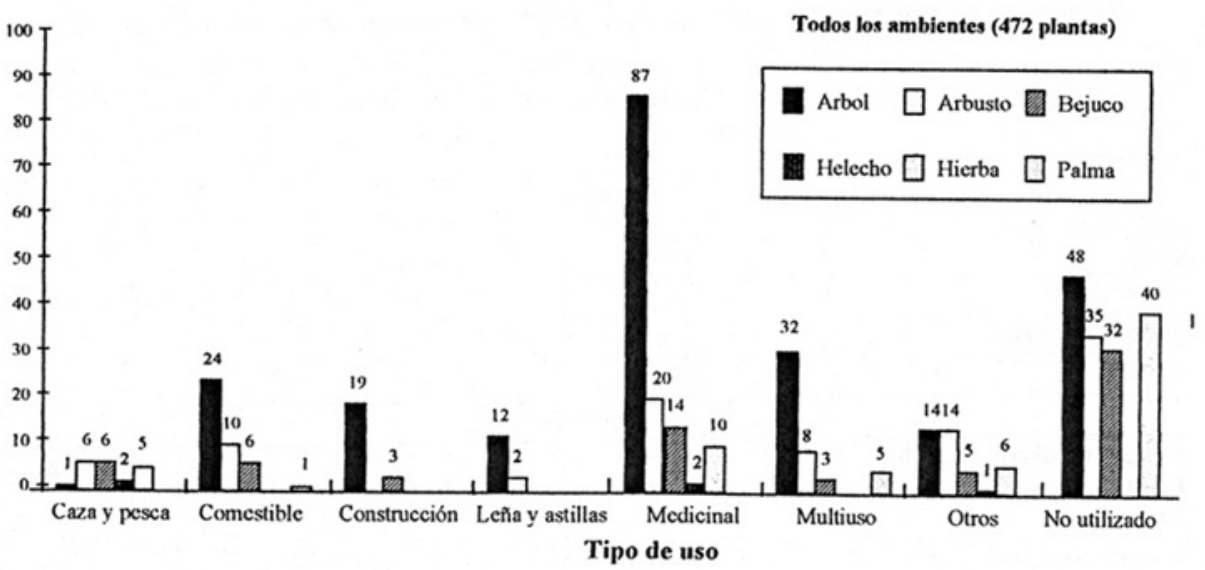

Gráfico 9: Los diferentes tipos de plantas utilizadas en todos los ambientes

\section{Al nivel de cada uno de los ambientes}

Considerando cada tipo de ambiente (ver Tabla 20 y Gráfico 10):

- En el bosque de tierra firme (225 plantas registradas), el patrón de uso de los diferentes tipos de plantas, es bastante similar a lo observado en todos los ambientes. Los árboles entran en todas las categorías de uso, esencialmente en el uso medicinal, (más de 52 especies diferentes son utilizadas). Por otro lado, muchas de las especies de árboles (25) tienen un uso múltiple. Los arbustos y bejucos entran casi en todas las categorías de uso excepto en la construcción (arbustos) y leña y/o astillas (bejucos). Las hierbas y palmas entran en dos a tres categorías de uso, y las palmas se caracterizan por su uso múltiple o diversificado.

- En los barbechos (94 especies registradas), se destaca el uso medicinal, y tanto los árboles, arbustos, como hierbas y bejucos son utilizados. Por otra parte, se observa también que la gran mayoría de las plantas registradas en este estudio no tiene uso.

- En el bosque ribereño, donde se recolectaron 54 diferentes plantas, los árboles, y de manera más secundaria, los arbustos predominan para la mayoría de los usos. Por otro lado, los bejucos entran también en varias categorías de uso (caza y pesca, comestible, multi-uso), mientras que las hierbas son solamente utilizadas en la caza y pesca.

- Por último, en la sabana donde 99 plantas fueron registradas, podemos mencionar que para los usos comestible, medicinal, multi-uso y otros, casi todos los diferentes tipos de plantas son utilizados. Para los demás usos, los tipos de plantas utilizados difieren: por ejemplo, arbustos y hierbas son utilizados en la caza y pesca mientras que los árboles son solamente utilizados en la construcción y leña y astillas. Por otro lado, la proporción de hierbas no utilizada, es también bastante importante (10 sobre 19). 
Bergeron S., 1998. Uso de las plantas por los Chácobos (Alto Ivón, Beni, Bolivia)

Tabla 20: Los diferentes tipos de plantas utilizadas por cada tipo de ambiente

\begin{tabular}{|c|c|c|c|c|c|c|c|}
\hline $\begin{array}{c}\text { Tipo } \\
\text { biológico/Uso } \\
\text { según los tipos de } \\
\text { ambientes }\end{array}$ & $\begin{array}{c}\text { Número } \\
\text { de } \\
\text { árboles }\end{array}$ & $\begin{array}{l}\text { Número } \\
\text { de } \\
\text { arbustos }\end{array}$ & $\begin{array}{l}\text { Número } \\
\text { de } \\
\text { bejucos }\end{array}$ & $\begin{array}{l}\text { Número de } \\
\text { helechos }\end{array}$ & $\begin{array}{c}\text { Número } \\
\text { de } \\
\text { hierbas }\end{array}$ & $\begin{array}{c}\text { Número } \\
\text { de } \\
\text { palmas }\end{array}$ & Totales \\
\hline \multicolumn{8}{|c|}{ Caza y pesca } \\
\hline $\begin{array}{l}\text { Bosque de tierra } \\
\text { firme }\end{array}$ & 1 & 1 & 4 & 2 & 2 & & 10 \\
\hline Barbechos & . & - & . & - & - & - & - \\
\hline Bosque ribereño & . & 1 & 2 & . & 1 & . & 4 \\
\hline Sabana & . & 4 & . & . & 2 & . & 6 \\
\hline \multicolumn{8}{|c|}{ Comestible } \\
\hline $\begin{array}{l}\text { Bosque de tierra } \\
\text { firme }\end{array}$ & 8 & 2 & 1 & 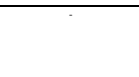 & - & 1 & 12 \\
\hline Barbechos & 6 & 1 & $\overline{-}$ & 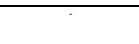 & - & & 7 \\
\hline Bosque ribereño & 4 & - & 3 & - & - & & 7 \\
\hline Sabana & 6 & 7 & 2 & - & & & 15 \\
\hline \multicolumn{8}{|c|}{ Construcción } \\
\hline $\begin{array}{l}\text { Bosque de tierra } \\
\text { firme }\end{array}$ & 11 & - & 3 & 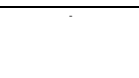 & - & 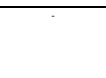 & 14 \\
\hline \multicolumn{8}{|l|}{ Barbechos } \\
\hline Bosque ribereño & 2 & & & 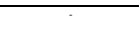 & 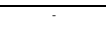 & & 2 \\
\hline Sabana & 6 & . & & 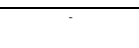 & & & 6 \\
\hline \multicolumn{8}{|c|}{ Leña y astillas } \\
\hline $\begin{array}{l}\text { Bosque de tierra } \\
\text { firme }\end{array}$ & 8 & 1 & - & 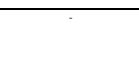 & $\bar{r}$ & 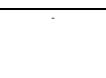 & 9 \\
\hline \multicolumn{8}{|l|}{ Barbechos } \\
\hline Bosque ribereño & 1 & 1 & & & & & 2 \\
\hline Sabana & 3 & & & & & & 3 \\
\hline \multicolumn{8}{|c|}{ Medicinal } \\
\hline $\begin{array}{l}\text { Bosque de tierra } \\
\text { firme }\end{array}$ & 52 & 7 & 11 & 2 & 2 & & 74 \\
\hline Barbechos & 11 & 8 & 3 & & 6 & & 28 \\
\hline Bosque ribereño & 7 & 1 & & & & & 8 \\
\hline Sabana & 17 & 4 & & & 2 & & 23 \\
\hline \multicolumn{8}{|c|}{ Multiuso } \\
\hline $\begin{array}{l}\text { Bosque de tierra } \\
\text { firme }\end{array}$ & 25 & 5 & 2 & 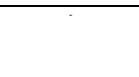 & & 4 & 36 \\
\hline Barbechos & & 1 & & 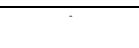 & & - & 1 \\
\hline Bosque ribereño & 3 & 1 & 1 & 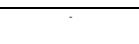 & & - & 5 \\
\hline Sabana & 4 & 1 & & & & 1 & 6 \\
\hline
\end{tabular}


Bergeron S., 1998. Uso de las plantas por los Chácobos (Alto Ivón, Beni, Bolivia)

Tabla 20: (continuación): Los diferentes tipos de plantas utilizadas por cada tipo de ambiente

\begin{tabular}{|c|c|c|c|c|c|c|c|}
\hline $\begin{array}{c}\text { Tipo } \\
\text { biológico/Uso } \\
\text { según los tipos } \\
\text { de ambientes }\end{array}$ & $\begin{array}{l}\text { Número } \\
\text { de } \\
\text { árboles }\end{array}$ & $\begin{array}{l}\text { Número } \\
\text { de } \\
\text { arbustos }\end{array}$ & $\begin{array}{l}\text { Número } \\
\text { de } \\
\text { bejucos }\end{array}$ & $\begin{array}{c}\text { Número } \\
\text { de } \\
\text { helechos }\end{array}$ & $\begin{array}{l}\text { Número } \\
\text { de } \\
\text { hierbas }\end{array}$ & $\begin{array}{l}\text { Número } \\
\text { de } \\
\text { palmas }\end{array}$ & Totales \\
\hline \multicolumn{8}{|c|}{ Otros } \\
\hline $\begin{array}{l}\text { Bosque de } \\
\text { tierra firme }\end{array}$ & 12 & 8 & 4 & 1 & 3 & - & 28 \\
\hline Barbechos & - & 1 & - & - & 2 & - & 3 \\
\hline $\begin{array}{l}\text { Bosque } \\
\text { ribereño }\end{array}$ & 2 & 1 & 1 & - & - & - & 4 \\
\hline Sabana & 1 & 4 & - & - & 1 & - & 6 \\
\hline \multicolumn{8}{|c|}{ No utilizado } \\
\hline $\begin{array}{l}\text { Bosque de } \\
\text { tierra firme }\end{array}$ & 17 & 5 & 13 & - & 7 & - & 42 \\
\hline Barbechos & 8 & 14 & 12 & - & 21 & - & 55 \\
\hline $\begin{array}{l}\text { Bosque } \\
\text { ribereño }\end{array}$ & 7 & 7 & 6 & - & 2 & - & 22 \\
\hline Sabana & 14 & 9 & 1 & - & 10 & - & 34 \\
\hline Totales & 236 & 95 & 69 & 5 & 61 & 6 & 472 \\
\hline
\end{tabular}


Bergeron S., 1998. Uso de las plantas por los Chácobos (Alto Ivón, Beni, Bolivia)
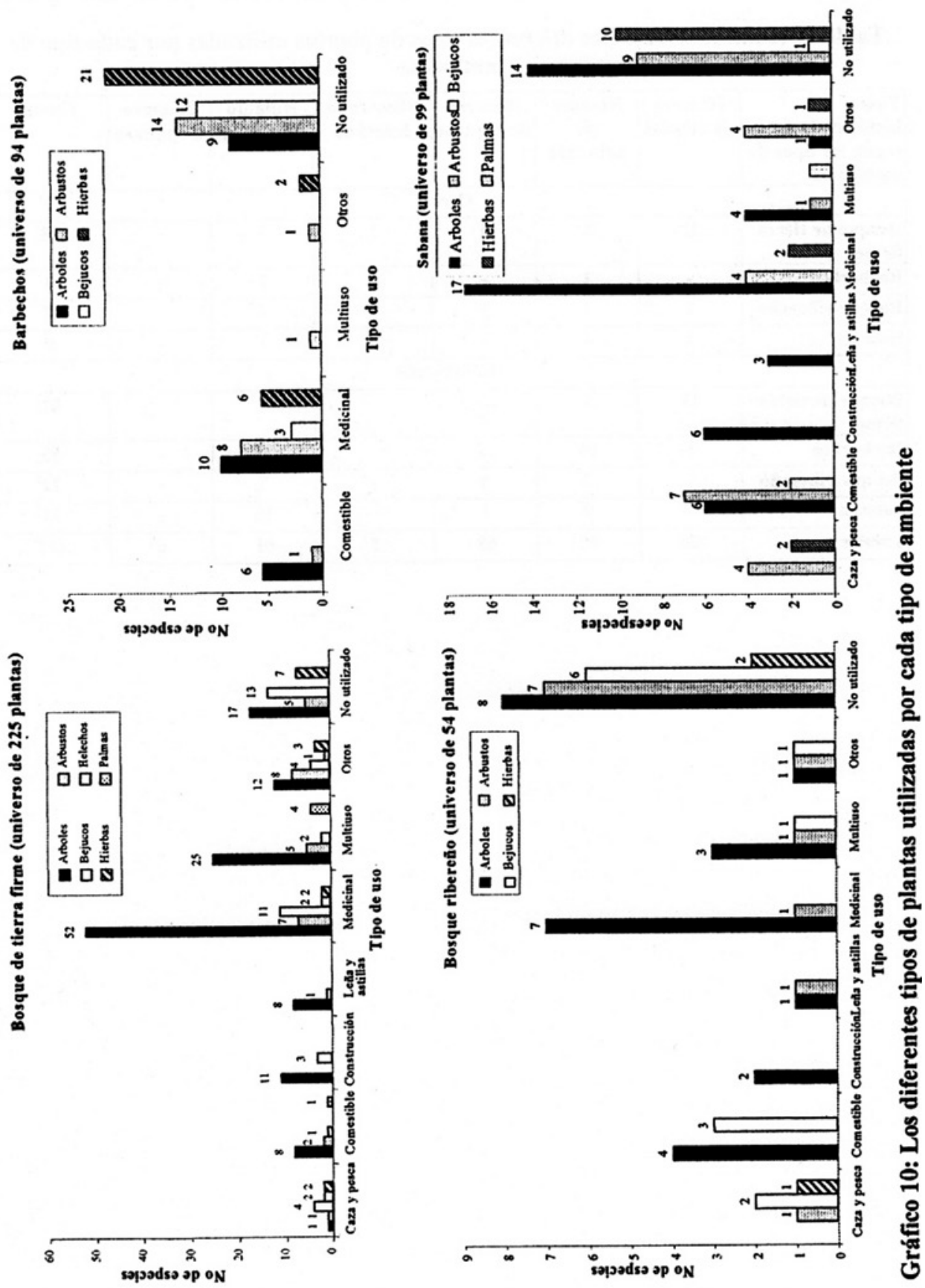


\section{EI caso particular de la parcela de bosque de tierra firme de Alto-Ivón}

A partir de la información registrada sobre los individuos inventariados en la parcela, hemos obtenido la Tabla 21 y el Gráfico 11 , los mismos pueden interpretarse de la manera siguiente:

El $95.9 \%$ de especies botánicas encontradas en la parcela del bosque de tierra firme (correspondientes al $97.8 \%$ de individuos inventariados), tiene uso. Por otra parte, el uso del bosque es por lo general diversificado ya que encontramos las siete categorías de uso definidas anterior- mente.

Se destacan las especies con uso medicinal, (el $48 \%$ de las especies inventariadas son medicinales). Las especies utilizadas en la construcción o con otros usos son también mayoritarias $(12.2 \%$ de las especies botánicas). Solamente, 3 especies (2.4\%) sirven para la pesca y caza. El bajo porcentaje de especies comestibles o utilizadas para la leña y/o astillas, se debe a que estas especies entran también en la categoría multiuso.

Tabla 21: Uso de las plantas inventariadas en la parcela del bosque de tierra firme

\begin{tabular}{|l|c|c|c|c|}
\hline \multirow{2}{*}{ Categoría de uso } & \multicolumn{2}{|c|}{ No de individuos } & \multicolumn{2}{c|}{ No de especies } \\
\cline { 2 - 5 } & Va & $\%$ & Va & $\%$ \\
\hline Caza y pesca & 3 & 0.5 & 3 & 2.4 \\
\hline Comestible & 11 & 1.7 & 6 & 4.9 \\
\hline Construcción & 65 & $\mathbf{1 0 . 2}$ & 15 & 12.2 \\
\hline Leña y astillas & 61 & $\mathbf{9 . 6}$ & 7 & 5.7 \\
\hline Medicinal & 385 & $\mathbf{6 0 . 6}$ & 60 & $\mathbf{4 8 . 8}$ \\
\hline Multiuso & 54 & $\mathbf{8 . 5}$ & 12 & 9.8 \\
\hline Otros & 42 & $\mathbf{6 . 6}$ & 15 & 12.2 \\
\hline No utilizado & 14 & 2.2 & 5 & 4.1 \\
\hline Total & $\mathbf{6 3 5}$ & $\mathbf{1 0 0}$ & $\mathbf{1 2 3}$ & $\mathbf{1 0 0}$ \\
\hline
\end{tabular}




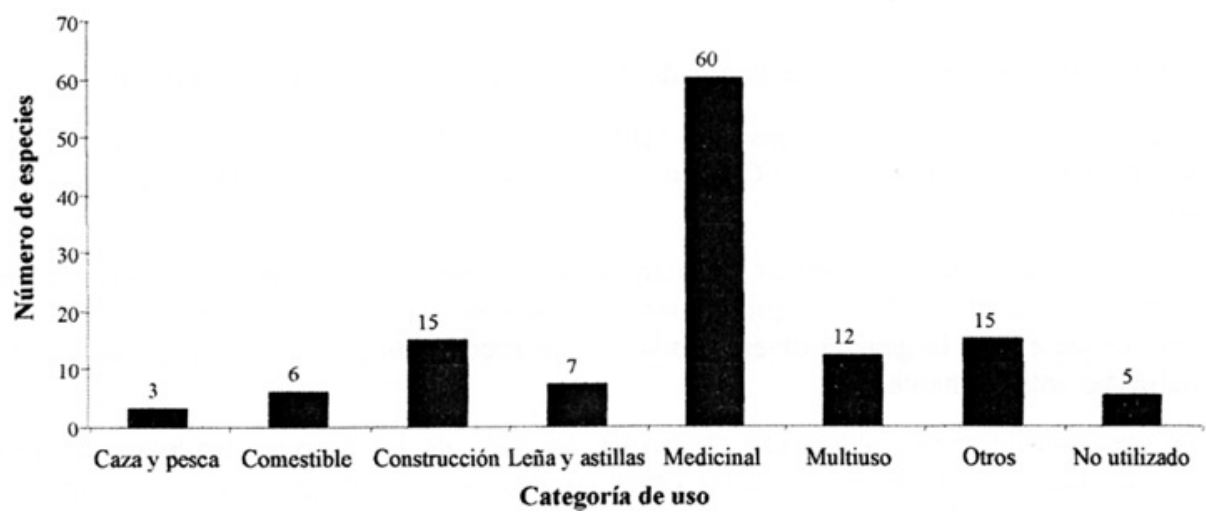

Gráfico 11: Uso de las plantas inventariadas en la parcela del bosque de tierra firme Por último, la Tabla 22 y el Gráfico 12 muestran con mayor detalle el uso de las plantas según los diferentes tipos biológicos (árboles, bejucos y palmas).

Tabla 22: El uso de los árboles, palmas y bejucos en la parcela del bosque de tierra firme

\begin{tabular}{|c|c|c|c|c|c|c|c|c|c|c|c|c|}
\hline \multirow{3}{*}{ Categoría de uso } & \multicolumn{4}{|c|}{ Arboles } & \multicolumn{4}{|c|}{ Bejucos } & \multicolumn{4}{|c|}{ Palmas } \\
\hline & \multicolumn{2}{|c|}{$\begin{array}{c}\text { No } \\
\text { individuos }\end{array}$} & \multicolumn{2}{|c|}{ No especies } & \multicolumn{2}{|c|}{$\begin{array}{c}\text { No } \\
\text { individuos }\end{array}$} & \multicolumn{2}{|c|}{ No especies } & \multicolumn{2}{|c|}{$\begin{array}{c}\text { No } \\
\text { individuos }\end{array}$} & \multicolumn{2}{|c|}{ No especies } \\
\hline & $\mathrm{Va}$ & $\%$ & Va & $\%$ & Va & $\%$ & $\mathrm{Va}$ & $\%$ & Va & $\%$ & Va & $\%$ \\
\hline Caza y pesca & 1 & 0.2 & 1 & 0.9 & 2 & 33.3 & 2 & 33 & & & & \\
\hline Comestible & 6 & 1.1 & 3 & 2.7 & & & & & 4 & 6.56 & 2 & 40 \\
\hline Construcción & 29 & 5.1 & 12 & 10.7 & 1 & 16.7 & 1 & 17 & 35 & 57.4 & 1 & 20 \\
\hline Leña y astillas & 61 & 10.7 & 7 & 6.3 & & & & & & & & \\
\hline Medicinal & 188 & 33.1 & 49 & 43.8 & 2 & 33.3 & 2 & 33 & 21 & 34.4 & 1 & 20 \\
\hline Multiuso & 228 & 40.1 & 21 & 18.8 & & & & & 1 & 1.64 & 1 & 20 \\
\hline Otros & 42 & 7.4 & 15 & 13.4 & & & & & & & & \\
\hline No utilizado & 13 & 2.3 & 4 & 3.6 & 1 & 16.7 & 1 & 17 & & & & \\
\hline Total & 568 & 100 & 112 & & 6 & 100 & 6 & 100 & 61 & 100 & 5 & 100 \\
\hline
\end{tabular}

Los árboles entran en todas las categorías de uso, siendo el uso medicinal predominante, (el $51 \%$ de las especies representando el $63.7 \%$ de los individuos de la parcela, son medicinales). Las palmas entran también en varias categorías de uso, como construcción, uso medicinal, alimenticio y multi-uso. En este último caso, a pesar de estar representados por muchos individuos, solamente una especie es medicinal o comestible, o sirve para la construcción. Los bejucos, poco representados en número de individuos son utilizados con fines de caza y pesca, construcción y medicinal. 
Bergeron S., 1998. Uso de las plantas por los Chácobos (Alto Ivón, Beni, Bolivia)
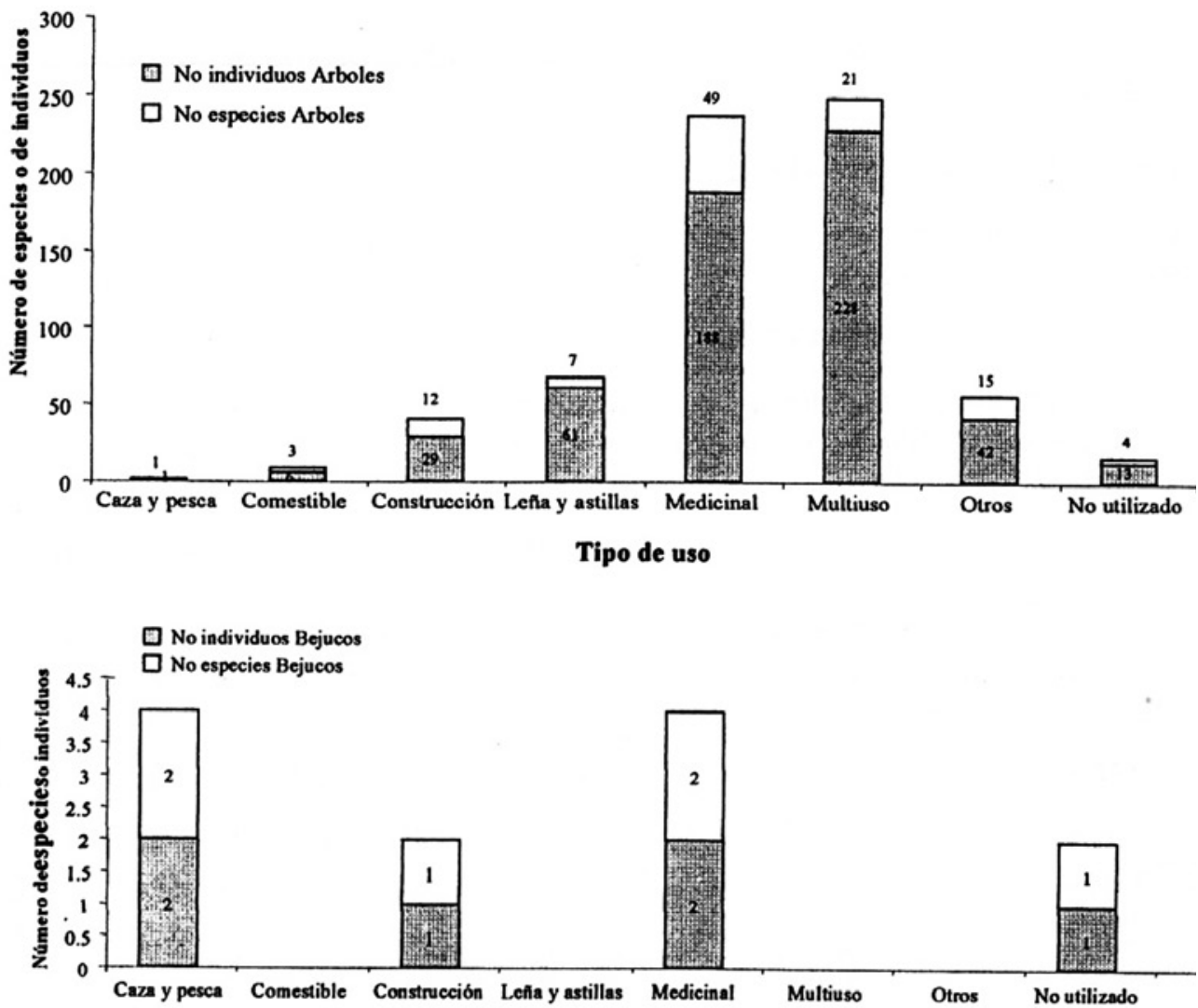

Tipo de uso

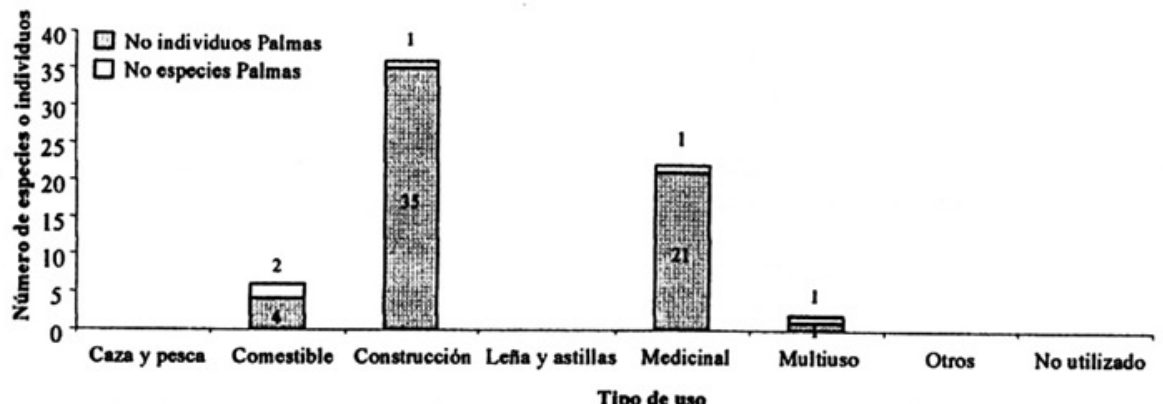

Gráfico 12: Uso de los árboles, palmas y bejucos inventariados en la parcela del bosque de tierra firme 


\section{Las plantas utilizadas por los Chácobos según su categoría de uso}

En este subcapítulo, se detallan las diferentes especies que entran en las categorías de uso definidas previamente.

\section{Plantas utilizadas para la caza y pesca}

De las 472 plantas abarcadas en este estudio y distinguidas por los Chácobos, 20 de ellas sirven para la caza y pesca.

De esas plantas, podemos diferenciar:

- Las plantas que actúan "directamente" sobre los peces o sea, los adormecen o los matan Estas plantas "ictiotóxicas" son localmente llamadas "barbascos". Por lo general, la corteza, madera, raíces y, a veces, las hojas son utilizadas.

- Las plantas que llevan suerte para la pesca o caza, o mejoran la mirada del cazador. En este caso, las hojas son utilizadas.

Asimismo, si bien los "barbascos" (bejucos por lo general), se encuentran más en el bosque ribereño, las plantas que Ilevan suerte para la pesca o caza, se distribuyen tanto en la sabana como el bosque de tierra firme.

Asimismo, se mencionan en la Tabla 23, los "barbascos" por orden de eficiencia.

Tabla 23: grupo de los "barbascos" (bejucos) distinguidos por los Chácobos

\begin{tabular}{|c|l|l|l|l|}
\hline $\begin{array}{c}\text { Nombre } \\
\text { Chácobos }\end{array}$ & \multicolumn{1}{|c|}{ Tipo de ambiente } & Género y especie & \multicolumn{1}{|c|}{ Familia } & $\begin{array}{c}\text { No de } \\
\text { colección }\end{array}$ \\
\hline Axa o Axaria & $\begin{array}{l}\text { Bosque ribereño y más } \\
\text { escaso en bosque de tierra } \\
\text { firme }\end{array}$ & Derris amazónica & Papilionaceae & 582,960 \\
\hline Capëhitsa & $\begin{array}{l}\text { Bosque ribereño y más } \\
\text { escaso en bosque de tierra } \\
\text { firme }\end{array}$ & Derris amazónica & Papilionaceae & 178 \\
\hline Axacoro & $\begin{array}{l}\text { Bosque ribereño y más } \\
\text { escaso en bosque de tierra } \\
\text { firme }\end{array}$ & Serjania sp. & Sapindaceae & $\begin{array}{l}947,359, \\
690\end{array}$ \\
\hline Carahinahaxa & $\begin{array}{l}\text { Bosque ribereño y más } \\
\text { escaso en bosque de tierra } \\
\text { firme }\end{array}$ & Serjania sp. & Sapindaceae & 326,919, \\
& $\begin{array}{l}\text { Bosque ribereño y más } \\
\text { escaso en bosque de tierra } \\
\text { firme }\end{array}$ & Derris sp & Papilionaceae & 692,948 \\
\hline Jënëhaxahua & & & $\begin{array}{l}545,664, \\
688,946, \\
289\end{array}$ \\
\hline
\end{tabular}

Los Chácobos "barbasquean" en época seca ya que el río baja hasta casi desaparecer, quedando charcos y pozos de agua en algunos sitios. Asimismo, cortan el tronco y las raíces en pequeños trozos (con un largo de 5 a $10 \mathrm{~cm}$ ), los cuales se echan en el pozo de agua. 
El efecto producido sobre los peces varía en función del tipo de "barbasco" utilizado. Con Axacoro y Carahinahaxa, el agua se vuelve negra y los peces aparecen muertos en la superficie. Cuando se utiliza Capehitsa, Axaria, Jénéhaxahua, aparece una espuma blanca, y los peces se encuentran adormecidos. Asimismo, los Chácobos, recogen los peces muertos o adormecidos en la superficie del agua, matándolos con machete o con flechas en el último caso.

En cuanto a las plantas que llevan suerte para pescar y/o cazar (ver Tabla 24), el modo de utilización es variable según la especie. Generalmente, se tratan de arbustos o hierbas, rara vez de árboles o bejucos, cuyas hojas son utilizadas. En el caso de la pesca, se soba el anzuelo con la hoja de la planta (Pachamahinonihi, Xabaomacamahinónihi, Omacanihi, Ahuaxonihi) la cual se pone en el bolsillo. En el caso de la caza, se soba al perro con algunas hojas y se las hace oler (Jonoshia, Xabachaxonihi. Xabajonotapo, Jonotapo, Jononihi). Luego se pone las mismas o nuevas hojas en el bolsillo. Ocurre a veces (caso de Tétémabaspa y Xabachacatetémasbaspa) que se estruje las hojas y se pone unas gotas en el ojo del cazador para ver mejor las presas.

Cabe mencionar, que tres otras plantas sirven para pescar (a partir de las cuales se hacen las flechas), pero por tener otros usos, esas últimas han sido consideradas en la categoría multiuso.

Tabla 24: Plantas que llevan suerte en la pesca y caza

\begin{tabular}{|c|c|c|c|c|}
\hline Nombre Chácobo & $\begin{array}{c}\text { Tipo biológico y de } \\
\text { ambiente }\end{array}$ & Género y especie & Familia & $\begin{array}{c}\text { No de } \\
\text { colección }\end{array}$ \\
\hline Ahuaxonihi & $\begin{array}{l}\text { Hierba del bosque } \\
\text { denso húmedo de } \\
\text { tierra firme }\end{array}$ & & & 349 \\
\hline Jononihi & $\begin{array}{l}\text { Hierba del bosque } \\
\text { denso húmedo de } \\
\text { tierra firme }\end{array}$ & & & 305 \\
\hline Jonotapo & $\begin{array}{l}\text { Hierba del bosque } \\
\text { ribereño }\end{array}$ & $\begin{array}{l}\text { Brunfelsia } \\
\text { grandiflora }\end{array}$ & Solanaceae & 837 \\
\hline Omacanihi & $\begin{array}{l}\text { Hierba de la } \\
\text { sabana arbórea } \\
\text { húmeda }\end{array}$ & & & 400 \\
\hline Xabajonotapo & $\begin{array}{l}\text { Hierba de la } \\
\text { sabana arbórea } \\
\text { húmeda }\end{array}$ & & Vochysiaceae & 580 \\
\hline Jonoshia & $\begin{array}{l}\text { Arbusto del bosque } \\
\text { denso húmedo de } \\
\text { tierra firme }\end{array}$ & & & $\begin{array}{l}299, \\
801,662\end{array}$ \\
\hline Jonoshia & $\begin{array}{l}\text { Arbusto del bosque } \\
\text { ribereño }\end{array}$ & $\begin{array}{l}\text { Piper } \\
\text { consanguineum }\end{array}$ & Piperaceae & 554 \\
\hline Xabachacatëtëmasbaspa & $\begin{array}{l}\text { Arbusto de la } \\
\text { sabana }\end{array}$ & & & 397 \\
\hline Xabachaxonihi & $\begin{array}{l}\text { Arbusto de la } \\
\text { sabana }\end{array}$ & Sapium sp. & Euphorbiaceae & 605 \\
\hline Xabajonotapo & $\begin{array}{l}\text { Arbusto de la } \\
\text { sabana }\end{array}$ & $\begin{array}{l}\text { Heteropterys } \\
\text { coriacea }\end{array}$ & Malphigiaceae & 429 \\
\hline Xabaomacamahinónihi & $\begin{array}{l}\text { Arbusto de la } \\
\text { sabana }\end{array}$ & Roupalea sp. & Proteaceae & 434 \\
\hline
\end{tabular}


Bergeron S., 1998. Uso de las plantas por los Chácobos (Alto Ivón, Beni, Bolivia)

Tabla 24 (continuación): Plantas que llevan suerte en la pesca y caza

\begin{tabular}{|c|c|c|c|c|}
\hline Nombre Chácobo & $\begin{array}{c}\text { Tipo biológico y de } \\
\text { ambiente }\end{array}$ & Genero y especie & Familia & $\begin{array}{c}\text { No de } \\
\text { colección }\end{array}$ \\
\hline Jonopaxpi & $\begin{array}{l}\text { Helecho del bosque } \\
\text { denso húmedo de } \\
\text { tierra firme }\end{array}$ & Campyloneurum sp. & Pterydophytae & 279,344 \\
\hline Jorojina & $\begin{array}{l}\text { Helecho del bosque } \\
\text { denso húmedo de } \\
\text { tierra firme }\end{array}$ & & & 340 \\
\hline Tëtëmabaspa & $\begin{array}{l}\text { Árbol del bosque } \\
\text { denso húmedo de } \\
\text { tierra firme }\end{array}$ & & Mimosaceae & 369 \\
\hline Xabachacatëtëmabaspa & $\begin{array}{l}\text { Arbusto de la } \\
\text { sabana }\end{array}$ & & & 397 \\
\hline Pachamahinonihi & $\begin{array}{l}\text { Bejuco del bosque } \\
\text { denso húmedo de } \\
\text { tierra firme }\end{array}$ & & & 312 \\
\hline
\end{tabular}

\section{Plantas comestibles}

Las plantas abarcadas en este estudio, se encontraron 41 diferentes especies comestibles. Aquellas plantas pueden ser árboles, palmas, arbustos o bejucos, y se encuentran en los diversos ambientes de Alto-Ivón (ver Tabla 25). Generalmente, son las frutas que se comen. Los Chácobos pueden comer las frutas en el lugar mismo, (al recorrer el bosque o los demás ambientes para sus actividades diarias), y en algunos casos llevan los excedentes a la casa. Por otro lado, en la época de fructificación y de abundancia de cierta especie, van a cosechar las frutas (palmas y árboles).

Se encontraron también otras 32 especies comestibles, pero por tener otros usos, se describen la categoría multi-uso.

Por otra parte, de las 360 especies botánicas recolectadas por Boom (1989: 83), incluyendo las plantas cultivadas, 102 de ellas eran comestibles.

Tabla 25: Plantas comestibles

\begin{tabular}{|l|l|l|l|c|}
\hline \multicolumn{1}{|c|}{ Nombre Chácobo } & $\begin{array}{l}\text { Tipo biológico y de } \\
\text { ambiente }\end{array}$ & Género y especie & \multicolumn{1}{|c|}{ Familia } & $\begin{array}{c}\text { No de } \\
\text { colección }\end{array}$ \\
\hline Ahuapixënanë & $\begin{array}{l}\text { Arbol de los } \\
\text { barbechos }\end{array}$ & Inga cf. fagifolia & Mimosaceae & 906 \\
\hline Bimimoishi & $\begin{array}{l}\text { Arbol del bosque } \\
\text { ribereño }\end{array}$ & $\begin{array}{l}\text { Micropholis } \\
\text { lanceolata }\end{array}$ & Sapotaceae & 738, \\
\hline Chana & Styrax sp. & Styracaceae & 809 \\
\hline Huaihuatixënane & $\begin{array}{l}\text { Arbusto de los } \\
\text { barbechos }\end{array}$ & $\begin{array}{l}\text { Hirtella racemosa } \\
\text { var. racemosa }\end{array}$ & Chrysobalanaceae & 685,541 \\
& $\begin{array}{l}\text { Arbol del bosque } \\
\text { denso húmedo de } \\
\text { tierra firme }\end{array}$ & Inga sp. & Mimosaceae & 308 \\
\hline
\end{tabular}

24 Todas las plantas comestibles consideradas en este estudio, son plantas silvestres, ya que no se han considerado las plantas cultivadas. 
Bergeron S., 1998. Uso de las plantas por los Chácobos (Alto Ivón, Beni, Bolivia)

Tabla 25 (continuación): Plantas comestibles

\begin{tabular}{|c|c|c|c|c|}
\hline Nombre Chácobo & $\begin{array}{c}\text { Tipo biológico y de } \\
\text { ambiente }\end{array}$ & $\begin{array}{l}\text { Género y } \\
\text { especie }\end{array}$ & Familia & $\begin{array}{c}\text { No de } \\
\text { colección }\end{array}$ \\
\hline Ishimoishinexoquérimati & $\begin{array}{l}\text { Arbol del bosque } \\
\text { ribereño }\end{array}$ & Salada sp. & Hippocrateaceae & 790 \\
\hline Jënëbatabi & $\begin{array}{l}\text { Arbol de bosque } \\
\text { ribereño }\end{array}$ & Pouteria sp. & Sapotaceae & 833,909 \\
\hline Jenërononopa & $\begin{array}{l}\text { Bejuco del bosque } \\
\text { ribereño }\end{array}$ & $\begin{array}{l}\text { Annona } \\
\text { hypoglauca }\end{array}$ & Annonaceae & 888 \\
\hline Jimixënanë & $\begin{array}{l}\text { Arbol del bosque } \\
\text { denso húmedo de } \\
\text { tierra firme }\end{array}$ & Inga sp. & Mimosaceae & 372 \\
\hline Motoha & Arbol de los barbechos & & Clusiaceae & 876,950 \\
\hline Nahuëshi & $\begin{array}{l}\text { Arbol del bosque } \\
\text { denso húmedo de } \\
\text { tierra firme }\end{array}$ & $\begin{array}{l}\text { Ocotea aff. } \\
\text { diospyrifolia }\end{array}$ & Lauraceae & 764 \\
\hline Nëxoquërimati & $\begin{array}{l}\text { Bejuco del Bosque } \\
\text { ribereño }\end{array}$ & Salada sp. & Hippocrateaceae & $\begin{array}{l}736,865 \\
885,1008 \\
\end{array}$ \\
\hline Nishiboconobimi & $\begin{array}{l}\text { Bejuco del bosque } \\
\text { denso húmedo de } \\
\text { tierra firme }\end{array}$ & $\begin{array}{l}\text { Rourea } \\
\text { camptoneura }\end{array}$ & Connaraceae & 494 \\
\hline Nishicoxi & $\begin{array}{l}\text { Bejuco del bosque } \\
\text { denso húmedo de } \\
\text { tierra firme }\end{array}$ & & & 415 \\
\hline Nishishoshapo & $\begin{array}{l}\text { Bejuco del bosque } \\
\text { denso húmedo de } \\
\text { tierra firme }\end{array}$ & & & 332,937 \\
\hline Omacabëro & $\begin{array}{l}\text { Arbol del bosque } \\
\text { denso húmedo de } \\
\text { tierra firme }\end{array}$ & & & 60,167 \\
\hline Quërimati & $\begin{array}{l}\text { Bejuco del bosque } \\
\text { ribereño }\end{array}$ & Tontalea sp. & Hippocrateaceae & 832 \\
\hline Rayoxënanë & Arbol de los barbechos & Inga sp. & Mimosaceae & 306 \\
\hline Rispixenané & Arbol de los barbechos & Inga sp. & Mimosaceae & $\begin{array}{l}659,1001, \\
311\end{array}$ \\
\hline Rohonosëbi & $\begin{array}{l}\text { Arbusto del bosque } \\
\text { denso húmedo de } \\
\text { tierra firme }\end{array}$ & $\begin{array}{l}\text { Cheiloclinium } \\
\text { cognatum }\end{array}$ & Hippocrateaceae & $\begin{array}{l}44,207 \\
252,345 \\
455,170\end{array}$ \\
\hline Rohoxënanë & Bosque ribereño & Inga sp. & Mimosaceae & $\begin{array}{l}894,914 \\
668\end{array}$ \\
\hline Shinixëjoxo & $\begin{array}{l}\text { Bosque denso húmedo } \\
\text { de tierra firme }\end{array}$ & & & 280,711 \\
\hline Xabacácama & Arbusto de la sabana & & & 78,597 \\
\hline Xabachacaahuaxtëpoco & Bejuco de la sabana & & Vochysiaceae & 558 \\
\hline Xabachacanëxoquërimati & Bejuco de la sabana & & Vochysiaceae & 398 \\
\hline Xabachacarohoxënanë & Arbusto de la sabana & Inga sp. & Mimosaceae & 583 \\
\hline Xabachacashoshapo & Arbusto de la sabana & $\begin{array}{l}\text { Byrsonima } \\
\text { crassifolia }\end{array}$ & Malphigiaceae & 571 \\
\hline Xabachacataporapi & Arbusto de la sabana & & & 405 \\
\hline
\end{tabular}


Bergeron S., 1998. Uso de las plantas por los Chácobos (Alto Ivón, Beni, Bolivia)

Tabla 25 (continuación): Plantas comestibles

\begin{tabular}{|c|c|c|c|c|}
\hline Nombre Chácobo & $\begin{array}{c}\text { Tipo biológico y de } \\
\text { ambiente }\end{array}$ & Género y especie & Familia & $\begin{array}{c}\text { No de } \\
\text { colección }\end{array}$ \\
\hline Xabachacatëtëchopishi & Arbusto de la sabana & Antonia ovala & Loganiaceae & 394,588 \\
\hline Xabachacayohisi & Arbol de la sabana & & & 404 \\
\hline Xabahuicama & Arbusto de la sabana & Bellucia acutata & Melastomataceae & $\begin{array}{l}402, \\
614 \text { bis }\end{array}$ \\
\hline Xabamotoha & Arbol de la sabana & $\begin{array}{l}\text { Hanchornia } \\
\text { speciosa }\end{array}$ & Apocynaceae & 77 \\
\hline Xabaomacabëro & Arbusto de la sabana & Eugenia sp. & Myrtaceae & 391,601 \\
\hline Xabashoshapo & Arbusto de la sabana & & & 390,423 \\
\hline Xabaxëchi & Arbusto de la sabana & $\begin{array}{l}\text { Byrsonima } \\
\text { chrysophylla }\end{array}$ & $\begin{array}{l}\text { Malphigiaceae } \\
\text { Vochysiaceae }\end{array}$ & 396,607 \\
\hline Xabayohisi & Arbol de la sabana & $\begin{array}{l}\text { Tabebuia } \\
\text { serratifolia }\end{array}$ & Bignoniaceae & 560 \\
\hline Xënanë & $\begin{array}{l}\text { Arbol del bosque } \\
\text { denso húmedo de } \\
\text { tierra firme }\end{array}$ & Inga sp. & Mimosaceae & 187 \\
\hline Xënanë & $\begin{array}{l}\text { Arbol del bosque } \\
\text { denso húmedo de } \\
\text { tierra firme }\end{array}$ & Inga cf. fagifolia & Mimosaceae & 766 \\
\hline Yahë & $\begin{array}{l}\text { Arbusto de los } \\
\text { barbechos }\end{array}$ & $\begin{array}{l}\text { Pouteria } \\
\text { macrophylla }\end{array}$ & Sapotaceae & 650,773 \\
\hline
\end{tabular}

\section{Plantas utilizadas en la construcción}

De las 472 plantas identificadas por los Chácobos, se han encontrado 22 plantas utilizadas únicamente para la construcción de las casas. La mayoría de esas plantas pertenecen al bosque de tierra firme, pocos árboles se encuentran en la sabana y menos en el bosque ribereño (ver Tabla 26).

Tabla 26: Plantas que sirven únicamente para la construcción

\begin{tabular}{|l|l|l|l|l|}
\hline \multicolumn{1}{|c|}{ Nombre Chácobo } & $\begin{array}{c}\text { Tipo biológico y de } \\
\text { ambiente }\end{array}$ & Género y especie & \multicolumn{1}{|c|}{ Familia } & $\begin{array}{c}\text { No de } \\
\text { colección }\end{array}$ \\
\hline Ahuabaca & $\begin{array}{l}\text { Arbol del bosque } \\
\text { denso húmedo de } \\
\text { tierra firme }\end{array}$ & $\begin{array}{l}\text { Guatteria } \text { aff. } \\
\text { schomburgkiana } \\
\text { Guatteria } \text { cf. } \\
\text { boliviana }\end{array}$ & Annonaceae & $\begin{array}{l}15,32,910 \\
301\end{array}$ \\
\hline Bisatamanë & $\begin{array}{l}\text { Arbol del bosque } \\
\text { denso húmedo de } \\
\text { tierra firme }\end{array}$ & & Vochysiaceae & 409 \\
\hline Bisatamanëjoni & $\begin{array}{l}\text { Arbol del bosque } \\
\text { denso húmedo de } \\
\text { tierra firme }\end{array}$ & Qualea paraensis & Vochysiaceae & $\begin{array}{l}181,213, \\
226,482, \\
527,531\end{array}$ \\
\hline Cashimëtsisi & $\begin{array}{l}\text { Bejuco del bosque } \\
\text { denso húmedo de } \\
\text { tierra firme }\end{array}$ & $\begin{array}{l}\text { Manaosella } \text { cf. } \\
\text { cordifolia }\end{array}$ & Bignoniaceae & 293 \\
\hline Jihuijoxo & $\begin{array}{l}\text { Arbol del bosque } \\
\text { denso húmedo de } \\
\text { tierra firme }\end{array}$ & & Papilionaceae & 524 \\
\hline
\end{tabular}


Bergeron S., 1998. Uso de las plantas por los Chácobos (Alto Ivón, Beni, Bolivia)

Tabla 26 (continuación): Plantas que sirven únicamente para la construcción

\begin{tabular}{|c|c|c|c|c|}
\hline Nombre Chácobo & $\begin{array}{c}\text { Tipo biológico y de } \\
\text { ambiente }\end{array}$ & Género y especie & Familia & $\begin{array}{c}\text { No de } \\
\text { colección }\end{array}$ \\
\hline Matsaquiti & $\begin{array}{l}\text { Arbol del bosque } \\
\text { denso húmedo de } \\
\text { tierra firme }\end{array}$ & Poeppigia procera & Caesalpiniaceae & 218 \\
\hline Mitisa & $\begin{array}{l}\text { Bejuco del bosque } \\
\text { denso húmedo de } \\
\text { tierra firme }\end{array}$ & & Bignoniaceae & 327 \\
\hline Shinoyáquixi & $\begin{array}{l}\text { Bejuco del bosque } \\
\text { denso húmedo de } \\
\text { tierra firme }\end{array}$ & Clytostoma sp. & Bignoniaceae & 283 \\
\hline Shishaxë & $\begin{array}{l}\text { Arbol del bosque } \\
\text { denso húmedo de } \\
\text { tierra firme }\end{array}$ & Licania sp. & Chrysobalanaceae & $\begin{array}{l}148,178, \\
516\end{array}$ \\
\hline Tëtëmëtsisi & $\begin{array}{l}\text { Arbol del bosque } \\
\text { denso húmedo de } \\
\text { tierra firme }\end{array}$ & Xilopia sp. & Annonaceae & 290 \\
\hline Xababisatamanë & Arbol de la sabana & & Vochysiaceae & 606 \\
\hline Xabachacajiminishi & Arbol de la sabana & & & 595 \\
\hline Xabachacamani & Arbol de la sabana & Maprounea sp. & Euphorbiaceae & 72 \\
\hline Xabatërë & Arbol de la sabana & & & 389 \\
\hline Xabaxahui & Arbol de la sabana & Xilopia aromatica & Annonaceae & 602 \\
\hline Xabayonishi & Arbol de la sabana & & & 71 \\
\hline Xahui & $\begin{array}{l}\text { Arbol del bosque } \\
\text { denso húmedo de } \\
\text { tierra firme }\end{array}$ & $\begin{array}{l}\text { Xilopia cf. peruana } \\
\text { Xilopia cf. cuspidata }\end{array}$ & Annonaceae & $\begin{array}{l}158,199 \\
443,729\end{array}$ \\
\hline Xahuipëixoco & $\begin{array}{l}\text { Arbol del bosque } \\
\text { ribereño }\end{array}$ & Xilopia cf. Peruana & Annonaceae & 898 \\
\hline Xahuiria & $\begin{array}{l}\text { Arbol del bosque } \\
\text { denso húmedo de } \\
\text { tierra firme }\end{array}$ & Xilopia polyantha & Anonaceae & 917 \\
\hline Xahuisi & $\begin{array}{l}\text { Arbol del bosque } \\
\text { ribereño }\end{array}$ & $\begin{array}{l}\text { aff. Bocageopsis } \\
\text { multíflora }\end{array}$ & Annonaceae & 866 \\
\hline Xahuisi & $\begin{array}{l}\text { Arbol del bosque } \\
\text { denso húmedo de } \\
\text { tierra firme }\end{array}$ & $\begin{array}{l}\text { No ident. } \\
\text { Duguetia cf. spixiana } \\
\text { Guatteria discolor } \\
\text { Gualterio boliviana }\end{array}$ & Annonaceae & $\begin{array}{l}\text { 486, 507, } \\
728, \\
929921\end{array}$ \\
\hline Yonishi & $\begin{array}{l}\text { Arbol del bosque } \\
\text { denso húmedo de } \\
\text { tierra firme }\end{array}$ & Gustavia hexapetala & Lecythidaceae & $\begin{array}{l}247,615 \\
877\end{array}$ \\
\hline
\end{tabular}


Normalemente, los postes y/o las vigas están hechos con madera durable y pesada utilizando las especies tales como Bisatamanëjoni, Bisatamanë, Xababisatamanë (Vochysiaceae), Jihuijoxo (Papilionaceae), Matsaquiti (Caesalpiniaceae), Yonishi (Lecythidaceae), que por lo general, son árboles de gran tamaño.

Los árboles más pequeños y más delgados tales como, el grupo de los Xahui y Tetëmëtsisi (Annonaceae), Shishaxe (Chrysobalanaceae), sirven para las tijeras.

Se utilizan los bejucos tales como Cashimetsisi, Mitisa, Shinoyáquixi (Bignoniaceae), y también la corteza interna de Ahuabaca o del grupo de árboles $\underline{X a-}$ hui (Annonaceae) para amarrar las vigas y tijeras.

Cabe mencionar que otras 11 plantas sirven para la construcción Por ejemplo, las palmas tales como Onipa (Socratea exhorriza), Xëbichoqui (Maximiliano maripa), son utilizadas también en la construcción y sirven para hacer las paredes (Onipa), o los techos (Xëbichoqui) de las casas. Esas plantas serán descritas más en detalle en la categoría multiuso.
Por otro lado, las hojas de la hierba Mani (Phenakospermum guianensis), no recolectada en este estudio, son muy frecuentemente utilizadas para techar las casas.

\section{Plantas que sirven para la leña y/o astillas}

Se encontraron 14 plantas que sirven solamente para la leña y/o astillas (ver Tabla 27), además de 11 plantas que tienen otros usos a parte de este último. La gran mayoría son árboles del bosque de tierra firme, algunos son de la sabana. Esas plantas son consideradas como buen combustible. Por otra parte, Boom (1989: 92) encontró 22 especies botánicas registradas con ese uso.

Salvo Bëpasti que sirve para la leña y para "astillas", las demás plantas tienen uno de esos dos usos. En efecto, las plantas que sirven para las astillas, además de ser un buen combustible deben tener la particularidad de liberar mucho humo para poder fumar la goma, lo que no ocurre siempre con las especies utilizadas para la leña.

Tabla 27: Plantas que sirven para la leña y/o astillas

\begin{tabular}{|l|l|l|l|l|l|}
\hline Nombre Chácobo & \multicolumn{1}{|c|}{$\begin{array}{c}\text { Uso } \\
\text { particular }\end{array}$} & $\begin{array}{l}\text { Tipo biológico y de } \\
\text { ambiente }\end{array}$ & Género y especie & Familia & $\begin{array}{c}\text { No de } \\
\text { colección }\end{array}$ \\
\hline Bëpasti & $\begin{array}{l}\text { Leña y } \\
\text { astillas }\end{array}$ & $\begin{array}{l}\text { Arbol del bosque } \\
\text { denso húmedo de } \\
\text { tierra firme }\end{array}$ & $\begin{array}{l}112,617, \\
239,649\end{array}$ \\
\hline Bishatë & Astillas & $\begin{array}{l}\text { Arbol del bosque } \\
\text { denso húmedo de } \\
\text { tierra firme }\end{array}$ & $\begin{array}{l}\text { Protium } \\
\text { subserratum }\end{array}$ & Burseraceae & 159,700 \\
\hline $\begin{array}{l}\text { Cocohuarahuara } \\
\text { o Nihicoca }\end{array}$ & Leña & $\begin{array}{l}\text { Arbol del bosque } \\
\text { denso húmedo de } \\
\text { tierra firme }\end{array}$ & $\begin{array}{l}\text { Erylhroxylum coca } \\
\text { cf. macrophyllum }\end{array}$ & Erythroxylaceae & 378,961, \\
\hline Chaxohuitaxojoni & Astillas & $\begin{array}{l}\text { Arbol del bosque } \\
\text { denso húmedo de } \\
\text { tierra firme }\end{array}$ & $\begin{array}{l}\text { Lindackeria } \\
\text { paludosa }\end{array}$ & Flacourtiaceae & 818 \\
\hline
\end{tabular}

${ }^{25}$ Fumar el caucho o la goma, se refiere al proceso de coagular la leche con el fin de transformarla en "bolachas", listas para vender. 
Tabla 27 (continuación): Plantas que sirven para la leña y/o astillas

\begin{tabular}{|c|c|c|c|c|c|}
\hline Nombre Chácobo & $\begin{array}{c}\text { Uso } \\
\text { particular }\end{array}$ & $\begin{array}{c}\text { Tipo biológico y de } \\
\text { ambiente }\end{array}$ & Género y especie & Familia & $\begin{array}{c}\text { No de } \\
\text { colección }\end{array}$ \\
\hline Mairao & Astillas & Bosque ribereño & Licania sp. & Chrysobalanaceae & $\begin{array}{l}537,719, \\
831\end{array}$ \\
\hline Paxaini & Astillas & $\begin{array}{l}\text { Arbol del bosque } \\
\text { denso húmedo de } \\
\text { tierra firme }\end{array}$ & $\begin{array}{l}\text { Metrodorea } \\
\text { flavida }\end{array}$ & Rutaceae & $\begin{array}{l}24,31,92, \\
145,211, \\
476,477, \\
479,485, \\
493,913\end{array}$ \\
\hline Quixpi & Astillas & $\begin{array}{l}\text { Arbol del bosque } \\
\text { denso húmedo de } \\
\text { tierra firme }\end{array}$ & $\begin{array}{l}\text { Turpinia } \\
\text { occidentalis }\end{array}$ & Flacourtiaceae & $\begin{array}{l}95,264, \\
903\end{array}$ \\
\hline Samomaquëti & Leña & $\begin{array}{l}\text { Arbol del bosque } \\
\text { denso húmedo de } \\
\text { tierra firme }\end{array}$ & Senna macrophylla & Caesalpiniaceae & $\begin{array}{l}500,926 \\
660,724 \\
816,899\end{array}$ \\
\hline Shiuë & Leña & $\begin{array}{l}\text { Arbusto del bosque } \\
\text { denso húmedo de } \\
\text { tierra firme }\end{array}$ & Rinoreocarpus ulei & Violaceae & $\begin{array}{l}25,29,88, \\
102,111, \\
456,465, \\
901,933\end{array}$ \\
\hline Xababishatë & Astillas & Arbol de la sabana & $\begin{array}{l}\text { Protium } \\
\text { subserratum }\end{array}$ & Burseraceae & 561 \\
\hline $\begin{array}{l}\text { Xabachacabëisiti- } \\
\text { corihua }\end{array}$ & Astillas & Arbol de la sabana & $\begin{array}{l}\text { Tetragastris o } \\
\text { Dacryodes sp. }\end{array}$ & Burseraceae & 587 \\
\hline Xabachacapaxaini & $\begin{array}{l}\text { Leña y } \\
\text { astillas }\end{array}$ & Arbol de la sabana & Myrcia sp. & Myrtaceae & 594 \\
\hline $\begin{array}{l}\text { Xabachaca- } \\
\text { samomaquëti }\end{array}$ & Leña & Arbol de la sabana & & & 584 \\
\hline
\end{tabular}

\section{Plantas medicinales}

De las 472 plantas consideradas por los Chácobos y recolectadas, las plantas que solamente tienen un uso medicinal fueron las que más se encontraron, alcanzando un número total de 133 . Existen otras 33 plantas medicinales, pero se encuentran en la categoría multi-uso. En su estudio etnobotánico, Boom (1989: 94) encontró 174 especies botánicas con uso medicinal.

Para una mayor comprensión del capítulo siguiente, hemos definido cuatro grupos de plantas según el tipo de uso medicinal, los dos primeros grupos siendo los que agrupan la mayoría de plantas.

Por otro lado, como también lo indicó Boom en su estudio etnobotánico (1989: 94), no se tiene en este estudio, información muy detallada sobre el modo de preparación y las cantidades necesarias para curar la enfermedad o aliviar el dolor. Más bien, se destacarán unas formas de preparación de las plantas, descritas juntamente con los cuatro grupos de plantas medicinales. 


\section{Primer grupo de plantas medicinales:}

De las plantas medicinales recolectadas, 31 pertenecen a este grupo. Sirven para combatir la disentería, diarrea, las cuales muchas veces pueden ser acompañadas de dolores de estómago, vómitos o estar relacionadas con la presencia de parásitos como amebas" ${ }^{\prime \prime}$. También están incluidas en este grupo, las plantas que sirven para luchar contra el paludismo, la fiebre, la misma puede acompañarse de dolor de cabeza.

La mayoría de esas plantas son árboles del bosque de tierra firme, pero también pueden encontrarse bejucos, arbustos y hierbas de los barbechos, bosque ribereño y sabana (ver Tabla 28).
Por lo general, para curar o aliviar los problemas de disentería, diarrea, dolores de estómago, las partes de las plantas utilizadas son mayormente la corteza o "cáscara" del árbol o del bejuco (Sitoiihui, Xabacorama, Xabatarari, Ahuaramacha, Yobini, Cascarayobini, Xabajihuimoca, Nishitsanona, Huápamo, Chachama entre otros árboles y bejucos. Asimismo, el modo de preparación constituye en una "decocción" de la planta: se raspa o se corta la corteza en pequeños trozos, la misma se hace hervir (o se "sancocha") en un poco de agua. Luego se deja enfriar la preparación (como té), y se toma media o una taza ("caneco"), una, dos o tres veces al día hasta parar los síntomas, (dependiendo sí la planta es muy fuerte o sí la enfermedad es muy grave).

Tabla 28: Primer grupo de plantas medicinales

\begin{tabular}{|l|l|l|l|l|c|}
\hline $\begin{array}{r}\text { Nombre } \\
\text { Chácobo }\end{array}$ & $\begin{array}{l}\text { Uso } \\
\text { particular }\end{array}$ & $\begin{array}{c}\text { Tipo biológico y } \\
\text { de ambiente }\end{array}$ & Genero y especie & Familia & $\begin{array}{r}\text { No de } \\
\text { colección }\end{array}$ \\
\hline Nishirajoxo & Diarrea & $\begin{array}{l}\text { Bejuco del } \\
\text { bosque denso } \\
\text { húmedo de tierra } \\
\text { firme }\end{array}$ & Arrabidea sp. & Bignoniaceae & $\begin{array}{c}\text { 267, } 307, \\
631\end{array}$ \\
\hline Sitojihui & Diarrea & $\begin{array}{l}\text { Arbol de los } \\
\text { barbechos }\end{array}$ & Bertiera guianensis & Rubiaceae & 754 \\
\hline Xabacorama & $\begin{array}{l}\text { Diarrea, } \\
\text { disentería, } \\
\text { fiebre }\end{array}$ & $\begin{array}{l}\text { Arbol de la } \\
\text { sabana }\end{array}$ & Hymenea courbaril & Caesalpiniaceae & 79 \\
\hline Xabatarari & $\begin{array}{l}\text { Diarrea, } \\
\text { dolor de } \\
\text { estómago }\end{array}$ & $\begin{array}{l}\text { Arbol de la } \\
\text { sabana }\end{array}$ & $\begin{array}{l}\text { Bowdichia } \\
\text { virgilioides }\end{array}$ & Papilionaceae & $\begin{array}{c}74,563, \\
953\end{array}$ \\
\hline Ahuaramacha & $\begin{array}{l}\text { Diarrea, } \\
\text { vómitos }\end{array}$ & $\begin{array}{l}\text { Arbusto de los } \\
\text { barbechos }\end{array}$ & Potalia amara & Loganiaceae & $\begin{array}{c}262,805 \\
\text { Yobini }\end{array}$ \\
$\begin{array}{l}\text { Diarrea, } \\
\text { vómitos }\end{array}$ & $\begin{array}{l}\text { Arbol del bosque } \\
\text { denso húmedo } \\
\text { de tierra firme }\end{array}$ & $\begin{array}{l}\text { No determinado } \\
\text { Neclandra cuspidala } \\
\text { Ocotea sp. }\end{array}$ & $\begin{array}{l}\text { No determinado } \\
\text { Lauraceae }\end{array}$ & $\begin{array}{c}217,916 \\
528, \\
\text { Lauraceae }\end{array}$ & 468 \\
\hline Xabajihuimoca & $\begin{array}{l}\text { Diarrea, } \\
\text { vómitos, } \\
\text { paludismo }\end{array}$ & $\begin{array}{l}\text { Arbol de la } \\
\text { sabana }\end{array}$ & Toulicia patentinervis & Sapindaceae & 611 \\
\hline Birabira & $\begin{array}{l}\text { Diarreas, } \\
\text { vómitos }\end{array}$ & $\begin{array}{l}\text { Hierba de los } \\
\text { barbechos }\end{array}$ & Lantana sp. & Verbenaceae & 870 \\
\hline
\end{tabular}


Bergeron S., 1998. Uso de las plantas por los Chácobos (Alto Ivón, Beni, Bolivia)

Tabla 28 (continuación): 1er grupo de plantas medicinales

\begin{tabular}{|c|c|c|c|c|c|}
\hline $\begin{array}{l}\text { Nombre } \\
\text { Chácobo }\end{array}$ & $\begin{array}{c}\text { Uso } \\
\text { particular }\end{array}$ & $\begin{array}{l}\text { Tipo biológico y } \\
\text { de ambiente }\end{array}$ & Género y especie & Familia & $\begin{array}{c}\text { No de } \\
\text { colección }\end{array}$ \\
\hline $\begin{array}{l}\text { Jihuimoca } \\
\text { arbusto }\end{array}$ & Disenteria & $\begin{array}{l}\text { Arbusto de los } \\
\text { barbechos }\end{array}$ & & & 852 \\
\hline Nihitarari & Disenteria & $\begin{array}{l}\text { Arbol del bosque } \\
\text { denso húmedo } \\
\text { de tierra firme }\end{array}$ & & Simaroubaceae & $\begin{array}{l}932,951, \\
956\end{array}$ \\
\hline Tusa & Disentería & $\begin{array}{l}\text { Arbusto de los } \\
\text { barbechos }\end{array}$ & Alíbertía edulis & Rubiaceae & 1,73 \\
\hline Xëtatënëti & Disentería & $\begin{array}{l}\text { Arbol del bosque } \\
\text { denso húmedo } \\
\text { de tierra firme }\end{array}$ & & Papilionaceae & 620,879 \\
\hline Corama & $\begin{array}{l}\text { Dolor de } \\
\text { estómago, } \\
\text { Diarrea }\end{array}$ & $\begin{array}{l}\text { Arbol de los } \\
\text { barbechos }\end{array}$ & Hymenea courbaril & Caesalpiniaceae & 379 \\
\hline Cascarayobini & $\begin{array}{l}\text { Dolor de } \\
\text { estómago, } \\
\text { Diarrea, } \\
\text { vómitos } \\
\end{array}$ & $\begin{array}{l}\text { Arbol del bosque } \\
\text { denso húmedo } \\
\text { de tierra firme }\end{array}$ & Ouratea macrobotrys & Ochnaceae & $\begin{array}{l}47,210 \\
227,351 \\
621\end{array}$ \\
\hline Nishitsanona & $\begin{array}{l}\text { Dolor de } \\
\text { estómago, } \\
\text { Diarrea, } \\
\text { vómitos }\end{array}$ & $\begin{array}{l}\text { Bejuco del } \\
\text { bosque denso } \\
\text { húmedo de tierra } \\
\text { firme }\end{array}$ & $\begin{array}{l}\text { Sparattanthelium } \\
\text { amazonum spp. } \\
\text { Amazonum }\end{array}$ & Hernandaceae & 365,819 \\
\hline Ponochi & $\begin{array}{l}\text { Dolor de } \\
\text { estómago, } \\
\text { Diarrea, } \\
\text { vómitos }\end{array}$ & $\begin{array}{l}\text { Bejuco del } \\
\text { bosque denso } \\
\text { húmedo de tierra } \\
\text { firme }\end{array}$ & $\begin{array}{l}\text { No determinado No } \\
\text { determinado }\end{array}$ & $\begin{array}{l}\text { No determinado } \\
\text { Malpighiaceae }\end{array}$ & $\begin{array}{l}7, \\
632\end{array}$ \\
\hline $\begin{array}{l}\text { Yobini- } \\
\text { bimixoco }\end{array}$ & $\begin{array}{l}\text { Dolor de } \\
\text { estómago, } \\
\text { Diarrea, } \\
\text { vómitos } \\
\end{array}$ & $\begin{array}{l}\text { Arbol del bosque } \\
\text { ribereño }\end{array}$ & Ocotea sp. & Lauraceae & 715 \\
\hline Jihuimoca & $\begin{array}{l}\text { Dolor de } \\
\text { estómago, } \\
\text { paludismo, } \\
\text { vómitos }\end{array}$ & $\begin{array}{l}\text { Arbol del bosque } \\
\text { denso húmedo } \\
\text { de tierra firme }\end{array}$ & $\begin{array}{l}\text { Coutarea hexandra } \\
\text { Geissospermum laeve }\end{array}$ & $\begin{array}{l}\text { Rubiaceae } \\
\text { Apocynaceae }\end{array}$ & $\begin{array}{l}33,188 \\
236,272 \\
519,703 \\
768,701\end{array}$ \\
\hline Sicomitsa & $\begin{array}{l}\text { Dolores de } \\
\text { estómago }\end{array}$ & $\begin{array}{l}\text { Arbol de los } \\
\text { barbechos }\end{array}$ & & & $337 \mathrm{bis}$ \\
\hline Nananihi & $\begin{array}{l}\text { Dolor de } \\
\text { cabeza, } \\
\text { cuerpo }\end{array}$ & $\begin{array}{l}\text { Bejuco de los } \\
\text { barbechos }\end{array}$ & $\begin{array}{l}\text { Pithecoctenium cf. } \\
\text { crucigerum }\end{array}$ & Bignoniaceae & 643 \\
\hline Pabo & $\begin{array}{l}\text { Dolor de } \\
\text { cabeza, } \\
\text { fiebre }\end{array}$ & $\begin{array}{l}\text { Arbol del bosque } \\
\text { denso húmedo } \\
\text { de tierra firme }\end{array}$ & $\begin{array}{l}\text { Hirtella sp. } \\
\text { Cordia ucayaliensis } \\
\text { Cordia sp. } \\
\text { Cordia sp. }\end{array}$ & $\begin{array}{l}\text { Chrysobalanaceae } \\
\text { Boraginaceae } \\
\text { Boraginaceae } \\
\text { Boraginaceae }\end{array}$ & $\begin{array}{l}163,179, \\
242,474, \\
490,918, \\
488\end{array}$ \\
\hline Paro & $\begin{array}{l}\text { Dolor de } \\
\text { cabeza, } \\
\text { fiebre }\end{array}$ & $\begin{array}{l}\text { Arbol del bosque } \\
\text { denso húmedo } \\
\text { de tierra firme }\end{array}$ & $\begin{array}{l}\text { Alchornea sp. } \\
\text { Cordia bicolor } \\
\text { Triunfetta altheoides }\end{array}$ & $\begin{array}{l}\text { Euphorbiaceae } \\
\text { Boraginaceae } \\
\text { Tiliaceae }\end{array}$ & $\begin{array}{l}743,193 \\
855845\end{array}$ \\
\hline
\end{tabular}


Bergeron S., 1998. Uso de las plantas por los Chácobos (Alto Ivón, Beni, Bolivia)

Tabla 28 (continuación): 1er grupo de plantas medicinales

\begin{tabular}{|l|l|l|l|l|l|}
\hline $\begin{array}{l}\text { Nombre } \\
\text { Chácobo }\end{array}$ & $\begin{array}{c}\text { Uso } \\
\text { particular }\end{array}$ & $\begin{array}{l}\text { Tipo biológico y } \\
\text { de ambiente }\end{array}$ & Género y especie & \multicolumn{1}{|c|}{ Familia } & \multicolumn{1}{c|}{$\begin{array}{c}\text { No de } \\
\text { colección }\end{array}$} \\
\hline Poatë & $\begin{array}{l}\text { Dolor de } \\
\text { cabeza, } \\
\text { fiebre }\end{array}$ & $\begin{array}{l}\text { Arbol de los } \\
\text { barbechos }\end{array}$ & $\begin{array}{l}\text { Turpinia } \\
\text { occidentalis }\end{array}$ & Staphylacaceae & 752 \\
\hline Mani & Fiebre & $\begin{array}{l}\text { Arbol del bosque } \\
\text { denso húmedo } \\
\text { de tierra firme }\end{array}$ & Apuleia leiocarpa & Caesalpiniaceae & $\begin{array}{l}54,233, \\
241,765, \\
807\end{array}$ \\
\hline Moxoquë & Fiebre & $\begin{array}{l}\text { Arbol del bosque } \\
\text { denso húmedo } \\
\text { de tierra firme }\end{array}$ & Apeiba tibourbou & Tiliaceae & 744,380 \\
\hline Moxoquëjoni & Fiebre & $\begin{array}{l}\text { Arbol del bosque } \\
\text { denso húmedo } \\
\text { de tierra firme }\end{array}$ & $\begin{array}{l}\text { Apeiba echinata } \\
\text { Luheopsis sp. }\end{array}$ & $\begin{array}{l}\text { Tiliaceae } \\
\text { Tiliaceae }\end{array}$ & $\begin{array}{l}116,419, \\
848\end{array}$ \\
\hline Nisho & Fiebre & $\begin{array}{l}\text { Arbol del bosque } \\
\text { denso húmedo } \\
\text { de tierra firme }\end{array}$ & $\begin{array}{l}\text { Tabebuia } \\
\text { serratifolia }\end{array}$ & Bignoniaceae & $39,89,216$, \\
\hline $\begin{array}{l}\text { Xabachaca- } \\
\text { nisho }\end{array}$ & Fiebre & $\begin{array}{l}\text { Arbol de la } \\
\text { sabana }\end{array}$ & Qualea sp. & Vochysiaceae & 570 \\
\hline $\begin{array}{l}\text { Xabachaca- } \\
\text { xaxëjina }\end{array}$ & Fiebre & $\begin{array}{l}\text { Hierba de la } \\
\text { sabana }\end{array}$ & Roupala montana & Proteaceae & 383 \\
\hline Chachama & $\begin{array}{l}\text { Fiebre, } \\
\text { paludismo }\end{array}$ & $\begin{array}{l}\text { Arbol del bosque } \\
\text { denso húmedo } \\
\text { de tierra firme }\end{array}$ & Aspidosperma sp. & Apocynaceae & 37,161 \\
\hline Huápamo & $\begin{array}{l}\text { Fiebre, } \\
\text { paludismo }\end{array}$ & $\begin{array}{l}\text { Arbol del bosque } \\
\text { ribereño }\end{array}$ & Maquiria coriacea & Moraceae & 691 \\
\hline
\end{tabular}

Por otra parte, ciertos bejucos como Ponochi, Nishirajoxo, tienen agua, por lo cual se toma directamente el líquido de la planta, en las mismas proporciones que precedentemente. Para algunas hierbas, tales como Birabira, arbustos (Jihuimoca, Tusa) o árboles (Sicomitsa), se utilizan las frutas (Birabira, $\underline{\text { Tusa) }}$ ), las raíces o las hojas ( $\underline{\text { ihuimoca) }}$, de las cuales se hace una decocción.

En los casos de fiebre, dolor de cabeza o de cuerpo, se puede utilizar la corteza del árbol en forma de decocción (Nisho, Mani), pero generalmente se utilizan las hojas del árbol o de la hierba (Moxoqué, Pabo, Paro, Moxoquéioni, Xabachacanisho, Xabachacaxaxéi ina). Asimismo, se hace remojar las hojas en agua tibia, y uno se baña en esta agua para hacer rebajar la fiebre.

\section{Segundo grupo de plantas medicinales}

Se reportaron 58 especies en este grupo. Se encuentran plantas que sirven para sanar heridas, picaduras de insectos como mosquitos, irritaciones de la piel provocadas por el calor, las cuales llegan a infectarse ${ }^{27}$, "empeine" (tipo de hongo), y también para cicatrizar las cortaduras. Otras especies sirven a calmar las inflamaciones y dolores provocadas por picaduras de insectos como abejas, "petos" (avispas), "buna" (hormigas grandes), "burro" (larva de insecto con 
abundantes pelos), "boros" (gusanos), mordeduras de víboras, o simplemente inflamaciones provocadas por golpes, lastimadas. Por último, ciertas especies mencionadas en este grupo, sirven para curar las ampollas de la boca, aliviar las quemaduras.
Esas plantas son por lo general, árboles y arbustos, rara vez, hierbas. Se encuentran tanto en el bosque de tierra firme, como en los barbechos y sabana, rara vez en el bosque ribereño (ver Tabla 29).

Tabla 29: Segundo grupo de plantas medicinales

\begin{tabular}{|c|c|c|c|c|c|}
\hline $\begin{array}{l}\text { Nombre } \\
\text { Chácobo }\end{array}$ & $\begin{array}{c}\text { Uso } \\
\text { particular }\end{array}$ & $\begin{array}{l}\text { Tipo biológico y } \\
\text { de ambiente }\end{array}$ & Género y especie & Familia & $\begin{array}{l}\text { No de } \\
\text { colección }\end{array}$ \\
\hline Cama & "Caracha" & $\begin{array}{l}\text { Arbol de los } \\
\text { barbechos }\end{array}$ & & & 759 \\
\hline Huarachësti & "Caracha" & $\begin{array}{l}\text { Arbol del bosque } \\
\text { ribereño }\end{array}$ & $\begin{array}{l}\text { Eugenia uniflora } \\
\text { No identificado }\end{array}$ & Myrtaceae & 573735 \\
\hline Huasicano & "Caracha" & $\begin{array}{l}\text { Arbol del bosque } \\
\text { denso húmedo } \\
\text { de tierra firme }\end{array}$ & $\begin{array}{l}\text { Sclerolobium } \\
\text { radlkoferi }\end{array}$ & Caesalpiniaceae & 374 \\
\hline Mërabi & "Caracha" & $\begin{array}{l}\text { Arbol de los } \\
\text { barbechos }\end{array}$ & Cassearia sp. & Flacourtiaceae & 741 \\
\hline Mëtëquë & "Caracha" & $\begin{array}{l}\text { Arbol de la } \\
\text { sabana }\end{array}$ & Qualea sp & Vochysiaceae & 76,789 \\
\hline Morochësti & "Caracha" & $\begin{array}{l}\text { Arbol de la } \\
\text { sabana }\end{array}$ & Hirtella pilosissima & Chrysobalanaceae & 399,836 \\
\hline Nihipëpëcho & "Caracha" & $\begin{array}{l}\text { Arbol del bosque } \\
\text { denso húmedo } \\
\text { de tierra firme }\end{array}$ & Qualea paraensis & Vochysiaceae & $\begin{array}{l}164,449, \\
944\end{array}$ \\
\hline Pacachësti & "Caracha" & $\begin{array}{l}\text { Arbol del bosque } \\
\text { denso húmedo } \\
\text { de tierra firme }\end{array}$ & $\begin{array}{l}\text { Licania } \\
\text { intrapetiolaris }\end{array}$ & Chrysobalanaceae & 175,862 \\
\hline Raramá & "Caracha" & $\begin{array}{l}\text { Arbusto de los } \\
\text { barbechos }\end{array}$ & Piper hispidum & Piperaceae & $\begin{array}{l}\text { 497, 669, } \\
746,748, \\
323\end{array}$ \\
\hline Rarasá & "Caracha" & $\begin{array}{l}\text { Arbusto del } \\
\text { bosque denso } \\
\text { húmedo de tierra } \\
\text { firme }\end{array}$ & $\begin{array}{l}\text { Piper } \\
\text { hostmannianum }\end{array}$ & Piperaceae & 747 \\
\hline Rarasajoni & "Caracha" & $\begin{array}{l}\text { Arbusto de los } \\
\text { barbechos }\end{array}$ & Piper aleyreanum & Piperaceae & 684,687 \\
\hline Shia & "Caracha" & $\begin{array}{l}\text { Arbol del bosque } \\
\text { denso húmedo } \\
\text { de tierra firme }\end{array}$ & $\begin{array}{l}\text { Mimosaceae } \\
\text { No identificado }\end{array}$ & Mimosaceae & 58,204 \\
\hline Sipamë & "Caracha" & $\begin{array}{l}\text { Arbol del bosque } \\
\text { ribereño }\end{array}$ & Hymenea sp. & Caesalpiniaceae & $\begin{array}{l}539,782 \\
825,1009\end{array}$ \\
\hline Xabahuarataro & "Caracha" & $\begin{array}{l}\text { Arbol de la } \\
\text { sabana }\end{array}$ & & & 384 \\
\hline Xabahuasicano & "Caracha" & $\begin{array}{l}\text { Arbol de la } \\
\text { sabana }\end{array}$ & $\begin{array}{l}\text { Sclerolobium } \\
\text { guianense }\end{array}$ & Caesalpiniaceae & 381,591 \\
\hline
\end{tabular}


Bergeron S., 1998. Uso de las plantas por los Chácobos (Alto Ivón, Beni, Bolivia)

Tabla 29 (continuación): Segundo grupo de plantas medicinales

\begin{tabular}{|c|c|c|c|c|c|}
\hline $\begin{array}{l}\text { Nombre } \\
\text { Chácobos }\end{array}$ & $\begin{array}{l}\text { Uso } \\
\text { particular }\end{array}$ & $\begin{array}{l}\text { Tipo biológico y } \\
\text { de ambiente }\end{array}$ & Género y especie & Familia & $\begin{array}{l}\text { No de } \\
\text { colección }\end{array}$ \\
\hline Xabayobini & "Caracha" & $\begin{array}{l}\text { Arbol de la } \\
\text { sabana }\end{array}$ & & Malpighiaceae & 433 \\
\hline Bimichëxëjoni & $\begin{array}{l}\text { Ampollas } \\
\text { de la boca }\end{array}$ & $\begin{array}{l}\text { Arbusto de los } \\
\text { barbechos }\end{array}$ & Miconia puncíata & Melastomataceae & 750 \\
\hline Mëquënobita & $\begin{array}{l}\text { Ampollas } \\
\text { de la boca }\end{array}$ & $\begin{array}{l}\text { Arbol del bosque } \\
\text { denso húmedo } \\
\text { de tierra firme }\end{array}$ & $\begin{array}{l}\text { Iryanthera laevis } \\
\text { Iryanthera } \\
\text { juruensis }\end{array}$ & Myristicaceae & $\begin{array}{l}27,72786, \\
96,221,451\end{array}$ \\
\hline Yorabita & $\begin{array}{l}\text { Ampollas } \\
\text { de la boca }\end{array}$ & $\begin{array}{l}\text { Arbol del bosque } \\
\text { denso húmedo } \\
\text { de tierra firme }\end{array}$ & $\begin{array}{l}\text { Iryanthera laevis } \\
\text { Iryanthera } \\
\text { juruensis }\end{array}$ & Myristicaceae & $\begin{array}{l}114,144, \\
223,26,86, \\
91,110,\end{array}$ \\
\hline Bachirao & $\begin{array}{l}\text { Ampollas } \\
\text { de la boca, } \\
\text { picadas de } \\
\text { "burro", } \\
\text { "buna". }\end{array}$ & $\begin{array}{l}\text { Arbol del bosque } \\
\text { denso húmedo } \\
\text { de tierra firme }\end{array}$ & $\begin{array}{l}\text { Brosimum } \\
\text { guianense }\end{array}$ & Moraceae & $\begin{array}{l}209,245 \\
553,407 \\
619,623 \\
839\end{array}$ \\
\hline Tahuatë & $\begin{array}{l}\text { Ampollas } \\
\text { de la boca, } \\
\text { picadas de } \\
\text { "burro", } \\
\text { "buna". }\end{array}$ & $\begin{array}{l}\text { Arbol del bosque } \\
\text { denso húmedo } \\
\text { de tierra firme }\end{array}$ & Virola flexuosa & Myristicaceae & $\begin{array}{l}48,83,132, \\
143,475\end{array}$ \\
\hline Tëco & $\begin{array}{l}\text { Ampollas } \\
\text { de la boca, } \\
\text { picadas de } \\
\text { "burro", } \\
\text { "buna". }\end{array}$ & $\begin{array}{l}\text { Arbol del bosque } \\
\text { denso húmedo } \\
\text { de tierra firme }\end{array}$ & $\begin{array}{l}\text { Perebea aff. } \\
\text { Acutifolium }\end{array}$ & Moraceae & $\begin{array}{l}16,53,106, \\
115,130, \\
155,156, \\
244,454, \\
459\end{array}$ \\
\hline Xanatëchëquë & $\begin{array}{l}\text { Ampollas } \\
\text { de la boca, } \\
\text { picadas de } \\
\text { "burro", } \\
\text { "buna". }\end{array}$ & $\begin{array}{l}\text { Arbol del bosque } \\
\text { denso húmedo } \\
\text { de tierra firme }\end{array}$ & $\begin{array}{l}\text { Brosimum } \\
\text { lactenses }\end{array}$ & Moraceae & $\begin{array}{l}234,235 \\
760\end{array}$ \\
\hline Canopëhihua & Cortaduras & Arbol & $\begin{array}{l}\text { Sclerolobium aff. } \\
\text { Chrysophyllum }\end{array}$ & Caesalpiniaceae & $\begin{array}{l}446,460, \\
502,\end{array}$ \\
\hline Canopëixoco & Cortaduras & $\begin{array}{l}\text { Arbol del bosque } \\
\text { denso húmedo } \\
\text { de tierra firme }\end{array}$ & $\begin{array}{l}\text { Sclerolobium aff. } \\
\text { Rugosum }\end{array}$ & Caesalpiniaceae & $\begin{array}{l}49,157 \\
224,445 \\
471,508, \\
472 \text { bis }\end{array}$ \\
\hline $\begin{array}{l}\text { Xabajihui- } \\
\text { rashia }\end{array}$ & Cortaduras & $\begin{array}{l}\text { Arbol de la } \\
\text { sabana }\end{array}$ & & & 436,777 \\
\hline $\begin{array}{l}\text { Xabachaca- } \\
\text { huarachësti }\end{array}$ & $\begin{array}{l}\text { Cortaduras, } \\
\text { "Caracha" }\end{array}$ & $\begin{array}{l}\text { Arbol de la } \\
\text { sabana }\end{array}$ & Simaba sp. & Simaroubaceae & 392 \\
\hline $\begin{array}{l}\text { Xabahuara- } \\
\text { chësti }\end{array}$ & $\begin{array}{l}\text { Cortaduras, } \\
\text { Caracha }\end{array}$ & $\begin{array}{l}\text { Arbol de la } \\
\text { sabana }\end{array}$ & & & 779 \\
\hline Xabashia & $\begin{array}{l}\text { Cortaduras, } \\
\text { "Caracha" }\end{array}$ & $\begin{array}{l}\text { Arbol de la } \\
\text { sabana }\end{array}$ & & & 781 \\
\hline Maxëjoni & $\begin{array}{l}\text { Cortaduras, } \\
\text { "Caracha" }\end{array}$ & $\begin{array}{l}\text { Arbol de los } \\
\text { barbechos }\end{array}$ & $\begin{array}{l}\text { Aparisthmium } \\
\text { cordatum }\end{array}$ & Euphorbiaceae & $\begin{array}{l}742,499, \\
702\end{array}$ \\
\hline
\end{tabular}


Tabla 29 (continuación): Segundo grupo de plantas medicinales

\begin{tabular}{|c|c|c|c|c|c|}
\hline $\begin{array}{l}\text { Nombre } \\
\text { Chácobo }\end{array}$ & $\begin{array}{c}\text { Uso } \\
\text { particular }\end{array}$ & $\begin{array}{l}\text { Tipo biológico y } \\
\text { de ambiente }\end{array}$ & Género y especie & Familia & $\begin{array}{l}\text { No de } \\
\text { colección }\end{array}$ \\
\hline Maxëisnepa & "Empeine" & $\begin{array}{l}\text { Bejuco del } \\
\text { bosque denso } \\
\text { húmedo de tierra } \\
\text { firme }\end{array}$ & $\begin{array}{l}\text { No identificado } \\
\text { Acacia sp. }\end{array}$ & $\begin{array}{l}\text { Mimosaceae } \\
\text { Mimosaceae }\end{array}$ & $\begin{array}{l}313,857, \\
552\end{array}$ \\
\hline Nahinishi & "Empeine" & $\begin{array}{l}\text { Bejuco de los } \\
\text { barbechos }\end{array}$ & Gurania sp. & Cucurbitaceae & 654 \\
\hline Isistaho & "Empeine" & $\begin{array}{l}\text { Bejuco del } \\
\text { bosque denso } \\
\text { húmedo de tierra } \\
\text { firme }\end{array}$ & Celtis & Ulmaceae & 366 \\
\hline Isnëpa & "Empeine" & $\begin{array}{l}\text { Bejuco del } \\
\text { bosque denso } \\
\text { húmedo de tierra } \\
\text { firme }\end{array}$ & & Mimosaceae & 358 \\
\hline Xoa & $\begin{array}{l}\text { "Empeine" } \\
\text {, Gusanos } \\
\text { de la piel } \\
\text { ("borro") }\end{array}$ & $\begin{array}{l}\text { Arbol del bosque } \\
\text { denso húmedo } \\
\text { de tierra firme }\end{array}$ & Ficus cf. maxima & Moraceae & 52,1002 \\
\hline Jenëpiri & $\begin{array}{l}\text { Gusanos } \\
\text { de la piel } \\
\text { ("borro") }\end{array}$ & $\begin{array}{l}\text { Arbol del bosque } \\
\text { ribereño }\end{array}$ & Quiina florida & Quiinaceae & 714 \\
\hline Jihuipama & $\begin{array}{l}\text { Gusanos } \\
\text { de la piel } \\
\text { ("borro") }\end{array}$ & $\begin{array}{l}\text { Arbol del bosque } \\
\text { ribereño }\end{array}$ & $\begin{array}{l}\text { Pseudolmedia } \\
\text { laevigata }\end{array}$ & Moraceae & $\begin{array}{l}867 \\
1006\end{array}$ \\
\hline Piri & $\begin{array}{l}\text { Gusanos } \\
\text { de la piel } \\
\text { ("borro") }\end{array}$ & $\begin{array}{l}\text { Arbol de los } \\
\text { barbechos }\end{array}$ & $\begin{array}{l}\text { Mabeafistulifera } \\
\text { ssp. robusta }\end{array}$ & Euphorbiaceae & 642 \\
\hline Saramataca & $\begin{array}{l}\text { Gusanos } \\
\text { de la piel } \\
\text { ("borro") }\end{array}$ & $\begin{array}{l}\text { Hierba de los } \\
\text { barbechos }\end{array}$ & & & 648 \\
\hline Xanajoxo & $\begin{array}{l}\text { Gusanos } \\
\text { de la piel } \\
\text { ("borro") }\end{array}$ & $\begin{array}{l}\text { Arbol del bosque } \\
\text { denso húmedo } \\
\text { de tierra firme }\end{array}$ & $\begin{array}{l}\text { Brosimum cf. } \\
\text { lactescens Sorocea } \\
\text { muriculata }\end{array}$ & Moraceae & $\begin{array}{l}94, \\
270,762, \\
699\end{array}$ \\
\hline Bahuaquëxti & $\begin{array}{l}\text { Heridas } \\
\text { del perro }\end{array}$ & $\begin{array}{l}\text { Arbol del bosque } \\
\text { denso húmedo } \\
\text { de tierra firme }\end{array}$ & $\begin{array}{l}\text { Tabernaemontana } \\
\text { sp. }\end{array}$ & Apocynaceae & $\begin{array}{l}185,945 \\
803,813\end{array}$ \\
\hline Boa & Hinchazón & $\begin{array}{l}\text { Bejuco de los } \\
\text { barbechos }\end{array}$ & $\begin{array}{l}\text { Mussatia } \\
\text { hyacinthina }\end{array}$ & Bignoniaceae & 726 \\
\hline Jihuicharishi & Hinchazón & $\begin{array}{l}\text { Arbo del bosque } \\
\text { denso húmedo } \\
\text { de tierra firme }\end{array}$ & $\begin{array}{l}\text { Toulicia } \\
\text { patentinervis }\end{array}$ & Sapindaceae & $\begin{array}{l}11,40, \\
90,137 \\
138,160 \\
737\end{array}$ \\
\hline Shibiri & $\begin{array}{l}\text { Picada de } \\
\text { víbora }\end{array}$ & $\begin{array}{l}\text { Hierba de los } \\
\text { barbechos }\end{array}$ & Zingiber officinale & Zingiberaceae & 838,874 \\
\hline Xahuëmëtëquë & $\begin{array}{l}\text { Picada de } \\
\text { víbora }\end{array}$ & $\begin{array}{l}\text { Hierba de la } \\
\text { sabana }\end{array}$ & Zania boliviensis & Cycadaceae & 75,608 \\
\hline Batahua & $\begin{array}{l}\text { Picada de } \\
\text { víbora, } \\
\text { "buna", } \\
\text { "burro" }\end{array}$ & $\begin{array}{l}\text { Arbol del bosque } \\
\text { denso húmedo } \\
\text { de tierra firme }\end{array}$ & $\begin{array}{l}\text { Capirona } \\
\text { decorticans }\end{array}$ & Rubiaceae & 171,4 \\
\hline
\end{tabular}


Bergeron S., 1998. Uso de las plantas por los Chácobos (Alto Ivón, Beni, Bolivia)

Tabla 29 (continuación): Segundo grupo de plantas medicinales

\begin{tabular}{|c|c|c|c|c|c|}
\hline $\begin{array}{l}\text { Nombre } \\
\text { Chácobo }\end{array}$ & Uso particular & $\begin{array}{l}\text { Tipo biológico y } \\
\text { de ambiente }\end{array}$ & Género y especie & Familia & $\begin{array}{l}\text { No de } \\
\text { colección }\end{array}$ \\
\hline Carihua & $\begin{array}{l}\text { Picada de } \\
\text { víbora, } \\
\text { "buna", } \\
\text { "burro" }\end{array}$ & $\begin{array}{l}\text { Hierba del } \\
\text { bosque denso } \\
\text { húmedo de tierra } \\
\text { firme }\end{array}$ & & Malvaceae & 328 \\
\hline Ronpjihui & $\begin{array}{l}\text { Picada de } \\
\text { víbora, } \\
\text { "buna", } \\
\text { "burro" }\end{array}$ & $\begin{array}{l}\text { Arbusto del } \\
\text { bosque denso } \\
\text { húmedo de tierra } \\
\text { firme }\end{array}$ & & & 347 \\
\hline Xabapiri & $\begin{array}{l}\text { Picada de } \\
\text { víbora, } \\
\text { "buna", } \\
\text { "burro" }\end{array}$ & $\begin{array}{l}\text { Arbol de la } \\
\text { sabana }\end{array}$ & $\begin{array}{l}\text { Mabea fistulifera } \\
\text { spp. robusta }\end{array}$ & Euphorbiaceae & 596,955 \\
\hline Xëtohitsa & $\begin{array}{l}\text { Picadas de } \\
\text { "burro", } \\
\text { "buna" }\end{array}$ & $\begin{array}{l}\text { Arbol del bosque } \\
\text { denso húmedo } \\
\text { de tierra firme }\end{array}$ & $\begin{array}{l}\text { Trattinnickia } \\
\text { rhoifolia }\end{array}$ & Burseraceae & 10,151 \\
\hline Jihuimoishi & $\begin{array}{l}\text { Picadas de } \\
\text { "burro", } \\
\text { "buna" }\end{array}$ & $\begin{array}{l}\text { Arbol del bosque } \\
\text { denso húmedo } \\
\text { de tierra firme }\end{array}$ & Guatteria sp & Annonaceae & 421 \\
\hline Piochao & $\begin{array}{l}\text { Picadas de } \\
\text { "burro", } \\
\text { "buna" }\end{array}$ & $\begin{array}{l}\text { Arbol del bosque } \\
\text { denso húmedo } \\
\text { de tierra firme }\end{array}$ & Clarisia racemosa & Moraceae & 406,842 \\
\hline Shiquishi & $\begin{array}{l}\text { Picadas de } \\
\text { "burro", } \\
\text { "buna" }\end{array}$ & $\begin{array}{l}\text { Arbol del bosque } \\
\text { denso húmedo } \\
\text { de tierra firme }\end{array}$ & $\begin{array}{l}\text { Rheedia cf. } \\
\text { macrophylla }\end{array}$ & Clusiaceae & $\begin{array}{l}350,550, \\
671\end{array}$ \\
\hline Toxa & $\begin{array}{l}\text { Picadas de } \\
\text { "burro", } \\
\text { "buna" }\end{array}$ & $\begin{array}{l}\text { Arbol del bosque } \\
\text { denso húmedo } \\
\text { de tierra firme }\end{array}$ & $\begin{array}{l}\text { Crepidospermum } \\
\text { goudotianum }\end{array}$ & Burseraceae & 50,851 \\
\hline $\begin{array}{l}\text { Xabachaca- } \\
\text { shishohitsa }\end{array}$ & $\begin{array}{l}\text { Picadas de } \\
\text { "burro", } \\
\text { "buna" }\end{array}$ & $\begin{array}{l}\text { Arbusto de la } \\
\text { sabana }\end{array}$ & $\begin{array}{l}\text { Siparuna } \\
\text { guianensis }\end{array}$ & Monimiaceae & 578 \\
\hline Xabashishoitsa & $\begin{array}{l}\text { Picaduras de } \\
\text { "burro", } \\
\text { "buna" }\end{array}$ & $\begin{array}{l}\text { Arbusto de la } \\
\text { sabana }\end{array}$ & Palicourea rígida & Rubiaceae & 957 \\
\hline Capanahahuati & Quemaduras & $\begin{array}{l}\text { Arbol del bosque } \\
\text { denso húmedo } \\
\text { de tierra firme }\end{array}$ & $\begin{array}{l}\text { Pterocarpus aff. } \\
\text { amazonum }\end{array}$ & Papilionaceae & 152,939 \\
\hline
\end{tabular}

El modo de preparación de estas plantas medicinales depende de la enfermedad.

- Generalmente, para los problemas de "caracha", cortaduras, se utiliza muy frecuentemente la corteza del árbol (Nihipëpëcho, Xabayobini, Cama, Morochësti, Pacachësti, Shia, Xabashia, Xabajihuirashia, Si parnë, Xabahuasicano, Xabahuarachësti entre otros). Asimismo, se pone la corteza sobre el fuego y luego, las cenizas son aplicadas sobre la piel. En el caso de Mëtëquë y Bahuaquëxti, Mërabi, se utiliza también la raíz machacada, y el líquido obtenido se aplica directamente sobre la piel. Lo mismo ocurre con Huarachësti, y Maxëjoni cuya corteza se exprime para aplicar el líquido sobre la herida. También, para algunas plantas tales como Rarasá, Raramá, Rarasajoni (arbustos y hierbas), se mascan algunas hojas, y se aplica la saliva sobre la piel. 
- En los casos de "empeine", generalmente se calienta al fuego el bejuco (Maxnëisnëpa, Isistaho, Nahinishi), esperando que salga una espuma, la cual se aplica sobre el "empeine".

- Para las ampollas de la boca, las picadas de insectos y gusanos, se utiliza la resina del árbol, del arbusto o hierba (Mëquënobita, Yorabita, Tahuatë, Bachirao, Teco, Xanatëchëquë, Toxa, Jënëpiri, Jihuipama, PiriXanajoxo, Saramataca, entre otras plantas), la cual se aplica directamente en la boca o sobre la picada. En los casos de Shishohitsa y Xabashishohitsa, las hojas son estrujadas y aplicadas sobre la picada.

- En los casos de mordeduras de víbora, quemaduras u otros tipos de inflamaciones de la piel ("hinchazones"), se raspa por lo general la corteza interna del árbol (Jihuicharishi, Batahua) sobre un trapo, el cual se pone como cataplasma sobre la inflamación. En el caso de Shibiri y Xahuëmëtëquë, el modo de preparación es el mismo, pero se utiliza la raíz. En el caso de Boa, son las hojas que se utilizan.

\section{Tercer grupo de plantas medicinales}

Se encuentran en forma menor (27 plantas), plantas para apendicitis, insomnios de los niños, problemas renales, sarampión, viruela, gripe y resfrío, dolores de oído o muelas, infecciones de ojos. También están consideradas en este grupo plantas utilizadas para hacer caminar a los bebés cuando no quieren pararse $\mathrm{e}^{28}$, o para dar fuerza cuando uno es débil.

Esas especies se encuentran por lo general en el bosque de tierra firme y barbechos, menos a menudo en la sabana y bosque ribereño. Pueden ser arboles, arbustos, helechos y hierbas (ver Tabla 30).

Tabla 30: Tercer grupo de plantas medicinales

\begin{tabular}{|l|l|l|l|l|l|}
\hline $\begin{array}{c}\text { Nombre } \\
\text { Chácobo }\end{array}$ & $\begin{array}{c}\text { Uso } \\
\text { particular }\end{array}$ & $\begin{array}{l}\text { Tipo biológico y } \\
\text { de ambiente }\end{array}$ & Género y especie & Familia & $\begin{array}{c}\text { No de } \\
\text { colección }\end{array}$ \\
\hline Nishibëpiya & Apendicitis & $\begin{array}{l}\text { Bejuco del } \\
\text { bosque denso } \\
\text { húmedo de tierra } \\
\text { firme }\end{array}$ & & & 355,551 \\
\hline Tiorahuitaxo & Apendicitis & $\begin{array}{l}\text { Helecho del } \\
\text { bosque denso } \\
\text { húmedo de tierra } \\
\text { firme }\end{array}$ & & Perridophytae & 371,637 \\
\hline Ascana & Dar fuerza & $\begin{array}{l}\text { Bejuco del } \\
\text { bosque denso } \\
\text { húmedo de tierra } \\
\text { firme }\end{array}$ & $\begin{array}{l}\text { Mascagnia cf. } \\
\text { macrophylla }\end{array}$ & Malphigiaceae & 258,940 \\
\hline Quëototi & $\begin{array}{l}\text { Dolor de } \\
\text { muela }\end{array}$ & $\begin{array}{l}\text { Arbol de los } \\
\text { barbechos }\end{array}$ & & & \\
\hline Nibosa & $\begin{array}{l}\text { Dolor de } \\
\text { muela }\end{array}$ & $\begin{array}{l}\text { Arbusto de los } \\
\text { barbechos }\end{array}$ & Piper darienense & Piperaceae & 277,667, \\
\hline
\end{tabular}


Bergeron S., 1998. Uso de las plantas por los Chácobos (Alto Ivón, Beni, Bolivia)

Tabla 30 (continuación): Tercer grupo de plantas medicinales

\begin{tabular}{|c|c|c|c|c|c|}
\hline $\begin{array}{l}\text { Nombre } \\
\text { Chácobo }\end{array}$ & $\begin{array}{c}\text { Uso } \\
\text { particular }\end{array}$ & $\begin{array}{l}\text { Tipo biológico y } \\
\text { de ambiente }\end{array}$ & Género y especie & Familia & $\begin{array}{c}\text { No de } \\
\text { colección }\end{array}$ \\
\hline Nibosajoni & $\begin{array}{l}\text { Dolor de } \\
\text { muela }\end{array}$ & $\begin{array}{l}\text { Arbusto del } \\
\text { bosque denso } \\
\text { húmedo de tierra } \\
\text { firme }\end{array}$ & Piper divaricatum & Piperaceae & 295 \\
\hline Huáquibi & $\begin{array}{l}\text { Dolor de } \\
\text { oidos }\end{array}$ & $\begin{array}{l}\text { Arbol del bosque } \\
\text { denso húmedo } \\
\text { de tierra firme }\end{array}$ & Jacaratia digitata & Caricaceae & 140,43 \\
\hline Nahuabëxë & $\begin{array}{l}\text { Dolor de } \\
\text { oidos }\end{array}$ & $\begin{array}{l}\text { Arbol del bosque } \\
\text { denso húmedo } \\
\text { de tierra firme }\end{array}$ & $\begin{array}{l}\text { Didymopanax } \\
\text { morototoni }\end{array}$ & Araliaceae & 105,658 \\
\hline $\begin{array}{l}\text { Xabachaca- } \\
\text { nahuabëxë }\end{array}$ & $\begin{array}{l}\text { Dolor de } \\
\text { oidos }\end{array}$ & $\begin{array}{l}\text { Arbol de la } \\
\text { sabana }\end{array}$ & $\begin{array}{l}\text { Didymopanax } \\
\text { morototoni }\end{array}$ & Araliaceae & 585,954 \\
\hline Pëxcanishi & $\begin{array}{l}\text { Dolor de } \\
\text { ojos }\end{array}$ & $\begin{array}{l}\text { Bejuco del } \\
\text { bosque denso } \\
\text { húmedo de tierra } \\
\text { firme }\end{array}$ & $\begin{array}{l}\text { Pourouma cf. } \\
\text { minor }\end{array}$ & Moraceae & 333,647 \\
\hline Bëromo & $\begin{array}{l}\text { Dolor de } \\
\text { ojos }\end{array}$ & $\begin{array}{l}\text { Arbusto del } \\
\text { bosque ribereño }\end{array}$ & $\begin{array}{l}\text { Cymbopetalum } \\
\text { brasiliense }\end{array}$ & Annonaceae & 555 \\
\hline Poicorëbixpi & $\begin{array}{l}\text { Dolor de } \\
\text { ojos }\end{array}$ & $\begin{array}{l}\text { Arbol del bosque } \\
\text { denso húmedo } \\
\text { de tierra firme }\end{array}$ & $\begin{array}{l}\text { Aspidosperma } \\
\text { macrocarpon }\end{array}$ & Apocynaceae & 861 \\
\hline $\begin{array}{l}\text { Tiorahuitaxo } \\
\text { (otro) }\end{array}$ & $\begin{array}{l}\text { Dolor de } \\
\text { ojos }\end{array}$ & $\begin{array}{l}\text { Hierba de los } \\
\text { barbechos }\end{array}$ & $\begin{array}{l}\text { Phlebodium } \\
\text { decumanum }\end{array}$ & Araceae & 637 \\
\hline Yoquiria & $\begin{array}{l}\text { Dolor de } \\
\text { ojos }\end{array}$ & $\begin{array}{l}\text { Arbusto del } \\
\text { bosque denso } \\
\text { húmedo de tierra } \\
\text { firme }\end{array}$ & & & 297 \\
\hline Bahuarëxa & $\begin{array}{l}\text { Gripe, } \\
\text { resfríos }\end{array}$ & $\begin{array}{l}\text { Hierba del } \\
\text { bosque denso } \\
\text { húmedo de tierra } \\
\text { firme }\end{array}$ & & Verbenaceae & 341 \\
\hline Shishohitsa & $\begin{array}{l}\text { Gripe, } \\
\text { resfríos }\end{array}$ & $\begin{array}{l}\text { Arbusto del } \\
\text { bosque denso } \\
\text { húmedo de tierra } \\
\text { firme }\end{array}$ & $\begin{array}{l}\text { Siparuna } \\
\text { guianensis }\end{array}$ & & $\begin{array}{l}375,495, \\
697,749, \\
652\end{array}$ \\
\hline $\begin{array}{l}\text { Xaba- } \\
\text { bahuarëxa }\end{array}$ & $\begin{array}{l}\text { Gripe, } \\
\text { resfríos }\end{array}$ & $\begin{array}{l}\text { Arbusto de la } \\
\text { sabana }\end{array}$ & & Rubiaceae & 599 \\
\hline Boshishi & $\begin{array}{l}\text { Infección } \\
\text { urinaria }\end{array}$ & $\begin{array}{l}\text { Hierba de los } \\
\text { barbechos }\end{array}$ & $\begin{array}{l}\text { Cosius sp. } \\
\text { Costus cf. arabicus }\end{array}$ & $\begin{array}{l}\text { Zingiberaceae } \\
\text { Zingiberaceae }\end{array}$ & $\begin{array}{l}316,663, \\
796,698 \\
817,\end{array}$ \\
\hline Batajihui & $\begin{array}{l}\text { Insomnías } \\
\text { (niños) }\end{array}$ & $\begin{array}{l}\text { Arbol del bosque } \\
\text { denso húmedo } \\
\text { de tierra firme }\end{array}$ & & Simaroubaceae? & $\begin{array}{l}42,194 \\
444\end{array}$ \\
\hline Nihitichaca & $\begin{array}{l}\text { Ayuda a } \\
\text { los ninos a } \\
\text { pararse }\end{array}$ & $\begin{array}{l}\text { Hierba de los } \\
\text { barbechos }\end{array}$ & $\begin{array}{l}\text { Monstera oblique } \\
\text { Dichorisandra sp. }\end{array}$ & $\begin{array}{l}\text { Araceae } \\
\text { Commelinaceae }\end{array}$ & 670,815 \\
\hline Pora & Sabayón & $\begin{array}{l}\text { Arbol de los } \\
\text { barbechos }\end{array}$ & & Bombacaceae & 758 \\
\hline
\end{tabular}


Bergeron S., 1998. Uso de las plantas por los Chácobos (Alto Ivón, Beni, Bolivia)

Tabla 30 (continuación): Tercer grupo de plantas medicinales

\begin{tabular}{|l|l|l|l|l|l|}
\hline \multicolumn{1}{|c|}{$\begin{array}{c}\text { Nombre } \\
\text { Chácobo }\end{array}$} & \multicolumn{1}{|c|}{$\begin{array}{c}\text { Uso } \\
\text { particular }\end{array}$} & $\begin{array}{l}\text { Tipo biológico y } \\
\text { de ambiente }\end{array}$ & Género y especie & \multicolumn{1}{|c|}{ Familia } & \multicolumn{1}{c|}{$\begin{array}{c}\text { No de } \\
\text { colección }\end{array}$} \\
\hline Mitaisi & Sarampión & $\begin{array}{l}\text { Helecho del } \\
\text { bosque denso } \\
\text { húmedo de tierra } \\
\text { firme }\end{array}$ & $\begin{array}{l}\text { No determinado } \\
\text { Adiantum } \\
\text { tetraphyüum }\end{array}$ & $\begin{array}{l}\text { Pteridophyte } \\
\text { Pteridophyte }\end{array}$ & $\begin{array}{l}294,804, \\
644\end{array}$ \\
\hline Jënëocotsëmo & Tos & $\begin{array}{l}\text { Arbol del bosque } \\
\text { ribereño }\end{array}$ & Quiina florida & Quiinaceae & 826 \\
\hline Ocotsémo & Tos & $\begin{array}{l}\text { Arbol del bosque } \\
\text { denso húmedo } \\
\text { de tierra firme }\end{array}$ & Miconia sp. & $\begin{array}{l}\text { Myrtaceae } \\
\text { Melastomataceae }\end{array}$ & $\begin{array}{l}911,925, \\
376\end{array}$ \\
\hline Xëquihahëhua & Viruela & $\begin{array}{l}\text { Arbusto de los } \\
\text { barbechos }\end{array}$ & Piper callosum & Piperaceae & 638 \\
\hline
\end{tabular}

El modo de preparación varía según la enfermedad.

- En forma de cataplasmas para la apendicitis: se utiliza la parte interna de la corteza (Tiorahuitaxo) o la leche del bejuco (Nishibëpiya).

- Resina de la planta: en el caso de dolor de oído o de ojos, se exprime la corteza interna del árbol o arbusto (Huáguibi, Nahuabëxë, Xabanahuabëxë, Poicorëbixpi, Beromo, Yoquiria), del bejuco (Pëxcanishi), o de la hierba (Tiorahuitaxo), y se aplica el líquido obtenido en forma de gotas en el oído o en el ojo. Para los dolores de muelas, una pequeña parte de la raíz (Nibosa, Nibosajoni), se mastica. Para curar el sabayón, el modo de preparación es el mismo que para el "Empeine".

- Baños: en casos de insomnios, sarampión o cuando los bebés no quieren pararse, las hojas de Batajihui, Nihiticaha, Mitaisi, se remojan en agua tibia y se baña a los niños. Para la viruela, se hace hervir primero toda la planta (Xéquihahëhua) y uno se baña tres veces al día.

- Inhalaciones: para la gripe y resfrío se estrujan generalmente las hojas, las cuales se respiran (Bahuarexa, Xababahuarëxa), también se puede poner la corteza y las hojas en agua tibia (Shishohitsa).

- Decocción: para las infecciones urinarias se hace hervir toda la hierba (Boshishí), y una vez enfriada se toma la decocción. Lo mismo ocurre con Ocotsëmo y Jënëocotsémo, utilizados para calmar la tos.

\section{Cuarto grupo de plantas medicinales}

Se han encontrado 16 plantas con varios usos medicinales, por ejemplo sirven para la tos o dolores de los riñones y a la vez, para la "caracha". Todas esas plantas pertenecen al bosque de tierra firme y la gran mayoría son árboles.

En estos casos, la parte de la planta utilizada y el modo de preparación será diferente (referirse al modo de preparación de las plantas pertenecientes a los gaipos anteriores) (ver Tabla 31). 
Tabla 31: Cuarto grupo de plantas medicinales

\begin{tabular}{|c|c|c|c|c|c|}
\hline $\begin{array}{l}\text { Nombre } \\
\text { Chácobo }\end{array}$ & Uso particular & $\begin{array}{l}\text { Tipo biológico y de } \\
\text { ambiente }\end{array}$ & $\begin{array}{l}\text { Género y } \\
\text { especie }\end{array}$ & Familia & $\begin{array}{l}\text { No de } \\
\text { colección }\end{array}$ \\
\hline Canamashia & $\begin{array}{l}\text { "Caracha". } \\
\text { Ríñones }\end{array}$ & $\begin{array}{l}\text { Arbol del bosque denso } \\
\text { húmedo de tierra firme }\end{array}$ & & & $\begin{array}{l}59,197 \\
473,941\end{array}$ \\
\hline Jihuirashia & $\begin{array}{l}\text { "Caracha". } \\
\text { Dolor de oído }\end{array}$ & $\begin{array}{l}\text { Arbol del bosque denso } \\
\text { húmedo de tierra firme }\end{array}$ & & Mimosaceae & 696,849 \\
\hline $\begin{array}{l}\text { Jihuiracharishi } \\
\text { o Ahuarari }\end{array}$ & $\begin{array}{l}\text { "Caracha". } \\
\text { Tos. Vitamina }\end{array}$ & $\begin{array}{l}\text { Arbol del bosque denso } \\
\text { húmedo de tierra firme }\end{array}$ & Qualea sp. & Vochysiaceae & 243 \\
\hline Jihuiracharishi & Caracha.Tos & $\begin{array}{l}\text { Arbol del bosque denso } \\
\text { húmedo de tierra firme }\end{array}$ & $\begin{array}{l}\text { Chaetocarpus } \\
\text { echinocarpus } \\
\text { No } \\
\text { determinado }\end{array}$ & Flacourtiaceae & $\begin{array}{l}12,526, \\
480\end{array}$ \\
\hline Jihuiracharishi & $\begin{array}{l}\text { "Caracha". } \\
\text { Tos. }\end{array}$ & $\begin{array}{l}\text { Arbol del bosque denso } \\
\text { húmedo de tierra firme }\end{array}$ & $\begin{array}{l}\text { Miconia cf. } \\
\text { molvbdea }\end{array}$ & $\begin{array}{l}\text { Melastomatacea } \\
\text { e }\end{array}$ & 492 \\
\hline Comacoro & $\begin{array}{l}\text { Crisis de } \\
\text { temblores } \\
\text { Inconti-nencia. } \\
\text { Picaduras de } \\
\text { "burro". }\end{array}$ & $\begin{array}{l}\text { Arbol del bosque denso } \\
\text { húmedo de tierra firme }\end{array}$ & $\begin{array}{l}\text { Lindackeria } \\
\text { paludosa }\end{array}$ & Flacourtiaceae & $\begin{array}{l}87,142 \\
411,923 \\
704\end{array}$ \\
\hline Huacamatiapi & $\begin{array}{l}\text { Diarrea. } \\
\text { Inflamaciones } \\
\text { debidas a } \\
\text { golpes }\end{array}$ & $\begin{array}{l}\text { Bejuco del bosque } \\
\text { denso húmedo de } \\
\text { tierra firme }\end{array}$ & & & 304 \\
\hline Quixono & $\begin{array}{l}\text { Dolor de } \\
\text { cabeza. } \\
\text { Inflamaciones } \\
\text { debidas a } \\
\text { golpes. }\end{array}$ & $\begin{array}{l}\text { Arbol del bosque denso } \\
\text { húmedo de tierra firme }\end{array}$ & $\begin{array}{l}\text { Amburana } \\
\text { cearensis }\end{array}$ & Papilionaceae & 215,647 \\
\hline Jihuibara & $\begin{array}{l}\text { Dolor de } \\
\text { estómago.Tos }\end{array}$ & $\begin{array}{l}\text { Arbol del bosque denso } \\
\text { húmedo de tierra firme }\end{array}$ & Myrcia sp. & Myrtaceae & $\begin{array}{l}\text { 41, 776, } \\
732\end{array}$ \\
\hline Isonaraja & $\begin{array}{l}\text { Fiebre, } \\
\text { paludismo, } \\
\text { ríñones }\end{array}$ & $\begin{array}{l}\text { Arbol del bosque denso } \\
\text { húmedo de tierra firme }\end{array}$ & Hortia sp. & Rutaceae & $\begin{array}{l}14,122 \\
240,835\end{array}$ \\
\hline Jihuipisi & $\begin{array}{l}\text { Insomnías } \\
\text { (niños). } \\
\text { Picaduras de } \\
\text { ""burro"" }\end{array}$ & $\begin{array}{l}\text { Arbol del bosque denso } \\
\text { húmedo de tierra firme }\end{array}$ & $\begin{array}{l}\text { Vataireopsis } \\
\text { speciosa }\end{array}$ & Papilionaceae & $\begin{array}{l}201,363 \\
457,472 \\
532,534\end{array}$ \\
\hline Huicama & $\begin{array}{l}\text { Picadas de } \\
\text { "burro", } \\
\text { "buna". } \\
\text { Diarreas }\end{array}$ & $\begin{array}{l}\text { Arbol del bosque denso } \\
\text { húmedo de tierra firme }\end{array}$ & $\begin{array}{l}\text { Bellucia } \\
\text { grossulariodes }\end{array}$ & $\begin{array}{l}\text { Melastomatacea } \\
\text { e }\end{array}$ & 257,506 \\
\hline Jihuirononopa & $\begin{array}{l}\text { Picadas de } \\
\text { "burro", } \\
\text { "buna". } \\
\text { Reumatismo }\end{array}$ & $\begin{array}{l}\text { Arbol del bosque denso } \\
\text { húmedo de tierra firme }\end{array}$ & $\begin{array}{l}\text { Prunus } \\
\text { amplifolia }\end{array}$ & Rosaceae & $\begin{array}{l}154,628 \\
854,612\end{array}$ \\
\hline Chaxoromë & $\begin{array}{l}\text { Picadas de } \\
\text { "burro", } \\
\text { "buna". } \\
\text { Reumatismo }\end{array}$ & Arbol de los barbechos & $\begin{array}{l}\text { Tabebuia } \\
\text { impetiginosa }\end{array}$ & Bignoniaceae & 808 \\
\hline $\begin{array}{l}\text { Chaxoromë o } \\
\text { Chaxohuitaxo }\end{array}$ & $\begin{array}{l}\text { Picadas de } \\
\text { "burro", } \\
\text { "buna". } \\
\text { Reumatismo }\end{array}$ & $\begin{array}{l}\text { Arbol del bosque denso } \\
\text { húmedo de tierra firme }\end{array}$ & & Sapindaceae & 263 \\
\hline
\end{tabular}


Bergeron S., 1998. Uso de las plantas por los Chácobos (Alto Ivón, Beni, Bolivia)

\section{Plantas que tienen otros usos}

Se han encontrado un total de 39 plantas que sirven para otros usos (fabricación de flautas, canastas, utensilios domésticos, vestimienta de los antiguos, adornos, entre otros). Otras 11 plantas se encuentran también en la categoría multiuso (ver Tabla 32).

La mayoría de esas plantas se encuentran en el bosque de tierra firme, menos en sabana y rara vez en barbechos y bosque ribereño. Por otra parte, se encuentran tanto árboles, arbustos, como bejucos y hierbas.

Tabla 32: Plantas con otros usos

\begin{tabular}{|c|c|c|c|c|c|}
\hline Nombre Chácobo & $\begin{array}{c}\text { Uso } \\
\text { particular }\end{array}$ & $\begin{array}{l}\text { Tipo biológico y } \\
\text { de ambiente }\end{array}$ & Género y especie & Familia & $\begin{array}{c}\text { No de } \\
\text { colección }\end{array}$ \\
\hline Bimichëxë propio & $\begin{array}{l}\text { Las frutas } \\
\text { sirven de } \\
\text { tinta }\end{array}$ & $\begin{array}{l}\text { Arbol del bosque } \\
\text { denso húmedo } \\
\text { de tierra firme }\end{array}$ & Neea ovalifolia & Nyctaginaceae & 99,36 \\
\hline Bimichëxë & $\begin{array}{l}\text { Las frutas } \\
\text { sirven de } \\
\text { tinta }\end{array}$ & $\begin{array}{l}\text { Arbusto del } \\
\text { bosque denso } \\
\text { húmedo de tierra } \\
\text { firme }\end{array}$ & & & 253 \\
\hline Bimichëxë & $\begin{array}{l}\text { Las frutas } \\
\text { sirven de } \\
\text { tinta }\end{array}$ & $\begin{array}{l}\text { Arbusto del } \\
\text { bosque denso } \\
\text { húmedo de tierra } \\
\text { firme }\end{array}$ & Miconia nervosa & Mel astomataceae & 339 \\
\hline $\begin{array}{l}\text { Bimichëxëjoni o } \\
\text { Maiyochi }\end{array}$ & $\begin{array}{l}\text { Las frutas } \\
\text { sirven de } \\
\text { tinta }\end{array}$ & $\begin{array}{l}\text { Arbusto del } \\
\text { bosque denso } \\
\text { húmedo de tierra } \\
\text { firme }\end{array}$ & $\begin{array}{l}\text { Psychotria } \\
\text { prunifolia }\end{array}$ & Rubiaceae & 342 \\
\hline $\begin{array}{l}\text { Bimichëxë- } \\
\text { mishni }\end{array}$ & $\begin{array}{l}\text { Las frutas } \\
\text { sirven de } \\
\text { tinta }\end{array}$ & $\begin{array}{l}\text { Arbusto del } \\
\text { bosque denso } \\
\text { húmedo de tierra } \\
\text { firme }\end{array}$ & Psychotria sp. & Rubiaceae & 319 \\
\hline Maiyochijoni & $\begin{array}{l}\text { Las frutas } \\
\text { sirven de } \\
\text { tinta }\end{array}$ & $\begin{array}{l}\text { Arbusto de los } \\
\text { barbechos }\end{array}$ & $\begin{array}{l}\text { Psychotria } \\
\text { prunifolia }\end{array}$ & Rubiaceae & 677 \\
\hline Nihixëchi & $\begin{array}{l}\text { Las frutas } \\
\text { sirven de } \\
\text { tinta }\end{array}$ & $\begin{array}{l}\text { Arbusto del } \\
\text { bosque denso } \\
\text { húmedo de tierra } \\
\text { firme }\end{array}$ & & Myrtaceae & 767 \\
\hline Tsamiti & $\begin{array}{l}\text { La corteza } \\
\text { sirve para } \\
\text { tintar }\end{array}$ & $\begin{array}{l}\text { Arbusto del } \\
\text { bosque ribereño }\end{array}$ & Mouriri sp. & Melastomataceae & $\begin{array}{l}546,710, \\
892\end{array}$ \\
\hline $\begin{array}{l}\text { Xabachacabimi } \\
\text { chëxë }\end{array}$ & $\begin{array}{l}\text { Las frutas } \\
\text { sirven de } \\
\text { tinta }\end{array}$ & $\begin{array}{l}\text { Arbusto de la } \\
\text { sabana }\end{array}$ & Miconia tiliaefolia & Melastomataceae & 576 \\
\hline Xahuaxëchi & $\begin{array}{l}\text { La corteza } \\
\text { sirve para } \\
\text { tintar }\end{array}$ & $\begin{array}{l}\text { Arbol del bosque } \\
\text { denso húmedo } \\
\text { de tierra firme }\end{array}$ & $\begin{array}{l}\text { Cassearia } \\
\text { combaymensis }\end{array}$ & Flacourtiaceae & 166 \\
\hline Bistocoshi & $\begin{array}{l}\text { Fabricació } \\
\text { n de flauta }\end{array}$ & $\begin{array}{l}\text { Hierba del } \\
\text { bosque denso } \\
\text { húmedo de tierra } \\
\text { firme }\end{array}$ & & Poaceae & 287 \\
\hline $\begin{array}{l}\text { Bistoratëquëmi } \\
\text { shni }\end{array}$ & $\begin{array}{l}\text { Fabricació } \\
\text { n de flauta }\end{array}$ & $\begin{array}{l}\text { Hierba de los } \\
\text { barbechos }\end{array}$ & & & 639 \\
\hline $\begin{array}{l}\text { Bistoratëquë- } \\
\text { xoco }\end{array}$ & $\begin{array}{l}\text { Fabricació } \\
\text { n de flauta }\end{array}$ & $\begin{array}{l}\text { Hierba de los } \\
\text { barbechos }\end{array}$ & & Graminae & 315 \\
\hline
\end{tabular}


Bergeron S., 1998. Uso de las plantas por los Chácobos (Alto Ivón, Beni, Bolivia)

Tabla 32 (continuación): Plantas con otros usos

\begin{tabular}{|c|c|c|c|c|c|}
\hline $\begin{array}{l}\text { Nombre } \\
\text { Chácobo }\end{array}$ & $\begin{array}{c}\text { Uso } \\
\text { particular }\end{array}$ & $\begin{array}{l}\text { Tipo biológico y } \\
\text { de ambiente }\end{array}$ & Género y especie & Familia & $\begin{array}{l}\text { No de } \\
\text { colección }\end{array}$ \\
\hline Jihuibisto & $\begin{array}{l}\text { Fabricación } \\
\text { de flautas }\end{array}$ & $\begin{array}{l}\text { Hierba del } \\
\text { bosque denso } \\
\text { húmedo de tierra } \\
\text { firme }\end{array}$ & & & 324,641 \\
\hline Camabisto & $\begin{array}{l}\text { Fabricación } \\
\text { de flautas }\end{array}$ & $\begin{array}{l}\text { Hierba del } \\
\text { bosque denso } \\
\text { húmedo de tierra } \\
\text { firme }\end{array}$ & Olyra sp. & Poaceae & 284 \\
\hline Cacataho & $\begin{array}{l}\text { Fabricación } \\
\text { de canastas }\end{array}$ & $\begin{array}{l}\text { Bejuco del } \\
\text { bosque denso } \\
\text { húmedo de tierra } \\
\text { firme }\end{array}$ & $\begin{array}{l}\text { Uncaria guianensis } \\
\text { Uncaria sp. }\end{array}$ & Rubiaceae & 646,291 \\
\hline Bocono & $\begin{array}{l}\text { Cuerdas para } \\
\text { hamacas }\end{array}$ & $\begin{array}{l}\text { Arbol del bosque } \\
\text { denso húmedo } \\
\text { de tierra firme }\end{array}$ & Pourouma sp. & Moraceae & $\begin{array}{c}57,202 \\
489\end{array}$ \\
\hline Boëxëni & $\begin{array}{l}\text { Limpieza de la } \\
\text { piel } \\
\text { ("mascara") }\end{array}$ & $\begin{array}{l}\text { Arbol del bosque } \\
\text { denso húmedo } \\
\text { de tierra firme }\end{array}$ & $\begin{array}{l}\text { Platymiscium } \\
\text { fragrans }\end{array}$ & Papilionaceae & $\begin{array}{l}123,176, \\
481,505, \\
370,693 \\
\end{array}$ \\
\hline Caiosho & $\begin{array}{l}\text { Las plantas } \\
\text { jóvenes } \\
\text { sirven de } \\
\text { estaca para } \\
\text { sembrar el } \\
\text { aiToz }\end{array}$ & $\begin{array}{l}\text { Arbol del bosque } \\
\text { denso húmedo } \\
\text { de tierra firme }\end{array}$ & $\begin{array}{l}\text { Amaioua } \\
\text { guianensis }\end{array}$ & Rubiaceae & $\begin{array}{c}30,103, \\
146,169, \\
251,442, \\
450,458, \\
616\end{array}$ \\
\hline Carama & Comercial & $\begin{array}{l}\text { Arbol del bosque } \\
\text { denso húmedo } \\
\text { de tierra firme }\end{array}$ & Hevea brasiliensis & Euphorbiaceae & 268 \\
\hline Huanicohuësa & $\begin{array}{l}\text { Las hojas } \\
\text { sirven de } \\
\text { juguetes para } \\
\text { los niños }\end{array}$ & $\begin{array}{l}\text { Bejuco del } \\
\text { bosque denso } \\
\text { húmedo de tierra } \\
\text { firme }\end{array}$ & A bula grandifolia & Menispermaceae & 338 \\
\hline Maquëtashi & $\begin{array}{l}\text { La corteza } \\
\text { sirve para } \\
\text { envolver el } \\
\text { pescado para } \\
\text { asar }\end{array}$ & $\begin{array}{l}\text { Arbol del bosque } \\
\text { ribereño }\end{array}$ & $\begin{array}{l}\text { Eishweilera } \\
\text { parviflora } \\
\text { No determinado }\end{array}$ & Lecythidaceae & 891,544 \\
\hline Paniboxcata & $\begin{array}{l}\text { Las hojas } \\
\text { sirven para } \\
\text { envolver el } \\
\text { pescado para } \\
\text { asar }\end{array}$ & $\begin{array}{l}\text { Hierba del } \\
\text { bosque denso } \\
\text { húmedo de tierra } \\
\text { firme }\end{array}$ & & & 282 \\
\hline Taparisti & $\begin{array}{l}\text { La corteza } \\
\text { sirve a rayar } \\
\text { la castañas }\end{array}$ & $\begin{array}{l}\text { Arbol del bosque } \\
\text { denso húmedo } \\
\text { de tierra firme }\end{array}$ & Micropholis sp. & Sapotaceae & 117,487 \\
\hline Mëhi & $\begin{array}{l}\text { Fabricación } \\
\text { de cerámica }\end{array}$ & $\begin{array}{l}\text { Arbol del bosque } \\
\text { denso húmedo } \\
\text { de tierra firme }\end{array}$ & Licania sp. & Chrysobalanaceae & 174 \\
\hline Mëhihua & $\begin{array}{l}\text { Fabricación } \\
\text { de cerámica }\end{array}$ & $\begin{array}{l}\text { Arbol del bosque } \\
\text { ribereño }\end{array}$ & Couepia sp. & Chrysobalanaceae & 708 \\
\hline $\begin{array}{l}\text { Xabamanihuas } \\
\text { hiri }\end{array}$ & $\begin{array}{l}\text { Juguetes de } \\
\text { las frutas }\end{array}$ & $\begin{array}{l}\text { Arbusto de la } \\
\text { sabana }\end{array}$ & Eugenia sp. & Myrtaceae & 579 \\
\hline
\end{tabular}


Bergeron S., 1998. Uso de las plantas por los Chácobos (Alto Ivón, Beni, Bolivia)

Tabla 32 (continuación): Plantas con otros usos

\begin{tabular}{|c|c|c|c|c|c|}
\hline $\begin{array}{l}\text { Nombre } \\
\text { Chácobo }\end{array}$ & $\begin{array}{c}\text { Uso } \\
\text { particular }\end{array}$ & $\begin{array}{l}\text { Tipo biológico y } \\
\text { de ambiente }\end{array}$ & Género y especie & Familia & $\begin{array}{c}\text { No de } \\
\text { colección }\end{array}$ \\
\hline Xëcojihui & $\begin{array}{l}\text { Juguete para } \\
\text { los niños }\end{array}$ & $\begin{array}{l}\text { Arbol del bosque } \\
\text { denso húmedo } \\
\text { de tierra firme }\end{array}$ & & & 278 \\
\hline Yotabi & $\begin{array}{l}\text { Juguete para } \\
\text { los niños }\end{array}$ & $\begin{array}{l}\text { Arbusto del } \\
\text { bosque denso } \\
\text { húmedo de tierra } \\
\text { firme }\end{array}$ & Psychotria deflexa & Rubiaceae & 322,657 \\
\hline Isacapoi & $\begin{array}{l}\text { Vestidos de } \\
\text { los antiguos }\end{array}$ & $\begin{array}{l}\text { Arbol del bosque } \\
\text { denso húmedo } \\
\text { de tierra firme }\end{array}$ & Ficus spenophylla & Moraceae & 864 \\
\hline Pió & $\begin{array}{l}\text { Vestidos de } \\
\text { los antiguos }\end{array}$ & $\begin{array}{l}\text { Arbol del bosque } \\
\text { denso húmedo } \\
\text { de tierra firme }\end{array}$ & $\begin{array}{l}\text { Brosimum utile } \\
\text { subsp. ovatifolium }\end{array}$ & Moraceae & $\begin{array}{lr}61, & 172, \\
325, & 441 \\
841, & 881\end{array}$ \\
\hline Yomëno & $\begin{array}{l}\text { Vestidos de } \\
\text { los antiguos }\end{array}$ & $\begin{array}{l}\text { Arbol del bosque } \\
\text { denso húmedo } \\
\text { de tierra firme }\end{array}$ & Ficus gomelleira & Moraceae & 147,206 \\
\hline $\begin{array}{l}\text { Jënëjiminishi } \\
\text { o } \\
\text { Jënëpanëxë }\end{array}$ & $\begin{array}{l}\text { Collares de } \\
\text { los antiguos }\end{array}$ & $\begin{array}{l}\text { Bejuco del } \\
\text { bosque ribereño }\end{array}$ & $\begin{array}{l}\text { Machearium } \\
\text { multifoliolatum }\end{array}$ & Papilionaceae & 734 \\
\hline Capëtëjina & $\begin{array}{l}\text { Indicador de } \\
\text { lluvia cuando } \\
\text { se corta la } \\
\text { planta }\end{array}$ & $\begin{array}{l}\text { Arbusto del } \\
\text { bosque denso } \\
\text { húmedo de tierra } \\
\text { firme }\end{array}$ & & & 368 \\
\hline $\begin{array}{l}\text { Shaquisha- } \\
\text { quitianihi }\end{array}$ & $\begin{array}{l}\text { Si se recoge } \\
\text { la planta, se } \\
\text { hace picar } \\
\text { por una } \\
\text { víbora }\end{array}$ & $\begin{array}{l}\text { Hierba de la } \\
\text { sabana }\end{array}$ & $\begin{array}{l}\text { Byrsonima } \\
\text { cíchrysophylla } \\
\text { puncticulata }\end{array}$ & Malpighiaceae & 426 \\
\hline Xëquihua & $\begin{array}{l}\text { Indicador } \\
\text { biológico }\end{array}$ & $\begin{array}{l}\text { Helecho del } \\
\text { bosque denso } \\
\text { húmedo de tierra } \\
\text { firme }\end{array}$ & & Perridophytae & 274 \\
\hline $\begin{array}{l}\text { Xabachaxo- } \\
\text { romë }\end{array}$ & Tabaco & $\begin{array}{l}\text { Arbusto de la } \\
\text { sabana }\end{array}$ & Vochysia cf. rufa & Vochysiaceae & 424 \\
\hline Yëbocanishi & $\begin{array}{l}\text { Halucinó- } \\
\text { geno }\end{array}$ & $\begin{array}{l}\text { Bejuco del } \\
\text { bosque denso } \\
\text { húmedo de tierra } \\
\text { firme }\end{array}$ & & Malpighiaceae & 962 \\
\hline Xabacarama & $\begin{array}{l}\text { Parches de } \\
\text { bicicleta }\end{array}$ & $\begin{array}{l}\text { Arbol de la } \\
\text { sabana }\end{array}$ & $\begin{array}{l}\text { Himatanthus } \\
\text { obovatus }\end{array}$ & Apocynaceae & 386,572 \\
\hline
\end{tabular}

De las plantas utilizadas para teñir o pintar, se utilizan por ejemplo las frutas de los Bimichëxë para pintar el cuerpo, (las frutas son remojadas en poco de agua tibia, la cual se vuelve entre negra y azul). En el caso de Tsamiti y Xahuachëchi, se utiliza la corteza, se hace remojar esta última en agua tibia, la cual sirve par tintar las flechas (Tsamiti), o para las cerámicas (Xahuachëchi).
Las demás plantas mencionadas en la Tabla 32 son mayormente plantas que sirven para la casa. Por ejemplo, la madera y la corteza de Cacataho sirven para la fabricación de canastas, la corteza del Bocono se utiliza como amarres de las hamacas, las hojas de Maquëtashi y Paniboxcata son utilizadas para asar el pescado, la corteza de Taparisti sirve a rayar las almendras (castañas), las cenizas de la corteza de Méhi, se mezclan al barro para la fabricación de cerámicas. 
También encontramos, plantas tales como Isacapoi, Pío, Yomëno, utilizadas por los antiguos en la confección de la ropa. Asimismo, se sacaba la corteza interna del árbol, se machacaba y se dejaba secar al sol. Por otra parte, las semillas de Jënëpanëxë se utilizaban en la fabricación de collares.

Ciertas de estas plantas pueden consideradas como malos agüeros (Shaquishaquitianihi, Capëtëjina), o indicadores de buena tierra (ëquihua) para hacer los "chacos".

Por último, encontramos plantas con diversos usos, por ejemplo Xabaxachoromë es el tabaco salvaje, la resina de Xabacarama sirve a hacer parches, el grupo de los Bisto se utiliza en la fabricación de las flautas.

\section{Plantas que tienen varios usos (multi-uso)}

De las 472 plantas consideradas en este estudio, 49 tiene varios usos (ver Tabla 33).

La gran mayoría de esas especies se encuentran en el bosque de tierra firme, pocos en el bosque ribereño, sabana $y$ barbechos. Por otra parte, se encuentran tanto árboles, como arbustos, bejucos y palmas.

Por otra parte, como lo hemos mencionado anteriormente, la mayoría de esas especies, tienen frutas comestibles y son medicinales.

Tabla 33: Las plantas que tienen varios usos (multi-uso)

\begin{tabular}{|c|c|c|c|c|c|}
\hline $\begin{array}{l}\text { Nombre } \\
\text { Chácobo }\end{array}$ & $\begin{array}{l}\text { Tipo de uso } \\
\text { particular }\end{array}$ & $\begin{array}{c}\text { Tipo biológico } \\
\text { y de } \\
\text { ambiente }\end{array}$ & Género y especie & Familia & $\begin{array}{c}\text { No de } \\
\text { colección }\end{array}$ \\
\hline \multicolumn{6}{|c|}{ Comestible; Construcción } \\
\hline Cotibi & $\begin{array}{l}\text { Frutas } \\
\text { comestibles } \\
\text { Maderable. } \\
\text { (vigas, } \\
\text { postes). }\end{array}$ & $\begin{array}{l}\text { Arbol del } \\
\text { bosque denso } \\
\text { húmedo de } \\
\text { tierra firme }\end{array}$ & $\begin{array}{l}\text { Unonopsis } \\
\text { floribunda }\end{array}$ & Annonaceae & $\begin{array}{l}136,139, \\
195,200, \\
730,928, \\
103\end{array}$ \\
\hline Quëho & $\begin{array}{l}\text { Frutas } \\
\text { comestibles. } \\
\text { Maderable } \\
\text { (tijeras). }\end{array}$ & $\begin{array}{l}\text { Arbol del } \\
\text { bosque denso } \\
\text { húmedo de } \\
\text { tierra firme }\end{array}$ & Pouteria caimito & Sapotaceae & $\begin{array}{l}254,408 \\
549,893\end{array}$ \\
\hline Xëbichoqui & $\begin{array}{l}\text { Frutas } \\
\text { comestibles. } \\
\text { Hojas para } \\
\text { techo. }\end{array}$ & $\begin{array}{l}\text { Palma del } \\
\text { bosque denso } \\
\text { húmedo de } \\
\text { tierra firme }\end{array}$ & $\begin{array}{l}\text { Maximiliano } \\
\text { maripa }\end{array}$ & Palmae & 23,269 \\
\hline
\end{tabular}


Tabla 33 (continuación): Las plantas que tienen varios usos (multi-uso)

\begin{tabular}{|c|c|c|c|c|c|}
\hline $\begin{array}{l}\text { Nombre } \\
\text { Chácobo }\end{array}$ & $\begin{array}{l}\text { Tipo de uso } \\
\text { particular }\end{array}$ & $\begin{array}{c}\text { Tipo biológico } \\
\text { y de } \\
\text { ambiente }\end{array}$ & Género y especie & Familia & $\begin{array}{c}\text { No de } \\
\text { colección }\end{array}$ \\
\hline \multicolumn{6}{|c|}{ Comestible; Leña y astillas } \\
\hline $\begin{array}{l}\text { Jënëtioro- } \\
\text { querihua }\end{array}$ & $\begin{array}{l}\text { Frutas } \\
\text { comestibles; } \\
\text { Leña. }\end{array}$ & $\begin{array}{l}\text { Arbol del } \\
\text { bosque } \\
\text { ribereño }\end{array}$ & Panopsis rubescens & Proteaceae & 834 \\
\hline Jihuishini & $\begin{array}{l}\text { Frutas } \\
\text { comestibles; } \\
\text { Leña. }\end{array}$ & $\begin{array}{l}\text { Arbusto de los } \\
\text { barbechos }\end{array}$ & $\begin{array}{l}\text { Tovomita } \\
\text { schomburgkii }\end{array}$ & Clusiaceae & 761 \\
\hline $\begin{array}{l}\text { Tioro- } \\
\text { quërihua }\end{array}$ & $\begin{array}{l}\text { Frutas } \\
\text { comestibles. } \\
\text { Astillas. }\end{array}$ & $\begin{array}{l}\text { Arbol del } \\
\text { bosque denso } \\
\text { húmedo de } \\
\text { tierra firme }\end{array}$ & $\begin{array}{l}\text { Micropholis } \\
\text { guyanensis }\end{array}$ & Sapotaceae & $\begin{array}{l}17,34,168, \\
173, \\
231,246, \\
452\end{array}$ \\
\hline $\begin{array}{l}\text { Xabachaca- } \\
\text { pëpëcho }\end{array}$ & $\begin{array}{l}\text { Frutas } \\
\text { comestibles. } \\
\text { Diarrea. }\end{array}$ & $\begin{array}{l}\text { Arbol de la } \\
\text { sabana }\end{array}$ & Roupala montana & Proteaceae & 69 \\
\hline \multicolumn{6}{|c|}{ Comestible; Medicinal } \\
\hline Ahuaxtepoco & $\begin{array}{l}\text { Frutas } \\
\text { comestibles. } \\
\text { Diarrea. }\end{array}$ & $\begin{array}{l}\text { Bejuco del } \\
\text { bosque denso } \\
\text { húmedo de } \\
\text { tierra firme }\end{array}$ & $\begin{array}{l}\text { Salada aff. } \\
\text { Gigantea }\end{array}$ & Hippocrateaceae & $\begin{array}{l}360,420, \\
938\end{array}$ \\
\hline $\begin{array}{l}\text { Bimichëxë o } \\
\text { Chaxohuitaxo }\end{array}$ & $\begin{array}{l}\text { Frutas } \\
\text { comestibles. } \\
\text { Reumatismo } \\
\text {, picada de } \\
\text { "buna" }\end{array}$ & $\begin{array}{l}\text { Arbol del } \\
\text { bosque denso } \\
\text { húmedo de } \\
\text { tierra firme }\end{array}$ & $\begin{array}{l}\text { Miconia } \\
\text { lourtcigiana }\end{array}$ & Melastomataceae & 28 \\
\hline $\begin{array}{l}\text { Bimichëxë- } \\
\text { joni }\end{array}$ & $\begin{array}{l}\text { Frutas } \\
\text { comestibles. } \\
\text { Ampollas de } \\
\text { la boca. }\end{array}$ & $\begin{array}{l}\text { Arbusto del } \\
\text { bosque denso } \\
\text { húmedo de } \\
\text { tierra firme }\end{array}$ & $\begin{array}{l}\text { Miconia } \\
\text { longispicata }\end{array}$ & Melastomataceae & 863 \\
\hline $\begin{array}{l}\text { Bimichëxë- } \\
\text { joni } \\
\text { (otro) }\end{array}$ & $\begin{array}{l}\text { Frutas } \\
\text { comestibles. } \\
\text { Ampollas de } \\
\text { la boca. }\end{array}$ & $\begin{array}{l}\text { Arbusto del } \\
\text { bosque denso } \\
\text { húmedo de } \\
\text { tierra firme }\end{array}$ & Miconia serrulata & Melastomataceae & 377 \\
\hline $\begin{array}{l}\text { Camamë- } \\
\text { quënë }\end{array}$ & $\begin{array}{l}\text { Frutas } \\
\text { comestibles. } \\
\text { Picada de } \\
\text { "burro", } \\
\text { "buna" }\end{array}$ & $\begin{array}{l}\text { Arbol del } \\
\text { bosque denso } \\
\text { húmedo de } \\
\text { tierra firme }\end{array}$ & Perebea mollis & Moraceae & $\begin{array}{l}184,222 \\
232,513\end{array}$ \\
\hline Canapa & $\begin{array}{l}\text { Frutas } \\
\text { comestibles. } \\
\text { Picada de } \\
\text { "burro", } \\
\text { "buna", } \\
\text { víbora, } \\
\text { quemaduras } \\
\text {. }\end{array}$ & $\begin{array}{l}\text { Arbol del } \\
\text { bosque denso } \\
\text { húmedo de } \\
\text { tierra firme }\end{array}$ & $\begin{array}{l}\text { Helicostylis } \\
\text { tomentosa }\end{array}$ & Moraceae & $\begin{array}{l}120, \\
121,149, \\
150,180, \\
220,509, \\
533\end{array}$ \\
\hline
\end{tabular}


Tabla 33 (continuación): Las plantas que tienen varios usos (multi-uso)

\begin{tabular}{|c|c|c|c|c|c|}
\hline $\begin{array}{l}\text { Nombre } \\
\text { Chácobo }\end{array}$ & $\begin{array}{l}\text { Tipo de uso } \\
\text { Particular }\end{array}$ & $\begin{array}{c}\text { Tipo biológico } \\
\text { y de } \\
\text { ambiente }\end{array}$ & Género y especie & Familia & $\begin{array}{c}\text { No de } \\
\text { colección }\end{array}$ \\
\hline Canapa & $\begin{array}{l}\text { Frutas } \\
\text { comestibles. } \\
\text { Picada de } \\
\text { "burro", } \\
\text { "buna", } \\
\text { víbora, } \\
\text { quemaduras. }\end{array}$ & $\begin{array}{l}\text { Arbol del } \\
\text { bosque denso } \\
\text { húmedo de } \\
\text { tierra firme }\end{array}$ & $\begin{array}{l}\text { Helicostylis } \\
\text { tomentosa }\end{array}$ & Moraceae & $\begin{array}{l}120, \\
121,149, \\
150,180, \\
220,509, \\
533\end{array}$ \\
\hline Capetërobo & $\begin{array}{l}\text { Frutas } \\
\text { comestibles. } \\
\text { "Empeine" }\end{array}$ & $\begin{array}{l}\text { Bejuco del } \\
\text { bosque } \\
\text { ribereño }\end{array}$ & $\begin{array}{l}\text { Amona hypoglauca } \\
\text { Maytenus cf. } \\
\text { erythrocarpa }\end{array}$ & $\begin{array}{l}\text { Annonaceae } \\
\text { Celastraceae }\end{array}$ & 542,828 \\
\hline Chanajoni & $\begin{array}{l}\text { Frutas } \\
\text { comestibles. } \\
\text { "Caracha". }\end{array}$ & $\begin{array}{l}\text { Arbol del } \\
\text { bosque denso } \\
\text { húmedo de } \\
\text { tierra firme }\end{array}$ & Hirtella pilosissima & Chrysobalanaceae & $\begin{array}{l}503,522, \\
723\end{array}$ \\
\hline Nohotë & $\begin{array}{l}\text { Frutas } \\
\text { comestibles. } \\
\text { Picada de } \\
\text { "burro", "buna" }\end{array}$ & $\begin{array}{l}\text { Arbusto del } \\
\text { bosque denso } \\
\text { húmedo de } \\
\text { tierra firme }\end{array}$ & $\begin{array}{l}\text { Theobroma } \\
\text { speciosum }\end{array}$ & Sterculiaceae & $\begin{array}{l}35,134, \\
135\end{array}$ \\
\hline Pamabara & $\begin{array}{l}\text { Frutas } \\
\text { comestibles. } \\
\text { Gusanos } \\
\text { ("borros") }\end{array}$ & $\begin{array}{l}\text { Arbol del } \\
\text { bosque denso } \\
\text { húmedo de } \\
\text { tierra firme }\end{array}$ & $\begin{array}{l}\text { Pseudolmedia } \\
\text { laevis } \\
\text { Pseudolmedia } \\
\text { macrophylla }\end{array}$ & Moraceae & 884,868 \\
\hline Pamacoro & $\begin{array}{l}\text { Frutas } \\
\text { comestibles. } \\
\text { Gusanos } \\
\text { ("borros") }\end{array}$ & $\begin{array}{l}\text { Arbol del } \\
\text { bosque denso } \\
\text { húmedo de } \\
\text { tierra firme }\end{array}$ & $\begin{array}{l}\text { Pseudolmedia } \\
\text { macrophylla }\end{array}$ & Moraceae & $\begin{array}{l}625,629, \\
840\end{array}$ \\
\hline Pamaxacaya & $\begin{array}{l}\text { Frutas } \\
\text { comestibles. } \\
\text { Gusanos } \\
\text { ("borros") }\end{array}$ & $\begin{array}{l}\text { Arbol del } \\
\text { bosque denso } \\
\text { húmedo de } \\
\text { tierra firme }\end{array}$ & $\begin{array}{l}\text { Pseudolmedia cf. } \\
\text { murure } \\
\text { Pseudolmedia } \\
\text { laevis }\end{array}$ & Moraceae & $\begin{array}{l}198,478, \\
511,624, \\
94320\end{array}$ \\
\hline Pamaxoco & $\begin{array}{l}\text { Frutas } \\
\text { comestibles. } \\
\text { Gusanos } \\
\text { ("borros") }\end{array}$ & $\begin{array}{l}\text { Arbol del } \\
\text { bosque denso } \\
\text { húmedo de } \\
\text { tierra firme }\end{array}$ & $\begin{array}{l}\text { Pseudolmedia } \\
\text { macrophylla } \\
\text { Pseudolmedia } \\
\text { laevis }\end{array}$ & Moraceae & $\begin{array}{l}19,21, \\
85,205, \\
438 \\
93,113, \\
119,439, \\
440,453, \\
450 \text { bis }\end{array}$ \\
\hline Panabi & $\begin{array}{l}\text { Frutas } \\
\text { comestibles. Da } \\
\text { fuerza. }\end{array}$ & $\begin{array}{l}\text { Palma del } \\
\text { bosque denso } \\
\text { húmedo de } \\
\text { tierra firme }\end{array}$ & Euterpe precatoria & Palmae & 101 \\
\hline $\begin{array}{l}\text { Quëxqui- } \\
\text { xaquini }\end{array}$ & $\begin{array}{l}\text { Frutas } \\
\text { comestibles. } \\
\text { Ampollas de la } \\
\text { boca. Picada de } \\
\text { "burro", } \\
\text { "buna". }\end{array}$ & $\begin{array}{l}\text { Arbol del } \\
\text { bosque denso } \\
\text { húmedo de } \\
\text { tierra firme }\end{array}$ & $\begin{array}{l}\text { Pourouma } \\
\text { guianensis }\end{array}$ & Moraceae & $\begin{array}{l}418,448, \\
464\end{array}$ \\
\hline
\end{tabular}


Bergeron S., 1998. Uso de las plantas por los Chácobos (Alto Ivón, Beni, Bolivia)

Tabla 33 (continuación): Las plantas que tienen varios usos (multi-uso)

\begin{tabular}{|c|c|c|c|c|c|}
\hline $\begin{array}{l}\text { Nombre } \\
\text { Chácobo }\end{array}$ & $\begin{array}{l}\text { Tipo de uso } \\
\text { particular }\end{array}$ & $\begin{array}{c}\text { Tipo biológico } \\
\text { y de } \\
\text { ambiente }\end{array}$ & Genero y especie & Familia & $\begin{array}{c}\text { No de } \\
\text { colección }\end{array}$ \\
\hline Rononopa & $\begin{array}{l}\text { Frutas } \\
\text { comestibles. } \\
\text { Lastimadas }\end{array}$ & $\begin{array}{l}\text { Arbusto del } \\
\text { bosque denso } \\
\text { húmedo de } \\
\text { tierra firme }\end{array}$ & Annona arnbotay & Annonaceae & $\begin{array}{l}853,679, \\
581\end{array}$ \\
\hline Shoshapo & $\begin{array}{l}\text { Frutas } \\
\text { comestibles. } \\
\text { Ampollas de } \\
\text { la boca. }\end{array}$ & $\begin{array}{l}\text { Arbusto del } \\
\text { bosque } \\
\text { ribereño }\end{array}$ & & Vochysiaceae & 725 \\
\hline $\begin{array}{l}\text { Tëtëmëtsisi- } \\
\text { joni }\end{array}$ & $\begin{array}{l}\text { Frutas } \\
\text { comestibles. } \\
\text { Picada de } \\
\text { víbora, } \\
\text { "burro", } \\
\text { "buna". }\end{array}$ & $\begin{array}{l}\text { Arbusto del } \\
\text { bosque denso } \\
\text { húmedo de } \\
\text { tierra firme }\end{array}$ & Xilopia peruviana & Annonaceae & 273,501 \\
\hline Xabaxanatë & $\begin{array}{l}\text { Frutas } \\
\text { comestibles. } \\
\text { Diarrea. } \\
\text { Ampollas de } \\
\text { la boca. } \\
\text { Picada de } \\
\text { víbora, } \\
\text { "burro", } \\
\text { "buna". }\end{array}$ & $\begin{array}{l}\text { Arbusto de la } \\
\text { sabana }\end{array}$ & & & 64 \\
\hline Xaquini & $\begin{array}{l}\text { Frutas } \\
\text { comestibles. } \\
\text { Ampollas de } \\
\text { la boca. } \\
\text { Picada de } \\
\text { "burro", } \\
\text { "buna". }\end{array}$ & $\begin{array}{l}\text { Arbol del } \\
\text { bosque denso } \\
\text { húmedo de } \\
\text { tierra firme }\end{array}$ & $\begin{array}{l}\text { Pourouma } \\
\text { cecropiifolia }\end{array}$ & Moraceae & $\begin{array}{l}56,346, \\
186,523, \\
248\end{array}$ \\
\hline $\begin{array}{l}\text { Xoque- } \\
\text { xoquërë }\end{array}$ & $\begin{array}{l}\text { Frutas } \\
\text { comestibles. } \\
\text { Picadas de } \\
\text { "burro", } \\
\text { "buna". }\end{array}$ & $\begin{array}{l}\text { Arbol del } \\
\text { bosque denso } \\
\text { húmedo de } \\
\text { tierra firme }\end{array}$ & Sorocea guilleminia & Moraceae & 46,192 \\
\hline $\begin{array}{l}\text { Xabaisco- } \\
\text { chaishi }\end{array}$ & $\begin{array}{l}\text { Frutas } \\
\text { comestibles. } \\
\text { "Caracha". }\end{array}$ & $\begin{array}{l}\text { Arbol de la } \\
\text { sabana }\end{array}$ & & & 382 \\
\hline \multicolumn{6}{|c|}{ Comestible; Otros } \\
\hline Tapa & $\begin{array}{l}\text { Frutas } \\
\text { comestibles. } \\
\text { Comercial. }\end{array}$ & $\begin{array}{l}\text { Arbol del } \\
\text { bosque denso } \\
\text { húmedo de } \\
\text { tierra firme }\end{array}$ & Berthollelia excelsa & Lecythidaceae & 229 \\
\hline Tapa & $\begin{array}{l}\text { Frutas } \\
\text { comestibles. } \\
\text { Comercial. }\end{array}$ & $\begin{array}{l}\text { Arbol del } \\
\text { bosque denso } \\
\text { húmedo de } \\
\text { tierra firme }\end{array}$ & Berlholletia excelsa & Lecythidaceae & 229 \\
\hline
\end{tabular}


Bergeron S., 1998. Uso de las plantas por los Chácobos (Alto Ivón, Beni, Bolivia)

Tabla 33 (continuación): Las plantas que tienen varios usos (multi-uso)

\begin{tabular}{|c|c|c|c|c|c|}
\hline $\begin{array}{l}\text { Nombre } \\
\text { Chácobo }\end{array}$ & $\begin{array}{l}\text { Tipo de uso } \\
\text { particular }\end{array}$ & $\begin{array}{c}\text { Tipo biológico } \\
\text { y de } \\
\text { ambiente } \\
\end{array}$ & Genero y especie & Familia & $\begin{array}{l}\text { No de } \\
\text { colección }\end{array}$ \\
\hline $\begin{array}{l}\text { Xabahua- } \\
\text { nahua }\end{array}$ & $\begin{array}{l}\text { Frutas } \\
\text { comestibles. } \\
\text { Adornos } \\
\text { (anillos) }\end{array}$ & $\begin{array}{l}\text { Palma de la } \\
\text { sabana }\end{array}$ & $\begin{array}{l}\text { Allagropfea } \\
\text { leucocalyx }\end{array}$ & Palmae & 430 \\
\hline \multicolumn{6}{|c|}{ Comestible; Otros; Medicinal } \\
\hline Pananë & $\begin{array}{l}\text { Frutas } \\
\text { comestibles } \\
\text { y sirven de } \\
\text { colorante. } \\
\text { Dar fuerza. }\end{array}$ & $\begin{array}{l}\text { Palma del } \\
\text { bosque denso } \\
\text { húmedo de } \\
\text { tierra firme }\end{array}$ & & & 281 \\
\hline \multicolumn{6}{|c|}{ Construcción; Leña y Astillas } \\
\hline Jihuijoxo & $\begin{array}{l}\text { Maderable } \\
\text { (postes, } \\
\text { vigas). Leña. }\end{array}$ & $\begin{array}{l}\text { Arbol del } \\
\text { bosque denso } \\
\text { húmedo de } \\
\text { tierra firme }\end{array}$ & $\begin{array}{l}\text { Qualea paraensis } \\
\text { Qualea sp. }\end{array}$ & Vochysiaceae & $\begin{array}{l}82 \\
183\end{array}$ \\
\hline \multicolumn{6}{|c|}{ Construcción: Leña y astillas; Otros } \\
\hline Xabajiminishi & $\begin{array}{l}\text { Maderable. } \\
\text { La corteza } \\
\text { sirve en la } \\
\text { construcció } \\
\text { n para } \\
\text { amarres y la } \\
\text { elaboración } \\
\text { de canastas }\end{array}$ & $\begin{array}{l}\text { Arbol de la } \\
\text { sabana }\end{array}$ & $\begin{array}{l}\text { Chaelocarpus } \\
\text { echinocarpus }\end{array}$ & Euphorbiaceae & 387 \\
\hline \multicolumn{6}{|c|}{ Construcción; Otros } \\
\hline Coyomoro & $\begin{array}{l}\text { Maderable. } \\
\text { Vestidos de } \\
\text { los antiguos. }\end{array}$ & $\begin{array}{l}\text { Arbol del } \\
\text { bosque } \\
\text { ribereño }\end{array}$ & Ficus paraensis & Moraceae & 722 \\
\hline Onipa & $\begin{array}{l}\text { Maderable } \\
\text { (paredes), } \\
\text { Hojas para } \\
\text { techar. Raíz } \\
\text { para rayar la } \\
\text { yuca. }\end{array}$ & $\begin{array}{l}\text { Palma del } \\
\text { bosque denso } \\
\text { húmedo de } \\
\text { tierra firme }\end{array}$ & Socratea exorrhiza & Palmae & 100,535 \\
\hline Panaxë & $\begin{array}{l}\text { Amarres. } \\
\text { Adornos } \\
\text { (pulseras de } \\
\text { los } \\
\text { antiguos). }\end{array}$ & $\begin{array}{l}\text { Bejuco del } \\
\text { bosque denso } \\
\text { húmedo de } \\
\text { tierra firme }\end{array}$ & $\begin{array}{l}\text { Machaeñum sp. } \\
\text { Lonchocarpus sp. } \\
\text { No determinado }\end{array}$ & Papilionaceae & $\begin{array}{l}265,1003 \\
873\end{array}$ \\
\hline Panaxë & $\begin{array}{l}\text { Amarres. } \\
\text { Adornos } \\
\text { (pulseras de } \\
\text { los } \\
\text { antiguos). }\end{array}$ & $\begin{array}{l}\text { Bejuco del } \\
\text { bosque denso } \\
\text { húmedo de } \\
\text { tierra firme }\end{array}$ & $\begin{array}{l}\text { Machaerium sp. } \\
\text { Lonchocarpus sp. } \\
\text { No determinado }\end{array}$ & Papilionaceae & $\begin{array}{l}265 \\
1003 \\
873\end{array}$ \\
\hline \multicolumn{6}{|c|}{ Leña y Astillas; Otros } \\
\hline Caxcochëquë & $\begin{array}{l}\text { Leña. } \\
\text { Elaboración } \\
\text { de tiesto y } \\
\text { jabón } \\
\text { (cenizas) }\end{array}$ & $\begin{array}{l}\text { Arbol del } \\
\text { bosque denso } \\
\text { húmedo de } \\
\text { tierra firme }\end{array}$ & $\begin{array}{l}\text { Albizia sp. } \\
\text { Pithecellobiwti sp. }\end{array}$ & Mimosaceae & 915,858 \\
\hline
\end{tabular}


Bergeron S., 1998. Uso de las plantas por los Chácobos (Alto Ivón, Beni, Bolivia)

Tabla 33 (continuación): Las plantas que tienen varios usos (multi-uso)

\begin{tabular}{|c|c|c|c|c|c|}
\hline $\begin{array}{l}\text { Nombre } \\
\text { Chácobo }\end{array}$ & $\begin{array}{l}\text { Tipo de uso } \\
\text { particular }\end{array}$ & $\begin{array}{l}\text { Tipo biológico } \\
\text { y de } \\
\text { ambiente }\end{array}$ & Género y especie & Familia & $\begin{array}{l}\text { No de } \\
\text { colección }\end{array}$ \\
\hline Caxcono & $\begin{array}{l}\text { Leña. } \\
\text { Elaboración } \\
\text { de tiesto y } \\
\text { jabón } \\
\text { (cenizas) }\end{array}$ & $\begin{array}{l}\text { Arbol del } \\
\text { bosque denso } \\
\text { húmedo de } \\
\text { tierra firme }\end{array}$ & $\begin{array}{l}\text { Parapiptadenia } \\
\text { excelsa }\end{array}$ & Mimosaceae & $\begin{array}{l}13,109, \\
196,237 \\
530\end{array}$ \\
\hline Caxcopisi & $\begin{array}{l}\text { Leña, } \\
\text { ustensilios } \\
\text { domésticos, } \\
\text { jabón }\end{array}$ & $\begin{array}{l}\text { Arbol del } \\
\text { bosque denso } \\
\text { húmedo de } \\
\text { tierra firme }\end{array}$ & $\begin{array}{l}\text { cf. Piptadenia } \\
\text { buchtienii }\end{array}$ & Mimosaceae & $\begin{array}{l}18,108, \\
190,260, \\
461,514, \\
929\end{array}$ \\
\hline Potasti & $\begin{array}{l}\text { Leña. } \\
\text { Algodón } \\
\text { (frutas) }\end{array}$ & $\begin{array}{l}\text { Arbol del } \\
\text { bosque denso } \\
\text { húmedo de } \\
\text { tierra firme }\end{array}$ & Platymiscium sp. & $\begin{array}{l}\text { Papilionaceae } \\
\text { Bombacaceae }\end{array}$ & $\begin{array}{l}447,466 \\
520\end{array}$ \\
\hline Xabamëhihua & $\begin{array}{l}\text { Leña. } \\
\text { Fabricación } \\
\text { de } \\
\text { cerámicas. }\end{array}$ & $\begin{array}{l}\text { Arbol de la } \\
\text { sabana }\end{array}$ & & & 388,598 \\
\hline \multicolumn{6}{|c|}{ Medicinal; Caza y pesca } \\
\hline Bëisiticorihua & $\begin{array}{l}\text { "Caracha", } \\
\text { Hinchazón. } \\
\text { Resina } \\
\text { utilizada } \\
\text { para la } \\
\text { confección } \\
\text { de las } \\
\text { flechas }\end{array}$ & $\begin{array}{l}\text { Arbol del } \\
\text { bosque denso } \\
\text { húmedo de } \\
\text { tierra firme }\end{array}$ & $\begin{array}{l}\text { Protium } \\
\text { unifoliatum } \\
\text { Protium } \\
\text { sagotianum }\end{array}$ & Burseraceae & $\begin{array}{l}45,673, \\
718,847, \\
162,250,\end{array}$ \\
\hline Corihua & $\begin{array}{l}\text { Hinchazón. } \\
\text { Resina } \\
\text { utilizada } \\
\text { para la } \\
\text { confección } \\
\text { de las } \\
\text { flechas }\end{array}$ & $\begin{array}{l}\text { Arbol del } \\
\text { bosque denso } \\
\text { húmedo de } \\
\text { tierra firme }\end{array}$ & $\begin{array}{l}\text { Trattinnickia } \\
\text { lawrencei var. } \\
\text { bolivianum }\end{array}$ & Burseraceae & 521,846 \\
\hline $\begin{array}{l}\text { Jënëbëisiti- } \\
\text { corihua }\end{array}$ & $\begin{array}{l}\text { Hinchazón. } \\
\text { Resina } \\
\text { utilizada } \\
\text { para la } \\
\text { confección } \\
\text { de las } \\
\text { flechas }\end{array}$ & $\begin{array}{l}\text { Arbol del } \\
\text { bosque } \\
\text { ribereño }\end{array}$ & $\begin{array}{l}\text { Protium } \\
\text { unifoliatum }\end{array}$ & Papilionaceae & 822 \\
\hline \multicolumn{6}{|c|}{ Medicinal; Construcción } \\
\hline Itsa & $\begin{array}{l}\text { Fiebre, } \\
\text { vómitos, } \\
\text { paludismo. } \\
\text { Maderable } \\
\text { (postes, } \\
\text { vigas) }\end{array}$ & $\begin{array}{l}\text { Arbol del } \\
\text { bosque denso } \\
\text { húmedo de } \\
\text { tierra firme }\end{array}$ & Cedrela fissilis & Meliaceae & $\begin{array}{l}177,228, \\
483,498, \\
618\end{array}$ \\
\hline Jihuicoshi & $\begin{array}{l}\text { Tos. } \\
\text { Maderable. }\end{array}$ & $\begin{array}{l}\text { Arbol del } \\
\text { bosque denso } \\
\text { húmedo de } \\
\text { tierra firme }\end{array}$ & $\begin{array}{l}\text { Diplotropis } \\
\text { purpurea } \\
\text { No determinado }\end{array}$ & $\begin{array}{l}\text { Papilionaceae } \\
\text { Vochysiaceae }\end{array}$ & 469,548 \\
\hline
\end{tabular}


Bergeron S., 1998. Uso de las plantas por los Chácobos (Alto Ivón, Beni, Bolivia)

Tabla 33 (continuación): Las plantas que tienen varios usos (multi-uso)

\begin{tabular}{|c|c|c|c|c|c|}
\hline $\begin{array}{l}\text { Nombre } \\
\text { Chácobo }\end{array}$ & $\begin{array}{l}\text { Tipo de uso } \\
\text { particular }\end{array}$ & $\begin{array}{c}\text { Tipo biológico } \\
\text { y de } \\
\text { ambiente } \\
\end{array}$ & Genero y especie & Familia & $\begin{array}{c}\text { No de } \\
\text { colección }\end{array}$ \\
\hline \multicolumn{6}{|c|}{ Medicinal; Leña y astillas } \\
\hline Xahuamachi & $\begin{array}{l}\text { "Caracha". } \\
\text { Astillas. }\end{array}$ & $\begin{array}{l}\text { Arbol del } \\
\text { bosque denso } \\
\text { húmedo de } \\
\text { tierra firme }\end{array}$ & $\begin{array}{l}\text { Sloanea guianensis } \\
\text { Sloanea cf. cichleri } \\
\text { Sloanea gracilis }\end{array}$ & Elaeocarpaceae & $\begin{array}{l}141,214, \\
189,463, \\
518,931, \\
484, \\
942\end{array}$ \\
\hline \multicolumn{6}{|c|}{ Medicinal; Otros } \\
\hline $\begin{array}{l}\text { Xaxohati o } \\
\text { Xanëyobini }\end{array}$ & $\begin{array}{l}\text { Vómitos. } \\
\text { Madera } \\
\text { utilizada } \\
\text { para la } \\
\text { elaboración } \\
\text { del batán }\end{array}$ & $\begin{array}{l}\text { Arbol del } \\
\text { bosque denso } \\
\text { húmedo de } \\
\text { tierra firme }\end{array}$ & & Flacourtiaceae & $\begin{array}{l}55,414, \\
763\end{array}$ \\
\hline
\end{tabular}

Respecto a las plantas medicinales, o utilizadas con otros fines, el modo de preparación depende de su uso, y es similar a lo que se ha descrito para los diferentes grupos de plantas medicinales. 


\section{Capítulo 4}

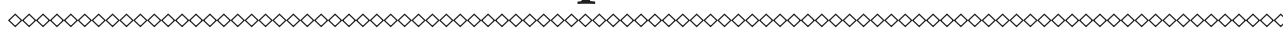

\section{Guía Popular de las Plantas Chácobo}

A manera de ilustrar el uso de las plantas por los Chácobos, se han seleccionado cincuenta plantas según los criterios mencionados en la introducción.

Asimismo, la guía de las plantas Chácobos ha sido elaborada a partir del universo de 472 plantas encontradas en los diferentes ambientes de Alto-Ivón, y recolectadas como muestras de herbario. Hace excepción, la hierba Mani (Phmakospermum guyanensis), que ha sido descrita en esta guía por ser una planta bastante utilizada por los Chácobos y abundante en el bosque.

La descripción de las plantas mencionadas a continuación (por orden alfabético), ha sido realizada a partir de la información recopilada en el campo con los comunarios Chácobos, así como información secundaria relacionada con trabajos botánicos y etnobotánicos tales como, Boom (1989), Gentry, (1993), Killeen et al., (1993), entre otras fuentes bibliográficas).

Debido a que el capítulo consiste en una guía popular, no se han detallado las características botánicas de cada planta. Por lo tanto, se ha intentado, en lo posible, simplificar y/o explicar los términos técnicos empleados a lo largo de la redacción y se explican a continuación algunos términos científicos en base al glosario de la guía de árboles (Killeen, García, Beck, 1993: 844 - 868):

Alciones: Raíces tabulares (raíces aplanadas como tablas).

Arilo: Tejido generalmente carnoso que recubre la semilla.

Baya: Fruto carnoso con pericarpo suculento y varias semillas sumergidas en la pulpa.

Caulifloro: con flores sobre el tronco y las ramas gruesas.

Coriaceo: Que tiene la consistencia del cuero.

Dehiscente: Se dice de los órganos como los frutos que se abren a su madurez.

Dioica: Planta con flores masculinas (planta "macho"), o con flores femeninas (planta "hembra").

Drupa: fruto carnoso con una sola semilla. 
Exudado: Cualquier líquido que fluye al hacer un corte en la corteza o "cascara" del árbol por ejemplo.

Ferrugíneo: De color castaño puro con ligero tinte rojo (como el color del hierro).

Fisurado: Corteza o "cascara" con surcos o costillas a lo largo de la corteza.

Folíolo: Hojuela, segmento foliar de una hoja compuesta.

Fuste: tronco o el "palo" mismo.

Fulcrea: Raiz aérea ubicada a cierta altura del tronco y que cae al suelo como las raíces de Onipa.

Indehiscente: Se dice de los órganos como los frutos que no se abren a su madurez.

Látex: Exudado por lo general de color blanco, de consistencia lechosa pegajosa.

Leñoso: De la consistencia de la leña.

Pubescente: Cubierto con pelos finos, cortos y suaves.

Raquis: Nervio medio de la hoja.

Rugoso: Con arrugas irregulares.

Sámara: Fruto seco, indehiscente, alado, con una sola semilla.

Savia: Jugo contenido en la planta.

Siempreverde: verde todo el año.

Vaina o legumbre: Fruto seco dehiscente que se abre a lo largo de dos suturas.

Verrugoso: Se aplica por ejemplo a la corteza o "cáscara" que tiene en su superficie prominencia en forma de verrugas. 


\section{Axacoro \\ Paulinia sp. \\ Sapindaceae}

\section{DESCRIPCION}

Axacoro (Paulinia sp), es un bejuco común en bosque secundario avanzado (Amazonia del Oeste) (Boom, 1987).

Según Killeen, Beck, García (1993), es un bejuco leñoso con secreción venenosa de saponinas. Las hojas son compuestas imparipinadas o trifolioladas.

En Alto Ivon, se ha encontrado la planta en el bosque ribereño, el "grosor" del bejuco era de aproximadamente $31 \mathrm{~cm}$, (diámetro de $10 \mathrm{~cm}$ ). Es de color marrón, la corteza interna es rojiza y la madera, amarilla.

El nombre Axacoro viene de "Axa": "Barbasco" y de "Coro": arañado, porque la "cáscara" parece arañada.

USO

La planta es un "barbasco" y sirve para pescar.

En época seca, el río baja hasta secarse, quedando en algunos sitios, charcos o pozos de agua, los cuales son aprovechados para pescar. Se botan en el agua, trozos del tronco y de las raíces del bejuco. El agua se vuelve negra y los peces que aparecen muertos en la superficie, son cosechados por los Chácobo.

\section{Batahua \\ Capirona decorticans Spruce Rubiaceae}

\section{DESCRIPCION}

La especie Batahua (Capirona decorticcins) es común en los barbechos viejos (bosque secundario en estado avanzado (Boom, 1987). Batahua está representada por "árboles hasta $23 \mathrm{~m}$. La corteza es verdosa y corchosa, se cae periódicamente. Las hojas son grandes. Los frutos son cápsulas (frutos que se abren solos). La especie se encuentra en bosque húmedo amazónico. El género Capirona cuenta con 2 especies distribuidas en los Trópicos de Sur América" (Killeen, Beck, García, 1993). Batahua es abundante en el bosque de tierra firme ("monte alto") de Alto-Ivón. Muchas veces, se encuentra en grupos de árboles. Se han inventariado 14 árboles de altura promedia de $15 \mathrm{~m}$, cuyo 
"grosor" variaba entre 35-73cm (DAP de 11 a 23cm). El tronco es recto, de color verde, la corteza o "cáscara" interna es verde amarillenta, y la madera, blanca. Las hojas son grandes, simples opuestas con 4 estípulas.

El nombre Chácobo Batahua no tiene traducción en castellano, es el nombre propio de la planta.

\section{USO}

Batahua sirve para las mordeduras de víbora. Se raspa la "cáscara" interna y se aplica sobre la piel con un trapo como cataplama. También, muchas veces se hace hervir la "cáscara" del Batahua (decocción), al mismo tiempo que las hojas del Mani (plátano) o la corteza del Chachama (Aspidosperma sp.). Se deja enfriar y se toma el líquido tres veces al día, al mismo tiempo que se hacen los cataplasmas de Batahua.

Según Boom (1987), se utilizan las hojas (en decocción y cataplasmas) para las mordeduras de serpientes. La decocción de la "cáscara" sirve para las infecciones de la piel.

\section{Bëisiticorihua \\ Protium sagotianum Marchand/Protium unifoliolatum Engl. Burseraceae}

\section{DESCRIPCION}

La especie Bëisiticorihua (Protium sagotianum y $P$. unifoliolatum) está representada por "árboles pequeños hasta $4 \mathrm{~m}$. Los frutos son carnosos, rojos en su interior. Se ha recolectado la especie con flores entre septiembre y diciembre, con frutos entre diciembre y mayo, en bosque amazónico entre otros ambientes. El género Protium cuenta con alrededor de 90 especies distribuidas en bosques húmedos desde México hasta Bolivia y sur de Brasil." (Killeen, Beck, García, 1993).

En la parcela permanente de Alto Ivon, solamente se ha inventariado un árbol de Bëisiticorihua, pero se ha encontrado también la planta en los barbechos de 15 años y en el bosque ribereño. La altura de los árboles recolectados era de aproximadamente $8 \mathrm{~m}$, con un "grosor" de $31.5 \mathrm{~cm}$ (DAP de $10.5 \mathrm{~cm}$ ). El tronco es recto, de color marrón, la corteza interna es rojiza, la madera amarilla. Tiene resina transparente olorosa. Las hojas son simples alternas.

El nombre de Bëisiticorihua viene Bëisiti: espejo, y Corihua: el árbol, porque la corteza del árbol tiene placas rectangulares como espejos. 
USO

La resina de Bëisiticorihua se utiliza como barniz para las flechas. Se aplica la resina sobre el hilo que amarra la punta de la flecha, hecha con la madera dura y negra de Panima (Astrocaryum aculeatum) o de Bëcona (Erisma ciuncinatum), con el tallo hecho con Tahua (Gynerium sagittatum). También la planta es medicinal: la resina sirve para las infecciones de piel e hinchazones. En este caso se aplica simplemente la resina sobre la piel.

\section{Bocono \\ Pourouma sp. Moraceae}

\section{DESCRIPCION}

La especie Bocono (Pourouma sp.) está representada por "árboles medianos, frecuentemente con raíces zancudas, con savia acuosa volviéndose negra al secarse. Las plantas son dioicas (o sea, la planta es "macho" o es "hembra")" (Killeen, Beck, García, 1993).

En la parcela permanente del "monte alto", solamente se han inventariado 3 árboles de este tipo de Bocono. La altura de los árboles varía entre 12 y $18 \mathrm{~m}$, y el "grosor" entre 38 y $65 \mathrm{~cm}$ (DAP entre $12 \mathrm{y} 20,5 \mathrm{~cm}$ ).

El tronco tiene raíces zancudas, es de color marrón gris, la corteza interna es amarilla, la madera blanca. Tiene savia (exudado) transparente y líquida. Las hojas son alternas, palmatífídas con savia transparente.

Bocono no tiene traducción en castellano, es el nombre propio de la planta.

\section{USO}

Al igual que el algodón cultivado (Gossypium barbadensé), la corteza interna de Bocono sirve de materia prima para la elaboración de las hamacas. Asimismo, se saca las fibras de la corteza de Bocono, las cuales son secadas al sol, para ser luego utilizadas en los tejidos. 


\section{Cacataho Uncaria guianensis (Aubl.) Gmel. Rubiaceae}

\section{DESCRIPCION}

Cacataho es un bejuco común del bosque secundario (barbechos) (Boom, 1987).

En Alto - Ivon, Cacataho se encontró a menudo en el bosque de tierra firme ("monte" alto) y en los barbechos. El "grosor" de los bejucos colectados no sobrepasaba de los $31 \mathrm{~cm}(\mathrm{DAP}<10 \mathrm{~cm})$. Los bejucos son de color marrón, la corteza o "cáscara" interna rojiza y la madera amarilla.

USO

Cacataho sirve para hacer canastas. La madera se utiliza como armazón de la canasta (o cacano) y la "cáscara" está empleada para realizar para la malla de la canasta.

Según Boom (1987), Cacataho es también medicinal y sirve para las diarreas: el agua (exudado) del bejuco se mezcla con agua y se toma hasta parar los síntomas.

\section{Caiosho Amaioua guianensis Aublet Rubiaceae}

\section{DESCRIPCION}

La especie Caiosho (Amaioua guianensis) se llama Tutumillo en el Beni.

Está representada por "árboles hasta $17 \mathrm{~m}$. El tronco es acanalado y la corteza marrón suave. Se encontró la especie con flores entre noviembre y diciembre, y con frutos de marzo a junio. Se distribuye en bosque amazónico hasta húmedo montano, bosques secundarios y bosques de galería (250 - 1550m).

Según Boom (1987) esta especie es común en bosque secundario en estado avanzado (barbecho viejo) y tiene una distribución amplia en Amazonia y Guyana.

El género Amaioua cuenta con 25 especies, distribuidas en América tropical desde México hasta Bolivia" (Beck, García, 1993).

En Alto Ivon, se han inventariado 10 plantas de Caiosho. La especie es bastante abundante y tiene una distribución regular en el bosque de tierra firme.

La altura de las plantas recolectadas varía entre 8 y $15 \mathrm{~m}$ y el tronco tenía un "grosor" entre 36 y $55 \mathrm{~cm}$ (DAP entre 11.5 yl7.5cm). El tronco es acanalado, de color marrón, la corteza o "cascara" es delgada, la corteza interna amarilla clara y la madera amarilla. Las hojas son simples opuestas con 4 estípulas. 
USO

Cuando la planta es bien joven, el tronco sirve de "estaca" para sembrar el arroz.

\section{Camabisto \\ Olyra sp. \\ Poaceae}

\section{DESCRIPCION}

La especie Camabisto, así como las otras especies del grupo Bisto, son hierbas (tipo bambú) que se encuentran tanto en los barbechos, como en el bosque de tierra firme o bosque ribereño. El tamaño puede variar según la planta, entre 2 y $4 \mathrm{~m}$, siendo Џihuibisto la más grande de todas.

\section{USO}

Esas plantas tienen la particularidad de no tener madera, por lo cual sirven para hacer las sampoñas (flautas), instrumentos de música que tuvieron y tienen todavía importancia en la cultura Chácobo.

\section{Canopëixoco Sclerolobium aff rugosum C.M.\&B. Caesalpiniaceae}

\section{DESCRIPCION}

Canopëixoco (Sclerolobium aff. rugosum) está representado por "grandes árboles, alcanzando los $35 \mathrm{~m}$. El tronco (fuste) es cilindrico, la corteza lisa, las hojas son compuestas paripinadas. Las flores son pequeñas en racimos terminales. Los frutos son legumbres (vainas) con una o pocas semillas. Se ha recolectado la especie en el bosque amazónico de tierra firme, con flores en mayo, y con frutos verdes en mayo y junio. El género Sclerolobium cuenta con alrededor de 35 especies distribuidas en América tropical, particularmente en Amazonia." (Killeen, Beck, García, 1993).

En el bosque de tierra firme ("monte alto") de Alto Ivon, se han encontrado 8 árboles de Canopëixoco. Esta especie no es muy abundante, tampoco se encuentra de manera muy regular. La altura de los árboles encontrados varía entre 20 y $25 \mathrm{~m}$. Tenían un "grosor" variando desde $38 \mathrm{~cm}$ hasta más de $4 \mathrm{~m}$ (DAP entre $12 \mathrm{~cm}$ y l,4m). El tronco, de color marrón rojo, presenta pequeñas raices en su base (incipientes), la corteza o "cáscara" interna es rojiza, y la madera blanca.

El nombre Chácobo Canopëixoxo viene de "Cano", (nombre propio del árbol) y de "Peixoco" que significa pequeñas hojas, o sea, es un Cano con pequeñas hojas. 
USO

La planta sirve para construcciones domésticas. La madera sirve en el armazón de la casa (tijeras).

Es también medicinal y sirve como cicatrizante de las cortaduras. Se pone la corteza al fuego y las cenizas son aplicadas sobre la piel hasta que esta última se cicatrice.

\section{Capëhitsa \\ Derris amazónica Killip vel aff. Papilionaceae}

\section{DESCRIPCION}

Capëhitsa (Derris amazónica) es un bejuco común en bosque secundario (Amazonia del Oeste) (Boom, 1987). Las hojas son compuestas imparipinadas con 7 o 10 folíolos opuestos. Las flores son pequeñas, los frutos son legumbres dehicentes (Killeen, Beck, García, 1993).

En Alto Ivón, se ha encontrado este bejuco en el bosque ribereño. Su "grosor" era de aproximadamente $31 \mathrm{~cm}$, (diámetro de $10 \mathrm{~cm}$ ). Es de color marrón negra, la corteza interna es naranjiza y la madera blanca.

USO

Al igual que Axocoro. la planta sirve para "barbasquear" (mata los peces).

Se machaca las raíces y el tronco, se bota al agua y aparece espuma.

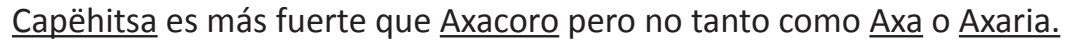

\section{Carama \\ Hevea brasiliensis Muell. Arg. Euphorbiaceae}

\section{DESCRIPCION}

Carama (Hevea brasiliensis) es una especie típica de la Amazonia. "Los árboles llegan hasta $40 \mathrm{~m}$, con aletones poco desarrollados o ausentes, tronco cilindrico y recto con flores en agosto y septiembre. Tiene látex (leche) pegajoso y abundante. Se encuentran en bosque húmedo de tierra firme. El género Hevea cuenta con unas 10 especies restringidas a la cuenca amazónica." (Killeen, Beck, García, 1993).

En Alto Ivon, se han encontrado 3 árboles en la parcela inventariada del "monte" alto. 
La especie no es muy abundante pero se encuentra regularmente en el "monte" alto. La altura promedio de los árboles era de $15-20 \mathrm{~m}$, con un "grosor" entre 35 y $57 \mathrm{~cm}$ (diámetro entre 10 y $178 \mathrm{~cm}$ ). El árbol es marrón, la corteza interna rosada y la madera, blanca con leche blanco.

USO

Del Carama, los Chácobos sacan el caucho cuya cosecha se extiende desde abril hasta junio-julio (entre época lluviosa y época seca). Cada familia tiene su estrada asignada. En época de cosecha, los Chácobos van desde muy temprano por la mañana, recorriendo los diferentes árboles de goma. Rayan cada árbol en forma de $V$ y ponen una "tichela" (lata) debajo de la incisión, dejando que la leche escurra. Luego, cosechan la leche y al final de la tarde, vuelven a la comunidad o al "centro" (lugar de descanso y dormida en el bosque), para procesar el caucho ("fumar la goma").

Procesar el caucho consiste en coagular la leche. Asimismo, se va echando poco a poco la leche recolectada en el día, sobre un palo giratorio, aprovechando el fuerte humo liberado por las "astillas" como Paxaini o Xahuamachi. Se obtiene una "bolacha", la cual se vende en Riberalta, a través de la cooperativa de Alto-Ivón.

El caucho constituye un recurso económico para los Chácobos. Sin embargo los precios en Riberalta son muy fluctuantes y a veces muy bajos, lo que no compensa los gastos de transporte. Por ejemplo entre 1992 - 1994, el precio del kilo era de 0,80 a IBs (entre 0,19 y 0,24 US \$), mientras que la ida - vuelta en camioneta representaba entre 480 y 500BS (aproximadamente 100US \$).

También ocasionalmente, los Chácobos elaboran zapatos de caucho, a partir de un molde tallado en la madera.

\section{Cascarayobini Ouratea macrobotrys Rusby Ochnaceae}

\section{DESCRIPCION}

Cascarayobini (Ouratea macrobotrys) está representado por "árboles pequeños o arbustos hasta $6 \mathrm{~m}$, con flores amarillas y frutos negros. La especie se encuentra en bosque húmedo de piedemonte y de llanura ( 250 - 900m.s.m.). Se ha recolectado con flores en septiembre, con frutos inmaduros en octubre y con frutos maduros en mayo. El género Ouratea cuenta con alrededor de 210 especies pantropicales, la mayoría son de América Tropical. Algunas especies presentan frutas comestibles; las hojas en infusión están utilizadas por los campesinos del Beni, para problemas de hígado" 
(Killeen, Beck, García, 1993).

En Alto Ivon, Cascarayobini es bastante escasa y los árboles se encuentran aislados uno del otro en el bosque. En la parcela de "monte alto", se han inventariado solamente 3 árboles pequeños, cuya altura varía entre 8 y $15 \mathrm{~m}$, con un "grosor", entre 33 y $58 \mathrm{~cm}$ (DAP entre 10.5 y $18.5 \mathrm{~cm}$ ).

Los árboles de Cascarayobini son rectos, de color marrón verde, la corteza o "cáscara" interna tiene un color rojo oscuro, la madera es blanca las hojas son aserradas (como serrucho).

El nombre Chácobo Cascarayobini no tiene traducción en castellano, es el nombre propio de la planta.

USO

Cascarayobini sirve para parar los dolores de estómago, diarrea, vómitos y fiebre de origen diversa.

Se raspa la "cáscara" y se sancocha. Se deja enfriar y se toma el jugo (1/2 caneco). Se repite las tomas hasta parar los dolores, la fiebre o los vómitos.

\section{Caxcopisi o Sipiricaxcono cf. Piptadenia buchtienii Barneky Mimosaceae}

\section{DESCRIPCION}

En Alto Ivon, se han numerado 5 árboles de Caxcopisi en la parcela permanente del bosque de tierra firme.

La planta no es muy abundante pero se encuentra regularmente en el bosque. El grosor de los árboles encontrados varían entre $31,5 \mathrm{~cm}$ y $109 \mathrm{~cm}$ (diámetro entre 10 y 35cm), y su altura, entre 10 y $20 \mathrm{~m}$.

El tronco o "palo" es de color marrón, recto o tiene incipientes, la corteza interna es rosada y la madera amarilla clara. Las hojas son compuestas bipinnadas.

El nombre de Caxcopisi viene de "Caxcono" y de "Pisi": mal olor, ya que el árbol uele mal.

USO

Los Chácobo utilizan Caxcopisi para la leña (uso doméstico) pero tiene otros usos:

Antes la planta servía para hacer el jabón. Asimismo, cuando los Chácobo tenían ganado 
las cenizas de la corteza se mezclaban con la manteca de la vaca para elaborar el jabón. También sirve para hacer tiesto (utensilios domésticos): las cenizas de la corteza se mezclan con la arcilla, la cual se moldea y se hace cocer para obtener el tiesto.

\section{Chana \\ Hirtella racemosa Lam. var. racemosa/ Hirtella pilosissima C.Martius \& Zucc Chrysobalanaceae}

\section{DESCRIPCION}

La especie Chana (Hirtella racemosa) es común de los barbechos y se distribuye desde Panamá, Colombia hasta las Guyanas y norte de Bolivia (Boom, 1987). Está representada por arbustos o árboles hasta los $5 \mathrm{~m}$. Se coleccionó con flores y frutos en mayo, en bosque amazónico inundable (230-350m).

El Género Hirtella cuenta con alrededor 93 especies distribuidas desde México hasta Bolivia y al Sur de Brasil. Tres especies se distribuyen en Africa y Madagascar. Son árboles pequeños, rara vez hasta $22 \mathrm{~m}$, o arbustos con exudado rojo; hojas glabras o hirsutas, los pecíolos sin glándulas. Flores en panículas o racimos elongados; el fruto es una drupa carnosa elipsoide, glabro o pubescente" (Killeen, Beck, García, 1993).

El nombre Chácobo de Chana del insecto del mismo nombre, ya que este último se come las hojas del árbol.

En Alto Ivón, la especie es abundante en casi todos los ambientes (en el sotobosque del "monte"alto, los barbechos y bosque ribereño). Las plantas que se han encontrado no sobrepasaban los $4 \mathrm{~m}$ de altura, el "grosof'de los "palos"era de $15 \mathrm{~cm}$ aproximadamente. El tronco es recto, de color marrón, la corteza es delgada, la corteza interna es roja y tiene un poco de resina, la madera es amarilla clara. Las hojas son simples alternas a veces pubecentes (con pelos).

USO

Las frutas (drupas carnosas) de la planta se comen. 


\section{Comacoro \\ Lindackeria paludosa (Benth.) Gilg \\ Flacourtiaceae}

\section{DESCRIPCION}

Comacoro (Lindackeria paludosa) está representada por "arbustos o árboles hasta IOm; La especie fue recolectada con flores en mayo, agosto y septiembre. Se encuentra en bosque húmedo amazónico de tierra firme y bosque ribereño.

El género Lindackeria cuenta con 13 especies, 7 de Africa tropical y 6 en Centro y Sur América, particularmente en la cuenca amazónica”. (Killeen, Beck, García, 1993).

Comacoro no se ha encontrado mucho en el bosque de tierra firme ("monte alto" de Alto-Ivón), solamente se han inventariado dos árboles pequeños (de 8 y $10 \mathrm{~m}$ ), con un "grosor" de aproximadamente 33 y $41 \mathrm{~cm}$ (DAP de 10.5 a $13 \mathrm{~cm}$ ). También se ha encontrado la especie en el bosque ribereño.

El tronco es recto, de color marrón oscuro, la corteza o "cáscara" interna es rosada y la madera, amarilla. Las hojas son simples alternas.

El nombre Chácobo Comacoro viene de "Coma": perdiz azul, porque las hojas y el tronco son medio azul.

\section{USO}

Comacoro es medicinal. Sirve para las hinchazones, y la incontinencia de los niños (cuando mojan la cama).

- En el caso de las hinchazones, se raspa la corteza o "cáscara" interna, la cual se aplica sobre el hinchazón con un trapo, como cataplasma.

- Para la incontinencia de los niños, se estrujan las hojas, las cuales se ponen en agua tibia, luego se baña al niño.

\section{Cótibi \\ Unonopsis floribunda Diels \\ Annonaceae}

\section{DESCRIPCION}

Cótibi (Unonopsis floribunda) se llama Chocolatillo en castellano.

"Son árboles medianos con poco exudado rojo oscuro y denso, las hojas ovales y oblongas alrededor de $20 \mathrm{~cm}$ de largo. Los frutos son globosos y negros cuando son 
maduros. Se ha recolectado la especie con frutos en agosto en bosque amazónico (180 - 240m).

El género Unonopsis cuenta con alrededor 30 especies distribuidas desde Centro América hasta el sur de Brasil" (Killeen, Beck, García, 1993).

En Alto Ivon, a pesar de no ser muy abundante, Cótibi es frecuente. Por ejemplo se han inventariado 5 plantas de Cótibi en la parcela del "monte" alto.

La altura de los árboles varía entre 10 y $18 \mathrm{~m}$, y el "grosor" entre 33 y $73 \mathrm{~cm}$ (diámetro entre 10,5 y $23 \mathrm{~cm}$ ). El tronco es recto, de color marrón gris, la corteza es espesa, la corteza o "cáscara" interna, rojiza y reticulada, tiene un poco de resina roja, la madera es blanca. Las hojas son simples alternas.

El nombre Chácobo Cótibi no tiene traducción en castellano, es el nombre propio del árbol.

USO

Las frutas de Cótibi (drupas carnosas) de la planta se comen.

También la corteza interna sirve de cuerdas o amarres ("pancho"), pero son más ordinarios que los "panchos" de Xahui, Xahuisi.

\section{Huápamo \\ Maquira coriacea (Karsten) C.C Berg \\ Moraceae}

\section{DESCRIPCION}

La especie Huápamo (Maquira coriáceo) está representada por "árboles grandes hasta $40 \mathrm{~m}$, con látex crema. La corteza se desprende fácilmente de las ramas, la cara superior de las hojas es brillante. Los frutos tienen semillas grandes. Se ha coleccionado la especie con frutos maduros en febrero e inmaduros en octubre.

El género Maquira cuenta con más de cinco especies en América Tropical" (Killeen, Beck, García, 1993).

En Alto Ivon, solamente pocos árboles de Huápamo se han encontrado en el bosque ribereño. Eran árboles grandes (aproximadamente $20 \mathrm{~m}$ ), de color marrón rojo, con incipientes (pequeñas raíces en la base del tronco). La corteza o "cáscara" interna es rojiza, y la madera blanca. Tienen leche blanco. Las hojas son simples alternas, con leche blanco.

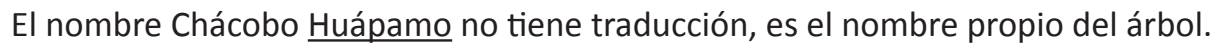


USO

Huápamo sirve para rebajar la fiebre y curar el paludismo.

Se raspa la "cáscara" del tronco o de las raices, las cuales se hacen hervir (se "sancochan"). Luego se toma el jugo (1/2 taza o "caneco") y se repite las tomas hasta parar la enfermedad.

\section{Isonaraja Hortia sp. Rutaceae}

\section{DESCRIPCION}

En Alto-Ivón Isonaraja es una especie bastante común ya que se han inventariado 14 árboles en la parcela permanente del bosque de tierra firme ("monte alto") Los árboles se encontraban muchas veces en grupos. Eran árboles grandes (aproximadamente $20 \mathrm{~m}$ ), con incipientes (pequeñas raíces en la base del tronco). El "grosor" varía entre 34 y $122 \mathrm{~cm}$ (DAP entre 11 y $39 \mathrm{~cm}$ ).

El tronco, de color marrón gris, es bien recto, la corteza o "cáscara" interna es medio anaranjada, y la madera, amarilla clara. La corteza o "cáscara" es muy espesa, rugosa, y amarga. Las hojas son simples, alargas, distribuidas en racimos. Las flores rosadas también se distribuyen en racimos. Las frutas son unas drupas (carnosas) amarillas cuando maduran.

Isonaraja viene de "Iso": nombre Chácobo del marimono, y de "Naraja": Naranja, por los frutos parecidos a la naranja y comidos por el marimono.

\section{USO}

Isonaraja sirve a rebajar la fiebre y combatir el paludismo. Según el comunario Chácobo, Caco Ortiz, la planta es también utilizada para los problemas de ríñones (infecciones). Se hace hervir un trozo de la "cascara" en un poco de agua. Se deja enfriar y se toma el líquido hasta que se paren los síntomas. 


\section{Itsa \\ Cedrela fissilis Vell. \\ Meliaceae}

\section{DESCRIPCION}

La especie Itsa (Cedrela fissilis), está representada por "grandes árboles que pierden sus hojas (deciduos), con corteza externa característica, grisácea, internamente rosada y aromática, las semillas son aladas.

El género Cedrela cuenta con siete especies, restringidas a América Tropical desde México hasta Argentina" (Killeen, Beck, García, 1993).

En Alto Ivon, solamente unos pocos árboles de Itsa se encontraron en el "monte alto". Asimismo, se han inventariado 3 árboles en la parcela. Eran grandes árboles (aproximadamente 25m de altura), con un "grosor" entre 58 y $192 \mathrm{~cm}$ (DAP entre 18.5 y $61 \mathrm{~cm}$ ). El tronco, de color marrón, tiene incipientes (pequeñas raices en su base), la corteza o "cáscara" interna es rojiza, y la madera blanca. La corteza es espesa y tiene olor a ajo.

El nombre Chácobo Itsa no tiene traducción, es el nombre propio del árbol.

\section{$\underline{\text { USO }}$}

Al igual que Jihuimoca (árboles del mismo grupo según la clasificación de las plantas por los Chácobo), Itsa sirve para bajar la fiebre, vómitos y paludismo.

Se corta unos pedazos de la "cáscara", los cuales se hacen hervir o "sancochar" en un poco de agua. Se deja enfriar y se toma el líquido varias veces al día hasta que se paren los síntomas.

También la madera de Itsa sirve para las construcciones de las casas.

\section{Jihuicharishi Toulicia patentínervis Ralk Sapindaceae}

\section{DESCRIPCION}

La especie Jihuicharishi (Toulicia patentinervis) está representada por "árboles de 15m, Las flores están en panículas terminales o subterminales, los frutos son indehiscentes (que no se abren por si mismo). Se encuentra la especie en bosque amazónico.

El género Toulicia es un género sudamericano con 14 especies aproximadamente" (Killeen, Beck, García, 1993). 
Jihuicharishi no es muy abundante en el bosque de Alto - Ivon. En la parcela solamente se han encontrado 4 árboles cuya altura variaba entre 12 y $22 \mathrm{~m}$, y el "grosor", entre 31.5 y $62 \mathrm{~cm}$ (DAP entre 10 y $19.80 \mathrm{~cm}$ ). Los árboles recolectados tenían un fuste (tronco) recto, de color marrón oscuro, la corteza o "cáscara" interna es amarilla oscura, y la madera amarilla. Las hojas son compuestas alternas imparipinadas, folíolos opuestos

\section{USO}

Jihuicharishi para las hinchazones (debidas a lastimadas o golpes).

Se raspa la corteza o "cáscara", la cual se aplica sobre el hinchazón con un trapo como cataplasma.

\section{Jihuimoca \\ Coutarea hexandra (Jacq.) Schumann Rubiaceae/ Geissospermum laeve (Vellozo) Miers Apocynaceae}

\section{DESCRIPCION}

Por ser muy parecidas por su tronco y corteza, las especies Coutarea hexandra (Rubiaceae) y Geissospermum laeve (Apocynaceae) tienen el mismo nombre Chácobo, Jihuimoca.

"Coutarea hexandra está representada por árboles o arbustos hasta $8 \mathrm{~m}$, ramas glabras (sin pelos) a pubescentes (con pelos). Se ha recolectado la especie con flores en enero y febrero, y con frutos (cápsulas) en junio. Se encuentra en bosque de llanura, semideciduo submontano y en bosque secundario (barbechos). El género Coutarea cuenta con unas cuatro especies distribuidas desde México hasta Argentina y en las Antillas. La corteza de estos árboles se utiliza para curar el paludismo.

Geissospermum laeve está representada por árboles de IOm; se ha encontrado con flores en octubre, en bosque amazónico alto. El género Geissospermum está representado por pocas especies distribuidas en Brasil tropical, Guyanas, Venezuela y posiblemente Perú. Son árboles con ramas densamente pubescentes con látex blanco, hojas alternas. Las flores son pequeñas, las semillas pequeñas planas y sin alas" (Killeen, Beck, García, 1993).

En Alto Ivon, Jihuimoca (tanto Coutarea hexandra como Geissospermum laeve) no se encuentra mucho (no es abundante) y los árboles se encuentran aislados uno del otro en el bosque. En la parcela de "monte" alto, se han inventariado solamente 4 árboles grandes de Coutarea hexandra. También se ha encontrado la especie en el bosque ribereño. Por otra parte solamente ha encontrado un árbol de Geissospermum laeve 
en el bosque ribereño. No se han inventariado árboles pertenecientes a este última especie en la parcela del "monte alto".

Los Jihuimoca (Coutarea hexandra y Geissospermum laeve) recolectados tenían una altura de aproximadamente $20 \mathrm{~m}$, y un "grosor" entre 68 y $112 \mathrm{~cm}$ (DAP entre 22 y $36 \mathrm{~cm}$ ). Son árboles acanalados, de color marrón claro, la corteza o "cáscara" interna es amarilla, la madera, blanca. La "cáscara" se desprende en placas (es decir que se cae por pedazitos) y es muy amarga.

El nombre Chácobo Jihuimoca viene de "Jihui", el árbol y "Moca": amargo por la "cáscara" amarga que tiene el árbol.

\section{USO}

Jihuimoca sirve para parar la diarrea, vómitos y fiebre de origen diversa, y para curar el paludismo.

Se raspa la "cáscara" y se "sancocha". Se deja enfriar y se toma el jugo (1/2 taza) y se repite las tomas hasta parar la enfermedad.

\section{Jihuipisi \\ Vataireopsis speciosa Ducke Papilionaceae}

\section{DESCRIPCION}

Jihuipisi (Vataireopsis speciosa) es una especie que se encuentra frecuentemente en los barbechos viejos (bosque secundario en estado avanzado). (Boom, 1987).

Está representada por "árboles de $15 \mathrm{~m}$; la corteza es escamosa; los frutos son alados (samaras) con una semilla. El género Vataireopsis cuenta con 4 especies en Bolivia, Brasil y Surinam" (Killeen, Beck, García, 1993).

En el bosque de Alto - Ivon ("monte alto"), Jihuipisi se encuentra comúnmente (especie frecuente). En la parcela permanente, se han inventariado 5 grandes árboles $(20-25 \mathrm{~m})$, con un "grosor" entre $43 \mathrm{~cm}$ y $2.40 \mathrm{~m}$ (DAP de 13.7 a $76.5 \mathrm{~cm}$ ).

El tronco es recto o presenta aletones (grandes raíces sobre el árbol), de color marrón, la corteza o "cáscara" interna anaranjada y la madera, amarilla clara.

El nombre Chácobo Jihuipisi viene de "Pisi": olor a podrido, porque el árbol huele mal.

USO

Jihuipisi es medicinal. Se utiliza para las picaduras de "buna", "burro", y para curar el insomnio de los niños.

- Para las picaduras de insectos, se raspa la corteza o "cascara" interna, y se aplica 
sobre la picadura.

- Para los insomnios, se estrujan las hojas y se ponen en agua tibia, luego se baña al niño.

\section{Jonoshia \\ Piper consanguineum Kunth \\ Piperaceae}

\section{DESCRIPCION}

En Alto Ivon, Jonoshia (Piper consanguineum) es arbusto común y se encuentra en el sotobosque (abajo de los árboles) del "monte" alto y del bosque ribereño. Tiene una altura de aproximadamente 0,7 a Im. La corteza es marrón verde, la corteza interna verde y la madera blanca. Las hojas son simples opuestas.

"El género Piper es un género pantropical grande con unas 500 especies en el América Tropical. Generalmente son plantas comunes en el sotobosque del bosque húmedo y vegetación secundaria (barbechos). Es mayormente representado por arbustos trepadores o pequeños árboles; los tallos tienen nudos hinchados. Las flores son dispuestas en espigas simples, opuestos a las hojas" (Killeen, Beck, García, 1993).

El nombre Chácobo de Jonoshia viene de "Joño": "taitetú" y de "Shia": armarga, ya que la planta es amarga y sirve para cazar el "chancho de monte".

USO

La planta sirve para cazar, en particular el "taitetú", y es estimulante para los perros. Se hace respirar la hoja al perro y se le soba todo el cuerpo.

\section{Maní \\ Phenakospermum guianensis (L. C. Rich) Endl. ex. Miq Strelitziaceae}

\section{DESCRIPCION}

Mani (Phenakospermum guianensis) está representado por "Hierbas (herbáceas) gigantes que pueden llegar hasta $12 \mathrm{~m}$, y que son parecidas al plátano. Las hojas son grandes ( $3 \mathrm{~m}$ de largo sobre $0,75 \mathrm{~m}$ de ancho). Normalmente fructifican una sola vez; Los frutos son unas cápsulas grandes, gruesas y leñosas con muchas semillas grandes. El género Phenakospermum está representado por una sola especie (género monotípico), ditribuida en América tropical, desde las Guyanas hasta Bolivia" (Killeen, 
Beck, García, 1993).

El nombre Chácobo Maní no tiene traducción en castellano.

En Alto-Ivón, se ha encontrado la planta en todos los ambientes pero esencialmente en el "monte" alto, distribuyéndose como manchas en el bosque, ocupando más de $100 \mathrm{~m}^{2}$ de superficie.

\section{USO}

La planta sirve para construcciones domésticas.

Las hojas sirven para techar las casas. Se recolectan las hojas, se doblan, se ponen a secar al sol, y luego se techa la casa.

\section{Mani \\ Apuleia leiocarpa (J.Vogel) J. F. Macbr \\ Caesalpiniaceae}

\section{DESCRIPCION}

Mani (Apuleia leiocarpa) está representado por "árboles de $35 \mathrm{~m}$ que pierden sus hojas (árboles deciduos). La corteza externa tiene cicatrices. Los frutos son legumbres indehiscentes (no se abren solos).

El género Apuleia cuenta con una o dos especies desde el noreste del Perú hasta el sudeste de Brasil, Bolivia y el norte de Argentina" (Killeen, Beck, García, 1993).

En la parcela del "monte" alto, se han inventariado 6 árboles aislados uno del otro. Eran por lo general, grandes árboles (entre 20 y $25 \mathrm{~m}$ de altura), con un "grosor" entre 132 y $315 \mathrm{~cm}$ (DAP entre 42 y $100 \mathrm{~cm}$ ). El tronco, de color marrón rojo, tiene incipientes (pequeñas raíces en la base del tronco), la corteza o "cáscara" interna es rojiza, y la madera blanca. Se han encontrado árboles con frutos medio rojizos, en diciembre de 1992.

El nombre Chácobo Mani no tiene traducción, es el nombre propio del árbol.

USO

Mani sirve para rebajar la fiebre.

Se hace sancochar unos trozos de corteza o "cáscara" en un poco de agua, se deja enfriar y se toma el líquido hasta que pare la fiebre.

Según Boom (1987), Mani sirve también para parar la fiebre, pero en este caso se hacen hervir las frutas y las hojas. 


\section{Mëquënobita y Yorabita Iryanthera juruensis Warburg / Iryanthera laevis Markgraf Myristicaceae}

\section{DESCRIPCION}

Mëquënobita y Yorabita (.Iryanthera laevis e I. juruensis), a menudo llamados "Bita" en Chácobo, han sido considerados juntos porque son plantas muy parecidas. Sin embargo, los Chácobo distinguen muy bien esas dos plantas ya que los frutos de Mëquënobita se encuentran en las ramas, mientras que los de Yorabita están sobre el tronco mismo.

Por lo general, Mëquënobita y Yorabita (Iryanthera laevis e Iryanthera juruensis) son "árboles hasta $20 \mathrm{~m}$, las ramas jóvenes son frecuentemente pubescentes (con pelos). También las hojas pueden tener pelos o no tener. Las flores son pequeñas y se encuentran sobre el tronco (cauliflores) o sobre las ramas (ramiflores). Los frutos son cápsulas (se abren). Estas especies se encuentran en bosque amazónico" (Killeen, Beck, García, 1993).

Iryanthera es un género tropical con más de 30 especies.

El nombre Chácobo Mëquënobita viene de "Mëquëno": brazo, porque los frutos se encuentran sobre las ramas.

El nombre Chácobo Yorabita viene de "Yora": cuerpo porque los frutos se encuentran sobre el tronco.

En Alto Ivon, Mëquënobita (probablemente, Iryanthera juruensis) es muy abundante, se han inventariado 44 árboles cuya altura varía entre 18 y $25 \mathrm{~m}$, con un "grosor" entre 36 y $117 \mathrm{~cm}$ (DAP entre 11,5 y $37 \mathrm{~cm}$ ).

Yorabita (probablemente, Iryanthera laevis) no es tan abundante como Mëquënobita. Se han inventariado 13 árboles en la parcela del "monte"alto. Eran árboles más pequeños que los Mëquénobita (altura entre 10 y $15 \mathrm{~m}$ ), con un "grosor" entre 33 y $74 \mathrm{~cm}$ (DAP entre 11,5 y $23,5 \mathrm{~cm})$.

Los árboles de Méquénobita y Yorabita son rectos, de color marrón, la corteza interna es rosada, la madera es blanca. Tienen exudado (savia) rojo.

$\underline{\text { USO }}$

Mëquënobita y Yorabita son plantas medicinales. La savia (el líquido de la corteza) sirve para curar las ampollas de la boca. Se aplica el exudado, es decir el líquido, directamente sobre la ampolla.

Según Boom (1987), Mëquënobita y Yorabita sirven para provocar vómitos (se toma la savia del árbol). La madera de Mëquënobita sirve también de astillas para fumar la goma. 


\section{Morochësti \\ Hirtella pilosissima C. Martius \& Zucc. Chrysobalanaccae}

\section{DESCRIPCION}

La especie Morochësti está representada por “árboles o arbustos hasta $15 \mathrm{~m}$. Las hojas son pubescentes (tienen pelos), los frutos son drupas carnosas. Se encuentra en bosque húmedo amazónico de tierra firme y bosque secundario (barbechos). El género Hirtella cuenta con alrededor de 93 especies distribuidas desde México hasta Bolivia y el sur de Brasil; tres especies se distribuyen en el este de Africa y Madagascar" (Killeen, Beck, García, 1993).

La especie Morochësti es muy común, (se encuentra a menudo) en Alto-Ivón, tanto en el bosque o "monte alto" como en los barbechos. Por el hecho de que la mayoría de los árboles no tenían un "grosor" suficiente para ser numerados, solamente se han inventariado 4 árboles pequeños en la parcela permanente. La altura promedia de los árboles era entre 8 y IOm, y el "grosor" entre 31.5 y $44 \mathrm{~cm}$ (DAP de $14 \mathrm{~cm}$ ). El tronco es recto, de color marrón, la corteza o "cáscara" interna roja con exudado pegajoso, y la madera amarilla clara. La corteza es delgada. Las hojas son simples alternas y con pelos (pubescentes).

Morochësti viene de "Moro": ropa, vestidos, y de "Chésti", nombre del árbol, porque su madera servía a aplanar los vestidos de los antiguos.

USO

Morochësti es medicinal y sirve para curar la "caracha", (infecciones de la piel debido a picaduras o heridas entre otros). Se raspa la corteza o "cáscara", la cual se pone directamente sobre el fuego. Las cenizas obtenidas se aplican sobre la piel infectada. Se repite la aplicación hasta que se cicatrice completamente la piel.

\section{Moxoquë Apeiba tibourbou Aublet Tiliaceae}

\section{DESCRIPCION}

La especie Moxoquë tiene varios nombres en castellano: balsa, cabeza de mono, erizo, jopo de mono. Se encuentra en los barbechos (bosque secundario) y en las orillas entre barbechos y pastos (Boom, 1987). "Son árboles pequeños a medianos. El tronco es cilindrico, la madera es amarilla. Las hojas son pubescentes, (pelos en forma de 
estrella). Los frutos son cápsulas espinosas, las semillas son numerosas y pequeñas. Se ha encuentra la especie con flores desde marzo hasta diciembre, y con frutos en marzo, septiembre y noviembre. El género Apeiba cuenta con alrededor de 12 de América tropical" (Killeen, Beck, García, 1993).

En Alto - Ivon, Moxoquë se encuentra por lo general los barbechos, aunque se han recolectado también algunos árboles en el "monte" alto. Los árboles recolectados de Moxoquë tenían una altura entre 10 y $15 \mathrm{~m}$, con un "grosor" aproximada de $49 \mathrm{~cm}$. El tronco es recto, de color marrón rojo, la corteza o "cáscara" interna es amarilla clara, y madera amarilla. La corteza tiene resina pegajosa.

El nombre Chácobo Moxoquë no tiene traducción, es el nombre propio del árbol.

USO

Moxoquë sirve para rebajar la fiebre: Se estrujan las hojas en agua tibia, y uno se baña, (también la cabeza).

Según Boom (1987), Moxoquë (Apeiba tibourbou) tiene diferentes usos: La madera sirve para fabricar pequeños "tocos" o taburetes. La corteza interna era antes utilizada para la fabricación de la ropa. Las hojas y la corteza son añadidas a la leche del Carama (Hevea brasiliensis) para espesarla.

\section{Nihibosa \\ Piper darienense C.DC \\ Piperaceae}

\section{DESCRIPCION}

Nihibosa (Piper darienense) es un arbusto común en Alto - Ivon. Se encuentra en todos los ambientes como bosque de tierra firme ("monte" alto), bosque secundario o barbechos y bosque ribereño.

La especie Piper darienense se encuentra desde el sur de Panamá hasta la amazonia boliviana (Boom, 1987).

Las plantas de Nihibosa recolectadas eran rectas, tenían una altura promedia de $50 \mathrm{~cm}$ (pueden alcanzar Im), la corteza o "cáscara" es verde y la madera, blanca. Las hojas son simples opuestas con olor aromático.

El nombre Chácobo Nihibosa viene de "Ni": de pie, porque la plante crece bien recto.

USO

Nihibosa sirve para calmar los dolores de muela.

Simplemente se mastica la raíz o la rama (que no es tan fuerte como la raíz), la cual se aplica sobre el diente dolido. Después de menos de medio minuto, el diente se encuentra anestesiado. 


\section{Nishiratëquëva Tanecium jaroba SW \\ Bignoniaceae}

\section{DESCRIPCION}

Nishiratëquëva (Tanecium jaroba) es un bejuco leñoso (que tiene madera) que se encuentra bastante escaso en el "monte alto" de Alto -Ivon y bosque ribereño.

El nombre Chácobo Nishiratëquëva viene de "Nishi": bejuco y "Tequenehua": tobillo o canilla larga, porque los nudos del bejuco se encuentran lejos uno del otro, están esparcidos en el cuerpo del bejuco.

En Alto-Ivón, solamente se ha inventariado 1 bejuco en la parcela, con un "grosor" de 44 era (DAP de $13 \mathrm{~cm}$ ). Aquello se debe a que la especie no es muy abundante, y por otra parte, los bejucos de Nishiratëquëva encontrados, tenían un "grosor" demasiado pequeño para ser numerados.

El tronco o cuerpo del bejuco, de color marrón, es medio aplastado, medio cuadrado, la "cáscara" interna es rojiza y la madera blanca. Las hojas son compuestas bipinnadas con estípulas.

\section{$\underline{\text { USO }}$}

Nishiratëquëva es medicinal y tiene varios usos:

Sirve para parar la diarrea y los vómitos: se raspa la "cáscara" y se "sancocha" (decocción de la corteza), se toma el líquido tibio hasta que pare las diarreas y vómitos.

Sirve para hacer disminuir las hinchazones (debidos a golpes por ejemplo): se raspa la corteza ("cáscara") interna y se aplica sobre la hinchazón en forma de cataplasmas.

\section{Nisho Tabebuia serratifolia (Vahl) Nicholson Bignoniaceae}

\section{DESCRIPCION}

La especie Nisho (Tabebuia serratifolia), está representada por "árboles de 30m; que pierden sus hojas (árboles deciduos). Los frutos son cápsulas (frutas que se abren solos) y las semillas son delgadas y aladas. Se ha coleccionado la especie con flores en agosto y octubre. Generalmente, la madera es utilizada para la construcción de horcones, postes y ejes de ruedas.

El género Tabebuia cuenta con alrededor de 100 especies" (Killeen, Beck, García, 1993). Nisho se ha encontrado más que todo en el "monte" alto de Alto-Ivón, pero no es una 
especie muy abundante en este tipo de bosque. En la parcela permanente, 3 árboles fueron numerados. La altura promedia de los árboles era de $15 \mathrm{~m}$, y el "grosor" de $41 \mathrm{~cm}$ (DAP de $13 \mathrm{~cm}$ ). El tronco es recto, de color marrón gris, la "cáscara" interna rosada, y la madera blanca.

El nombre Chácobo Nisho no tiene traducción, es el nombre propio del árbol.

\section{USO}

Nisho sirve para rebajar la fiebre.

Se hace hervir pedazos de la corteza o "cáscara" en un poco de agua, se deja enfriar y se toma el líquido hasta que pare la fiebre.

Nisho hace parte de un grupo de árboles cuya madera es muy dura y que la hacha no puede tumbar.

\section{Nishitsanona \\ Sparattanthelium amazonum Mart. spp. Amazonum Hernandiaceae}

\section{DESCRIPCION}

La especie Nishitsanona es un bejuco que se distribuye en los diferentes ambientes de Alto-Ivón, como sotobosque del "monte alto" y barbecho. Se recolectó la especie en la parcela del bosque de tierra firme y en el bosque, camino al primer centro.

El bejuco no es muy grueso, es acanalado y de color marrón negro, la "cáscara" interna es rojiza y la madera blanca. Las hojas son simples opuestas con tres nervaduras bien marcadas.

El nombre Chácobo Nishistanona viene de "Nishi": bejuco y "Tsanona": negra, por el mismo color la corteza o "cáscara".

\section{USO}

Nishitsanona es medicinal y sirve para dolores de estómago, diarrea y vómitos. Al igual que Nishiratequeva, se sancocha la "cáscara" y se toma el líquido hasta que se pare la diarrea o los vómitos.

Según Boom (1987), Nishistanona es también utilizado para los dolores de estómago, pero en este caso, se "sancocha" una mezcla de "cáscara" y hojas, y se toma el líquido. 


\section{Nohote \\ Theobroma speciosum Willd. ex Spreng. Sterculiaceae}

\section{DESCRIPCION}

Nohote (Theobroma speciosum) se Ilama Chocolatillo en castellano. Es una especie común de los barbechos viejos (bosque secundario en estado avanzado) que se cultiva también en las cercanías de las casas (Boom, 1987).

"Son pequeños árboles con hojas grandes (envés blanco o grisáceo). Los frutos son generalmente grandes con una "cáscara" (exocarpo) dura (coriáceo leñoso). Las semillas son lisas e inmersas en una pulpa dulce. La especie se distribuye en bosque amazónico y temporalmente inundado (230 - 260m). Se la encontró con flores en septiembre y con frutos verdes en octubre. El género Theobroma cuenta con alrededor 22 especies distribuidas desde México hasta Bolivia" (Killeen, Beck, García, 1993).

En Alto Ivon, Nohote es abundante y se distribuye en manchas o en grupos de árboles. Se han inventariado 15 árboles en la parcela del "monte alto". Los árboles tenían aproximadamente $10 \mathrm{~m}$ de altura, y en grosor entre 33 y $54 \mathrm{~cm}$ (diámetro entre 10.5 y $17 \mathrm{~cm})$. El tronco es recto, de color marrón oscuro, la corteza interna es amarilla oscura, la madera amarilla. Las hojas son simples alternas con envés blanco.

El nombre Chácobo Nohote no tiene traducción en castellano, es el nombre propio del árbol.

$\underline{\text { USO }}$

La pulpa de las frutas, alrededor de las semillas, se come. También la planta es medicinal y sirve para calmar los dolores provocados por las picaduras de "burros" (guzanos con pelos), "buna" (hormiga grande). En este caso se aplica la pulpa sobre la picadura.

\section{Onipa \\ Socratea exorrhiza (Mart.) Wendl Palmae}

\section{DESCRIPCION}

Onipa (Socratea exorrhiza) es una palma común en bosque secundario o en secundario avanzado (Boom, 1987).

"Se caracteriza por tener grandes raíces espinosas (raíces fulcreas). Se encontró la especie con flores en agosto y diciembre, frutos en abril, mayo, julio, septiembre y diciembre en bosque amazónico y submontano (220 - 700m)" 
El género Socratea se distribuye desde el sur de Nicaragua hasta Bolivia y desde el este de Venezuela hasta Brasil" (Killeen, Beck, García, 1993).

El nombre Chácobo Onipa no tiene traducción en castellano, es un nombre propio.

En Alto-Ivón, la especie es muy abundante, se han encontrado 35 plantas en la parcela permanente del "monte" alto. El tamaño de las palmas varía de 15 a $20 \mathrm{~m}$, y su "grosor", entre 31,5 a $66 \mathrm{~cm}$ (DAP entre 10 y $21 \mathrm{~cm}$ ), con un promedio de $42 \mathrm{~cm}$ (DAP: $12,5 \mathrm{~cm}$ ). La palma posee unas raíces aéreas espinosas, el tronco es de color marrón, la corteza o "cascara" interna es rayada de negro y blanco y la "madera" blanca.

USO

La planta sirve para las construcciones de las casas.

Del tronco, se obtienen láminas que sirven para hacer las paredes, los pisos, o las camas. También, las raíces espinosas sirven como rallador de yuca, aunque usualmente se utilizan latas con huecos.

A parte de esos usos, Boom menciona que es Onipa es también medicinal y sirve para rebajar la fiebre. Se hierven las frutas, se deja enfriar y se toma la preparación.

\section{Pamaxoco, Pamaxacaya Pseudolmedia laevis (R\&P) J.F. Macbr, Pseudolmedia macrophylla trécul / Pseudolmedia cf. murure Moraceae}

\section{DESCRIPCION}

Como en el caso de Mëquënobita y Yorabita, Pamaxoco. Pamaxacava han sido considerados juntos por ser muy parecidos, pero la primera especie tiene hojas pequeñas, mientras que la segunda, hojas grandes.

Pamaxoco y Pamaxacava, son especies muy comunes en bosque húmedo y barbechos viejos. Son representadas por "árboles medianos y altos entre 20 y $40 \mathrm{~m}$, con látex (leche) de color café, hojas generalmente enteras. Son plantas dioicas (es decir, plantas macho o hembra). Los frutos son carnosos (drupas), comestibles y sirven de alimentos a monos y otro animales.

El género Pseudolmedia cuenta con aproximadamente nueve especies en América tropical.

El nombre Chácobo Pamaxoco viene del árbol Pama y de "Xoco": pequeño, por las hojas pequeñas, mientras que Pamaxacava viene de "Xacaya": grande, por las hojas grandes. En Alto Ivon, Pamaxoco (probablemente, Pseudolmedia laevis y en menor proporción $P$. macrophylla) es muy abundante siendo la especie que más se ha encontrado en la parcela permanente. Se han inventariado 134 árboles cuya altura varía entre 8 y $15 \mathrm{~m}$ y 
el "grosor", entre 33 y $116 \mathrm{~cm}$ (DAP entre 10,5 y $37 \mathrm{~cm}$ ).

Pamaxacava (probablemente, Pseudolmedia vs mururé) se encontró en menos abundancia. Se han inventariado 15 árboles en la parcela del "monte alto". Eran árboles más grandes que los Pamaxoco (altura de 15 y 20m), con un "grosor" entre 37 y $123 \mathrm{~cm}$ (DAP entre 11,8 y $39 \mathrm{~cm}$ ).

Los árboles de Pamaxoco y Pamaxacava son rectos, de color marrón verde, la corteza interna es rosada, la madera es blanca. Tienen leche color blanca y café.

\section{USO}

Además de tener frutas que se comen, Pamaxoco, Pamaxacava, y las demás especies del grupo Pama (Pamacoro, Pamabara .Tihuipama) son medicinales y tienen el mismo uso.

La leche sirve principalmente para sacar "los borros" (larvas de moscas) de la piel. Se pone la leche sobre la piel hasta que el gusano se muera.

También sirve para calmar las picaduras de "burros" (gusanos con pelos), "buna" (hormiga grande) y curar las ampollas de la boca al igual que Mëquënobita y Yorabita. Se aplica la leche sobre la picadura o la ampolla de la boca.

Según Boom (1987), Pamaxacaya y Pamaxoco sirven para calmar los dolores provocados por reumatismos: se aplica la leche sobre un trapo y se aplica sobre la piel en forma de cataplasma.

\section{Panabi \\ Euterpe precatoria Mart Palmae}

\section{DESCRIPCION}

Panabi (Euterpe precatoria) es una palma arborescente muy común en bosque secundario (barbechos) y secundario a estado avanzado (barbechos viejos). Tiene una distribución amplia en Amazonia y Guyana (Boom, 1987). La especie se explota al nivel comercial por su palmito. "Puede alcanzar los $17 \mathrm{~m}$, el tronco es recto, delgado y liso. Euterpe precatoria ha sido recolectada con frutos en abril, julio, agosto y octubre en bosque amazónico de tierra firme, bosque montano (de 150m hasta $1740 \mathrm{~m}$ ). El género Euterpe cuenta con 28 especies distribuidas en las Antillas, Centro América hasta Brasil y Bolivia" (Killeen, Beck, García, 1993).

En Alto Ivon, Panabi es abundante, se distribuye en todo el bosque de tierra firme. Se han encontrado 21 plantas en la parcela permanente. Las palmas tenían una altura de aproximadamente 10-15m, y su "grosor" varía de 32 a $50 \mathrm{~cm}$ (DAP entre 10,5 y 16cm). El tronco es recto de color marrón gris, la "madera" es blanca.

El nombre Chácobo de Panabi es un nombre propio, no tiene traducción en castellano. 
USO

Panabi (Euterpe precatoria) sirve a techar las casas y se combina generalmente con Mani (Phenakospermum guianensis). También las frutas se comen y son vitamínicos (vitaminas). Se remojan para ablandarlos y asimismo, comer la pulpa. También se toma el jugo hervido de las frutas, con azúcar.

Según Boom (1987), las hojas del Panabi son también medicinales y sirven para el mal de pecho. Asimismo, se hacen "sancochar" las hojas y se toma el jugo.

\section{Paxaini Metrodorea flavida Krause Rutaceae}

\section{DESCRIPCION}

Paxaini (Meírodorea flavidá) es un árbol de amplia repartición en Amazonia (Boom, 1987).

"Los árboles pueden alcanzar los $20 \mathrm{~m}$. Las hojas son opuestas simples o trifolioladas; las flores son pequeñas y los frutos (cápsulas) verrugosos hasta espinosos.

El género Metrodorea cuenta con cinco especies, principalmente de Brasil." (Killeen, Beck, García, 1993).

El nombre Paxaini viene de "Paxa" que significa crudo y de "Hini": árbol, porque la madera tarda mucho en secarse.

En la parcela permanente, se han encontrado 10 árboles, (es una planta común), con una altura promedia de $10-15 \mathrm{~m}$ y un "grosor" entre 31 y $67 \mathrm{~cm}$ (diámetro entre 10 y $21 \mathrm{~cm}$ ). El "palo" (o tronco) presenta incipientes, con un color marrón verde, la corteza interna es rosada y la madera amarilla.

USO

La planta sirve para "fumar" la goma (astillas). Es decir que la leña, al consumirse, provoca un humo intenso, que permite hacer coagular la leche de la goma. Asimismo, se hacen las "bolachas", vendidas en Riberalta. 


\section{Quixono \\ Amburana cearensis (Allemao) A.C. Smiíh \\ Papilionaceae}

\section{DESCRIPCION}

Según el departamento de Bolivia en el que se encuentra (Beni, La Paz, Santa Cruz), la especie Quixono (Amburana cearensis) tiene un nombre castellano diferente: tumi (Beni), sorioco (La Paz) y roble (Santa Cruz). Está representada por "árboles hasta 40m; con corteza rojiza, lisa, con olor agradable, con exudación. Los frutos son vainas, dehiscentes (que se abren sólo), con una semilla alada (dispersión por el viento). La especie se encuentra en el bosque húmedo de llanura entre otros tipos de bosque El género Amburana cuenta con alrededor de 1 - 2 especies desde el sur-este de Perú hasta el noreste de Brasil y al sur de la Argentina" (Killeen, Beck, García, 1993).

La especie Quixono no es abundante en el bosque de Alto-Ivón, solamente se han inventariado 2 árboles en la parcela permanente. La altura promedia de los árboles era de 12 - 15m, y el "grosor" varía entre 38 y 44cm (DAP de $12-14 \mathrm{~cm}$ ). El tronco es recto, de color marrón oscuro, la corteza o "cáscara" interna rosada con olor aromático, y la madera blanca. Las hojas son compuestas alternas imparipinnadas. La "cáscara" se deshace en láminas.

El nombre Chácobo Quixono viene de "Xono": planta de la région del Benicito porque en esa región existe una planta parecida a Quixono de Alto-Ivón.

USO

A parte de ser considerado como buena madera, Quixono es también medicinal. Sirve para los dolores de cabeza y las hinchazones. Se raspa la corteza interna sobre un trapo. Luego, se aplica el trapo sobre la frente para los dolores de cabeza, o sobre la hinchazón, como cataplasma.

\section{Rarasá \\ Piper hostmannianum (Miq) C.D.C. \\ Piperaceae}

\section{DESCRIPCION}

Rarasá (Piper hostmannianum) es un "arbusto común e bosque secundario (barbechos) con distribución amplia en los Neotrópicos" (Boom, 1987). 
Rarasá es común en los barbechos y caminos, también se encuentra en el sotobosque del "monte" alto (es decir debajo de los árboles). La altura de los Rarasá recolectados, no sobrepasaba los $50 \mathrm{~cm}$, con corteza, verde marrón y madera blanca. Las hojas eran simples opuestas y ásperas.

El nombre Chácobo Rarasá no tiene traducción en castellano, es el nombre propio de la plantas.

USO

Rarasá sirve para la "caracha".

Se mastica una hoja y se pone la saliva (de color verde por haber masticado la hoja) sobre la piel infectada.

Según Boom (1987), Rarasá (Piper hostmannianum) sirve también para la caracha, pero además de las hojas, se mastica también la corteza o "cáscara" de la planta.

\section{Rohonosëbi Cheiloclinium cognatum (Miers) A.C. Smith Hippocrataceae}

\section{DESCRIPCION}

Rohonosëbi (Cheiloclinium cognatum), es un arbusto hasta $8 \mathrm{~m}$. Se ha encontrado la especie con flores y frutos en febrero y octubre en bosque amazónico y bosque submontano húmedo (150-900m).

El género Cheiloclinium comprende aproximadamente 20 especies de América tropical distribuidas desde Centro América hasta Bolivia y Paraguay" (Killeen, Beck, García, 1993).

En Alto Ivon, Rohonosëbi es abundante y se encuentra frecuentemente en el sotobosque. En el caso de la parcela permanente, solamente se han inventariado 4 árboles porque el "grosor" de los troncos era demasiado pequeño para entrar en el inventario. La altura de los árboles inventariados era de aproximadamente $5-8 \mathrm{~m}$, y su grosor varía entre 32 y $41 \mathrm{~cm}$ (diámetro entre 10 y $13 \mathrm{~cm}$ ). Los árboles son rectos, de color marrón gris, la corteza interna es rosada, la madera es blanca y los frutos amarillos.

Rohonosëbi en Chácobo viene de "Roho", un tipo de mono que vive en este árbol.

USO

Las frutas (bayas carnosas amarillas) de la planta se comen. 


\section{Samomaquëti}

\section{Senna macrophylla Kunth var. gigantifolia (B\&K) Irvin \& Barneky \\ Caesalpiniaceae}

\section{DESCRIPCION}

La especie Samomaquëti (Senna macrophylla var. gigantifolia) está representada por "arbustos de $2 \mathrm{~m}$. Ha sido recolectada con flores en noviembre en bosque amazónico de tierra firme y en bosque secundario. Las hojas son compuestas paripinnadas en espiral. Tiene flores amarillas. La fruta es una legumbre (vaina).

Según Boom (1987), Samomaquëti es un arbusto común en bosque secundario y con distribución amplia en el norte de Sur América.

El género Senna cuenta con 240 especies de distribución pantropical (en todas las regiones tropicales), numerosas especies se encuentran en América, Africa y Australia, pocas en Asia y Oceanía” (Killeen, Beck, García, 1993).

El nombre Chácobo Samomaquëti viene de "Samoma": abeja, porque las abejas polinizan las flores del árbol.

En Alto-Ivón, si bien no se ha encontrado la especie en la parcela permanente del bosque, se han encontrado árboles en el bosque de tierra firme y más aún, en los barbechos de 5 años.

Los arbustos no sobrepasan de los $10 \mathrm{~m}$ de altura (de 6 a $10 \mathrm{~m}$ ) y el "grosor" es máximo de $31 \mathrm{~cm}$ (diámetro de $10 \mathrm{~cm}$ ). El tronco ("palo"), de color marrón tiene la corteza interna amarilla y la madera blanca.

$\underline{\text { USO }}$

Los Chácobo utilizan Samomaquëti (Senna macrophylla var. Gigantifolia) como leña. Según Boom (1987), la planta es también medicinal: las hojas se utilizan para aliviar los reumatismos. Se hierven las hojas en el agua y se toma la infusión como maté (decocción). 


\section{Shishaxë \\ Licania sp. \\ Chrysobalanaceae}

\section{DESCRIPCION}

El género Licania cuenta con 157 especies distribuidas en bosques y sabanas de las Guyanas y Cuenca amazónica, con una sóla especie en Asia tropical. Las especies son representadas por "arbustos o árboles que pueden alcanzar los 30m, con exudado rojo, las hojas pueden ser hojas lanosas (tener pelos) o glabras (sin pelos) (Killeen, Beck, García, 1993).

En Alto-Ivón, se han encontrado solamente 3 árboles de Shishaxë. Esta especie no es abundante, pero se encuentra de manera regular en el bosque.

La altura promedia de los árboles varía entre 10 y 15 m, y tenían un "grosor" entre 35 y $52 \mathrm{~cm}$ (DAP entre 11 y $22 \mathrm{~cm}$ ). Los árboles de color marrón, presentan pequeñas raíces en su base (incipientes). La corteza o "cáscara" interna es rosada y la madera amarilla. Las hojas son simples alternas con estípulas.

El nombre Shishaxë viene de "Shisha": "Coati", porque allí vive el animal.

\section{USO}

La planta sirve para construcciones domésticas.

La madera sirve para armazones de la casa (tijeras y otros componentes).

Shishaxë sirve también de astillas para fumar la goma.

\section{Shishohitsa \\ Siparuna guianensis Aublet \\ Monimiaceae}

\section{DESCRIPCION}

La especie Shishohitsa (Siparuna guianensis) es muy común de los barbechos (en bosque secundario) (Boom, 1987).

Está representada por "árboles o arbustos aromáticos hasta 3m; las son hojas opuestas (Killeen, Beck, García, 1994). La especie se encuentra en bosque húmedo amazónico de tierra firme. Fue recolectada con flores de septiembre a noviembre y con frutos en febrero y diciembre.

El género Siparuna cuenta con alrededor de 125 especies (Killeen, Beck, García, 1993). En Alto-Ivón Shishohitsa es un arbusto abundante y se encuentra en todos los ambientes, 
("monte alto", el bosque ribereño, barbechos cercanos a la comunidad de Alto-lvón). Por el hecho de que el tamaño de los arbustos era demasiado pequeño, ésos no fueron inventariados en la parcela permanente.

Los arbustos recolectados tenían una altura promedia de $3 \mathrm{~m}$, el tronco recto, de color marrón, la corteza es interna, amarilla, y la madera amarilla clara. Las hojas, simples opuestas sin estípulas. Por lo general, toda la planta (corteza, hojas) huele a limón.

USO

Shishohitsa es medicinal. Sirve para la gripe y resfríos. Se remoja la "cáscara" y las hojas en agua tibia, y luego se respira este agua.

\section{Shiuë \\ Rinoreocarpus ulei (Melchior) Ducke Violaceae}

\section{DESCRIPCION}

Shiuë se llama Blanquillo en castellano.

La especie Shiuë está representado por "árboles pequeños o medianos. Se encuentran en el sotobosque con flores probablemente durante todo el año. El fruto es una cápsula con 3 valvas, cada una con 2 a 4 semillas.

El género Rinoreocarpus tiene una sola especie y se extiende en la Amazonia y regiones vecinas". (Killeen, Beck, García, 1993).

El nombre Chácobo Shiuë no tiene traducción en castellano, es el nombre propio del árbol.

Shiué es abundante en el bosque., (se encuentra mucho en el "monte alto"). En la parcela permanente se han inventariado 23 plantas de Shiuë. Su "grosor" varía de $33 \mathrm{~cm}$ a $50 \mathrm{~cm}$ (diámetro entre 10,5 y $16 \mathrm{~cm}$ ) y su altura, entre 10 y $15 \mathrm{~m}$. El tronco ("palo") es recto, de color marrón, la corteza interna es amarilla y la madera, anaranjada y muy dura.

\section{USO}

Los Chácobo utilizan Shiué (Rinoreocarpus ulei) para la leña (uso doméstico). 


\section{Tapa \\ Bertholletia excelsa H. \& B. Lecythidaceae}

\section{DESCRIPCION}

Tapa (Bertholletia excelsa) es una especie común de la Amazonia.

"Se encuentra en bosque húmedo de tierra firme $(150-280 \mathrm{~m})$ y generalmente los árboles son dejados a propósito cuando el bosque es desmontado.

Los árboles pueden alcanzar $45 \mathrm{~m}$. El tronco es recto, las hojas son grandes (entre $17 \mathrm{y}$ $36 \mathrm{~cm}$ de largo), y aparecen flores en octubre. Los frutos (pixidios) son redondos, muy duros al igual que las semillas. La maduración de los frutos es larga (más de un año) y la cosecha tiene lugar entre noviembre y febrero del otro año. El género Bertholletia cuenta con una sola especie amazónica" (Killeen, Beck, García, 1993).

En Alto-Ivón, se han encontrado 4 árboles en la parcela inventariada del "monte" alto. Al igual que Carama, esta planta no es muy abundante pero se encuentra regularmente en el bosque alto. Generalmente son árboles grandes (de 25 a 30m), con un "grosor" entre 51 y $252 \mathrm{~cm}$ (diámetro entre 31 y $80 \mathrm{~cm}$ ). El tronco es de color marrón oscuro, la corteza interna marrón y la madera blanca.

\section{USO}

Al igual que el Carama, los Chácobo obtienen ciertos recursos económicos a partir de la venta de las semillas de Tapa. A la diferencia del caucho, no existen estradas asignadas a cada familia, cada uno pudiendo ir a cosechar las frutas. La época de cosecha empieza en noviembre y termina en febrero.

Debido al peligro que representa la caída de las frutas, las semillas son cosechadas cuando los frutos ya están caídos al sucio. Estos últimos son abiertos con machete en el lugar mismo del árbol, y asimismo se recogen las semillas, dejando las "cáscaras" de las frutas en el piso. Las semillas son depositadas en el almacén de la comunidad, para ser luego vendidas por cajas en Riberalta. Esas cajas tienen un tamaño estándar (peso de aproximadamente una arroba).

Los precios de las cajas de castaña varían según los años. En 1992 y 1993, la castaña proveía mayores recursos que la goma, (la caja se vendía aproximadamente 15Bs en la comunidad y $18 B$ s en Riberalta).

Por otra parte, se utiliza una pequeña parte de la cosecha para el consumo familiar (crudas o tostadas).

Según Boom (1987), los Chácobo obtienen también aceite de las semillas de Tapa y la utilizan como aceite de comer, ya que la consideran de mejor sabor que el aceite comercial. 


\section{Tioroquërihua \\ Micropholis guianensis A.DC. Pierre \\ Sapotaceae}

\section{DESCRIPCION}

La especie Tioroquërihua (Micropholis guianensis) es común en Amazonia y Guyana (Boom, 1987).

"Los árboles tienen hasta $18 \mathrm{~m}$ de altura, el tronco (fuste) es más o menos recto, acanalado en la base, y tiene exudado. El fruto es rojo y de sabor dulce. Ha sido colectado con botones florales en agosto, con frutos en noviembre y febrero.

En Bolivia, la especie se encuentra en bosque húmedo de llanura y montano (200$1530 \mathrm{~m})$.

El género Micropholis cuenta con 38 especies distribuidas en Centro y Sur América" (Killeen, Beck, García, 1993; Boom, 1987).

En la parcela permanente, se han encontrado 13 árboles (especie abundante), con una altura promedia de $10-15 \mathrm{~m}$ y un "grosor" promedio entre 31 y $100 \mathrm{~cm}$ (DAP entre 10 y $31 \mathrm{~cm}$ ). El tronco, de color marrón verde, es recto o tiene pequeños incipientes, la corteza interna es verde y la madera blanca. Tiene leche blanco.

El nombre Chácobo Tioroquérihua no tiene traducción en castellano, es el nombre propio del árbol.

USO

Al igual que Paxaini y Xahuamachi, Tioroquërihua sirve para "fumar" la goma. También, las frutas se comen.

Según Boom (1987), la planta es también medicinal, y sirve para los reumatismos. Se hacen hervir o sancochar las hojas, se deja enfriar el líquido y se toma.

\section{Xahuamachi Sloanea guianensis (Aublet) Benth Elaeocarpaceae}

\section{DESCRIPCION}

Xahuamachi (Sloanea guianensis) se llama urucusillo en castellano.

La especie está representada por "árboles hasta $30 \mathrm{~m}$, con hojas heteromorfas, (que no tienen la misma forma). Se han encontrado árboles con flores de junio a agosto, con ñutos en junio y septiembre, en bosque húmedo de llanura y piedemonte. 
El género Sloanea cuenta con unas 120 especies, distribuyéndose en Asia y América Tropical. En América, se extiende desde México, Las Antillas, hasta Bolivia y el sur-este de la costa del Brasil" (Killeen, Beck, García, 1993).

El nombre Xahuamachi viene de "Xahuanë": Paraba, porque este pájaro come las frutas del árbol.

En la parcela permanente del bosque de tierra firme ("monte alto"), se han encontrado 7 árboles de Xahuamachi. Tenían una altura promedia de $10-15 \mathrm{~m}$ y un "grosor" promedio entre 38 y $147 \mathrm{~cm}$ (diámetro entre 12 y $47 \mathrm{~cm}$ ). El tronco es de color marrónrojo, presentaba aletones. La corteza interna es rojiza y la madera blanca, las hojas tienen un tamaño irregular.

$\underline{\text { USO }}$

Al igual que Paxaini, la planta sirve de astillas para "fumar" la goma.

También es una planta medicinal que sirve para sanar la "caracha" (ver capítulo 3 p.). En este caso, se hace quemar la corteza o "cáscara" del árbol, y se aplican las cenizas sobre la piel.

\section{Xahuaxëchi \\ Casearia combaymensis Tul. / Casearía membranacea Britton Flacourtiaceae}

\section{DESCRIPCION}

La especie Xahuaxëchi (Casearia combaymensis) es común en bosque secundario en estado avanzado (barbechos viejos) (Boom, 1987).

Está representada por "árboles hasta $15 \mathrm{~m}$ que crecen en bosque amazónico inundado (200- 230m). Se han coleccionado árboles con flores en abril y septiembre" (Killeen, Beck, García, 1993).

"El género Casearia se encuentra en todas las regiones tropicales del mundo (género pantropical) con 180 especies, 75 correspondiendo a América tropical. En Bolivia existen unas 14 especies" (Killeen, Beck, García, 1993).

En Alto-Ivón, solamente se han inventariado 2 plantas de Xahuaxéchi con una altura respectiva de 10 y 15m, y un "grosor" de 66 y $75 \mathrm{~cm}$ (DAP entre 21 y $24 \mathrm{~cm}$ ). El tronco es recto, de color marrón gris, la corteza interna es marrón oscura y la madera blanca. Las hojas son simples alternas.

USO

La corteza sirve para teñir. Se mete en el agua tibia para obtener el baño de tintura para cerámicas, algodón u otra fibra. 


\section{Xahui o Xahuiria Xylopia cf. peruana R.E. Fries \\ Annonaceae}

\section{DESCRIPCION}

La especie Xahui (Xylopia cf. polyantha) es muy común en bosque secundario (barbechos) (Boom, 1987).

Está representada por "árboles medianos con aletones extendidos. Se ha encontrado con flores en bosque amazónico en febrero (200m).

El género Xylopia es pantropical (se encuentra en todos los países tropicales con alrededor de 160 especies)" (Killeen, Beck, García, 1993).

En el bosque de tierra firme ("monte alto") de Alto Ivon, se han encontrado algunos árboles de Xahui. El "grosor" de los árboles no superaba los $31 \mathrm{~cm}$ (DAP inferior a $10 \mathrm{~cm}$ ). El tronco es recto, de color marrón gris, la corteza interna amarilla oscura, reticulada (pareciendo a una malla de pescar) y olorosa. Se encontró un árbol con botones florales en octubre de 1993.

Xahui no tiene traducción en castellano, es el nombre propio de la planta.

\section{$\underline{\text { USO }}$}

La corteza de Xahui o Xahuiria, de color medio amarilla se utiliza en las construcciones de las casas y sirve a amarrar las tijeras u otros tipos de madera. Comúnmente esas cuerdas se llaman "panchos".

A parte de esos usos, Boom menciona que el Xahuiria servía antes para hacer los vestidos de los antiguos como Yoméno y Pío, entre otros árboles.

Del grupo de los Xahui (Annonaceae), Xahuiria es la especie de la cual se sacan los mejores "panchos".

\section{Xënanë \\ Inga spp. \\ Mimosaceae}

\section{DESCRIPCION}

El grupo de los Xenanë (Inga spp.) es grande y lleva el nombre castellano de Pacay. Casi todas las especies tienen frutas comestibles. "El género Inga comprende unas 250 especies distribuidas en las regiones cálidas y húmedas de América. Son árboles pequeños hasta medianos, o arbustos. Las hojas son compuestas paripinadas con 1 a 6 pares de folíolos grandes y opuestos, raquis alado o no, y glándulas. El fruto es 
una vaina (legumbre), aplastada (comprimida lateralmente) o cilindrica, coriácea, casi indehiscente. Las semillas están envueltas en una pulpa blanca (arilo blanco), y dulce, generalmente comestible" (Killeen, Beck, García, 1993).

En Alto-Ivón, esas plantas se distribuyen en todos los ambientes ("monte alto", barbechos, bosque ribereño, "pampa"). Se han recolectado 8 diferentes plantas de Xënanë en esos lugares, pero en la parcela del "monte" alto, solamente se ha recolectado el Huaihuatixënanë. Dentro del grupo Xënanë, encontramos: $\underline{\text { Ahuapixenanë, }}$ Huaihuatixënanë, Rispixënanë, Jimi(homa)xënanë, Rayoxënanë, Rohoxënane, Shipixënanë (Inga heterophylla), Tsacoxënanë, Xabachacarohoxënanë (pampa). Boom (1987) encontró también el Siritësaxënanë (Inga cf. adenophylla). Generalmente los árboles tienen entre 10 y $15 \mathrm{~m}$ de altura, el tronco es de color marrón gris, la corteza interna rojiza y la madera blanca. Las hojas son compuestas paripinadas con 1 a 6 pares de foliolos.

\section{USO}

La pulpa de las frutas (alrededor de las semillas) se comen. Todos los Xénané mencionados se comen.

\section{Yomëno \\ Ficus gomelleira Kunth \& Bouché Moraceae}

\section{DESCRIPCION}

"El Uso De Las Plantas Por Los Chácobos (Alto-Ivón, Beni, Bolivia)" La especie Yomëno (Ficus gomelleira) es llamada en el Beni Mata palo. Está representada por "árboles grandes (hasta $37 \mathrm{~m}$ ). Tienen látex (leche) blanco que se oxida a anaranjado. Los frutos son pequeños.

El género Ficus cuenta con más de 1000 especies en las regiones tropicales; en América se encuentran más de 150 especies distribuidas desde el sur de Estados Unidos hasta el norte de Argentina." (Killeen, Beck, García, 1993).

En Alto Ivon, solamente se han inventariado 2 árboles de Yomëno cuya altura sobrepasaba los $30 \mathrm{~m}$, y un "grosor" entre 1,5 y $3 \mathrm{~m}$ (DAP entre 45 y $95 \mathrm{~cm}$ ).

El tronco, de color marrón tiene aletones tabulares, la corteza interna es rosada, la madera blanca. Tiene leche blanco que se oxida. Las hojas son simples alternas con leche blanca.

Yomëno no tiene traducción en castellano, es el nombre propio de la planta.

\section{USO}

Antiguamente, la corteza interna servía para hacer la ropa. Se machacaba la corteza y 
Bergeron S., 1998. Uso de las plantas por los Chácobos (Alto Ivón, Beni, Bolivia)

se dejaba secar al sol algunos días.

Actualmente, los Chácobo no utilizan este tipo de ropa, pero siempre utilizan la corteza

interna de esas plantas para hacer los "maricos" (canasta que sirve para llevar la leña, yuca u otro cultivo). 


\section{Conclusión}

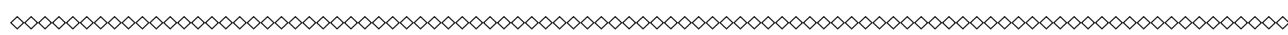
Los Chácobos se han adaptado desde siglos a su medio ambiente. A través de un contacto diario con la selva amazónica, han acumulado conocimientos que se han transmitido de generación a generación a través del paso de los siglos. El trabajo realizado con los colaboradores y comunarios Chácobos ha permitido conocer mejor las relaciones que existen entre los indígenas y su entorno vegetal. Pero cabe recalcar que la información que se ha presentado a lo largo de este libro, representa solamente una pequeña parte de los conocimientos que puede tener la etnia Chácobo respecto a su entorno vegetal. En efecto, la investigación fue muy puntual, tanto en el tiempo como en el espacio; ya que se trató de un estudio de sólo 6 meses, concentrado en el área de Alto - Ivon.

Los resultados más importantes contenidos en los diferentes capítulos de este libro pueden resumirse de la siguiente manera:

\section{La diversidad biológica del bosque de tierra firme de Alto-Ivón}

El bosque de tierra firme de Alto-Ivón es un bosque no muy alto y en estado de equilibrio: el aporte continuo de los árboles jóvenes (especies confundidas), más numerosos que los árboles adultos, asegura la regeneración de las especies del bosque y por consiguiente su regeneración.

El bosque de tierra firme o "monte alto", es bastante rico en especies (123 especies/ha, distribuidas en 112 especies de árboles, 5 de palmas y 6 de bejucos), sin ser por lo tanto tan rico como en otras áreas amazónicas.

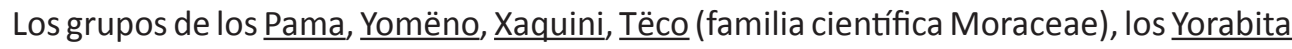
y Mëquënobita (Myristicaceae), los Onipa, Pananë (Palmae), los Cano (Caesalpiniaceae) y Shia, Canamashia, Maní etc. (Papilionaceae) son las 5 familias más importantes del bosque de tierra firme de Alto-Ivón.

Las ocho especies (diferentes clases de plantas) realmente "características" de la parcela inventariada, en el sentido de que se encuentran mucho y de manera regular en el bosque (abundantes y frecuentes), y los árboles tienen un diámetro o "grosor" (especies dominantes) bastante grande, son: Pamaxoco (Pseudolmedia laevis y P. macrophylla), Yorabita y Mëquënobita (Iryan/hera juruensis), Onipa (Socratea exorrhiza), Tëco (Perebea aff. acutifolium), Tioroquërihua (Micropholis guianensis), Isonaraja (Horda sp.), Canapa (Helicostylis tomentosa). Por lo general el índice de valor de importancia de estas especies es elevado, variando entre 6.1 y 40.9.

Asimismo, se distinguen las especies que tienden a distribuirse en grupos mono específicos, o sea en forma de manchas en el bosque: Pamaxoco (Pseudolmedia laevis), 
y con menor intensidad Mëquënobita y Yorabita (Iryanlhera juruensis), Onipa (Socratea exorrhiza), Shiuë (Rinoreocarpus ulei), Pamaxoco (Pseudolmedia macrophylla) y Paxaini (Melrodorea flavida). Estas especies son, al mismo tiempo, abundantes y frecuentes en el bosque.

Por otro lado, existen otras especies como Caiosho (Amaioua guianensis), Batahua (Capirona decorticans), Mëquënobita y Yorabita (Iryanthera laevis), Tioroquérihua (Micropholis guianensis), Teco (Perebea aff. acutifolium), Isonaraja (Hortia sp.), Bisatamanëjoni (Qualea paraensis) que, a pesar de no ser tan abundantes como las primeras, son frecuentes. En este caso, los árboles de una misma especie se encuentran de manera aislada y no en grupos.

Por último, se destacan especies cuya abundancia, frecuencia o dominancia es muy poco elevada (especies con IVI del grupo IV), y que por consiguiente se encontrarán de manera aleatoria en el bosque (especies escasas).

Asimismo, los resultados obtenidos sobre la diversidad florística del bosque de tierra firme, corroboran los estudios de Ribera (1992: 58), en el sentido de que, por sus condiciones geográficas y climáticas (clima tropical de carácter estacional), así como sus características florísticas, el bosque de tierra firme de Alto-Ivón puede ser considerado como un bosque húmedo amazónico (siempreverde estacional con elementos de la Hylea), donde muchas especies típicamente amazónicas tienen su límite de distribución y no avanzan a mayor latitud.

Por último, podemos hacer unas recomendaciones respecto a los diferentes ambientes que se encuentran en el área de Alto-Ivón

- Se recomienda realizar más inventarios florísticos en el bosque de tierra firme ("monte alto"), por ejemplo en el área del bosque- camino al primer centro, a manera de ampliar el área de muestreo en este tipo de ambiente, y de esta forma, complementar los resultados del presente estudio y los trabajos de Boom (1987).

- Es necesario realizar investigaciones en el bosque ribereño, "pampa" (sabana) y barbechos (bosques secundarios), ya que no existe ningún tipo de estudios florísticos cuantitativos en estas áreas. En este último caso, sería conveniente emplear el método de línea y punto de intercepción, (metodología utilizada para este tipo de formación abierta), con la finalidad de poder comparar con otros estudios realizados en las pampas de la zonal central del Beni.

- Se recomienda hacer recolecciones generales de material fértil (plantas con flores o frutos) a manera de venir precisando y/o corroborando las identificaciones botánicas de las especies recolectadas en el presente estudio o anteriores.

- Se recomienda realizar estudios sobre la fenología (épocas de floración y fructificación, dispersión de las semillas) de las principales especies utilizadas por los 
comunarios, con la finalidad de conocer mejor la biología y la regeneración de estas especies.

- Tomando en cuenta los puntos mencionados anteriormente, sería recomendable realizar estudios a más largo plazo, sobre la dinámica del bosque en general (¿Cómo y en cuánto tiempo se regenera?).

- Por otro lado, es imprescindible realizar estudios faunisticos (de los animales) en el área de Alto-Ivón, ya que no se ha hecho ningún tipo de investigación respecto al tema. Sería conveniente realizar las investigaciones, a través de metodologías participativas y de censos biológicos, empezando por las especies de animales más consumidas por los comunarios y por lo tanto, las que se están acabando. Estos estudios permitirían plantear lincamientos para el manejo de estas especies de animales.

- También hace falta realizar estudios de suelos en el área ya que hasta la fecha no se conocen los usos actuales y potenciales de la tierra. Esos estudios contribuirían a realizar una zonifícación para un manejo sostenible del área de Alto - Ivon.

\section{La clasificación de las plantas por los Chácobos}

Considerando un universo de aproximadamente 530 plantas (de las cuales 472 han sido recolectadas) abarcado en este capítulo, podemos resumir las principales características de la clasificación botánica Chácobos, de la manera siguiente:

Referiéndose al modelo de clasificación de Brent (1972), y considerando los diferentes grupos de plantas distinguidos por los Chácobos, podemos decir que la clasificación botánica tradicional se enmarca en dos principales lineamientos, los cuales se resumen también en la Tabla 34:

Tabla 34: Resumen de la clasificación botánica Chácobos

\begin{tabular}{|l|c|c|c|c|c|}
\hline \multirow{2}{*}{ Criterios } & \multicolumn{5}{c|}{ Número de grupos } \\
\cline { 2 - 6 } & Arboles & Palmas & Bejucos & Hierbas & Totales \\
\hline \multicolumn{7}{|c|}{ 1. Criterios morfológicos } \\
\hline lera forma de distribución & 4 & & & & 4 \\
\hline 2da forma de distribución & 2 & & & & 2 \\
\hline Jera forma de distribución & 28 & 2 & 2 & 9 & 41 \\
\hline \multicolumn{7}{|c|}{ Otros criterios de clasificación } \\
\hline Uso \\
\hline Carácter especial de las plantas & 5 & 2 & 5 & 4 & 16 \\
\hline Totales & 4 & & 1 & 2 & 7 \\
\hline
\end{tabular}


La clasificación tradicional se basa en criterios morfológicos:

- Las plantas están agrupadas por tener semejanzas por ejemplo, en la forma del árbol, hierba, o bejuco, en la forma de las hojas, o de las frutas. En este caso, los grupos de plantas responden al modelo de clasificación etno-biológica de Brent. Este tipo de clasifícación se encontró mayormente en el caso de los árboles y en segundo lugar, para las hierbas.

- Por otro lado, hemos visto que dentro de este mismo modelo de clasificación, podían existir diferencias. De las tres formas de distribución posibles, la tercera forma se encontró más frecuentemente (ver Tabla 34), lo que corrobora los principios de la clasificación de Brent, donde, la mayoría de las taxas genéricas, no incluyen categorías inferiores como específicas y varietales.

La clasificación tradicional se basa en otros tipos de criterios:

Generalmente puede ser el uso mismo de las plantas, o también las plantas tienen una característica especial en común (por ejemplo, madera muy dura, corteza muy amarga, pelos irritantes entre otros caracteres). En este caso, no se puede aplicar el modelo de clasificación de Brent. Este tipo de clasificación se encontró principalmente para los bejucos (ver Tabla 34).

Por otro lado, el análisis, aunque superficial, de los nombres Chácobos ha demostrado una gran variabilidad respecto a la nomenclatura de los nombres:

Muchas veces, para un mismo grupo, los nombres de las plantas tienen una raíz común. Ocurre también que las plantas que pertenecen al mismo grupo, no llevan una raíz común. Por otro lado, una misma planta puede ser nombrada de diferentes maneras. Respecto a las formas de vida, por lo general los nombres de los árboles no llevan el nombre de la forma de vida ¡ihui mientras que para las hierbas y los bejucos, es muy variable.

En cuanto a la significación de los nombres Chácobos, el nombre de la planta puede ser su nombre propio sin poder ser traducido en castellano. También puede basarse en función de sus características morfológicas, en su uso, en una semejanza o en una relación que existe entre la planta y un animal. Esto demuestra con claridad la estrecha relación que existe entre las plantas y animales y por lo tanto, no se puede concebir el mundo de las plantas sin el mundo de los animales.

Como recomendaciones podemos mencionar que

Es necesario profundizar los sistemas de clasificación de las plantas, enfocando más el estudio en la lingüística y en los sistemas de clasificación "folk" o tradicional, (tomando como ejemplo, los estudios de Berlin Brent, 1992). 
$>$ Es recomendable realizar esos tipos de estudios con los animales y los suelos. En efecto, el conocimiento de los sistemas de clasificación y de uso de las plantas, animales, suelos entre otros ejemplos, contribuirá grandemente al desarrollo socio-económico y cultural de los Chácobos, respondiendo de esa forma a sus necesidades.

\section{El uso de las plantas por los Chácobos}

Sobre un universo de 472 diferentes plantas diferenciadas por los Chácobos, y recolectadas para muestras botánicas, el $68 \%$ tiene uso, y de estas plantas, el $15 \%$ se utiliza para varios fínes (multi-uso). Aunque que no pudimos comparar el uso de las plantas según los diferentes ambientes, podemos sin embargo mencionar que los Chácobos aprovechan todos los ambientes probablemente, con mayor o menor intensidad. Por ejemplo, de las plantas inventariadas en la parcela del bosque de tierra firme, el $96 \%$ de las especies botánicas inventariadas (correspondiendo al $97 \%$ de los individuos de la parcela) tiene uso. Asimismo, eso refleja los grandes conocimientos que tienen los indígenas respecto al bosque de tierra firme, y particularmente, a las plantas leñosas, lo cual les permite hacer un uso integral y diversificado de este tipo de ambiente.

Cabe mencionar que este saber no es propio de algunas personas, sino más bien, es general a los comunarios de Alto-Ivón, tanto los hombres como las mujeres, jóvenes, adultos y ancianos comparten este saber transmitido de generación a generación.

Por lo general, todos los tipos biológicos (árboles, arbustos, bejucos, y hierbas) se utilizan. Los árboles y arbustos entran en todas las categorías de uso, salvo, respectivamente, caza y pesca, y construcción. Por otro lado, los bejucos y palmas también tienen un uso diversificado (sirven para varios fines), mientras que las hierbas son más utilizadas para caza y pesca así como, medicina.

Las plantas medicinales son las que más se encontraron, luego aparecen las plantas comestibles, plantas que sirven para construcción, pesca, leña y astillas, las otras plantas siendo utilizadas en proporciones menores para otros fines. Por otro lado, muchas de las plantas registradas pueden tener varios usos, siendo el uso comestible y medicinal, más común.

Las plantas medicinales más frecuentemente encontradas sirven para los problemas de estómago, diarrea, paludismo, fiebre, o se utilizan para sanar la "caracha", cicatrizar la piel, calmar dolores de picadas de insectos. Asimismo, el modo de preparación depende de la enfermedad. Se utiliza muy frecuentemente la corteza del árbol o del bejuco, en forma de "decocción" para tomar, o en forma de cenizas aplicadas sobre la piel. También pueden utilizarse las hojas (en forma de baños) o la resina misma de la planta. Las plantas que sirven para otras enfermedades son más escasas (dolores de oídos, infección de ojos, insomnios entre otros) y el modo de preparación es similar a 
Bergeron S., 1998. Uso de las plantas por los Chácobos (Alto Ivón, Beni, Bolivia)

lo mencionado anteriormente. Por otra parte, no se registraron en este estudio, plantas que sirven para problemas pulmonares, reumatismo, plantas anticonceptivas, plantas insecticidas entre otros ejemplos.

Respecto a las plantas alimenticias, son por lo general, las frutas que se comen.

Por otro lado, se destacan en este estudio, las plantas que sirven para pescar o cazar, que pueden ser "barbascos" (método frecuentemente utilizado para la pesca) o que tienen una acción "indirecta", considerándose como plantas "mágicas".

También hay que destacar la gran diversidad de uso que pueden tener otras plantas (por ejemplo, juguetes de los niños, utensilios domésticos, canastas). Además, si bien no se utilizan directamente, sirven de indicadoras o son consideradas como malos agüeros, lo que demuestra una vez más la estrecha relación que existe entre los Chácobos y su entorno vegetal. Por otro lado, si bien ciertas plantas ya no se utilizan (adornos, vestimienta de los antiguos, tintas del cuerpo y/o cerámicas), siempre permanecen los conocimientos respecto a sus usos.

Como recomendaciones, podríamos mencionar lo siguiente:

> Falta precisar la identificación botánica de ciertas plantas como Pseudolmedia laevis, Pseudolmedia macrophylla, Iryan/hera juruensis, Iryan/hera laevis entre otras especies a manera de ver si realmente un nombre Chácobo corresponde a varias especies científicas, $v$ viceversa.

> Por otro lado, es imprescindible realizar estudios cuantitativos sobre el uso de las plantas en los diferentes ambientes, considerando áreas definidas como se ha hecho para la parcela permanente del bosque de tierra firme. Esto permitirá comparar la intensidad de uso de los diferentes ambientes. Asimismo, es necesario profundizar el estudio sobre el uso de las plantas (cualquier sea su tipo biológico), especialmente, las especies de la pampa, el bosque ribereño y barbechos, involucrando a toda la comunidad, tanto hombres, como mujeres y niños.

> También, falta profundizar el estudio sobre la intensidad de uso de las plantas, ver cuáles son las más importantes para los Chácobos, y en el caso de que una planta tenga varios usos, conocer cuál de éstos es predominante. Este tipo de estudio podría realizarse a través de metodologogias participativas, y permitiría dar unas pautas para proyectos de desarrollo productivo.

$>$ Falta investigar el uso de los helechos, bejucos, epífitas y hierbas, en todos los tipos de ambiente.

$>$ Sería muy conveniente profundizar los conocimientos sobre las plantas medicinales en un sentido "etno-médico", enfocando sobre los síntomas exactos de la enfermedad, cantidades y frecuencias exactas de toma, bioquímica de la planta entre 
otros componente. Aquello permitiría por una parte, profundizar los conocimientos sobre las enfermedades existentes y más frecuentes del área, y asimismo, buscar soluciones a los problemas de salud que tienen los Chácobos. Por otra parte, ayudaría a que los mismos comunarios puedan compilar sus conocimientos en forma de una guía "etnomedicinal", propia de ellos.

> Se recomienda realizar investigaciones aplicadas sobre la castaña y goma (principal fuente de recursos económicos de los Chácobos). Esto permitiría definir lineamientos de manejo, mejorar la explotación y comercialización de esas especies, tanto al nivel familiar, como comunal, y asimismo, contribuiría al desarrollo productivo y sostenible del área de Alto - Ivon.

Por otra parte, en un futuro próximo, sería muy conveniente realizar estudios sobre ciertas especies ya utilizadas por los comunarios (otras que castaña y goma), en el sentido de ecología de las especies, posibilidad de comercialización al nivel, local, regional, o nacional, factibilidad económica, socio-cultural, y ambiental. En efecto, estas plantas podrían consistir en una alternativa de desarrollo para los Chácobos.

En conclusión, la información mencionada en el presente libro demuestra el alto conocimiento que tienen los Chácobos de la vegetación y la relación estrecha que existe entre el hombre y su entorno vegetal y por lo tanto, con la naturaleza en general.

Más allá del estudio, estos resultados confirman el papel fundamental que juegan los Chácobos, así como otras etnias indígenas, en el manejo y desarrollo sostenible del bosque amazónico, corroborando asimismo, la necesidad de seguir en el proceso de intercambios de conocimientos, experiencias y tecnologías entre las culturas tradicional y occidental. Asimismo, este presente trabajo sólo representa un hilo conductor que sumado a otros, contribuirá a rescatar los conocimientos indígenas, lograr el intercambio de dos escuelas distintas de conocimientos, y de esta forma, coadyuvará a mantener tanto la identidad indígena como manejar y preservar los recursos naturales. 


\section{Bibliografía}

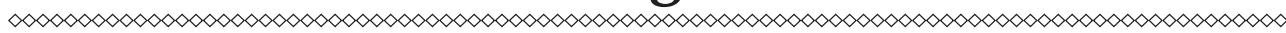

\section{ARMENTIA, FR. NICOLAS,}

1887.

"Navegación del Madre de Dios" Biblioteca Boliviana de Geografía e Historia. La Paz.

\section{ATLAS DE BOLIVIA,}

1989.

Ed.Geomundo, Barcelona. 215p.

\section{BALEE, W.}

1993.

Footprinls of the foresl. Ka'apor Ethnobotany-the Histórical Ecology of Plant Util izat ion by an Amazonian People. Colombia University Press., New York. 396p.

\section{BECK, S.,}

1988.

Las ecoregiones ecológicas y las unidades fitogeográficas de Bolivia. En Manual de Ecología, C. de Morales. Instituto de Ecología-UMSA. La Paz. pp.233-267.

\section{BERGERON S.,}

\section{2.}

La régénération naturelle de quelques espéces útiles de la forét de terre ferme sur terrasse basse (Araracuara, Amazonas, Colombie). Thése de doctorat, Bordeaux III. 2vol. 292p. + 196 p.

Approche préliminaire de la classification botanique Chácobos (Beni, Vaca Diez, Bolivie). Proyecto financiado por el Instituto Francés de Estudios Andinos. Lima, Pérou. 12p.

Rapport anuel. Approche préliminaire de la classification botanique Chácobos (Beni, Vaca Diez, Bolivie). Proyecto financiado por el Instituto Francés de Estudios Andinos. Lima, Pérou. 12p.
1993.

Rapport anuel. Approche préliminaire de la classification botanique Chácobos (Beni, Vaca Diez, Bolivie). Proyecto financiado por el Instituto Francés de Estudios Andinos. Lima, Pérou. 12p.

1995.

Informe semestral IBIS Dinamarca. CIDDEBENI. Trinidad. 80p. + Anexos.

1996

Guía Popular de tas plantas de los Chácobos. Versión preliminar. Fondo Nacional para el Medio Ambiente (FONAMA). La Paz. 50p.

\section{BOOM, B. M.}

1985a.

Amazonian Indians and the forest environment Nature 314: 324.

1985b.

Ethnopteridology of the Chácobos Indians in Amazonian Bolivia. Amer. Fern. J. 75 (1)

\section{6a}

A forest inventory in Amazonian Bolivia. Biotropica 18 (4): 287-294.

\section{$1986 b$}

The Chácobos and their palms. Principes 30 (2): 63-70.

1987.

Ethnobotany of the Chácobos Indians, Beni, Bolivia. Advances in Economic tíotany 4: 1- 68.

1989.

Use of Plant Resources by the Chácobos. In: Resource Management in Amazonia: Indigenous and Folk Strategies. Advances in Economic Botany 7: 78-96. 


\section{BRENT, B.}

1972.

Speculations on the growth ofEthtnobotanical nomenclature. Lang. And Soc. 1: 51-86.

1973

The Relation of Folk Systematics to Biological Classification and Nomenclature. Ann. Rev. Ecol. and Systematics 4: 259-71.

\section{$1976 a$}

The Concept of Rank in Ethnobiological Classification: Some evidence from Aguaruna Folk Botany. Amer. Ethnol. 3 (special issue on Folk Biology) 381-399.

1978a.

Elhnobiological Classification. In Cognition and Categorization. Ed. Rosch E., Lloyd B., 9-26. Hillsdale, N.J.: Lawrence Erlbaum Associates.

\section{2}

Ethobiological classification: principies of categorization of plantas and animals in tradicional societies. Princeton University Press. Princeton, New Jersey. $335 \mathrm{p}$.

\section{CARDUS, J.}

\section{6.}

Las misiones franciscanas entre los infieles de Bolivia: Descripción del estado de ellas en 1883 y 1884 con una noticia sobre los caminos y tribus salvajes. Barcelona.

CONKLIN, H. C.

1954

The relation ofHanunóo Culture lo the Plant World. Ph.D. 3-32

\section{D'ORBIGNY, A.}

1944.

"El Hombre Americano"'” Ed. El Futuro, Colección Eurindia de la edición de 1839, Buenos Aires. Argentina.

1946.

"Descripción geográfica, histórica y Estadística de Bolivia", Tomo Y, reimpresión Librería Editorial Don Bosco de la edición de 1845. La Paz. Bolivia.

\section{ELLENBERG, $\mathrm{H}$.,}

1981.

Mapa simplificado de las ecoregiones de Bolivia. En Desarrollar sin destruir. Instituto de Ecología, UMSA, La Paz.

FAO,

1970.

The soils of South America. Rome.

GENTRY, A.H.,

1983.

Dispersal ecology and diversity in Neotropical Forest communities. Sonderbd. Naturwiss. Ver Hamburg 7: 303-314.

1988.

Changes in plant community diversity and floristic composition on environmental and geographic gradients. Annals of the Missouri Bolanical Carden 75: 1-34.

1993.

A field Cuide lo the Families and Genera of Woody Plantas of Northwest South America (Colombia, Ecuador, Perú), with supplimentary notes on herbaceous taxa. Conservation International Washington. 
HAASE, $R$.

1990.

Plants communities of a savanna in northen Bolivia II. Palm swamps, dry grassland, and shrubland.

Phytocoenologia, 18 (2\3) 343 - 370. Berlin-Stuttg.

\section{HAENKE, W.}

1957.

"Los indios Chácoboss del río Benicito", revista Khana, $\mathrm{N}^{\circ} 27 / 28$. OctubreDiciembre 1957. pp. 3955.

The Chácobos in Bolivia. Ethnos 23: 100125.

\section{HARRINGTON, J. P.,}

1947.

Ethnobiology. Acia Amer. 5:224-247.

\section{HARSHBURGER, J.W.,}

1896.

Purposes of Ethnobotany. Bol. Gazetle 21: 146-154.

\section{HNLPB, CIBE, 1BBA, IIQ, IIFB, ORSTOM,} 1993.

Propuesta de conservación ambiental a través de la valoración etnobotánica y etnofarmacológica en Bolivia. Proyecto financiado por Fondo Nacional para el Medio Ambiente (FONAMA). HNLPB (Herbario Nacional de Bolivia), CEBE (Centro de Investigaciones Botánicas y Ecológicas), IBBA (Instituto Boliviano de Biología de Altura), IIQ (Instituto de Investigaciones Químicas), IIFB (Instituto de Investigaciones FarmacoBioquímicas), ORSTOM (Instituí Franjáis de Recherche Scientifique pour le Développement en Coopération). La Paz, Bolivia.
HUECK,

1978.

Los bosques de Sudamérica. Ecología, composición e importancia económica. GTZ Alemania R.F. 476p. 1 mapa.

KELM, II.

1972.

Chácobos 1970; Eine Restgruppe der Sudost-Pano em Oriente Boliviens. Tribus 21: 129- 246.

\section{KAHN, F.,}

1983.

Architecture comparée des foréts tropicales denses humides et dynamique de la rizhosphére. Thése de Doctorat dEtat, Montpellier, pp. 142-224.

KILLEEN, T., BECK, S., GARCÍA, E., 1993.

Guía de árboles de Bolivia. Herbario Nacional de Bolivia, Missouri Botanical Garden. La Paz, Bolivia. 958 p.

\section{KREBS, C.J.,}

1989.

Species diversily measures. University British Colombia, Harper and Row Publishers, New-york, pp.328-367.

\section{KROEGER, A., BA RBIRA-FREEDMAN, F.,} 1982.

Cultural Changes and health: The case of the South American Rainforests Indians. Verlag Peter Lang, Frankfurt am Main. pp.22I- 235.

\section{LARA, R.,}

1983.

Mapa generalizado de la vegetación. En Atlas de Bolivia. IGM. Escala 1: 5.000.000. 


\section{LEVI STRAUSS, C.,}

1966.

The Savage Mind. London: Weidenfelf and Nicolson.

MACA,

1975.

Mapa ecológico de Bolivia. Ministerio de Asuntos Campesinos y Agropecuarios. La Paz, Bolivia. Escala: 1: 1.000.000.

\section{MARTIN, G.J.,}

1995.

Ethnobotany: A methods manual. Wild World Fundation, UNESCO, Royal Botanic Gardens, Kew. UK. Ed. Chapman \&Hall. Londres. 267p.

\section{METRAUX, A.,}

1948.

The Southeasthern Panoan tribes. In J.H. Steward (ed.) Handbook of South American indians. Vol.3. Cooper Square Publishers, New York. pp. 449-452.

\section{MONTANO ARAGON M.,}

\section{7.}

Guía etnográfica lingüística de Bolivia (tribus de la selva). Tomo I. Ed. Don Bosco. La Paz, Bolivia. pp. 1-21.

\section{MORAES M., BECK, M.,}

1992.

Diversidad florística de Bolivia. En: Conservación de la Biodiversidad en Bolivia. CDC- Bolivia, USAID/Bolivia. La Paz. pp.73-111.

MORALES DE, C. B., 1990.

Bolivia, Medio ambiente y Ecología aplicada. Instituto de Ecología, Universidad Mayor de San Andrés, La Paz. 318p.
MUELLER-DOMBOIS, D., ELLENBERG, II., 1974.

Aims and methods of vegetation ecology. John Wiley, New York, 547 p.

\section{NORDENSKIOLD E.,}

1911.

Indios y Blancos. Trad. de Indianer och Hyita, Ammér C., Salas R., E. Cap. X- XIV.

\section{3.}

Indianer und Weisse in Nordostbolivien. Stuggart.

\section{PRANCE, G.T.,}

1976.

Inventario forestal de um hectare de Terra Firme da Estrada da Manaus. Acta amazónica 6 (1): 9-35.

\section{PROYECTO RA DA RG RAM E FRICO DEL AMAZONAS,}

1979.

La Amazonia Colombiana y sus recursos. Bogotá: IGAC; CIAF. 3v. FFAA.

\section{PROST, G.}

1960.

"Fonemas de la lengua Chácobos". Notas lingüísticas de Bolivia $\mathrm{N}^{\circ} 2$, La Paz. Instituto lingüístico de Verano, Riberalta.

PROST, G. Y M., 1965.

"Chácobos". Gramáticas estructurales de lenguas bolivianas, Vol. II. Instituto lingüístico de Verano, Riberalta.

\section{PROST, M. D.,}

1970.

Costumbres, habilidades y cuadro de la vida humana entre los Chácobos. Instituto lingüístico de Verano, Riberalta. 
RIBERA A., M.,

1992.

Regiones Ecológicas. En: Conservación de la diversidad biológica de Bolivia. CDC- Bolivia, USAID/Bolivia. Ed. Marconi, M. La Paz. pp.I 1-71.

\section{ROLLET, B.}

\section{4.}

"L'architecture des foréts denses humides sempervirentes de plaineNogent sur Marne, CTFT, 1974,298 p.,' 8 pl., 155 tabl. + annexes.

\section{SANCHEZ S., M., RODRIGUEZ, A.,}

1990.

Aproximación preliminar al conocimiento de la clasificación botánica Muinane. Bogotá, Colombia. Colombia Amazónica, Vol.4: 2. pp. 67-75.

\section{SAE, UDAPSO, INE, CIDOB, PNUD,} 1994.

Primer censo Indígena Rural de Tierras Bajas Oriente, Chaco, y Amazonia. La Paz. p.40, 306.
UICN, PNUMA, WWF,

1980.

Estrategia Mundial para la Conservación. 57 p.+ mapas.

1991.

Cuidar la Tierra. Estrategia para el Futuro de la Vida.

UNESCO, 1973.

Clasificación internacional y cartografía de la vegetación. Serie Ecología y Conservación. UNESCO Switz. 92 p.

UNESCO, PNUE, FAO, 1979.

"Les écosystémesforesiiers tropicaux". Presses universitaires de France, Vendóme, 740p.

UNIVERSIDAD NACIONAL DE COLOMBIA (SECCIONAL MEDELLIN), 1986.

Análisis estructural de un Bosque no pertubado, Araracuara, Amazonas, parte I. Prácticas de sivilcutura tropical campamento ingeniera forestal, 53p. 


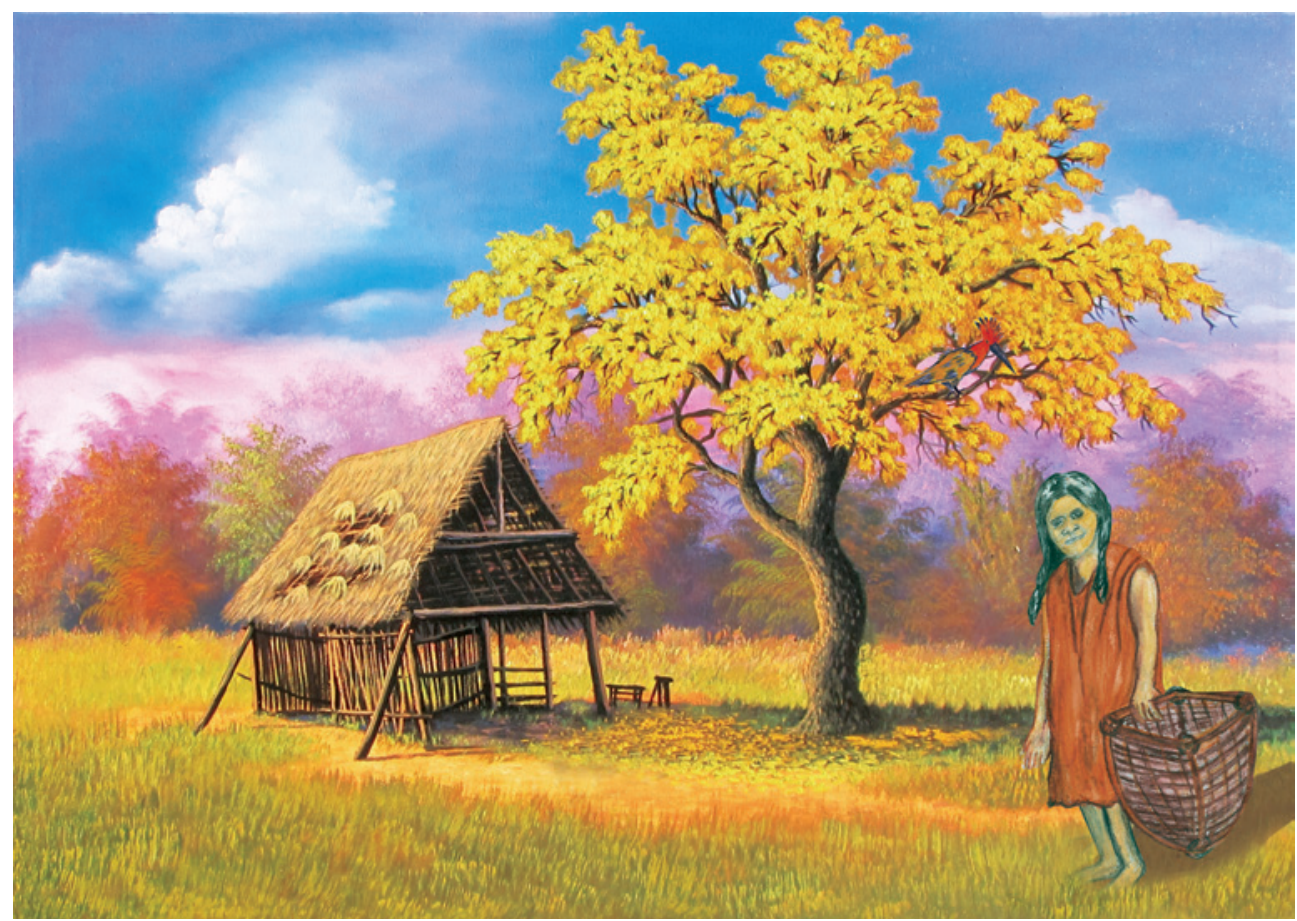

\section{ASHINÁ o la historia de Los Chácobo y el fuego}

En aquellos tiempos cuando los Chácobo, eran cazadores, pescadores y recolectores, tampoco disponían de las yucas y el maíz para comer, y aun contando con tierras fértiles para la agricultura, carecían de semillas para la siembra y tampoco tenían fuego para cocinar, por lo que comían la carne cruda, luego de secarla al sol.

Por la misma época en esta región de la amazonia boliviana, habitaba también Ashiná, despiadada y egoísta mujer que hablaba Chácobo, pero que era de una raza distinta, única dueña de la yuca, del maíz y del fuego, elementos que no quiso compartir con los demás.

Cuando le pedían semillas de maíz o yuca, ella siempre les negaba y si insistían mucho, les entregaba las semillas carbonizadas después de quemarlas, por lo que jamás crecían cuando las sembraban en sus "chacos".

Por esta razón la gente siempre intentó robarle el fuego y las semillas, pero ella tenía un pájaro espía llamado "tareche", el cual poseía un pico muy largo parecido a la de un tucán, el cual siempre alertaba a la vieja cuando alguien se acercaba, entonces ella iba al encuentro de la gente con una canasta grande, al llegar a ellos primero los inmovilizaba con sus malévolos poderes y luego los capturaba y cargaba dentro del canasto, finalmente los hervía y devoraba.

Cierto día mientras Ashiná estaba sembrando maíz, se le acercó sigilosamente 
un personaje mágico que era un grillo-humano, el cual robó una de las semillas arrojadas y se escapó cavando un túnel en la tierra, al darse cuenta de lo sucedido, la vieja hirvió agua y llenó de ella el túnel, pero fue demasiado tarde el grillohumano había logrado escapar y llegar hasta la aldea de los Chácobo, lugar donde sembró la semilla, luego creció una planta muy grande, de la cual cosecharon todas la variedades de maíz: el duro, el colorado, el blando, el morado y otros. Entonces todos los hombres trabajaron para proteger a la planta del viento, construyendo un cerco muy fuerte, y en lugar de comer las semillas, las sembraron nuevamente las cuales cuando dieron nuevos frutos se repartieron para que todos los hombres pudieran sembrar y cosechar.

Sin embargo todavía no tenían el fuego, el que necesitaban para hervir maíz y hacer chicha. Así que un día cuando Ashiná, descansaba en su hamaca de algodón, el "tareche" cansado del maltrato de su ama, tomó una brasa de fuego con su pico y fue llevándola hasta los Chácobo, protegiéndola en un árbol seco.

Lamentablemente durante el trayecto el calor quemo su pico, el cual se redujo hasta quedar muy pequeño. Cuando Ashiná descubrió el hurto tuvo tanta rabia que provocó una tempestad con lluvia muy fuerte para apagar el fuego robado, sin embargo los Chacobó haciendo uso de cortezas de árboles secos llamado "pancho", cuidaron el fuego para que no se apagara, luego la repartieron entre sus familias.

Ya tenían maíz y fuego pero aún les faltaba la yuca, así que los Chácobo planearon dar muerte a la vieja, para robarle. Así que un día mientras ella se encontraba distraída y triste por la partida de su único hijo llamado Wirika, algunos hombres cavaron un hoyo muy profundo en medio de su casa a modo de trampa, la cual finalmente funcionó y Ashiná cayó en el pozo muriéndose y convirtiéndose en un animal llamado "pejichi", la condena de este animal es la de vivir siempre bajo tierra.

Sin embargo los poderes malévolos de Ashiná, no murieron con ella y alcanzaron a aquellas personas que festejaron su muerte, transformándolos en aves y otros animales. Y la gente que no se alegró ni burlo de la bruja, tomaron la semilla de yuca de su "chaco" y lo llevaron a sembrarlos en sus parcelas, logrando así tener diferentes variedades de yucas, las cuales son cultivadas hasta la actualidad por los Chácobo.

Esta historia me fue narrada por Berta Chavez Moran, durante el trabajo de campo del Proyecto Etnobotánica de los Chácobo, desarrollado en Alto Ivón a finales del 2013, y la escribí como homenaje al pueblo Chácobo y al equipo de investigadores del mencionado proyecto.

Carlos M. Vega Ocaña 

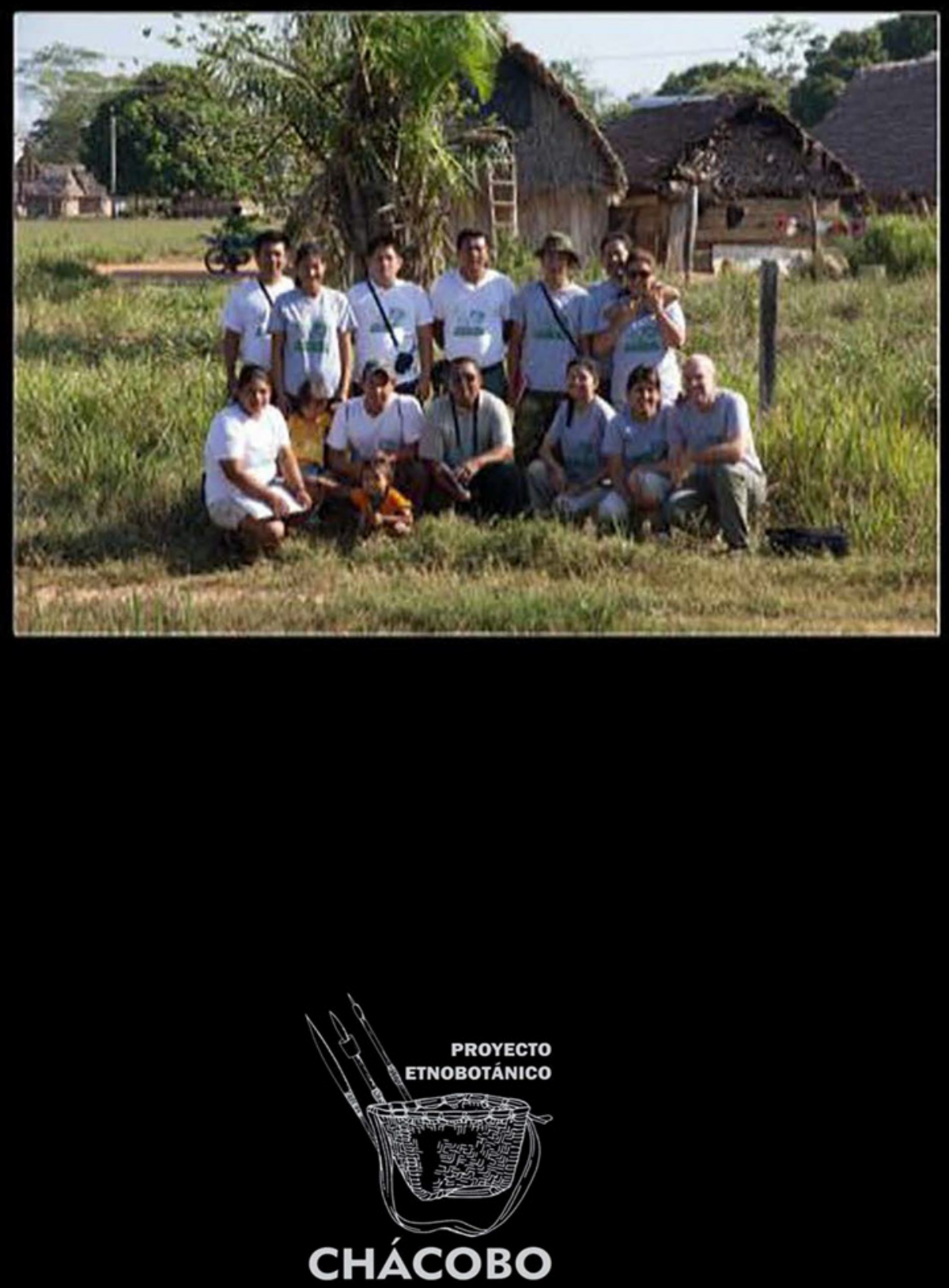